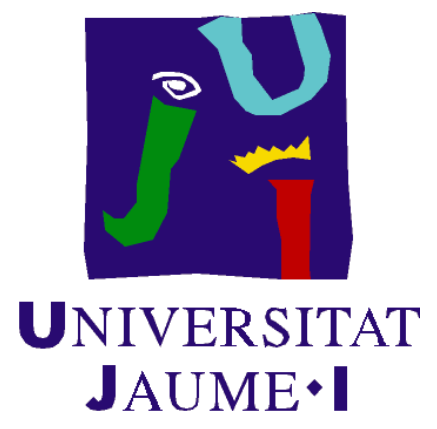

PROGRAMA DE DOCTORADO EN ESTUDIOS INTERNACIONALES DE PAZ, CONFLICTOS Y DESARROLLO

Escuela de Doctorado de la Universidad Jaume I

\title{
APRENDER A DISCREPAR. LA CLAVE, EL DEBATE TELEVISIVO Y LA FORMACIÓN DE UNA CULTURA POLÍTICA DEMOCRÁTICA EN ESPAÑA (1976-1985)
}

Memoria presentada por Sergio Rochera Miravet para optar al grado de doctor por la Universidad Jaume I

Dirigida por Dr. Vicent Sanz Rozalén y Dra. Carole Egger 

A mis padres 



\section{Agradecimientos:}

Después de varios años de trabajo, espero que estas breves líneas que componen este texto sirvan para dar las gracias a todas aquellas personas que me han ayudado en esta investigación. Ha pasado casi una década desde que decidiese escribir una tesis doctoral. Por aquel entonces todavía cursaba mis estudios de licenciatura. Allí conocí al que es uno de mis referentes: mi director de tesis Vicent Sanz. Agradecerle, en primer lugar, su ayuda intelectual y emocional que conlleva toda tesis doctoral. Por su esfuerzo y por mostrarme su pasión por investigar. Si no fuese por él, no estaría donde estoy hoy. Han pasado muchos años desde entonces, y todavía sigue ahí, muestra de su compromiso conmigo, y a lo que siempre le estaré agradecido.

A mis amigos. A muchos los conocí con ocho años cuando llegué desde Sabadell. Edu, Valero, Juan, Juanba... Hemos crecido desde entonces y hay mucho de lo que enorgullecerse. A otros, cuando solo pensábamos en marcar goles. Luis, Gil, López, Aitor, Alberto, Tamborero, Pedro, Ximo, Gabri, Salva... Nunca fuimos goleadores, pero sí dejamos nuestras huellas en muchos campos. $Y$ nos hicimos grandes con Josep, Isi, Penelo, Pepe, Alfredo, Miguel, Terrer, Inés, Noelia, Félix... Gracias por todo.

Y un día acabas la carrera, donde conociste a Elena, Saray, Andrea, Paula, Bea... y te marchas a otro país, otra casa (si puede decirse de un minúsculo espacio de pocos metros cuadrados), y ves otro amanecer junto a Anna y Carlos. La etapa francesa me dejó otro puñado de amigos: Sara, Silvia, Chantal, René... Besançon fue el inicio del viaje. Alemania, Holanda, Suiza, Bélgica, Turquía, Camboya, Vietnam... me dejaron algunas de las mejores experiencias de mi vida. De vuelta a Francia me trasladé a Estrasburgo para trabajar en la Universidad. Allí conocí a Isabelle, Nathalie, Irene, Lucy, Laura, Erwan, Kuko, Khagani, Angélica, y a mi directora, Carole Egger, quien me guio en el trabajo y supo inculcarme grandes valores. Otra muestra de compromiso emocional e intelectual, esta vez en un país que no era el mío. Gracias a todos por hacer que una estancia de seis meses se convirtiese en siete años.

No fue fácil dejar atrás a mi familia. A ellos les debo todo. Las navidades se hacían cortas junto a mis tíos, mis primos y mis padres. A vosotros os dedico esta tesis doctoral, porque sin vuestra ayuda no habría sido posible. A mi mejor amigo, Manuel, porque los días son largos sin ti. A mi hermano, José Miguel, por estar siempre ahí a pesar de la distancia. A mi madre, Marisol, quien me ha dado más de lo que yo jamás le podré devolver. Y a mi padre, Pepe, mi mayor referente. Os quiero dar mi más sincero agradecimiento por haber estado a mi lado.

Y de vuelta a los orígenes. Barcelona me dio precisamente lo que necesitaba. Marina, Kevan, Íñigo, y mis compañeros del Salvador Espriu (Román, Jordi, Dani, Joan, Teresa, Xavier, Jaume, Roser, Mar, Mònica, Montse, Luisa, Nanda, Ma Antonia, David, Maria, Ferran...) que hicieron mi vuelta a casa más fácil. Gracias por creer en mí y persistir diariamente para que finalizase esta tesis doctoral. A mis estudiantes, por hacerme disfrutar de la enseñanza. A mis amigos madrileños, Cristina, Luis Pablo y, especialmente, a Julia Mesonero. Gracias por todo.

Porque muchas veces uno se siente cansado y derrotado, y este trabajo habría sido imposible sin todos vosotros.

La India me cambió la vida. Todo el mundo merece una oportunidad en su camino. A mi amigo Nicky, porque la más larga caminata comienza con un paso... 


\section{Resumen:}

La clave (1976-1985) fue el primer programa de debates en directo que hubo en España. Dirigido y presentado por José Luis Balbín, fue un programa innovador que dio voz a colectivos históricamente discriminados y permitió visibilizar las aspiraciones, las demandas y las presiones de la sociedad española.

Por primera vez se abordaron en televisión temas inéditos como la pena de muerte, las drogas, el aborto, la homosexualidad, la Iglesia, el Ejército o la guerra civil, que ayudaron a erosionar los valores sociales que el franquismo había permeabilizado en la sociedad española durante casi cuarenta años de dictadura. A lo largo de los 408 programas pasaron un total de 2.708 invitados, entre los que figuraban algunas de las personalidades más influyentes del panorama político español (Adolfo Suárez, Manuel Fraga, Santiago Carrillo, Enrique Tierno Galván, Federica Montseny, Jordi Pujol, Gil Robles, Raimundo Fernández-Cuesta...) y del ámbito internacional como Olof Palme, Neil Armstrong, Mário Soares, Truman Capote o J. K. Galbraith. Un pluralismo que conllevó un principio demoledor del franquismo: ningún invitado era acusado por sus ideas políticas.

Este trabajo parte del análisis de numerosa documentación de archivo, fuentes periodísticas, publicaciones oficiales de RTVE, y la última entrevista concedida por José Luis Balbín para defender la hipòtesis que La clave, a través de sus debates televisivos, contribuyó a la formación de una cultura política democrática en la España de la Transición.

Palabras clave: Debate, La clave, Balbín, Televisión, Cultura política, Transición española, Les Dossiers de l'écran.

\section{Abstract:}

La clave (1976-1985), the first live debate TV programme in Spain, directed and conducted by José Luis Balbín, was an innovative programme that gave a voice to groups of people who had historically been subjected to discrimination and (enabled the visualization of) fashioned the aspirations, sensitivities, claims and pressure of Spanish society.

For the first time, television raised unprecedented (unthinkable) issues such as death penalty, drugs, abortion, homosexuality, the Church, the Army or the Civil War, eroding the social values that Francoism had instilled in Spanish society for about forty years of dictatorship. Throughout the 408 programmes, a total of 2,708 guests, among whom there were some of the most outstanding (influential) personalities of Spanish political scene (Adolfo Suárez, Manuel Fraga, Santiago Carrillo, Enrique Tierno Galván, Federica Montseny, Jordi Pujol, Gil Robles, Raimundo Fernández-Cuesta...) and of international scope, such as Olof Palme, Neil Armstrong, Mário Soares, Truman Capote o J. K. Galbraith. Such cultural diversity and pluralism entailed a demolishing principle of Francoism: no guest was ever accused by their political ideas.

This thesis is based on the analysis of extensive archival documentation, media sources, RTVE official publications, and the last interview given by José Luis Balbín, to defend the hypothesis that La clave, throughout its TV debates, fostered a democratic political culture in the Spanish Transition.

Keywords: Debate, La clave, Balbín, Television, Political culture, Spanish Transition, Les Dossiers de l'écran. 


\section{ÍNDICE}

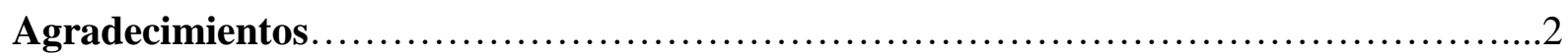

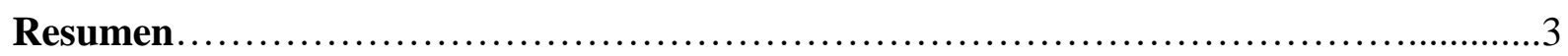

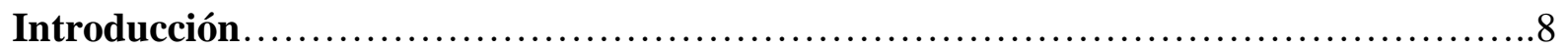

PARTE I. TELEVISIÓN ESPAÑOLA Y LA CLAVE DE JOSÉ LUIS BALBÍN.......30

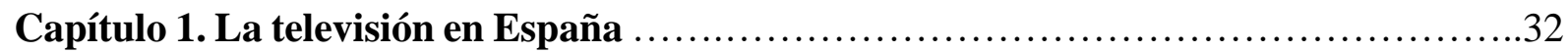

1.1. Planteamiento teórico y cuestiones metodológicas.........................33

1.2. La televisión: un objeto múltiple...........................................43

1.3. La televisión como servicio público: la misión educativa........................48

1.4. La televisión en España (1956-1975) ........................................51

1.4.1. Transferencias culturales en televisión: Les Dossiers de l'écran........52

1.5. Televisión Española durante la Transición.....................................57

1.5.1. Los directores generales de RTVE..................................61

1.6. Del telespectador como público a la dictadura de la audiencia............................63

1.6.1. La UHF. Cobertura y audiencia de La clave ........................66

1.6.2. La crisis del modelo fundacional: el triunfo del entretenimiento.........68

Capítulo 2. Apuntes para una biografía de José Luis Balbín.............................72

2.1. José Luis Balbín: ¿una biografía?..........................................................................73

2.2. Asturias y el Frente de Juventudes.....................................74

2.3. Periodismo y Colegios Mayores (1958-1963) ............................77

2.3.1. El Sindicato Español Universitario (SEU) ............................84 


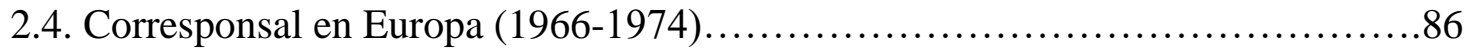

2.4.1. La primavera de Pravia.............................................. 87

2.4.2. París no es una fiesta............................................. 89

2.5. La clave de José Luis Balbín................................................91

2.5.1. Historial académico y sindical..................................92

2.5.2. Trayectoria posterior..............................................96

2.6. Face à face. Una entrevista a José Luis Balbín................................98

Capítulo 3. La clave y el debate televisivo en España................................... 104

3.1. La clave: ¿historia de la Transición?.....................................................................104

3.1.1. Las etapas internas del programa................................110

3.1.2. Selección de programas y análisis temático.......................117

3.2. El debate televisivo.................................................120

3.2.1. El arte de tematizar......................................... 123

3.2.2. Un cine para el debate........................................ 126

3.2.3. Interacción social: la participación del público en televisión................133

3.3. El invitado experto ................................................ 134

Capítulo 4. Los inicios del debate televisivo en España (1976-1978).

4.1. Génesis del programa y primeros debates en directo (1976)...................... 144

4.1.1. Detrás de la pantalla: el arte de programar............................147

4.1.2. Primer directo... primera prohibición............................150

4.2. Final de etapa. Good night, and good luck.................................. 158

4.2.1. Entre reforma y ruptura: el Referéndum de $1976 \ldots \ldots \ldots \ldots \ldots \ldots \ldots . \ldots 160$

4.3. El discurso televisivo en las elecciones del 15 de junio de $1977 \ldots \ldots \ldots \ldots \ldots \ldots . . . . .169$

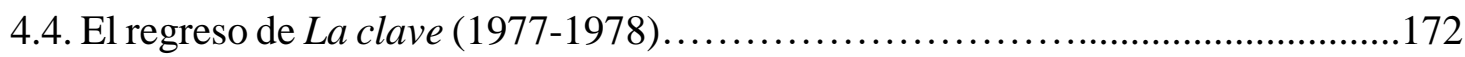

4.4.1. El cese de Rafael Ansón y la llegada de Fernando Arias-Salgado.........177 
Capítulo 5. El debate en España. De la Constitución al golpe de Estado. 184

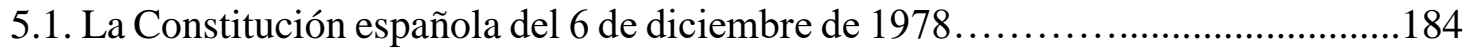

5.2. El Estatuto de RTVE y la auditoría de Hacienda.............................. 194

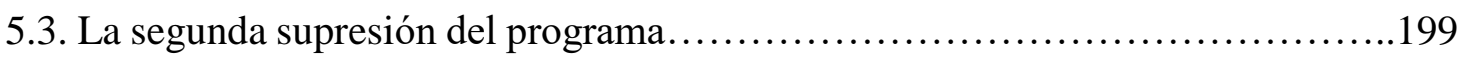

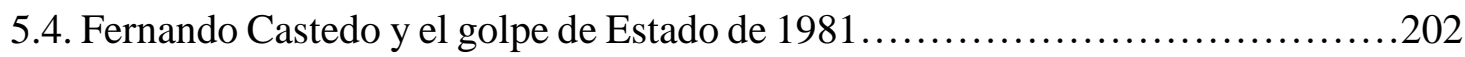

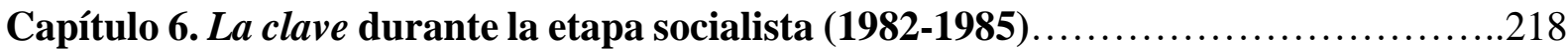

6.1. La entrada en la OTAN y las elecciones generales de $1982 \ldots \ldots \ldots \ldots \ldots \ldots \ldots \ldots \ldots \ldots . .218$

6.2. José Luis Balbín y los Servicios Informativos (1982-1983)_..................225

6.2.1. El caso Alonso Puerta...............................................227

6.2.2. La España autonómica..........................................234

6.3. La etapa final de La clave (1983-1985) ....................................................242

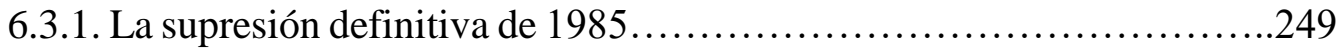

6.3.2. Movida en el Palace..............................................254

Capítulo 7. La clave y la cultura política en la Transición española........................262

7.1. Debate y cultura política en España .....................................263

7.2. Siete debates para la formación histórica....................................267

7.3. Siete debates para la formación política.................................281

CONCLUSIONES.

BIBLIOGRAFÍA.

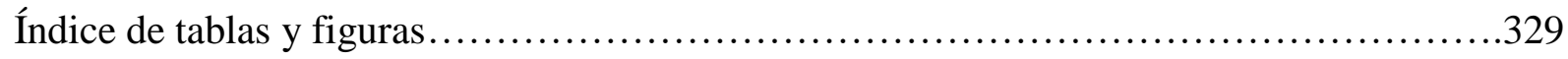

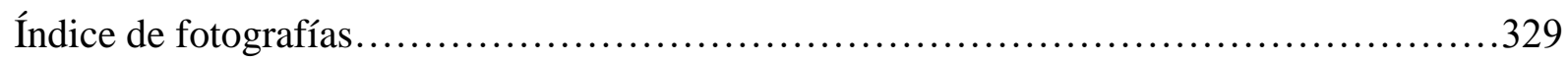

ANEXOS

DVD.

Listado de programas e invitados

Entrevista a José Luis Balbín 


\section{Listado de siglas}

AGA Archivo General de la Administración.

BBC British Broadcasting Corporation.

EGM Estudio General de Medios.

ETA Euskadi Ta Askatasuna (País Vasco y Libertad).

INA Institut National de l'Audiovisuel.

NBC National Broadcasting Company (cadena estadounidense).

OCDE Organización para la Cooperación y el Desarrollo Económico.

ORTF Office de Radiodiffusion-Télévision Française.

OTAN Organización del Tratado del Atlántico Norte.

PYRESA Periódicos y Revistas Españolas. Servicio de Agencia.

RNE Radio Nacional de España.

RTF Radiodiffusion-Télévision Française.

RTVE Radiotelevisión Española.

SER Sociedad Española de Radiodifusión.

SEU Sindicato Español Universitario.

TVE Televisión Española.

UHF Ultra High Frequency (segunda cadena de TVE).

UMD Unión Militar Democrática.

UNESCO United Nations Educational, Scientific and Cultural Organization.

VHI Very High Frequency (primera cadena de TVE).

ZDF Zweites Deutsches Fernsehen (cadena alemana).

Partidos políticos:
AP
Alianza Popular.
CDS Centro Democrático y Social.
FET Falange Española Tradicionalista.
ORT Organización Revolucionaria de Trabajadores.
PSOE Partido Socialista Obrero Español.
PCE Partido Comunista Español.
PSP Partido Socialista Popular.
UCD Unión de Centro Democrático. 


\section{Introducción}



La presente tesis doctoral tiene como objeto de estudio un programa de televisión durante la Transición española. Se trata de La clave, dirigido y presentado por el periodista asturiano José Luis Balbín. La clave fue un programa semanal de debates en directo entre distintos invitados que, con película introductoria, permitía la reflexión sobre una temática a través del diálogo y la confrontación de ideas. Este programa tuvo dos grandes etapas en televisión: la primera se desarrolla entre 1976 y 1985 y se emite por la segunda cadena de Televisión Española, también llamada UHF (Ultra High Frequency). La segunda etapa se desarrolla entre 1990 y 1993 y se emite en Antena 3 Televisión (primera cadena privada de televisión que hubo en España). Nuestra tesis doctoral se centra en la primera etapa (19761985) en la que se emitieron un total de 408 programas. Nos centramos en ella y justificamos esta elección con el propósito de observar la construcción de un modelo de debate que fue llevado a cabo durante la "larga" Transición Española.

Nuestro objetivo principal es abordar la formación de una cultura política en España a partir de un programa de televisión. Nuestro acercamiento conlleva, por tanto, una reflexión donde la televisión se inscribe de enlace entre cultura y política. Apostamos por la aplicación de un enfoque histórico que evite las explicaciones monocausales y se centre, a partir de las investigaciones y trabajos interdisciplinares, en una historia cultural, social y política de la Transición española. Este programa, en sus diez años de debates, nos ayudará a comprender las relaciones existentes entre una televisión estatal que va definiéndose a lo largo de este periodo y los distintos gobiernos que transcurrieron entre 1975 y 1985. En todo este periodo, La clave abordó gran cantidad de temas, algunos silenciados durante el franquismo como las drogas, la homosexualidad o la pena de muerte, y otros, de marcada sensibilidad como el aborto, el divorcio o la Guerra Civil española.

Presentamos, por tanto, un amplio ámbito de acción: televisión, Transición democrática, y cultura política. Conviene, en primer lugar, subrayar la función ejercida por los medios de comunicación sobre el cambio producido en España, que pasó, en pocos años, de un sistema dictatorial a un sistema democrático. La elección de este programa de televisión se debe a distintas razones. La clave nos permite observar la Transición (con sus continuidades y rupturas) desde la óptica televisiva (concretamente a través de los debates en directo que se llevaron a cabo por primera vez en televisión). La importancia del directo «en un momento en el que algunas televisiones como la italiana tenían vedada la emisión de programas informativos en vivo» (Palacio 2012: 101), hacía que este programa pudiese escapar a uno de los muchos controles que se realizaban en televisión. El directo, característica esencial del programa, podía 
presentarse sin embargo como un peligro permanente que podía volatilizar en un instante el consenso que trataba de instaurarse en la sociedad española. Por esta razón, no solo prohibían algunas emisiones, también el propio programa sería suprimido de la programación en distintas ocasiones. La primera de ellas, al cabo de doce emisiones, siendo Gabriel Peña Aranda director general de RTVE.

Una primera hipótesis de trabajo podría formularse en los siguientes términos: La clave articuló y construyó el debate televisivo en España durante el proceso de transición hacia la democracia. En un momento en el que se construía un nuevo sistema político en España, este programa funcionó de plataforma democrática y ayudó a la formación de una cultura política con el cambio de valores que esto suponía- que rompía directamente con la dictadura franquista. Un ejemplo, la aparición por primera vez en un debate de televisión del pluralismo político, conllevaba un principio demoledor del franquismo: ningún invitado era acusado por sus ideas políticas. Esta tesis doctoral se propone presentar una aproximación a la cultura política de la Transición que tenga en cuenta no solo el papel histórico y fundamental que tuvo Televisión Española, también la conformación de estados de opinión y de imaginarios colectivos. Una mayor reflexión sobre el fenómeno televisivo responde al interés de explicar un objeto múltiple que nos permita profundizar en los marcos culturales de la política. La clave como espacio y lugar de representación que formalizó el debate entre diferentes corrientes de opinión. Creemos por tanto que los argumentos que allí se dirimieron fueron esenciales en la formación de una cultura política, y ésta, en la dirección concreta que tomaron los acontecimientos durante el proceso de transición hacia la democracia.

Pero dicha tarea conlleva toda una serie de pasos. El primero es delimitar el concepto de cultura política. Gabriel Almond y Sidney Verba emplearon el término de cultura política para referirse a «orientaciones específicamente políticas, posturas relativas al sistema político y sus diferentes elementos, así como actitudes con relación al rol de uno mismo dentro de dicho sistema» (Almond y Verba: 1970: 30) ${ }^{1}$. Se trataba, por tanto, de la formación de una «cultura cívica» entendida como el surgimiento de una serie de valores y creencias que hacían posible o facilitaban la aparición y el funcionamiento de un régimen democrático ${ }^{2}$. En esta tesis doctoral

\footnotetext{
${ }^{1}$ La versión original es de 1963. G. A. Almond y S. Verba, The Civic Culture: Political Attitudes and Democracy in Five Nations, Little Brown \& Co, Boston, 1963.

${ }^{2}$ Véase W. L. Pye y S. Verba, Political Culture and Political Development, University Press, Princeton, 1965.
} 
seguimos la definición de cultura política que proponen Jean-François Sirinelli ${ }^{3}$ y Serge Berstein $^{4}$; y que entienden por cultura política el sistema de representaciones culturales compartidas por grupos humanos que el individuo ha interiorizado al socializarse, y que hace referencia al medio cultural en el que el individuo está inmerso ${ }^{5}$. Trataremos este concepto con mayor profundidad en el último capítulo, al considerar necesaria una reflexión acerca de los vínculos entre televisión y cultura política ${ }^{6}$. Para ello, abordaremos algunos planteamientos y cuestiones relacionadas con la cultura política que explique la cohesión que existió entre un grupo de personas que por primera vez debatieron en directo en la única televisión existente en el país.

La clave se aprobó un mes antes de la muerte de Francisco Franco, en octubre de 1975, bajo la dirección de Jesús Sancho Rof, que acabó siendo el último director general de RTVE nombrado durante el franquismo. José Luis Balbín conocía a Sancho Rof de su época en la Universidad, y con la ayuda de Miguel Ángel Toledano (director adjunto de TVE) se puso en marcha el nuevo programa. Sin embargo, la primera emisión tendría lugar en enero de 1976 con Gabriel Peña Aranda (primer director general de TVE tras la muerte del dictador nombrado el 22 de diciembre de 1975). Nos centraremos en la figura del director general de RTVE, que utilizamos como variable para estructurar el programa en las diferentes etapas, debido a los diversos cambios que se generan a raíz de sus respectivos nombramientos.

La primera emisión del programa se llevó a cabo el 18 de enero de 1976. Como título y tema El juego. Una ambigüedad en el tema (breve, monográfico y presentado sin mucha polémica) que se convirtió, como veremos más adelante, en una de las principales armas del programa. En esta primera emisión se debatió en torno a si el Estado debía o no legalizar los juegos de azar en España, que por entonces eran ilegales. Y diez años más tarde, el 20 de diciembre de 1985, se realizaría la última emisión del programa en TVE bajo el título 20 años de Vaticano II. Porque a los pocos días, la dirección de RTVE comunicaría a José Luis Balbín que la emisión del viernes 27 de diciembre sería la última de La clave. La razón oficial de los

\footnotetext{
${ }^{3}$ J. F. Sirinelli, "Pour une histoire des cultures politiques : le référent républicain”, en Daniel Cefaï (dir.), Cultures politiques, PUF, París, 2001, p. 157.

${ }^{4}$ S. Berstein, “La culture politique”, en J. P. Rioux y J. F. Sirinelli (dir.), Pour une histoire culturelle, Seuil, París, 1997, pp. 385-386.

${ }^{5}$ M. A. Cabrera, "La investigación histórica y el concepto de cultura política”, en M. Pérez Ledesma y M. Sierra (eds.), Culturas políticas: teoría e historia, Institución Fernando el Católico, Zaragoza, 2010, pp. 36-39.

${ }^{6}$ Sobre la dificultad de aunar televisión y cultura, véase F. Rodríguez, Cultura y televisión. Una relación de conflicto, Gedisa, Madrid, 2003.
} 
directivos para suspender el programa fue la bajada de audiencia ${ }^{7}$. Sin embargo, si bien había descendido en el último año, continuaba siendo el programa de mayor audiencia en la segunda cadena. Envuelto en polémica, como veremos, el día antes de la emisión, los directivos de RTVE prohibirían también el último programa alegando que su director había cambiado el tema para debatir finalmente sobre la OTAN. Un cambio sutil en el título (de La movida a La movida nacional), que no pasó desapercibido a los responsables de Televisión Española. Pese a la prohibición, su director acabaría realizando el debate, bajo una gran expectación, en un céntrico hotel madrileño. José Luis Balbín sería cesado de su cargo, y el programa La clave suprimido definitivamente de la programación de TVE.

Pero antes volvamos a sus orígenes. La clave fue un programa inspirado del francés Les Dossiers de l'écran (1967-1991), producido por Armand Jammot ${ }^{8}$. Haremos referencia a este programa en nuestro primer capítulo para explicar las transferencias culturales que recibe TVE durante el franquismo y la Transición. En relación al formato, La clave se estructuraba a raíz del debate en directo, y constaba de seis partes diferenciadas: 1. Anuncio e introducción del tema. 2. Presentación de los invitados al programa. 3. Proyección de una película relacionada con el tema. 4. Debate en directo con distintos invitados, generalmente seis. 5. Preguntas de los telespectadores. 6. Clausura del debate y bibliografía sobre el tema abordado. La duración total del programa superaba las tres horas (llegando a las cinco horas en algunas etapas), que convertían a La clave en el programa de mayor duración en televisión en esos momentos. En su primer año (1976) el programa se emitió los domingos por la noche, en torno a las 21:30 h. A su regreso, en 1977 y hasta 1980, el programa pasó a emitirse los sábados a las 20:00 h, y finalmente entre 1981 y 1985 , manteniendo el mismo horario, los viernes ${ }^{9}$.

En relación a los invitados, destacamos en primer lugar el paso por el programa de un total de 2708 invitados. La lista de invitados, en su mayoría expertos y personalidades representativas de distintos ámbitos, la presentamos junto al listado oficial de programas en el DVD. Entre los invitados, figuras de gran relevancia como Adolfo Suárez, Neil Armstrong, Truman Capote, Mário Soares, Olof Palme, Severo Ochoa, Mateo Emiliano Zapata, Alfonso

\footnotetext{
${ }^{7}$ Véase también, M. Palacio y C. Ciller, “La clave de TVE, un programa de debate en la historia...", en Estudios sobre el Mensaje Periodístico. Vol. 20. Núm. especial (2014), p. 234.

${ }^{8}$ Productor de programas como Des Chiffres et des Lettres, que tuvo su implantación en muchos países, entre ellos, España (Cifras y letras).

${ }^{9}$ Cfr. V. Martín Jiménez, Televisión Española y la Transición democrática. La comunicación política del Cambio (1976-1979), Ediciones Universidad de Valladolid, Valladolid, 2013, p. 49, y M. Palacio, La televisión durante la Transición española, Cátedra, Madrid, 2012, pp. 258-259.
} 
Guerra, Manuel Fraga, Santiago Carrillo, Enrique Tierno Galván, Daniel Cohn-Bendit, Fernando Savater.... Una diferencia reseñable en el programa que permitirá después distinguir la figura del intelectual respecto a la del tertuliano. Un dato llama la atención: de los 2708 invitados, 679 fueron extranjeros. Profundizaremos en los invitados en el tercer capítulo con el propósito de abordar el tipo de opinión, principalmente cualificada (por la cantidad de expertos que pasaron por el programa y por su relevancia en el ámbito nacional e internacional), que normalizaba el discurso y asentaba los valores esenciales de las democracias.

En el tercer capítulo, además de un análisis sociopolítico de los invitados, presentaremos el organigrama del programa para comprender su dinámica de funcionamiento interno. En síntesis, integraron La clave un conjunto de profesionales de la información (centrados en abordar temas de interés y actualidad), así como de profesionales técnicos (dedicados a la difusión del programa en televisión). Al frente del programa, dirigiendo y moderando en los diez años en los que centramos esta investigación estuvo José Luis Balbín.

La clave tuvo un papel muy activo en la creación y difusión de pensamiento, ciencia, educación y cultura en general ${ }^{10}$. Pero, ¿puede una emisión de televisión contribuir a crear un nuevo imaginario político democrático que permitiese la negociación política y el diálogo social? Para responder a esta pregunta intentaremos demostrar cómo La clave presentó novedades que rompieron cuantitativamente y cualitativamente con la dictadura y, más fundamental, permitieron crear un nuevo imaginario político en televisión al funcionar como un espacio social democrático. Detengámonos un momento en este punto pues se trata de nuestra principal hipótesis. Siendo la televisión un producto y un instrumento diseñado y dirigido desde arriba, La clave se convirtió en un escenario que lograba visualizar las aspiraciones, presiones y demandas que tenía la sociedad.

Decimos que La clave rompió con la televisión realizada durante el franquismo al presentar novedades tan significativas como el debate en directo, la temática tratada, el pluralismo político, la participación de los telespectadores (no fueron las únicas rupturas que realizaría el programa en relación a la televisión realizada durante el franquismo) que ayudarían a erosionar los valores sociales que el franquismo había permeabilizado en la sociedad española durante casi cuarenta años. Sin embargo, después de cuarenta años de dictadura, en el debate también se reproducen estereotipos como la cuestión de género que analizaremos más adelante.

\footnotetext{
${ }^{10}$ Una idea de cultura que implica como indica P. Burke en «la idea de tradición, de ciertas clases de conocimientos y destrezas transmitidos de una generación a la siguiente» (Burke 2006: 41).
} 
Creemos que La clave contribuyó desde la televisión a la formación de una cultura democrática a través del aprendizaje democrático (aprender a debatir, discrepar, respetar las distintas opiniones entre las diferentes opciones políticas que se presentaban en la España de la Transición $)^{11}$. Tanto el debate como el propio programa se enmarcan en numerosas reglas democráticas (libertad de opinión, de expresión, pluralismo, derecho a la información, necesidad de una información objetiva, respeto a las diferentes ideas políticas, convivencia entre las distintas posiciones...). ¿No es precisamente el fomento de una nueva cultura política la que explicaría el éxito de la Transición española?

En primer lugar, hemos de tener en cuenta el contexto en el que se emite el programa. Como argumenta François Jost, los programas no aparecen por fuertes rupturas, sino más bien por transformaciones progresivas de formatos y dispositivos (Jost 2013: 7). Desde finales de los años sesenta se producen en España toda una serie de cambios económicos y sociopolíticos que se vieron reflejados en el incremento del desarrollo urbano, la aparición de una clase media o las nuevas formas de consumo. Cambios, en definitiva, que se observan en diferentes dominios como el cine, con el llamado Nuevo Cine español (Juan Antonio Bardem, Luis GarcíaBerlanga, Carlos Saura, Basilio Martín Patino...), el teatro (Fernando Fernán-Gómez, Miguel Romeo Esteo, Albert Boadella...), la literatura (Manuel Vázquez Montalbán, Juan Goytisolo, Juan Marsé, Jorge Semprún...), la música (Raimon, Joan Manuel Serrat...), el arte (Pablo Picasso, Antoni Tàpies, Estampa Popular ${ }^{12}$... o la prensa (Cuadernos para el diálogo, Destino, Triunfo $\left.^{13} \ldots\right)^{14}$. El terreno abierto desde otros campos no era tan evidente, en cambio, en televisión, que continuaba sometida a un férreo control. Es con la muerte del dictador cuando surgen en televisión programas más implicados en el proceso democrático que se está llevando a cabo, entre los que destaca La clave.

¿Fue la televisión un instrumento decisivo del Estado en la instauración de la democracia en España? María Antonia Paz y Julio Montero sostienen en su estudio el fundamental papel que ocupó Televisión Española en la Transición y la búsqueda de nuevas

\footnotetext{
${ }^{11}$ Véase la obra de J. C. Mainer y S. Juliá, El aprendizaje de la libertad, 1973-1986, Alianza, Madrid, 2000.

${ }^{12}$ Nombre genérico que hace referencia a un grupo de artistas que surgieron en España en los años sesenta.

${ }^{13}$ Un estudio más detallado en G. Plata, La razón romántica. La cultura política del progresismo español a través de Triunfo (1962-1975), Biblioteca Nueva, Madrid, 1999.

${ }^{14}$ Pero teniendo en cuenta, tal y como argumentó Juan José Linz que «a veces el entusiasmo por el cambio que se está operando lleva a confundir los procesos de liberalización, de apertura, de distensión, y el proceso de democratización», J. J. Linz, "La transición a la democracia en España en perspectiva comparada", en R. Cotarelo (Comp.), Transición política y consolidación democrática. España (1975-1986), CIS, Madrid, 1992, p. 438.
} 
fórmulas basadas en formatos de éxito, como los programas de debate ${ }^{15}$. Aunque estudian $\mathrm{La}$ clave, se centran principalmente en programas posteriores como Tribuna de la historia y La víspera de nuestro tiempo (ambos de 1978 a 1985). Su tesis principal es que para hablar de historia, Televisión Española optó por el coloquio entre posturas diversas que permitiese a través del diálogo fomentar una nueva cultura política. Volveremos a este estudio en diferentes capítulos, aunque podemos avanzar que estos dos programas son posteriores a La clave y surgen precisamente a raíz de sus polémicas.

En este trabajo nos proponemos también analizar el rol que ocupó la televisión en España durante la Transición. La primera parte de la tesis doctoral, “Televisión Española en su contexto histórico", aborda, en primer lugar, los criterios, la estructura y la metodología que hemos llevado a cabo. En segundo lugar, realizamos un breve recorrido por los antecedentes de la televisión con el objetivo de explicar teóricamente su funcionamiento, sus estrategias de control de la información y su papel, en definitiva, durante la Transición. Esto nos permite situar los orígenes del programa y realizar un recorrido histórico desde su primera emisión en 1976 hasta su final en 1985, analizando su propia evolución en el contexto de los cambios sociopolíticos y económicos que se producen en España. ¿Cuándo surge realmente este programa? ¿Por qué lo hace? ¿Evoluciona? Como hemos dicho anteriormente, presentamos un planteamiento de historia cultural a través de La clave. Este análisis cronológico nos permite una apertura del campo de investigación, y para ello deberemos exponer los procedimientos más adecuados para la investigación de un programa de televisión que a su vez forma parte de una televisión estatal controlada por el poder político.

A nivel historiográfico, Fernand Braudel argumentaba que a cada época, una cierta representación del mundo (Braudel 1987: 54) ${ }^{16}$. La historia cultural como factor dinámico con el que abordar una explicación de la actividad humana, sus actores, sus mentalidades, sus ideas, sus representaciones, y sus formas de pensamiento. La construcción del debate televisivo en España nos permite observar formas de representación de una sociedad así como las

\footnotetext{
${ }^{15}$ M A A. Paz y J. Montero, “Usos públicos de la historia en la Transición española. Divulgación histórica y debate en Televisión Española (1978 a 1985)”, en Historia y Política, n 33, Madrid, enero-junio (2015), pp. $275-302$.

16 “À chaque époque, une certaine représentation du monde et des choses, une mentalité collective dominante anime, pénètre la masse entière de la société. Cette mentalité qui dicte les attitudes, oriente les choix, enracine les préjugés, incline les mouvements d'une société est éminemment un fait de civilisation", F. Braudel, Grammaire des civilisations, Arthaud, París, 1987, p. 54. [A cada época, una cierta representación del mundo y de las cosas, una mentalidad colectiva dominante que dirige y penetra la gran masa social. Esta mentalidad que dicta las actitudes, orienta las opciones, arraiga los prejuicios, inclina los movimientos de una sociedad, es eminentemente un hecho de civilización] (traducción propia).
} 
explicaciones que eran formuladas y difundidas sobre determinados hechos históricos y procesos colectivos. Después de cuarenta años de dictadura, se observa en La clave un debate político/intelectual de discrepancia política que parece hacer frente a la idea de «consenso» que va instaurándose en la sociedad española. También se observa la idea del pluralismo político como la representación de todas las ideas políticas, incluso antagónicas (a favor o en contra, abortista-antiabortista, militar-pacifista, pobre-rico, izquierda-derecha...) que dificulta centrar el debate exclusivamente a través del "mejor argumento"17.

Porque detrás del debate hay toda una construcción y puesta en escena. En una entrevista en 2005, José Luis Balbín reconoce que para debatir con más intensidad, junto a colaboradores como Máximo San Juan, trataban de buscar el conflicto (Satué 2005: 491) ${ }^{18}$. Esta puesta en escena, como veremos más adelante, no podía acabar de definirse de artificial, pues el debate se construía en directo.

José Ramón Pérez Ornia (crítico televisivo del periódico El País durante todo este periodo), definió La clave en su tesis doctoral como «un buen baremo de los techos de libertad alcanzados durante la Transición en TVE» (Pérez Ornia 1988: 52) ${ }^{19}$. Sirva como ejemplo la asistencia al programa de un miembro del $\mathrm{Ku}$ Klux Klan vestido con los hábitos de la organización, o el hijo de Rudolf Hess (jefe del Partido Nazi y segundo de la jerarquía durante la Alemania nazi).

El equipo de La clave buscaba entre sus invitados puntos de vista completamente divergentes. Sin embargo, pese a la divergencia ideológica, los invitados nacionales acaban hablando un mismo lenguaje y una misma terminología: “la nueva España, las fuerzas democráticas, consenso, reconciliación, ley, Constitución...”. Como argumenta Rafael del Águila:

«Las propias condiciones de la lucha de la oposición, la moderación del público implicado, el surgimiento de valores democráticos, etc., fueron haciendo que, poco a poco, los distintos sectores de la oposición al franquismo fueran convergiendo en una serie de mensajes

\footnotetext{
${ }^{17}$ Fuera de nuestras fronteras, en Alemania, se ha realizado un estudio que explora la historia cultural del "mejor argumento", observando el interés existente en debatir temas que se anclaban en las discusiones en la vida cotidiana durante la posguerra en la Alemania Occidental. Véase N. Verheyen, Diskussionslust. Eine Kulturgeschichte des »besseren Arguments«, en Westdeutschland, Vandenhoeck \& Ruprecht, Universidad de Berlín, 2003.

18 «Quiero que venga la Pasionaria, Enrique Líster, Tierno Galván..., pero también quiero, por la derecha, a Blas Piñar, a Fernández Cuesta, a Serrano Suñer». José Luis Balbín, en F. J. Satué, Los secretos de la Transición. Del Batallón Vasco Español al proceso de los GAL, La Esfera de los libros, Madrid, 2005, p. 492.

${ }^{19}$ J. R. Pérez Ornia, La televisión y los socialistas. Actividades del PSOE respecto a TVE durante la Transición (1976-1981), Universidad Complutense de Madrid, Madrid, 1988. Tesis doctoral defendida en octubre de 1986.
} 
democráticos y democratizantes que respondían y creaban a un tiempo un refuerzo de la legitimación a través de valores argumentativos tales como la libertad, autonomía, pluralismo, diálogo, etc.» (Del Águila 1992: 54).

Un diálogo y un lenguaje que contrastan con ciertos acontecimientos que se producen durante el proceso de transición hacia la democracia. Creemos que La clave permitió en televisión la negociación política y el diálogo democrático y mostró los límites permitidos en televisión durante este periodo. En más de una ocasión el programa logró evidenciar el desafío que suponía la democracia televisiva. En este sentido, una regla a la que no podía escapar el debate en directo, era el simple hecho de no poder controlar aquello que los invitados iban a decir exactamente. De ahí la importancia de quiénes son los invitados. En el análisis general que presentamos de los invitados observamos la fuerte presencia de la figura del político (y al partido que representa), y la figura del experto (un catedrático, sociólogo, antropólogo, escritor...), que nos ha permitido detectar no solo la creación y difusión de una opinión cualificada a través de este programa, también la legitimación que conlleva el saber experto y su relevancia, permitiendo al programa escapar, en parte, a las presiones e injerencias externas.

Muchos ciudadanos interpretaron los acontecimientos que se produjeron durante la Transición a través de los medios de comunicación. La construcción visual de una imagen oficial de la Transición pasa indudablemente por ellos. Sin embargo, como argumenta Peter Burke, «La tentación a la que no debe sucumbir el historiador cultural es la de tratar los textos y las imágenes de un periodo determinado como espejos, como reflejos no problemáticos de su tiempo» (Burke 2006: 35). Si una emisión no es el reflejo de la sociedad del momento, sí influye de forma recíproca en la realidad y nos puede aportar ciertas características de esa sociedad. Es decir, una televisión que actuaría como «un espejo fiel y deformante, tendiendo a dotar de verosimilitud a sus discursos mediante diferentes estrategias» (Rueda Laffond 2011: 27). Un ejemplo, las huelgas producidas en enero de 1976 pasan desapercibidas en Televisión Española. Una ausencia en televisión que refleja la realidad del medio (como el férreo control a la que está sometida), y el tipo de retransmisión que se quería hacer de esa realidad. La televisión funcionó como un medio difusor de imaginarios políticos. Obvio es decir que promoviendo unos hechos, y omitiendo otros, se crea también en televisión una memoria concreta de la historia. ¿Cómo abordó y representó La clave el terrorismo, la Monarquía, o la Guerra Civil?

Tras la reconstrucción del programa a través de los distintos archivos, y a partir de nuestra hipótesis de trabajo, vamos a organizar e interpretar La clave como hecho histórico. Para presentar un análisis de la difusión cultural que realiza este programa es necesaria una 
metodología interdisciplinar. La definición del objeto trae aparejado toda una serie de cuestiones metodológicas que deben ser definidas. Como argumenta Virginie Philippe, la televisión es un objeto de estudio complejo por la pluralidad de dimensiones que la rodean. La dimensión económica (financiación, audiencia, competencia...), la dimensión social (incidencia social, socialización de valores y referentes simbólicos, comunicación...), la dimensión política (la relación del medio con el gobierno), etc. (Philippe 2007: 16). Sin embargo, ¿cómo comprender la televisión si no es en su conjunto? ¿Es inevitable su fragmentación? ¿Cómo medir su significación y transcendencia ${ }^{20}$ La complejidad de un objeto de estudio que puede ser analizado desde múltiples disciplinas y enfoques requiere de una justificación metodológica. A este respecto, destacamos la aportación de Marc Bloch sobre las herramientas de investigación histórica: la méthode régressive (partir del presente para estudiar el pasado), la aproximación del testimonio -incluido el suyo propio- y el método comparativo, son herramientas fundamentales en nuestro estudio ${ }^{21}$.

De la historia cultural francesa, seguimos el método de análisis denominado «historia serial» que consiste en el análisis de una serie cronológica de documentos (Burke 2006: 36). En este caso, presentamos en la segunda parte de la tesis doctoral un análisis serial de los programas emitidos en La clave. Como método de estudio, hemos optado por una división temática en bloques que nos permita focalizar el contenido del mismo y observar cómo se construye el debate televisivo en España en tres áreas concretas: las claves políticas, históricas, y sociales. Esto nos permite un seguimiento cronológico del programa y poder focalizar precisamente en el tipo de debate que se va construyendo. El objetivo no es solo estudiar un programa de televisión, sino qué ideas difunde y cuáles son los comportamientos a su alrededor en el marco de las condiciones sociales en el que este surge. A través de este programa, trataremos de captar la cultura política que se difunde (¿construye?) en televisión. ¿Sobre qué se debatió? ¿Se producen variaciones sobre lo previsto por causas externas? ¿Cuál fue la causa de estas variaciones? Para ello, vamos a analizar la tematización que realiza: qué temas emite y cuáles omite, qué temas se califican de sensibles y qué temas fueron prohibidos en un momento determinado (cuándo lo hacen, en qué contexto, si siguen o no motivaciones internas o externas). Por último, abordaremos el impacto del programa (audiencia, reacción de la prensa...) y su repercusión en la sociedad (¿influyó el programa en la legislación?).

\footnotetext{
${ }^{20}$ Preguntas ya planteadas por F. Jost, en su obra Comprendre la télévision et ses programmes, Armand Colin, París, 2013 (2 edición).

${ }^{21}$ M. Bloch, Histoire et historiens, (textes réunis par Etienne Bloch), Armand Colin, París, 1995.
} 
No podemos obviar el cine emitido. Presentamos un análisis de las películas que se utilizaron para ilustrar los debates (procedencia, directores, películas más utilizadas), y nos preguntamos si se utilizaron durante el debate o pasaron desapercibidas, si se emitieron por primera vez en televisión, o qué valores se querían transmitir a partir de ellas. En televisión no solo se importan películas, programas o series, también ideas, modelos, y formas de hacer y representar. Un estudio de la televisión basado en el análisis del medio (difusión), del mensaje (contenido) o del punto de vista del telespectador (receptor), podría ayudar a delimitar el estudio, pero el programa quedaría reducido exclusivamente a estos aspectos. Del mismo modo quedaría reducido a un breve análisis si solo se tuviesen en cuenta los datos y cifras que aporta La clave (número de debates, invitados, films emitidos). Sin embargo, estos datos tampoco pueden pasar desapercibidos. El valor de las estadísticas reside en la exactitud de los datos, por lo que nuestra primera tarea ha sido la reconstitución total del programa entre 1976 y 1985 (día de emisión, tema del debate, película proyectada e invitados).

Trabajar sobre la imagen que difunde TVE significa trabajar sobre la información, y las estrategias de control que emplearon los responsables de RTVE y las directrices gubernamentales que estos seguían. La televisión durante la Transición se convierte en un medio estratégico al presentar a los actores en la escena política. Muchos españoles pueden ver quiénes son los políticos y los artífices del cambio a través de los medios de comunicación. En este sentido, la misión educativa de la televisión, la difusión de la democracia, y la especificidad del conocimiento especializado, podrían explicar parte de las transformaciones políticas operadas en las últimas décadas en España.

Nuestra fuente principal para la elaboración de esta investigación son las cintas del Centro de Documentación de RTVE que se encuentran en las instalaciones de Prado del Rey, en Madrid. No se conservan todos los programas, aunque sí la mayor parte de ellos, sin embargo, hay errores de inventario y es frecuente encontrarse grabaciones posteriores encima de otros programas ${ }^{22}$. Este problema nos sitúa en los años de la Transición, puesto que la mala conservación de algunas cintas en Prado del Rey se debe a la política de "reciclaje" que se hizo en aquella época. Dicho de otro modo, de reutilización del material audiovisual ${ }^{23}$. Como han planteado algunos autores, no sería hasta finales de la década de los setenta cuando se llevaría

\footnotetext{
${ }^{22}$ En el programa dedicado a Los espías en 1976, al finalizar la segunda cinta se puede encontrar un documental con imágenes de Alfonso XIII y Victoria Eugenia, al parecer, de 1929.

${ }^{23}$ Algunos programas de TVE de esta época no se conservan en los archivos y algunas emisiones no fueron registradas, como por ejemplo, los Telediarios. Cfr. V. Martín, Televisión Española y la Transición democrática, op. cit. p. 26.
} 
a cabo un planteamiento global de la Documentación en Radiotelevisión Española con el objetivo de conservar el material audiovisual ${ }^{24}$. La información anterior a 1979 está, por tanto, incompleta. A estos problemas de conservación audiovisual, añadir la falta de recursos (económicos, de personal y de medios) para la digitalización de dichos archivos, que provocan que la consulta íntegra de los programas se realice exclusivamente en el Centro de Documentación de Prado del Rey (Madrid). Por último, como indica Virginia Martín, el usuario no tiene acceso directo a la base de datos y la búsqueda de información la llevan a cabo los documentalistas del propio archivo (Martín 2014: 26), lo que dificulta la fluidez de acceso y consulta.

En relación a La clave, como bien argumenta Manuel Palacio, «muchas claves se encuentran en mal estado de conservación o han sido dadas de baja en las bases de datos de Televisión Española» (Palacio 2012: 259). Hay emisiones de La clave que por duración han podido registrarse hasta en tres cintas, no conservándose alguna de ellas. En la web de RTVE sobre el programa, se encuentran disponibles algunas emisiones, y la tendencia en los próximos años conlleva la digitalización de la mayor parte de programas $^{25}$. Hasta 2013 se habían venido privilegiando programas «de sesgo social o cultural: Planificación familiar, Brujería, Lucifer, Siempre la droga, La homosexualidad, Opus Dei, Los hijos del exilio» (Palacio y Ciller 2014: 229). En 2016 se revirtió en parte esta tendencia y ya son más de cuarenta los programas digitalizados, algunos de corte político como ¿Por qué políticos?, Elecciones. II ¿Para quién los votos?, o Balance los municipios de izquierda. En la actualidad, José Luis Balbín, mantiene todavía un pulso con Televisión Española por los derechos de propiedad intelectual del $\operatorname{programa}^{26}$.

Otra fuente principal que se ha utilizado ha sido un libro que encargó el propio José Luis Balbín al equipo del programa para recolectar los datos de una gran parte de las emisiones de La clave $^{27}$. Publicado el 25 de octubre de 1985 para conmemorar las 400 emisiones de La clave, pese a algunos errores, el libro subsana en parte el problema de documentación del archivo, y nos sirvió para contrastar algunos datos. Sin embargo, se realizaron pocos ejemplares, su accesibilidad es muy reducida y ha acabado por convertirse en artículo de coleccionista. El

\footnotetext{
${ }^{24}$ J. Martín Muñoz y J. López Pavillard, "La documentación audiovisual en RTVE", Documentación de las ciencias de la Información, $\mathrm{n}^{\circ}$ 18, Servicio de Publicaciones Universidad Complutense, Madrid, 1995, p. 144.

25 Véanse las dos webs de RTVE dedicadas a La clave: http://www.rtve.es/alacarta/videos/la-clave/, y http://www.rtve.es/archivo/mi-programa-preferido-de-la-tele/la-clave/ [consultado 18/11/2013].

26 “Polvorín entre José Luis Balbín y RTVE por los derechos de La clave”, El confidencial, 9/06/2018.

${ }^{27}$ Libro- Anuario LA CLAVE, 25 de octubre 1985.
} 
libro, pese a ofrecer un amplio índice temático, no presentaba análisis alguno y era una recopilación de emisiones. No había, por tanto, tiempo histórico ni evolución del programa.

Evidentemente no podemos aislar artificialmente el programa y sus debates del contexto social y del cambio de sistema político que se está produciendo en España durante la Transición. Este programa está ligado a un contexto histórico y a una sociedad determinada, de ahí la elección de realizar un seguimiento diacrónico de La clave. Su análisis temporal nos permite observar la construcción y difusión del debate televisivo durante la transición hacia la democracia. Cuando José Luis Balbín anunciaba el tema a tratar en el siguiente programa ya apuntaba hacia la construcción de un debate. Pero no pretendemos realizar un análisis de cada una de las emisiones por la diversidad temática que mostró este programa y se ha optado por observar su trayectoria a través de bloques temáticos. Además de las claves políticas e históricas también atendemos algunos temas por su relevancia, tratamiento, prohibición o repercusión, como fueron la homosexualidad, el divorcio, o las drogas. A este respecto, ¿es el mismo el tratamiento otorgado a la homosexualidad o al divorcio en 1976 que en 1985? La importancia de la temporalidad del programa es fundamental para comprobar nuestra tesis: cómo La clave articula y construye el debate político televisivo durante el proceso de transición en España, lo que contribuirá a la formación de una cultura política democrática.

Para acabar de completar las fuentes utilizadas, hemos recurrido a la documentación procedente de distintos archivos, de los que destacamos el Archivo General de la Administración (AGA), en Alcalá de Henares (Madrid), y en concreto los Fondos correspondientes a la Dirección General de Radiodifusión y Televisión del Ministerio de Información y Turismo. También los archivos personales sobre José Luis Balbín de dicho ministerio, y del Sindicato Español Universitario (SEU). Se han consultado los fondos hemerográficos del Archivo Gunther del Instituto Juan March (Madrid), y los archivos audiovisuales procedentes de la web de $\mathrm{RTVE}^{28}$. En relación a las audiencias durante este periodo, se han consultado datos procedentes del Estudio General de Medios (EGM) ${ }^{29}$, y a nivel bibliográfico, la Biblioteca Nacional de España (Madrid). Uno de los problemas encontrados ha sido la escasez de documentos escritos custodiados sobre televisión. Ante la carencia de estos, hemos optado por la utilización de algunas publicaciones oficiales de la propia RTVE. Se trata de distintos informes editados en 1976 y 1978, como RTVE/ 1976, o RTVE, Informe

\footnotetext{
${ }^{28}$ Véase: http://www.rtve.es/archivo/ [consultado el 12/12/2016].

${ }^{29}$ Muchos datos referentes a la audiencia fueron publicados en prensa a lo largo de este periodo así como en los distintos anuarios de RTVE.
} 
1978. También la revista Mensaje y medios (que venía a sustituir a Cuadernos de Documentación y cuyo primer número fue publicado en octubre de 1977) $)^{30}$, y La Revista Española de Investigaciones Sociológicas (REIS), publicada por el Centro de Investigaciones Sociológicas (CIS) entre 1978-1985 ${ }^{31}$. En este sentido, en el CIS se consultaron las distintas encuestas y estudios de opinión que se realizaron durante la Transición, y son una evidente muestra del fuerte interés que centró el medio televisivo en este periodo.

Para un análisis de la televisión, creemos que han sido infravaloradas las fuentes periodísticas que nosotros utilizamos por diversos motivos: la prensa no solo muestra el fuerte interés que centró el medio televisivo también nos permite mesurar el impacto del programa. Como argumenta François Jost, la televisión es un medio que moviliza la atención de todos los otros (Jost 2013: 7). Al ser la única televisión existente en el país, se observa con atención al medio, traducible en multitud de artículos que hacen referencia a ella. Periodista de formación, José Luis Balbín pasó por distintos medios escritos y, al igual que otros muchos trabajadores de RTVE, se utilizó de la prensa en distintas ocasiones para expresar y difundir sus opiniones. Se han seleccionado los artículos dedicados al programa y a su director en distintos medios como ABC, El País, Mediterráneo, La Hoja del lunes, La Nueva España y Diario 16. También las revistas Teleprograma y Tele-Radio ${ }^{32}$. Con el objetivo de poder observar la recepción que hacía la prensa del programa y de los temas que abordaba, prestaremos especial atención a la opinión de los críticos y especialistas de televisión de tres medios (El País, ABC y Diario 16).

Sin embargo, en un contexto internacional de control de la información por parte de los gobiernos, ¿cómo definir la situación de monopolio en el panorama audiovisual español? España solo tiene una televisión estatal que cuenta con dos cadenas: la primera cadena (que surge en España con las primeras emisiones regulares el 28 de octubre de 1956), y la segunda cadena o UHF (que las inicia el 15 de noviembre de 1966). Esta situación se mantendrá hasta 1990 con el surgimiento de las primeras televisiones privadas (entre ellas, Antena 3, cadena a la que José Luis Balbín trasladaría La clave tras su definitiva supresión en TVE). Esta situación de monopolio nos lleva a preguntarnos por el espacio de difusión de TVE en aquella época. Virginie Philippe argumenta que uno de cada dos españoles solo tiene la televisión como medio

\footnotetext{
${ }^{30}$ Mensaje y medios, Instituto de RTVE, Madrid, octubre 1977.

${ }^{31}$ Véase: http://www.reis.cis.es/REIS/jsp/REIS.jsp?opcion=jsp/numeros.jsp [consultado el 23/06/2014].

${ }^{32}$ Sin embargo, como explica Rafael Gómez, el acceso a este tipo de publicaciones (en referencia a Tele-Radio) es complicado hasta el punto de convertirse en piezas de coleccionismo y no en material de biblioteca. Véase R. Gómez, "Investigar la historia de la televisión en España: algunos problemas documentales y metodológicos", en Área Abierta, $\mathrm{n}^{\mathrm{0}}$ 7, enero 2004, Universidad Complutense de Madrid, p. 3.
} 
de difusión (Philippe 2007: 59) ${ }^{33}$. Si en 1976, Televisión Española tenía una audiencia diaria de 15.428.871 de telespectadores mayores de catorce años ${ }^{34}$, en 1978, TVE obtuvo un promedio diario de más de 18 millones de telespectadores mayores de 15 años $^{35}$. En referencia a la segunda cadena -y teniendo en cuenta que su cobertura no llegaba a toda la población-, la audiencia de La clave y su evolución, merecen especial atención. A la altura de 1979, La clave era el programa de mayor audiencia con 2.181.000 telespectadores, y algunas emisiones, como Muerte de García Lorca (ficha 160) fueron rotundos éxitos de audiencia ${ }^{36}$. Para 1981, la audiencia media del programa en el momento en el que se emitía la película era de 4.291.000 personas $^{37}$.

En lo que coinciden la mayoría de los historiadores y especialistas en medios de comunicación es que Televisión Española tuvo un rol primordial durante la Transición como principal medio de difusión ${ }^{38}$. Nuestra tesis doctoral se integra en una problemática más amplia al buscar la creación y difusión de formas de representación en las relaciones que se producen entre política y televisión. Sin embargo, en los estudios realizados en España sobre televisión, observamos que en su mayoría son estudios generales sobre el medio, y muy pocos los centrados en programas concretos de televisión. Algunos autores mencionan La clave en sus trabajos como José Ramón Pérez Ornia (1988), Virginie Philippe (2007), Manuel Palacio (2012), y Virginia Martín (2013) ${ }^{39}$.

Virginia Martín, desde el punto de vista de la comunicación política, demuestra que TVE «constituyó un instrumento más de la maniobra de consenso que se puso en marcha tras la llegada de Suárez» (Martín 2013: 24). Si damos por válida esta afirmación ¿por qué se prohibía entonces el programa o se censuraban ciertas emisiones? ¿Fue La clave un programa independiente del poder político? Creemos que esta tesis doctoral presenta una novedad al

\footnotetext{
${ }^{33}$ La autora añade además otros datos de interés como el tiempo que los españoles consagraban a la televisión durante la Transición (tres horas al día frente a los 10 minutos que consagraban a la prensa).

${ }^{34}$ RTVE, 1976, p. 155. Cfr. V. Martín, Televisión Española y la Transición democrática, op. cit. p. 42.

${ }^{35}$ J. R. Pérez Ornia, “Contradicciones sobre la audiencia de TVE”, El País, 17/08/1979.

${ }^{36}$ El periódico The New York Times escribió que fue la mayor audiencia de la televisión en España de aquellos años. Véase A. Holmberg, "Five Years After Franco, Lorca Is Alive Again in Spain; Spain Rediscovers the Theater of Lorca", The New York Times, 19/10/1980, p. D3.

${ }^{37}$ Fuente: J. R. Pérez Ornia, "La audiencia del UHF”, El País, 20/04/1979, y "19 millones de españoles ven diariamente los programas de televisión", El País, 09/09/1981.

${ }^{38}$ M. Palacio, La televisión durante la Transición española, op. cit. p. 10.

39 J. R. Pérez Ornia (1988), La televisión y los socialistas... op. cit. V. Philippe (2007), Transition et télévision en Espagne, op. cit. M. Palacio (2012), La televisión durante la Transición española, op. cit. V. Martín (2013), Televisión Española y la Transición democrática, op. cit.
} 
centrarse exclusivamente en un programa de televisión. Presentamos La clave como objeto de estudio y como hilo conductor, y a partir de él, poder observar la televisión y las posibles interferencias entre el poder político y el medio televisivo. Para ello se analizarán las películas proyectadas, la temática abordada, y los invitados, a partir de su contextualización.

Una vez delimitado nuestro objeto de estudio y su problematización, presentamos nuestro plan de trabajo y su articulación a través de las dos partes en las que hemos dividido esta tesis doctoral. Pasamos a ver una breve descripción del contenido de cada una de ellas, y de los capítulos en los que se han estructurado.

PARTE I. “Televisión Española y La clave de José Luis Balbín”. La primera parte se articula en torno a tres ejes: televisión, José Luis Balbín, y La clave, y ha sido estructurada en tres capítulos. El primero, "La televisión en España” se inicia con el planteamiento teórico y las cuestiones metodológicas con las que pretendemos trazar los objetivos, la estructura de análisis y la metodología empleada que hemos llevado a cabo. A continuación analizamos la televisión como objeto histórico y, para ello, partimos desde el origen de la televisión como servicio público con el objetivo de contextualizar La clave durante la Transición española. El segundo capítulo, “Apuntes para una biografía de José Luis Balbín”, pretende profundizar en la figura del periodista que dirigió en España el primer programa de debates en directo. Y en el tercer capítulo, “La clave y el debate televisivo en España”, presentamos un análisis general del programa a través de su estructura (película, debate, participación del público) con la que observar el directo, los invitados, la filmografía, o las prohibiciones llevadas a cabo. Pasamos a ver en mayor profundidad cada uno de los capítulos y las conclusiones alcanzadas.

Capítulo 1. La televisión en España. El primer capítulo de esta tesis doctoral se inicia con el planteamiento teórico y las cuestiones metodológicas con el propósito de explicar los criterios generales, la estructura y el método de estudio. A partir de un enfoque de historia cultural presentamos un estudio analítico de un programa de televisión durante el proceso de transición en España. Como argumenta Vicente J. Benet «se entiende la historia cultural como la parte de la historia dedicada a observar los procesos de cambio social a través de los productos culturales» (Benet 2012: 15). Abordaremos La clave desde una óptica interdisciplinar que nos permita abrir nuevas perspectivas de análisis y tenga en cuenta los aspectos teóricos y metodológicos más adecuados para su contextualización. 
Este capítulo, de carácter teórico, pretende problematizar el fenómeno televisivo y sus dinámicas con el propósito de contextualizar el periodo de Transición en España. Para ello, realizaremos un estudio teórico que nos lleve a entender el modelo fundacional de la televisión como servicio público a través de sus misiones fundacionales: informar, educar, y entretener. Un breve recorrido histórico de los orígenes de la televisión nos permite, por una parte, conocer sus antecedentes inmediatos (la televisión durante el franquismo) y por otra, comparar las transformaciones acaecidas en las distintas televisiones europeas. Nuestro interés se centrará en examinar las transferencias culturales que se producen en Televisión Española. Del programa francés Les Dossiers de l'écran, José Luis Balbín realiza una adaptación en España durante la Transición, momento de crisis del modelo fundacional de la televisión pública. El aumento progresivo de televisores, y los estudios de audiencia nos permitirán observar el tratamiento de la imagen que se realizó durante la Transición y su ruptura respecto a la imagen de la televisión durante el franquismo. Con la llegada de las nuevas libertades democráticas, se re-configura tanto la estructura como el uso social de la televisión.

Capítulo 2. Apuntes para una biografía de José Luis Balbín. En este capítulo pretendemos trazar la trayectoria de José Luis Balbín, director y moderador La clave. Pese a su labor al frente del programa durante diez años y haber sido galardonado en multitud de ocasiones, pocos estudios han atendido su figura. En la historiografía de la Transición española se han estudiado mucho los actores políticos del cambio y abundan las biografías de figuras políticas, siendo menores las investigaciones hacia otros actores sociales y otras categorías profesionales. Este capítulo pretende escapar de esta tendencia con el propósito de abordar la trayectoria personal y profesional de un periodista que dirigió en España el primer programa de debates en directo.

José Luis Balbín nace en Pravia (Asturias) en 1940. En 1960 se inscribió en la Escuela Oficial de Periodismo de Madrid, y en primero de carrera entró a trabajar en prácticas en el diario La Nueva España de Oviedo. Tras diplomarse Periodismo en 1963, trabajó en distintos medios de comunicación: escribió algunos artículos para el periódico Arriba, realizó prácticas en la agencia de Estado Pyresa (abreviatura de Periódicos y Revistas Españolas. Servicio de Agencia), y trabajó en el diario Pueblo de Madrid. En esa época fue nombrado Jefe del Departamento Nacional de Información del Sindicato Español Universitario (SEU). Posteriormente trabajó de corresponsal, primero de prensa -en Alemania y Austria- y posteriormente corresponsal en París de Televisión Española (TVE) y Radio Nacional de 
España (RNE). Es durante su estancia en la capital francesa cuando entra en contacto con el programa Les Dossiers de l'écran. A su regreso en España en 1974, es designado por Rodolfo Martín Villa jefe nacional de Prensa y director de los Servicios Informativos del Ministerio de Obras Públicas. En 1976 y hasta 1985 dirigió en Televisión Española el programa La clave, corpus central de esta tesis doctoral.

Capítulo 3. La clave y el debate televisivo en España. En este capítulo presentamos, a modo general, una descripción y análisis de La clave (organigrama, estructura, funcionamiento interno...) para posteriormente poder analizar el papel que desempeña el programa durante la Transición española. Un programa que se guía por estándares y representaciones colectivas que tuvieron fuerte incidencia en la sociedad española en un momento en el que se trataba de construir un nuevo sistema político en España. En este capítulo abordamos un análisis sociopolítico de La clave siguiendo la propia estructura del programa (tema, invitados, y películas proyectadas). Entender la historia del debate televisivo en España pasa indudablemente por este programa. A través de él, se articula y se construye el debate televisivo al ser el único programa de debates en directo en esos momentos. Se ha dividido este capítulo en distintos apartados que nos permite observar su estructura y funcionamiento interno así como toda una serie de características que nos ayudarán a entender la creación y difusión de una opinión cualificada a través de la figura del experto.

PARTE II. “Debate televisivo y cultura política en España”. La segunda parte de nuestra tesis doctoral, es la parte central y se ha estructurado en cuatro capítulos con el objetivo de abordar La clave y la formación de una cultura política durante los diez años que este programa estuvo en antena. Presentamos una historia serial de La clave por etapas, que se han estructurado a partir de los distintos directores generales de RTVE que pasaron durante este periodo. Estas son las cinco etapas: 1. Génesis del programa y primeros debates en directo (1976). 2. El regreso de La clave (1977-1978). 3. Fernando Castedo y el golpe de Estado de 1981. 4. José Luis Balbín y los Servicios Informativos (1982-1983), y 5. La etapa final de La clave (1983-1985). En el transcurso de La clave pasaron cuatro presidentes del Gobierno y ocho directores generales de RTVE, tantos directores generales como durante todo el franquismo, una muestra de la inestabilidad de la televisión durante la Transición. Pasamos a ver en mayor profundidad los cuatro últimos capítulos y las conclusiones alcanzadas. 
Capítulo 4. Los inicios del debate televisivo en España (1976-1978). Tras haber fijado una plantilla de observación para el visionado de programas (Jost 2013: 117), se ha realizado una selección entre los 408 programas que fueron emitidos. Este capítulo abarca los primeros años del programa, y aborda La clave en su contexto sociopolítico. El objetivo es mostrar la micro-historia del programa durante la Transición española: su surgimiento, su evolución, y sus límites, desde la propia historia política del país. Presentamos La clave como eje central pero también hilo conductor, desde el surgimiento del programa en 1976 hasta la Constitución de 1978. La clave fue una emisión pionera en muchos aspectos que logró abordar temas que habían sido silenciados hasta el momento. También, por primera vez en televisión, favoreció el intercambio de opiniones y la participación del telespectador. De este modo, permitieron acabar con muchas barreras culturales impuestas durante el franquismo.

Capítulo 5. El debate en España. De la Constitución al golpe de Estado. Este capítulo se inicia precisamente con la Constitución española aprobada por referéndum el 6 de diciembre de 1978 y se prolonga hasta el golpe de España que tuvo lugar en el Congreso de los Diputados el 23 de febrero de 1981. De este modo, siguiendo la cronología propia del proceso de Transición, nuestro propósito es observar el papel que desempeña el programa en la articulación y construcción del debate televisivo. Los debates televisivos incidieron en la apertura y en la democratización del sistema político español, ayudando a la formación de una ciudadanía democrática.

Capítulo 6. La clave durante la etapa socialista (1982-1985). Este capítulo, se estructura a partir de un marco temporal que se extiende entre 1982 y 1985 y traza las últimas etapas del programa. Este capítulo se inicia con la victoria del Partido Socialista en las elecciones de octubre de 1982 y finaliza con la definitiva suspensión del programa en 1985. La clave fue un programa de debates que informaba, orientaba, y creaba opinión. Sin embargo, ¿podía un programa de televisión construir un debate político que ayudase a cambiar la legislación del momento? ¿Y a acabar con ciertas desigualdades? Examinamos con especial interés los debates históricos y políticos, pero también aquellos dirigidos a acabar con ciertas desigualdades. No porque un programa pueda acabar de lleno con la desigualdad, sino por el hecho de que las desigualdades que subsisten no son vividas del mismo modo. 
Capítulo 7. La clave y la cultura política en la Transición española. El último capítulo de nuestra tesis doctoral pretende profundizar en los programas históricos y políticos con los que abordar la formación de la cultura política en España. Se estructura, por tanto, en torno al concepto de cultura política: la cultura del debate en España. En primer lugar, por tanto, delimitaremos el concepto de cultura política. Como argumentan Almond y Verba «cuando hablamos de cultura política de una sociedad, nos referimos al sistema político que informa los conocimientos, sentimientos y valoraciones de su población. Las personas son inducidas a dicho sistema, lo mismo que socializadas hacia roles y sistemas sociales no políticos» (Almond y Verba 1970: 30). La socialización política, como indica Jacqueline Peschard, «hace referencia al tema de cómo, qué y cuándo aprende la población acerca de la política, es un proceso de aprendizaje e interiorización de valores, símbolos y actitudes frente a la política» (Peschard 2012: 42).

Conclusiones. Estos capítulos son las principales líneas de investigación que conforman esta tesis doctoral. Un análisis del programa La clave nos ha permitido entender la complejidad del medio televisivo en un contexto de transformación de un régimen dictatorial a otro democrático. Este programa de televisión en directo es, por tanto, un retrato de la sociedad española de ese momento. En este sentido, La clave logró situar temáticas y conceptos en el centro del debate político español y, sobre estos conceptos, se tejieron muchos de los nuevos consensos. A través de la televisión, por primera vez, los telespectadores podían reflexionar sobre el nuevo modelo de sociedad, y participar de él. Este programa permitió abrir cauces para la participación política dentro de un sistema que tenía como una de sus bases estructurales la movilización política de la población. Partiendo de la construcción del debate televisivo que hizo La clave, hemos observado la formación de una determinada cultura política en España: la cultura de la discrepancia. Su contribución cultural, social y política, han convertido a este programa en el emblema en televisión del diálogo de toda una generación durante la Transición. 


\section{PARTE I \\ TELEVISIÓN ESPAÑOLA Y LA CLAVE DE JOSÉ LUIS BALBÍN}





\section{Capítulo 1. La televisión en España}

Como bien propuso Ramón Cotarelo en su trabajo Visiones de la Transición, habría que estudiar la influencia que pudieron tener programas de debate como La clave en la difusión de actitudes de tolerancia entre la población: «Más de una sorpresa nos llevaríamos si pudiera hacerse un estudio acerca de cómo influyó sobre los hábitos y la conciencia de los españoles (probablemente comenzando por las capas más intelectualizadas y generalizándose después) un programa como el que tuvo en TV2 durante largos años con La clave, José Luis Balbín. ¿Cómo podría definirse aquel programa? Quizá como el termómetro de una opinión pública cada vez más impaciente y progresivamente liberal, tolerante, democrática» ${ }^{1}$.

La presente tesis doctoral se plantea como una investigación en torno al programa de televisión La clave entre 1976 y 1985 . Nuestro objetivo es presentar un análisis cultural de este programa como hecho histórico, dentro del conjunto histórico que representa la Transición española. A lo largo de la investigación defendemos la siguiente hipótesis: La clave articuló y construyó el debate televisivo durante el proceso de transición en España, que ayudaría a la formación de una cultura política democrática. En ese sentido, su análisis nos permite observar el debate político y cultural que fue llevado a cabo en televisión en este periodo. Presentamos un análisis del programa en su contexto histórico: la Transición española. La Transición es la etapa que transcurre desde la muerte de Francisco Franco hasta la introducción y consolidación de una democracia parlamentaria. Durante este periodo se abrió en España un proceso de cambio político, social, económico y cultural, que llevó al país a una paulatina apertura internacional a través de una progresiva normalización de su política exterior con su integración a la OTAN y a la Comunidad Económica Europea. Una Transición de cierta faceta paternalista que diseñada desde arriba, bien define la expresión «De la ley a la ley», y que significó en realidad, como señala Ferran Gallego, «Del poder al poder» (Gallego 2008: 381).

En primer lugar, debemos partir de la historia social como factor dinámico con el que abordar una explicación de la actividad humana, las mentalidades colectivas, las ideas, las representaciones, las formas de pensamiento y los actores sociales que la componen. Siguiendo la historiografía francesa, la Nouvelle Histoire (Jacques Le Goff, Pierre Nora...) pretendió reconstruir imaginarios sociales y establecer una historia serial de las mentalidades. Pero no fue hasta la década de 1960 y 1970 cuando se desarrolló principalmente la historia cultural a partir

\footnotetext{
${ }^{1}$ R. Cotarelo, "Visiones de la Transición", en Revista del Centro de Estudios Constitucionales, nº 18, mayo-agosto de 1994, p. 31. (nota a pie de página).
} 
de la problemática que planteaba definir el concepto de «mentalidades» ${ }^{2}$. Emancipada de la historia de las mentalidades, la historia cultural, corriente historiográfica correspondiente a la tercera generación de l'École des Annales ${ }^{3}$, aportaba ciertos cambios y nuevos objetos de estudio: las prácticas culturales, las creencias, los imaginarios, la vida cotidiana... y entendía por cultura el conjunto de representaciones colectivas propias de una sociedad (Ory 2011: 8). El foco de atención se trasladaba de lo social a lo cultural y acabó estructurándose en los años 80 y 90 como historia cultural. Philippe Poirrier la definió como una historia social de las representaciones (Poirrier 2008: 27) ${ }^{4}$.

\subsection{Planteamiento teórico y cuestiones metodológicas}

En este primer apartado trazaremos, en líneas generales, la estructura de análisis y la metodología empleada que hemos llevado a cabo en la presente tesis doctoral. El corpus central de nuestra tesis doctoral son los 408 programas que emitió La clave entre 1976 y 1985. Presentamos en el DVD el listado oficial de los programas en 408 fichas con los siguientes datos: fecha de emisión, película proyectada e invitados al debate. En relación a los invitados, se ha respetado el cargo que ocupaba en esos momentos. Las emisiones prohibidas por la dirección de RTVE que no llegaron a emitirse en televisión -seis en concreto-, se representan con la letra $\mathrm{C}$ (de censura o prohibición). Se han tenido en cuenta además dos programas posteriores al marco temporal: el programa 500 claves de la Transición, emitido el 1 de noviembre de 1991 en Antena 3 Televisión, y el programa La Constitución española 20 años

\footnotetext{
${ }^{2}$ Un panorama general sobre el estudio de temas culturales desde el siglo XVIII alemán hasta la llamada "nueva historia cultural francesa" en la década de los ochenta del siglo XX, en P. Burke, What is cultural history?, Polity Press, Cambridge, 2004. Obra traducida ¿Qué es la historia cultural?, Paidós, Barcelona, 2006. Véase también J. Serna, La historia cultural, Akal, Madrid, 2005.

${ }^{3}$ En 1929 los historiadores franceses Marc Bloch y Lucien Febvre fundaron la revista Annales d'histoire économique et sociale, que marcaría la nueva corriente historiográfica conocida como Escuela de los Annales. Véase M. Bloch y L. Febvre, "À nos lecteurs" (Editorial), Annales d'histoire économique et sociale, Vol. 1, $\mathrm{n}^{\circ} 1$, 1929, pp. 1-2.

${ }^{4}$ Del mismo autor véase, Les enjeux de l'histoire culturelle, Seuil, París, 2004. En los últimos años, esta corriente historiográfica ha generado una importante bibliografía. Trabajos teóricos de tipo general puede hallarse, entre otros, en R. Chartier, Les origines culturelles de la Révolution française, Le Seuil, París, 1990 (del mismo autor, véase "Le monde comme représentation", Annales E.S.C., noviembre-diciembre 1989, nº 6, pp. 1505-1520. Obra traducida, El mundo como representación. Historia cultural: entre práctica y representación, Gedisa, 1996); J. P. Rioux y J. F. Sirinelli (dir.), Pour une histoire culturelle, Seuil, París, 1997; Geoff Eley, La línea torcida. De la historia cultural a la historia de la sociedad, Publicacions de la Universitat de València, Valencia, 2008; y de P. Burke, véanse las obras La revolución historiográfica francesa: la escuela de los Annales, 1929-1989, Gedisa, Barcelona, 1996; ¿Qué es la historia cultural?, Paidós, Barcelona, 2006; y Formas de historia cultural, Alianza, Madrid, 2006.
} 
después, emitido el 5 de diciembre de 1998 en TVE. Ambos pueden encontrarse en la web ${ }^{5}$. Justificamos estos dos programas por la relación directa con La clave durante la Transición española. Sin embargo, escapa de nuestro análisis la etapa posterior del programa en Antena 3 (1990-1993) que, pese a tratarse de la primera experiencia de la televisión privada en España, se encuentra más allá del periodo de Transición y es, por tanto, de menor influencia. Ya se ha configurado una cultura política (aunque sea en lo más rudimentario).

Delimitado el corpus pasamos a ver un estado de la cuestión. La producción historiográfica se inscribe en el tiempo en que se produce y, por lo tanto, se encuentra condicionada al desarrollo global del pensamiento científico y a la forma de enfocar la realidad. Los procesos de construcción de la realidad por parte de los medios de comunicación han sido estudiados desde distintos ámbitos, enfoques y perspectivas. Sin embargo, los estudios sobre la televisión durante el proceso de transición son relativamente recientes. Con el objetivo de aportar un eje común a las distintas investigaciones en la historia de la comunicación en España surgidas en los últimos años, empezamos con la obra de Manuel Palacio, La televisión durante la Transición española (2012) ${ }^{6}$. El autor presenta un recorrido histórico de la televisión desde 1974 hasta 1981, destacando la enorme contribución de la televisión como acelerador del cambio durante el proceso de transición ${ }^{7}$. La obra aportaba un resumen de los programas emitidos por La clave hasta 1979 que había publicado la revista Tele-Radio (revista oficial de los organismos rectores de Televisión Española $)^{8}$. Palacio destacaba que «la colaboración de $L a$ clave en el proceso de creación de un espacio público democrático es su aportación de mayor calado histórico. Los debates del programa se presentaban a los españoles como una zona de diálogo entre pares de unos invitados que partían de puntos de vista completamente diversos, que discrepaban y no por ello pasaba nada grave» (Palacio 2012: 261) ${ }^{9}$.

\footnotetext{
${ }^{5}$ Véanse 500 claves de la Transición en: https://www.youtube.com/watch?v=rOfjZNEsL7g, y La Constitución española 20 años después en: https://www.youtube.com/watch?v=Ga6vXB-BVTs [consultados el 15/12/2016].

${ }^{6}$ M. Palacio, La televisión durante la Transición española, Cátedra, Madrid, 2012. La portada del libro es una fotografía realizada durante el programa de La clave El intelectual y la política (ficha 378), emitido el 24 de mayo de 1985. En ella aparece en primer plano José Luis Balbín y Alfonso Guerra.

${ }^{7}$ Manuel Palacio, catedrático de Comunicación Audiovisual de la Universidad Carlos III de Madrid, dirige el proyecto: Los medios audiovisuales en la Transición española (1975-1985), que aborda las imágenes del cambio democrático y el papel que ocupan las representaciones cinematográficas y televisivas en la España democrática.

${ }^{8}$ Tele-Radio, $\mathrm{n}^{\mathrm{o}}$ 1124, 9-15 de julio de 1979, p. 36, en Manuel Palacio, La televisión durante la Transición en España, op. cit.pp. 260-261.

${ }^{9}$ Como única excepción, veremos que al finalizar uno de los programas, los guardaespaldas del dirigente falangista Raimundo Fernández-Cuesta intentan agredir al historiador Ian Gibson. Cfr. M. Palacio y C. Ciller, "La clave de TVE, op. cit.", p. 238. Será la única excepción en todo el programa porque precisamente La clave se caracterizó por ser un lugar donde se podía debatir desde puntos de vista encontrados sin ningún tipo de altercado.
} 
La obra incluía además un documental titulado Las lágrimas del presidente (2009), con fragmentos de La clave durante $1976^{10}$. En el documental intervienen algunos historiadores como Ferran Gallego y Rafael R. Tranche. Para Gallego La clave formó opinión ciudadana y movió una cultura democrática; y para Tranche su «éxito fundamental estaba en la forma en que se construía el debate, un debate abierto donde la opinión especializada se respetaba, se oía y se confrontaba, y un espacio de discusión política en torno a las ideas, propio de la democracia» ${ }^{11}$.

Cuando ya había empezado la redacción de esta tesis doctoral, Manuel Palacio y Carmen Ciller publicaron el único estudio realizado hasta el momento sobre el programa. Se trata de un artículo de 2014 titulado "La clave de TVE, un debate en la historia de la televisión en España..."12. A través de un corpus de veintisiete programas, abordaban los elementos característicos del formato que habían contribuido a su legitimación en el imaginario colectivo. Presentaban La clave como «uno de los hitos de la historia de la televisión española» (Palacio y Ciller 2014: 228), por su conexión con «el aire de los tiempos y con el entramado político español» (Palacio y Ciller 2014: 234). A pesar de compartir gran parte de sus planteamientos hay, sin embargo, algunas diferencias en las conclusiones alcanzadas. Para estos autores, la herencia del programa llegaba hasta la actualidad, como podía ser el programa $59 \operatorname{segundos}^{13}$, mientras que nuestro planteamiento considera que la misión educativa del modelo fundacional de la televisión - de la que el programa es heredero- se diluye durante la Transición y se transforma en el nuevo modelo televisivo de los años noventa (con programas de menor reflexión y mayor espectáculo) y que coincide en España con la entrada de la televisión privada.

Trataremos de mostrar cómo en los orígenes de la televisión, las misiones fundacionales formuladas por la $\mathrm{BBC}$ como pilar del funcionamiento de una televisión como servicio público (informar, educar, entretener), son formuladas con breves matices por las televisiones europeas.

\footnotetext{
${ }^{10}$ Las lágrimas del presidente es un documental elaborado a partir de material de archivo con guion de M. Palacio y G. Roldán. Puede verse online en la web: http://www.rtve.es/alacarta/videos/archivos-tema/archivo-temaslagrimas-del-presidente/868442/ [consultado 22/01/2013].

${ }^{11}$ Véanse especialmente los minutos 17-20 del documental. Cfr. V. Martín, Televisión Española y la Transición democrática, op. cit. p. 49.

${ }^{12}$ M. Palacio y C. Ciller, "La clave de TVE, un debate en la historia de la televisión en España...", en Estudios sobre el Mensaje Periodístico, Vol. 20, Núm. especial (2014), pp. 227-241. Haremos referencias a este trabajo a lo largo de la tesis doctoral.

${ }^{13}$ Programa de debate sobre asuntos de actualidad política y social en TVE que inició sus emisiones el 4 de octubre de 2004. Cfr. J. F. Gutiérrez Lozano, "La presencia del debate en televisión y su utilidad en la calidad de las programaciones", en Comunicar. Revista científica iberoamericana de comunicación y educación, $\mathrm{n}^{\circ} 25, \mathrm{Vol} .2$, 2005 .
} 
Fueron el caso de la televisión francesa (informer, cultiver, distraire), y la española (informar, formar, entretener). Matices que ya señalaban distintas maneras de entender y proceder en una de las misiones en las que había de sustentarse la televisión pública. Creemos que la misión educativa-formativa en España va perdiendo su status quo en el momento en que la audiencia se va situando como eje central y regulador del modelo televisivo. Los programas educativos o formativos no desaparecen de la programación, pero se rigen desde el nuevo modelo de la televisión pública (de carácter más comercial y de marcado entretenimiento), que será el que marque las nuevas directrices.

Abordaremos estos aspectos en los siguientes puntos partiendo del propio origen de la televisión con el propósito de mostrar cómo durante la Transición española se desvirtúa la esfera educativa en detrimento de la esfera informativa (que logra mantener su estatus inicial aunque no logra desprenderse del férreo control del poder político) y de la esfera del entretenimiento (que va incrementando al tiempo que lo hace la audiencia). Por tanto, es la misión educativa la que no consigue el protagonismo marcado en su fundación como servicio público. Una tendencia que se observa, si bien con ciertos desajustes y variaciones de intensidad, en las distintas televisiones europeas ${ }^{14}$.

En España fueron determinantes otros modelos televisivos europeos (especialmente el modelo inglés y francés). Influencias y transferencias culturales que hemos analizado con el propósito de realizar ciertos paralelismos en el auge del entretenimiento y observar el devenir de la misión educativa. Iniciado el proceso de transición, La clave lograría introducirse desde la misión educativa del modelo fundacional de la televisión como servicio público. Un modelo en el que hasta entonces la audiencia no marcaba ni condicionaba la emisión de programas culturales. Dicho de otro modo, la televisión tenía la obligación de ofertar dichos programas (opera, teatro, emisiones literarias...), de ámbito más minoritario, sin considerar el número de telespectadores que estaban frente a la pantalla.

Otras diferencias respecto al trabajo de Manuel Palacio y Carmen Ciller son, en primer lugar, que sí creemos en el carácter diferencial de La clave respecto a otros espacios informativos que emite televisión en esos momentos (se diferenciaba precisamente en las

\footnotetext{
${ }^{14}$ Una historia cultural en Europa desde la televisión como servicio público a la tele-realidad, en J. Bourdon, Du service public à la télé-réalité. Une histoire culturelle des télévisions européennes 1950-2010, INA, Bry-surMarne, 2011. Sobre los medios de comunicación en España nos remitimos a la bibliografía por los numerosos trabajos que se han abordado en España. Sin embargo, cabría reparar aquí en algunos autores como J. Timoteo Álvarez et. al. Historia de los medios de comunicación en España. Periodismo, imagen y publicidad (1900-1990), Ariel, Barcelona, 1989; J. M. Baget Herms, Historia de la televisión en España (1956-1975), Feed Back, Barcelona, 1993; y las obras previamente citadas de Manuel Palacio.
} 
directrices que llevó a cabo José Luis Balbín en su programa como veremos más adelante), y el asentamiento de las normas cívicas de convivencia en televisión que creemos sí favoreció este programa. Compartimos, a pesar de ello, la mayor parte de ideas y planteamientos de este trabajo como la participación de La clave en la difusión de valores democráticos a la audiencia ${ }^{15}$ (Palacio y Ciller 2014: 229); y la idea de «La clave es Balbín y Balbín es La clave» (Palacio y Ciller 2014: 234). La figura de José Luis Balbín es determinante para entender el origen del programa y su posterior evolución. En el segundo capítulo precisamente presentamos una aproximación biográfica de un periodista que ya en 1976 (con treintaiséis años) dirige en España el primer programa de debates en directo.

En el mismo número monográfico, Virginia Martín abordaba de manera general los principales programas de debate entre 1975 y 1980, y cómo estos pasaron a ser «un marco de referencia para la sociedad que no solo encontraba en la pequeña pantalla patrones de conducta en relación a las principales cuestiones de interés político; sino que también, consumiendo esos espacios de la programación aprendía a emplear un nuevo lenguaje democrático que incluía vocablos carentes de contenido durante la dictadura franquista ${ }^{16}$. En la obra Radio y televisión en España. Historia de una asignatura pendiente (2006), Enrique Bustamante toma como punto de partida el franquismo y se adentra en el periodo de transición, calificando el modelo de RTVE de continuista. Para el autor se trata de un modelo intacto que no sufre cambios sustanciales hasta el primer intento frustrado de Fernando Castedo (1981), primer director general de televisión pactado entre el Gobierno y la oposición. Destacamos que el propio Enrique Bustamante participó en La clave el 11 de mayo de 1984, en el programa Impacto de los medios de comunicación (ficha 324). Califica La clave de programa emblemático que sufrió numerosas censuras durante la Transición (Bustamante 2006: 59 y 89). Censuras y prohibiciones que serán analizadas en nuestra tesis doctoral - tanto de emisiones concretas como del propio programa-, que acaban revelando aquellos temas que la dirección de RTVE consideraba inoportunos hasta el límite de no emitirse en televisión, y la lucha del gobierno por

\footnotetext{
15 Aunque finalmente sea el término de audiencia el que se imponga, seguimos preferentemente, en esos momentos, el de telespectador. Cfr. J. F. Gutiérrez Lozano, "La audiencia de la televisión en España y su historia. Un acercamiento a la memoria de los primeros telespectadores", en A. Company, J. Pons y S. Serra (eds.), La comunicació audiovisual en la història. Aportacions de la comunicació a la comprensió i construcció de la història del segle XX, Universitat de les Illes Balears, Palma, 2003, pp. 690.

${ }^{16}$ Cfr. V. Martín, "El parlamento catódico: los programas de debate sobre la actualidad política durante la transición (1976-1979)", en Estudios sobre el Mensaje Periodístico. Vol. 20, Núm. especial (2014), pp. 123-124. Pese a distinguir el formato del debate con la tertulia televisiva, acaba incluyendo programas como Sío no (abril de 1975, dirigido por Victoriano Fernández Asís), Cara y Cruz (mayo de 1976, presentado por Enrique Meneses); España, hoy (noviembre de 1976, dirigido por José Javaloyes); y Cara a cara (noviembre 1977, Federico Ysart).
} 
controlar el medio durante la Transición. Sujeta a los intereses políticos -y económicos-, la televisión, no solo muestra el férreo control del medio durante el proceso de democratización del sistema político español sino también a qué principios de autoridad fue sometida.

La mayor parte de trabajos sobre televisión que hacen referencia a La clave resaltan, de manera descriptiva, el directo y la relevancia de algunos invitados. Para Juan Carlos Ibáñez lo más novedoso de La clave fue «la presencia de personajes hasta entonces censurados y de temas anteriormente prohibidos» (Ibáñez 2006: 71) ${ }^{17}$. Con el propósito de escapar de esta descripción, presentamos en este trabajo un análisis de los invitados que pasaron por el programa (número de invitados, procedencia de los mismos, categoría socio-profesional...). A través de este análisis observamos no solo la baja participación de las mujeres en el programa (aproximadamente 250 de más de 2.700 invitados), también las aportaciones que realiza $L a$ clave, como la creación de una opinión cualificada a través de la figura del experto. Es decir, aquel invitado que precisamente destacaba por ser uno de los mejores expertos en el campo en el que se debatía (Neil Armstrong para debatir sobre el universo, Truman Capote sobre literatura, Herbert Marcuse sobre sistemas políticos...). Calificado «de debate intelectual» ${ }^{18}$, la autora francesa Virginie Philippe, se utiliza de algunas emisiones en su tesina de máster sobre la televisión durante la Transición ${ }^{19}$. En ella, subraya la enorme contribución que tuvieron en el proceso democrático programas como Informe Semanal, o La clave (Philippe 2007: 47 y 59$60)$.

Es reseñable que la única transcripción escrita de un programa de La clave entre 1976 y 1985 es el programa Marxismo (ficha 129), emitido el 10 de noviembre de $1979^{20}$. Posteriormente, en 1992, la revista Psicología Política publicaría la reproducción escrita del debate 500 claves de la Transición ${ }^{21}$. A nivel audiovisual, tal como indican Manuel Palacio y Carmen Ciller, «el diario El Mundo comercializó a finales de la década de los noventa una

\footnotetext{
${ }^{17}$ «Repertorio muy atractivo de invitados. En ocasiones por su relevancia política, social o intelectual (presidentes, ministros, premios Nobel, figuras de la historia del siglo XX, Truman Capote, Neil Armstrong o Daniel CohnBendit). En otros casos, por su cercanía a los personajes que centran el coloquio (como Pía Luciani, sobrina de Juan Pablo I, el gobernador civil de Granada en julio de 1936, o el hijo de Emiliano Zapata). Y generalmente por su peso en la vida social, cultural y política española (como Adolfo Suárez o el fiscal Jesús Vicente Chamorro, expedientado por participar en el programa», J. C. Ibáñez, "La clave", en M. Palacio, Las cosas que hemos visto. 50 años y más de TVE, Instituto de RTVE, Madrid, 2006, pp. 70-71.

${ }^{18}$ J. Muñoz Soro, “La transición de los intelectuales antifranquistas”, en Ayer, no 81, 2011, p. 32.

${ }^{19}$ V. Philippe, Transition et télévision en Espagne. Le rôle de la TVE, 1973-1978, L’Harmattan, París, 2007.

${ }^{20}$ Transcripción realizada por la revista Triunfo, 24/11/1979. Cfr. M. Palacio y C. Ciller, "La clave de TVE...", en Estudios sobre el Mensaje Periodístico. op. cit. p. 237 (en la nota a pie de página).

${ }^{21}$ Psicología Política, no 4, I-III, Promolibro, Valencia, 1992, pp. 85-124.
} 
selección de programas» (Palacio y Ciller 2014: 228) ${ }^{22}$. Con la llegada masiva de Internet a los hogares españoles, nostálgicos del programa comenzaron a subir a la plataforma online de reproducción de vídeos YouTube algunas emisiones.

De nuevo desde la comunicación política, la reciente obra de Virginia Martín (2013), se ha centrado en descifrar el lugar que ocupa la televisión gubernamental en la estrategia democratizadora que fue llevada a cabo entre 1976 y $1979^{23}$. En relación a La clave, argumenta que el programa fue «todo un símbolo de lo que representaba la ampliación de libertades que traía consigo la democracia» (Martín 2013: 49)²4. Por último, destacamos la obra del periodista Justino Sinova al aportar una gran cantidad de datos sobre La clave en un momento concreto (el nombramiento en 1982 de José Luis Balbín como director de los Servicios Informativos de RTVE) ${ }^{25}$. En 1983 se produjo entre José Luis Balbín y Diario 16 -del que Justino Sinova es director adjunto- una disputa por unos artículos publicados en Diario 16 y Cambio 16, a los que José Luis Balbín denuncia por calumnias a su persona ${ }^{26}$. Justino Sinova decide escribir esta obra (en 1983) centrándose especialmente en el asunto Alonso Puerta, invitado que sería vetado a asistir al programa por los socialistas (a través de Enrique Tierno Galván), y razón principal de la prohibición de Balance de los municipios de izquierda (ficha 254-C) ${ }^{27}$.

En los últimos años se ha venido apreciando un creciente interés en el ámbito científico a través de investigaciones centradas principalmente en la televisión como objeto de estudio. Se han realizado estudios generales, comparativos, históricos, sociológicos, antropológicos, monografías, y algunas tesis doctorales que han hecho avanzar en el terreno de la

\footnotetext{
22 Selección centrada en algunos temas políticos como La Constitución (ficha 72), Marxismo (ficha 129), Elecciones ¿Para quién los votos?, (242), o Cataluña (ficha 316), que apenas suscitó el interés de las bibliotecas universitarias (Palacio y Ciller 2014: 228). Algunos de estos programas se encuentran en la web de RTVE.

${ }^{23}$ V. Martín Jiménez, Televisión Española y la Transición democrática. La comunicación política del Cambio (1976-1979), Ediciones Universidad de Valladolid, Valladolid, 2013. Realiza alusiones a algunas emisiones sobre las que volveremos más adelante.

${ }^{24}$ Otros autores como Juan Munsó Cabús (2001), Juan Francisco Gutiérrez Lozano (2005), y Lorenzo Díaz (2006), también han realizado algunas referencias al programa en sus trabajos. J. Munsó Cabús, La otra cara de televisión. 45 años de historia y política audiovisual, Flor del Viento, Barcelona, 2001, pp. 140-141. J. F. Gutiérrez Lozano, "La presencia del debate en televisión y su utilidad en la calidad de las programaciones", en Comunicar. op. cit. p. 3, y L. Díaz, 50 años de TVE, Alianza, Madrid, 2006, pp. 263-264.

${ }^{25}$ J. Sinova, La gran mentira. El tinglado de la televisión al descubierto, Planeta, Barcelona, 1983.

${ }^{26}$ A raíz del artículo “Tres balbines en La clave: él, su hermana y su cuñada”, Diario 16, 26/03/1983, p. 47.

${ }^{27}$ El primer capítulo de la obra de Sinova, "La historia empieza con escándalo", se inicia con las siguientes palabras: «-¿Han liberado ya a Balbín? -No. La Redacción se niega a pagar el rescate. (Chiste oído en los Servicios Informativos de TVE)», en Justino Sinova, La gran mentira, op. cit. p. 15.
} 
investigación ${ }^{28}$. A diferencia de los estudios que se centran en explicar el rol de la televisión durante la Transición a través de un conglomerado de programas, esta tesis doctoral tiene como objeto de estudio un único programa de televisión con el que observar su incidencia política y social en España. Creemos que La clave juega un protagonismo político esencial durante la Transición española. Es llamativo, por tanto, que los análisis sobre televisión no hayan empezado por lo que precisamente conforma la televisión: los programas. No se han realizado estudios de programas concretos durante el proceso de Transición en España como podrían ser los casos de A fondo (1976-1981), Un, dos, tres... responda otra vez (1972-1984), Encuentro con las letras y las Artes (1976 y 1981), La bola de cristal (1984-1988)... Como única excepción encontramos un estudio del programa Informe Semanal (llamado en 1973 Semanal Informativo $)^{29}$.

Los documentos audiovisuales, cada vez más utilizados en el ámbito histórico, han tratado últimamente de explicar la historia reciente de la televisión en España. Un ejemplo es el documental aludido anteriormente, Las lágrimas del presidente (2010). El propio Manuel Palacio indicará que «con la circulación de las imágenes originales, éstas son utilizadas, reapropiadas y recicladas en ficciones y contextos diversos tensando hasta el límite de deformar el sentido original» (Palacio 2012: 341). Siguiendo esta línea creemos que, en los años noventa, uno de los errores de la televisión fue precisamente el representar la historia de España mezclando imágenes del pasado con discursos del presente, como fue el caso del documental La Transición (1995) dirigido por Victoria Prego y Elías Andrés ${ }^{30}$. Un documental que

\footnotetext{
${ }^{28}$ Los estudios sobre la comunicación han experimentado importantes avances a nivel internacional gracias a los aportes de la historia social y de la historia cultural. Véanse I. Fernández y F. Santana, Estado y Medios de comunicación en la España democrática, Alianza, Madrid, 2000. B. Casey et al., Television Studies. The key concepts, Routledges, Nueva York, 2002. J. C. Rueda Laffond y M. M. Chicharro, "La televisión y sus públicos: una aproximación interdisciplinar", en Historia y Comunicación Social, $\mathrm{n}^{\circ}$ 9, Universidad Complutense de Madrid, 2004, pp. 81-99. De los mismos autores, La televisión en España (1956-2006). Política, consumo y cultura televisiva, Fragua, Madrid, 2006. R. Quirosa-Cheyrouze, Prensa y democracia. Los medios de comunicación en la Transición, Biblioteca Nueva, Madrid, 2009. J. C. Rueda Laffond et al., "Parallel Stories differentiated histories. Exploring Fiction and Memory in Spanish and Portuguese Television", en VIEW, Jounal of European Television History \& Culture, Vol. 3, febrero 2012, pp. 37-44. N. Mínguez (ed.), Ficción y no ficción en los discursos creativos de la cultura española, Iberoamericana, Madrid, 2013. J. S. Duran Froix (ed.), La télévision espagnole en point de mire, Centre de Recherche sur l'Espagne Contemporaine, Université de la Sorbonne Nouvelle - Paris III, abril de 2013. También se ha incrementado el número de congresos, coloquios, y seminarios a través de investigaciones centradas en el cine, la radio y la televisión, revelando la importancia que tuvieron los Mass Media en el proceso democratizador. Algunos ejemplos: "El papel de los medios de comunicación". III Congreso Internacional Historia de la Transición en España, Almería, noviembre de 2007; La réforme politique : stratégies et acteurs: De la Loi sur la presse à la CEE (1966-1986), París, junio de 2014; y "Carisma e imagen política. Poderes y contrapoderes durante la Transición democrática", Madrid, junio de 2014.
}

${ }^{29}$ Véase B. Magro, Informe semanal: 30 años de historia, Plaza \& Janés, Barcelona, 2003.

${ }^{30}$ Serie documental de trece episodios emitida por TVE desde julio hasta octubre de 1995. Podríamos decir que la propia Victoria Prego prolongó dicha serie en la obra Así se hizo la Transición, Plaza \& Janés, Barcelona, 1995. 
invisibiliza cualquier movilización, y no pone en cuestión dicho proceso por el hecho de haber alcanzado las diferentes fuerzas políticas un consenso. En su intento audiovisual de representar la historia de la Transición en España, presentaba a Juan Carlos como la única figura capaz de traer la democracia. Como si cualquier otra vía de organización social estuviese sometida desde el inicio al fracaso más absoluto ${ }^{31}$. Presentaban los hechos históricos justificando y legitimando acciones del pasado por un futuro que todavía no existe. Es decir, concediendo su importancia al resultado «posteriori» ${ }^{32}$. Dicho de otro modo, construyen un discurso histórico que mezcla los hechos históricos con proyecciones futuras, obviando que la comunicación se da en unas coordenadas espacio-temporales específicas y que es el presente el tiempo propio de la acción comunicativa $^{33}$. El problema radicaba en la cercanía de los acontecimientos y en construir y representar desde la televisión un pasado demasiado inmediato. Como bien argumenta Ferran Gallego, el análisis del proceso de transición política en el momento en que esta se iba produciendo parte de una distorsión,

«construyendo una narración periodística que ha acabado por convertirse, junto a los libros de memorias convenientemente distanciados de los acontecimientos, en un material indispensable para el historiador. En definitiva, ha ayudado a crear la representación que se construye de un pasado muy inmediato y que empezó a incluir sus ingredientes de proyección hacia el futuro en el mismo momento en que se daban los acontecimientos, al ser conscientes de que, entre otras cosas, estaban construyendo un futuro que necesitaba la legitimidad que no podía proporcionar el franquismo tal y como lo habia hecho hasta entonces. Esta construcción académica y popular, social y política del proceso de transición tiene una importancia de primer orden porque constituye el proceso fundacional de nuestra realidad política, de las evidentes deficiencias de nuestra democracia, y del significado que damos a la sociedad en la que nos encontramos, a sus agentes políticos, a su sistema institucional, a sus relaciones sociales, como si tuvieran el carácter de un acuerdo, entusiasta y decidido, casi naturalmente salido de las entrañas de los españoles de buena fe que querían resolver el futuro del país atendiendo solamente a lo que no ha dejado de llamarse, en una

\footnotetext{
31 En este sentido, la distorsión alcanza su magnitud en los países que retoman estas reconstrucciones audiovisuales. Siguiendo esta línea se encuentran los documentales franceses Juan Carlos, naissance d'un roi, realizado por Jean-Pierre Garnier (1995), y Juan Carlos, l'enfance d'un chef (2008), dirigido por Daniel Leconte y Anne-Elisabeth Lozano. Representaciones que eliminan el recorrido del rey durante el franquismo y algunos de sus discursos anteriores por contradecir su recorrido democrático posterior.

${ }^{32}$ Evitaban presentar la causa misma por la que tuvo lugar el cambio sin cuestionar el proceso ni el modo, y lo hacían por el simple hecho del resultado al que se llegó.

${ }^{33}$ Véase A. Checa, Historia de la Comunicación: de la crónica a la disciplina científica, Netbiblo, La Coruña, 2008, pp. 41-43.
} 
clara exposición de la negativa a aceptar la esencia conflictiva de una sociedad, el bien común. Este proceso cultural creó un espacio de identidad, de comunidad de esfuerzo realizado por todos, en una fase cuyas dificultades parecían deberse a elementos sin responsabilidad política o social alguna, sino como tenaces accidentes geográficos o impredecibles cambios de temperatura que estaban más allá de la política, pero que solo se resolvían con la voluntad de quienes, en los puestos de responsabilidad, tenían los medios, para hacer frente a estas circunstancias» ${ }^{34}$.

Esta tesis doctoral parte desde una visión menos determinista de los acontecimientos y presta especial atención a las decisiones que fueron tomadas por sus protagonistas tanto individuales como colectivas. De este modo, apostamos por una perspectiva que trate de superar el sentido general del fenómeno televisivo para trascender sobre el estudio de un caso concreto. Hay que tener en cuenta que la televisión tiene la capacidad de crear y difundir su propia imagen e historia, hablar de sí misma, analizarse, autopublicitarse, representarse. Ejemplos de la construcción histórica del medio a través del propio medio, pueden encontrarse en televisión cada 28 de octubre (fecha que marca el inicio de las emisiones regulares en televisión: el 28 de octubre de 1956). El $25^{\circ}$ aniversario en 1981. El $30^{\mathrm{a}}$ aniversario en 1986, o el $55^{\circ}$ aniversario en 2011. En este último, desde el Ministerio de Educación, Cultura y Deporte, se realizaron distintos trabajos ${ }^{35}$, y se pusieron a disposición online distintos reportajes sobre la televisión realizados por y para el programa Informe Semanal (Historias de la tele, El mundo ante nuestros ojos, y La tele que nos cambió) $)^{36}$.

Para observar la construcción del debate televisivo en España y la formación de una cultura política durante la Transición en España, hemos querido mantener cierto equilibrio entre una perspectiva general de la televisión durante la Transición y un análisis más detallado del programa La clave. Partiendo de herramientas metodológicas de la historia cultural y la historia comparada, nuestro propósito es analizar dicho programa y contextualizar el proceso de transición en España. Son numerosos los estudios que han analizado la Transición ${ }^{37}$. Para tener

\footnotetext{
${ }^{34}$ F. Gallego, El mito de la transición. La crisis del franquismo y los orígenes de la democracia (1973-1977), Barcelona, Crítica, 2008, pp. 698-699.

${ }^{35} \mathrm{http}: / / \mathrm{tv} \_m a v . c n i c e . m e c . e s /$ siglo/50/ [consultado el 1/07/2015].

${ }^{36}$ Los documentales pueden encontrarse en la web de RTVE: http://www.rtve.es/rtve/20111028/anos-televisionespanola/471637.shtml [consultado el 15/12/2016].

${ }^{37}$ De manera cronológica, véase para el proceso de transición: J. M. Maravall, La política de la transición, Taurus, Madrid, 1982; J. F. Tezanos, R. Cotarelo y A. de Blas (eds.), La transición democrática española, Sistema, Madrid, 1989; R. Morodó, La transición política, Tecnos, Madrid, 1984; R. Cotarelo, Transición política y consolidación
} 
una visión de conjunto de la compleja realidad de la televisión, presentamos a continuación un apartado teórico que, a partir de los estudios e investigaciones que se han llevado a cabo, nos permita profundizar en las transferencias culturales televisivas que se producen en Europa. Nuestro propósito es contextualizar y analizar el programa La clave durante la Transición española, para posteriormente observar el debate político y cultural que fue llevado a cabo en televisión. Para esta aproximación abordaremos, en primer lugar, la televisión como servicio público, con el objetivo de observar las misiones fundacionales de la televisión y las transferencias culturales que se producen a través de ella.

En los siguientes apartados nos proponemos analizar la televisión con el objetivo de contextualizar La clave. Para abarcar con mayor amplitud el fenómeno televisivo hemos estructurado cinco grandes bloques. El primero de ellos, "La televisión: un objeto múltiple", está dedicado al problema que supone analizar el medio como sujeto de cambios sociales y culturales. A continuación, abordaremos la misión educativa del servicio público para contextualizar el tercer bloque: "La televisión en España (1956-1975)", con el que se pretende exponer los orígenes del medio televisivo en España. Los dos últimos bloques tendrán como objeto observar el surgimiento de La clave a partir del modelo fundacional, y evidenciar la crisis de dicho modelo a través del análisis del concepto de audiencia y el auge del entretenimiento. A partir de estos bloques queremos evidenciar la crisis que sufre el modelo fundacional en el proceso de transición en España, contexto en el que se desarrolla el programa La clave (19761985).

\subsection{La televisión: un objeto múltiple}

Las investigaciones sobre televisión se han desarrollado a partir de diferentes tradiciones, trayectorias y contextos, que han influido en las perspectivas empleadas. Autores como Michel Foucault (1975), Anthony Smith (1979), Umberto Eco (1995), Pierre Bourdieu (1996), o John B. Thompson (1998), han ayudado a observar y considerar la televisión -o el

\footnotetext{
democrática. España (1975-1986), CIS, Madrid, 1992; J. Tusell y A. Soto (Eds.), Historia de la transición $1975-$ 1978, Alianza, Madrid, 1996; J. Tusell, La transición española a la democracia, Historia 16, Madrid, 1997 ; J. M. Colomer, La transición a la democracia: el modelo español, Anagrama, Barcelona, 1998; A. Soto, La transición a la democracia. España. 1975-1982, Alianza, Madrid, 1998; C. Powell, España en democracia, 1975-2000. Las claves de la profunda transformación de España, Plaza \& Janés, Barcelona, 2001; J. Tusell, "Por una historia revisionista de la transición”, en Claves de Razón Práctica, nº 115, septiembre de 2001, pp. 11-21; F. Gallego, El mito de la Transición, op. cit.; y S. Baby, Le mythe de la transition pacifique. Violence et politique en Espagne (1975-1982), Casa de Velázquez, Madrid, 2012.
} 
fenómeno televisivo- desde diversos campos de estudio y desde múltiples facetas ${ }^{38}$. Se hace mención a estos autores, que no a todos, a la vez que es difícil resumir en un apartado las aportaciones realizadas por los mismos. Desde la historiología, semiología, historia económica, filosofía, historia política, social y cultural, se ha tratado de captar y definir un mismo objeto: la televisión ${ }^{39}$. En todos ellos se contemplan aspectos que de una u otra forma consideran la diversidad de interpretación para un objeto de estudio y un concepto que «ha ido variando a lo largo del tiempo» (Pérez Sanjuán 2008: 15).

Sin embargo, ¿cómo hacer frente a la multitud de significados? ¿Cómo entender la televisión sino es a través de su conjunto? Un análisis de los principales enfoques históricos y sociológicos sobre el fenómeno televisivo nos permite señalar algunos puntos esenciales. Adorno postuló el holismo como la mejor metodología ${ }^{40}$. Al igual que Juan Francisco Gutiérrez, argumentando que «la interdisciplinariedad aparece como la única vía de acometer una historia tan problemática como la de la televisión» (Gutiérrez 2003: 689) ${ }^{41}$. Al margen de las definiciones e incursiones llevadas a cabo en este campo por los autores previamente citados, no podemos obviar, si atendemos la historiografía, los estudios que definen y analizan la televisión como empresa, su programación, los actores sociales que la integran, la capacidad de crear realidades y representaciones nacionales, o su influencia y repercusión social ${ }^{42}$. Sin olvidar tampoco los estudios comparativos o de carácter transnacional que atienden

\footnotetext{
${ }^{38}$ M. Foucault, Surveiller et punir. Naissance de la prison, Gallimard, París, 1975. A. Smith (ed.), Television and political Life. Studies in six European countries, MacMillan, Londres, 1979. U. Eco, "Apocalyptic and Integrated Intellectuals: Mass communications and theories of mass culture", en Apocalypse Postponed, Flamingo, Londres, 1995, pp. 27-52. P. Bourdieu, Sur la télévision, suivi de l'Emprise du journalisme, Raisons d'agir, París, 1996. J. B. Thompson, Los medias y la modernidad. Una teoría de los medios de comunicación, Paidós, Barcelona, 1998, y M. Palacio, Historia de la televisión en España, Gedisa, Madrid, 2001.

${ }^{39}$ Véanse T. Bethencourt, ¿Qué es la televisión?, Ediciones Granada, Madrid, 1991, y B. Casey et al., Television Studies. The key concepts, Routledges, Nueva York, 2002.

${ }^{40}$ T. W. Adorno, "Prologue to Television", en Critical Models: Interventions and Catchwords, Columbia University Press, Nueva York, 1988, pp. 49-50. De la obra "Prolog zum Fernsehen" (1953), en Gesammelte Schriften, Suhrkamp Verlag, Frankfurt, 1977, pp. 507-517.

${ }^{41}$ Véase también J. M. Piemme, La televisión: un medio en cuestión, Fontanella, Barcelona, 1980.

${ }^{42}$ Véanse, J. Capin, L'effet télévision, Grasset, París, 1980. J. C. Grande, La influencia de la televisión, Editorial e Imprenta Universitaria, El Salvador, 1999. V. Fuenzalida, Televisión y cultura cotidiana: la influencia social de la TV percibida desde la cultura cotidiana de la audiencia, Corporación de Promoción Universitaria, Santiago de Chile, 1997. L. Vilches et. al., Televisión y cultura, una relación posible, Consejo Nacional de la Cultura y las Artes, Santiago de Chile, 2007, y M. McLuhan y Q. Fiore, El medio es el masaje: un inventario de efectos, Paidós, Barcelona, 1998.
} 
principalmente las transferencias culturales que se producen entre distintos países ${ }^{43}$, o la capacidad de la televisión en la construcción de consensos y la socialización de valores ${ }^{44}$.

En España, algunos problemas relacionados con la historiografía de la televisión han sido señalados por algunos autores como Juan Francisco Gutiérrez, quien incide en la falta de perspectiva histórica de las obras de los años sesenta, y en la politización y el control estatal del medio en los trabajos aparecidos durante la Transición ${ }^{45}$. No por ello, para precisar nuestro enfoque, sería necesario señalar las propuestas de algunos autores respecto al rol central que ocupó la televisión en la articulación del sistema político español. Como indican Juan Carlos Rueda Laffond y $\mathrm{M}^{\mathrm{a}}$ del Mar Chicharro, la televisión «ha testificado los acontecimientos, pero también ha transmitido evaluaciones, ha señalado los puntos de interés y los ha tematizado, ha direccionado el sentido de la opinión pública, e incluso ha ejercido las veces de actor político» (Laffond y Chicharro 2006: 14). Nuestro interés precisamente es situar La clave como actor político durante el proceso de transición en España. Sin duda, La clave fue un programa que presentó actores a la escena pública, señaló puntos de interés, y tematizó. Pero, si defendemos la idea que este programa ayudó a formar una cultura política a través de televisión durante este proceso, inmediatamente surgen innumerables dificultades. ¿Cómo analizar la cultura política de una sociedad a través de un programa de televisión?

Uno de los elementos de modernización y transformación social que alumbraron las sociedades del siglo XX fue, sin lugar a dudas, el desarrollo de los nuevos medios de comunicación como la radio, el cine y la televisión. En ellos intervinieron otros fenómenos como la industrialización, el desarrollo del capitalismo, el avance de la ciencia y sus aplicaciones técnicas, el surgimiento de la clase media y su acceso a niveles significativos de consumo, el urbanismo... Entre los rasgos más destacados de los nuevos medios de comunicación sobresale el concepto sociológico de masas, en referencia al enorme público al

\footnotetext{
${ }^{43}$ Véanse J. Bourdon, Du service public à la téléréalité. Une histoire culturelle des télévisions européennes, 1950 2010, op. cit. pp. 9-52. M. F. Lévy, M. N. Sicard, Les lucarnes de l'Europe : Télévisions, cultures, identités, 1945 2005, Publications de La Sorbonne, París, 2008.

${ }^{44}$ Cfr. J. C. Rueda Laffond y M. M. Chicharro, La televisión en España (1956-2006). Política, consumo y cultura televisiva, Fragua, Madrid, 2006, p. 17. Véase también la obra de M. Vázquez Montalbán, El libro gris de la Televisión Española, Ediciones 99, Madrid, 1973.

${ }^{45}$ J. F. Gutiérrez Lozano, "La audiencia de la televisión en España y su historia. Un acercamiento a la memoria de los primeros telespectadores", en A. Company, J. Pons y S. Serra (eds.), La comunicació audiovisual en la història. Aportacions de la comunicació a la comprensió i construcció de la història del segle XX, Universitat de les Illes Balears, Palma, 2003, pp. 685-686. Pere Ysàs señala con acierto que «parte de la historiografía española de la dictadura a la democracia, la mayoría de la producción periodística y memorialista, y las reconstrucciones dramatizadas que empiezan a proliferar en los medios audiovisuales han dirigido y dirigen el foco de atención hacia una parte, sin duda importante pero parcial» (Ysàs 2010: 32).
} 
que estos se dirigían. Respecto a la televisión, sus inicios se producen el 26 de enero de 1926, cuando el ingeniero y físico británico John Logie Baird, ideó un mecanismo capaz de transmitir a distancia sonido, voz y movimiento ${ }^{46}$. Sin embargo la televisión, al igual que ocurriese con la prensa o la radio, estuvo ligada desde sus inicios a la necesidad de capital y a los intereses políticos ${ }^{47}$. Concebida como un medio de masas capaz de transformar la sociedad, se convirtió en un instrumento integrador y en un recurso esencial que funcionó como una extensión institucional del poder ${ }^{48}$.

En este proceso de desarrollo del medio televisivo, uno de los primeros pasos se produjo en los años treinta con el nacimiento de las cadenas y los inicios de las primeras emisiones regulares. Surgen en esta época la NBC (National Broadcasting Company) en Estados Unidos, la BBC (British Broadcasting Corporation) en Gran Bretaña, la cadena estatal del III Reich en Alemania (inaugurada oficialmente con los Juegos Olímpicos de Berlín de 1936), o la francesa Paris Télévision, que funcionaba con carácter experimental ${ }^{49}$. En este sentido, la extensión y cobertura del territorio en un espacio definido convirtieron a la televisión en un medio técnicamente nacional ${ }^{50}$. Sin embargo, el incipiente desarrollo se ve frenado, incluso paralizado, por el estallido de la Segunda Guerra Mundial. La televisión, instrumento capaz de ofrecer información, también orientaba e influía a la opinión pública (la guerra como experimento propagandístico $)^{51}$, regulaba hábitos y modelos de comportamiento social ${ }^{52}$, creaba corrientes

\footnotetext{
${ }^{46}$ Véanse M. Hallett, John Logie Baird and Television, Priory Press, Hove, 1978, p. 19, y R. W. Burns, John Logie Baird: Television Pioneer, The Institution of Engineering and Technology, Londres, 2001, p. 103.

${ }^{47}$ Véase especialmente la obra de Jérôme Bourdon, Du service public à la téléréalité. Une histoire culturelle des télévisions européennes, 1950-2010, Institut National de l’Audiovisuel, Bry-sur-Marne, 2011.

${ }^{48} \mathrm{Si}$ la información es poder, este se concentra en sus inicios en los Estados y posteriormente en oligarquías que deciden no solo quien recibe la información, también quién es objeto de ella. Véase D. W. Hursh y E. Wayne Ross, Democratic Social Education: Social Studies for Social Change, Routledge, Nueva York, 2000, p. 116.

${ }^{49}$ Cfr. C. Kellison, D. Morrow y K. Morrow, Producing for TV and New Media. A Real-World Approach for Producer, Focal Press, Nueva York, 2013, pp. 25-26.

${ }^{50}$ Como argumenta Jérôme Bourdon, la televisión tiene la capacidad de "hacer nación", es decir, la voluntad de utilizar la televisión para construir, consolidar, forjar o reanimar una cultura nacional (Bourdon 2011: 28).

${ }^{51}$ Véanse principalmente E. Bordería, A. Laguna y F. A. Martínez, Historia de la Comunicación Social: Voces, Registros y Conciencias, Síntesis, Madrid, 1996; y B. Selznick, Global Television: Co-Producing Culture, Temple University Press, Philadelphia, 2008.

52 Véase T. Fernández García y A. García Rico (coord.), Medios de comunicación, sociedad y educación, Universidad de Castilla-La Mancha, Cuenca, 2001, p. 131.
} 
de opinión promocionando o eliminando ciertos temas ${ }^{53}$, y legitimaba mensajes y sistemas económicos y políticos ${ }^{54}$.

Tras la hecatombe a la que se había llegado con la Segunda Guerra Mundial surgió la idea de construir una Europa común. Para ello, eran necesarias iniciativas que acordasen un papel central a la educación -también en los medios de comunicación ${ }^{55}$ - y sentar las bases de una política cultural europea alrededor de tres grandes cuestiones: reconciliación, reconstrucción y educación (Lévy y Sicard 2008: 30). Tras la guerra, hubo un nuevo impulso y fue creciendo el número de aparatos receptores en los distintos países. Con la definición de las misiones fundacionales se dieron los primeros pasos en las televisiones europeas hacia el modelo fundacional de servicio público (más cultural, pedagógico y educativo) ${ }^{56}$. Este modelo de televisión, en síntesis, entró en crisis en España durante el proceso de transición al introducirse paulatinamente el modelo comercial (más centrado en el entretenimiento) ${ }^{57}$; y finalmente, con la entrada y reglamentación de las televisiones privadas en Europa (en el caso español efectiva en los años noventa), se puso fin al modelo fundacional.

Para finalizar el fenómeno televisivo será necesario definir qué aspectos observamos y cuáles ocultamos en este trabajo. Por lo tanto, para abordar la televisión durante el proceso de Transición en España, nos centramos, en primer lugar, en el significado histórico de la televisión como servicio público a través de las tres misiones sobre las que se asentó el medio en sus orígenes (informar, educar, y entretener) ${ }^{58}$. A partir de estas misiones abordaremos el surgimiento de La clave para, posteriormente, analizar la formación de una cultura política. No obstante, para hacer frente a la complejidad del medio televisivo, hemos optado por una

\footnotetext{
${ }^{53}$ Véase F. Jost, Introduction à l'analyse de la TV, Ellipses, 2007, París, p. 21. El autor incide en la idea que las cadenas de televisión, al igual que las instituciones, se destinan para actuar sobre el futuro.

${ }^{54}$ Véase R. Ahumada, El papel del Estado mexicano como emisor televisivo, Universidad Autónoma de México, México, p. 76.

${ }^{55}$ E. Messer Hunt, Social Education, Vol. 19, National Council for the Social Studies, 1955, p. 6.

${ }^{56}$ J. Bourdon, Du service public à la téléréalité. Une histoire culturelle des télévisions européennes, op. cit. p. 13. Véase también la obra de H. Isar, Le service public et la communication audiovisuelle, Economica, París, 1995.

57 Algunos autores han situado la crisis en los años ochenta. Véase por ejemplo, P. O. Costa, La crisis de la televisión pública, Paidós, Barcelona, 1986.

${ }^{58}$ De entrada habría que distinguir, de un lado, la misión educativa o formativa, y de otro, la televisión educativa o escolar. De la triple misión de informar, educar y entretener surge posteriormente la iniciativa de realizar una televisión educativa en las escuelas. Ésta queda fuera del campo de nuestra investigación, puesto que no influye ni determina el surgimiento o evolución de La clave, como sí lo hace en cambio la misión educativa de la televisión como servicio público. Una relación entre televisión y escuela puede verse en J. Merino, Televisión educativa en España: historia, metodología y planificación, Universidad Complutense, Madrid, 1983; J. M. Pérez Tornero, Televisión educativa, UNED, Madrid, 1993; y J. Ferrés, Televisión y educación, Paidós, Barcelona, 1994.
} 
metodología descriptiva que acentúe los procesos que llevaron a cabo las televisiones estatales europeas a autodefinirse como servicio público. Será necesario, por tanto, recurrir a sus propios fundamentos para entender cómo se definieron en sus orígenes las televisiones europeas de ámbito estatal. Sin embargo, como indica Jérôme Bourdon, aplicar en televisión la noción de "servicio público" es problemática. En parte, debido al contexto en el que surge y se consolida el medio (Bourdon 2011: 13).

\subsection{La televisión como servicio público: la misión educativa}

Para comprender la televisión y su mecánica es imprescindible observar las tres misiones fundacionales de las que se dotaron las televisiones europeas: informar, educar, y entretener. Una fórmula y definición- cuyo origen se encuentra en Sir John Reith, director general de la cadena británica BBC entre 1922 y 1938 (Bourdon 2011: 28). Esta fórmula, como ahora veremos, será copiada por otros países europeos. Sin embargo, cada nación tuvo que hacer frente no solo a unos patrones apegados a su tradición cultural, también al concepto de modernidad, a los intereses económicos, y a las nuevas formas de consumo, empleo libre y $\mathrm{ocio}^{59}$. El resultado fue la adaptación de la fórmula del modelo televisivo propuesto por la BBC (information, education, and entertainment), que siguieron algunas televisiones europeas como la francesa (informer, cultiver, distraire), o la española (informar, formar, entretener). Variaciones que si bien no escapan al propósito social dado de una televisión que debía satisfacer diversas necesidades (Bourdon 2001: 27), evidenciaba, en cambio, el problema que suponía conceptualizar una de sus misiones (educar, cultivar, formar) ${ }^{60}$. A través de las tres grandes misiones fundacionales, se inicia la primera fase en el modelo televisivo de servicio público de las televisiones europeas.

Si bien no podemos obviar el desarrollo de una potente industria del entretenimiento anterior y paralela a la televisión, es a partir de las misiones fundacionales que se clasifican los géneros y los formatos televisivos ${ }^{61}$. Los formatos establecían el campo en el que cumplir dichas funciones, y los programas se creaban con elementos que fortalecían las distintas esferas:

\footnotetext{
59 Véanse A. Mattelart y J. M. Piemme, La televisión alternativa, Anagrama, Barcelona, 1981. J. Becker, "El pensamiento posmoderno. Su comportamiento en la teoría de la información”, en Telos, n 38, 1994, pp. 17-38, y la obra de J. B. Thompson citada previamente, Los medias y la modernidad. Una teoría de los medios de comunicación, Paidós, Barcelona, 1998.

${ }^{60}$ En España surgen a mediados de los sesenta estudios de faceta sociológica que ahondaban en la capacidad educativa del medio. Véanse J. M. Baget, Televisión, un arte nuevo, Rialp, Madrid, 1965, у J. García Jiménez, Televisión, educación y desarrollo en una sociedad de masas, CSIC, Madrid, 1965.
}

${ }^{61}$ J. Bourdon, Du service public à la téle-réalité, op. cit. pp. 20-21. 
informativos, educativos o de entretenimiento ${ }^{62}$. Por tanto, se podía llegar a conocer cómo se construían y organizaban cada uno de los espacios televisivos y, más importante aún, los objetivos y la finalidad que tenían. Desde esta tendencia inicial de considerar la televisión como servicio público y la triple misión de informar, educar y entretener, surgirá en España La clave.

Es relevante reconstruir la historia de la televisión desde sus orígenes para una lectura adecuada de la televisión como servicio público porque fue, en este contexto, en el que la televisión se vincula al proceso educativo. Tal y como argumenta Bourdon, la misión primera de la televisión fue política y educativa (Bourdon 2011: 13). La televisión como servicio público ilustra el compromiso de cada nación de usar la televisión con fines pedagógicos y contribuir a mejorar los niveles educativos de su población. Pero, educar bajo qué política, qué sistema económico, qué cultura ${ }^{63}$.

En la década de los cincuenta y sesenta se cree firmemente en la televisión como servicio público y especialmente en su vertiente pedagógica (Lévy y Sicard 2008: 9). En 1956, la Organización de las Naciones Unidas para la Educación, la Ciencia y la Cultura (UNESCO) publicó una colección de estudios titulada: Prensa, cine y radio en el mundo de hoy, que tenía como objetivo fomentar el conocimiento del medio entre las distintas naciones ${ }^{64}$. La obra reflexionaba sobre el poder cultural de la televisión -las posibilidades culturales que tenían ciertas emisiones- y abogaba por utilizar la televisión como un instrumento para elevar el nivel educativo ${ }^{65}$. Desde esta premisa se fue definiendo el modelo de servicio público en su vocación de prolongar el sistema educativo y del que surgiría la idea de crear una televisión escolar. En 1965, Baget Herms, uno de los primeros historiadores sobre el medio en España, escribió sobre las posibilidades que ofrecía la televisión, que pronto podría incluso sustituir al maestro (Baget 1965: 73).

Es en este punto, momento en el que se asienta la noción de la televisión como servicio público, que vamos a tener presente las interrelaciones y transferencias que se producen entre algunos países de Europa, pues la televisión no actúa exclusivamente en el ámbito nacional. Es más, a través de la televisión se producen influencias culturales entre muchos países. Una

\footnotetext{
${ }^{62}$ A grandes rasgos, la misión informativa consiste en explicar la actualidad. La misión educativa se centra en la educación, aprendizaje, desarrollo de las personas, y en la transmisión de valores. Y el entretenimiento, está relacionado con la distracción, la diversión, el ocio y el espectáculo (Pérez 2004: 7).

${ }^{63}$ En el proceso de aprendizaje e interiorización de valores, símbolos y actitudes frente a la política, tal y como indica Jacqueline Peschard «un factor que ha probado ser un agente de socialización específicamente democrático ha sido la educación» (Peschard 2012: 44).

${ }^{64}$ Press, Film and Radio in the World Today, UNESCO, París, 1956.

${ }^{65}$ Es decir, utilizar la televisión como «auxiliar educativo» (Lévy y Sicard 2008: 41).
} 
circulación internacional que favorece a la homogeneidad de formatos en la parrilla televisiva y repercute, como argumentan algunos autores, en la identidad cultural (Moran 1998: 170). La televisión se va definiendo como un medio de comunicación de carácter nacional, que adapta formas de hacer y formatos extranjeros. En los años cincuenta y concretamente en los años sesenta (durante el periodo de expansión y consolidación del medio televisivo, siguiendo la periodización que propone Manuel Palacio), se observa con mucha atención lo que están realizando otras televisiones ${ }^{66}$.

Las corrientes europeas son determinantes al plantear un modelo televisivo como alternativa al modelo estadounidense, país en el que se estaba produciendo el desarrollo más rápido del nuevo medio. Como indica Jérôme Bourdon, se tuvo que esperar a 1964 para que Francia formulara oficialmente las misiones de la televisión, casi calcadas de la BBC (informar, educar, distraer), aunque diferentes en la práctica: informer, cultiver, distraire ${ }^{67}$. La versión francesa no situaba educación en segundo lugar, sino cultura, concepto más vago pero con connotaciones políticas más fuertes en Francia, país de la política cultural (Bourdon 2011: 33). Queremos subrayar este hecho, pues tres años más tarde se inició en Francia el programa Les Dossiers de l'écran, del que se inspirará José Luis Balbín. Este programa (modelo, formato y objetivo que debía cumplir) procede de la misión educativa y, cuando José Luis Balbín exporta el formato en España, lo hace también desde dicha misión del modelo fundacional de servicio público, pese a que el modelo ya ha entrado en crisis ${ }^{68}$. Por lo tanto, si pretendemos analizar las relaciones entre televisión y cultura política, debemos partir de las misiones fundacionales y observar cómo estas misiones se asientan en cada país atendiendo al contexto histórico en el que se desarrolla el nuevo medio.

\footnotetext{
${ }^{66}$ Manuel Palacio, siguiendo la periodización de John Ellis, ha establecido en España tres periodos para una historia de la televisión. El periodo de escasez (scarcity), que transcurre desde el inicio de las emisiones regulares en octubre de 1956, hasta mediados de los sesenta, cuando se inauguran las instalaciones en Prado del Rey (1964) y se inician las emisiones de la segunda cadena o UHF (1966). Una segunda etapa de disponibilidad (availyty), que correspondería a la edad de oro del servicio público en España y abarcaría hasta el inicio de las emisiones de titularidad privada (1990). Y una última etapa, periodo de abundancia (plenty), que llegaría hasta la actualidad con la TDT e Internet, en M. Palacio, "Cincuenta años de televisión en España", en Medios de comunicación Tendencias '06. Fundación Telefónica, Madrid, 2006, p. 315.

${ }^{67}$ La ley que creó en 1964 la ORTF (Office de Radiodiffusion-Télévision Française) que sustituía a la RTF (Radiodiffusion-Télévision Française), definió, por primera vez, el rol que debía ocupar la televisión: «satisfaire les besoins d'information, de culture, d'éducation et de distraction du public». [trad. Satisfacer las necesidades de información, cultura, educación y distracción del público]. Sobre la televisión francesa en esta época, véanse J. Bourdon, Histoire de la télévision sous de Gaulle, Anthropos/INA, París, 1990; A. Vassallo, La télévision sous de Gaulle : Le contrôle gouvernemental de l'information (1958/1969), De Boeck, París, 2005; M. F. Levy (dir.), La télévision dans la République. Les années 50, Editions Complexe, IHTP-CNRS, Bruselas, 1999; y J. P. Esquenazi, Télévision et démocratie. La politique à la télévision française, 1958-1990, PUF, París, 1999.

${ }^{68}$ Pese a la crisis del modelo fundacional, en la España de la Transición todavía se reivindican las misiones fundacionales y «los clásicos cometidos de informar, formar y entretener», RTVE, 1976, p. 100.
} 


\subsection{La televisión en España (1956-1975)}

En España, la televisión inició sus emisiones el 28 de octubre de 1956. Para comprender cómo y de qué manera se desarrollaron programas culturales y formativos durante la Transición española, resulta inevitable partir de los orígenes y entender su desarrollo en el marco de las profundas transformaciones que experimenta España en la década de los sesenta y setenta. Con el objetivo de contextualizar el complejo marco que supone la televisión en España pretendemos hacer un breve recorrido de la historia de la televisión ${ }^{69}$. Los orígenes de TVE es quizás uno de los aspectos más estudiados ${ }^{70}$. La mayor parte de los estudios toman como punto de partida el 28 de octubre de 1956 cuando, tras el discurso inaugural del ministro de Información y Turismo Gabriel Arias-Salgado, comienzan las emisiones regulares en Televisión Española.

El nacimiento de la televisión significó una nueva muestra del modernismo del se pretendía infundir a la sociedad española. En los primeros años de la televisión, la cobertura era limitada a Madrid. Apenas había seiscientos televisores en toda España y la programación diaria no superaba las tres horas (desde las 18:00 horas a las 21:00 horas) ${ }^{71}$. Si bien es cierto que las primeras pruebas en España son anteriores ${ }^{72}$, se observa en España un retraso en relación a otros países europeos ${ }^{73}$. Durante el franquismo la televisión nació como monopolio estatal al servicio

\footnotetext{
${ }^{69}$ Como enfoques históricos de conjunto sobre la televisión en España véanse M. Palacio, Una historia de la televisión en España. Arqueología y modernidad, Consorcio de Madrid Capital Europea de la Cultura, Madrid, 1992. J. M. Baget Herms, Historia de la televisión en España (1956-1975), Feed Back, Barcelona, 1993. E. Bustamante, Historia de la radio y la televisión en España. Una asignatura pendiente de la democracia, Gedisa, Barcelona, 2006, y M. Palacio, Historia de la televisión en España, Gedisa, Barcelona, 2001.

${ }^{70}$ Véanse F. J. Ruiz del Olmo, Orígenes de la televisión en España, Universidad de Málaga, 1997, y I. Rodríguez y J. Martínez, La Televisión: Historia y desarrollo. Los pioneros de la televisión, Mitre/RTVE, Barcelona, 1992.

${ }^{71}$ Fuente: "El ministro de Información inauguró oficialmente la televisión en Madrid", $A B C, 30 / 10 / 1956$, p. 41. Las emisiones se realizaban desde el Paseo de la Habana, $\mathrm{n}^{\circ}$ 77. La primera programación puede verse en V. M. Amela, Història cultural de l'audiovisual, UOC, Barcelona, 2008, pp. 158. Y una evolución de las parrillas de televisión, en J. M. Contreras y M. Palacio, La programación de televisión, Síntesis, Madrid, 2001.

${ }^{72}$ Sobre la prehistoria de televisión en España, Baget Herms toma como punto de partida las primeras pruebas realizadas por el ingeniero Vicente Guiñau (que acabó falleciendo en su taller a causa de una explosión) quien, en 1932, había instalado un aparato receptor en su casa, o la demostración de Joaquín Sánchez-Cordovés en 1934 en la sala Werner de Barcelona. Véanse 18 años de TVE, Diafora, Barcelona, 1975, pp. 49-50, e Historia de la televisión en España (1956-1975), Feed Back, Barcelona, 1993. Otro punto de partida fue la XVI Feria de Muestras de Barcelona en 1948. Véase L. Díaz, La televisión en España 1949-1995, Alianza, Madrid, 1995, y J. Barrosso y R. Rodríguez Tranche, "Historia de la televisión en España", en Archivos de la Filmoteca. Revista de estudios históricos sobre la imagen, $\mathrm{n}^{\circ}$ 23-24, Generalitat Valenciana, Valencia, junio-octubre de 1996.

${ }^{73}$ Basta una comparación con Francia para observar las diferentes temporalidades. Una década antes que en España, el 9 de marzo de 1945, comenzaron las emisiones regulares en Francia (Jost 2007: 8). Su primer telediario fue el 29 de junio de 1949, mientras que en España fue el 15 de septiembre de 1957 (Marín 2006: 40). También se observan diferencias respecto a la posesión de un receptor de televisión (fuertemente condicionada por la capacidad adquisitiva de cada país). En 1950 había en Francia 3.500 televisores aproximadamente, y un millón en 1958. Mientras que en España, se estiman unos 600 televisores en 1956 y 3.000 en 1958.
} 
de un régimen autoritario. Como indican varios autores, los informativos y espacios de opinión estaban politizados y manipulados acorde a la programación del Movimiento, y eran ocupados por un nutrido «grupo de intelectuales orgánicos al régimen, como Juan Beneyto, Valentín Gutiérrez, Adolfo Muñoz Alonso, Jesús Suevos, Victoriano Fernández Asís...» (Laffond y Chicharro 2006: 73). Una fuerte dependencia gubernamental que pronto se tradujo en una fuerte politización del medio mientras se extendía la cobertura a las principales ciudades ${ }^{74}$.

Este trabajo se centra desde el desarrollo de la triple misión de educar, informar y entretener hasta la formación de una televisión cultural. Sin embargo, teniendo en cuenta que en los años cincuenta tener un receptor de televisión era todavía un lujo inaccesible para muchas personas, ¿qué hacer en una época en la que la televisión no llegaba a todos los hogares? Para favorecer el progreso cultural y alcanzar a un mayor público surgieron los llamados teleclubs ${ }^{75}$. Una influencia que en España permitió en los años sesenta cierta política cultural en las zonas rurales. Aunque, a medida que fue creciendo el parqué de televisores, su actividad fue más irregular y limitada hasta prácticamente desaparecer a inicios de la Transición ${ }^{76}$. Siguiendo la tendencia de los teleclubs, comienzan a producirse en el medio televisivo influencias entre distintos países que logran introducir todo tipo de programas y formatos foráneos.

\subsubsection{Transferencias culturales en televisión: Les Dossiers de l'écran}

Al estudiar la cuestión social y cultural de la televisión, las nuevas corrientes historiográficas han enfatizado aspectos como las transferencias culturales entre diferentes países $^{77}$. Si partimos del principio que estas transferencias son exclusivamente fenómenos de

\footnotetext{
${ }^{74}$ Sobre la televisión durante el franquismo véanse M. Pérez Calderón, La televisión, Editora Nacional, Madrid, 1965. A. Arias, La televisión en España, Publicaciones españolas, Madrid, 1970; J. García Jiménez, Radiotelevisión y política cultural en el franquismo, CSIC, Madrid, 1980, y J. C. Rueda Laffond, "Franquismo banal: España como relato televisivo (1966-1975)", en F. Archilés e I. Saz (eds.), Naciones y Estado. La cuestión española, Publicacions de la Universitat de València, 2014.

${ }^{75}$ Los teleclubs surgieron en Francia en los años cincuenta en los pueblos del departamento del Aisne, en la región de Picardía, y nacieron con el objetivo de elevar la cultura de los campesinos en las zonas rurales (Pasztor 1956: 204-209). Una aproximación a la época en J. Dumazedier, "Television and Rural Adult Education. The Tele-clubs in France", en Press, Film and Radio in the World Today, UNESCO, París, 1956. En España, tal y como argumenta Giulia Quaggio «en una aldea de Zamora cercana a la frontera con Portugal se fundó el primer teleclub. Corría el año 1964» (Quaggio 2014: 71).

${ }^{76}$ Promovidos por Manuel Fraga, llegaron a existir entre 4.000 y 6.000 teleclubs por toda la geografía española. Véase C. Llorca, Los teleclubs en España, Publicaciones españolas, Madrid, 1971. En Francia se contabilizaron cerca de 350.000, en Gran Bretaña sobre los 5.000.000, y en Estados Unidos 32.000.000 (Pasztor 1956: 204-209).

77 Véanse principalmente, J. D. Straubhaar, World Television: From Global to Local, Sage, California, 2007 , y J. Bourdon, Du service public à la téléréalité. Une histoire culturelle des télévisions européennes, op. cit. 2011.
} 
naturaleza política, asumimos la fuerza de lo político frente a lo cultural. Esta investigación parte de lo cultural (un programa de televisión) con el propósito de analizar su incidencia política. Para entender los orígenes del programa La clave es preciso partir de la noción de servicio público e indagar en las influencias televisivas que se producen entre países extranjeros como Francia, Gran Bretaña o EE.UU. Países que además de unirles lazos históricos, sociales, culturales, políticos, literarios..., habían logrado una hegemonía cultural como consecuencia de una hegemonía política. Entre estas influencias, nos centramos principalmente en la introducción durante el franquismo de formatos y programas extranjeros así como formas de hacer y entender la televisión. Al adaptar un programa que había tenido éxito en otro país se conocía previamente el resultado (audiencia, valoración, reacción del público, rentabilidad económica). Sin embargo, teniendo en cuenta el carácter nacional y el férreo control de los medios de comunicación durante la dictadura ¿cómo logran introducirse estos programas?

Para ello, vamos a centrar nuestra mirada en la televisión francesa (pese a que las influencias no son exclusivamente francesas), y observar qué tipo de programas adapta Televisión Española. Uno de los primeros fue Cinq colonnes à la une (1959-1968), programa de reportajes de actualidad que adaptó Televisión Española a mediados de la década de los sesenta con el programa $A$ toda plana $^{78}$. Sin embargo, en Europa ya existía este tipo de emisiones: fue en Inglaterra cuando en 1953 surgió el programa original Panorama (del productor Paul Fox), y de ahí la adaptación en otros países: en Bélgica Neuf millions (1959), en Suiza Continents sans visa (1959), en Francia Cinq colonnes à la une (1959), en Alemania Panorama (1961), hasta llegar a España A toda Plana $(1965)^{79}$. Es llamativo, por una parte, que el programa español no se inspira del original sino del francés (A toda Plana reproduce Cinq colonnes à la une y no el inglés Panorama), y por otra, que pese a que cada país adaptaba el programa a sus propias tradiciones e intereses (contenido, día de emisión o duración del mismo), el formato se respetaba. En este caso el programa giraba en torno a grandes reportajes de actualidad de entre cinco y quince minutos a través del llamado periodismo de investigación, que se caracterizaba en la época por enviar reporteros al lugar de los hechos ${ }^{80}$. Otro de los

\footnotetext{
${ }^{78}$ Se emitía cada quince días a partir de las 22:00 horas. Fuente: $A B C, 29 / 01 / 1967$, p. 87.

${ }^{79}$ En 1965 surgió además Panorama: le magazine de l'actualité télévisée y, un año más tarde en España, Panorama de Actualidad, un programa de entrevistas y reportajes que incluía comentarios cinematográficos. Fuentes: $A B C$, 26/04/1966, p. 101, y Teleprograma, no 29, 24-30 de octubre de 1966.

${ }^{80}$ Una evolución del periodismo en España, en J. Timoteo Álvarez et. al., Historia de los medios de comunicación en España. Periodismo, imagen y publicidad (1900-1990), Ariel, Barcelona, 1989. Para el caso francés, J. N. Jeanneney y M. Sauvage, Télévision, nouvelle memoire. Les magazines de grand reportaje, Seuil, París, 1982.
} 
programas que adaptó TVE fue el programa Face à face $(1966)^{81}$. Tuvo su adaptación primero en el programa Cara a cara, presentado por el periodista Federico Ysart ${ }^{82}$, y posteriormente su influencia en Sin fronteras, dirigido por Joaquín Soler Serrano. En prensa se podía leer: «Será un «boom» tan grande como en la $O R T F$, y en toda Francia lo es Face à face, cuya repercusión -por personajes entrevistados y temas- rebasa fronteras» ${ }^{83}$. Un año más tarde, en 1967, surge el programa Les Dossiers de l'écran del que, como veremos a continuación, se inspira La clave.

Hay que tener en cuenta primero que en la década de los sesenta, mientras continúan las influencias entre distintos países ${ }^{84}$, se asiste en Europa a la implantación de las llamadas segundas cadenas de los entes públicos de televisión. Eran cadenas que tendían hacia una diversificación de los contenidos con un marcado componente cultural (cine, música, literatura, arte...). En Italia Secondo Programma (1961), en Alemania ZDF (1963), en Francia Deuxième chaîne de l'ORTF (1963), en Reino Unido BBC 2 (1964), y en España la UHF (1966). Con la llegada de la UHF en los años sesenta, la influencia francesa en España se incrementa ${ }^{85}$. Sin embargo, teniendo en cuenta que en televisión abundan las producciones "basadas en" (películas basadas en libros, en obras de teatro, series de televisión...), ¿cómo medir la influencia? ¿Dónde situar el límite en la adaptación de un formato de televisión que acaba transformándose en otro contexto?

De la televisión como servicio público y de la emisión educativa surgió en Francia el programa Les Dossiers de l'écran (1967-1991) del productor Armand Jammot (1922-1998) ${ }^{86}$. El programa inició sus emisiones el 6 de abril de 1967 en la segunda cadena de la ORTF y estuvo en antena, con algunos cambios en la programación, más de veinte años (desde 1967 a

\footnotetext{
${ }^{81}$ Programa que emitió la primera cadena de la $O R T F$ entre el 24 de febrero de 1966 y el 3 de octubre de 1966.

${ }^{82}$ En la primera emisión de Cara a cara, el 17 de noviembre de 1977, debatieron los dos líderes sindicales, Marcelino Camacho (Comisiones Obreras) y Nicolás Redondo (UGT), que luchaban por el voto en las primeras elecciones sindicales que tuvieron lugar en invierno de 1977 y primavera de 1978 (Palacio 2012: 243-244).

${ }^{83}$ Hoja del lunes, 28/01/1980, p. 39. Sin fronteras se inició el 23 de enero de 1980 con una entrevista a Henry Kissinger, transmitida en directo desde Washington, vía satélite.

${ }^{84}$ Uno de los programas que mejor podría explicar las relaciones e influencias que se producen en Europa es Journal de l'Europe (1963-1968); un programa organizado alrededor de temas estrictamente europeos destinados a un público trasnacional. Véase M. F. Lévy y M. N. Sicard, Les lucarnes de l'Europe : Télévisions, cultures, identités, 1945-2005, Publications de La Sorbonne, París, 2008, pp. 79-83.

${ }^{85}$ La influencia de la televisión francesa en España era tan visible que, como constata Josetxo Cerdán, una publicación tan importante como Cuadernos para el diálogo trató por primera vez el medio televisivo en 1966, y no lo hizo precisamente en referencia a TVE, sino a la televisión francesa (Cerdán 2002: 1).

${ }^{86}$ Armand Jammot había creado en 1965 el programa formativo y de entretenimiento Le mot le plus longue, que pasó a llamarse Des Chiffres et des Lettres a partir de 1972, de gran éxito internacional como constataron las múltiples adaptaciones, entre ellas, la británica Countdown (1982), o la española Cifras y letras (1991).
} 
$1991)^{87}$. Les Dossiers de l'écran era un programa de debates en directo tras la previa proyección de una película. Constaba de tres partes diferenciadas: introducción del programa; proyección de una película relacionada con el tema a tratar; y debate en directo con distintos invitados, generalmente seis. Formato que adaptó, con diferencias y matices, José Luis Balbín en La clave. Una comparación de ambos programas nos permite observar similitudes y diferencias televisivas.

Como argumenta Sébastien Rouquette, Les Dossiers de l'écran abordó gran cantidad de temas, muchos de carácter histórico (especialmente dedicados a la Segunda Guerra Mundial y al nazismo). Solo en su primer año, dos de cada tres debates trataron sobre un tema histórico (Rouquette 2002: 213) ${ }^{88}$. En La clave, como veremos más adelante, no fueron exclusivamente los temas históricos los que predominaron, también los políticos y sociales. Otra diferencia fue la importancia acordada a cada una de las partes: mientras que el primer paso en Les Dossiers de l'écran fue la elección del film, en La clave fue la temática del debate, a partir de la cual se elegían los invitados y la película. Por último, la ausencia en pantalla del propio creador del programa Armand Jammot, al que Jacques Chancel calificó de "hombre invisible" 89 . Fueron varios los presentadores en Les Dossiers de l'écran mientras que en La clave estaría dirigida y moderada en todas sus etapas televisivas por José Luis Balbín,

Es en la noción de una televisión como servicio público y en las influencias de la televisión francesa de los años setenta, que hay que buscar los orígenes de La clave. Lo que precisamente unía emisiones como Les Dossiers de l'écran, La clave, o Cifras y letras fue la idea del productor francés Armand Jammot de hacer una televisión de carácter formativo/educativo. En una entrevista el 29 de mayo de 1975 (una de sus pocas intervenciones públicas), Armand Jammot habló de la gran responsabilidad de aquellos que hacían posible la televisión. «Nosotros somos los maestros del siglo XXI, tenemos la misma responsabilidad que los maestros (...). Conocemos el famoso eslogan de la televisión: distraer, informar, cultivar

\footnotetext{
${ }^{87}$ Les Dossiers de l'écran tuvo una programación semanal hasta 1981, mensual entre 1982-1987, y bimensual entre 1987-1991. Fuente: INA. Véase también "El programa francés Les Dossiers de l'écran termina tras 25 años en antena”, El País, 6/08/1991, y “Obituary: Armand Jammot”, The Independent, 1/05/1998.

${ }^{88}$ La primera emisión de Les Dossiers de l'écran fue el 6 de abril de 1967, y estuvo dedicada al tema del nazismo, proyectándose la película Los malditos (Les maudits, René Clément, 1947). Se dedicaron temas a la guerra (La guerre clandestine, la guerre secrète, l'homme face à la guerre...), la mafia, la revolución rusa, la trata de negros y se abordaron figuras históricas como la de Adolf Hitler, Luis XIV, Napoleón, Rasputín o María-Antonieta...

${ }^{89}$ Entrevista a Armand Jammot, Radioscopie, 29 de mayo de 1975. Institut National de l'Audiovisuel (INA).
} 
(...). Nosotros estamos aquí para cultivar la gente, para ayudar a comprender mejor los problemas y a cultivarnos nosotros mismos al mismo tiempo» ${ }^{90}$.

Merece especial atención subrayar aquí una de las principales ideas de la televisión cultural que defendemos en esta tesis doctoral. El programa La clave y su formato (que procede de las influencias que se introdujeron en Televisión Española durante el franquismo) se desarrolla alrededor de la misión educativa-formativa del modelo de televisión como servicio público. Desde los inicios del programa, José Luis Balbín reconoce esta influencia: «El programa nació en Francia. El programa no es original, aunque yo he intentado que fuera parecido, aunque no igual» ${ }^{91}$. Y es precisamente durante la Transición española (momento de la crisis del modelo fundacional de la televisión como servicio público con el declive de la misión educativa) cuando La clave inicia sus emisiones.

Pero el entretenimiento era, desde los inicios de la televisión, una esfera que difícilmente se equilibraba con las otras dos: la informativa y la educativa. El dominio de los programas de entretenimiento (especialmente los deportes y concretamente el fútbol), se evidencia en la enorme expectación que generaban en los telespectadores. Un ejemplo del aplastante dominio del entretenimiento en la siguiente fotografía:

\section{Barcelona en 1959}

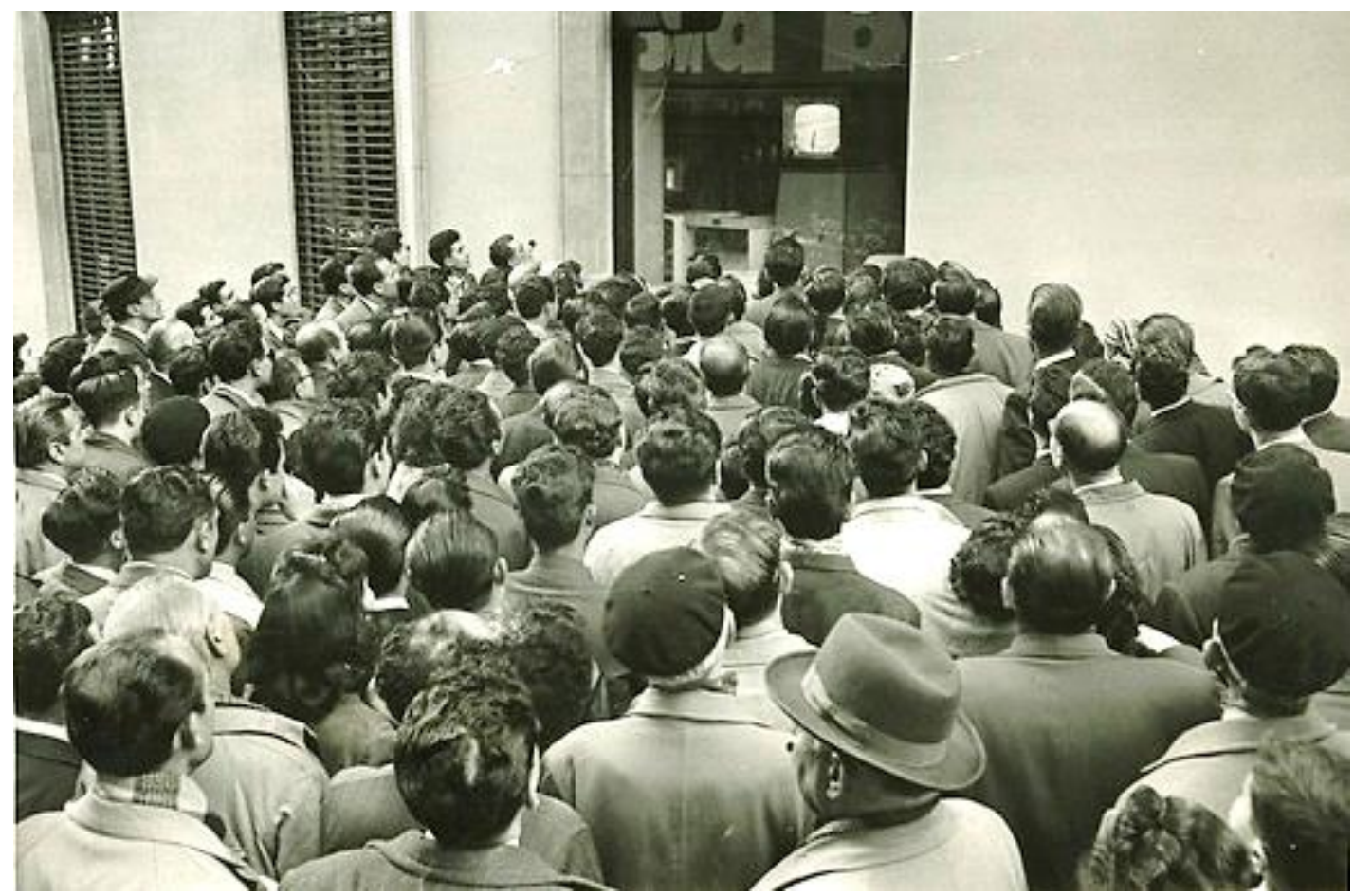

Fotografía n ${ }^{o}$ 1. Fuente: Carlos Pérez De Rozas. Archivo fotográfico El Mundo. Barcelona, 15/02/1959.

\footnotetext{
${ }^{90}$ Entrevista a Armand Jammot, Radioscopie, 29 de mayo de 1975. (INA). Traducción propia.

${ }^{91}$ Entrevista a José Luis Balbín, Mediterráneo, 14/03/1976, p. 10.
} 
En la fotografía observamos a numeroso público congregado en plena calle frente a una televisión instalada en un establecimiento siguiendo la retransmisión del partido de fútbol entre el Real Madrid y el F. C. Barcelona celebrado en 1959 en el estadio Santiago Bernabéu. Durante el franquismo se estimuló la diversificación del tratamiento comunicativo en torno a una serie de programas que dominaban la programación: magazines, musicales, deportes, concursos, toros... A nivel informativo, algunos documentales del NO-DO, fuertemente politizados, eran la única fuente de noticias que tenían muchos españoles ${ }^{92}$.

Esta tesis doctoral se centra principalmente en analizar el papel que ocupó el programa La clave durante la Transición, periodo que corresponde, siguiendo la periodización de Manuel Palacio, a la segunda etapa (availyty) ${ }^{93}$. Sin embargo, el criterio de la propia historia política facilita la interpretación al diferenciar etapas, como la televisión durante el franquismo o la televisión durante la Transición española. Respecto a la televisión durante el franquismo, creemos que ha sido importante realizar una breve contextualización desde los orígenes de la televisión para señalar algunos aspectos determinantes como fueron las trasferencias culturales en televisión. Durante la Transición española se va a continuar prestando atención a la televisión extranjera, especialmente a la francesa, como muestra la prensa a finales de 1975: «En la ORTF, programas como Face à face, Cinq colonnes à la une, o Les Dossiers de l'écran, abordan temas que preocupan y que influyen en la programación española» ${ }^{94}$. La clave, por tanto, ¿es una continuidad o una ruptura respecto al tratamiento de la imagen televisiva a inicios de la Transición?

\subsection{Televisión Española durante la Transición}

«... en estas horas históricas que ha vivido España en estos días, tienen aquí su punto final tras el enterramiento de Francisco Franco, que tuvo lugar, recordémoslo para la historia, a las 14 horas 11 minutos del domingo 23 de noviembre de $1975 »^{95}$.

\footnotetext{
${ }^{92}$ Véase T. Antona Jimeno, "El entretenimiento como pilar de la programación televisiva durante el periodo 195875”, en Communication \& Society, 30 (2), 2017, pp. 31-45.

${ }^{93}$ La edad de oro del servicio público en España, que Manuel Palacio define como etapa de disponibilidad (availyty), abarca cambios importantes. El 26 de marzo de 1964, Jesús Aparicio Bernal fue nombrado director general de RTVE, y el 18 de julio de 1964 se inauguraron oficialmente los estudios de RTVE en Prado del Rey, acabando con la precariedad técnica de los orígenes. En los años sesenta se asienta el monopolio televisivo en España, y su estrategia de favorecer el entretenimiento por delante de la información o la educación. Véase M. Palacio, "Cincuenta años de televisión en España", en Medios de comunicación, op. cit. p. 315.

${ }^{94}$ Hoja del lunes, 22/12/1975, p. 47.

${ }^{95}$ Retransmisión en directo del funeral de Francisco Franco. Centro de Documentación RTVE.
} 
Aunque el punto final de la Transición española ha sido discutido en muchas ocasiones, las opiniones parecen ser unánimes acerca del momento de inicio: la muerte de Francisco Franco Bahamonde el 20 de noviembre de $1975^{96}$. Con la muerte del dictador se inició en España un proceso de transición hacia la democracia marcado por profundos cambios políticos, sociales y culturales, y toda una serie de reformas y transformaciones de su sistema político. Una de las expresiones que más se ha utilizado en la Transición española ha sido la de «ruptura pactada», que viene a sintetizar, de manera general, que dicho proceso fue resultado de la cooperación entre las élites procedentes del régimen anterior y la oposición democrática ${ }^{97}$. Sin embargo, esta expresión tiende a olvidar uno de los rasgos principales de la Transición española: haber sido impulsada desde el régimen anterior ${ }^{98}$. El paso controlado de un sistema político a otro no es ajeno a los medios de comunicación social, y la televisión, se convierte en un medio que determina -y a la vez es determinado- por el proceso de democratización. Durante la Transición española la televisión contribuyó a dar visibilidad al proceso de construcción de un marco democrático con la preparación del referéndum de 1976, las elecciones generales de 1977, y la aprobación de la Constitución en 1978. De esta forma, detrás de procesos que parecieron exitosos en términos de construcción de hegemonía a corto plazo, es determinante observar la construcción que hace la propia televisión.

El 20 de noviembre de 1975, TVE realizó un gran «despliegue de medios: 500 trabajadores, nueve unidades móviles, 34 cámaras electrónicas -15 de ellas en color- y trece cámaras de cine para retransmitir los actos primero desde la capilla ardiente situada en el Palacio de El Pardo y luego la que pusieron en el Palacio de Oriente» ${ }^{99}$. El día del fallecimiento de Francisco Franco, la prensa no es ajena a lo que sucede en televisión y a la retransmisión que

\footnotetext{
${ }^{96}$ Véase J. Tusell y A. Soto, Historia de la transición 1975-1986, Alianza, Madrid, 1996. J. M. Colomer, La transición a la democracia: el modelo español, Anagrama, Barcelona, 1998. J. Aróstegui "La Transición política y la construcción de la democracia (1975-1996)", en J. Martínez (ed.), Historia de España. Siglo XX, 1939-1996, Cátedra, Madrid, 1999, y J. Tusell, La transición a la democracia. España, 1975-82, Espasa, Madrid, 2007.

${ }^{97}$ Algunas obras generales sobre la Transición española: R. Carr y J. P. Fusi, España de la dictadura a la democracia, Planeta, 1979. C. Molinero (Ed.), La Transición treinta años después. De la dictadura a la instauración de la democracia, Península, Barcelona, 2006. R. Quirosa-Cheyrouze (coord.), Historia de la Transición Española. Los inicios del proceso democratizador, Biblioteca Nueva, Madrid, 2007. J. Vidal-Beneyto, Memoria democrática, Foca Ediciones, Madrid, 2007, y M. Ortiz Heras (cood.), Los movimientos sociales en la crisis de la dictadura y la Transición, Almund, Ciudad Real, 2008.

${ }^{98}$ En este proceso, como argumentan algunos autores, se evitó poner «énfasis en los factores estructurales en la explicación del cambio político y, sobre todo, resaltó la importancia de las élites políticas en su dirección» (Morán 1995: 99). Para un análisis crítico del proceso de transición véase principalmente la obra de F. Gallego, El mito de la Transición. La crisis del franquismo y los orígenes de la democracia (1973-1977), Crítica, Barcelona, 2008.

${ }^{99}$ M. Palacio, "Francisco Franco y la Televisión”, Revista de Estudios históricos sobre la imagen, no 42-43, 2002, p. 95. En su obra posterior, amplía esta información y proporciona datos que ratifican la gran movilización de TVE (más de 500 trabajadores, 55 de ellos periodistas), véase La televisión durante la Transición, op. cit. pp. $75-85$.
} 
hace: «la televisión no ha vacilado en dedicar todo su noticiario del medio día a informar y comentar, con las imágenes de rigor, sobre la muerte de un hombre que le ha dado a España la paz, la independencia y el bienestar» ${ }^{100}$.

La crónica periodística continuaba anunciando la llegada de Valéry Giscard d'Estaing para el acto de coronación de Juan Carlos del 27 de noviembre, y describía el rol de TVE en esos momentos convulsos: «En la televisión, la fuerza de la imagen le ha dado una más cálida y vigorosa emoción al relato informativo. Nadie ha podido mantenerse indiferente, excepto los mal nacidos, que nunca faltan, ante un jefe del Gobierno, conmovido hasta las lágrimas, que le anuncia al país la muerte del hombre que forjó su destino». Así anunció -y respondió- $A B C$ a «los ecos en el exterior» procedentes desde París tras la noticia de la muerte del dictador ${ }^{101}$.

La Transición española se convirtió desde sus inicios (hecho que no pudo ocurrir con los inicios del franquismo) en un asunto seguido por diferentes cadenas internacionales como la alemana ZDF (Zweites Deutsches Fernsehen) o las francesas TF1 y Antenne 2. Es interesante observar el contraste entre Televisión Española y las televisiones internacionales. En diciembre, líderes de partidos ilegales como Felipe González (secretario general del PSOE), Joaquín RuizGiménez (Plataforma de Convergencia Democrática) o Xabier Arzalluz (líder nacionalista vasco) iniciaron una serie de declaraciones en la segunda cadena alemana $\mathrm{ZDF}^{102}$. También hicieron declaraciones a medios extranjeros Manuel Fraga (vicepresidente para Interior y Gobernación) y José María de Areilza (ministro de Asuntos Exteriores); el primero para vender el proyecto reformista, y el segundo, el proyecto de democracia.

En 1976, comenzó en Televisión Española la nueva programación con el incremento de emisiones en color ${ }^{103}$, que no para una segunda cadena cuya cobertura además no llegaba a todo el territorio nacional. En Madrid, el nuevo año comenzó con dos semanas de huelgas que

\footnotetext{
100 “Objetivo despliegue informativo”, $A B C, 21 / 11 / 1975$, p. 22. En la web p. 50.

101 “Objetivo despliegue informativo", $A B C, 21 / 11 / 1975$, p. 22. En cambio, L'Humanité, periódico fundado por Jean Jaurès que funcionaba como órgano central del Partido Comunista Francés fue algo más crítico: «Y como en otras ocasiones, el gran capital de España busca apoyos en el exterior. Es por ello que el pueblo de Francia observa con atención y vigila el comportamiento de Giscard. Ahora bien, el presidente de la República, quien guardó silencio cómplice de los últimos crímenes de Franco, ayer por la mañana rindió homenaje a los que "durante casi cuarenta años dominaron la historia” de España». [Traducción propia], en L'Humanité, 21/11/1975, n 9, 723.
}

${ }^{102}$ Declaraciones que no podían hacer en esos momentos en España. Sería interesante realizar un análisis de ellas, puesto que las declaraciones realizadas a medios extranjeros muestran temas más sensibles como sí hizo la segunda cadena de la televisión alemana con el tema del terrorismo realizando entrevistas a miembros de ETA, impensable en España. Jorge Marín llevó a cabo para la BBC una serie de entrevistas bajo el título "España en la encrucijada europea". Fuente: Destino, nº 1984, 9-15 de octubre de 1975.

${ }^{103}$ Durante 1975 «un total de 5.348 horas, 1.143 fueron en color, y en los primeros meses de 1976 el porcentaje ascendía un 41\%», Historia de TVE. Coleccionable, Diario Ya, 1986, p. 104. 
afectaron principalmente a Correos, Renfe, Telefónica, empresas del metal, y el metro ${ }^{104}$. El gobierno recurrió a la militarización para encargase de estos servicios. TVE no informó de las grandes huelgas ni de las manifestaciones que se estaban produciendo en Madrid, Cataluña y País Vasco ${ }^{105}$. El férreo control informativo en TVE hizo que no se informara ni se retransmitiera ninguna imagen. Las únicas imágenes que se disponen son domésticas o de cine militante. Similar tratamiento tendrán otros acontecimientos posteriores como los sucesos de Vitoria (en los que murieron cinco trabajadores) o los hechos de Montejurra (con dos carlistas muertos).

Presentaremos en mayor profundidad un análisis de la televisión durante la Transición en la segunda parte de esta tesis doctoral. Hemos considerado presentar exclusivamente algunas pinceladas a inicios de la Transición antes del surgimiento del programa el 18 de enero de 1976. Se observa la importancia que adquiere controlar el medio televisivo; un control, que siguió a inicios de la Transición. Durante este proceso, como indica Manuel Palacio, la televisión transmite el proceso siguiendo el modelo político de las élites procedentes del franquismo: «TVE estuvo siempre al servicio de los intereses de un poder político, inicialmente no democrático y luego emanado del resultado de las elecciones» (Palacio 2012: 10). Virginia Martín, por su parte, argumenta que la televisión «sirvió para hacer llegar a los españoles un plan muy concreto de democratización. Este proyecto, liderado por el Rey y dirigido por Suárez, hizo de la pequeña pantalla una de sus armas estratégicas fundamentales para socializar a los españoles en la cultura democrática y hacerles creer que el cambio, tal y como lo planteaban los dirigentes de la Transición, no solo era posible sino que además no existían alternativas que condujeran al país a la estabilidad democrática» (Martín 2013: 45). En este sentido, en los equilibrios de poder durante la Transición se considera necesario el control gubernamental de la televisión, convirtiéndose en trascendental incluso para la actividad parlamentaria ${ }^{106}$. A continuación pasamos a observar la dirección general de RTVE, que consideramos la variable principal en La clave.

\footnotetext{
${ }^{104}$ En estas huelgas hubo distintas reivindicaciones, entre ellas, mejorar las condiciones de trabajo, subida de salario, exigencia de libertades, legalización de partidos...

${ }^{105}$ No se informó pese a alcanzar casi el medio millón de manifestantes, convirtiéndose en el mayor movimiento huelguístico hasta esa fecha en España. La revista Triunfo publicó un editorial criticando la actuación del Gobierno y la represión ejercida. Triunfo, $\mathrm{n}^{\circ} 685,13 / 03 / 1976$.

${ }^{106}$ Véanse, R. Maxwell, The Spectacle of Democracy. Spanish Television, Nationalism and Political Transition, University of Minnesota Press, Minneapolis, 1995, y F. Huertas (coord.), Televisión y política, Editorial Complutense, Madrid, 1994, pp. 67-73.
} 


\subsubsection{Los directores generales de RTVE}

Durante el periodo que transcurre entre 1975 y 1985 pasaron ocho directores generales de RTVE, mismo número que durante el franquismo (de 1956 a 1975), que nos indica el grado inestabilidad que vivió la propia RTVE durante la Transición ${ }^{107}$. Como argumentan algunos autores «el cargo de director general de RTVE adquiere un sello tan intensamente político que quema rápidamente a sus responsables para finalmente ser cesados, al menos como detonante, por alguna emisión incontrolada o por un simple cambio de fuerzas internas del partido gobernante» (Bustamante 2006: 61) ${ }^{108}$. El cargo de director general de RTVE era nombrado por el ministro de Información y Turismo, y necesariamente atendía a unas consignas gubernamentales.

El Ministerio de Información y Turismo se creó en 1951 y dejó de existir durante la Transición, diluyéndose entre el Ministerio de Cultura ${ }^{109}$. Nuestra investigación no se centra en los distintos ministros de Información y Turismo ${ }^{110}$. La elección de no atender dicho Ministerio y los distintos cargos que se suceden en él, no radica precisamente en su importancia. Al contrario, como argumenta Manuel Palacio, el Ministerio de Información y Turismo se encargaba, «a grandes rasgos, de gestionar la información que se daba a los españoles en los medios de comunicación, responsable de todos los procesos de autorización y censura de películas, canciones, libros... y era la voz con la que las decisiones del gobierno se comunicaban a los españoles» (Palacio 2012: 17). Sin embargo, tras realizar una exploración retrospectiva sobre las biografías de los ministros, en relación a La clave, su estudio no determina, al menos directamente, la evolución política del programa. Sobre el papel solo había dos figuras que podían determinar el devenir del programa: el director general de RTVE y el propio José Luis Balbín. Aunque como veremos, finalmente fueron algunas más.

\footnotetext{
${ }^{107}$ Durante el franquismo pasaron por la dirección de RTVE, el falangista Jesús Suevos (1956-1957), el abogado y político José María Revuelta Prieto (1957-1962), el militar Roque Pro Alonso (1962-1964), el abogado y político Jesús Aparicio Bernal (1964-1969), el vicesecretario general del Movimiento y futuro presidente del Gobierno, Adolfo Suárez (1969-1973), el abogado Rafael Orbe Cano (1973-74), y los políticos Juan José Rosón (1974), y Jesús Sancho Rof (1974-1975). Todos procedían de Falange y/o el SEU (Sindicato Español Universitario).

${ }^{108}$ Cfr. V. Martín, Televisión Española y la Transición democrática, op. cit. p. 46.

${ }^{109}$ Durante el franquismo, el primer titular del Ministerio de Información y Turismo fue Gabriel Arias-Salgado (1951-1962). Le siguieron Manuel Fraga Iribarne (1962-1969), el católico Alfredo Sánchez Bella (1969-1973), Fernando de Liñán y Zofio (1973-1974), Pío Cabanillas (1974), y León Herrera Esteban (1974-1975). Ya con los gobiernos de la Monarquía, los titulares del Ministerio hasta su disolución fueron Adolfo Martín-Gamero (19751976) y Andrés Reguera Guajardo (1976-1977).

${ }^{110}$ Un organigrama de dicho ministerio en los años 1975 y 1978, en G. Quaggio, La cultura en Transición. Reconciliación y política cultural en España, 1976-1986, Alianza, Madrid, 2014, pp. 103-104.
} 
A partir del cargo de director general de RTVE (con sus continuidades y rupturas), hemos estructurado las distintas etapas por las que transcurre La clave en TVE. Ante esta variable, presentamos un análisis posopográfico (tratamiento cualitativo de biografías) con el objetivo de trazar y comprender la trayectoria de un determinado grupo social. Los ocho directores generales de RTVE en los que centramos nuestro estudio son: Jesús Sancho Rof (1974-75), último director durante el franquismo y quien aprueba el programa, Gabriel Peña Aranda (1975-76), primer director general de la Transición y con quien se produce la primera emisión y prohibición; Rafael Ansón (1976-77); Fernando Arias-Salgado (1977-1981); Fernando Castedo Álvarez (1981); Carlos Robles Piquer (1981-82), Eugenio Nasarre Goicochea (1982), y José María Calviño (1982-1986), quien suspende definitivamente el programa en 1985.

Hay que tener en cuenta que dejar el cargo de director general de RTVE no significaba el ostracismo absoluto, como constatarían las posteriores trayectorias de todos ellos ${ }^{111}$. En octubre de 1975 (mes en el que se aprueba La clave), el director general de RTVE Jesús Sancho Rof -nombrado el 22 de noviembre de 1974- concede una entrevista en la que se le pregunta si Televisión Española es un organismo azul. «La verdad es que no sé por qué viene la pregunta (...) Televisión Española es una televisión normal. Mi antecesor, Juan Rosón, también era azul según su planteamiento porque fue secretario del SEU; o Adolfo Suárez, que estuvo en Secretaria General; o Aparicio Bernal, que fue jefe nacional del SEU. ¿Qué sentido tiene ser azul? Si lo dice usted por la idea de servicio, pues sí, azul. La gente que hoy está en Televisión Española es la gente que estaba. Apurando, salvo el director de Televisión y el director general, el resto son las mismas personas de antes» ${ }^{112}$. Y así era, pese a signos de cierta apertura, Televisión Española continuaba siendo un medio político que necesitaba ser controlado por personas que siguiesen las directrices gubernamentales.

En la segunda parte de esta tesis doctoral, siguiendo la estructura del programa, tendremos en cuenta la determinante figura que representa el director general de RTVE para la televisión y para el propio programa. Por La clave pasaron como invitados un importante número de directores generales de RTVE como el falangista Jesús Suevos (El Valle de los caídos), y toda una serie de directores generales del periodo que analizamos: Jesús Sancho Rof

\footnotetext{
${ }^{111}$ Un ejemplo, Jesús Sancho Rof, último director general del franquismo. A su salida, fue nombrado director general de Política Interior y número dos de Rodolfo Martín Villa. En 1979, con Adolfo Suárez, fue nombrado ministro de Obras Públicas y Urbanismo, y con Leopoldo Calvo Sotelo, ministro de Trabajo Sanidad y Turismo. Ya en 1989 sería fue miembro del Consejo de Administración de RTVE a proposición del Partido Popular.

112 Blanco y Negro, 4/10/1975, p. 7.
} 
(Epidemias), Rafael Ansón (Líderes de opinión), Fernando Arias-Salgado (Las 400 claves), Eugenio Nasarre Goicoechea (Los dineros de la Iglesia), Fernando Castedo (La difícil convivencia) y José María Calviño (Pluralismo informativo). Los únicos directores que no asistieron fueron Gabriel Peña Aranda y Carlos Robles Piquer. Por lo tanto, entender de qué manera los directores generales de RTVE han ido aplicando las directrices televisivas gubernamentales, además de abrir nuevas perspectivas de estudio sobre la materia, favorece la comprensión de la televisión en España.

\subsection{Del telespectador como público a la dictadura de la audiencia}

«Quince millones de personas están viendo en estos momentos la televisión en España. Ningún espectáculo, ningún fenómeno público, convoca a tanta gente en el mismo periodo de tiempo. Es la televisión».

Primera página. Especial Televisión, hoy (12/02/1980)

El desarrollo, extensión y cobertura nacional de la televisión fueron en España fenómenos tardíos con respecto a otros países europeos. No así los análisis cuantitativos en la investigación de la audiencia, que ya venían utilizándose en la radio y fueron aplicados en televisión a medida que se popularizaba el medio. Las investigaciones empíricas funcionalistas americanas (así como la creación de áreas de investigación para medir y cuantificar la audiencia) se fueron extendiendo a otros países ${ }^{113}$. En España, en los años sesenta, a medida que se incrementó la cobertura y el parqué de televisores, comenzaron las primeras investigaciones para cuantificar la audiencia con el propósito de conocer al público que se dirigía $^{114}$. Surgen así las primeras investigaciones a través de cuestionarios del Estudio General de Medios (EGM) ${ }^{115}$. En 1968 se creó en España una unidad para observar el tiempo que la población española pasaba delante del televisor, que pasó a llamarse a partir de 1972 Gabinete

\footnotetext{
113 Véanse D. Morley, Televisión, audiencias y estudios culturales, Amorrortu, Buenos Aires, 1996; C. Méadel, Quantifiquer le public. Histoire des mesures d'audience de la radio et de la télévision, Economica, Col. «Médias et Publicités», París, 2010; y A. Huertas, La audiencia investigada, Gedisa, Barcelona, 2002.

${ }^{114}$ Sobre la evolución del concepto de audiencia y su investigación, véanse J. F. Gutiérrez Lozano, "La audiencia de la televisión en España y su historia. Un acercamiento a la memoria de los primeros telespectadores", en A. Company, J. Pons y S. Serra (eds.), La comunicació audiovisual en la història. op.cit., pp. 683-703. J. Callejo, Investigar las audiencias. Un análisis cuantitativo, Paidós, Barcelona, 2001. Del mismo autor, "Un análisis de la audiencia y su investigación con técnicas cualitativas”, en J. Benavides (ed.), El debate de la Comunicación, Fundación General de la UCM, Madrid, 1998, pp. 501-516.

${ }^{115}$ Durante el franquismo no hay estudios de audiencia para emisiones concretas, aunque sí encuestas del Instituto de Opinión Pública y algunos datos procedentes del Estudio General de Medios. Véase La audiencia de la Televisión en España, Ministerio de Información y Turismo, Madrid, 1969. Para el periodo de Transición véase, R. López Pintor, La opinión pública española: del franquismo a la democracia, CIS, Madrid, 1982.
} 
de Investigación de Audiencias de RTVE ${ }^{116}$. Su propósito era conocer el impacto de los medios de comunicación y su influencia en el cambio de actitudes y opiniones del telespectador ${ }^{117}$.

RTVE fijó la audiencia de 1976 en 15.428 .871 telespectadores ${ }^{118}$. Pero antes, habría que precisar la metodología empleada para dichos estudios. Para cuantificar la audiencia se utilizó el sistema de medición conocido como recuerdo de la víspera. Un método de cuestionable fiabilidad ya trataba de medir, a través de encuestas, el recuerdo de lo que los telespectadores habían visto el día anterior ${ }^{119}$. Como bien indica Manuel Palacio, «El sistema de estudios de audiencia que se hacía en aquel tiempo difiere mucho del actual, pero según aquellas metodologías de estimación de audiencia, casi diecisiete millones y medio de espectadores mayores de quince años sintonizan diariamente las dos cadenas de Televisión Española» (Palacio 2012: 10).

En octubre de 1977 apareció el primer número de la revista Mensaje y medios (en sustitución de Cuadernos de Documentación) ${ }^{120}$. En la obra aparecía un apartado titulado “Audiencia de RTVE y empleo del tiempo de la población española”, estudio que fue llevado a cabo en los meses de noviembre y diciembre de 1976. Con el método "recuerdo de la víspera", se realizó una encuesta a individuos mayores de quince años que residían en núcleos de población de más de 50 familias $^{121}$. Los resultados de audiencia de 1976 fueron los siguientes: el 93\% de los españoles mayores de 15 años veían alguna vez la televisión, lo que suponía un total de 20.498.357 telespectadores, y una audiencia diaria de 15.428.871 telespectadores. Los viernes, sábados y domingos eran los días de mayor audiencia, y el horario de máxima audiencia (que no prime time, término que se utilizará posteriormente) se producía entre las 22 y 23 horas.

\footnotetext{
${ }^{116}$ Mensaje y medios, $\mathrm{n}^{\mathrm{o}}$ 9, Instituto Oficial de Radiodifusión y televisión, diciembre de 1981, p. 28.

117 Como defiende el sociólogo Manuel Castells, los medios de comunicación de masas son decisivos en la formación de la opinión pública que acaba condicionando la decisión política, de ahí la importancia de su análisis y conocimiento. Véase "Comunicación, poder y contrapoder en la sociedad red (I). Los medios y la política", en Telos: Cuadernos de comunicación e innovación, $\mathrm{n}^{\mathrm{o}}$ 74, 2008, pp. 13-24.

${ }^{118}$ RTVE, 1976, p. 155.

119 Técnica que recogía información a partir de una serie de entrevistas telefónicas a un núcleo definido a partir de una muestra nacional aleatoria, y en la que los encuestados recordaban qué habían visto el día antes, RTVE, 1976, p. 154.

${ }^{120}$ Editada por el Instituto Oficial de Radiodifusión y Televisión, la revista estaba dirigida a «los profesionales de la comunicación, a los que trabajan en los medios de comunicación de masas: radio, televisión, prensa, publicidad, relaciones públicas, investigación social y cine», Rafael Ansón, Mensaje y medios, $\mathrm{n}^{\circ}$ 1, Instituto Oficial de Radiodifusión y Televisión, Madrid, octubre de 1977, p. 5.

121 «La encuesta se realizó, personalmente, en el domicilio del consultado. El universo de la investigación está constituido por individuos de quince y más años, residentes en hogares de núcleos de población de 50 o más familias, de la Península e Islas Baleares. Este universo supone un total de 20.505.224 individuos. El estudio viene integrado por siete submuestras diarias de 2.415 entrevistas», en Mensaje y medios, $\mathrm{n}^{\circ}$ 1, op. cit. p. 92.
} 
El informe añadía entre otros datos que «la proporción de mujeres y de amas de casa ante el televisor es superior a la de hombres, excepto para el periodo de los domingos entre 20 y 22 horas, coincidente con la transmisión del partido de fútbol» ${ }^{122}$. Este anuario que Rafael Ansón había encargado con la intención de «abrir nuestra casa, para que los españoles entren y la vean» ${ }^{123}$, concedió gran importancia a la investigación de la audiencia y sus procedimientos ${ }^{124}$. Para 1977 iban a realizarse 67.536 entrevistas con información recogida para cada estación del año ${ }^{125}$.

Otra herramienta de análisis de los programas de televisión fue el Panel de aceptación, que tenía el propósito de medir el contenido. Este panel se utilizó para elaborar un índice de interés y un índice de aceptación (que servía, por tanto, para juzgar el grado y los gustos televisivos). La metodología empleada consistía en emitir una valoración sobre aquellos programas que se habían visto en una escala numérica del 0 al 10, y se realizaba del mismo modo que el análisis de audiencia: a través de una muestra aleatoria ${ }^{126}$. Pero no se medían todos los programas «dada la idiosincrasia de los programas religiosos e informativos (...). La razón es obvia. En un programa religioso concurren circunstancias tales que preguntar si ha gustado o no ha gustado no parece pertinente» ${ }^{127}$.

En 1979, José Ramón Pérez Ornia publicó un artículo en El País sobre la audiencia de 1978 bajo el título "La audiencia del UHF", con datos del Estudio General de Medios. La primera cadena tenía una audiencia máxima de 14.283.000 telespectadores los sábados, entre las 22:30 horas y las 23:00 horas (horario que corresponde a la emisión de Sábado cine). Para la segunda cadena, «con una cobertura que apenas llega al 50\% de la población», la máxima audiencia se producía con la emisión de La clave, con un tope máximo de audiencia de 2.181.000 telespectadores ${ }^{128}$. Y con datos de la Agencia Efe se informaba que, entre enero y junio de 1979 «la media de individuos adultos mayores de quince años que ven diariamente la televisión supera los diecisiete millones» ${ }^{129}$.

\footnotetext{
${ }^{122}$ Mensaje y Medios, 1977, op. cit. p. 92.

${ }^{123}$ Rafael Ansón, RTVE, 1976, p. 7.

${ }^{124}$ RTVE, 1976, pp. 154-159.

${ }^{125}$ Ibídem, p. 155.

${ }^{126}$ Un panel que «otorgaba sistemáticamente cada semana a La clave los mayores índices de valoración», en http://tv_mav.cnice.mec.es/siglo/50/index.swf [consultado 12/12/2016].

${ }^{127}$ RTVE, 1976, p. 156.

128 J. R. Pérez Ornia “La audiencia del UHF”, El País 20/04/ 1979.

129 “Contradicciones sobre la audiencia de TVE”, El País, 17/08/1979.
} 
Los estudios y análisis a través de distintas investigaciones se hacen evidentes en España durante todo el periodo, cuyos datos y resultados se publicaron regularmente en prensa. Sin embargo, un análisis más profundo sobre las audiencias de este periodo, nos permite observar no solo el incremento cuantitativo de estudios de análisis, sus peculiaridades, campos de actuación, y limitaciones. También la importancia adquirida por conocer quién se encontraba detrás del medio televisivo. Es decir, la televisión se convertía en un instrumento con el que poder recopilar datos y ofrecer estadísticas a nivel estatal. De esta forma, las encuestas, estudios y paneles se convirtieron desde el primer momento en un instrumento con el que medir la audiencia, su comportamiento, y grados de satisfacción o frustración ante los programas emitidos. Y con el pretexto de conocer exactamente el número de telespectadores, se analizaban las condiciones sociales, culturales y políticas en las cuales se desenvolvían los sujetos ${ }^{130}$.

\subsubsection{La UHF. Cobertura y audiencia de La clave}

En relación a la segunda cadena, las audiencias eran cuantitativamente menores debido a la deficiente cobertura que no llegaba a todo el territorio nacional. Estas diferencias de audiencia entre las dos cadenas, ayudaron a definir el carácter minoritario de la UHF. Sin embargo, La clave fue una excepción. Pese a que en su primera etapa «La clave era un programa muy minoritario que acogía a menos de 100.000 espectadores» (Palacio 2012: 259), su audiencia fue incrementándose a lo largo de todo el proceso de transición situándolo como el programa de mayor audiencia en la segunda cadena. Como indica Manuel Palacio, «en los tiempos de la etapa 1977-1980 se produjo un salto cualitativo y cada programa alcanzaba una audiencia acumulada cercana a los dos millones de espectadores, que puede considerarse como un gran éxito para la segunda cadena de TVE» ${ }^{131}$. Efectivamente, pasar de 100.000 espectadores en 1976, a dos millones de espectadores en 1977 fue sorprendente para una segunda cadena calificada de minoritaria. No se puede considerar La clave de programa minoritario (por el número de telespectadores) pero sí se puede observar un tipo de público diverso más interesado en la cultura que en el entretenimiento. El carácter de monopolio estatal del medio y el aumento progresivo del parqué de televisores a lo largo de la Transición, convirtieron a la televisión en un instrumento capaz de llegar a muchos hogares españoles y a públicos muy diversos. Es

\footnotetext{
${ }^{130}$ Véanse N. Mamere, La dictature de l'Audimat. Voyage à l'intérieur du paysage audiovisuel français, La Découverte, París, 1988, y A. Grimson y M. Valera, Audiencias, cultura y poder. Estudios sobre la televisión, Eudeba, Buenos Aires, 1999.
}

${ }^{131}$ M. Palacio, La televisión durante la Transición española, op. cit. p. 259. 
llamativo que pese a emitirse en segunda cadena, muchas de sus emisiones superaron en audiencia al programa de la primera cadena, de mayor cobertura. Siguiendo esta tendencia favorable, el programa incrementa y diversifica su público. En 1980, El País hizo público un informe de Tele-Radio que cifraba una audiencia media del segundo canal en 485.000 espectadores (para un 69\% de la población que recibía cobertura), mientras que en el momento que se emitía La clave su audiencia media era de 2.620 .000 espectadores ${ }^{132}$. El aumento de la cobertura de la segunda cadena y los cambios producidos en una televisión que se va reestructurando constantemente beneficiaron, a priori, al programa, que en estos diez años conservaría el horario de mayor audiencia.

En relación a la cobertura (es decir, la extensión de la red) observamos distintos resultados entre publicaciones oficiales y la prensa, llegando a contradecirse en muchas ocasiones (también entre las publicaciones oficiales). En 1977 la revista Mensaje y medios publicó que «la cobertura de la primera cadena de TVE está alcanzando ya cerca del $90 \%$ de la población española, y la cobertura de la segunda cadena, con los planes en curso llegará pronto al 70\% de dicha población» ${ }^{133}$. Tres años más tarde, en 1980, un informe de Tele-Radio todavía cifraba en un $69 \%$ la población total española que recibía el segundo canal ${ }^{134}$. Pese a la cobertura, La clave logró atraer a un porcentaje considerable de telespectadores lo que llevó a un aumento progresivo de publicidad. Pero ésta no dependía del programa sino de la propia RTVE, por lo que no afectaba profesionalmente a la independencia del equipo. Durante el debate se evitaba hacer publicidad, permitiendo únicamente nombrar la obra de algún invitado. No por ello hubo telespectadores descontentos de ver cómo se interrumpía el programa en dos ocasiones para insertar publicidad, a diferencia de las televisiones estatales de otros países ${ }^{135}$. En la primera etapa (1976) no hubo publicidad. A partir de la segunda etapa del programa (1977) se insertó en dos bloques, y hacia el final del programa, se incrementó en cuatro bloques, que ilustra de manera significativa la dependencia publicitaria de TVE y el camino que seguía su modelo de televisión como servicio público ${ }^{136}$.

\footnotetext{
${ }^{132}$ El País, 24/04/1980.

133 J. A. Alberich, "Cobertura TV por satélite convencional”, en Mensaje y medios, $\mathrm{n}^{\circ}$ 1, Instituto Oficial de Radiodifusión y Televisión, octubre de 1977, p. 36

${ }^{134}$ El País, 24/04/1980.

${ }^{135}$ Cartas de los lectores enviadas y publicadas en El País, 31/03/1979.

${ }^{136}$ La estructura financiera de TVE, a diferencia de otros países europeos (que basaban su modelo en el pago de un canon por tenencia de aparatos), se basó en los ingresos publicitarios «un recurso atípico en el marco de un servicio público en régimen de monopolio como el que disfrutaba TVE» (Tijeras 2012: 6). Lo que provocó una
} 


\subsubsection{La crisis del modelo fundacional: el triunfo del entretenimiento}

En televisión, tal como argumenta François Jost, elegir los contenidos y ubicarlos en un horario determinado, al que llama «el arte de programar», no es un acto neutro (Jost 2013: 32). La trasformación del telespectador en audiencia se produce con la crisis del modelo fundacional de la televisión como servicio público y hace referencia a la crisis de un sistema que ve cómo declina la misión educativa e informativa ante la enorme supremacía del entretenimiento. Los estudios de audiencia determinaron los intereses de los telespectadores favoreciendo una mayor oferta por el entretenimiento, en perjuicio de los programas culturales ${ }^{137}$. El mismo concepto de prime time (horario de máxima audiencia) ${ }^{138}$, es un término que podría explicar el giro comercial al que se dirigió tanto la televisión pública como las primeras televisiones privadas. En España, al igual que en Europa, se introduce paulatinamente un modelo comercial de la televisión a medida que se legitiman los intereses económicos y la rentabilidad que se obtiene por la audiencia ${ }^{139}$.

Algunos autores han hecho referencia a la crisis del modelo fundacional de las televisiones europeas ${ }^{140}$. Al igual que propone Bourdon, creemos que explicar la historia de las televisiones europeas fundamentándose en el servicio público es contar la historia de una crisis (Bourdon 2011: 13) ${ }^{141}$. En España la crisis del modelo fundacional se incrementa a inicios de la Transición, aunque la segunda cadena, de carácter minoritario, logra en un inicio retrasar sus efectos. En 1978, el director de la segunda cadena Miguel Ángel Toledano (quien había ayudado a que La clave saliese en antena en 1975), puso de manifiesto que «sobre el medio

fuerte dependencia de los ingresos publicitarios complementada con subvenciones procedentes de los Presupuestos Generales del Estado.

${ }^{137}$ No solo intervino la audiencia, también la lógica del mercado y la privatización. Véanse M. F. Lévy y M. N. Sicard, Les lucarnes de l'Europe : Télévisions, cultures, identités, 1945-2005, op. cit. p. 10; y A. Grimson y M. Valera, Audiencias, cultura y poder. Estudios sobre la televisión, Eudeba, Buenos Aires, 1999.

${ }^{138}$ El prime time es un término americano que será adaptado por los profesionales del medio en los años ochenta (Bourdon 2011: 22). El prime time varió según el país: en Reino Unido esta franja se iniciaba en torno a las 19:00 h; en EEUU o en Francia, en torno a las 20:00 h, mientras que en España se situó en torno a las 22:00 h.

139 Véase la obra de J. Bourdon y C. Méadel (ed.), Television Audiences Across the World: Deconstructing the Ratings Machine, Palgrave Macmillan, Basingstoke, 2014.

${ }^{140}$ En este proceso, «la lógica de la demanda de las audiencias ha sustituido a la lógica de la oferta del monopolio del servicio público de la comunicación», M. García, "Treinta años de televisión pública: el caso de TVE en Europa", en R. Pérez-Amat y A. Pérez-Ugena (codir.), Sociedad, integración y televisión en España, Laberinto, Madrid, 1992, p. 27. Algunas de las obras que analizan la crisis de los sistemas públicos de la televisión en Europa, P. O. Costa, La crisis de la televisión pública, op. cit. 1986, y M. Murciano, "Canvis en la televisió pública europea: una visió panorámica dels darrers quinze anys", en Treballs de Comunicació, Societat Catalana de Comunicació, Barcelona, no 3, octubre de 1992, pp. 83-86.

141 Otros autores proponen acertadamente que el espíritu de mayo del 68 mató en gran parte el paternalismo didáctico que consistía en transmitir desde arriba la cultura de las élites a las masas (Lévy y Sicard 2008: 10). 
televisivo únicamente puede ejercer su dictadura la audiencia, los espectadores que siguen los programas; y la misión de quienes la rigen es la de conocer cuáles son los deseos de la audiencia para cubrir esos deseos con los programas adecuados» ${ }^{142}$. Afirmación que mostraba nítidamente el camino que también seguiría la UHF.

Aunque la crisis del modelo fundacional se inició años antes, es en la década de los setenta cuando la audiencia empieza a legitimar una televisión de eminente entretenimiento ${ }^{143}$. Y desde entonces será la audiencia el concepto legitimador de los intereses televisivos a los que deben responder los nuevos programas. El poder legitimador de una audiencia que incrementaba semana a semana, dio como resultado la producción en serie de programas de entretenimiento y un drástico descenso de los programas educativos y culturales. No significa, por tanto, que no existan iniciativas relacionadas con la formación o programas de carácter educativo o cultural en el nuevo modelo, pero sí son posteriores al fracaso del modelo fundacional. En España, desde los inicios de la Transición, el modelo fundacional está en crisis. El telespectador comienza a considerarse exclusivamente en términos de audiencia fortaleciendo la esfera del entretenimiento, en detrimento de la informativa y educativa.

La clave surgió en España en el momento de crisis del modelo televisivo fundacional pero el programa era continuador de la tendencia inicial de considerar la televisión como servicio público y su triple misión de informar, educar, y entretener. La progresiva transición hacia un consumo masivo por la creciente audiencia se manifestaría en la necesidad de implantar una nueva conceptualización de la programación televisiva ${ }^{144}$. De esta forma, el carácter comercial se infundiría paulatinamente en el modelo de televisión de servicio público: la inmediatez, la disponibilidad de imágenes emocionalmente fuertes (el drama de la imagen), y las historias simples que poco ayudan a la resolución de los conflictos, se fueron imponiendo paulatinamente en una programación, cada vez más interesada en atraer la mayor audiencia posible ${ }^{145}$. La lucha y la competencia directa que se produce por los índices de audiencia crean en televisión la llamada sociedad del espectáculo, sentando las bases incluso en el modelo de televisión pública que debía competir con la entrada de las nuevas televisiones privadas.

\footnotetext{
142 “Televisión Española, a debate”, $A B C, 17 / 10 / 1978$, p. 105.

${ }^{143}$ Como argumenta Monique Dagnaud, en los años setenta se asienta la idea de una televisión de entretenimiento. Véase M. Dagnaud, “L'exception culturelle profite-t-elle vraiment à la création ?”, En temps réel, Les Cahiers de l'association, $\mathrm{n}^{\mathrm{0}}$ 16, París, octubre de 2004, p. 5.

${ }^{144}$ Véanse T. W. Adorno, "Television and the Patterns of Mass Culture”, en Television: The Critical View, Oxford, Nueva York, 1976, pp. 239-259, y E. Giordano y C. Zeller, Políticas de televisión, Icaria, Barcelona, 1999.

145 Véase principalmente, E. Subirats, La cultura como espectáculo, Fondo de Cultura Económica, México, 1988.
} 
Autores como Javier Tusell dirigen su mirada en las consecuencias de una televisión fruto de la crisis del modelo fundacional. «Me parece que la clave de la cuestión reside precisamente en este punto. Quien depende de la publicidad únicamente puede tener justificado no querer arriesgarse a perder niveles de audiencia y dilatar hasta el momento en que lo exija el espectador el momento de elevar la calidad de su propia oferta» ${ }^{146}$. El modelo comercial de televisión inició otra forma de entender y hacer televisión, cuyo principio rector fue el incremento del beneficio (y no exclusivamente económico). La esfera que mostró mayor capacidad de satisfacer estas necesidades fue el entretenimiento y, a partir de ella, se estructuró la misión informativa y educativa. En sus inicios, las tres esferas equilibran la programación, pero tras la crisis del modelo fundacional, fue la esfera del entretenimiento la que estructuró, insertó y definió la necesidad informativa y formativa de la televisión. Por esta razón discrepamos, como defienden algunos autores, que la tradicional división de funciones sigue siendo válida en la actualidad ${ }^{147}$. No se trata de que no existan programas con contenido cultural, educativo o formativo (que continúan en la programación), sino que estos se realizan tras la crisis del modelo fundacional.

Tampoco se trata de una crítica al modelo comercial, pues dicho modelo llevó a nuevos modos narrativos y a otras formas de entender la televisión. El fuerte potencial que se acordó a la audiencia condicionó el naciente modelo comercial legitimando la tesis del aumento de demanda y de opciones para el telespectador ${ }^{148}$. Sin embargo, no por ello conllevó una mayor diversidad de pensamiento en pantalla. Además, muchos programas, principalmente de difusión de arte, teatro, danza, ópera, música clásica, literatura... así como diversas temáticas que tenían lugar en el modelo fundacional se diluyeron hasta prácticamente desaparecer de la programación con el modelo comercial. De la cultura formativa inicial se pasó a la cultura de ocio y espectáculo, cuya máxima legitimadora fue la audiencia (cada vez más interesada en una televisión de entretenimiento que en su capacidad formativa o educativa). A partir de los años ochenta se intensificó el debate en España para regular la entrada de la televisión privada, que se hizo efectiva en los años noventa con la llegada de Antena 3, Telecinco y Canal Plus. A partir de entonces, cine, series, concursos, información, y especialmente deportes (pilar del entretenimiento), conformaron la programación del modelo comercial de televisión.

\footnotetext{
${ }^{146}$ J. Tusell Gómez, “La televisión, ¿un medio que se suicida?”, Cuenta y razón, no 105, 1998, p, 22.

${ }^{147}$ B. León, Transformar la televisión. Otra televisión es posible, Comunicación Social, Sevilla, 2009, p. 50.

${ }^{148}$ Véanse T. W. Adorno, "How to Look at Television”, en The Culture Industry: Selected Essays on Mass Culture, Routledge, Londres, 1991; y R. Thomas, Le sport et les médias, Vigot, París, 1993.
} 



\section{Capítulo 2. Apuntes para una biografía de José Luis Balbín}

Antes de presentar un análisis general del programa y observar la difusión cultural que realiza en televisión La clave, abordaremos la figura de José Luis Balbín. Con el objetivo de averiguar las razones que llevaron a los altos directivos de RTVE a delegar en él la dirección del programa, presentamos un capítulo que aborda su trayectoria personal y profesional. Desde el inicio de esta tesis doctoral se hizo imprescindible un encuentro con este periodista, director y moderador del programa. No se podía entender el surgimiento del programa ni su posterior trayectoria si no se atendíamos antes la figura de José Luis Balbín. Pero presentar una biografía era una tarea tan compleja como extensa había sido su trayectoria: trabajó en distintos medios de comunicación (prensa, radio y televisión), y vivió en otros países como Alemania y Francia. Durante la Transición española estuvo al frente del programa La clave (1976 y 1985), ocupando diferentes cargos directivos en RTVE (con UCD en el gobierno, y Fernando Castedo director general de RTVE, fue nombrado en 1981 director de Programas Especiales y, tras la victoria del PSOE en octubre de 1982, y José María Calviño director general, fue nombrado director de los Servicios Informativos de TVE, uno de los cargos más importantes y relevantes en RTVE).

La trayectoria profesional de José Luis Balbín y su labor al frente del programa durante diez años en TVE le valieron numerosos premios y reconocimientos. En 2015 le fue concedido el Premio Nacional de Televisión ${ }^{1}$. Sin embargo, pocos son los estudios que han atendido su figura (escasa es la historiografía que presenta a los periodistas como un actor político del cambio producido en España durante la Transición) ${ }^{2}$. Partíamos, por tanto, alejados de los estudios y biografías de personalidades políticas que predominan en la historiografía de la Transición española, para centrarnos en la figura de un periodista. Para abordar la trayectoria de José Luis Balbín hemos utilizado fuentes primarias, periódicas, testimoniales, correspondencia, memorias, documentos y entrevistas que a continuación pasamos a detallar. No sin antes problematizar sobre el propio concepto de biografía.

\footnotetext{
${ }^{1}$ Premio concedido el 17 de junio de 2015 por el Ministerio de Educación, Cultura y Deporte. José Luis Balbín está en posesión de más de cien premios relacionados con las humanidades y la comunicación entre los que destacan el premio a "La Libertad de Expresión", concedido por la Unión de Periodistas, premio de "La Paz", concedido por la Asociación de Naciones Unidas, premio "Ondas" en 1979, premio "Fotogramas", premio "Pablo Iglesias", o el premio "Popular" del diario Pueblo...

${ }^{2}$ Como excepción encontramos la obra de Justino Sinova que, por momentos, llega a centrarse exclusivamente en José Luis Balbín. Véase La gran mentira. op. cit. Algunas obras que han hecho referencia a su figura son: J. Munsó Cabús, La otra cara de televisión. op. cit. pp. 140-141; J. C. Ibáñez, "La clave", en M. Palacio (ed.), Las cosas que hemos visto. op. cit. pp. 70-71; J. R. Pérez Ornia, La televisión y los socialistas. op. cit. p. 50; y M. Palacio, La televisión durante la Transición española, op. cit. pp. 101 y 258.
} 


\subsection{José Luis Balbín: ¿una biografía?}

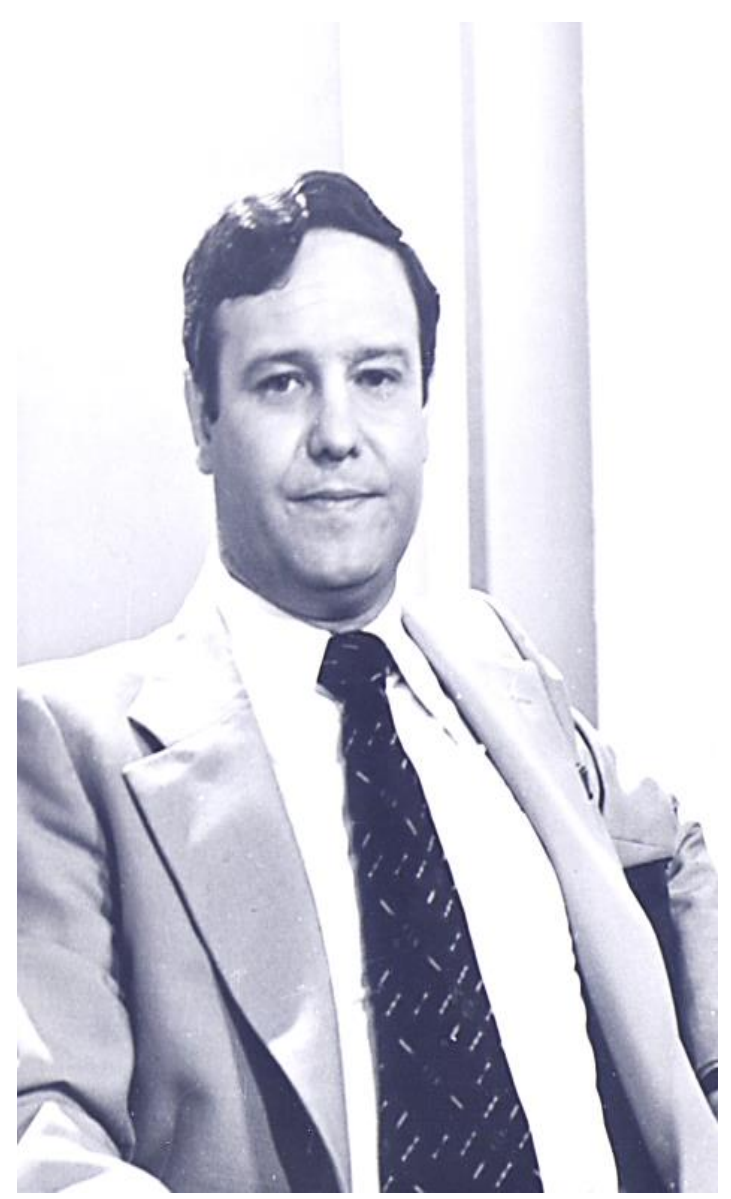

La biografía es un género que ha sido objeto de constantes críticas ${ }^{3}$. Sin embargo, el problema de objetividad o la llamada ilusión biográfica ${ }^{4}$, no han acabado con la pretensión histórica de interpretar y narrar las experiencias vividas por una persona. De entrada, este capítulo pretende ser una aproximación analítica de una trayectoria que consideramos imprescindible para entender no solo el origen de La clave en 1975, sino también las razones que llevaron a los directivos de televisión a delegar en José Luis Balbín la dirección del programa. Con el firme interés de centrar nuestra mirada en una historia cultural del proceso de transición en España, creemos que el estudio de su figura no es aislado sino común a una generación y a la conformación de una serie de grupos que serán determinantes en la Transición española.

Fotografía no 2. José Luis Balbín en 1976. Fuente: Archivo General de la Administración 5 .

Hemos estructurado el siguiente capítulo a partir de las diferentes etapas que componen su trayectoria personal y profesional. Son aquellas etapas que le marcan de por vida: los antecedentes familiares, su infancia y adolescencia en Asturias; la etapa madrileña que gravita en torno al periodismo; la alemana y parisina como corresponsal, y sobre todo, su trayectoria posterior en Televisión Española (TVE). Hay muchos factores que hacen difícil una aproximación biográfica porque es necesario recurrir a una perspectiva amplia y global que contextualice y enmarque los principales hechos históricos.

\footnotetext{
${ }^{3}$ Un conjunto de críticas puede verse en S. Loriga, "La biographie comme problème", en J. Revel (comp.), Jeux d'échelles. La micro-analyse à l'expérience, Seuil/Gallimard, París, 1996, pp. 201-231.

${ }^{4}$ P. Bourdieu, “L’illusion biographique”, Actes de la recherche en sciences sociales, n 62-63, 1986, pp. 69-72.

${ }^{5}$ Fotografía procedente del Gabinete de Prensa de TVE, 1976. Archivo General de la Administración (AGA), Alcalá de Henares, Madrid.
} 
José Luis Balbín escribió con dieciocho y veinte años dos biografías para poder acceder a la Escuela de Periodismo de Madrid. La Escuela exigía a los candidatos presentar una memoria autobiográfica de veinte folios. En el Archivo General de la Administración se conservan las dos memorias autobiográficas escritas por José Luis Balbín, resultado de dos convocatorias. La primera, con dieciocho años, se presentó en 1958, la segunda, con veinte, en 1960, y con la que ingresó en Periodismo. Fuentes que a continuación analizamos, en ellas José Luis Balbín habla especialmente de su trayectoria vital en Asturias. Por último, Javier Morán publicó en 2010 en La Nueva España de Oviedo una sección por entregas de cuatro capítulos bajo el título de "Memorias" de José Luis Balbín. En ellas, relataba su posterior trayectoria profesional en el mundo del periodismo ${ }^{6}$. Sabemos que ninguna biografía es definitiva ${ }^{7}$. No obstante, esperamos que el siguiente capítulo profundice en un periodista que dirigió en España el primer programa de debates en directo $^{8}$.

\subsection{Asturias y el Frente de Juventudes}

José Luis Balbín nació el 19 de agosto de 1940 en el municipio de Pravia, en Asturias9. Fue el tercer hijo de Rafael Balbín Cavanilles y María del Pilar Meana Méndez-Trelles ${ }^{10}$. La familia residía en un inmueble de tres plantas en Pravia, en la calle Jovellanos, aunque el padre trabajaba en Oviedo, como empleado del Banco Herrero. En torno a los dos años de edad, José Luis Balbín sufrió una pleuresía que le dejaría sin una costilla. En esos momentos acababan de destinar a su padre a Astorga (León) y allí se trasladó toda la familia, regresando habitualmente a Pravia en vacaciones y en verano. En Astorga vivió parte de su infancia. Se pasaba las tardes en el Cuartel de Artillería debido a la amistad que unía a sus padres con los jefes de aquel regimiento ${ }^{11}$. Una muestra del entorno familiar y religioso en el que vivió en esta época es que

\footnotetext{
6 "Memorias” de José Luis Balbín, La Nueva España de Oviedo, 21 a 24 de marzo de 2010.

${ }^{7}$ Cfr. F. Dosse, El arte de la biografía: entre historia y ficción, Universidad Iberoamericana, México, 2007. Véase J. Tusell, "Historia, biografía, política", en Claves de Razón Práctica, no 7, 1990, pp. 54-58.

${ }^{8}$ Una primera versión de la biografía que aquí presentamos puede encontrase en "Estudio introductorio. Balbín, un periodista clave para la Transición Española", en VVAA, La prensa que leen los asturianos, Ed. Colegio profesional de Periodistas de Asturias, 2016, pp. 23-47.

${ }^{9}$ Acta de Nacimiento, $\mathrm{n}^{\circ}$ 099074, Tomo 49, folio 80. AGA. En 2014 le fue concedida la distinción de Hijo Predilecto de esta ciudad.

${ }^{10}$ Tras los primogénitos Rafael e Ignacio nació José Luis Balbín. Posteriormente la familia se vería incrementada con los nacimientos de otros cuatro hijos: Cristina, María del Carmen, Carlos y Fernando.

${ }^{11}$ Fuente: Autobiografía de José Luis Balbín, 1958, AGA.
} 
se convierte en monaguillo y participa en multitud de actos religiosos hasta la Primera Comunión, como resaltaría en ambas autobiografías ${ }^{12}$.

En 1948 la entidad financiera destinó de nuevo a su padre a Oviedo (Asturias), y tras reunión familiar, decidieron regresar a Pravia por la fácil conexión que presentaba Pravia con la capital de provincia. Allí pasó gran parte de su adolescencia. Inició sus estudios académicos en el colegio San Luis, situado enfrente de su casa. Fundado en 1894, fue «uno de los primeros colegios privados que hubo en España (...) vivero de ministros o secretarios de Estado» ${ }^{13}$. En palabras posteriores, José Luis Balbín narra que se trataba de «un colegio muy tradicional, muy clásico, muy ultra, casi un correccional, pero no me ha quedado trauma, ni religioso ni educacional en general ${ }^{14}$. Los estudiantes entraban a las ocho y media de la mañana y salían a las ocho y media de la tarde. «Fue una época educativa dura» ${ }^{15}$.

En los artículos escritos en 2010 por Javier Morán, José Luis Balbín guarda un magnífico recuerdo de su familia ${ }^{16}$. Reconoce que «pertenecía a una familia de derechas, pero no militante; conservadora, pero sin que mis padres fueran aficionados a la política». Su padre, Rafael Balbín, «de cierta ascendencia aristocrática (...), fue muy liberal con los hijos, jamás nos impuso nada (...) nos daba libertad, pero era muy exigente en las notas académicas, (...) no nos condicionó en la elección de carrera» ${ }^{17}$.

Uno de los hechos que marcaría su adolescencia, como quedaría reflejado en ambas memorias autobiográficas (1958 y 1960), fue el primer campamento de verano al que asistió, organizado por el Frente de Juventudes ${ }^{18}$. El Frente de Juventudes fue una sección creada en 1940 por la Falange (Falange Española Tradicionalista y de las J.O.N.S.) para el adoctrinamiento político de los jóvenes españoles según los principios del Movimiento Nacional ${ }^{19}$. El campamento había sido organizado en Pola de Gordón y asistió junto a sus

\footnotetext{
${ }^{12}$ Autobiografía y Memoria autobiográfica de José Luis Balbín para su ingreso en Periodismo, 1958 y 1960, AGA.

13 José Luis Balbín en "La educación es La Clave”, La Nueva España, 17/09/2010. En el artículo se añade que José Luis Balbín fue «sobrino nieto del sacerdote fundador del San Luis».

${ }^{14}$ José Luis Balbín, en La Nueva España, 21/03/2010.

${ }^{15}$ José Luis Balbín, en "La educación es La Clave”, La Nueva España, 17/09/2010.

16 “Memorias" de José Luis Balbín, del 21 al 24 de marzo de 2010.

${ }^{17}$ La Nueva España, 21/03/2010. Véase también la entrevista realizada en el DVD anexo.

18 «Es probable que el tal campamento haya cumplido una función decisiva en relación a mi vida». Autobiografía de José Luis Balbín, 1958, AGA. También recordaría su paso por dichos campamentos en alguna emisión posterior como Vivir en postguerra (ficha 232), emitido el 16 de julio de 1982.

${ }^{19}$ Un análisis de las propuestas llevadas a cabo por los falangistas durante la dictadura del general Franco y su fracaso respecto a su influencia en el sistema educativo, en J. I. Cruz Orozco, El yunque azul: Frente de Juventudes
} 
hermanos mayores. «Si llegué al campamento afanado en aventura, logré adquirir en aquellos veinte días, las nuevas ideas de las que aún me siento orgulloso» ${ }^{20}$. Encuadrado en la legión de cadetes, José Luis Balbín era el más joven del campamento y, atraído especialmente por el carácter militar de dicha organización, fue ascendiendo hasta lograr el título de Jefe de Centuria Nacional ${ }^{21}$. «Después de haber pasado por numerosos campamentos y cursillos en los que había ido ascendiendo paulatinamente, me habían puesto al frente de los muchachos que encuadraban la Delegación Local de Pravia. (...) Era yo un convencido de la bondad del Frente de Juventudes; sin embargo como no era capaz de conocer su doctrina trataba de plasmarla en una seriedad en la forma. Había cumplido quince años» ${ }^{22}$.

En el colegio, pronto comenzó a destacar entre los estudiantes por su nivel académico. Sus notas en la escuela le permitieron obtener becas con la que seguir financiando sus estudios. Tras realizar un examen en la Diputación (con Matrícula de Honor), obtuvo una beca desde su ingreso en Bachillerato. De los más de veinte alumnos que iniciaron bachiller solo terminaron dos, y él fue uno de ellos ${ }^{23}$. Con la ley de enseñanza media de 1953, el Bachillerato quedaba dividido en dos etapas: la etapa elemental y la superior; lo que permitía por primera vez, como argumenta Elena Hernández, «una cierta apertura en el nivel inferior, permeable a capas que resultaban menos favorecidas» ${ }^{24}$. En 1956 obtuvo el título de Bachiller Superior, acreditado en el Instituto Nacional de Enseñanza Media de Avilés ${ }^{25}$. Comenzó a mostrar interés por la lectura (apasionándole la generación del 98), y presentó algunos trabajos a concursos literarios.

Fue en Pravia donde se inició su pasión por el cine, debido a que un tío suyo llevaba uno de los dos cines que había en la localidad ${ }^{26}$. Cuando con la mayoría de edad se traslada a

y sistema educativo: razones de un fracaso, Alianza Editorial, Madrid, 2001. Para diferentes perspectivas, véanse también, J. Sáez Marín, El Frente de Juventudes. Política de juventud en la España de la postguerra (1937-1960). Siglo XXI, Madrid, 1988; y M. Parra Celaya, Juventudes de vida española. El Frente de Juventudes, historia de un proyecto pedagógico, Fundación San Fernando, Madrid, 2001.

${ }^{20}$ Autobiografía de José Luis Balbín, 1958, AGA.

${ }^{21}$ Ibídem.

${ }^{22}$ Memoria Autobiográfica de José Luis Balbín, 1960, AGA.

${ }^{23}$ «La educación es La Clave», La Nueva España, 17/09/2010.

${ }^{24}$ E. Hernández Sandoica, "La dictadura franquista y la Universidad, 1951-1975. (Con especial atención al caso de Madrid)", en Cuadernos del Instituto Antonio Nebrija, no 5, Dykinson, Madrid, 2002, p. 133.

${ }^{25}$ Fuente: Instituto Nacional de Enseñanza Media Carreño Miranda de Avilés. Folio 31, no 824. Carta enviada desde el Ayuntamiento de Pravia al Rector de la Universidad de Oviedo. AGA.

${ }^{26}$ Autobiografía de José Luis Balbín, 1958, AGA. Véase también La Nueva España, 21/03/2010. 
Madrid, su primera opción es estudiar en la Escuela Oficial de Cinematografía ${ }^{27}$, pero habiendo transcurrido las fechas de inscripción, se ve obligado a descartar esa opción, convirtiendo el cine en su vocación frustrada ${ }^{28}$. Su otra pasión, y a la que ligaría su trayectoria profesional, fue el periodismo, que inició también en esta época y ya no abandonaría. «Yo mismo, en mi época adolescente, conseguí refundar El Sol de Pravia, de éxito notorio y corto, porque dos artículos, "Viridiana" y "Un amigo fidelista", fueron víctimas de la censura de aquel tiempo» ${ }^{29}$. Con la idea de estudiar cine o periodismo se presentó en Madrid. Tenía dieciocho años y «había conseguido ayuda de Francisco Labadie Otermín, presidente del Instituto Nacional de Previsión ${ }^{30}$.

\subsection{Periodismo y Colegios Mayores (1958-1963)}

«Solamente podría destacar que cada día estaba más enterrado en la rama de letras, entre poesías y prosas, con cientos de casos publicados y no publicados que acabaron de orientarme en mi vocación: "Sería periodista". Mis amigos me lo aconsejaban, el Director del Colegio insistía... solamente había personas que rechazaban tal opinión, cuando trataban la parte económica. Aun así... me gustaba. Por una parte podría escribir. Y escribiendo pongo en orden los pensamientos y hallo verdad en ellos. Por otra parte me gustaban los hombres de inquietudes, llegando a atraerme locos como Hitler y alcohólicos como Rubén Darío» ${ }^{31}$.

En su época estudiantil en Madrid, José Luis Balbín pasó por tres colegios mayores: Antonio de Nebrija, Diego de Covarrubias y Nuestra Señora de Guadalupe. Los colegios mayores surgieron en España albergando a colegiales varones de todas las licenciaturas y carreras técnicas y superiores. Pero cabría reparar, en primer lugar, en la función que cumplían

\footnotetext{
${ }^{27}$ Véase también, M. Palacio y C. Ciller, “La clave de TVE, un programa de debate en la historia...”, en Estudios sobre el Mensaje Periodístico. Vol. 20. Núm. especial (2014), p. 235.

${ }^{28}$ «Yo también he sido siempre un gran apasionado del cine y, de hecho, quise dedicarme a ello», José Luis Balbín, en I. Reguera Pascual y J. J. Aparicio Arriola, Carlos Pumares: Un grito en la noche, Club Universitario, Alicante, 2006, p. 56.

${ }^{29}$ José Luis Balbín, en La Nueva España, 24/09/2012.

${ }^{30}$ Memoria autobiográfica de José Luis Balbín, 1960, AGA. Otermín había sido voluntario en la División Azul, combatiendo en el frente ruso, y después procurador en Cortes, Consejero Nacional por Oviedo, y Jefe provincial de la FET y de les JONS.

${ }^{31}$ Autobiografía de José Luis Balbín, 1958, AGA. Párrafo que desaparece en la segunda versión de 1960.
} 
dichos colegios, pues, como argumenta Miguel A. Ruiz Carnicer, «cumplían una importante labor en el SEU, que era la de preparar minorías y que éstas estableciesen lazos entre sí que podrían ser útiles políticamente en el futuro» (Ruiz 1996: 348). Como veremos posteriormente en su trayectoria, redes de sociabilidad comunes a una generación (no solo económicas sino también de parentesco, amistad e ideológicas), que serán determinantes para entender la trayectoria de José Luis Balbín y también la conformación de ciertos grupos durante la Transición española.

José Luis Balbín comenzó la carrera de Derecho en 1959, con residencia en el Colegio Mayor Antonio de Nebrija, en Madrid ${ }^{32}$. El Nebrija había sido inaugurado oficialmente el 7 de marzo de 1951 y se ubicaba en la Ciudad Universitaria de Madrid. Allí permanecería un año. En 1958 se había presentado a las pruebas de ingreso en la Escuela Oficial de Periodismo de Madrid pero suspendió la prueba oral en el examen, primer suspenso en su carrera estudianti1 ${ }^{33}$. Lo volvería a intentar en la convocatoria de 1960, esa vez con éxito. Para acceder a Periodismo se requería estar en posesión del título de Bachiller Superior, contar con una edad inferior a treinta y cinco años y presentar «una memoria autobiográfica de una extensión aproximada de veinte folios mecanografiados en la que se expongan las razones que el solicitante estima como signos de su vocación periodística y disposición profesional, así como sus reacciones subjetivas ante los acontecimientos más importantes de carácter público y privado» ${ }^{34}$.

Existen por tanto en el Archivo General de la Administración dos memorias autobiográficas escritas por José Luis Balbín, resultado de dos convocatorias: la correspondiente al curso escolar 1958/59, con el título de “Autobiografía de José Luis Balbín” (convocatoria que no superaría la prueba oral); y la realizada dos años después, para el curso 1960/1961, con el título de "Memoria autobiográfica de José Luis Balbín” (año de su ingreso). Con ciertas diferencias -aunque en ambas sigue el mismo hilo argumental-, José Luis Balbín se sincera y describe en primera persona el recorrido que le lleva a tomar la decisión de estudiar Periodismo ${ }^{35}$.

\footnotetext{
${ }^{32}$ Expediente personal de José Luis Balbín Meana, como miembro del personal político del SEU. Archivo General de la Administración, caja 51/20341. En Derecho coincidió con Fernando Castedo (director general de RTVE en 1982), y con quien mantiene, todavía hoy, una gran amistad.

${ }^{33}$ Autobiografía de José Luis Balbín Meana, 1958, AGA.

${ }^{34}$ Convocatoria 1960/61. Dirección General de Prensa, 29 de junio de 1960. AGA.

${ }^{35}$ La fuente autobiográfica, como han señalado algunos autores, «goza ciertamente de una importancia en la medida en que da la ilusión al biógrafo de penetrar en el centro de la interioridad de su personaje, lo más cerca posible de su intencionalidad» (Dosse 2007: 39).
} 
Luis Meana Méndez-Trelles, tío y padrino de José Luis Balbín, había coincidido en la Universidad de Oviedo con Sabino Fernández Campo y Torcuato Fernández-Miranda ${ }^{36}$. Fernández Campo (en esos momentos secretario del ministro del Ejército), recomendó a su tío que José Luis Balbín entrara en el Colegio Mayor Diego de Covarrubias. El colegio había sido fundado en 1952 en honor al jurista Diego de Covarrubias, Obispo de Segovia, y albergaba preferentemente a estudiantes y opositores de las carreras de Letras. Logrando mantener la beca, José Luis Balbín entraba en 1960 en el Colegio Diego de Covarrubias. El director del centro era Fernando Suárez González (quien años después sería ministro con Carlos Arias Navarro en el primer gobierno de la Monarquía) ${ }^{37}$, y el subdirector, José Luis Merino, quien tendría un papel relevante en La clave, primero como asesor jurídico y documentalista, y posteriormente como redactor jefe, saliendo en pantalla leyendo las preguntas de los telespectadores (llegando incluso a presentar alguna emisión con ocasión de algún viaje al extranjero de su director). En su primer año tuvo de tutor precisamente a Fernández $\mathrm{Campo}^{38}$. En el centro no había televisor, pero sí una cultura de trabajo importante, realizándose todas las semanas diferentes actos culturales. Entre ellos, un coloquio semanal titulado "Semáforo" que contaba con la participación de distintos invitados del ámbito del cine, el arte, la poesía o el humor (participaron entre otros, Buero Vallejo, Juan Antonio Bardem, o Luis García Berlanga).

Cuando hacía segundo de Derecho, logró pasar las pruebas escritas y orales e inscribirse en la Escuela Oficial de Periodismo de Madrid $^{39}$. La Escuela de Periodismo, ubicaba en la calle Capitán Haya de Madrid, era un centro académico superior cuyos estudios conducían a la obtención del título de periodista. Creada en 1942 por Juan Aparicio López (ex redactor de Ya),

\footnotetext{
${ }^{36}$ En 1960 Torcuato Fernández-Miranda (Catedrático de Derecho Político en la Universidad de Oviedo) empieza a dar clases de Derecho Constitucional al joven Juan Carlos. «Iniciado en la política como director general de Enseñanza Media (bajo J. Ruiz-Giménez) y de Enseñanza Universitaria (bajo J. Rubio), había sido designado por Franco, en 1960, tutor del príncipe Juan Carlos», M. Pastor, "Las postrimerías del franquismo", en R. Cotarelo (Comp.), Transición política y consolidación democrática. España (1975-1986), CIS, Madrid, 1992, p. 42. Entre 1969 y 1974 ocuparía el cargo de Secretario General del Movimiento, y durante la Transición sería quien diseñaría la Ley para la reforma política de 1976 (Ley 1/1977, de 4 de enero de 1977).

${ }^{37}$ Fernando Suárez había sido nombrado director del Diego de Covarrubias por Torcuato Fernández-Miranda en diciembre de 1959, y permanecería en ese cargo diez años, hasta 1969. Anteriormente, entre 1954 y 1956 había sido jefe nacional del SEU en Oviedo. Durante el año escolar 1956-57, fue director del Colegio Mayor Santa María, del SEU, y del Colegio Mayor Menéndez Pelayo. Véase F. Suárez González, Teoría del colegio mayor. Colegio Mayor Diego de Covarrubias, Ed. Universidad de Madrid, Madrid, 1966.

${ }^{38}$ En 1977, Sabino Fernández Campo fue subsecretario de Información y Turismo. Después de La clave, José Luis Balbín mantuvo relación con él, y cuando surgió en 2001 la revista La Clave, Fernández Campo formó parte del Consejo de Administración.

${ }^{39}$ Expediente personal de José Luis Balbín Meana como alumno de la Escuela Oficial de Periodismo de Madrid. AGA (Escuela Oficial de Periodismo de Madrid) caja 83/00042, exp. 345.
} 
estaba dirigida en esos momentos por Juan Beneyto ${ }^{40}$. Su secretario era Manuel Vázquez-Prada, hermano de Ricardo Vázquez-Prada, director del periódico Región. A la altura de 1962, con el nuevo reglamento, la Escuela Oficial de Periodismo quedaba adscrita como organismo autónomo de la Dirección General de Prensa del Ministerio de Información y Turismo, en manos de Manuel Fraga Iribarne (Gordon 1991: 75). Todavía falta por profundizar el destacado papel que juega la irrupción en los años sesenta de una nueva generación de periodistas de la Escuela Oficial de Periodismo y su influencia durante el proceso de Transición ${ }^{41}$.

Pese a certificar el título de beneficiario de familia numerosa, al no ser una carrera universitaria, José Luis Balbín no tenía derecho a beca. Para conservarla tuvo que combinar Periodismo con la carrera de Derecho. Y, aunque por momentos compaginó ambas, mostró más interés y dedicó más tiempo a las asignaturas de Periodismo. Finalmente, al no conseguir llegar a la nota para mantener la beca de Derecho - gracias a la que estudiaba en el Covarrubias«puestos a elegir, prefirió seguir con Periodismo y abandonar Derecho y el Diego de Covarrubias» ${ }^{42}$.

En 1961 ingresó en el Colegio Mayor Hispanoamericano Nuestra Señora de Guadalupe, ubicado también en Madrid, donde siguió su formación universitaria. Según los estatutos del colegio, funcionó de residencia de importantes personalidades de la cultura y de la política. Para otros, servía de "laboratorio de la dictadura para integrar el mundo hispánico"43. En la residencia de estudiantes dirigió un grupo de teatro y una serie de coloquios que se hacían en el centro con el nombre de "El Casinillo"44. Continuó su interés por la literatura, escribiendo en revistas universitarias (Marzo, Rombo...) y participando en concursos literarios.

En los colegios mayores, en la universidad, en revistas, o desde diversas plataformas culturales, jóvenes que no habían vivido la Guerra Civil comenzaron a crear «nodos de debate, de información y unas redes invisibles y marginales al régimen» (Ruiz 2013: 107). Como argumenta Ruiz Carnicer, 1956 es el origen de la visualización de la ruptura entre las nuevas

\footnotetext{
40 Sobre las directrices a seguir el periodismo en aquella época véase la obra del propio J. Beneyto, "La formalización del saber periodístico en España”, en Revista Nacional de Educación, Madrid, 1962, pp. 121-130.

${ }^{41}$ Sobre las escuelas oficiales y la enseñanza del Periodismo en España, véase A. Tápia López, "Las primeras enseñanzas de documentación en periodismo", en Documentación de las Ciencias de la Información, n 24, 2001, pp. 231-253, y la tesis doctoral de M. Gordon, La enseñanza del periodismo en el mundo occidental. Estudio histórico y comparado de tres escuelas, Universidad Complutense de Madrid, 1991.

${ }^{42}$ Conversación mantenida con José Luis Balbín. Madrid-Estrasburgo, 30/01/2014.

${ }^{43}$ F. Sánchez, "El laboratorio franquista de la integración hispánica”, El País, 25/09/2016.

${ }^{44}$ Aunque José Luis Balbín confirma esta información, al contactar con el colegio, no nos proporcionan ningún dato de su estancia, amparándose en la Ley Orgánica de Protección de Datos de Carácter Personal.
} 
generaciones letradas y el régimen, que se materializaría en 1965 con la manifestación estudiantil de Madrid y la expulsión de catedráticos de la Universidad Complutense como José Luis López Aranguren y Enrique Tierno Galván (Ruiz 2013: 109). Ambos intervendrían posteriormente en La clave. A partir de las protestas de los años sesenta, el movimiento universitario se convierte en uno de los principales frentes de la oposición antifranquista ${ }^{45}$.

El análisis de la trayectoria de José Luis Balbín permite observar esos nodos de debate, de información y de redes alrededor de su figura. No obstante, continúan vigentes preguntas y problemas acerca de los modos en que interactuó con políticos, intelectuales, artistas y profesionales que, ligados al franquismo, fueron alejándose para acabar en tendencias más aperturistas. José Luis Balbín estudió tres años periodismo con la XXIII promoción (1960$1963)^{46}$. Como constaría en el expediente personal del Sindicato Español Universitario (SEU), fue delegado de curso y delegado de escuela, en la Escuela Oficial de Periodismo ${ }^{47}$. A las pruebas de ingreso en 1960 se presentaron 308 candidatos al examen escrito, de los que solo 64 fueron declarados aptos para pasar a la prueba oral ${ }^{48}$. Tuvo como profesor, entre otros, a Luis María Ansón (presidente de la agencia de información EFE entre 1976 y 1983, y hermano de Rafael Ansón, director de RTVE entre 1976 y 1977).

Poseemos el examen de la prueba escrita que José Luis Balbín realizó en 1958 para su acceso en Periodismo. La prueba consistía en un cuestionario de 60 preguntas sobre curiosidades periodísticas $^{49}$, un ejercicio de redacción, y una prueba de idiomas (que consistió en la traducción de un texto del francés al castellano $)^{50}$. Con el objetivo de mostrar el Plan de Estudios de la Escuela Oficial de Periodismo entre 1960-1963, mostramos en el anexo 1 el

\footnotetext{
${ }^{45}$ Véanse P. Lizcano, La generación del 56. La Universidad contra Franco, Grijalbo, Barcelona, 1981; y C. Molinero y P. Ysàs, La izquierda en los años setenta", Historia y política: Ideas, procesos y movimientos sociales, $\mathrm{n}^{\mathrm{o}} 20,2008$, pp. 21-42.

${ }^{46}$ En su promoción coincidió entre otros con Juan Luis Cebrián (director de El País entre 1976 y 1988) o Manuel Martín Ferrand (primero de la promoción, y después director de Diario de Barcelona entre 1973 y 1974, y Nuevo Diario entre 1975 y 1976). También conoció a Gabriel Cisneros, uno de los padres de la Constitución de 1978.

${ }^{47}$ Historial académico y sindical de José Luis Balbín Meana, 1963. Ministerio de Información y Turismo. Gabinete de Enlace, caja 42/08788, exp. 3. AGA.

${ }^{48}$ Información extraída de una carta escrita el 29 de septiembre de 1960 por Enrique de Aguinaga (de la Escuela Oficial de Periodismo) dirigida al director del diario Levante de Valencia, Sabino Alonso Pueyo (quien previamente le había recomendado seguir la trayectoria de José Luis Balbín). AGA.

${ }^{49}$ Entre algunas preguntas destacamos: ¿Cuáles son las residencias veraniegas del jefe de Estado? ¿Qué es el Consejo Nacional de F.E.T. y de las J.O.N.S.? ¿Qué son los Colegios Mayores? ¿Qué es la Biblia? ¿Quién fue el fundador de $A B C$ ? Definición de despotismo ilustrado, opinión pública, tirada de un periódico, etc.

50 «El examen de ingreso se ha ido adaptando a esta mayor exigencia. Se combina el ejercicio de redacción con el de cultura de la actualidad, y el test de curiosidad periodística -piedra de toque de las aptitudes innatas-», J. Beneyto, "La formalización del saber periodístico en España", en Revista Nacional de Educación, Madrid, p. 126
} 
certificado de asignaturas y calificaciones de José Luis Balbín ${ }^{51}$. Entre las asignaturas que había que superar para ser periodista se encontraban, en primer curso: El mundo actual, La España contemporánea, Estilo periodístico, Teoría y técnica de la noticia, Francés, así como seminarios de redacción, reportaje, y crítica periodística; en segundo: Dogma y moral católicos, Sociología, Teoría y técnica de la publicidad, Técnica de las artes gráficas, Francés, Inglés y seminarios de radiodifusión, televisión, y publicidad; y en tercero: Historia del periodismo, Técnicas y organización de la transmisión de noticias, Cultura española contemporánea, Régimen jurídico de la información, Sistemas económicos y empresariales de información, Prácticas de inglés y francés, y seminarios de periodismo fílmico, periodismo impreso, periodismo televisivo, y periodismo radiofónico, finalizando el curso con el examen de grado ${ }^{52}$. Aprobó todas las asignaturas con trece notables y tres sobresalientes.

José Luis Balbín se graduó en la Escuela Oficial de Periodismo en 1963 con la tesina La prensa que leen los asturianos, dirigida por Pedro Gómez Aparicio (director la Agencia EFE entre 1944 y 1958 $)^{53}$. En su trabajo abordaba la lenta proliferación del periodismo impreso en Asturias, que pasaba de 3 periódicos en 1861 a 25 periódicos en 1915. Para ello, hacía un recorrido histórico de la prensa asturiana desde 1808 (con La Gaceta de Oviedo, primer periódico de Asturias) ${ }^{54}$, hasta 1963. Contó con el asesoramiento, entre otros, de Francisco Labadie Otermín, Torcuato Fernández-Miranda, Manuel Vázquez-Prada, Gonzalo Cerezo Barredo, Manuel Fernández Avello, y Juan Antonio Cabezas.

Desde que iniciase sus estudios, José Luis Balbín ejerció el periodismo. Desde el primer curso en la Escuela Oficial de Periodismo, entró a trabajar en prácticas en La Nueva España de Oviedo $^{55}$. Su director era Paco Arias de Velasco, y su redactor jefe, Juan Ramón Pérez de las

\footnotetext{
${ }^{51}$ En 1963, Revista de Educación publicó que España invertía en educación 3 dólares por habitante (en relación a los 108 \$ de Estados Unidos o los 35 de Francia), y según datos de la OCDE, había tres millones de analfabetos en España, de los cuales casi dos millones eran mujeres. Véase Revista de Educación, no 156, 1963, pp. 42 y 44. Sobre las posibilidades educativas según el origen social, y un sistema educativo elaborado por la clase privilegiada que detenta la cultura, véase P. Bourdieu y J. C. Passeron, Los estudiantes y la cultura, Labor, Barcelona, 1967.

${ }^{52}$ Una evolución sobre el periodismo, en J. Timoteo Álvarez et. al., Historia de los medios de comunicación en España. Periodismo, imagen y publicidad (1900-1990), Ariel, Barcelona, 1989.

${ }^{53}$ Dicha tesina, presentada el 8 de junio de 1963, se encuentra en el Archivo General de la Administración. Ministerio de Información y Turismo (Registro Oficial de periodistas), caja 52/13983, Expediente 4453, tomo II, folio 391. AGA. Fue proporcionada para su publicación en VVAA, La prensa que leen los asturianos, Ed. Colegio profesional Periodistas de Asturias, 2016, pp. 49-81. José Luis Balbín quedaría inscrito en el Registro oficial de Periodistas, en la Dirección General de Prensa, el 11 de febrero de 1966.
}

${ }^{54}$ Sobre este periódico véase A. Laspra Rodríguez, La Gaceta de Oviedo. El primer periódico de Asturias (junio 1808-julio 1809), Laria Editorial, Oviedo, 2009.

55 «Por medio del Frente de Juventudes también fui entrado en contacto con La Nueva España de Oviedo y Radio Oviedo, también de la capital. El contacto empezó con dos concursos literarios convocados por la Delegación 
Clotas, impulsor de la gente joven en la profesión, y uno de sus referentes profesionales ${ }^{56}$. Realizó prácticas en La Nueva España en dos ocasiones (1961 y 1962), ambas durante los meses de julio, agosto y septiembre ${ }^{57}$. Tras acabar Periodismo en 1963 tiene distintas ofertas laborales: la revista Aspa, La Verdad de Murcia como redactor jefe, o en prácticas en la agencia del Estado Pyresa (Periódicos y Revistas Españolas. Servicio de Agencia). Se inclina por esta última y comienza su etapa en Pyresa, donde escribe críticas y crónicas de cine y realiza entrevistas ${ }^{58}$. Permaneció seis meses. Tras las prácticas no consigue contrato, mostrando en multitud de ocasiones desavenencias con su director, Vicente Cebrián ${ }^{59}$.

A partir de ahí, escribe artículos en Arriba, periódico de Madrid perteneciente a la Prensa del Movimiento, que dirigía en esos momentos el asturiano Sabino Alonso Fueyo ${ }^{60}$. Arriba había sido fundado como semanario en 1935 por José Antonio Primo de Rivera, y funcionaba todavía como portavoz de Falange ${ }^{61}$. En una entrevista concedida en 1980, dedicó una breve frase en referencia a esta época: «Yo he hecho periodismo en medios notorios de información... en las épocas en las que yo no debía haberlo hecho probablemente» ${ }^{62}$. Sin embargo, son escasas las referencias hechas a esta etapa. Escribiría también en algunas revistas universitarias y fue jefe de Prensa de la Hermandad Sindical Nacional de Labradores y Ganaderos ${ }^{63}$.

Provincial», en Memoria Autobiográfica de José Luis Balbín Meana, 1960. AGA. Dos de los escritos fueron
"Razón de los sacrificios juveniles desde Matías Montero a Miguel Álvarez", y "La juventud actual fruto de la
gesta de la cota 300", con los que consiguió el primer y tercer puesto respectivamente. ${ }^{56}$ Autobiografía de José Luis Balbín, 1958, AGA. Véase también La Nueva España, 21/03/2010.

${ }^{57}$ En esa época entraron a trabajar en La Nueva España periodistas como Lorenzo Cordero, Graciano García, Nacho Artime, o Javier de Montini. Allí conoció a grandes amigos: Diego Carcedo, Alfonso Calviño (quien fue incluso compañero de piso), y Ladislao de Arriba Azcona (su hijo, Lalo Azcona, se encargó en 1976 de la presentación de la primera edición de Telediario y, a partir de 1977, trabajaría en La clave como coordinador nacional del programa).

${ }^{58}$ Escribió algunos artículos sobre la revolución de 1848 en Francia, o sobre el recién elegido Pontífice Pablo VI, titulado "Este Papa". Algunos artículos de su etapa en Pyresa pueden encontrarse en El eco de Canarias. Generalmente versaban sobre críticas de cine. Véase por ejemplo, 1/09/1963, p. 5, y 22/09/1963, p. 5.

59 «Nunca supe por qué a Vicente Cebrián le caí mal. (...) Al cabo de seis meses me llamó y me dijo: "No puede seguir usted con nosotros, no le vemos posibilidades". Creo que le molestaba el expediente de Manolo Martín Ferrand y el mío en Periodismo, que su hijo no aprobó. Esto es interpretación mía, pero luego la relación que he tenido con su hijo lo confirma». Véanse los apartados "Seis meses en Pyresa", en La Nueva España, 21/03/2010, y "El amigo fidelista de Juan Ramón”, La Nueva España, 3/03/2012.

${ }^{60}$ Exdirector del periódico Levante de Valencia, había pasado en 1962 a la dirección de Arriba en Madrid, cargo que desempeñaría hasta 1966.

${ }^{61}$ De semanario pasó a diario en 1939, propiedad del Movimiento (luego Medios de Comunicación Social del Estado). Vicente Cebrián fue su director entre 1957 y 1960.

${ }^{62}$ Entrevista a José Luis Balbín en 1980, Interviú, no 194, 31 de enero-6 de febrero de 1980, p. 80.

${ }^{63}$ Fuentes: $A B C, 8 / 03 / 1974$, p. 42; y 14/03/1974, p. 37. Sobre las Hermandades Sindicales, véase P. Gil García, Las Hermandades Sindicales de Labradores y Ganaderos (1944-1977). Historia, documentos y fuentes. Colección Almud, $n^{\circ}$ 2. Ediciones Universidad de Castilla-La Mancha, 2005. 


\subsubsection{EI Sindicato Español Universitario (SEU)}

Rodolfo Martín Villa había sido nombrado el 23 de febrero de 1962 Jefe Nacional del Sindicato Español Universitario (SEU), cargo que desempeñaría hasta septiembre de $1964^{64}$. El Sindicato Español Universitario fue durante más de veinte años el organismo obligatorio de encuadramiento de los estudiantes universitarios españoles ${ }^{65}$. En los sesenta tiene lugar la adaptación del SEU a un nuevo contexto universitario y político, precipitado en gran medida por la crisis de $1956^{66}$. En un informe de 1962, «el jefe del SEU constataba también de forma contundente el fracaso general de la socialización política franquista de los jóvenes universitarios; "la juventud se nos ha ido", afirmaba literalmente» ${ }^{67}$. José Luis Balbín no fue ajeno a la dependencia política del SEU. Pero, habría que partir del contexto de la propia universidad, de los universitarios y del propio régimen, pues el sindicato estudiantil, de carácter falangista, fue obligatorio para todos los universitarios.

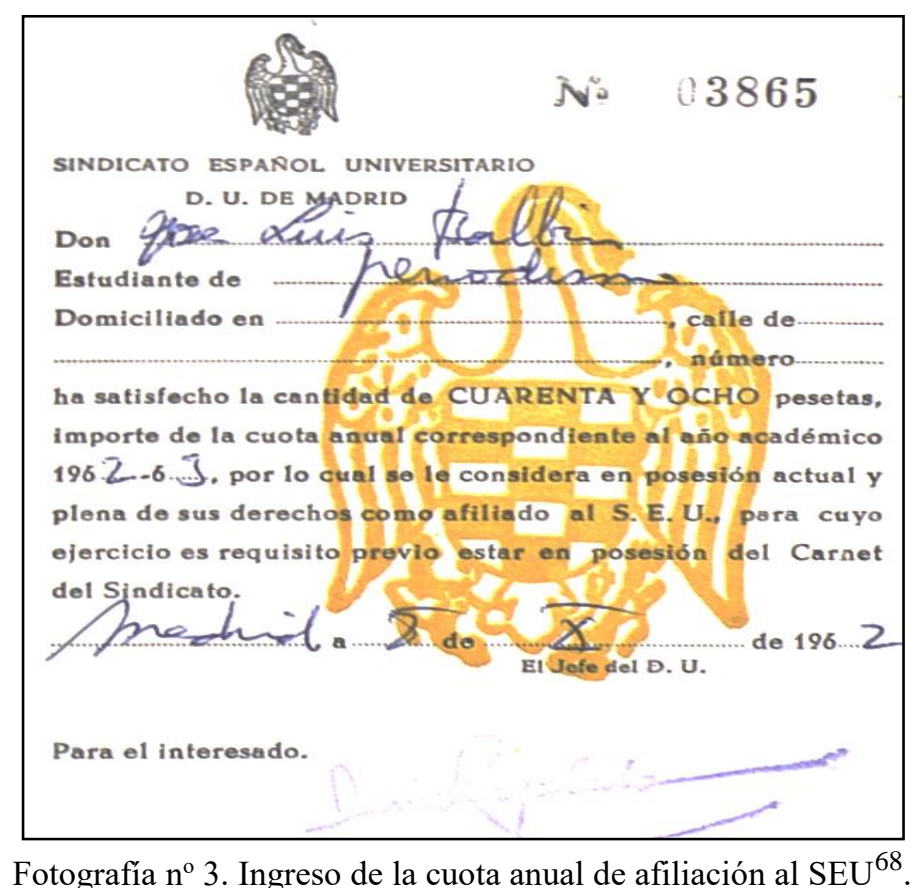

\footnotetext{
${ }^{64}$ Sobre esta etapa, véase M. Á. Ruiz Carnicer, El Sindicato Español Universitario (SEU), 1939-1965: la socialización política de la juventud universitaria en el franquismo. Siglo XXI, México, 1996, pp. 347-368. Como argumenta Jordi Gracia «Entre 1933 y 1965 transcurren los poco más de treinta años de vida de un Sindicato Español Universitario tempranamente fracasado en sus objetivos esenciales» (Gracia 1996: 39).

${ }^{65}$ M. A. Ruiz Carnicer, "Jóvenes, intelectuales y falangistas: apuntes sobre el proceso de ruptura con la dictadura en los años sesenta", en Cercles: revista d'història cultural, no 16, Barcelona, 2013, pp. 103-122. Véase también la obra del autor previamente citada, El Sindicato Español Universitario (SEU), 1939-1965, op. cit. pp. 347-368.

${ }^{66}$ M. A. Ruiz Carnicer, "La voz de la juventud. Prensa universitaria del SEU en el franquismo", en Bulletin Hispanique, t. 98, n 1,1996, p. 91.

${ }^{67} \mathrm{P}$. Ysàs, "El régimen franquista frente a la oposición”, en Cuadernos de la España Contemporánea, CEU, nº 3 , abril 2007, Madrid, p. 7.

${ }^{68}$ Para el curso académico 1962/63 José Luis Balbín abona la cuota anual de afiliación al SEU (48 pesetas). AGA.
} 
Rodolfo Martín Villa es una pieza clave en la biografía de José Luis Balbín. El 8 de noviembre de 1963, Martín Villa nombró a José Luis Balbín, Secretario del Departamento Nacional de Información del SEU, con un sueldo de 2.500 pesetas y otras 1.356 pesetas, en concepto de traslado de residencia ${ }^{69}$. Cesaría de este cargo el 23 de septiembre de 1974. De su amistad con Rodolfo Martín Villa, y el diálogo entre ellos, se evidencian las posteriores misivas que José Luis Balbín enviaría en su época de corresponsal al secretario general de la Organización Sindical.

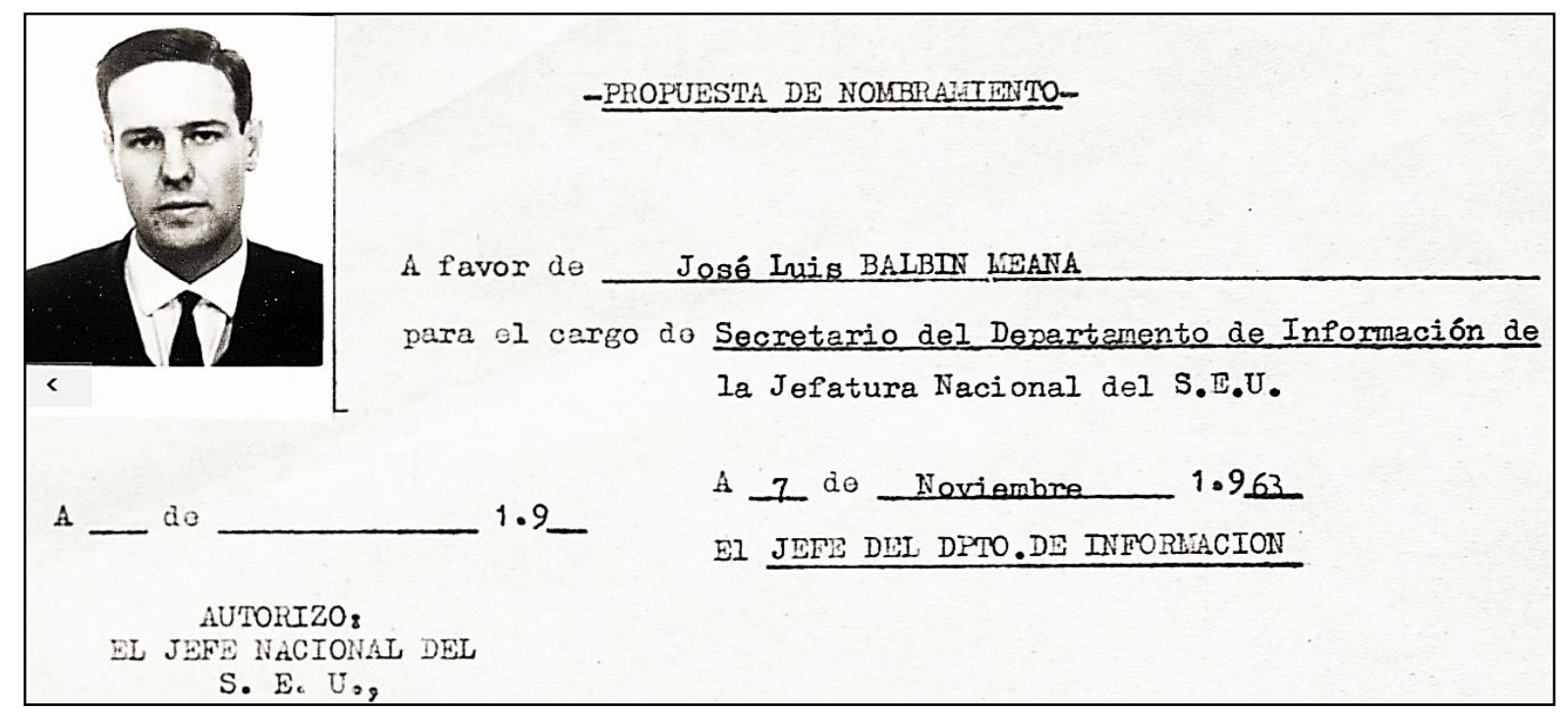

Fotografía no ${ }^{\circ}$. Nombramiento de José Luis Balbín Meana como Secretario del Departamento de Información de la Jefatura Nacional del SEU ${ }^{70}$.

Pese a relacionarse de alguna forma con medios falangistas, José Luis Balbín se definía por pertenecer a una generación posterior a la guerra (y a sus orígenes), que entendía que la construcción del futuro partía precisamente del diálogo como demostró en su paso por los distintos colegios mayores. Durante la dictadura mostró ser un hombre de marcada sensibilidad social, defensor de una apertura cultural en la comprensión de poetas, dramaturgos y pensadores alejados de las esferas del régimen, aunque también del régimen.

Pronto otro de sus referentes profesionales entraría en escena y la trayectoria de José Luis Balbín daría un nuevo giro. Tras leer el artículo que había escrito sobre el papa Montini (Pablo VI), Emilio Romero Gómez, director del periódico Pueblo de Madrid, le llama para trabajar en el periódico ${ }^{71}$. En un primer momento pretende que trabaje como editorialista en

\footnotetext{
${ }^{69}$ Expediente personal de José Luis Balbín Meana, como miembro del personal político del SEU. Fondo (09) 017.014. Sindicato Español Universitario. Caja 51/20341. AGA. Véase anexo $n^{\circ} 2$.

${ }^{70}$ Expediente personal de José Luis Balbín Meana, AGA.

${ }^{71}$ Emilio Romero fue su director desde 1958 hasta 1975.
} 
cuestiones agrarias (recordar que había ocupado el cargo de jefe de Prensa de la Hermandad Sindical Nacional de Labradores y Ganaderos) pero, tras conversar con él, le pasa a política internacional. En Pueblo trabajaría como editorialista de la Tercera Página, una de las páginas más aperturistas en la prensa de la época, escribiendo crónicas y editoriales sin firma ${ }^{72}$. Allí permaneció hasta que Emilio Romero le insta a marcharse de corresponsal. Le ofrece trabajar en Estados Unidos, pero puestos a irse, le atrae más Alemania como destino. En sus memorias deja constancia de esa atracción desde su adolescencia. Al día siguiente, el subdirector de Pueblo, Jesús de la Serna, le llama para trasladar la corresponsalía del periódico a Alemania (a la ciudad de Bonn), lo que le llevó a dejar definitivamente la carrera de Derecho.

\subsection{Corresponsal en Europa (1966-1974)}

En 1966, José Luis Balbín ocupó la corresponsalía del diario Pueblo en Bonn, especializándose en temas relativos a Europa del Este. En esos momentos le interesaba exclusivamente el periodismo escrito, al que consideraba más serio que el medio televisivo o radiofónico. Televisión Española contactó con él por primera vez siendo corresponsal en Alemania pero, en esos momentos, su trabajo le parecía gratificante y le llenaba a nivel profesional $^{73}$. Sin duda, su paso por Europa intensificaría su evolución ideológica a través de la circulación de libros, personalidades, programas de televisión e ideas inaccesibles fuera de la protección de la dictadura.

José Luis Balbín no hizo el servicio militar. Siendo corresponsal se produjo una controversia entre la caja de reclutamiento de España y el Consulado de España en Alemania ${ }^{74}$. En esta entrevista relata que tenía dispensa pero tuvo que regresar a España para solucionar el conflicto y hacer solo el periodo de instrucción ${ }^{75}$. Hay que tener en cuenta que finalizada la Guerra Civil se había establecido un servicio militar en el que los hombres de 19 años quedaban afiliados en su Ayuntamiento, y al año siguiente, pasaban a la Caja de Reclutas de su provincia

\footnotetext{
${ }^{72}$ Véase La Nueva España, 21/03/2010.

${ }^{73}$ Historia de Televisión. Coleccionable. Diario Ya, 1986, p. 119. Sobre esta etapa de corresponsal en Europa, véase La Nueva España, 22/03/2010.

74 “José Luis Balbín: “Me jugué la vida a los chinos”, La Razón.es, 29/11/2012.

${ }^{75}$ Para pedir una nueva prórroga del servicio militar necesitaba un certificado de estudios del año 1964/65 expedido por un centro docente oficial, con lo que no dudó en ponerse en contacto con su antiguo profesor Manuel VázquezPrada para pedirle consejo y ayuda. Carta enviada desde Alemania, el 11 de junio de 1966. AGA.
} 
para ser sorteados ${ }^{76}$. En Asturias había dos Cajas de Reclutas: Oviedo y Pravia. Los estudiantes a partir de 3 años de carrera podían pedir, previa superación de un curso de formación, prórrogas hasta los 27 años, como era el caso de José Luis Balbín, quien además, no quería hacer el servicio militar ${ }^{77}$. Hay que tener en cuenta que hasta los últimos años de franquismo no empezaron los primeros casos de objeción de conciencia. Los que se negaban a incorporarse al Ejército podían ser procesados por ello y acabar, como ocurrió en algunos casos, en prisiones militares. En 1984, el Congreso de los Diputados aprobaría la Ley de Objeción de Conciencia reconociendo el derecho de los objetores con la llamada Prestación Social Sustitutoria (PSS), que establecía un servicio civil de 18 meses de duración.

Como corresponsal de Pueblo viajó varias veces a Hungría donde conoció a Santiago Carrillo (y con quien tuvo una gran amistad), y a Nicolae Ceaucescu (quien en 1967 llegaría a la presidencia del Consejo de Estado de Rumanía). También viajó varias veces a Moscú. Allí conoció al político y militar croata Josip Broz (más conocido por su título de militar Mariscal Tito $)^{78}$, y a Alexander Dubček (del que fue amigo personal) ${ }^{79}$. Desde octubre de 1967, José Luis Balbín entraba y salía de estos países clandestinamente. El pasaporte español no era válido en países como la U.R.S.S. o la República Democrática Alemana ${ }^{80}$, con lo que para poder entrar a estos países, según su relato, debía hacerlo de incógnito o mediante pasaportes falsos ${ }^{81}$.

\subsubsection{La primavera de Pravia}

Desde su marcha como corresponsal de Pueblo en 1966, en contadas ocasiones José Luis Balbín había regresado a España. Para su 28 cumpleaños, en agosto de 1968, decidió regresar unos días a Pravia. El 21 de agosto, recién llegado a su ciudad natal, estalló la

\footnotetext{
${ }^{76}$ Sobre el funcionamiento y la evolución del servicio militar en España, véase la tesis doctoral de J. Fidel Molina, Quintas y servicio militar: Aspectos sociológicos y antropológicos de la conscripción (Lleida, 1878-1960), Servei de Publicacions Universitat de Lleida, 1996.

${ }^{77}$ Conversación mantenida con José Luis Balbín, Madrid, 18/07/2014.

${ }^{78}$ Jefe de Estado de Yugoslavia desde el final de la Segunda Guerra Mundial hasta su muerte en 1980.

${ }^{79}$ En octubre de 1967, Dubček y sus seguidores criticaron abiertamente la política de la dirección del Partido Comunista, desencadenando una crisis interna que culminó con su nombramiento como secretario general el 5 de enero de 1968. Desde ese cargo, Dubček lanzó un amplio programa de reformas conocido como la "Primavera de Praga" (marzo-agosto de 1968), a través de una política de liberalización que se definió como "socialismo de rostro humano". Falleció en 1992 a causa de las heridas sufridas en un accidente de coche.

${ }^{80}$ Tal y como figuraba en su pasaporte expedido en París el 11 de agosto de 1969, tampoco era válido en los siguientes países: «Albania, Mongolia exterior, Rep. Popular China, Rep. Popular Corea, Rep. Dem. Vietnam».

${ }^{81}$ La Nueva España, 22/03/2010.
} 
Primavera de Praga. Los evidentes signos de liberalización política en Checoslovaquia acabaron con la entrada de las tropas del Pacto de Varsovia en la capital. Tras una llamada de Emilio Romero -el director de Pueblo descubre que no está en Praga sino en Pravia- José Luis Balbín decide regresar a Viena. Relataría posteriormente que en el tren en dirección a Praga lo interpeló una patrulla rusa. Y, aunque no descubrieron que el pasaporte que llevaba era falso, le obligaron a volver a Viena ${ }^{82}$.

En la primavera de 1970, como corresponsal del diario Pueblo en Alemania, José Luis Balbín aparece como candidato para hacerse con el control de la Agregaduría Laboral de Bonn $^{83}$. En el Servicio Exterior de la Organización Sindical Española, en el Archivo General de la Administración, hay documentos que relacionan directamente a José Luis Balbín y a Rodolfo Martín Villa (quien había sido nombrado secretario general de Organización Sindical en noviembre de 1969), informando sobre actividades de otros periodistas. Un ejemplo de ello es la carta enviada por José Luis Balbín al propio Rodolfo Martín Villa:

«Nunca te habría propuesto algo que no me creyese capaz de hacer bien. Y si algo se me da, son los diputados centroeuropeos -comunistas incluidos-, los sindicalistas reticentes y los emigrantes contestatarios. Cara a los emigrantes, estoy convencido de que se podría encauzar mejor su politización evidente. Cara a los políticos del país, me comprometo desde ya a llevarte a cuantos quieras a España -si en su momento interesa- y no solo a los grupos adictos, como se viene haciendo tradicionalmente» ${ }^{84}$.

De nuevo, redes de sociabilidad -en este caso evidentemente políticas- que a finales de la dictadura podían serle útiles a su regreso a España como periodista. En su etapa en Alemania también conoció, entre otros, a Xabier Arzalluz, quien durante la Transición asumiría la dirección del Partido Nacionalista Vasco (PNV). Al cesar de Bonn como corresponsal de Pueblo, y regresar a España a inicios de 1970, dejó una deuda en el Deutsche Bank de 2.611 marcos. Una información personal que, sin embargo, retuvo junto a otras informaciones el Ministerio de Información y Turismo ${ }^{85}$.

\footnotetext{
${ }^{82}$ Sobre su liberación a cambio de una botella de coñac, véase La Nueva España, 22/03/2010. Es un acontecimiento que suele recordar José Luis Balbín en entrevistas posteriores. Véase "José Luis Balbín: «Me jugué la vida a los chinos»", La Razón.es, 29/11/2012.

${ }^{83}$ Cfr. A. Muñoz Sánchez, "El Sindicato Vertical 'al servicio de inmigrante'. La Agregaduría Laboral de la embajada española en Bonn durante los años sesenta”, en Historia, Trabajo y Sociedad, no 3, 2012, p. 156.

${ }^{84}$ Véase la carta que José Luis Balbín dirige a Rodolfo Martín Villa en julio de 1970 en el anexo n 3. AGA.

${ }^{85}$ Carta de José María Moliner, Consejero de Información, fechada el 19 de marzo de 1970. Ministerio de Información y Turismo. AGA.
} 


\subsubsection{París no es una fiesta}

Tras la corresponsalía en Alemania, su regreso a España fue fugaz. José Luis Balbín aceptaba ir a Televisión Española «con la condición de que me ofrecieran un sitio que me gustara» $^{86}$. Desde la distancia, había seguido el mayo francés con un amigo, Michel Platin (quien sería subdirector de Le Monde), que también influyeron en su decisión de aceptar ser corresponsal delegado de TVE en París. Aunque probablemente fuera una decisión que también consultara con Rodolfo Martín Villa, visto el comentario:

«esto de la radio y la televisión no me va nada: el 'micro' me pone nerviosísimo. Y además me parece un periodismo poco serio» ${ }^{87}$.

En 1970 acepta ser corresponsal de TVE y de RNE en París. Y a los tres meses es nombrado delegado de TVE en Francia. «Los corresponsales trabajábamos de la mañana a la noche, pues te estaban llamando continuamente de Madrid, incluida la rueda de prensa internacional que coordinaba Victoriano Fernández Asís» ${ }^{88}$. En esta entrevista añade que como delegado de TVE estaba obligado a hacer cuentas, negándose en muchas ocasiones, alegando que lo que realmente quería hacer era periodismo. Es en la capital francesa cuando se inspira para posteriormente adaptar La clave. La segunda cadena de la televisión francesa Antenne 2, emitía en esos momentos el programa de debates Les Dossiers de l'écran, que llevaba en antena desde 1967. Sin embargo, pasarían todavía cinco años para trasladar el formato francés en España, «intentando que fuera parecido, aunque no igual» ${ }^{89}$.

En España, el 3 de diciembre de 1970 se inició el llamado proceso de Burgos contra dieciséis miembros de la organización armada Euskadi Ta Askatasuna (ETA), que provocó una fuerte movilización internacional a través de manifiestos, comunicados y actos de solidaridad con los encausados ${ }^{90}$. José Luis Balbín relataría posteriormente el funcionamiento de la

\footnotetext{
${ }^{86}$ Entrevista 1986, Historia de TVE. Coleccionable Diario Ya, 1986, p. 119.

${ }^{87}$ Carta de José Luis Balbín a Rodolfo Martín Villa, fechada en julio de 1970. AGA. Véase anexo no 3.

${ }^{88}$ Entrevista 1986, Historia de TVE. Coleccionable Diario Ya, 1986, p. 119. Buenos días, París, era la rueda matinal de corresponsales. Para José Luis Balbín «la antítesis de un programa radiofónico. Era mentira que fuese en directo. Se grababa a las siete de la mañana y se emitía a las ocho», en "La clave, único programa de debate en directo de TVE, cumple hoy el número cien”, El País, 14/07/1979.

${ }^{89}$ Entrevista 1976, Mediterráneo, 14/03/1976, p. 10. «La clave no fue idea mía, sino una adaptación de Les Dossiers de l'écran», en A. Font, La transición política española. Los años Pujol, P.C. Publi Corinti, Barcelona, 2003, p. 485. «De mi paso por Europa, adquirí una serie de conocimientos para programas de televisión, entre ellos La clave; el programa nació en Francia», José Luis Balbín, Mediterráneo, 14/03/1976, p. 10.

${ }^{90}$ Sobre el proceso de Burgos, L. Bruni, ETA: historia política de una lucha armada, Txlaparta, Navarra, 2006, pp. 109-129.
} 
corresponsalía francesa en aquella época. «Te llamaban para decirte: qué dice a favor por ahí la prensa francesa. Y claro, a favor no decía nada; pero ellos se empeñaban en que dijera algo a favor de la prensa francesa o la inglesa» ${ }^{91}$. Con "ellos" se refería a los dirigentes de RTVE y, especialmente, a quien ocupaba en esos momentos la dirección de RTVE: Adolfo Suárez (19691973). El que sería primer Presidente de la democracia, antes de ocupar la dirección general de RTVE en 1969, había ocupado otros cargos en televisión: en noviembre de 1964 había sido nombrado secretario de las Comisiones Asesoras de TVE (que presidia Torcuato FernándezMiranda), y en enero de 1965, director de Programas de TVE. Como director general de RTVE se preocupó de cuidar y proyectar una imagen positiva del príncipe Juan Carlos de Borbón. Tuvo algunas discrepancias con el recién llegado José Luis Balbín. En un coloquio que preparaba la televisión francesa a raíz del proceso de Burgos, según el relato de José Luis Balbín, Adolfo Suárez le llama para que represente a España, pero se niega. Tiempo después, cuando se programó la serie Crónicas de un pueblo (dirigida por Antonio Mercero entre 1971$1974)^{92}$, Suárez le volvería a pedir regresar a España, pero decidió quedarse en París ${ }^{93}$.

El 23 de diciembre de 1973, ETA atentó mortalmente contra el presidente del Gobierno, Carrero Blanco. Días después, el 4 de enero de 1974, Carlos Arias Navarro fue nombrado nuevo presidente del Gobierno. Los casi cuarenta años de dictadura pesaban y el franquismo vivía su recta final con fuertes desafíos. En Francia, José Luis Balbín era testigo del fallecimiento en abril de 1974 del presidente Georges Pompidou. Francia se movilizó en unas elecciones que enfrentaban al socialista François Mitterrand contra Valéry Giscard d'Estaing. Las desavenencias continuas entre Adolfo Suárez y José Luis Balbín hicieron que el director general de RTVE le pidiese personalmente que abandonara París y regresara Madrid. En palabras del propio José Luis Balbín, «Las expectativas de un triunfo de la izquierda en las elecciones francesas no podían tener un portavoz a un hombre que no tenía toda la confianza de los directivos ${ }^{94}$. «Había que dar un cierto tono a las cosas que yo no le di. (...) Me sacaron de París ${ }^{95}$. París ya no era una fiesta. Atrás quedaban unas elecciones que darían el triunfo a Giscard d'Estaing. José Luis Balbín, tras casi una década en el extranjero, regresaba a España.

\footnotetext{
${ }^{91}$ Entrevista 1986, Historia de TVE. Coleccionable. Diario Ya, 1986, p. 119.

${ }^{92}$ Con el propósito de mostrar la evolución del país, esta serie de televisión narraba la vida cotidiana de un pueblo ficticio de Castilla.

${ }^{93}$ Véase el apartado “negativas a Suarez” en La Nueva España, 22/03/2010.

${ }^{94}$ Entrevista 1986, Historia de TVE. Coleccionable. Diario Ya, 1986, p. 119.

${ }^{95}$ Entrevista 1980, Interviú, no 194, 31 de enero-6 de febrero de 1980, p. 77.
} 


\subsection{La clave de José Luis Balbín}

¿Fue La clave una estrategia deliberada desde el poder político? Cuando Juan Luis Cebrián (futuro director de El País) es nombrado director de los Servicios Informativos, en febrero de 1974, como argumenta Ramón Tijeras, pasaban por rojos profesionales de TVE como José Luis Balbín ${ }^{96}$. A su regreso a España -y como un filtro interno de RTVE- lo tienen un periodo "haciendo pasillos"97. Sin embargo, inmediatamente es destinado a Viena, en Austria, con el fin de abrir una corresponsalía y hacer información sobre países del Este. «Me mandaron a Viena porque hablaba alemán y conocía los países del Este, pero el proyecto de corresponsalía se fue dilatando y estaba claro que era un destino ficticio, para quitarme del medio» ${ }^{98}$.

Al volver de nuevo a España se convierte en comentarista político internacional de los telediarios y en enviado especial. «Me enviaron a congresos internacionales, como el de los No Alineados, en la última época del mariscal Tito, y hasta me tuvieron de jurado del festival de Eurovisión» (Satué 2005: 486) ${ }^{99}$. Le llamaban para hacer concursos y programas musicales que descartaba alegando que no era lo suyo. «Prefiero estar castigado sin trabajar cuatro años, que estar haciendo algo que a mí no me gusta» ${ }^{100}$. Situación que no cambió hasta que Rodolfo Martín Villa le nombra, en marzo de 1974, jefe de Prensa y director de Servicios Informativos del Ministerio de Obras Públicas ${ }^{101}$. José Luis Balbín se convirtió, con treinta y tres años, en el responsable oficial ante los medios de información del Ministerio de Obras Públicas. Permaneció en el cargo tres meses ${ }^{102}$.

Posteriormente impartió alguna conferencia y participó en congresos que le suscitaban interés, como el organizado por la Escuela Oficial de Periodismo sobre el Mercado Común, que tenía como propósito examinar la problemática planteada por la crisis del petróleo en sus países

\footnotetext{
${ }^{96}$ R. Tijeras, “La transición en Radio Televisión Española bajo el influjo de Adolfo Suárez”, en Comunicación 21, Revista científica de estudios sobre cultura y medios, $\mathrm{n}^{\mathrm{O}} 2$, abril de 2012, p. 12, citando la obra de Pedro Muñoz, RTVE: la sombra del escándalo, Temas de Hoy, Madrid, 1990.

97 «Para un trabajador estar en el pasillo es estar sin cometido alguno, sin trabajo» (Sinova 1983: 152). Es una expresión que José Luis Balbín utiliza en distintas entrevistas: Historia de TVE. Coleccionable. Diario Ya, 1986, p. 119; A. Font, La transición política, op. cit. p. 486; o más recientemente en La Nueva España, 23/03/2010.

98 Historia de TVE. Coleccionable. Diario Ya, 1986, p. 119. «Me forzaron a irme a Viena a montar una corresponsalía para los países del este. Me pareció una injusticia enorme, pero pese a todo cedí. Fui a Viena y aguanté un mes y pico». Entrevista en 1980, Interviú, no 194, 31 de enero-6 de febrero de 1980, p. 77.

${ }^{99}$ Cfr. Historia de TVE. Coleccionable. Diario Ya, 1986, p. 119. Le envían de jurado a Eurovisión, a un festival de televisión en Luxemburgo y a una conferencia sobre el Tercer Mundo en Argel. La Nueva España, 23/03/2010.

${ }^{100}$ Entrevista 1980, Interviú, no 194,31 de enero-6 de febrero de 1980, p. 77.

${ }^{101}$ Fuente: $A B C, 6 / 03 / 1974$, p. 42.

102 Conversación con José Luis Balbín, Estrasburgo, 19/04/2014.
} 
miembros ${ }^{103}$. Crisis iniciada en agosto de 1973, será uno de los doce temas que examine $L a$ clave en 1976 con el título La banca del oro negro (ficha 9). El 23 de septiembre de 1974 José Luis Balbín cesa como Secretario del Departamento Nacional de Información del SEU, siendo Daniel Regalado Aznar su Jefe Nacional ${ }^{104}$.

\subsubsection{Historial académico y sindical}

Creemos relevante detenernos en el expediente personal de José Luis Balbín que poseía el Ministerio de Información y Turismo al mostrar la relevancia que adquirían las trayectorias de quienes llegaban a ser periodistas en España durante el franquismo. El Ministerio de Información y Turismo posee dos documentos sobre José Luis Balbín que hacen referencia a su trayectoria. El primer documento que creemos relevante mostrar hace un breve recorrido de su trayectoria hasta el 7 de noviembre de 1963, momento en el que es nombrado Secretario del Departamento de Información del SEU.

\section{-HIS"BIAL ACADEIICO Y STIDTCAL -}

Comenzó la carrera de Derecho a los dieciseis años, je en Miadrid, con residencia en ol Colegio Nayor "Nobrija". Más tarde pasó al Colegio liegyor "Diego de Covarmibias". Cuando hacia segundo de Derecho, ingresó en la Escuela Oficial de Periodismo, dondehizo los tres años con la XXIII promoción. Anteriormente habia pertenecido al Frente. de Juventudes, del que es Jefo de Centuria nacional.

Fue Delegado de Curso en la Escuela Oficial de Periodismo. Así miswo Delegado de Iscuela on la \$.O. de Periodismo y lliernbro de la Comisión permenente del D.U.

Fotografía $n^{0} 5$. Historial académico y sindical de José Luis Balbín ${ }^{105}$.

En esos momentos, el ministro de Información y Turismo es Manuel Fraga Iribarne (1962-1969). En el documento observamos los datos de su trayectoria que destaca dicho ministerio, como fue su paso por el Frente de Juventudes o los cargos que ocupó mientras realizaba sus estudios en Periodismo. El segundo documento que presentamos, retoma algunos

\footnotetext{
103 José Luis Balbín impartió el 27 de marzo una conferencia titulada "Europa bajo cero". Fuente: ABC, 2/03/1974, p. 62. Entre algunos conferenciantes, Laureano López Rodó, Luis González Seara, José María de Areilza, el falangista Dionisio Martín Sanz (procurador que votará en contra de la Ley para la Reforma Política el 18 de noviembre de 1976), Fernando Suárez, o Luis María Ansón. La conferencia de clausura fue pronunciada por Francisco Fernández Ordoñez, presidente del Instituto Nacional de Industria.

${ }^{104}$ Expediente personal de José Luis Balbín Meana como miembro del personal político del SEU. Caja 51/20341. AGA.

105 Fuente: Ministerio de Información y Turismo. Gabinete de Enlace, caja 42/08788, exp. 3. AGA. [presenta algunos errores. Comenzó la carrera de Derecho a los dieciocho años.]
} 
datos anteriores y se extiende temporalmente hasta noviembre de 1976. Figuran datos como la obtención del título de periodista en 1966, su estancia de corresponsal en Bonn o la deuda económica del Deutsche Bank. Pese a algunos errores [no estuvo en Londres sino en París como corresponsal de RTVE], el expediente del SEU sobre José Luis Balbín es bastante significativo, pues no solo se observa la trayectoria profesional y política de los periodistas, también los datos de los que desde el Ministerio de Información y Turismo se quería hacer constar (en este caso, el pertenecer al Frente de Juventudes, del que fue Jefe de Centuria Nacional).

Datos oficiales que contrastan, en cambio, con los primeros apuntes biográficos que aparecen en prensa a raíz de su nombramiento como Jefe del Gabinete de Prensa en el Ministerio de Obras Públicas ${ }^{106}$. Sin embargo, es reseñable el problema al que se apunta en la trayectoria de José Luis Balbín. Y una constante mientras dirija el programa durante la Transición española: dónde situar políticamente a José Luis Balbín ${ }^{107}$.

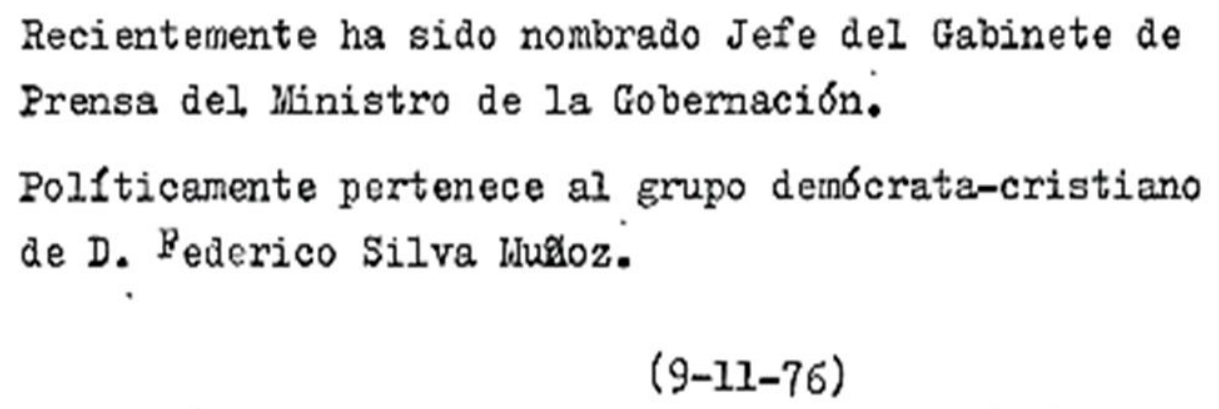

Fotografía $n^{\circ}$ 6. Dossier informativo de José Luis Balbín en $1976^{108}$.

Como observamos en este dossier informativo, el Ministerio de Información y Turismo situaba políticamente a José Luis Balbín al grupo demócrata-cristiano de Federico Silva Muñoz, quien había pertenecido a la Asociación Católica Nacional de Propagandistas (ACNP) y había sido ministro de Obras Públicas entre 1965-1970. Aunque sí provenía de la corriente democristiana no podría deducirse que se integrara en el grupo demócrata-cristiano. Al ser preguntado José Luis Balbín por su pertenencia al grupo de Silva Muñoz, lo niega y afirma que

\footnotetext{
${ }^{106}$ Datos que se den a conocer a la opinión pública cuando dirija La clave: «El señor Balbín fue editorialista del periódico Pueblo, jefe de Prensa de la Hermandad Sindical de Labradores y Ganaderos y corresponsal-delegado en París y comentarista y enviado especial de Radio Nacional de España y Televisión Española», ABC, 8/03/1974, p. 42.

107 ¿Dónde podríamos situar políticamente a José Luis Balbín en 1975? «Dicho con buena expresión, en ningún sitio». José Luis Balbín. Entrevistado el 16 de abril de 2014 en la Universidad de Estrasburgo. Véase la entrevista completa en el DVD anexo.

${ }^{108}$ Fuente: Ministerio de Información y Turismo. Gabinete de Enlace. Dossier informativo sobre José Luis Balbín Meana. Años 1974-1976. Caja 42/08788. exp. 3. Véase la información completa en el anexo ${ }^{\circ} 4$.
} 
era mucho más próximo a Joaquín Ruiz-Giménez, fundador de la revista Cuadernos para el Diálogo en $1963^{109}$. Tal y como argumenta Javier Tusell, en los años sesenta, la democracia cristiana «había jugado un papel importante en los medios de la oposición y, en el momento de la transición, un sector de ella, la Izquierda Democrática, dirigida por Ruiz-Giménez, vino a servir de intermediario entre gran parte de la oposición y de vehículo de contacto con el Gobierno» (Tusell 2003b: 102).

Observamos en la trayectoria de José Luis Balbín una progresiva separación del régimen a medida que avanzan las etapas. En su paso por los distintos colegios mayores coincide con una nueva generación universitaria (tanto en Derecho como en Periodismo); conexiones, por otra parte, que podrían explicar significativamente la connivencia que hubo entre los medios de comunicación y el poder político durante la Transición española. De carácter carismático, José Luis Balbín había ido creando toda una serie de determinados vínculos a través de círculos y de redes de distinto signo (políticas como Rodolfo Martín Villa, profesionales como Emilio Romero, o estudiantiles como Sabino Fernández Campo, Joaquín Ruiz-Giménez o Manuel Vázquez-Prada).

Redes que precisamente son claves. De estas redes estudiantiles y políticas procede la relación que mantenía con el director de RTVE, Jesús Sancho Rof ${ }^{110}$. Ambos habían nacido en 1940, y se conocían de la Universidad y del SEU. Sancho Rof tenía en esos momentos 33 años, era doctor en Ciencias Físicas por la Universidad Complutense de Madrid y había sido Procurador en Cortes ${ }^{111}$. Como indica Manuel Palacio, «estaba vinculado con las posiciones políticas de Rodolfo Martín Villa y pertenecía a los sectores provenientes del SEU» (Palacio 2012: 42). Añade además que su dirección «estuvo marcada por la dialéctica que gobernaba todo el fin de la época del franquismo: propugnar una apertura social y política desde parámetros fijados en el interior del Movimiento Nacional, y abrir levemente las ventanas de la ciudadela franquista» (Palacio 2012: 43).

Jesús Sancho Rof y José Luis Balbín mantuvieron a lo largo de 1975 distintas conversaciones sobre el devenir de la televisión. José Luis Balbín le argumentaría que «lo menos que debe tener TVE son programas en directo que en América o en Alemania son

\footnotetext{
${ }^{109}$ Conversación con José Luis Balbín, Madrid, 18/07/2014.

${ }^{110}$ Jesús Sancho Rof fue el último director general de RTVE durante el franquismo. Había sido nombrado el 22 de noviembre de 1974 en sustitución de Juan José Rosón. A estas alturas no era llamativo que tanto Sancho Rof como Rosón procedieran del mismo colegio mayor, en este caso por el Colegio Mayor Santa María.

${ }^{111}$ Fuente: Blanco y Negro, 4/10/1975, p. 4. Véase la entrevista a Sancho Rof completa, pp. 4-7.
} 
normales» ${ }^{112}$. En otoño de ese año hablaron de programas y propuestas concretas: «le presenté entonces una serie de proyectos, cinco o seis. En realidad eran propuestas, pensando cosas que se hacían por el mundo y aquí no se hacían» (Situé 2005: 487, Reguera y Aparicio 2006: 56) ${ }^{113}$. Entre esas propuestas, en última posición de la lista se encontraba el programa La clave. «Supongo que lo aceptaron precisamente porque habían descartado los demás» y, al tratarse de un programa de más de dos horas, la única alternativa era hacerlo en la segunda cadena, «aunque me daba cuenta de lo que eso significaba, porque hay que recordar que la televisión en aquellos momentos era en blanco y negro, y la cobertura de la segunda cadena todavía no llegaba a todo el país» (Situé 2005: 487). En octubre de 1975 llegaron a un acuerdo Jesús Sancho Rof y José Luis Balbín. La clave se aprobaba con un presupuesto de un millón ochocientas mil pesetas para los primeros trece programas y lo dirigiría y moderaría el propio José Luis Balbín ${ }^{114}$. Televisión Española estaba a punto de emitir el que sería el primer programa de debates en directo en España.

La propia temporalidad del programa nos permite, por tanto, definir y enmarcar los límites cronológicos de este trabajo. La primera emisión del programa se produjo el domingo 18 de enero de 1976 bajo el título de El juego. La última, el 20 de diciembre de 1985, titulada 20 años de Vaticano II. Tras ella, la dirección de RTVE anunciaría a José Luis Balbín que el programa finalizaría el viernes 27 de diciembre de 1985. Envuelto en polémica, un día antes de la emisión, los directivos de RTVE deciden también censurar el último programa alegando que José Luis Balbín había cambiado el tema y los invitados para debatir finalmente sobre la OTAN. Un cambio en el título (de La movida a La movida nacional), que fue determinante para su prohibición. Pese a ella, y bajo una gran expectación, su director acabó realizando el programa en el interior del Hotel Palace de Madrid. Años después diría que este hecho supuso que «para el PSOE fuera un traidor y para la derecha, un rojo» ${ }^{115}$. José Luis Balbín fue cesado de su cargo, y el programa La clave suprimido de la programación de TVE.

\footnotetext{
112 Entrevista 1986, Historia de Televisión. Coleccionable. Diario Ya, 1986, p. 120.

${ }^{113}$ Le propuso a Jesús Sancho Rof «programas muy diferentes; de literatura, de información internacional, de contenido social, digamos que yo intentaba convencerles de que no tenía interés en hacer una cosa política determinada», José Luis Balbín, entrevista de 1986, Historia de TVE. Coleccionable, Ya, 1986, p. 120.

${ }^{114}$ No se han encontrado las Actas del Consejo de Dirección que aprueba el programa porque no se conservaron. La información está extraída de distintas entrevistas y artículos en prensa. El propio José Luis Balbín ha reconocido en distintas ocasiones que el programa se aprobó un mes antes de la muerte de Francisco Franco.

115 La Nueva España, 20/03/2010. Para el periódico ABC, José Luis Balbín «representa a una generación de periodistas enmarcados en el cambio en Televisión Española tras la ascensión del Partido Socialista en 1982, que pasaron de una ideología progresista a concepciones más conservadoras de la actualidad política española por las desavenencias que tuvieron con el gobierno de Felipe González», ABC, 26/03/2008.
} 


\subsubsection{Trayectoria posterior}

La trayectoria de José Luis Balbín durante el proceso de Transición será analizada con mayor profundidad en la segunda parte de esta tesis doctoral. Destacar que entre 1976 y 1985 dirigió los 408 debates de La clave, pero también ocupó diferentes cargos directivos en RTVE: con UCD en el gobierno y Fernando Castedo director general de RTVE, fue nombrado director de Programas Especiales (1981) y, tras la victoria del PSOE en octubre de 1982 y José María Calviño en la dirección general, fue nombrado director de los Servicios Informativos de TVE (1982-83), uno de los cargos de mayor relevancia en RTVE.

Tras la supresión del programa en 1985 y su cese fulminante de TVE, se inició una nueva etapa en la trayectoria de José Luis Balbín. Pero desde entonces su nombre estará asociado al programa La clave. Tras más de una década en televisión, José Luis Balbín centró su carrera profesional en el ámbito de la radio. En 1988, estando en el paro, le llamó su compañero de promoción, Manuel Martín Ferrand, para encargarse de coordinar y presentar la tertulia de Hora Cero, en Antena 3 Radio. En pocas semanas situaría la audiencia del programa en primera posición, superando a la cadena $\mathrm{SER}^{116}$.

En 1990 regresó de nuevo a televisión para dirigir La clave, aunque en esta ocasión en Antena 3 Televisión. Su primera emisión se realizó el 26 de enero de 1990, un día después de la inauguración de la cadena. En esta nueva etapa, el programa se emitió los viernes y el formato fue el mismo en las dos primeras temporadas (1990-1992) pero, a partir de 1992, la cadena decidió eliminar la película centrándose exclusivamente en el debate ${ }^{117}$. El programa se mantuvo hasta junio de 1993, fecha en la que los responsables de Antena 3 decidieron suspenderlo de manera indefinida alegando motivos empresariales y caída de audiencia. Fuentes de la cadena privada manifestaron que era uno de los programas de mayor calidad que se habían hecho hasta esos momentos en Antena 3 Televisión, aunque no era lo suficientemente rentable como para mantenerlo en pantalla. Como vimos en el primer capítulo, ya no importaba la calidad de los programas si éstos no eran rentables en el nuevo modelo comercial de televisión.

\footnotetext{
116 «Fue una etapa irrepetible y todo gracias a Manolo Martín Ferrand, que hizo, con nosotros, que una emisora FM se colocase primera de audiencia y se cargase la hegemonía de la intocable cadena SER. Por entonces teníamos muchas zonas sin cobertura, era lo que llamábamos la "España en sombra", pero aun así, ganábamos a la SER. Eso fue lo que, precisamente, produjo su fin. Prisa, que es decir, Polanco, compró con una OPA hostil Antena 3. Fue algo totalmente ilegal, como se demostró en los tribunales», José Luis Balbín, en I. Reguera Pascual y J. J. Aparicio Arriola, Carlos Pumares: Un grito en la noche, op. cit. p. 67.

${ }^{117}$ Hasta esos momentos había ido variado de horario llegando a emitirse incluso de madrugada.
} 
En 1992, José Luis Balbín dejó Antena 3 Radio y se trasladó a la cadena Cope, para trabajar primero como colaborador de La Linterna y, posteriormente, de La Mañana, ambos dirigidos por Luis Herrero. En 1994 estrenó nuevo programa en Antena 3 Televisión, La senda, un espacio que combinaba el reportaje y la entrevista ${ }^{118}$. Trabajó de columnista en las revistas Interviú y O.T.R. También fue comentarista en Estrella Digital, primer diario español digital en Internet, moderador de la serie de televisión dedicada al IV centenario de Felipe II, y director de La noche de Urogallo y La voz de José Luis Balbín en Radio Voz hasta febrero de 1997, fecha en la que sería nombrado director de Comunicación y Programas del Museo del Prado ${ }^{119}$.

En 1998, trece años después de la suspensión de La clave en TVE, José Luis Balbín regresó a la cadena pública con un nuevo programa llamado Las claves... Fue un programa de entrevistas biográficas a grandes figuras del siglo XX como Mijaíl Gorbachov, Katharine Graham, Walter Cronkite, Giorgio Armani o el cocinero francés Paul Bocuse ${ }^{120}$. La clave regresaría en diciembre de 1998 con un último programa. Se trataba de un especial titulado $L a$ Constitución española a los 20 años que fue realizado en el interior del Congreso de los Diputados, y en el que nos centraremos a continuación.

Un año más tarde, en 1999, fue nombrado director del semanario de información general Artículo 20, sucediendo a Mario Conde. La revista cerró pocos meses después de su llegada, en enero de 2000, tras un Expediente de Regulación de Empleo. Finalmente, en 2001, José Luis Balbín cumplió uno de sus sueños profesionales: dirigir un semanario de opinión política. Ese año fundó La Clave, bajo el mecenazgo de Mercedes Cort, una aristócrata nostálgica del programa. José Luis Balbín optó por un espacio de producción más pausada y fue el director del semanario hasta su cierre definitivo en julio de $2008^{121}$. Desde entonces y hasta la actualidad, siguiendo con su vocación periodística, ha dirigido distintos debates en el Centro Cultural de la Villa de Madrid, y ha continuado escribiendo artículos en periódicos nacionales. El 17 de junio de 2015, el Ministerio de Educación, Cultura y Deporte concedió a José Luis

\footnotetext{
${ }^{118}$ El programa se estrenó el 20 de enero de 1994 con un reportaje sobre Nicolás Redondo, secretario general de UGT. Fuente: “José Luis Balbín entrevista a Woody Allen en Antena 3 TV”, El País, 24/01/1994.

119 “José Luis Balbín dice que su llegada al Prado no es un favor político”, El País, 14/03/1997.

${ }^{120}$ El programa se emitió desde septiembre de 1998 hasta abril de 1999. Se trataba de una mezcla de entrevista, biografía y documental. El primer invitado fue Mijaíl Gorbachov, expresidente de la URSS y artífice de la perestroika. Fuente: “José Luis Balbín regresa a TVE con una entrevista a Mijaíl Gorbachov", El País, 23/09/1998.

${ }^{121}$ Dirigió este semanario desde su fundación en 2001 hasta su cierre en 2008. Tras el cierre, la revista apareció en formato digital, alternando nuevos artículos con algunos anteriores. Véase La Clave digital en la web: http://laclave.com/ [consultado el 1/07/2015].
} 
Balbín el Premio Nacional de Televisión. Su figura, asociada al diálogo y a la libertad de expresión es a día de hoy unánimemente reconocida.

\subsection{Face à face. Una entrevista a José Luis Balbín}

Como ya han señalado algunos autores, durante la Transición española hubo una evidente connivencia entre periodismo y política ${ }^{122}$. Creíamos relevante rescatar la figura de José Luis Balbín no solo como director del programa, también como testimonio directo de TVE durante este periodo. El primer objetivo fue rescatar de la hemeroteca las entrevistas que había concedido a lo largo de su trayectoria en distintos medios de comunicación. Periodista por vocación, nunca ocultó su debilidad por el periodismo escrito, como relataba en una de sus primeras entrevistas al frente ya del programa La clave ${ }^{123}$.

A lo largo de toda su carrera profesional escribió artículos en diversos periódicos (Arriba, Pueblo, La Hoja del lunes, ABC...), y concedió numerosas entrevistas (ABC, El País, Diario de Pontevedra, La Razón, Interviú, Mediterráneo, La Nueva España, Diario de Pozuelo...). Sin embargo, en estas entrevistas se destacaban esencialmente las mismas ideas y generaban, a nivel biográfico, dispersión y vacíos en su trayectoria. Pese a ello, en las entrevistas concedidas entre 1976 a 1985 y las concedidas a partir del año 2000, llama la atención un discurso público que apenas sufre variaciones. De la abundante información en prensa, hemos destacado unos artículos señalados previamente de Javier Morán, escritos en 2010 en el periódico La Nueva España de Oviedo, a modo de memorias de José Luis Balbín ${ }^{124}$. En estos artículos se recordaban algunas etapas vitales desde su nacimiento en Pravia en 1940, y se llegaba hasta la fundación de la revista La Clave en 2001, lo que supone un esbozo biográfico de lo que sería su trayectoria personal y profesional.

En radio también tuvo una importante trayectoria posterior. Tras su etapa en televisión pasó por algunas emisoras como Antena 3 Radio, la cadena COPE, o Radio Voz. Una etapa que no analizamos al ser la radio otro medio de comunicación y exceder los límites cronológicos

\footnotetext{
${ }^{122}$ Cfr. V. Martín, Televisión Española y Transición democrática, op. cit. p. 81.

${ }^{123}$ Fuente: Entrevista a José Luis Balbín en Mediterráneo, 14/03/1976, p. 10.

${ }^{124}$ Sección por entregas de cuatro capítulos bajo el título de "Memorias" de José Luis Balbín, publicados entre el 21 y 24 de marzo de 2010. Pueden consultarse en la web de La Nueva España, en su formato digital (lne.es).
} 
que hemos establecido ${ }^{125}$. Sin embargo, en relación al programa La clave, concedió diversas entrevistas en programas radiofónicos como No es un día cualquiera, o Esto me suena, ambos en Radio Nacional de España (RNE). También el conducido por Alejandro Sánchez del Olmo, La otra mirada, con una emisión titulada La clave con José Luis Balbín, o el llevado a cabo por Isabel Gemio Te doy mi palabra, en Onda Cero ${ }^{126}$. Además intervino el 22 de octubre de 2013 en el programa La ventana dirigido por Carles Francino en la SER. En este programa, la periodista y documentalista Ángeles Afuera realizó un breve repaso de la historia de La clave, destacando las palabras del periodista José Javier Escarza: «La clave fue el programa idóneo para poner en escena la democracia» ${ }^{127}$. Idea central que desarrollaremos más adelante, estas entrevistas tampoco profundizaban en el programa, esta vez por el tiempo limitado que ofrecía el formato radiofónico.

Sugerente es que la televisión, pese a tener la capacidad de crear su propia historia, no suele atestiguar sobre las figuras que la han hecho posible, privilegiando y predominando, una vez más, las personalidades políticas. En su paso posterior por televisión, José Luis Balbín intervino en los programas España en la memoria, dirigido por Alfonso Arteseros -quien centró la entrevista en un único programa de La clave, el de José Antonio (ficha 201), emitido el 20 de noviembre de $1981^{128}$-; El gran debate de Telecinco, presentado por Jordi González, programa en el que intervino en dos ocasiones (el 21 de julio de 2012 y el 2 de febrero de 2013); y el programa Andalucía.es, dentro del bloque Tesis, en $2012^{129}$.

\footnotetext{
${ }^{125}$ No obstante, véase C. Barrera y P. Dobón, “Antena 3 Radio: nacimiento y primer desarrollo de una empresa periodística singular”, en Revista internacional de la Historia de la Comunicación, ${ }^{\circ}$ 4, vol. 1, Sevilla, 2015 , pp. 175-197.

${ }^{126}$ En estas entrevistas se destacaba su papel como director del programa, la música inquietante y angustiosa inicial compuesta por Carmelo Bernaola o el debate en directo, aunque sin llegar a profundizar realmente en el programa. Las entrevistas pueden encontrarse en la web [programas consultados el 3/10/2014]. Véanse:

- No es un día cualquiera (22 de octubre de 2005): http://www.rtve.es/alacarta/audios/radio/jose-luis-balbin-habla2005-del-programa-clave/757514/.

- Esto me suena (15 de noviembre de 2011): http://www.rtve.es/alacarta/audios/esto-me-suena-las-tardes-delciudadano-garcia/esto-suena-clave-hoy-pone-jose-luis-balbin-15-11-11/1249757/.

- La otra mirada (4 de mayo de 2013): http://www.ivoox.com/otra-mirada-6-temp-la-clave-con-audiosmp3_rf_2008390_1.html.

- Te doy mi palabra (1 de junio de 2013): http://www.ivoox.com/hablando-periodismo-jordi-evole-jose-audiosmp3_rf_2093918_1.html.

${ }^{127}$ http://cadenaser.com/programa/2013/10/22/audios/1382399479_660215.html [consultado el 5/03/2014].

128 Entrevista concedida el 4 de febrero de 2012. España en la memoria fue un programa conducido por el periodista y documentalista Alfonso Arteseros entre 2007 y 2013 en la cadena Intereconomía.

${ }^{129}$ Ese año, la Universidad de Málaga galardonó a José Luis Balbín con el Premio de Periodismo Manuel Alcántara y fue distinguido Miembro de Honor. Véase el programa en la web: http://www.cedecom.es/noticias/jose-luisbalbin/ [consultado el 9/09/2016].
} 
Llama la atención que sea precisamente en la ficción televisiva donde se realicen ciertas aportaciones y se aprecie un reconocimiento al programa y a su trayectoria. En 2008, la serie Cuéntame cómo pasó (2001 - ) utilizó La clave en su trama argumental. También lo hizo en 2009 con la participación en La clave de su principal protagonista Antonio Alcántara (Imanol Arias), que en esos momentos -siguiendo el guion de la serie- era diputado de UCD. Para ello, la voz de José Luis Balbín se grabó previamente desde su casa en Majadahonda. Utilizando la expresión de François Jost, algunas emisiones se convierten en lugares de nostalgia creando una memoria común a una generación (Jost 2013: 19). La clave en España es un claro ejemplo de ello. Sin embargo, ¿cómo hacer frente a la nostalgia televisiva creada a una generación de españoles que creció y se identificó con este programa?

La capacidad educativa de este este programa ha llegado al ámbito universitario. Siguiendo la tradición del programa, José Luis Balbín participaría en diferentes coloquios como el llevado a cabo en febrero de 2004 en el Colegio Mayor Diego de Covarrubias (del que habría que recordar que fue alumno) titulado "La clave", y en la mesa redonda que tuvo lugar con motivo del 25 aniversario del golpe de Estado del 23 de febrero de $1981^{130}$. También ha impartido distintas conferencias con títulos significativos como: "Del modelo de programación de calidad de La clave a la de la televisión basura"131 " "Auge y decadencia del periodismo"132, o "La España de la Transición. Crisis en Televisión Española”, evento del que fui responsable científico $^{133}$.

Por último, destacamos que José Luis Balbín también concedió diversas entrevistas, tanto en obras ${ }^{134}$, como a nivel audiovisual ${ }^{135}$. Para la presente tesis doctoral mantuve distintas

\footnotetext{
${ }^{130}$ Mesa redonda organizada por la Asociación de antiguos colegiales del Colegio Mayor. Se proyectó el documental El 23-F desde dentro (Joan Úbeda, 2001), y contó con la participación entre otros de Luis González Seara, Fernando Suárez González y Alonso Puerta.

${ }^{131}$ Conferencia pronunciada el 6 de mayo 2011 en las Jornadas de Diseño y Comunicación, organizadas por la Escuela Universitaria ESNE y la Escuela de Protocolo de Asturias.

${ }^{132}$ Conferencia pronunciada el 25 de abril de 2013 en la Universidad de Granada.

${ }^{133}$ Conferencia pronunciada el 17 de abril de 2014 en la Universidad de Estrasburgo.

${ }^{134}$ R. Cerecedo y J. M. G. Rayo, Una clase con: Moncho Alpuente, José Luis Balbín, Fernando Salas, Cristina Alberdi, José María Díez Alegría, Aula Abierta de Cultura. Vol. 2, Madrid, 1992. pp. 43-66. A. Font, La transición política española. Los años Pujol, P.C. Publi Corinti, Barcelona, 2003, pp. 449-468, y F. J. Satué, Los secretos de la Transición. Del Batallón Vasco Español al proceso de los GAL, La Esfera de los libros, Madrid, 2005. Véase el capítulo XIV, “Claves para el diálogo y televisión”, pp. 485-496.

135 J. F. Lamata realizó el 13 de marzo de 2012 una entrevista para el diario online Periodista Digital. Véase la web: https://www.youtube.com/watch?v=LNKmFttx5II [consultado el 11/10/2014]. Anteriormente, en 2006, y con motivo del 50 aniversario de la televisión en España, concedió una entrevista que puede consultarse en la siguiente web: http://tv_mav.cnice.mec.es/siglo/50/loaded_movies/guias/siglo/05_videos/01_la_clave.html [consultado el 3/10/2014].
} 
conversaciones con miembros del equipo de La clave, como fueron José Luis Merino (asesor jurídico, documentalista, y posteriormente redactor jefe de La clave) y Rosalía González de Haro (secretaria de redacción), así como con algunos invitados del programa como Ian Gibson (quien participó como invitado en tres ocasiones) o el cineasta José Luis Egea (director del documental Hilos de una trama, utilizado en el programa OTAN: de salida ¿qué?, emitido el 19 de abril de 1985), que me permitieron comparar y profundizar sobre las propias problemáticas surgidas en el programa. Sin embargo, para escapar de la ilusión biográfica ${ }^{136}$, algunos autores han señalado que «es conveniente mantener la distancia con un sujeto por quien, en general, tiene interés y que, por ello lo arrastra a una adhesión no solo intelectual, sino frecuentemente afectiva y pasional» (Dosse 2007: 197-198). A pesar de ello, y con el objetivo de analizar la trayectoria intelectual y política de José Luis Balbín durante la Transición, creímos relevante poder realizar una entrevista a este periodista.

Conocí a José Luis Balbín el 23 de octubre de 2013 en Majadahonda, Madrid. Había finalizado la reconstitución del programa (fecha de emisión, tema, invitados y película), y acababa de visionar todas las emisiones en Prado del Rey ${ }^{137}$. Fueron varias las entrevistas y conversaciones mantenidas con José Luis Balbín. En 2014 me firmó la autorización para poder acceder y consultar sus expedientes personales, custodiados en el Archivo General de la Administración.

El 16 de abril de 2014 pudimos concretar y realizar en la Universidad de Estrasburgo una entrevista filmada a José Luis Balbín. La entrevista puede encontrarse en el DVD junto al listado de programas ${ }^{138}$. Se trató de una entrevista de investigación que buscaba esclarecer algunos episodios y hechos puntuales del programa y entender qué interpretación y qué significado tenían para este periodista. Para llevar a cabo la entrevista estructuramos 25 bloques de preguntas que fueron argumentadas y desarrolladas durante una hora y veinte minutos. Estos fueron los 25 bloques de preguntas:

\footnotetext{
136 Pierre Bourdieu es su máximo exponente. Véase "L’illusion biographique", Actes de la recherche en sciences sociales, $\mathrm{n}^{\circ} 62-63,1986$, pp. 69-72.

${ }^{137}$ No es posible realizar el visionado total de emisiones (408) porque no todos los programas se conservan en la base documental de RTVE. En algunos casos se conserva solo una parte del programa, y son frecuentes los errores de inventario. Sin embargo, superados estos problemas, sí pueden consultarse gran parte de ellos.

${ }^{138}$ Esta entrevista fue posible gracias a la periodista Julia Mesonero y al apoyo de Isabelle Reck, directora del grupo CHER de la Universidad de Estrasburgo, y del equipo técnico de la Dun de dicha Universidad. Agradecer especialmente a un amigo, Carlos Penelo, quien me ayudó a editar dicha entrevista.
} 
1. ¿Qué significó para José Luis Balbín el programa La clave?

2. En relación al periodismo (La Nueva España de Oviedo, el periódico Arriba, la agencia de Estado Pyresa y el diario Pueblo de Madrid). ¿Qué nos podría decir de sus primeras experiencias en el ámbito profesional?

3. ¿Dónde podríamos situar políticamente a José Luis Balbín en 1975?

4. ¿Cuál era el objetivo inicial de La clave? ¿Qué pretendía hacer en octubre de 1975?

5. ¿Los responsables de televisión tenían miedo de La clave por aquello que pudiesen decir los invitados en directo?

6. El equipo de La clave se reunía semanalmente y se preparaban los programas con tres semanas de antelación. ¿Nos puede explicar cómo funcionaba el programa internamente? ¿En qué consistían estas reuniones?

7. La clave se suspendió por primera vez tras doce emisiones y no volvió hasta dos semanas después de las elecciones del 15 de junio de 1977. ¿Cree que La clave se adelantó políticamente a los reformistas del régimen en aspectos como el pluralismo político o la temática tratada?

8. ¿A qué se debía para usted el éxito del programa?

9. En relación a los invitados, ¿por qué era tan importante que en La clave estuviesen representados todos los partidos políticos?

10. En relación a los invitados extranjeros ¿por qué seleccionaban a figuras relevantes internacionalmente? ¿Qué criterios seguían para seleccionar a los invitados? ¿Fue complicado traer a alguno de ellos?

11. Durante este periodo (entre 1975 y 1985) José Luis Balbín pasó por cuatro presidentes del gobierno y por ocho directores generales de RTVE (tantos directores como hubo durante todo el franquismo). ¿Es una muestra de la inestabilidad que sufrió RTVE durante la Transición?

12. ¿Con qué director general de RTVE tuvo más dificultades para realizar La clave?

13. ¿Cómo define José Luis Balbín las injerencias del poder político en televisión?

14. El Estatuto de RTVE (aprobado en 1980), ¿no cree usted que fue precisamente la sumisión de RTVE al poder político?

15. ¿Cómo vivió José Luis Balbín el golpe de Estado del 23 de febrero de 1981? ¿Dónde se encontraba? ¿Qué pensó cuando al día siguiente se publicaron en prensa una lista de condenados a muerte entre los que figuraba su nombre?

16. La clave fue suprimida en distintas ocasiones y algunos programas prohibidos. ¿Cómo calificaría la censura en televisión en este periodo? 
17. ¿Hubo autocensura en La clave? ¿Por qué no se debatió sobre Monarquía o República? ¿Cree usted que la Monarquía era un tema tabú en la Transición?

18. En relación a la temática abordada (drogas, homosexualidad, aborto, pena de muerte, guerra civil...) ¿Recibió usted presiones por querer abordar estos temas? ¿En qué consistían estas presiones? ¿Cuál fue el tema más difícil que tuvo que hacer La clave? ¿Qué criterios siguieron para la selección de los temas?

19. Tras la victoria del PSOE en las elecciones en octubre de 1982, José Luis Balbín es nombrado director de los Servicios Informativos de TVE. En este cargo hubo tres temas que debían pasar por su previa consulta: ETA, la Monarquía y el Ejército. ¿Por qué eran temas de tanta sensibilidad todavía a inicios de 1983 ?

20. Con los socialistas en el poder, se produce el asunto Alonso Puerta (ex concejal socialista expulsado del PSOE tras destapar un caso de corrupción en el Ayuntamiento de Madrid). La clave iba a dedicar una emisión titulada Balance de los Ayuntamientos de izquierda el 14 de enero de 1983 en la que se encontraba el propio Alonso Puerta, pero la víspera de la emisión se decide suspender el programa. ¿Quién censuró ese programa? ¿José Luis Balbín, Enrique Tierno Galván, o José María Calviño?

21. Sobre la suspensión definitiva del programa el 27 de diciembre de 1985, ¿fue abordar la OTAN la causa principal? ¿Quién fue el responsable de esta suspensión?

Tras la suspensión decide realizar el programa en el Hotel Palace de Madrid. ¿Por qué hizo allí ese programa? ¿Cuál fue su relación con TVE después de este episodio?

22. ¿Cree usted que La clave ayudó a conformar una cultura política en la sociedad española?

23. Una de las ideas principales que se extraen de la Transición española es que los medios de comunicación emprendieron una tarea pedagógica. ¿Podría profundizar en esta idea?

24. En relación al cine emitido por La clave, ¿por qué se decantó por el cine-debate como el formato más adecuado para este programa?

25. Finalmente, ¿cómo define José Luis Balbín el proceso de Transición a la democracia? ¿Cómo califica el papel de TVE durante este periodo? ¿Fue la televisión independiente durante la Transición?

Todas estas preguntas fueron expuestas a José Luis Balbín en la entrevista realizada el 16 de abril de 2014. Algunas de sus declaraciones han sido empleadas como argumentos explicativos en el análisis de La clave. 


\section{Capítulo 3. La clave y el debate televisivo en España}

En el siguiente capítulo presentamos, en primer lugar, un análisis general del programa que da cuenta del organigrama, formato, estructura y presupuesto del que se dotaba. Para ello, abordamos la temática del debate, el cine emitido y los invitados que participaron. También se analizan algunas de sus características internas como la independencia del programa, el debate en directo y la audiencia. El objetivo es poder profundizar en el contexto histórico del programa. No todas las emisiones fueron en directo ni todas tuvieron la misma relevancia e impacto. De este modo, no se analizan todas las emisiones sino que hemos optado por su división en bloques temáticos que nos permita, a través del devenir temporal del programa, observar la articulación y la construcción del debate.

\subsection{La clave: ¿historia de la Transición?}

El sábado 5 de diciembre de 1998 se realizó, con motivo del veinte aniversario de la Constitución, un especial La clave en el interior del Congreso de los Diputados. Con ello se pretendía poner punto final a uno de los programas más emblemáticos de la televisión. Fue la primera vez -y única- que La clave se emitió en la primera cadena. Tras la sintonía de Carmelo Alonso Bernaola (misma que sonó entre 1976 y 1985), una cámara de televisión se adentró en el Congreso de los Diputados hasta el Salón de los Pasos Perdidos, donde esperaban los invitados. José Luis Balbín iniciaba este programa dando cuenta de las variantes de un especial titulado Constitución española 20 años después con el que se quiso abordar el significado y las consecuencias del año 1975 hasta la Constitución de 1978.

Tras la proyección de un reportaje realizado por el equipo de Informe Semanal ${ }^{1}$, José Luis Balbín presentó a los invitados indicando a qué claves habían asistido cada uno de ellos, tanto en la UHF como en Antena 3 Televisión. Se trataba de Gabriel Cisneros, Miguel Primo de Rivera, Rodolfo Martín Villa, Pablo Castellano, Santiago Carrillo y Alfonso Guerra. En palabras del moderador, «dos ponentes, dos vicepresidentes del gobierno, y dos líderes políticos». Hubo la habitual controversia en un debate que contaba con tres reformistas del régimen y tres referentes de la oposición democrática. Durante el coloquio se habló precisamente sobre el rol que tuvieron los reformistas del régimen (y su cambio o no de

\footnotetext{
${ }^{1}$ El equipo de Informe Semanal, dirigido en esos momentos por Baltasar Magro, preparó un reportaje con el objetivo de representar a la generación nacida con la Constitución, y para ello daba la palabra a siete jóvenes nacidos el 6 de diciembre de 1978.
} 
actitud $)^{2}$. Pero también de las debilidades de la oposición democrática, la ruptura pactada, la falsificación de la historia, la monarquía, la exigencia de responsabilidades de la dictadura, y el golpe de Estado de 1981. El debate se inició haciendo un repaso de las principales constituciones españolas (concretamente las de 1812, 1876, 1931 y 1978), y finalizó con una reflexión sobre si era necesario reformar o no la Constitución. José Luis Merino, al igual que hiciese en la época, dio voz a la ciudadanía leyendo una selección de preguntas de los telespectadores. José Luis Balbín ya se había despedido del programa en multitud de ocasiones, pero esa noche, cerró definitivamente el ciclo televisivo de La clave.

Veinte años antes habían surgido las bases del programa y los debates en directo. Presentamos en este capítulo un análisis general del programa que explica el funcionamiento, la estructura y el formato, con el propósito de abordar la implantación del debate televisivo en España (pluralidad de invitados, el directo, la controversia, el mejor argumento, la creación de una opinión cualificada...). Sin embargo, ¿puede un programa de televisión representar la expresión cultural de una sociedad? Como argumenta Juan Francisco Gutiérrez Lozano, La clave «simboliza como ningún otro la época histórica de la transición política televisiva» ${ }^{3}$. Retomando algunos datos, como ya hemos señalado, fue primer programa de debates en directo y estuvo en antena desde 1976 hasta finales de 1985, cuando fue suprimido de Televisión Española. El programa se aprobó en octubre de 1975 y su primera emisión se produjo el 18 de enero de 1976. La clave surgió como programa educativo, formativo y cultural, que apostaba por la igualdad en el acceso a la televisión, el pluralismo y la confrontación de ideas. Sus debates permitieron la discusión y la controversia sobre diversos temas, haciendo que los invitados buscaran los puntos fuertes y débiles de cada discurso. Diez años después del primer programa, el 27 de diciembre de 1985, La clave fue suprimida definitivamente de TVE.

Desde la primera emisión, el 18 de enero de 1976, hubo referentes simbólicos que permitieron al telespectador el reconocimiento inmediato del programa. Fueron referentes el

\footnotetext{
${ }^{2}$ Pablo Castellano argumentó «cómo se hizo la Constitución. Y se hizo en las condiciones que había que hacerla. Y se hizo y nos reclamamos todos de ella. Ahora, vamos a devolver a la historia su verdadero contenido porque quien estaba luchando efectivamente por una Constitución democrática no era precisamente la anterior situación, que lo que estaba luchando era por su propia perpetuación en un sistema absolutamente dictatorial y en un sistema negador de libertades». Para Alfonso Guerra «Las personas tienen derecho a cambiar. Las personas pueden estar en una posición que a uno le parece que no es la democrática, la acertada, y luego cambian a una democrática», Centro de Documentación RTVE: La Constitución española 20 años después. Emisión: 5 de diciembre de 1998.

${ }^{3}$ J. F. Gutiérrez Lozano, "La presencia del debate en televisión y su utilidad en la calidad de las programaciones", en Comunicar, op. cit. p. 3.
} 
símbolo del programa y la sintonía inicial ${ }^{4}$. Con respecto al primero, entendemos por símbolo la marca y la identidad del programa, pero también la representación perceptible de una idea. Se trataba de la adaptación en dibujo de «Los tres monos sabios», una escultura de madera atribuida a Hidari Jingorō (1594-1634) situada sobre el santuario de Tōshō-gū (1636), al norte de Tokio. En ella, se representaban los tres monos Mizaru, Kikazaru, Iwazaru, nombres japoneses de «No ver, no escuchar, no decir» 5 .
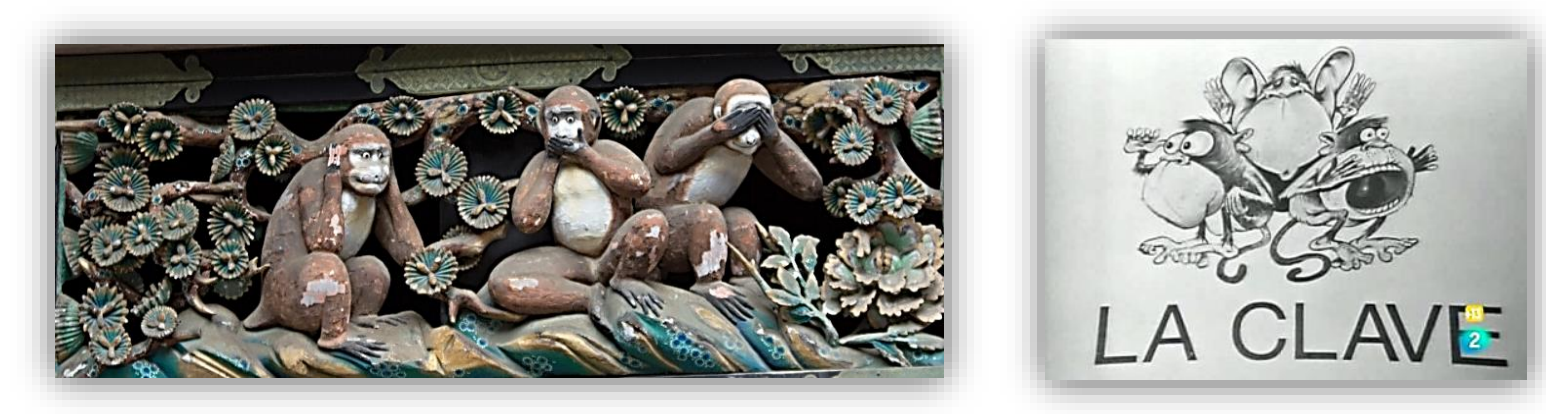

Fotografías $n^{\circ} 7$ y 8 . El símbolo de La clave 6

José Luis Balbín partió de la idea opuesta para adaptarla a La clave: «ver, oír, contar», toda una revelación de intenciones ${ }^{7}$. En las diferentes etapas, todas las emisiones siguieron el mismo esquema: mientras se desarrollaba la música de Carmelo Bernaola y se insertaban los rótulos de las personas que trabajaban en el programa, se distinguían al fondo los invitados hablando con su director, quien, tras la música, daba inicio al programa.

La principal función de programa era realizar un debate en directo con el que abordar un tema que suscitaba divergencia de opinión y controversia en la sociedad española. Pero la repercusión e influencia de La clave está relacionada con su propia dinámica y funcionamiento interno. Presentamos a continuación un organigrama de aquellas personas que integraron el programa en sus diferentes etapas. La estructura interna de La clave estaba formaba por el director, un productor, un realizador, un redactor jefe, y diferentes equipos de trabajo. En total, unos 20 profesionales aproximadamente formaban parte del equipo de La clave. Se trató

\footnotetext{
${ }^{4}$ Melodía que le acompañó en todas sus etapas, y «uno de los referentes sonoros de toda la historia de la televisión española» (Palacio 2012: 101). Sin embargo, de nuevo, una evidente influencia cultural con la sintonía de Les Dossiers de l'écran y la canción Protest del compositor estadounidense Morton Gould; canción que pertenece a la pieza musical Spirituals for String Choir and Orchestra (1941).

${ }^{5}$ E. Ohnuki-Tierney, The Monkey as Mirror: Symbolic Transformations in Japanese History and Ritual, Princeton University Press, Princeton, p. 68.

${ }^{6}$ La primera fotografía procede del archivo de RTVE dedicado al programa. La segunda, extraída de la web http://es.ipcdigital.com/2011/01/07/\%C2\%BFcual-es-la-equivalencia-en-espanol-de-los-refranes-o-dichosjaponeses/mizaru-kikazaru-iwazaru/ [consultado el 2/10/2016].

${ }^{7}$ Un símbolo que le acompañó en todas sus etapas televisivas, incluso en el semanario La Clave (2001-2008).
} 
prácticamente del mismo equipo aunque, a raíz de cambios producidos en sus diferentes etapas, hubo variaciones y cambios puntuales.

Al frente del programa se encontraba José Luis Balbín (director, presentador y moderador). Entre 1976 y 1985 hubo tres productores (encargados del ámbito económico y administrativo): Jesús González (1976), Gonzalo de Esquiroz (1977-1980) ${ }^{8}$, y Gerardo L. Zubiría (1981-1985). También tres realizadores: Pedro Rozas (1976), Adriano del Valle (19771980), y Carmelo José Barrera (1981-1985); y dos redactores jefe: Javier Vázquez (19771980) ${ }^{9}$, y José Luis Merino (1981-1985) ${ }^{10}$. El redactor jefe se encargaba de seguir el guion del programa, leer las preguntas de los telespectadores y sustituir al moderador en caso de ausencia. Al coordinador del programa ${ }^{11}$, se unían otros equipos de trabajo: un equipo de documentación $^{12}$, un equipo de coordinación nacional ${ }^{13}$, y un equipo de coordinación internacional ${ }^{14}$. También formaban parte del equipo un relaciones públicas (Marco Antonio Acevedo), una secretaria de redacción (Rosalía González de Haro), un asesor cinematográfico (Carlos Pumares), y un conjunto de profesionales técnicos encargados de la difusión del $\operatorname{programa}^{15}$.

Como argumenta Jérôme Bourdon, el debate en televisión es un género elaborado esencialmente por una categoría profesional, los periodistas, con la misión de informar sobre el mundo a un ritmo regular, en este caso semanal (Bourdon 2011: 21). José Luis Balbín se rodeó

\footnotetext{
${ }^{8}$ Gonzalo de Esquiroz desarrolló a lo largo de su trayectoria tres profesiones: militar, especialista de cine y productor de TVE.

${ }^{9}$ Javier Vázquez ingresó en Televisión Española en 1967. Presentó Telediario entre 1973 y 1975, así como algunas ediciones de Semanal Informativo (posteriormente Informe Semanal). En La clave ocupó en 1976 el cargo de locutor. Fuente: RTVE 1976, p. 24.

${ }^{10}$ José Luis Merino conoció a José Luis Balbín en 1960 el Colegio Mayor Diego de Covarrubias, del que era subdirector. Entre 1977 y 1980 había ocupado el cargo de asesor jurídico y documentalista, y partir de 1981 y hasta el final del programa, ocupó el cargo de redactor jefe.

${ }^{11}$ El coordinador del programa fue Javier Lacarra, licenciado en teología por la Universidad de Salamanca y en derecho por la Universidad Complutense de Madrid.

${ }^{12}$ El equipo de documentación estaba formado en 1976 por Concha Lacarra, Juan Sierra y Daniel Sueiro. Entre 1977-1980, por Juan Sierra, Daniel Sueiro y María Rosa Chamorro. Y entre 1982-1985, por Juan Sierra, Daniel Sueiro, Isabel Carrasco y Jesús Torbado.

${ }^{13}$ Ladislao de Arriba, Virginia Valdez y Adriana Valdez.

${ }^{14}$ El equipo de documentación estaba formado en 1976 por Ricardo Ciudad, Pedro de Castro y Francisco Lanz. Entre 1977-1980, por Joaquín Ruiz-Giménez Aguilar (hijo), Manuel Velasco, Juan Testa y Rafael Benedito. Y entre 1981-1985, por Joaquín Ruiz-Giménez Aguilar, Juan Testa, Lola Respaldiza y Sandra Muns.

${ }^{15}$ Había un equipo de traducción simultánea y un conjunto de azafatas que se encargaba de recibir a los invitados nacionales e internacionales. También colaboraron Vicky Valdez y Myriam Moreno (coordinación participación), Felipe Mellizo (redactor de programación), Luis de Castresana (guion), Begoña García Nebreda (coordinación redacción), y el dibujante Máximo Sanjuán, aportando ideas.
} 
durante este periodo de un conjunto de periodistas y profesionales de la información, generalmente jóvenes, de diferente ideología (principalmente democristianos, franquistas y socialistas). Según su director, la variedad interna del equipo fue uno de los aciertos del programa, como se evidenciaba en los documentalistas: Juan Sierra y Gil de la Cuesta (delegado nacional de Cultura del Movimiento ${ }^{16}$ y procurador en Cortes ${ }^{17}$ ) fue un declarado franquista ${ }^{18}$. En cambio, en el mismo equipo declarados antifranquistas como Daniel Sueiro (fallecido en 1986) o Jesús Torbado (que entró a trabajar en 1982 como documentalista en La clave tras haber desarrollado una importante actividad en Televisión Española) ${ }^{19}$.

La construcción del debate en La clave comenzaba en su puesta en escena al existir una previa planificación: el programa comenzaba a prepararse con tres semanas de antelación ${ }^{20}$. Sin embargo, como veremos más adelante, la lista definitiva de invitados no se concretaba hasta uno o dos días antes de la emisión, e incluso en algunos programas, hasta el inicio mismo del debate. Esto se debía a diferentes motivos: agenda de los propios invitados, cambios o anulaciones a última hora, dificultades internas de la propia RTVE, etc. José Luis Balbín explicó el funcionamiento interno de La clave en una entrevista en 2005:

«El equipo se reunía por lo menos dos veces cada semana. Entre todos se discutían temas de actualidad no inmediata y se seleccionaban. A partir de ese momento, tres o cuatro personas elaboraban unos dossiers de información y me los pasaban a mí. Se trataba de información no exhaustiva porque, según mi teoría, el papel del moderador debe ser repartir y fomentar el juego y la participación de los demás. No creo que el moderador deba intervenir demasiado ni ser el protagonista en ningún caso. Lo conseguía o no, pero ante todo yo quería desplegar un abanico de opiniones. No necesitaba hablar mucho sino introducir el tema y que intervinieran otros. (...) Esos documentalistas, que fueron Daniel Sueiro, José Luis Merino, Jesús Torbado y Felipe Mellizo, actuaban sin conocer uno el trabajo del otro. Cada uno me entregaba no más de cuatro folios, y cada cual trabajaba a su manera para que yo tuviera diferentes puntos de vista sobre el asunto» ${ }^{21}$.

\footnotetext{
${ }^{16}$ Véase BOE, ${ }^{\circ} 115,14$ de mayo de 1971.

${ }^{17} A B C, 14 / 07 / 1973$, p. 27.

18 José Luis Balbín durante el programa Francisco Franco (ficha 402), emitido el 8 de noviembre de 1985.

${ }^{19}$ Jesús Torbado había colaborado en los programas Encuentro con las letras (que se emitió entre 1976 y 1981), Estudio abierto (1970-1975), Directísimo (1975-1976), o Fantástico (1978-1980), del que fue subdirector.

${ }^{20}$ En palabras de José Luis Balbín, «La complejidad del programa y el hecho de contar con invitados extranjeros hace que sea necesario programar al menos con tres semanas de antelación», en Blanco y Negro, 5/10/1977, p. 10.

${ }^{21}$ José Luis Balbín, en F. J. Satué, Los secretos de la Transición, op. cit. p. 490.
} 
Tras la elección del tema se producía un debate interno en la propia redacción para elegir aquellos invitados que mejor pudiesen representar las diferentes corrientes, mientras Carlos Pumares se encargaba de elegir la película a proyectar:

«Nos reuníamos con temas para el coloquio semanal y pensábamos en la gente que podríamos traer al programa para que diesen opiniones diferentes o incluso encontradas. Normalmente había previstas quince personas en la lista de posibles invitados. Luego no solo había que ponerse en contacto con ellos, sino ver si había una proporción o un equilibrio entre los que defendían una opción y los que defendían otra diferente o contraria» ${ }^{22}$.

Para tratar con los invitados extranjeros se tenía en cuenta el idioma: para Inglaterra normalmente se encargaba Lola Respaldiza, para Francia, Juan Testa, y para Alemania, el propio José Luis Balbín. Algunos de los integrantes en el equipo también participaron como invitados en el programa, como fue el caso de Carmelo Bernaola (El negocio del fútbol...), Máximo San Juan (La Transición política...), Daniel Sueiro (El Valle de los caídos...), Javier Vázquez (Carreteras de miedo...), o Juan Ruiz-Giménez Aguilar (Salud para todos...). El día anterior a la emisión del programa se preparaba una cena para recibir a los distintos invitados, a quienes se trataba de impedir que hablaran del tema del debate. En palabras de Ladislao de Arriba: «Recuerdo las cenas previas, en las que los invitados al programa tenían prohibido hablar del tema del debate, porque entonces los demás veían por dónde iba cada cual. Entonces, entre invitado e invitado, se sentaba alguien del equipo y le daba conversación; y si eran extranjeros, se recurría a las azafatas traductoras ${ }^{23}$.

Cuando surge La clave, el debate televisivo se convierte en toda una referencia en España. Sin embargo, ¿cómo abordar la realidad política, social, económica y cultural de un país a través de un programa de televisión?, ¿cómo hacer frente a temáticas tan diversas?, o ¿cómo traspasar una emisión televisiva a una representación escrita? Para responder a estas preguntas empleamos una determinada metodología que pasamos a desglosar. A continuación presentamos una gráfica en la que se observan los 408 programas emitidos a lo largo de los diez años en los que centramos nuestro estudio.

\footnotetext{
${ }^{22}$ José Luis Balbín, en I. Reguera Pascual y J. J. Aparicio Arriola, Carlos Pumares: Un grito en la noche, Editorial Club Universitario, Alicante, 2006, p. 59.

${ }^{23}$ Ladislao de Arriba, en La Nueva España, 17/11/2010.
} 
Tabla no 1. Distribución de programas emitidos y prohibidos entre 1976 y 1985

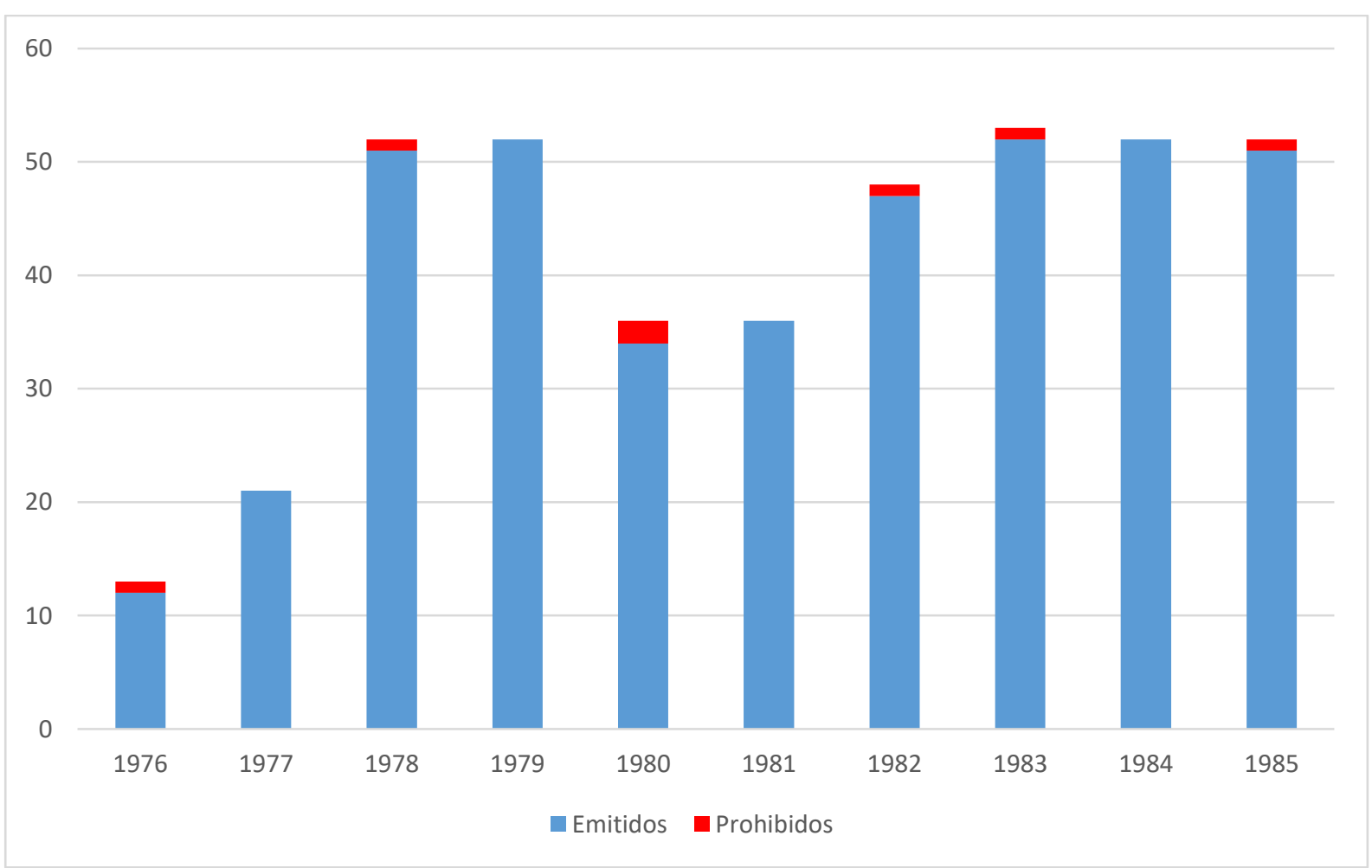

Elaboración propia.

Esta gráfica de programas emitidos y prohibidos nos permite observar la distribución temporal de La clave durante los diez años de emisión. Al ser un programa semanal, en un año podían realizarse alrededor de cincuenta emisiones. Los dos primeros años (1976 y 1977) y los años 1980-1981 -en los que se emitieron menor número de programas- son periodos que coinciden con la suspensión del programa. A pesar de ello, se constata que en todos estos años La clave logró emitir algún programa. Desde una perspectiva cronológica, vamos a mostrar cómo ya desde sus inicios en 1976 el programa asienta las bases, articula y construye el debate televisivo en España. Para entender la trayectoria y evolución del programa ha sido indispensable, en primer lugar, organizar de forma precisa sus diferentes etapas internas.

\subsubsection{Las etapas internas del programa}

La clave inició sus retransmisiones el 18 de enero de 1976 por el segundo canal de TVE, y finalizó el 27 de diciembre de 1985 cuando se suprime el programa ${ }^{24}$. En el transcurso de estos diez años, ¿evoluciona el programa?, y si es así, ¿por qué lo hace? Los cambios producidos

\footnotetext{
${ }^{24}$ El último programa no se retransmite en TVE y el debate se realiza en el interior del Hotel Palace de Madrid.
} 
en la dirección de televisión nos permiten dividir el programa en diferentes etapas internas. La variable observable se encuentra en la figura del director general de RTVE y, en consecuencia, en los cambios que se aplican en TVE a raíz de su nombramiento o destitución. Durante este periodo, La clave transitó por siete directores generales de RTVE (ocho contando Jesús Sancho Rof, quien aprobó el programa). El estudio de la figura del director general de RTVE nos permite comprender las dinámicas internas de TVE y, por tanto, estructurar las distintas etapas de La clave en sus diez años de emisión.

Utilizamos el programa La clave como eje central pero también hilo conductor a través de las distintas etapas que transcurren entre 1976 y 1985. A través del seguimiento cronológico del programa pretendemos mostrar cómo La clave, al tiempo que articula y construye el debate televisivo, acabó funcionando de plataforma democrática. Plataforma entendida como una organización de personas con intereses comunes (como poder debatir en directo en televisión sobre cualquier tema). Desde esta plataforma televisiva, el programa ayudará a conformar una cultura política democrática en la sociedad española. Desde esta perspectiva cronológica y a través de una estructura temática abordaremos el devenir del programa durante la Transición española.

Hemos dividido el programa en dos grandes periodos: el primero abarca desde 1976 hasta 1981. El segundo se inicia con la llegada al gobierno del PSOE en octubre de 1982 y finaliza con la supresión definitiva de La clave en 1985. Sin embargo, para abarcar estos dos periodos hemos optado, como hemos dicho previamente, por una distribución por etapas ya que nos permite un mejor análisis del programa y nos ayuda a comprender el porqué de su evolución en todo este proceso. Hemos dividido y estructurado La clave en estas cinco etapas: 1. Génesis del programa y primeros debates en directo (1976). 2. El regreso de La clave (1977-1978). 3. Fernando Castedo y el golpe de Estado de 1981. 4. José Luis Balbín y los Servicios Informativos (1982-1983), y 5. La etapa final de La clave (1983-1985) ${ }^{25}$. Profundizaremos en ellas en los siguientes capítulos. A continuación, mostramos la gráfica temporal de programas estructurada en estas etapas internas.

\footnotetext{
${ }^{25}$ Manuel Palacio, Juan Carlos Ibáñez o Virginia Martín, dividen el programa en tres etapas (a la que añaden una cuarta contando la etapa en Antena 3 Televisión). M. Palacio, La televisión durante la Transición española, op. cit. pp. 258-259. J. C. Ibáñez, "La clave", en M. Palacio (ed.) Las cosas que hemos visto, op. cit. p. 70. V. Martín, Televisión Española y la Transición, op. cit. p. 48, y M. Palacio y C. Ciller, "La clave de TVE...”, en Estudios sobre el Mensaje Periodístico, op. cit. p. 230.
} 
Tabla $n^{0}$ 2. Periodos y etapas internas del programa La clave

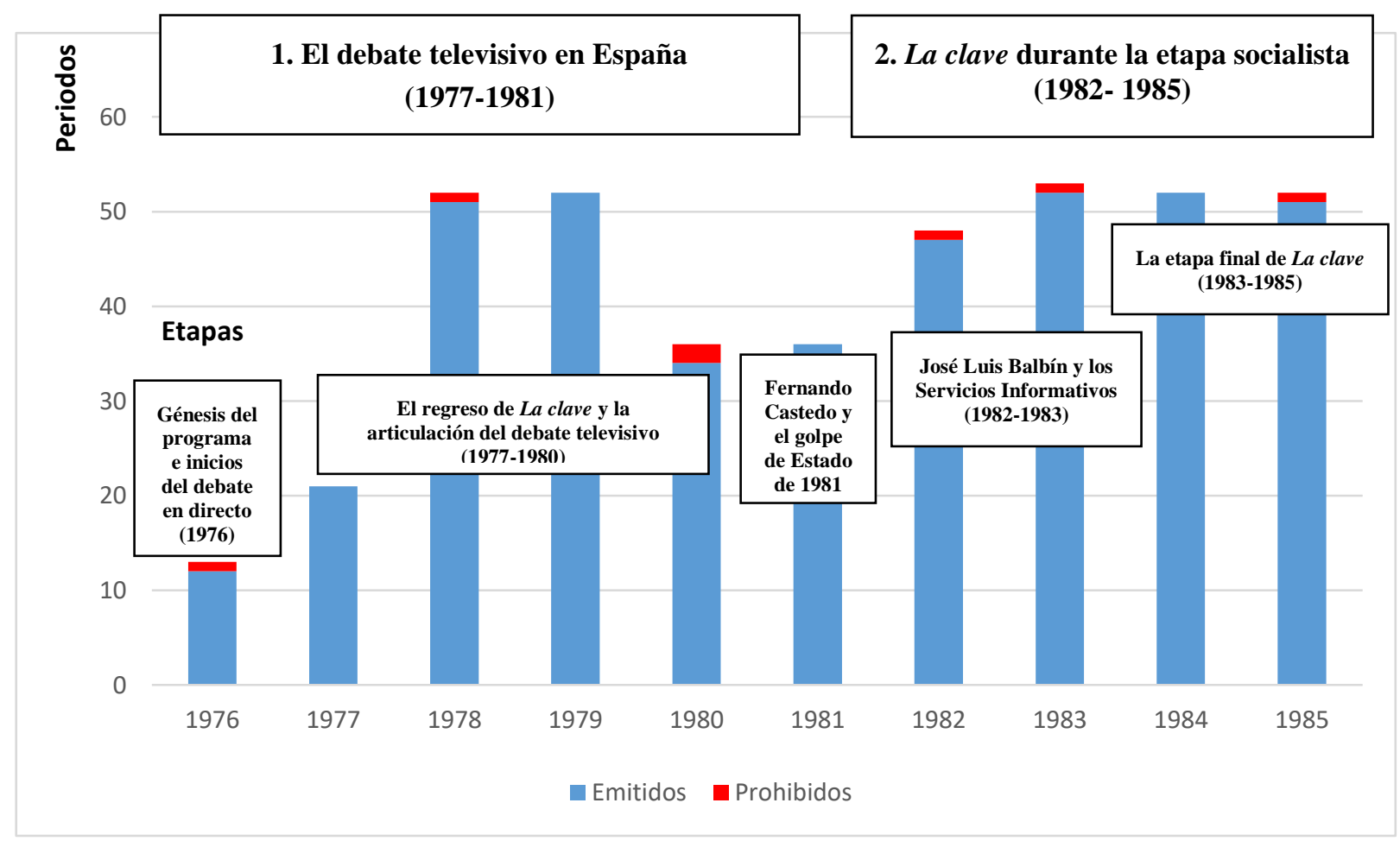

Elaboración propia.

El primer periodo, "El debate televisivo en España (1977-1981)", abarca las tres primeras etapas del programa. A continuación, profundizamos en cada una de ellas:

\section{$1^{\text {a }}$ Génesis del programa e inicios del debate en directo (1976)}

La primera emisión de La clave se produjo el 18 de enero de 1976. El día de emisión era el domingo, y su horario se extendía desde las nueve de la noche hasta el cierre de emisión, alrededor de la media noche. Se emitieron un total de doce programas, siendo uno prohibido y retirado de la programación ${ }^{26}$. El directo comenzó a partir de la tercera emisión, lo que convirtió a La clave en el primer programa de debates en directo en televisión. Es reseñable que el directo no fuese hasta el tercer programa lo que permitió a los responsables de televisión conocer previamente el funcionamiento y el contenido del mismo. Una de las causas del diferido era el miedo que podía provocar una emisión a inicios del nuevo periodo político abierto tras la muerte de Francisco Franco. La última emisión de esta etapa se produjo el 11 de abril de 1976. Tras

\footnotetext{
${ }^{26}$ Se prohibió el quinto programa dedicado a Los periodistas (ficha 5-C) por decisión del propio director general de RTVE. Al llevar poco tiempo en antena, esta prohibición pasó algo desapercibida.
} 
ella, llegó la primera supresión del programa siendo Gabriel Peña Aranda director general de $\mathrm{RTVE}^{27}$. Pero, ¿qué había ocurrido para que un programa que había adquirido gran audiencia y resonancia cesara tras el trascurso de doce emisiones? La clave desaparecería de la programación de TVE durante quince meses y no regresaría hasta el 30 de abril de 1977, dos semanas después de las elecciones del 15 de junio, primeras elecciones en España en más de cuarenta años.

Esta etapa sigue un marcado enfoque cronológico que difiere del enfoque temático de las siguientes etapas. Al ser la etapa que cuenta con menor número de emisiones (12), nos permite profundizar en su contextualización y observar ciertas características de La clave. En este corto periodo de tiempo - escasos tres meses- se sentaron las bases principales del programa (debate en directo, presencia de expertos e invitados de gran relevancia, participación del público...), así como las bases de lo que debía ser el debate televisivo (al no existir otro programa de debates). Su formato, audiencia y repercusión le concedieron cierto prestigio en televisión. Pero más allá del prestigio adquirido, la novedad de La clave fue permitir el cauce de expresión de pluralismos ideológicos y políticos que no habían tenido acceso a la televisión hasta esos momentos. Como veremos más adelante, La clave se adelantó a los propósitos de los reformistas del régimen que no dudaron, en abril de 1976, retirarlo de la parrilla de televisión ${ }^{28}$.

\section{$2^{a}$ El regreso de La clave y la articulación del debate televisivo (1977-1980)}

La segunda etapa, a diferencia de la primera, fue una etapa de cuatro años. Para abarcar todo este periodo, en esta etapa y en las sucesivas, hemos optado por un enfoque temático que nos permita continuar el análisis del programa de forma cronológica. De este modo, la división en bloques temáticos nos permite observar qué tipo de debate realiza, construye y retransmite el programa. Respecto a la primera etapa, cambió el día de emisión, pasando a emitirse en sábado, aunque mantuvo la franja horaria de mayor audiencia en España (entre las ocho de la tarde hasta media noche). En esta etapa, La clave trató de conquistar parcelas de libertad para convertirse definitivamente en un espacio de libre opinión, lo que le permitiría comenzar a articular el debate televisivo en España.

\footnotetext{
${ }^{27}$ Hay que tener en cuenta que la aprobación del programa había sido con el anterior director general de RTVE, Jesús Sancho Rof.

${ }^{28}$ La clave apostó desde sus inicios por un diálogo entre las diferentes fuerzas políticas, contrariamente a los planteamientos de Carlos Arias Navarro, más ligado al continuismo franquista.
} 
La clave regresó a televisión el 30 de julio de 1977 con el nuevo director general Rafael Ansón (nombrado un año antes por Adolfo Suárez). Pero meses después, en noviembre de 1977, Ansón fue sustituido de la dirección de RTVE por Fernando Arias-Salgado, quien estaría al frente de RTVE en toda esta etapa. En 1977, La clave emitió 21 programas; en 1978, 51 programas (uno prohibido) ${ }^{29}$; en 1979, 52 programas; y finalmente en 1980, 34 programas (dos prohibidos) ${ }^{30}$. En el verano de 1980, los responsables de RTVE quisieron obligar a emitir el programa en diferido, negándose su director alegando que parte del éxito de la emisión se encontraba precisamente en el directo. Nueva maniobra para acabar con el programa, La clave perdería de nuevo la batalla. El directo y el impacto social del que gozaba el programa le llevaron -por segunda vez- a una suspensión, en septiembre de 1980.

\section{$3^{a}$ Fernando Castedo y el golpe de Estado de 1981}

Nueve meses después de la suspensión, y tras un nuevo cambio en la dirección de RTVE, regresó La clave con mayor apoyo en el interior de RTVE. El programa dejó de emitir en fin de semana para hacerlo los viernes. Sin embargo, continuó emitiendo en directo y manteniendo la franja horaria de mayor audiencia (que incluso se vio incrementada al empezar el programa una hora antes). Hasta el final del programa en 1985, La clave mantendría el viernes como día de emisión. En esta etapa se produjeron diversos cambios en RTVE, y pasaron hasta tres directores generales en dos años. El primero de ellos, Fernando Castedo, puso en marcha el Estatuto de RTVE (promulgado un año antes, el 10 de enero de 1980, tras largos debates parlamentarios), y fue el primer director general pactado entre el Gobierno y la oposición (UCD y PSOE). Como nuevo director, reestructuró RTVE y nombró a José Luis Balbín con un cargo directivo: director de Programas Especiales (área de nueva creación). Desde allí pondría en antena distintos programas, con aportaciones y resultados diversos.

La clave regresó el 24 de abril de 1981 con un programa titulado Televisión en España (ficha 171). A pesar de que el Estatuto de RTVE estipulaba un mandato de cuatro años en la dirección de televisión (salvo disolución anticipada de las Cortes), Fernando Castedo fue destituido a los nueve meses. La elección del cargo de director general de RTVE la tenía el Gobierno, que tenía como único requisito (aunque no vinculante), haber oído al Consejo de

\footnotetext{
${ }^{29}$ Primero se prohibió el programa Caciques, que fue sustituido más tarde por Los orígenes del hombre, aunque finalmente no se emitió el debate y únicamente se proyectó la película (ficha 77-C).

${ }^{30} \mathrm{El}$ primero de ellos, Poder municipal en pequeñas poblaciones (ficha 146-C). El segundo, de nuevo el tema de El juego (ficha 170-C), que coincide con la supresión del programa.
} 
Administración. Una evidente muestra de las deficiencias en relación a la independencia de la televisión pública. A Fernando Castedo le sustituyó en octubre de 1981 Carlos Robles Piquer, cuñado de Manuel Fraga, que estuvo al frente también nueve meses. Y finalmente, Eugenio Nasarre, cuatro meses en la dirección, desde julio hasta la llegada al gobierno del Partido Socialista en octubre de 1982. Tres directores generales y 83 debates, siendo uno prohibido con Eugenio Nasarre ${ }^{31}$. El programa gozó de mayor libertad en sus inicios (con Castedo) realizando debates prohibidos en etapas anteriores.

El segundo periodo que analizamos, "La clave durante la etapa socialista (1982-1985)", se inicia con el triunfo del PSOE en las elecciones de octubre de 1982 (para algunos historiadores, final del proceso de Transición) ${ }^{32}$, y finaliza con la prohibición final del programa en 1985. Este bloque lo conforman las dos últimas etapas. Profundizamos a continuación en cada una de ellas:

\section{$4^{a}$ José Luis Balbín y los Servicios Informativos (1982-1983)}

La victoria de los PSOE llevó a nuevos nombramientos en RTVE: José María Calviño fue nombrado director general de RTVE, y José Luis Balbín director de los Servicios Informativos de televisión. La cuarta etapa se inicia precisamente el 10 de diciembre de 1982 cuando José María Calviño nombra a José Luis Balbín nuevo director de los Servicios Informativos de TVE, y finaliza el 23 septiembre de 1983 cuando es destituido del cargo. En este periodo compatibilizó la dirección de los Servicios Informativos con la dirección de $L a$ clave, llevando a algunos periodistas a calificar la etapa de "balbinato"33. José María Calviño fue el director general en las dos últimas etapas de La clave y, por tanto, el último director

\footnotetext{
${ }^{31}$ Se prohibió el programa Guerras médicas (ficha 239-C) por la participación de un invitado.

${ }^{32}$ Existen sin embargo diferentes opiniones entre los especialistas sobre el final del proceso. P. Preston considera que la victoria del PSOE en las elecciones del 28 de octubre de 1982 marca el final del proceso. Véase The Triumph of Democracy in Spain, Methuen, Londres, 1986, p. 227. Del mismo modo que M. Fraile, "El final de la transición: claves para la historia", en Tapia, diciembre de 1982, pp. 9-19. Otros, en cambio, consideran su final años antes, con la celebración de elecciones el 15 de junio de 1977 o la promulgación de la Constitución, al considerar normas jurídicas que suponen el final del sistema legal franquista. Véase J. J. Linz, "La transición a la democracia en España en perspectiva comparada”, en R. Cotarelo (comp.), Transición política y consolidación democrática, CIS, Madrid, 1992, p. 445. Seguimos preferentemente autores como J. Tusell, quien extiende el proceso de transición hasta 1986. Véase, La transición española a la democracia, Historia 16, Madrid, 1991, p. 11.

${ }^{33}$ Expresión utilizada por Lorenzo Díaz en su obra para definir las «grandes parcelas de poder» de las que gozó José Luis Balbín al compaginar el cargo de director y moderador de La clave con la dirección de los Servicios Informativos. Al igual que hiciese Justino Sinova, Díaz califica a José Luis Balbín de poco profesional: «tenía un problema personal, y es que era noctámbulo, que vivía la noche frenéticamente, y por las mañanas era imposible levantarle y era incapaz de llegar a los comités de dirección, y cuando llegaba era cuando estábamos casi terminando», en L. Díaz, 50 años de TVE, Alianza, Madrid, 2006, pp. 274-275.
} 
general que analizamos en nuestro estudio. A las pocas semanas del nombramiento de José Luis Balbín se prohibió un programa, precisamente el que tuvo mayor repercusión (observable en prensa y en la esfera política). Se trató del programa Balance de los municipios de izquierda (ficha 254-C), que se inició con el llamado affaire Alonso Puerta (exconcejal de Madrid expulsado del PSOE por denunciar un caso de corrupción en el Ayuntamiento de Madrid, que gobernaba en esos momentos el PSOE) $)^{34}$. Alonso Puerta, había sido invitado al programa, pero pronto se iniciaron maniobras para impedir que apareciese en televisión. Caso al que prestaremos especial atención, la decisión de suspender el programa vino dada por Enrique Tierno Galván. En 1983 se emitieron, por tanto, 52 de los 53 programas.

\section{$5^{\mathrm{a}}$ La etapa final de La clave (1983-1985)}

La última etapa se inicia el 23 septiembre de 1983 con la destitución de José Luis Balbín de los Servicios Informativos. El declive del programa se acentuará en esta etapa al igual que las presiones, en este caso procedentes del Partido Socialista. En 1984, se emitieron 52 programas y en 1985 (último año de emisión), 51 programas (se censuró el último titulado Movida Nacional, que supuso además la supresión definitiva de La clave). El programa fue retirado de televisión y, tras mutuas acusaciones, RTVE fue finalmente condenada a pagar a José Luis Balbín cinco millones de pesetas por haber atentado a su honor en el comunicado del cese del programa ${ }^{35}$. Sin embargo, el juez desestimó la petición de José Luis Balbín de reponer La clave. Punto de destino de nuestra tesis doctoral, el programa volvió a televisión años más tarde; lo hizo en Antena 3 Televisión entre 1990 y 1993. En 1998, José Luis Balbín regresó a la cadena pública con un programa de entrevistas a grandes figuras del siglo XX llamado Las claves... A finales de ese año, el 5 de diciembre de 1998, y como hemos visto al inicio de este capítulo, se hizo el último programa de La clave; el especial titulado La Constitución española a los 20 años, realizado en el interior del Congreso de los Diputados.

\footnotetext{
${ }^{34}$ Parte del libro de J. Sinova gira en torno a este hecho. «El PSOE se cansó de repetir que no había tenido nada que ver en la suspensión del programa La clave sobre Los Ayuntamientos de izquierda, a pesar de algunas realidades innegables, y ahí están impresas en el Diario de Sesiones las palabras de Calviño asegurando y jurando la enfermedad de Balbín, cuando fue una enfermedad inventada, ordenada y orquestada. Mentira, pura mentira para seguir conservando el poder», J. Sinova, La gran mentira, op. cit. p. 214.

${ }^{35}$ Fuentes: "RTVE, condenada a indemnizar a Balbín por el comunicado de suspensión de La clave", El País, 8/08/1987, y “El Supremo confirma que TVE lesionó el honor de Balbín”, El País, 19/04/1989.
} 


\subsubsection{Selección de programas y análisis temático}

Una vez recopilados los 408 programas, pasamos a explorar el tipo de metodología que hemos aplicado para validar o refutar nuestras hipótesis. Partiendo de la hipótesis inicial que el programa articula y construye el debate televisivo en España, ¿qué tipo de debate construye?, ¿qué temáticas impone? La clave abordó una temática tan variada que resultaba más fácil enumerar aquellos temas que no había tratado. Por lo tanto, ¿cómo seleccionar ante la enorme variedad? El gran número de programas emitidos nos obligaba desde el inicio a una distribución temática. También la duración del programa (hubo emisiones que junto a la película superaban las cinco horas de duración). Si estipulamos una media de tres horas por programa, esto supone 1.200 horas de emisión. De este modo, optamos por la selección de los programas a partir de bloques temáticos. En octubre de 1985, para conmemorar los 400 programas, el equipo del programa recopiló datos en un libro-anuario de los programas emitidos hasta ese momento. Este fue el índice que utilizó para agrupar los programas en áreas temáticas:

\begin{tabular}{|cr|}
\hline - Internacional & Economía \\
A. Áreas geográficas & A. Economía general \\
B. Ideologías. Organizaciones & B. Agricultura \\
C. Situaciones conflictivas & C. Consumo \\
- España & D. Dinero. Banca. Bolsa \\
A. Historia & E. Energía. \\
B. Política general & F. Hacienda Pública \\
C. Constitución. Elecciones & G. Industria \\
D. Gobierno. Administración & H. Obras públicas \\
E. Autonomías & Cultura \\
F. Guerra civil & A. Generalidades. Instituciones \\
G. Política exterior & B. Bellas Artes \\
Sociedad & C. Ciencia y técnica \\
A. Demografía. Familia & D. Cine y teatro \\
B. Ecología. Medio ambiente & E. Deportes. Toros \\
C. Educación & F. Literatura \\
D. Justicia. Derechos humanos & G. Estudios de comunicación \\
E. Minorías & H. Misterio \\
F. Laboral & I. Música \\
G. Sanidad & J. Religiones \\
H. Urbanismo & K. Sucesos \\
& L. Turismo \\
\hline
\end{tabular}

Figura $\mathrm{n}^{\circ}$ 3. Índice temático de programas. Libro-anuario LA CLAVE, 25 de octubre 1985.

Uno de los problemas de esta agrupación era la dificultad de abordar precisamente el debate que se había sido llevado a cabo. Además, muchos programas se podían incluir en 
diferentes áreas. Para observar la construcción del debate televisivo y abordar la formación de cultura política, hemos optado por un análisis a partir de tres temáticas concretas. El primer bloque temático lo conforman las claves políticas: aquellos programas que integrados en la esfera política ayudaron a crear una cultura política. Conforman este bloque, ¿Por qué políticos? (1977), Parlamentarismo (1978), La Constitución (1978), Democracia (1979), Sistemas políticos (1979), Futuro de la democracia (1980), Las armas de la democracia (1981), Elecciones (1982), La Transición política (1983), La difícil convivencia (1983), A la democracia desde la dictadura (1984), y Lo que va de ayer a hoy (1984).

El segundo bloque lo conforman las claves históricas. ¿Cómo aborda y construye $L a$ clave el debate en torno a su historia inmediata? Según Berstein, toda cultura política supone una lectura común del pasado y una proyección del futuro común (Berstein 1997: 372). La Guerra Civil es el hito fundacional del franquismo, razón por la que estos programas nos permiten centrar el objeto de estudio en el debate histórico que fue llevado a cabo. ¿Cómo representó el conflicto? ¿Lo hizo directamente o indirectamente? ¿Qué películas se proyectaron? Este segundo bloque lo conforman los siguientes programas: Extranjeros en la Guerra Civil (1979), Muerte de García Lorca (1980), El oro que se fue (1981), Cincuenta años después (1981), José Antonio (1981), Vivir en postguerra (1982), El Valle de los Caídos (1983), La revolución de Asturias (1984), y Francisco Franco (1985). Un proceso, la Transición española, que algunos autores han calificado de «amnesia colectiva de la Segunda República, la Guerra Civil y el Franquismo ${ }^{36}$. Podemos afirmar que en La clave no hubo amnesia colectiva al debatir en directo sobre la historia de España en distintas ocasiones. Al hablar del pasado español, La clave rompía precisamente con la ausencia que había sido llevaba a cabo durante todo el periodo franquista y parte de la Transición.

Otros programas de interés se expondrán a lo largo de nuestro análisis. Entre ellos, los que nos permiten observar la legislación del momento y la posición que adopta el programa respecto a una determinada temática, teniendo en cuenta que, en muchos casos, el simple hecho de plantear un tema era ya una posición al respecto. Conforman el bloque de claves sociopolíticas los programas Pena de muerte (1977), El divorcio (1978 y 1981), homosexuales (1983), Aborto (1983), y Mujeres y política (1983). El tema de la entrada de España en la OTAN (1980 y 1985), es otro de los temas que analizamos, al ser una de las causas de la suspensión definitiva del programa. Por último, hay que tener en cuenta que muchas temáticas como la

\footnotetext{
${ }^{36}$ Véase, R. Monlleó, A. Fornas y I. Medall, Biografies rescatades del silenci. Experiències de guerra i postguerra a Castelló, Publicacions de la Universitat Jaume I, Castellón, 2004, p. 12.
} 
educación, la información, los militares, o los intelectuales, se abordaron en más de una ocasión desde diferentes enfoques ${ }^{37}$.

El desarrollo de esta línea de trabajo pretende incorporarse al espacio de investigación abierto ya en Francia, Alemania o EE.UU. Hemos diseñado unidades de análisis como herramienta conceptual y metodológica con el propósito de observar el debate político y cultural que llevó a cabo este programa. Hemos establecido la siguiente ficha de análisis siguiendo la metodología propuesta por François Jost ${ }^{38}$ :

\section{Selección de programas y visionado}
a. Claves políticas
b. Claves históricas
c. Claves sociopolíticas

\section{Descripción del programa}
a. Contextualización
b. Temática abordada

\section{Fecha de emisión (día/mes/año)}

a. ¿Tiene consonancia con las cuestiones presentes?

b. Emitido o prohibido (motivo de la prohibición)

\section{Película proyectada}

a. Datos filmográficos: director, procedencia, año...

b. ¿Adecuación al tema? ¿Sirve para contextualizar el debate?

\section{Participantes al debate}
a. Datos: Procedencia, profesión...
b. Discrepancia a favor o en contra

\section{Análisis del contenido}
a. ¿Adecuación?
b. ¿Qué cuestiones se formulan durante el debate?
c. Resumen del contenido y agrupación temática

7. Difusión (número de telespectadores)

8. Repercusión (tanto en prensa como en la esfera política)

\footnotetext{
${ }^{37}$ Un ejemplo, los programas dedicados a medios de comunicación: La empresa de informar (1977), La televisión en España (1981), Libertad de información (1981), La información y el poder (1982), Impacto de los medios de comunicación (1984), Líderes de opinión (1984), Pluralismo informativo (1985), El estatuto de RTVE (1985).

${ }^{38}$ Véase F. Jost, Introduction à l'analyse de la télévision, Ellipses, París, 2007 (3ª edición).
} 
Estas son las líneas de análisis de los distintos programas. Su resultado nos lleva a definir La clave como un espacio televisivo creador de opiniones cualificadas con la capacidad de orientar corrientes de opinión. En este sentido, ¿qué argumentos se utilizan en el debate? ¿Legitima la propia dinámica de la política española?, y en definitiva, ¿fue La clave un instrumento básico del cambio? La metodología empleada combina su análisis dentro del conjunto histórico que representa la Transición. Desde esta perspectiva (cronológica y temática) pretendemos analizar un programa de televisión que crea una visión del mundo compartida y construye una cultura política concreta.

A lo largo de la tesis doctoral defendemos la idea que La clave articuló y construyó el debate político y cultural en televisión, lo que ayudó a la formación de una cultura política al otorgar espacios de difusión a sectores políticos silenciados durante el franquismo y con una participación muy limitada a inicios de la Transición ${ }^{39}$. En este capítulo nos preguntamos precisamente sobre el espacio cultural que ocupó el programa durante el proceso de transición en España. Autores como Manuel Palacio argumentan que «la colaboración de La clave en el proceso de creación de un espacio público democrático es su aportación de mayor calado histórico (...); una representación visual de la libertad y de la democracia» (Palacio 2012: 261). Al igual que Manuel Palacio, creemos que el programa nació para dar respuestas a las inquietudes de la ciudadanía y acabó mostrando que la televisión era una excelente tribuna para el debate político. A través de los mejores expertos en el campo, pronto demostró la enorme capacidad que tenía a la hora de difundir corrientes de opinión, y propagar nuevas ideas y valores democráticos que ayudaron en el aprendizaje en democracia.

\subsection{El debate televisivo}

Como ya hemos argumentado, con La clave se iniciaron en España los debates en directo en televisión. El debate de La clave era una exposición oral televisada entre distintos invitados en la cual existían dos o más tesis sobre un tema controvertido, y en el que cada uno de los invitados, individualmente, defendía su punto de vista. El moderador, José Luis Balbín, era el encargado de distribuir los turnos de palabra y hacer respetar las diferentes opiniones. El

\footnotetext{
39 «La cultura política democrática conlleva la idea de pluralidad y, muy ligada a ésta, la de competencia, en el sentido de lucha o juego político, pues se parte de la convicción de que cada cual tiene el mismo derecho a ejercer todas las libertades individuales (de creencia, de expresión, de agrupación, etc.), de manera que en ella solo tiene cabida una actitud de tolerancia frente a creencias diferentes y hasta contradictorias, y una convicción de que éstas pueden coexistir en un mismo espacio político» (Peschard 2012: 29).
} 
programa se estructuraba a raíz del debate en directo, y se producía simultáneamente ante los telespectadores, escapando del llamado bucle ${ }^{40}$. El directo, como argumenta François Jost, se encuentra a la base del edificio de la credibilidad televisual (Jost 2013: 67). Si bien la norma habitual era su emisión en directo, no todos los programas lo fueron. Se emitieron en diferido aquellos programas que coincidían con días festivos o durante los meses de verano. Entre 1976 y 1985, de los 408 programas, 338 fueron en directo. En las emisiones en diferido, sin embargo, no hubo montaje alguno, y la principal diferencia era que los telespectadores no podían hacer las preguntas a los invitados ${ }^{41}$. Al inicio del programa, José Luis Balbín indicaba si la emisión que estaban viendo los telespectadores era en directo o en diferido. La explicación de los mecanismos de funcionamiento interno y el carácter intelectual y cultural del programa también fueron determinantes para mantener una alta credibilidad en televisión. Por lo tanto, la relación de simultaneidad con la que se desarrollaba el programa y la fuerte credibilidad televisiva fueron algunas de sus principales características. La clave no se reducía exclusivamente a la proyección de una película y un debate, sino que llegaba a estructurarse hasta en seis partes diferenciadas. La estructura del programa seguía los siguientes puntos:

1. Anuncio e introducción del tema.

2. Presentación de los invitados (en la que se mencionaba la trayectoria personal de cada uno de ellos y se formulaban las primeras preguntas).

3. Proyección de la película.

4. Debate. Intervención de los distintos invitados aportando argumentos y defendiendo sus puntos de vista.

5. Intervención de los telespectadores mediante preguntas telefónicas.

6. Clausura del debate y bibliografía.

La introducción (de entre 15-20 minutos) no solo servía para introducir el tema y presentar a los invitados. Tampoco quedaba reducida a un simple rótulo inserto en el momento en el que hablaba dicho invitado, sino que precisamente el programa se iniciaba con una descripción de la trayectoria profesional de cada uno de ellos. Unos invitados que, como veremos a continuación, permitieron la difusión de una opinión cualificada a través de la figura del experto. La introducción también servía de editorial del programa. Como tal, defendía unos valores y asumía unas responsabilidades. Tras la presentación, se proyectaba una película

\footnotetext{
${ }^{40}$ El llamado bucle era el retraso de unos segundos en una emisión.

${ }^{41}$ Sobre el concepto de montaje, véase V. Sánchez-Biosca, Una cultura de la fragmentación: pastiche, relato y cuerpo en el cine y la televisión, IVAC, Valencia, 1995.
} 
relacionada con el tema del debate y se insertaba un rótulo con una breve filmografía. La clave contaba con un asesor cinematográfico encargado semanalmente de seleccionar la película que mejor se adaptara al tema. La contratación de las películas no dependía exclusivamente del programa sino de la propia TVE, lo que provocó, en más de una ocasión, la frustración de José Luis Balbín, haciendo que la producción propia (tal y como hacía Les Dossiers de l'écran) se convirtiese en uno de sus objetivos. Tras la película comenzaba el debate en directo con distintos invitados, generalmente seis, y un máximo de ocho. En esta parte nos centraremos en la capacidad del programa en tematizar y construir el debate político y cultural. Una vez transcurrido parte del debate, el telespectador podía participar en el programa mediante una sección de preguntas telefónicas, lo que supuso una ruptura respecto a la televisión unidireccional realizada hasta esos momentos. Finalmente el programa se cerraba con una bibliografía sobre el tema abordado ${ }^{42}$, una muestra de la misión educativa y su propósito de formar al telespectador.

José Luis Balbín introdujo en la parrilla de televisión un formato extranjero (procedente de la misión educativa de la televisión), que adaptó a los intereses y necesidades de la sociedad española. La duración total del programa (película, debate y preguntas de los telespectadores) podía superar las tres horas, llegando incluso, en algunas etapas, a las cuatro o cinco horas ${ }^{43}$. Para su director, lo ideal era contar con dos horas de debate incluyendo las preguntas de los telespectadores. Se iniciaba aproximadamente a las 21:00 h (en algunas etapas a las 20:00 h) y finalizaba en torno a la medianoche. Como hemos indicado anteriormente, los cambios que tuvo el programa afectaron principalmente al día de emisión, que pasó del domingo (1976), al sábado (1977-1980), para terminar en viernes (1981-1985).

Es importante señalar el presupuesto del programa (con el que se cubrían los desplazamientos, estancias de los invitados -a veces incluido acompañante- y los gastos de adquisición y emisión de la película). Por regla general los invitados no eran remunerados. Neil Armstrong o Truman Capote fueron algunas excepciones. Para José Luis Balbín, dinero simbólico, porque se trataba de personalidades «impagables» ${ }^{44}$. En RTVE no se conserva el

\footnotetext{
${ }^{42}$ Cfr. J. C. Ibáñez, "La clave", en M. Palacio, Las cosas que hemos visto. 50 años y más de TVE, Instituto de RTVE, Madrid, 2006, p. 70, y V. Philippe, Transition et télévision en Espagne. Le rôle de la TVE 1973-1978, L'Harmattan, 2007, París, p. 47.

${ }^{43}$ Cfr. M. Palacio, La televisión durante la Transición... op. cit. p. 258.

${ }^{44}$ Véase "La clave”, El País, 31/03/1979. De los más de dos mil invitados que intervinieron en el programa, menos de diez personas cobraron por participar. A todos los invitados al programa se les obsequió con un reloj de mesa. Cfr. M. Palacio y C. Ciller, “La clave de TVE, un programa de debate en la historia...”, op. cit. p. 237.
} 
presupuesto del programa en sus diferentes etapas pero, José Luis Balbín, lo hizo público en prensa en distintas ocasiones. Hay que tener en cuenta que dicho presupuesto tiene diferencias dependiendo de la etapa en la que transcurre el programa (y las dificultades financieras que atraviesa RTVE en ese momento), y varía mucho dependiendo de la emisión (ya que un programa podía contar con invitados nacionales y otro, con todos sus invitados extranjeros). En su primera etapa, el presupuesto del programa fue aproximadamente de 1.700 .000 pesetas por emisión. El funcionamiento era el siguiente: se asignaba a La clave un presupuesto de 22 millones de pesetas por trimestre (cubriendo 13 programas) que el equipo autogestionaba ${ }^{45}$. Este sistema le permitió desde sus inicios tener una gran libertad de decisión aunque, su previa planificación, dificultaba la improvisación. Presentamos a continuación, en mayor profundidad, la tematización, el cine emitido y la participación del público en el programa.

\subsubsection{El arte de tematizar}

Creemos que es uno de los logros tanto de José Luis Balbín como del propio programa el presentar el tema del debate con cierta ambigüedad. Es decir, el tema genérico del debate permitió desde sus inicios escapar al control que se hacía en Televisión Española al no saberse con exactitud las líneas por las que iba a transcurrir el debate. La clave realizó entre 1976 y 1985 un total de 408 programas con el objetivo de examinar los retos de las sociedades de finales de siglo y poner a disposición del ciudadano la información necesaria para emitir juicios de valor y argumentos. Presentamos a continuación la que creemos que es la metodología más adecuada para abordar las diferentes temáticas que trató La clave durante el periodo de Transición. Una tematización (o selección temática como han señalado algunos autores) ${ }^{46}$, que confería una fuerte capacidad a los medios de comunicación al poner el tema en el centro de la atención pública y, por tanto, en su capacidad de poder incidir de manera directa en el ámbito de la política ${ }^{47}$.

\footnotetext{
${ }^{45}$ Para tener algún ejemplo comparativo en relación a otros programas, Esta noche, fiesta, de José María Î́nigo, costaba cerca de dos millones doscientas mil pesetas, o el magazine 300 millones, dirigido por Gustavo Pérez Puig la noche del domingo, el doble que La clave por una hora de programación frente a las cinco de La clave.

${ }^{46}$ Seguimos preferentemente la noción de tema o tematización propuesta en 1978 por Niklas Luhmann. Los temas, que ordenan los procesos de comunicación, no sirven para determinar directamente las opiniones sino para capturar la atención. Véase N. Luhmann, Stato di Diritto e Sistema Sociale, Guida, Nápoles, 1978.

${ }^{47}$ Véase la obra de F. Guerrero-Solé, C. Pont-Sorribes y M. Palencia-Lefler, "La construcción de la imagen de la política en los noticiarios televisivos en España. Exo- y endo- equilibrios de la calidad de la información política", en Revista Latina de Comunicación Social, n 68, La Laguna, 2013, pp. 170-171.
} 
Precisamente La clave es uno de los programas que mejor recoge esta incidencia directa en la política por diversos motivos: el primero de ellos, la propia temática que fue abordada y su pretensión de buscar temas que no se habían tratado hasta entonces. Como argumenta Manuel Palacio, «la adaptación del formato francés, permitió a Balbín, introducir en la pequeña pantalla temas que, o bien no se habían tratado, o si lo habían hecho, el programa y su formato -en directo- le proporcionaban un nuevo enfoque en la temática». (Palacio 2012:). Es la elección del tema, por tanto, la que inicia la estructura del programa. Como explicaba el propio José Luis Balbín en 1977, «una vez escogido el tema, se procede a la selección de la película que mejor pueda ilustrarlo y de los expertos que habrán de participar en el coloquio sin limitaciones de ningún tipo» ${ }^{48}$.

En nuestra tesis doctoral, creemos necesario el análisis de aquellos temas que movilizaban a determinados grupos, centraban su mirada en la atención pública y obligaban a imponer soluciones políticas. Sin embargo, los debates de La clave se extendieron por diferentes ámbitos de signo económico, cultural, religioso, educativo, popular, familiar... En verano de 1979, la revista Tele Radio publicó un listado de temas abordados por el programa hasta ese año. El listado clasificaba los programas en los siguientes temas: Esoterismo (cinco programas), Economía (cinco), Política (siete), Técnica y ciencia (ocho), Medicina (nueve), Derechos Humanos (once), Sociología (catorce), Literatura, Arte y espectáculos (veinte) ${ }^{49}$. Llamaba la atención que quince programas se habían ubicado en una rúbrica titulada "Otros temas", toda una muestra de la diversidad pero también de la dificultad para ubicar sus programas.

Ese mismo año, el propio director tenía dificultades para sintetizar el tipo de temática que el programa había abordado: «Esoterismo, economía, política, medicina, diez programas sobre derechos humanos, sociología, ciencia y técnica, literatura, arte y espectáculo, religión, ecología, trabajo, etcétera son, en pocas palabras, los grandes temas de La clave» ${ }^{50}$. La temática fue tan amplia, diversa y variada que pocos ejemplos bastan para mostrar su disparidad: la huelga, el alcoholismo, el paro juvenil, la eutanasia, los dineros de la Iglesia, los mundiales de fútbol, el futuro sin libros, multinacionales, la educación, el teatro, fuga de cerebros, el Islam,

\footnotetext{
48 "La clave, a primera cadena en noviembre", Blanco y Negro, 5/09/1977, p. 10.

${ }^{49}$ Tele Radio, $\mathrm{n}^{\circ}$ 1.124, 9-15 de julio de 1979, p. 36, en M. Palacio, La televisión durante la Transición española, op. cit. pp. 260-261.

50 “La clave, único programa de debate en directo de TVE, cumple hoy el número cien”, El País, 14/07/1979.
} 
los Beatles, las autonomías, el contrabando, la televisión, sectas, Dalí, Hitler... ¿Cómo clasificar, por tanto, la diversidad de temas?

La tematización cobra vital importancia por lo que, con el propósito de abordar y analizar el debate político y cultural llevado a cabo, hemos estructurado el programa, como ya hemos adelantado previamente, en tres bloques temáticos. En primer lugar, las claves políticas que nos permiten centrar el debate político y posteriormente abordar la formación de una cultura política. En segundo lugar, las claves históricas, con las que abordar la construcción compartida o no- de una historia de España. Por último, las claves sociales, con las que observar la posición que adopta el programa. Su preocupación por los derechos humanos nos permite seleccionar un tipo de programas sociales con los que observar si se adelanta a la legislación del momento.

En relación a las prohibiciones y censuras, La clave permite constatar lo que se podía debatir en televisión, y más importante, aquello que no se podía debatir. En televisión, al igual que en otros medios de comunicación, tan importante es lo que se emite como lo que se prohíbe. Cuando se prohibía La clave no solo se prohibía un programa, también un determinado tema. Durante 1976 y 1985 fueron seis los programas que no llegaron a emitirse. Cronológicamente, Periodistas (1976), Caciques (1978), Poder municipal (1980), Guerras médicas (1982), Balance de los municipios de izquierda (1983), y La movida nacional (27/12/1985). Sin embargo, cada una de estas emisiones se enmarca en un determinado contexto. Tampoco son las mismas causas o motivaciones las que determinan que una emisión no salga en antena. La consigna, en palabras de José Luis Balbín era la siguiente: «Yo cuando entré puse una condición muy clara: si no te gusta lo que ves o escuchas, quita el programa de la programación de la cadena, pero ni se te ocurra censurarlo» ${ }^{51}$.

A través del programa se evidencian los temas que resultaban problemáticos o eran calificados de polémicos o sensibles en la época. Sin embargo, ¿hubo más prohibiciones? ¿Y autocensura? Efectivamente, hubo temas que no se debatieron, bien porque eran considerados tabús y eran prohibidos por los responsables de $\mathrm{RTVE}^{52}$, o bien por autocensura del propio programa, como reconoce José Luis Balbín en relación al tema del terrorismo de $\mathrm{ETA}^{53}$ « $\ll \mathrm{El}$

\footnotetext{
${ }^{51}$ José Luis Balbín, en I. Reguera Pascual y J. J. Aparicio Arriola, Carlos Pumares..., op. cit. p. 56.

52 Entendemos por temática tabú aquellos temas que se quiere evitar porque en algún momento determinado se consideran polémicos, duros, sensibles o inaceptables moralmente. En algunos casos, ciertas temáticas se sustituyeron con eufemismos, más suaves en televisión, como planificación familiar en lugar de aborto.

${ }^{53}$ Véase también, M. Palacio y C. Ciller, “La clave de TVE, un programa de debate en la historia...”, en Estudios sobre el Mensaje Periodístico. Vol. 20. Núm. Especial (2014), p. 237.
} 
único tema tabú que no he querido tocar en La clave es el terrorismo y por una exclusiva razón: como deseo que participen todos, hubiera tenido que llamar a varios terroristas, pero esto es ilegal y, por lo tanto, prefiero no hacer el programa» ${ }^{54}$. Sin embargo, como veremos en los próximos capítulos, sí llegó a debatirse sobre terrorismo en algunos programas pese a no ser el tema del debate ${ }^{55}$. ¿Qué temas no llegaron a debatirse porque eran considerados tabús? ¿Existieron presiones? ¿Qué temáticas no llegaron a concretarse ${ }^{56}$

Como veremos a lo largo de la tesis doctoral, La clave logró romper con ciertos tabús en televisión (la homosexualidad, el consumo de drogas, el exceso de alcohol, la pena de muerte, el sexo, la eutanasia...), y lo hizo a través de diferentes puntos de vista y contando con grandes expertos. Es importante un profundo análisis de la tematización, al igual que la temporización, porque hubo temas que no pudieron debatirse en un momento determinado (homosexuales, la Iglesia, o la banca...) que sí lo hicieron posteriormente. Durante el debate Homosexuales de 1983 José Luis Balbín diría: «Por una parte, algunos personajes públicos piensan que deben ser temas a no tratar en público. Y, por otra, corremos el riesgo que haya quien piense que el tratamiento no es suficiente. Pero con todos esos riesgos, era más importante mostrar que ha llegado el momento que no hay temas tabús» ${ }^{57}$. La clave permite constatar diferentes grados de libertad televisiva al mostrar los límites que eran permitidos en esos momentos. Es decir, nos permite medir periodos de mayor apertura televisiva con periodos de fuertes restricciones, pero sin olvidar que La clave no es un ente estático y también evoluciona en sus diferentes etapas. Antes de profundizar en ellas en el siguiente capítulo, pasamos a abordar el cine que emitió La clave en sus diferentes etapas.

\subsubsection{Un cine para el debate}

A continuación presentamos una reflexión e investigación cinematográfica como reflejo de la importancia que tuvo el cine emitido en La clave. Parece claro, como argumenta Manuel

\footnotetext{
54 "Balbín: en La clave hay pluralismo informativo", $A B C, 20 / 04 / 1985$, p. 84. En el programa sobre El Estatuto de RTVE (ficha 403) volvió a hacer referencia al terrorismo como «una limitación legal. Yo no puedo traer aquí terroristas porque me culparían a mí de terrorista». Fuente: Centro de Documentación RTVE. El Estatuto de RTVE. Emisión: 15 de noviembre de 1985.

${ }^{55}$ Fue el caso del debate Lo que va de ayer a hoy (ficha 356), emitido el 21 de diciembre de 1984.

${ }^{56}$ ¿Por qué no se debatió la cuestión sobre Monarquía o República? «Quizá porque en esa época nadie se planteaba Monarquía o República. Estaba todo el mundo a favor de que desapareciese el franquismo», José Luis Balbín durante la entrevista realizada en Estrasburgo el 16 de abril de 2014. Véase dicha entrevista en el DVD anexo.

${ }^{57}$ Centro de Documentación RTVE. Homosexuales (ficha 283). Emisión: 29 de julio de 1983.
} 
Palacio que «una forma de socialización y de autorreconocimiento cultural basada en la cinefilia será en la Transición un elemento muy fuerte de identificación generacional, algo que se aprovechará La clave» (Palacio 2012: 101). Pero tal y como argumenta Vicente J. Benet «el cine es una institución cultural compleja, en la que intervienen factores de distinta naturaleza que convergen en cada filme» (Benet 2014: 279) ${ }^{58}$. En este apartado, sin pretender realizar un análisis individual de las películas, presentamos algunas de las características del cine emitido en La clave $^{59}$. Hay que tener en cuenta que a la altura de 1979 se programaban a la semana seis películas, tres en la primera cadena (en espacios como Cine español o Sábado cine), y otras tres en la segunda cadena (en programas como Cine-club, Filmoteca TV, y La clave) ${ }^{60}$.

José Luis Balbín conoció a Carlos Pumares «por mediación de José María Otero, que me dio el contacto. Por entonces, Otero era algo así como el Director del Área de Cine de TVE y también llevó la Semana de Cine de Barcelona. Pumares, de todas formas, no era el único candidato para ser el asesor cinematográfico de La clave. Al final opté por él y no nos defraudó» ${ }^{61}$. En palabras de José Luis Balbín, «el mérito del programa y de Pumares fue emitir buenas películas y que de otra manera no se darían por censura o hasta por culto ${ }^{62}$. En más de una ocasión, su director dijo ante las cámaras que el ideal del programa sería hacer producción propia, como hacía Les Dossiers de l'écran. Sin embargo, no fue hasta la última etapa del programa cuando se logró este objetivo (experimento que duró tan solo una emisión y que provocó como veremos más adelante más de un problema). La función de la película era introducir el tema y poder entrar directamente en debate. En ocasiones pasó desapercibida pero en otras fue el centro del debate. A diferencia de su homólogo francés, la elección de la película era posterior al tema. En palabras de José Luis Balbín, La clave «no era un programa que

\footnotetext{
${ }^{58}$ Una cierta línea argumental respecto a la relación entre cine y televisión, en T. Valero, Historia de España Contemporánea vista por el cine, Universidad de Barcelona 2010. Véase también, N. Triana-Toribio, Spanish National Cinema, Routledge, Nueva York, 2003.

${ }^{59}$ No podemos separar el cine del debate que se llevó a cabo y su contexto. Analizaremos con mayor profundidad algunas de las películas proyectadas en La clave, en concreto, las proyectadas en los debates políticos e históricos, con todo un abanico, como veremos, de ideales y mensajes democráticos.

${ }^{60}$ Fuente: "El cine en TVE", El País, 28/07/1979. Para un mayor análisis del cine español véanse, M. Trenzado, Cultura de masas y cambio político: el cine español de la transición, CIS, Madrid, 1999, y V. J. Benet, El cine español. Una historia cultural, Paidós, Barcelona, 2012.

${ }^{61}$ José Luis Balbín, en I. Reguera Pascual y J. J. Aparicio Arriola, Carlos Pumares... op. cit. p. 56. «Carlos siempre estaba en nuestras reuniones y sugería películas para el tema que se proponía en cada programa. Muchas veces se quejaba y ponía el grito en el cielo porque o no teníamos los derechos para la película que pedía, o no había dinero, o ya la iba a programar la propia cadena o por la pura ignorancia de no saber cómo localizar esa película concreta. Aunque la verdad es que muchas veces nos decían de antemano cuando proponíamos algún título: “jésa no se puede!"».

${ }^{62}$ José Luis Balbín, en I. Reguera Pascual y J. J. Aparicio Arriola, Carlos Pumares... op. cit. p. 57.
} 
utilizase una película para hablar de ella, sino para profundizar el tema [tratando de] supeditar los invitados y la película al tema que habíamos elegido» ${ }^{63}$.

La filmografía emitida en La clave entre 1976 y 1985 destacó por abordar temáticas que se habían prohibido o censurado durante la dictadura (violencia, delincuencia, prostitución, homosexualidad, alcoholismo, drogadicción...). Algunas películas habían pasado por las tijeras de los censores durante el franquismo como El inquilino (José Antonio Nieves Conde, 1957) o directamente prohibidas como Canciones para después de una guerra (Basilio Martín Patino, 1971). Esta última se realizó de forma clandestina en 1971 y no fue estrenada hasta 1976, poco después de la muerte de Francisco Franco. Otro rasgo destacado de la filmografía del programa fue que algunos directores como Sergei M. Eisenstein, con películas como Octubre (Oktyabr, 1927) y Lo viejo y lo nиеvo (Staroie i Novoie, 1929), se estrenaron por primera vez en televisión a través del programa. Fueron estreno también películas como Ciudadano Kane (Citizen Kane, Orson Welles, 1941), El gatopardo (Il gatopardo, Luchino Visconti, 1963), y las películas de Vittorio de Sica, Ladrón de bicicletas (Ladri di biciclette, 1948) y Milagro en Milán (Miracolo a Milano, 1951) ${ }^{64}$. Otra característica del cine que emitió La clave fue la difusión de largometrajes de los años treinta ${ }^{65}$, y cuarenta ${ }^{66}$.

Elia Kazan y Frank Capra fueron los directores con mayor número de películas proyectadas en La clave. Ocho películas de Elia Kazan ilustraron doce debates: Mar de hierba (The Sea of Grass, 1947), Pánico en las calles (Panic in the Streets, 1950), ¡Viva Zapata! (1952), La ley del silencio (On the Waterfront, 1954), Al este del Edén (East of Eden, 1955), Un rostro en la multitud (A Face in the Crowd, 1957), Esplendor en la hierba (Splendor in the Grass, 1961), y El compromiso (The Arrangement, 1969). También se proyectaron ocho películas de Frank Capra en nueve debates: Sucedió una noche (It Happened One Night, 1934), Horizontes perdidos (Lost Horizon, 1937), Vive como quieras (You Can't Take it With You, 1938), Caballero sin espada (Mr. Smith Goes to Washington, 1939), Juan Nadie (Meet John

\footnotetext{
${ }^{63}$ Ibídem, p. 56.

${ }^{64}$ Ciudadano Kane ilustró los debates sobre Caciques (ficha 138) y La información y el poder (ficha 230), y El gatopardo ilustró el debate Calidad de vida (ficha 168). Ladrón de bicicletas ilustró El desempleo (ficha 57), y Milagro en Milán, el programa Suburbios (ficha 62), lo que supuso la entrada en televisión el neorrealismo italiano. Otra película de Vittorio de Sica fue Umberto D. (1952), proyectada en el debate Pensiones (ficha 384).

${ }^{65}$ Algunos ejemplos, las películas de King Vidor: El pan nuestro de cada día (Our Daily Bread, 1934), y La ciudadela (The citadel, 1938), y de Cecil B. de Mille: El signo de la cruz (The Sign of the Cross, 1932), y Las cruzadas (The Crusades, 1935).

${ }^{66}$ Como las películas Fruto dorado (Boom Town, Jack Conway, 1940), Esta tierra es mía (This Land is Mine, Jean Renoir, 1943) o Roma, ciudad abierta (Roma, città aperta, Roberto Rossellini, 1945).
} 
Doe, 1941), Arsénico por compasión (Arsenic and Old Lace, 1944), El Estado de la Unión (State of the Union, 1948), y Un gángster para un milagro (Pocketful of Miracles, 1961).

Tras Kazan y Capra, encontramos con siete películas a Richard Brooks, y con seis a John Ford. De Richard Brooks se proyectaron: El cuarto poder (Deadline, 1952), La última cacería (The Last Hunt, 1955), Sangre sobre la tierra (Something of Value, 1957), Los hermanos Karamazov (The Brothers Karamazov, 1958), El fuego y la palabra (Elmer Gantry, 1960), A sangre fría (In Cold Blood, 1967), y Dólares (\$ - Dollars, 1971); y de John Ford: Las uvas de la ira (The Grapes of Wrath, 1940), ¡Qué verde era mi valle! (How Green Was My Valley, 1941), El fugitivo (The Fugitive, 1947), Cuna de héroes (The Long Gray Line, 1955), El último hurra (The Last Hurrah, 1958), y El soñador rebelde (Young Cassidy, 1965), que dirigió junto a Jack Cardiff.

Para terminar el repaso de los directores más utilizados en La clave, encontramos con cuatro películas directores como Fritz Lang, Billy Wilder, Joseph L. Mankiewicz, y Robert Wise $^{67}$. Y con tres películas, directores como William Dieterle, Howard Hawks, William Wyler, Alfred Hitchcock, Otto Preminger, Stanley Kramer, François Truffaut, John Frankenheimer y Buzz Kulik ${ }^{68}$.

En relación al cine español, el director español con más películas proyectadas, seis en concreto, fue José Luis Sáenz de Heredia: Mariona Rebull (1947), La mies es mucha (1948), Historias de la radio (1955), Diez fusiles esperan (1959), La verbena de la Paloma (1963), e

\footnotetext{
${ }^{67}$ De F. Lang se proyectaron: M, el vampiro de Dusseldorf (M., 1931), El ministerio del miedo (Ministry of Fear, 1944), Más allá de la duda (Beyond a Reasonable Doubt, 1956), y Los crímenes del Doctor Mabuse (Die Tausend Augen des Dr. Mabuse, 1961); de B. Wilder: Días sin huella (The Lost Weekend, 1948), El gran carnaval (Ace in the Hole, 1951), Testigo de cargo (Witness for the Prosecution, 1957), y Uno, dos, tres (One, Two, Three, 1961); de J. L. Mankiewicz: Odio entre hermanos (House of Strangers, 1949), Eva al desnudo (All About Eve, 1950), Murmullos en la ciudad (People Will Talk, 1951), y Julio César (Julius Caesar, 1953). Y por último, de R. Wise: Ultimátum a la Tierra (The Day the Earth Stood Still, 1951), La torre de los ambiciosos (Executive Suite, 1954), Helena de Troya (Helen of Troy, 1956), y iQuiero vivir! (I Want to Live!, 1958).

${ }^{68}$ De W. Dieterle se proyectaron: La vida de Emilio Zola (The Life of Emile Zola, 1937), Juárez (1939), y Jennie (Portrait of Jennie, 1948); de H. Hawks: Solo los ángeles tienen alas (Only Angels Have Wings, 1939), Luna nueva (His Girl Friday, 1940), y Tierra de faraones (Land of the Pharaohs, 1955); de W. Wyler: La carta (The Letter, 1940), Brigada 21 (Detective Story, 1951), y La calumnia (The Children's Hour, 1961); de A. Hitchcock: Recuerda (Spellbound, 1945), Falso culpable (The Wrong Man, 1956), y Topaz (1969); de O. Preminger: Carmen Jones (1954), Tempestad sobre Washington (Advise and Consent, 1962), y Dime que me amas, Junie Moon (Tell Me that You Love Me, Junie Moon, 1970); de S. Kramer: No serás un extraño (Not As a Stranger, 1955), La hora final (On the Beach, 1959), y la dirigida junto a Philippe Spinelli, Escenas de la lucha de clases en Portugal (Scene from the class struggle in Portugal, 1977); de F. Truffaut: Los cuatrocientos golpes (Les quatre cents coups, 1959), Farenheit 451 (1966), y El pequeño salvaje (L'enfant sauvage, 1970); de J. Frankenheimer: Siete días de mayo (Seven Days in May, 1964), El tren (The Train, 1964), y French Connection II (1975); y de B. Kulik: La canción de Brian (Brian's Song, 1971), Un hombre llamado Juan (Portrait: A Man Whose Name Was John, 1973), y Mátenme si pueden (Kill Me If You Can, 1977).
} 
Historias de la televisión (1965). Le siguió con cinco películas Juan de Orduña: Pequeñeces (1950), La leona de Castilla (1951), Alba de América (1951), Cañas y barro (1954), y Teresa de Jesús (1961). También destacaron con cuatro largometrajes Luis García Berlanga: Bienvenido Mr. Marshall (1952), Calabuch (1956), Plácido (1961), y ¡Vivan los novios! (1970); y Pedro Lazaga: Los chicos del Preu (1967), El turismo es un gran invento (1968), ¡Vente a Alemania, Pepe! (1971), y ¡No firmes más letras, cielo! (1972).

Por último, con tres películas cada uno, directores como Juan Antonio Bardem, Rafael Gil, y Basilio Martín Patino. De Bardem se proyectaron: Calle mayor (1956), La venganza (1958), y Sonatas (1959); de Rafael Gil: Don Quijote de la Mancha (1947), La señora de Fátima (1951), y Samba (1964); y de Basilio Martín Patino (que participó como invitado en el programa Pena de muerte) las películas Caudillo (1977), Canciones para después de una guerra (1971), y el documental Queridísimos verdugos (1973) ${ }^{69}$.

En la obra El cine español. Una historia cultural (2012), Vicente J. Benet analiza cuatro películas realizadas en la Transición sobre la historia de España que «miraban hacia los espectros del pasado sin demasiados subterfugios ni veladuras; levantaban crónica tanto de las derivas delirantes de algunas propuestas políticas como de las visiones más lúcidas del presente» (Benet 2012: 359). De las cuatro películas que el autor analiza, La clave proyectó tres. Se trataba de Canciones para después de una guerra (Basilio Martín Patino, 1971), La vieja memoria (Jaime Camino, 1977), e Informe general sobre algunas cuestiones de interés para una proyección pública (Pere Portabella, 1977). La película Canciones para después de una guerra, «crónica de la posguerra realizada mediante imágenes de la vida diaria, la cultura popular y la música de aquellos años» (Estrada 2013: 88), se utilizó en 1982 para debatir Vivir en postguerra (ficha 232); La vieja memoria se utilizó en 1983 para debatir sobre La transición política (ficha 281); y por último, Informe general sobre algunas cuestiones de interés para una proyección pública, se utilizó en 1984 para debatir Lo que va de ayer a hoy (ficha 356), con el propio Portabella entre los invitados. Volveremos en nuestro último capítulo a estas películas al tratar precisamente de acercarnos a la historia española.

Un análisis del cine que emite La clave quedaría incompleto si nos fijáramos solo en la faceta del cineasta. Se proyectaron en tres ocasiones (es decir, en tres debates) las películas Muerte de un presidente (Śmierć Prezydenta, Jerzy Kawalerowicz, 1977), y Ultimátum a la

\footnotetext{
${ }^{69}$ También destacaron directores españoles como José Antonio Nieves Conde: Surcos (1951) y El inquilino (1958); Luis Buñuel: Un perro andaluz (Un Chien andalou, 1929) y Los olvidados (1950); Carlos Saura: Los golfos (1959) y Llanto por un bandido (1964); y Antonio Giménez-Rico: El hueso (1968) y El cronicón (1970).
} 
Tierra (The Day the Earth Stood Still, Robert Wise, 1951). En dos ocasiones se proyectaron las películas de Elia Kazan: Pánico en las calles (Panic in the Streets, 1950), ¡Viva Zapata! (Elia Kazan, 1952), Un rostro en la multitud (A Face in the Crowd, 1957), y El compromiso (The Arrangement, 1969), y las películas de Franklin J. Schaffner: El mejor hombre (The Best Man, 1964), y El planeta de los simios (Planet of the Apes, 1968). También destacamos entre otras muchas, películas como El Estado de la Unión (State of the Union, Frank Capra, 1948); El tercer hombre (The Third Man, Carol Reed, 1949); Don Camilo (Julien Duvivier, 1952); Teléfono rojo, volamos hacia Moscú (Dr. Strangelove or How I Learned to Stop Worrying and Love the Bomb, Stanley Kubrick, 1964); o Españolas en París (Roberto Bodegas, 1971).

El cine emitido en La clave no solo sirvió para introducir los debates, también tuvo una función social con la máxima de formar, educar y entretener. Fueron tiempos en que el cine de ficción se acercaba a la actualidad más inmediata, y esenciales fueron muchas de sus películas. Entre algunas destacamos El político (All the King's Men, Robert Rossen, 1949), Esta tierra es mía (This Land is Mine, Jean Renoir, 1943) o Sierra de Teruel (L`Espoir, André Malraux, 1939). Es reseñable que La clave permitió introducir en TVE películas del Este de Europa, y de directores poco conocidos en España pero que formaban parte del grupo más representativo de la segunda generación de directores polacos como fueron Andrzej Vajda (1926-2016) y Jerzy Kawalerowicz (1922-1982). De Andrew Vajda se proyectó la película Cenizas y diamantes (Popiól I Diament, 1958), y de Jerzy Kawalerowicz la película Muerte de un presidente (Śmierć Prezydenta, 1977). Precisamente esta última fue adquirida y subtitulada expresamente por $L a$ clave y estrenada en 1979 antes de estar en cartelera en el cine en febrero 1980. Fue además la película más utilizada por el programa, y con la que se ilustraron los siguientes debates: $E l$ defensor del pueblo (ficha 113), Las armas de la democracia (ficha 175) y La difícil convivencia (ficha 300$)^{70}$. Profundizaremos en estos debates en nuestro último capítulo.

El propio programa debatió sobre cine en distintas ocasiones. En 1979 debatió sobre La crisis del cine español (ficha 102) con la proyección de la película El espíritu de la colmena (Víctor Erice, 1973), y en 1983, El buen cine (ficha 269), con la película La carta (The Letter, William Wyler, 1940). Por el programa pasaron directores de cine (Basilio Martín Patino, Antonio Giménez Rico, Luis Alcoriza, Narciso Ibáñez Serrador, José Luis Garci, Pere Portabella, Roberto Bodegas, Liliana Cavani, Pilar Miró, José Luis Egea...), actores y actrices (Fernando Fernán-Gómez, José Sacristán, Carmen Maura, Imperio Argentina, Patricia Neal,

\footnotetext{
${ }^{70}$ Kawalerowicz abordó con este film los problemas de Polonia (falta de representatividad de sus líderes políticos, dependencia de la URSS, peso de la Iglesia, etc.) a través del asesinato de un dirigente político en 1922.
} 
Nadiuska, Mónica Randall, Analía Gadé...), productores (Elías Querejeta), así como todo un conjunto de guionistas, críticos e incluso propietarios de salas cinematográficas. Profundizaremos más en el cine que emitió el programa en los tres siguientes capítulos porque, como argumentan algunos autores, «ninguna corriente cinematográfica, temática o modo de hacer cine podrían separarse del entorno social que le envuelve» (Rodríguez 2015: 12). A continuación presentamos una gráfica que muestra la procedencia de las películas emitidas en La clave durante todo este periodo.

\section{Gráfica no 4. Procedencia de las películas emitidas en La clave entre 1976 y 1985}

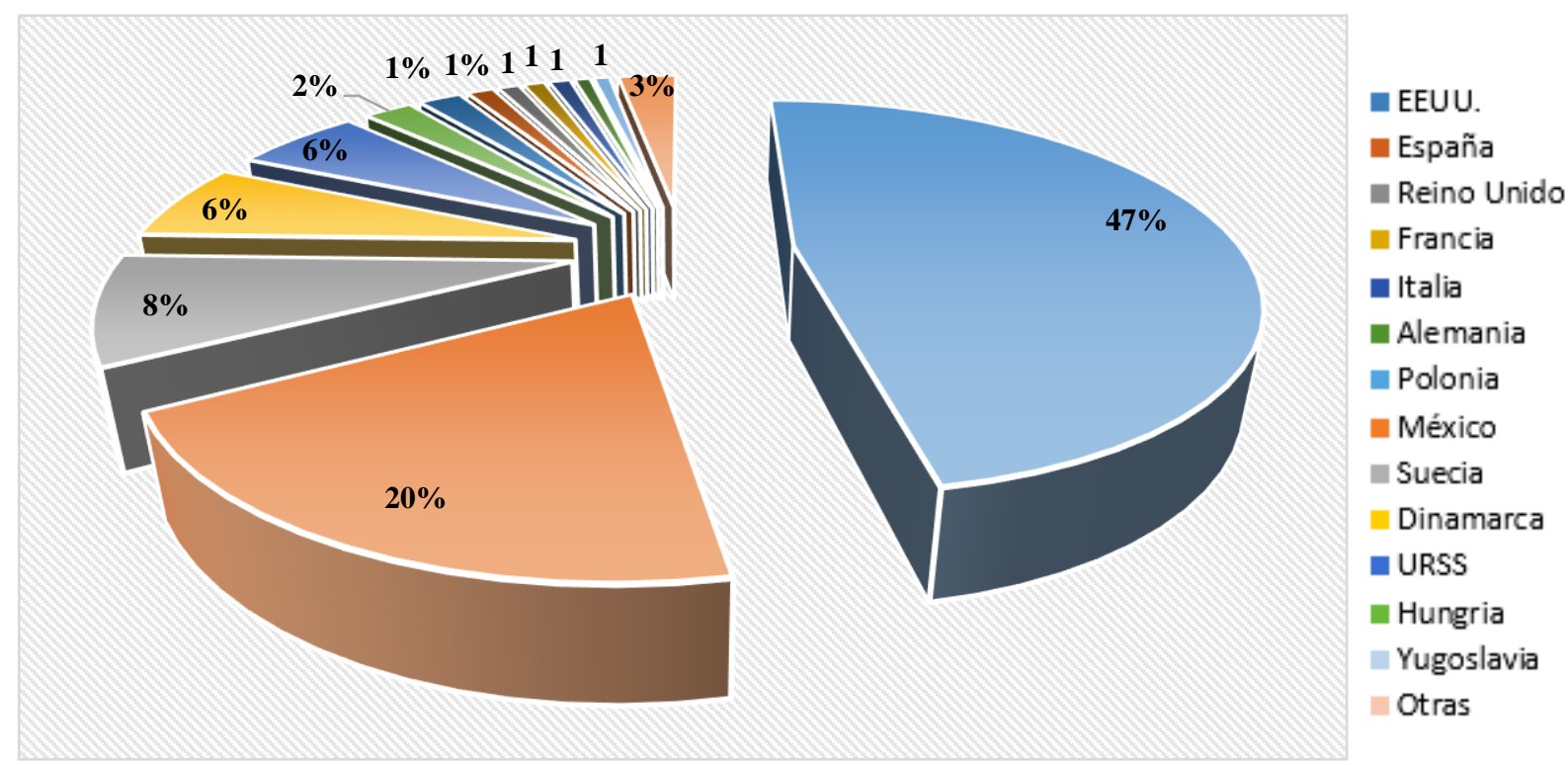

Elaboración propia.

Las producciones norteamericanas representan casi el 50\% del total de películas que emitió La clave (unas 200 películas), y las producciones nacionales el 20\% (poco más de setenta películas). No se puede negar que la potente industria norteamericana ofreció a La clave una enorme capacidad de elección que difícilmente habría conseguido en esos momentos con películas europeas, al tener una potente oferta con la que aportarle centenares de películas de todos los géneros. Sin embargo, las estadísticas totales no muestran la evolución del programa, las dificultades que tiene para realizar producción propia, o el paulatino incremento de cine español. Resulta significativo, por tanto, mostrar en los anexos la evolución del cine emitido en La clave durante el proceso de Transición ${ }^{71}$. De sus datos extraemos un distanciamiento con la propia política televisiva de TVE que, al evidente predominio de la producción norteamericana

\footnotetext{
${ }^{71}$ Sobre la evolución del cine emitido en La clave durante todo el periodo, véase el anexo n ${ }^{\circ} 6$.
} 
en la difusión cinematográfica, hay un descenso de la producción estadounidense a partir de 1982 y una apuesta por un tipo de producción más nacional y europea ${ }^{72}$.

Por último, otra de las características del cine que proyectó La clave fue la importancia que concedía a los medios de comunicación, al periodismo y a la noticia. En muchas películas se abordan los medios de comunicación como mundo representado: Sucedió una noche (It Happened One Night, Frank Capra, 1934), Luna Nueva (His Girl Friday, Howard Hawks, 1940), Ciudadano Kane (Citizen Kane, Orson Welles, 1941), Juan Nadie (Meet John Doe, Frank Capra, 1941), Sucedió mañana (It Happened Tomorrow, René Clair, 1944), El político (All the King's Men, Robert Rossen, 1949), Eva al desnudo (All About Eve, Joseph L. Mankiewicz, 1950), El gran carnaval (Ace in the Hole, Billy Wilder, 1951), El cuarto poder (Deadline, Richard Brooks, 1952), Historias de la radio (José Luis Sáenz de Heredia, 1955), Un rostro en la multitud (A Face in the Crowd, Elia Kazan, 1957), El fuego y la palabra (Elmer Gantry, Richard Brooks, 1960), Historias de la televisión (José Luis Sáenz de Heredia, 1965), A sangre fría (In Cold Blood, Richard Brooks, 1967), El candidato (The Candidate, Michael Ritchie, 1972), Historias para no dormir: El televisor (Narciso Ibáñez Serrador, 1974)... ${ }^{73}$.

\subsubsection{Interacción social: la participación del público en televisión}

Sin lugar a dudas, una de las grandes novedades que introdujo el programa fue que permitió la participación del público en televisión. Que el telespectador pudiese participar en una emisión de televisión por primera vez, rompía con la información unidireccional de la televisión del franquismo. Con la participación del telespectador se introdujo un cambio cualitativo en la televisión, menos unidireccional y más participativa. Es una de las apuestas más significativas del programa y un elemento fundamental al abrir nuevos canales de comunicación que antes no existían. En este sentido, la transmisión lineal del emisor al receptor no solo cambia con este programa, también muestra las ansias existentes de la sociedad española por liberar la palabra en televisión. En La clave, el telespectador podía participar directamente en el contenido de la propia emisión a través de sus preguntas.

Por medio de un sistema telefónico, La clave fue el primer programa en España en crear un nuevo espacio comunicativo para integrar al telespectador y hacerle partícipe en televisión.

\footnotetext{
${ }^{72}$ Véase la obra de P. Sorin, Cines europeos, sociedades europeas: 1939-1990, Paidós, Barcelona, 1996.

${ }^{73}$ También incluimos la película Todos los hombres del presidente (All the President's Men, Alan J. Pakula, 1976), que pese a no llegar a emitirse nunca, La clave intentó proyectar esta película en más de una ocasión.
} 
Nueva influencia de la televisión francesa en Televisión Española, Les Dossiers de l'écran utilizaba este sistema desde los años setenta ${ }^{74}$. Manuel Palacio y Carmen Ciller argumentan que «nunca se explicitaron los mecanismos de filtro para elegir una u otras preguntas o el número que se había recibido» (Palacio y Ciller 2014: 238). Sin embargo, sí se explicitó en la mayor parte de programas. Su funcionamiento era el siguiente: de las preguntas recibidas en la redacción, se realizaba una preselección clasificando las preguntas por temática. Se descartaban aquellas preguntas que ya habían sido abordadas o respondidas durante el debate, y se seleccionaban unas 20 preguntas que se insertaban en el tramo final cuando estaba finalizando el debate. También se indicaron el número de preguntas recibidas en muchos programas de gran expectación. Fue el caso de Elecciones (Parte 2) ¿Para quién los votos? (475 preguntas), El Valle de los Caídos (550 preguntas), A la democracia desde la dictadura (más de 500), OTAN: de salida ¿qué? (550 preguntas), y Francisco Franco (más de 600 preguntas), emisiones que analizaremos en el último capítulo. Con el propósito de hacer el mayor número posible de preguntas, Javier Vázquez, José Luis Merino, Lola Respaldiza, y en alguna ocasión Juan Testa, utilizaron esta sección como interlocutores de los telespectadores.

Por lo tanto, La clave aportó en televisión una cierta interacción social con los telespectadores, permitiéndole formular o trasladar preguntas, dudas, sugerencias, intereses, valoraciones, o comentarios, que acabaron por crear una retroalimentación semanal y una cultura más participativa con relación al medio. En definitiva, La clave, como referencia significativa del debate político, incluyó un mecanismo de participación ciudadana que enriqueció la interacción social del programa y mejoró la relación entre el político y el ciudadano porque el telespectador podía preguntar e interpelar al político. Por último, y como muestra del carácter educativo y pedagógico del programa, habría que destacar la filmografía (al acabar la película) y la bibliografía (al finalizar el debate), que permitieron al telespectador, desde una vertiente formativa, profundizar en el tema aportando datos sobre libros y películas.

\subsection{El invitado experto}

Para finalizar este capítulo, es importante señalar uno de los grandes aciertos del programa: contar con un elenco de invitados que dieron prestigio y seriedad a una televisión

\footnotetext{
${ }^{74}$ Se hacía mediante el llamado SVP, un standard telefónico que Les Dossiers de l'écran utilizó para que los telespectadores participaran en el programa mediante sus llamadas. Sobre este mecanismo véase Les programmes d'été / SVP, 25/04/1970, Institut National de l'audiovisuel (INA).
} 
con un bajo índice de credibilidad en esos momentos. Como veremos en los siguientes capítulos, los debates de La clave se convirtieron en un elemento dinamizador de la política y la cultura española. En parte se debía a la difusión de ideas y pensamiento, pero también a la creación de una opinión cualificada al tratarse de grandes expertos y personalidades internacionalmente reconocidas.

En los años cuarenta y cincuenta, sociólogos empíricos de la Universidad de Columbia realizaron diferentes estudios para analizar la influencia que tenían los medios de comunicación. Comenzaron los análisis a través de encuestas y sondeos de opinión que, con el objetivo de conocer los cambios de opinión en las elecciones políticas, acabaron por convertir algunos de sus fenómenos sociales en herramientas de evaluación y diagnóstico. En 1955, Paul F. Lazarsfeld y Elihu Katz, escribieron el libro Personal influence (de enorme repercusión) con el objetivo de comprobar empíricamente la influencia de los medios de comunicación (en concreto la radio $)^{75}$. Contrariamente a lo que cabría esperar, comprobaron que los medios tenían una menor influencia de lo que se esperaba. La radio no determinaba mecánicamente los comportamientos de los ciudadanos sino que había unas personas intermedias (líderes) que filtraban los mensajes masivos, y quienes acababan finalmente influyendo en un sentido u otro a la gente ${ }^{76}$. Lazarsfeld y Katz acuñaron la idea según la cual los mensajes circulan hacia la gran masa a través de los líderes de opinión que dan forma e interpretan el material informativo ${ }^{77}$. En la llamada sociedad de masas eran los líderes de opinión los que influían en la opinión política, y se convertían en un factor determinante en las nuevas estrategias comunicativas que la sociedad exigía a raíz de los nuevos mass media que habían surgido en las sociedades del siglo $\mathrm{XX}^{78}$. Los líderes, por tanto, se definían como aquellos individuos implicados e interesados por un tema, que tendrían los conocimientos por ser expertos en ese campo y actuarían de mediadores entre los medios de comunicación y la sociedad ${ }^{79}$.

\footnotetext{
75 Véase E. Katz y P. F. Lazarsfeld, Personal influence. The part played by people in the flow of mass communications, The Free Press, Nueva York, 1955. Obra traducida, La influencia personal, Ed. Hispano Europea, Barcelona, 1979. Considerado el primer enfoque teórico positivista sobre la comunicación de masas.

${ }^{76}$ E. Katz y P. F. Lazarsfeld, Personal influence... op. cit. p. 3. Una revisión crítica de los medios de comunicación y las corrientes sociológicas que los han abordado, en M. Wolf, La investigación de la comunicación de masas. Crítica y perspectivas, Paidós, Barcelona, 1991.

${ }^{77}$ Véase, J. C. Lozano Rendón, Teoría e investigación de la comunicación de masas, Pearson Educación, México, 2007, p. 29.

${ }^{78}$ Véanse, M. Justel, "El líder como factor de decisión y explicación de voto", Working Paper, n 51, Barcelona, 1992; y A. Kaufmann, "Liderazgo transformador y formación continua”, REIS, n 77-78, 1997, pp. 163-184.

${ }^{79}$ P. Lazarsfeld, P. F. Berelson y H. Gaudet, The People's Choise. How the voter up his mind in a presidential campaign, Columbia University Press, Nueva York, 1954, p. 151.
} 
La clave dedicó distintas emisiones a abordar los medios de comunicación. En 1984 abordó el Impacto de los medios de comunicación (ficha 324) y debatió sobre Líderes de opinión (ficha 335). En relación a la segunda, se preguntaba quiénes eran aquellos que movían a las masas, a la sociedad en general, y quiénes tenían la capacidad de introducir nuevas costumbres y provocar cambios en profundidad ${ }^{80}$. Para este debate se contó con la participación, entre otros, del sociólogo José Vidal-Beneyto, el catedrático de derecho político Óscar Alzaga y Rafael Ansón (director general de RTVE entre 1976 y 1977, y figura fundamental no solo para TVE, también para la imagen que se proyectó de don Juan Carlos de Borbón y del presidente Adolfo Suárez). Algunas de las preguntas abordadas en el transcurso del debate fueron: ¿Qué es un líder? ¿Existe la opinión pública? ¿Cómo se configura? ¿Estamos hoy peor informados $?^{81}$

La figura del experto es esencial en el programa a la hora de crear una opinión cualificada. A lo largo de los 408 programas pasaron un total de 2.708 invitados, aunque alrededor de 300 invitados repitieron en alguna ocasión. De ellos, muchos eran expertos en un determinado campo (profesores, historiadores, politólogos, filósofos, sociólogos, escritores, economistas, etc.), cuyas ideas tuvieron una importante difusión gracias a televisión y contribuyeron a esclarecer en la época, mediante el debate, algunas de las cuestiones que preocupaban a la sociedad española. Un análisis socioprofesional de los invitados nos muestra el pluralismo político ${ }^{82}$, pero sobre todo el tipo de debate (y de argumentación) que se llevó a cabo. La clave apostó por la figura del experto. Por el programa pasaron más de 200 catedráticos, más de 150 profesores y maestros, otros 150 escritores, más de 100 periodistas... El resultado es el siguiente: académicos (profesores, catedráticos, maestros), periodistas, escritores, médicos, y artistas, conforman el 50\%. Le siguieron con un 40\%, representantes políticos, militares, eclesiásticos, deportistas, empresarios, y figuras relacionadas con la televisión. El último 10\% se enmarcaría en profesiones como arquitectos, ingenieros, policías, ganaderos...

\footnotetext{
${ }^{80}$ Centro de Documentación RTVE: Líderes de opinión (ficha 335). Emisión: 27 de julio de 1983.

${ }^{81}$ Para Rafael Ansón, «el líder es el que sabe dónde hay que ir», Centro de Documentación RTVE. Líderes de opinión (ficha 335). Emisión: 27 de julio de 1983.

${ }^{82}$ A medida que transcurre el programa se incorporarían invitados que acabaron ampliando indudablemente el espectro ideológico. Por tanto, se puede medir el grado de pluralidad y observar qué corrientes de pensamiento divergentes estaban representadas en el debate. El sociólogo francés Robert Escarpit, tras conocer la suspensión del programa en 1985, escribió: «entre los centenares de invitados desde que José Luis Balbín ha creado su emisión, a raíz de la muerte de Franco, hay generales y sindicalistas, ministros franquistas, a veces incluso falangistas confesos y ministros socialistas en ejercicio, dignatarios del Opus Dei y militantes comunistas», R. Escarpit, "La clave", en Interviú, no 503, 31 de diciembre de 1985- 6 de enero de 1986, p. 93.
} 
En la introducción, su director no dudaba en decir los nombres y apellidos de aquellos invitados que no habían podido o no habían querido asistir al programa. Tiende a olvidarse la sección inicial del programa, que incluye la presentación del tema y de los invitados. Como argumentan Manuel Palacio y Carmen Ciller, «el debate propiamente dicho se iniciaba con frecuencia con un preámbulo de José Luis Balbín en el que justificaba los motivos sobre la elección de los invitados, las posibles ausencias, las razones que llevaron a elegir tal largometraje y las dificultades para optar por otros» (Palacio y Ciller 2014: 236 y 237). Nos centramos en ella con el propósito de explicar la formación de una opinión cualificada a través del programa, ya que esta sección, a la que se dedicaba aproximadamente entre quince y veinte minutos antes de proyectarse la película, era una forma de legitimar al invitado al reconocer su actividad profesional y su adecuación al tema a debatir.

La clave se convirtió en un referente televisivo que centró la atención de otros medios de comunicación. ¿Quién debatía? ¿Cuál era su trayectoria? El mismo día de la emisión, la prensa publicaba sistemáticamente los nombres de los invitados y los datos de la película. Una muestra de la importancia del invitado fue el hecho de que precisamente la prensa reparaba más en quién iba al programa, para intentar averiguar hacia dónde podría transcurrir el debate. En relación a los invitados, se elegía una primera lista de aproximadamente veinte invitados. La mayoría destacaba por sus conocimientos o méritos profesionales a lo largo de su carrera profesional. Se contactaba con los invitados que se creía más idóneos a la problemática planteada en el debate y se les proponía asistir al programa. Sin embargo, hasta el momento mismo de la emisión solían producirse cambios de última hora que afectaban, sin duda, al devenir del debate.

La clave fue el programa que permitió dar voz a un mayor número de personas durante la Transición (2708 invitados). Cabría reparar que los invitados extranjeros podían expresarse en su propia lengua al ser traducidos simultáneamente. La traducción simultánea fue otra novedad en televisión al no existir ningún programa de esas características en España. Al importante número, se unía una extensa lista de invitados entre los que figuraban algunas de las personalidades internacionales más influyentes como Olof Palme (ex primer ministro Sueco), Neil Armstrong (primer astronauta en pisar la Luna), Mário Soares (ex primer ministro de Portugal), Michel Jobert (exministro francés), Truman Capote (escritor de A sangre fría)... ${ }^{83}$.

\footnotetext{
${ }^{83}$ Es una de las grandes diferencias respecto a la televisión posterior a la crisis del modelo fundacional. En las tertulias políticas posteriores unos mismos invitados debaten sobre una enorme diversidad de temas (sin ser expertos en la mayoría de ellos).
} 
Figuras de todas las tendencias procedentes de diferentes ámbitos: escritores (José Luis Sampedro, Camilo José Cela, Dolores Medio, Manuel Vázquez Montalbán), abogados (Antonio García-Trevijano), militares (Enrique Líster), filósofos (Bernard-Henri Lévy), historiadores (Ian Gibson), sociólogos (Alain Touraine), economistas (John K. Galbraith), Premios Nobel (Severo Ochoa), asesores presidenciales (Theodore C. Sorensen), archiduques (Andrés Salvador Habsburgo-Lorena), periodistas (Indro Montanelli), actores (Fernando Fernán-Gómez), artistas (Lola Flores), deportistas (Ladislao Kubala, Alfredo Di Stéfano, Ángel Nieto, Manolo Santana)...

Por el programa pasaron cargos de importancia estatal: presidentes de gobierno y primer ministros (Alejandro Agustín Lanusse), líderes de la rebelión estudiantil de los años sesenta (Rudy Dutschke, Daniel Cohn-Bendit), representantes de grandes figuras internacionales como Mateo Emiliano Zapata (hijo del revolucionario mexicano Emiliano Zapata), Pía Luciani (sobrina de Juan Pablo I), Amelia Fleming (viuda de Alexander Fleming), e incluso pasó por el programa un miembro del Ku Klux Klan que acudió al debate con el hábito y la capucha de la organización. En relación a los invitados, pueden destacarse hasta sus ausencias, como la de Herbert Marcuse, filósofo y pensador alemán que no llegaría a intervenir en el programa, pero que dejaría su impronta como veremos en el último capítulo.

Figuras relevantes del momento en el ámbito internacional pero también nacional. En términos generales, los invitados fueron en su mayoría nacionales. Entre la élite política española que acudió al programa destacan algunos nombres propios como Adolfo Suárez, Santiago Carrillo, Manuel Fraga, Alfonso Guerra, Enrique Tierno Galván, Rodolfo Martín Villa, Raimundo Fernández-Cuesta, Joaquín Ruiz-Giménez, Jordi Pujol, Blas Piñar, Marcelino Camacho, Miquel Roca, Jorge Verstrynge, Gregorio Peces-Barba, Narciso Perales... ${ }^{84}$.

Sin embargo, no es nuestro propósito realizar un retrato individual de los invitados en La clave, ya que provocaría cierto alejamiento de la propia emisión y del tema que fue abordado. La falta de acuerdos y la discrepancia del propio debate fue un elemento determinante para los argumentos que allí se dirimían. Es de destacar que el equipo de La clave buscó un evidente equilibrio -no solo de invitados con posiciones divergentes- sino también de significaciones sociales antagónicas. Este ejemplo puede observarse desde la primera emisión. Al finalizar el

\footnotetext{
${ }^{84}$ Es difícil resumir en una lista los invitados españoles. Pasaron por el programa Fernando Savater, José Luis López Aranguren, Pilar Miró, Manuel Martín Ferrand, Eduardo Sotillos, Juan Luis Cebrián, Francisco Fernández Ordoñez, Antonio Garrigues Walker, Antonio de Senillosa, Fernando Díaz-Plaja, Guillermo Luca de Tena, Joaquín Almunia, Fernando Suárez González, Heleno Saña, Ernesto Giménez Caballero, Cristina Almeida, Nicolás Sánchez-Albornoz... Pueden consultarse todos los invitados mediante un índice albabético en el DVD anexo.
} 
debate sobre El juego (ficha 1), todos los invitados están a favor de su legalización, a pesar de pertenecer a instituciones que pudiesen tener posiciones, a priori, encontradas. Entre los invitados, un actor amante del juego, un sacerdote, un catedrático, un procurador en Cortes, un psiquiatra, y un director de casino.

También cabría reparar que unos 300 invitados aproximadamente pasaron en más de una ocasión por el programa. En este sentido, en la emisión que celebraba los 400 programas, José Luis Balbín dedicó más de diez minutos en descifrar aquellos invitados que habían repetido. Como argumenta Manuel Palacio y Carmen Ciller, «El periodista y ensayista Heleno Saña, luego colaborador en la revista $L a$ Clave, fue el invitado que intervino en mayor número de programas; lo hizo en siete ocasiones. Luego con seis participaciones Alfonso Guerra, Amando de Miguel, Antonio de Senillosa, Ignacio Francisco Taibo y Ramón Tamames y el dibujante Máximo. Y con cinco: Santiago Carrillo, Santiago Genovés, el francés Michel Jobert, Emilio Romero, José Luis Sampedro y Fernando Suárez González» (Palacio y Ciller 2014: 237 y 238). A esta lista habría que añadir Antonio Asensio, Carlos Luis Álvarez y Jorge Verstrynge. Con cuatro, un nutrido grupo de invitados como Eduardo Sotillos, Juan Luis Cebrián, Enrique Vázquez, Fabian Estapé, Fernando Fernán-Gómez, Jesús Vicente Chamorro, Gerhard Reddemann, Óscar Alzaga, José María Gil-Robles, Luis González Seara, o José María Calviño entre otros.

Otro dato a tener en cuenta es que casi el $80 \%$ de los invitados son de nacionalidad española al tratarse de un programa que tenía como propósito abordar precisamente la realidad española. Aunque no por ello, resulta bastante significativo que un $20 \%$ de invitados (más de 600) fueron extranjeros, lo que convertía a La clave en el único espacio durante la Transición en el que se podía debatir con personalidades extranjeras. Tal y como argumenta Manuel Palacio, «un aspecto hoy incomprensible, pero importante en la época, era que un porcentaje apreciable de los convidados eran extranjeros, algo que transmitía a la audiencia que España estaba (ahora) en el mapa mundial y que los nacionales eran iguales que los foráneos» (Palacio 2012: 261).

Otros datos destacables son el bajo número de mujeres que pasaron por el programa, que evidencia la baja representación de la mujer. Por el programa pasaron alrededor de 250 mujeres de un total de más de 2000 invitados. Datos procedentes de las estadísticas del programa que permiten deducir su bajo acceso al medio, pero también a puestos relevantes en la administración, en las instituciones, y en el interior de los partidos políticos. Ciertas causas del bajo índice que representó la mujer en La clave fueron expuestas por su director en distintas 
ocasiones. Su difícil acceso a las altas esferas del poder público y a cargos institucionales mermaba su participación, pues eran precisamente los lugares en los que se centraba el programa para buscar a sus invitados. Ante esta realidad, La clave dedicó alguna emisión a tratar la cuestión de género y la igualdad de oportunidades para las mujeres, su participación y representación en los puestos de toma de decisiones como fue Mujeres y política (ficha 303); programa y temática que será analizada en otro capítulo. A continuación presentamos un gráfico que muestra la procedencia de estos invitados.

\title{
Gráfica $n^{0}$ 5. Nacionalidad de los invitados extranjeros en La clave (1976-1985)
}

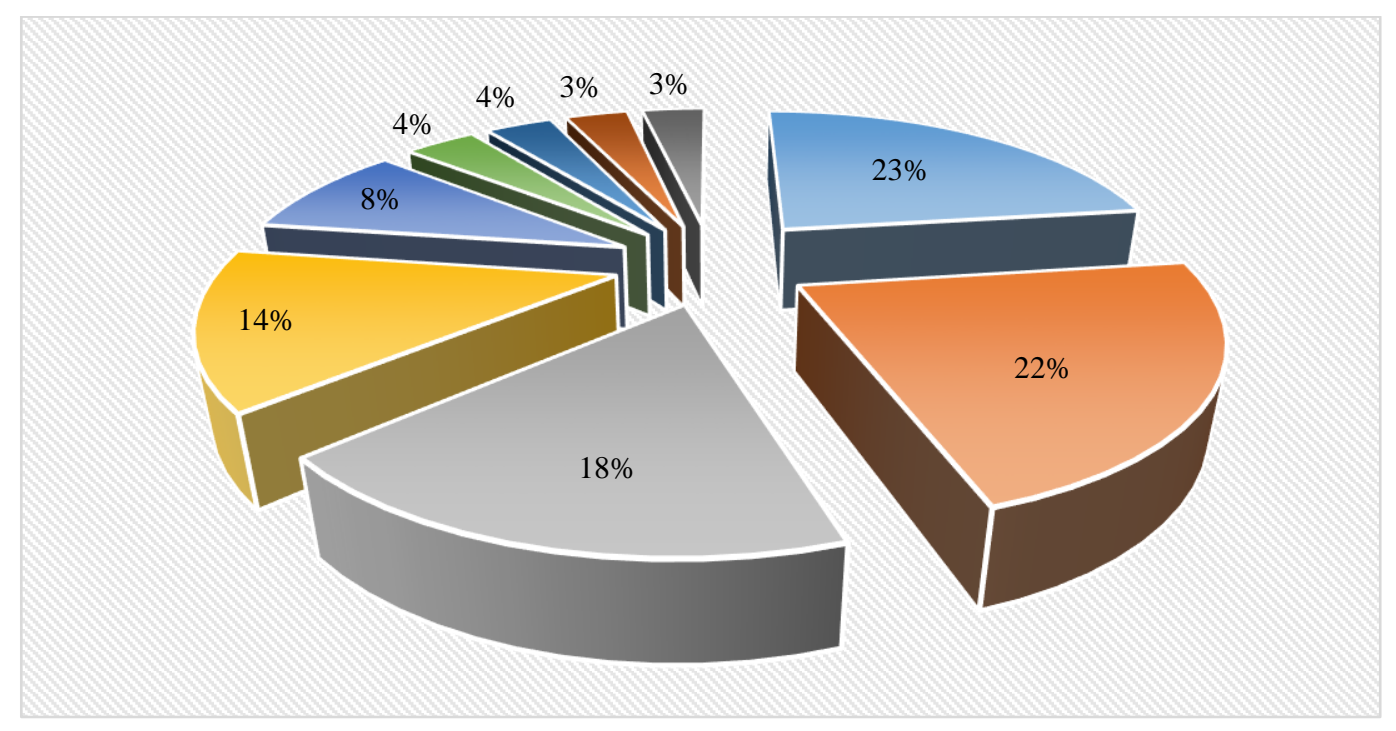

\author{
- EEUU \\ Francia \\ R.Unido \\ Alemania \\ - Italia \\ Belgica \\ Suecia \\ México \\ URSS
}

Elaboración propia.

Podemos extraer algunas conclusiones en el análisis de los datos globales del programa. Cinco países (EEUU, Francia, Reino Unido, Alemania e Italia) nutren la mayor parte de los invitados al programa con el $85 \%$. Sin embargo, el número de nacionalidades que pasaron por el programa superan las sesenta. Hubo invitados procedentes de África (Libia, Mauritania, Angola, Argelia, Egipto, Sierra Leona, Etiopía, etc.), Europa (Grecia, Austria, Holanda, Dinamarca, Noruega, Escocia, Bulgaria, Polonia, Portugal, Hungría, Suiza, etc.), América (Argentina, Bolivia, Brasil, Canadá, El Salvador, Uruguay, Ecuador, Honduras, Chile, Guatemala, Nicaragua, Costa Rica, Cuba, Venezuela, etc.), y de otras partes del mundo como China, la URSS, Turquía, India, Irak, Israel, Japón, Tíbet o Pakistán. Como hemos visto, la procedencia de los invitados internacionales proporciona una idea de los países en los que se centraba el programa a la hora de buscar a sus invitados. 
Finalmente, podemos concluir que La clave se convirtió desde sus inicios en un espacio televisivo difusor de una opinión cualificada, fundamental a la hora de orientar corrientes de opinión favorables al cambio. Cada semana contaba con la presencia de grandes expertos, académicos e invitados internacionales que debatían en público a través del mejor argumento. A pesar de la complejidad que supone analizar el contenido de cada una de las emisiones, es esencial el análisis de estos argumentos por el que transcurre el debate. En la interacción de discursos convergen diversas ideologías, creencias, opiniones y valores (como la tolerancia o el respeto por las opiniones del otro). Y en los argumentos empleados se observan conceptos que entran de lleno en las discusiones políticas. Es decir, sus invitados podían proporcionar argumentos y orientaciones e influir directamente en el ámbito de la política.

En la segunda parte de la tesis doctoral vamos a observar cómo a través de La clave se construye el debate político televisivo. Defendemos que el objetivo principal de este programa no era convencer al otro de sus ideas, sino que a través de la discrepancia y el conflicto, habían de ser capaces de llegar a conclusiones que pudiesen servir para acercar posturas. Como argumentan algunos autores como Jérôme Bourdon, los programas están rodeados de un contexto social, de textos escritos, críticas, reacciones, comentarios, cartas de telespectadores, en los que el historiador contemporáneo puede añadir numerosas entrevistas y recuerdos de los espectadores (Bourdon 2011: 19). En los siguientes capítulos, proponemos una perspectiva teórica más alejada del estudio general para dar cuenta del programa en su contexto histórico. Es en este acercamiento donde observamos la creación, a través de La clave, de una cultura política en España: la cultura política de la discrepancia. 


\section{PARTE II \\ DEBATE TELEVISIVO Y CULTURA POLÍTICA EN ESPAÑA}





\section{Capítulo 4. Los inicios del debate televisivo en España (1976-1978)}

Como ya hemos señalado previamente, presentamos un listado de programas en el DVD anexo que funciona como un segundo tomo para facilitar la consulta de sus datos. En los tres siguientes capítulos, parte central de nuestra tesis doctoral, analizamos el papel que desempeña el programa en la construcción y articulación del debate televisivo. Para ello, trazamos su trayectoria durante la Transición española a través de cinco etapas: 1. Génesis del programa y primeros debates en directo (1976). 2. El regreso de La clave (1977-1978). 3. Fernando Castedo y el golpe de Estado de 1981. 4. José Luis Balbín y los Servicios Informativos (1982-1983). 5. La etapa final de La clave (1983-1985). Cada etapa va precedida de una introducción y una contextualización con el objetivo de situar la emisión a través de algunas referencias históricas. En este capítulo abordaremos las dos primeras etapas. La presentación de la primera etapa (de doce programas) se guía por criterios cronológicos. Se inicia con la aprobación del programa en octubre de 1975 y transcurre durante los cuatro primeros meses de 1976. Se diferencia de las otras etapas en dos aspectos: todos los programas fueron en blanco y negro, y no hubo publicidad. Partiendo de la hipótesis que La clave articula las bases del debate televisivo en España ¿cómo se configura el programa en sus inicios?

\subsection{Génesis del programa y primeros debates en directo (1976)}

Retomando la trayectoria de José Luis Balbín, sus distintas etapas (la universidad, su estancia en Alemania, Francia...) son determinantes porque precisamente allí se encuentran los orígenes de La clave. En la universidad (y en el SEU) conoció en los años sesenta al que en esos momentos era el director general de RTVE Jesús Sancho Rof. En octubre de 1975 le propuso una lista de programas entre los que figuraba La clave. José Luis Balbín había estado casi una década en el extranjero (1966-1974) y había entrado en contacto con otras televisiones y otras formas de hacer y pensar la televisión. En Alemania conoció al que después fue su mayor apoyo dentro de RTVE, el director adjunto Miguel Ángel Toledano. Al igual que José Luis Balbín, Toledano trabajó de corresponsal en Bonn (1972) y en París (1973-74), aunque en su caso para el periódico $A B C$. Cuando llega la idea del programa a los Servicios Informativos, Miguel Ángel Toledano lo impulsa para su salida en antena: «Llegó a mí porque era la persona más sensible a que pudiera hacerse efectivo el proyecto de La clave. Bueno yo conocía a José 
Luis Balbín de otros avatares y otras coyunturas anteriores ajenas por completo a la televisión» ${ }^{1}$. Y de su etapa francesa, por último, será determinante la influencia que ejerce el programa producido por Armand Jammot: Les Dossiers de l'écran'2.

Las redes de sociabilidad que hemos visto en el capítulo biográfico y los apoyos internos que tenía José Luis Balbín en Televisión Española -el director general de RTVE y el director adjunto- le valieron para poner en marcha el nuevo programa. En octubre de 1975 Jesús Sancho Rof aprobó La clave. Sin embargo, los cambios políticos surgidos con la muerte de Francisco Franco el 20 de noviembre de 1975 produjeron cambios en la dirección de TVE, e hicieron retrasar la programación de la nueva temporada. Momentos políticos convulsos con la muerte del dictador, TVE afrontaba el reto de retransmitir en directo el funeral y la proclamación de don Juan Carlos; hechos que adquirieron el protagonismo político y fueron el centro de atención de la programación televisiva. Ante la cárcel de Carabanchel, en Madrid, se produjo una manifestación en favor de la amnistía que pasó desapercibida en TVE.

Con la ratificación en la Presidencia del Gobierno de Carlos Arias Navarro el 5 de diciembre de 1975, se inició el primer gobierno de la Monarquía ${ }^{3}$. En el Ministerio de Información y Turismo fue nombrado Adolfo Martín-Gamero ${ }^{4}$, y en la dirección general de RTVE, Gabriel Peña Aranda. El primer director general de RTVE de la Transición, ingeniero aeronáutico de profesión, nombrado el 22 de diciembre de 1975 sustituyendo a Jesús Sancho Rof, era el primer dirigente de RTVE que no procedía de Falange y/o el SEU. Procedía del grupo Tácito, que se había constituido en torno a personas vinculadas a la Editorial Católica

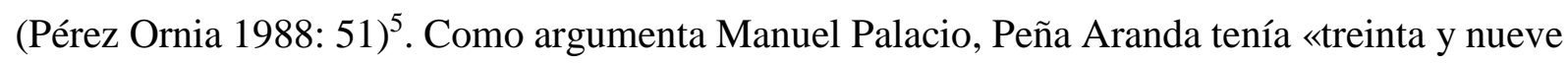

\footnotetext{
${ }^{1}$ Miguel Ángel Toledano en La difícil convivencia (ficha 300) el 25 de noviembre de 1983. «Sin su empeño y barreras defensivas para proteger el programa de los contradictorios y cambiantes colores políticos, La clave nunca hubiera salido en antena. (...) tenía una gran habilidad insuficientemente valorada para escamotear las censuras del franquismo y de esta democracia», José Luis Balbín, "Miguel Ángel Toledano ha muerto", La Clave digital, 21/01/2013.

${ }^{2}$ En todas las entrevistas, José Luis Balbín reconoce esta influencia. Le propuso a Jesús Sancho Rof «veinte cosas distintas para hacer. (...) Uno de los ejemplos que le puse fue Les Dossiers de l'écran, precedente claro de La clave», José Luis Balbín, Historia de TVE. Coleccionable, Ya, 1986, p. 120.

${ }^{3}$ El nuevo gabinete juró los cargos el 13 de diciembre, en el que destacamos Adolfo Suárez en la Secretaría General del Movimiento, Rodolfo Martín Villa en Relaciones Sindicales, y Carlos Robles Piquer (futuro director general de RTVE en 1981), ministro de Educación y Ciencia. Véase J. R. de Urquijo y Goitia, Gobiernos y ministros españoles en la edad contemporánea, CSIC, Madrid, 2008, pp. 141 y 142.

${ }^{4}$ BOE, 12/12/1975. Adolfo Martín-Gamero era licenciado en derecho. Ingresó en la carrera diplomática en 1945 y, tras ocupar el cargo de secretario de embajada en diferentes países, fue nombrado jefe de la Oficina de Información Diplomática del Ministerio de Asuntos Exteriores. En 1968 fue nombrado cónsul general en Nueva York, y más tarde, embajador de España en Marruecos.

${ }^{5}$ Como indica Manuel Palacio fue «el primer director general de RTVE que se confiesa monárquico. (...) pertenece a aquel grupo con aire democristiano liberal que fue el grupo Tácito, y es miembro del Consejo Rector del CEU y
} 
años y ninguna relación con el medio televisivo» (Palacio 2012: 86). Todavía faltan estudios que expliquen la relación que tuvo Carlos Arias Navarro y Gabriel Peña Aranda en su nombramiento como director general de RTVE. Sin embargo, como argumenta Juan Antonio Monroy, eran hombres preparados por la Iglesia católica hábilmente colocados en los altos puestos gubernamentales y en las direcciones generales «con la intención de ir preparando el asalto al poder» con la muerte de Franco ${ }^{6}$. Acorde con el clima del momento, Peña Aranda trató de evitar cualquier conflicto en televisión, nombrando en el cuadro ejecutivo de RTVE a tres periodistas ${ }^{7}$.

Es la prensa la que nos advierte de los cambios en televisión y las nuevas etapas. A finales de 1975, Enrique del Corral, crítico televisivo de $A B C$, ofrecía la solución para resolver el problema endémico que parecía sufrir Televisión Española: frente al control ideológico había que profesionalizarla, vertebrarla ampliando su base informativa, y canalizar espacios de debate y polémica a través de programas como los franceses Face à face o Cinq colonnes à la une ${ }^{8}$. En este caso, variaciones y restructuraciones que se producían principalmente en la segunda cadena con «espacios nuevos tales como La clave, que dirige el periodista José Luis Balbín, dentro de la tónica del debate sobre grandes temas con la proyección de producciones cinematográficas que hayan tenido gran impacto» ${ }^{9}$. Así presentaba la prensa el nuevo programa, conscientes de que se trataba del primer programa de debates en directo en España. «Los coloquios sobre grandes temas de nuestro tiempo conforman los espacios de más audiencia en la televisión (...). Solo las televisiones de países totalitarios se desentienden de todo eso. Al espectador se le conquista más por los temas que le preocupan» ${ }^{10}$.

del Patronato del Colegio Mayor San Pablo de Madrid, dos instituciones confesionales directamente implicadas en la formación privada universitaria» (Palacio 2012: 85 y 86). El grupo Tácito, de inspiración democristiana, lo formaban una veintena de personalidades vinculadas a la Asociación Católica Nacional de Propagandistas, y «se daría a conocer a partir de mayo de 1973 mediante la publicación de artículos semanales en el diario $Y a »$ (Tusell, Montero y Marín 1997: 249)

${ }^{6}$ J. A. Monroy, Obras completas, T. VII, Clie, Barcelona, 2000, p. 190. Véase especialmente el artículo escrito por Tácito, "Los sucesores”, en el periódico Ideal, 31/10/1975, p. 8.

${ }^{7}$ Rafael Ramos Losada (director de TVE), Luis Ezcurra (subdirector) y José de las Casas Acevedo (subdirector de los Servicios Informativos).

8 Enrique del Corral escribía en esos momentos bajo el seudónimo de Viriato, por el que era conocido periodísticamente. A inicios de la Transición, desde la prensa se pedía «una televisión ofensiva en lo cultural, en lo social, en lo político. Canalizar espacios de debate y polémica [a través de] programas radicalmente actuales en todos los aspectos sociales y políticos», en Hoja del lunes, 22/12/1975, p. 47.

${ }^{9}$ Hoja del lunes, 22/12/1975, p. 47 y 12/01/1976, p. 81. La clave no era la única novedad, también inició el programa $A$ fondo, dirigido por Joaquín Soler Serrano, quien entrevistaría a figuras relevantes de las ciencias, las artes y las letras.

${ }^{10}$ Hoja del lunes, 22/12/1975, p. 47. 


\subsubsection{Detrás de la pantalla: el arte de programar}

En la primera etapa se privilegiaron en La clave temas de marcada ambigüedad. Estos fueron los doce temas: el juego, espías, arquitectura, extraterrestres, fútbol, brujería, el universo, el hambre, el petróleo, campos de concentración, la educación y el arte. Más que una tematización, creemos que esta etapa permite el análisis concreto de algunas emisiones con las que observar cómo se configuran las bases del debate televisivo. La primera emisión de $L a$ clave se produjo el domingo 18 de enero de 1976 a las nueve de la noche, ocupando el lugar que dejaba el programa Cultura-2, que pasaba al lunes. Tras la inquietante música de Carmelo Bernaola, José Luis Balbín inició la primera emisión titulada El juego anunciando que el objetivo del programa era «plantear una serie de cuestiones sobre un tema o una problemática y presentar algunas claves para su solución a través de distintos puntos de vista» ${ }^{11}$.

En la primera emisión se formalizaron las principales bases del programa: debate en directo en torno a un determinado tema, una película introductoria, pluralidad de invitados, y participación del telespectador. Sin embargo, la primera emisión no fue en directo pese a que «nacía con la intención de ser un programa en directo, salvo si coincidía en día festivo» ${ }^{12}$. Para ilustrar el debate se emitió El jugador (Le Joueur, Claude Autant-Lara, 1958), en versión original subtitulada. No sería la norma a seguir pero, en ese momento, supuso una novedad en televisión por la obligatoriedad del doblaje durante el franquismo. Entre los invitados se encontraban los españoles Jaime de Mora y Aragón (aristócrata y actor, amante del juego aunque «ahora menos por razones económicas»), Fernando de Otazu (procurador en Cortes por Guipúzcoa y primer teniente de alcalde de San Sebastián), Francisco Vaquero (psiquiatra), y José Luis Sampedro (catedrático de estructura económica). Sobre Sampedro, José Luis Balbín declaró años después que los directivos lo consideraban «un hombre peligroso y no querían que lo invitásemos» ${ }^{13}$. Por último, en relación a la participación del público, se anunció que los telespectadores podrían llamar por teléfono y reaccionar a la emisión por medio de preguntas ${ }^{14}$. En esta ocasión, implicando a la prensa en su programa, las preguntas fueron realizadas por periodistas de Pueblo, El Correo Catalán, Pyresa, Actualidad Española, Fotogramas, y Nuevo Diario.

\footnotetext{
${ }^{11}$ Centro de Documentación RTVE. El juego (ficha 1). Emisión: 18 de enero de 1976.

${ }^{12}$ Ibídem.

${ }^{13}$ J. R. Pérez Ornia, "La clave, único programa de debate en directo de TVE, cumple hoy el número cien”, El País, $14 / 07 / 1979$

${ }^{14}$ Cfr. M. Palacio y C. Ciller, "La clave de TVE...”, en Estudios sobre el Mensaje Periodístico, op. cit. p. 231.
} 
La primera emisión de La clave no sorprendió tanto por el formato sino por lograr que el tema entrara de lleno en el debate político. Era la primera vez que se hablaba en televisión de la problemática del juego en España y su posible legalización. Hay que tener en cuenta que en esos momentos el juego era ilegal desde que el general Primo de Rivera decidiera prohibirlo en 1924, entre otras razones, «por el grado de corrupción al que habían llegado algunos locales en que se practicaba» ${ }^{15}$. A inicios de la Transición se producían frecuentemente redadas policiales para desmantelar locales en los que se jugaba clandestinamente ${ }^{16}$. Para ello, durante el debate se habló de la necesidad de modificar el Código Penal y Civil, crear una policía especial dedicada a la normativa en materia de juego y dotarse de edificios e infraestructuras ${ }^{17}$. Si bien no era la intención del programa, todos los participantes al coloquio se posicionaron a favor de su legalización. Lo que llevó a José Luis Balbín a finalizar el debate diciendo que le hubiese gustado una mayor oposición porque precisamente ese era el objetivo del programa.

Al día siguiente, la prensa recogía las primeras críticas favorables del nuevo programa. Enrique del Corral escribió en $A B C$ : «El programa tiene interés y está admirablemente conducido por el señor Balbín, cuya autoridad ante las cámaras es evidente. La realización, asimismo, obra de Pedro Rozas, es homogénea, directa y muy informativa, como requiere un espacio-coloquio de estas características que, por su resonancia, fondo, forma y temas, incluso merece, desde luego, mejor hora y día. Los domingos, a las 9,30, son malos» ${ }^{18}$. Para José Luis Balbín, en cambio, esta emisión «provocó un escándalo tremendo: recibí advertencias incluso del Consejo de Ministros» ${ }^{19}$.

En este sentido, hay que destacar la estrecha influencia que mantenía la ciudad de San Sebastián con el país galo. Su proximidad al casino de Biarritz evidenciaba la gran fuente de ingresos que podía representar el juego para una ciudad, todo un incentivo para atraer a turismo adinerado $^{20}$. Precisamente el turismo (como fuente de ingresos) hizo que muchas ciudades

\footnotetext{
15 “Los españoles ya pueden jugar”, 26/02/1977.

16 “La policía irrumpe una partida de juegos", El País, 11/06/1976.

${ }^{17}$ El procurador Fernando de Otazu propuso seguir la reglamentación francesa para legalizar el juego en España.

${ }^{18}$ ABC, 20/01/1976, p. 118. Véase también la Hoja del lunes, 19/01/1976, p. 39. En Blanco y negro otorgaron a José Luis Balbín el premio a mejor presentador semanal. Véase Blanco y negro, 24/01/1976, p. 69.

${ }^{19}$ José Luis Balbín, en A. Font, La transición política española... op. cit. p. 461.

${ }^{20}$ Desde que el Gran Casino de San Sebastián cerrara en 1924, solo en dos ocasiones abrió excepcionalmente y «en ambas ocasiones se pudo jugar a la ruleta con material prestado por casinos de Francia», en El País, "Los españoles quieren jugar", 15/08/1976. Entre los invitados extranjeros se encontraba el director de un casino francés, que en una de las preguntas de la redacción sobre la proporción de jugadores españoles en su casino, dijo que la clientela española suponía un 8-9\% de los ingresos en todo el territorio francés.
} 
(Málaga, Tarragona, Marbella...) solicitasen permisos para poder instalar casinos. El 15 de marzo se celebró en Perpiñán una reunión con diversas personalidades del sector turístico en la que participaron los alcaldes de algunas de las ciudades turísticas españolas más importantes (Málaga, Benidorm, Las Palmas de Gran Canaria, Mallorca...) ${ }^{21}$, con el objetivo de presionar a los ministerios de Gobernación, Hacienda, e Información y Turismo para despenalizar el juego $^{22}$.

Precisamente, dos meses después, en marzo de 1976, el procurador en Cortes invitado por La clave, Fernando Otazu, presentó en las Cortes una proposición de ley solicitando la modificación de artículos del Código Penal para la despenalización del juego y su reglamentación al igual que el resto de naciones europeas. En agosto de 1976 se anunció la creación de una comisión para el estudio de la legalización en España de los juegos de azar ${ }^{23}$, y un año después, en marzo de 1977, se publicaba en el BOE el Real Decreto-ley que regulaba «los juegos de suerte, azar y apuestas» ${ }^{24}$. Po lo tanto, desde la primera emisión, La clave se convirtió en una plataforma televisiva que permitía no solo la visibilidad de una temática determinada, también la defensa de ciertas ideas e intereses.

El segundo programa se emitió el 25 de enero de 1976 y estuvo dedicado a Los espías (ficha 2). Al igual que la primera emisión, fue grabado previamente, aunque no era la intención de su director, quien insistía en que «el debate se debe emitir siempre en directo» ${ }^{25}$. Este segundo programa situaba el tema del espionaje en el debate televisivo, y quizás los responsables pensaron que el directo podía esperar una semana más.

Un día antes, el 24 de enero, el rey recibió la visita del secretario de Estado norteamericano, Henry Kissinger, con el propósito de firmar el primer Tratado de Amistad y Cooperación con EE.UU. Con la firma de este Tratado, EE.UU. aseguraba la permanencia de sus bases en España -razón primordial del interés de Kissinger y del presidente Gerald Ford- y en contrapartida, EE.UU. apoyaría las reformas democráticas y la promoción de la monarquía ${ }^{26}$.

\footnotetext{
${ }^{21}$ Fuente: "Reuniones para hablar del juego en España”, El País, 11/05/1976.

${ }^{22}$ Durante varios días la prensa publicó noticias referentes a la legislación del juego en otros países como Portugal, Francia, Inglaterra y Grecia, que contaban con distintos casinos.

${ }^{23}$ Agencia Cifra, 28/08/1976.

${ }^{24} \mathrm{BOE} \mathrm{n}^{\mathrm{o}} 56$, de 7 de marzo de 1977, pp. 5302-5304.

${ }^{25}$ Centro de Documentación RTVE. Los espías (ficha 2). Emisión: 25 de enero de 1976.

${ }^{26}$ En 2011 WikiLeaks hizo público cables diplomáticos fechados entre 1973 y 1976 que mostraban conversaciones con políticos y las relaciones que Estados Unidos mantenía con España. La clave aparecerá en algún cable de WikiLeaks, como veremos a continuación, a raíz de la asistencia al programa de algún invitado.
} 
José Luis Balbín relató en 2002 que hizo esta emisión «simplemente porque a mí me gustaban mucho las novelas de John Le Carré y acabé teniendo que declarar ante el Estado Mayor del Ejército, porque se creían que estaba conchabado con el KGB, o poco menos, así que estuvo a punto de suprimirse el programa cuando solo llevaba [dos] emisiones ${ }^{27}$. Algunas de las preguntas formuladas durante el debate fueron: ¿Es necesario que todo el mundo espíe? ¿Es imprescindible en los Estados? ¿Por qué? ¿Cuál es el espionaje más importante? ¿Es difícil no ser espiado ${ }^{28}$

\subsubsection{Primer directo... primera prohibición}

El 1 de febrero de 1976 se produjo la primera emisión en directo. Bajo el título La moda Gaudí (ficha 3), los responsables creyeron que un tema de arquitectura finalmente podía encauzar el directo. Lejos de esta realidad, el título del tema no era precisamente el asunto a tratar y el tema derivó hacia la especulación y el problema social de la vivienda en muchas ciudades españolas. Durante el debate se abordaron temas como la ley del suelo -vigente desde 1956- y su inviabilidad actual, la carestía de la vivienda, la especulación, el fuerte crecimiento de algunas ciudades como Barcelona, Valencia o Madrid, y el problema del agua que esto conllevaba $^{29}$. Se proyectó la película Gaudí (Josep Maria Argemí, 1960) sobre la vida y muerte del arquitecto catalán. En estos primeros programas se evidencia algún problema principalmente con la emisión de las películas. Se había querido proyectar El pisito (Marco Ferreri, 1959) pero la copia se encontraba en mal estado. Tampoco se pudo proyectar $E l$ manantial (The Fountainhead, King Vidor, 1949), porque había llegado ese mismo día desde Nueva York, y la versión que tenían era en inglés. Sin embargo, por otro lado, muestra la minuciosa selección cinematográfica que semanalmente realizaba Carlos Pumares de intentar escoger, entre las distintas producciones cinematográficas, la más adecuada para ilustrar el debate.

\footnotetext{
${ }^{27}$ José Luis Balbín, en Á. Font, La transición política española. op. cit. pp. 463-466. En 2008, la serie Cuéntame cómo pasó utilizó este programa en su trama argumental. Sobre la serie, véase A. Corbalán, "Reconstrucción del pasado histórico: nostalgia reflexiva en Cuéntame cómo pasó”, Journal of Spanish Cultural Studies, 10 (3), 2009, pp. 341-357.

${ }^{28}$ Como veremos más adelante, la información fue una de las temáticas predilectas del programa. Dedicó emisiones a la libertad de información (fichas 123 y 203), a la relación entre información y poder (ficha 230), al pluralismo informativo (ficha 368), al impacto de los medios de comunicación (ficha 324), y a los líderes de opinión (ficha 335)...

${ }^{29}$ Los primeros rascacielos en España se construyeron en los años sesenta siendo Benidorm su claro exponente.
} 
En relación a la participación del telespectador, antes de proyectar la película se ofrecieron dos líneas telefónicas. Su director animaba a los telespectadores a reaccionar y participar en el programa señalando que, de todas las llamadas recibidas, seleccionaban «las de interés general, las más polémicas y más interesantes» ${ }^{30}$. Pero ante el número de llamadas recibidas se bloqueó la centralita y no pudieron atender todas las llamadas. A pesar de ello, se iniciaba con esta sección una ruptura respecto a la televisión del franquismo: los telespectadores podían llamar por teléfono y participar por primera vez en televisión. José Luis Balbín finalizó el programa recordando que el objetivo no era imponer una solución al problema, sino plantear un problema y ofrecer distintas claves para su solución. Durante el debate se formularon preguntas como: ¿Es necesaria la socialización del suelo? ¿Cómo será la ciudad del futuro?

La clave continuó su andadura con programas como Los extraterrestres (ficha 4), para el que se proyectó la película Ultimátum a la Tierra (The Day the Earth Stood Still, Robert Wise, 1951), «en la que los alienígenas explican a los terráqueos que como raza son un desastre y que, si no se corrigen por la buenas, ellos tendrán que intervenir» (Palacio 2012: 95) ${ }^{31}$. El programa recibió favorables críticas en prensa. En este sentido, la prensa nos permite observar qué repercusión tienen los debates y qué contenidos o declaraciones se destacan. Como bien indica Virginia Martín, había periódicos más complacientes respecto a los contenidos de la televisión pública $(A B C)$, y otros más críticos como El País o Diario 16 (Martín 2013: 242). Seguiremos la trayectoria del programa desde estos tres periódicos como tres perspectivas ideológicas que nos ayuden a medir el impacto de sus emisiones. En este caso, en ausencia todavía de El País y Diario 16 , desde $A B C$ se reconocía públicamente la calidad del nuevo programa. En su sección "los mejores en TV”, José Luis Balbín recibió el premio al "mejor director" de programa ${ }^{32}$.

Tras un mes en antena, y por decisión del director general de RTVE Gabriel Peña Aranda, se produjo el 15 de febrero de 1976 la primera suspensión. José Luis Balbín recibió presiones para no hacer en directo Periodistas (ficha 4-B) y, al negarse a ello, acabó por no emitirse. La decisión de la suspensión se tomó un día antes y algunos invitados ya se habían desplazado hasta Madrid. Si la prensa hablaba de un «momento delicado al tratarse de un tema

\footnotetext{
${ }^{30}$ Centro de Documentación RTVE. La moda Gaudí (ficha 3). Emisión: 1 de febrero de 1976.

${ }^{31}$ Centro de Documentación RTVE. Los extraterrestres (ficha 4). Emisión: 8 de febrero de 1976.

${ }^{32}$ Fuente: $A B C, 14 / 02 / 1976$, p. 69.
} 
de mucha actualidad» ${ }^{33}$, es llamativo que ni la prensa ni la televisión argumentaron las razones por las que se prohibía. Generalmente Televisión Española no informaba de sus propios cambios, y en esos momentos, la prensa focalizaba más sus críticas a la televisión en su conjunto sin tener que hacer referencia a nombres de directivos ni altos cargos. Una vez suspendida $L a$ clave, en abril de 1976, la prensa publicó que la suspensión había sido provocada por el propio director general de RTVE, Gabriel Peña Aranda ${ }^{34}$.

La principal causa de la suspensión fue el tratar de abordar un tema que podía hacer referencia a la Unión Militar Democrática (UMD). La detención en febrero del periodista Rodrigo Vázquez-Prada, acusado por no violar el secreto profesional ante una información publicada en Nuevo Diario sobre la UMD, provocó en Televisión Española una huelga de informadores y distintas manifestaciones por todo el país ${ }^{35}$. Manifestaciones que pasaron desapercibidas en televisión al igual que la huelga en Barcelona convocada por Assemblea per Catalunya, de fuerte repercusión internacional ${ }^{36}$. A raíz de estos últimos acontecimientos, y sabiendo que La clave también abordaba en sus debates la actualidad informativa, el director general de RTVE decidió prohibir el programa. Un mes más tarde, en marzo, se produjeron nuevas protestas por la detención y tortura del periodista José Antonio Martínez Soler, director de la revista Doblón, que había publicado una información sobre la Guardia Civil ${ }^{37}$. La propia revista publicó que «Televisión Española dio la noticia de forma tan tendenciosa que el telespectador recibía la impresión de que Martínez Soler fue torturado por ETA, cuando es evidente que se trata de la ultraderecha. No pocos profesionales se preguntaron ¿A quién trata de encubrir Televisión Española?» ${ }^{38}$.

Sí se movilizó Televisión Española para el primer viaje oficial de los Reyes a Cataluña en febrero de 1976. Esta visita, al igual que el posterior viaje del rey a los EEUU, nos sirve para

\footnotetext{
33 «La clave está empezando a tener una audiencia importante -se va a enfadar como el próximo domingo no aparezca en pantalla-», en "La clave, desclavada”, Blanco y Negro, 21/02/1976, p. 69.

${ }^{34}$ Véase, Blanco y Negro, “La clave, «desclavada» definitivamente”, 3/04/1976, p. 69. Cfr. M. Palacio y C. Ciller, "La clave de TVE...", en Estudios sobre el Mensaje Periodístico, op. cit. p. 237.

35 «Todos los periódicos del país se hacen eco del problema, generalmente defendiendo el secreto profesional, con más o menos matices, dependiendo de las coordenadas ideológicas de cada uno» (Rodríguez 2008: 95). En marzo, Triunfo abordó el tema de la libertad de expresión y tituló su portada "Periodistas por la libertad", Triunfo, n 687, 27 de marzo de 1976.

${ }^{36}$ Le Monde publicó en su editorial Le défi catalan (El desafío catalán), Le Monde, 10/02/1976.

37 Véase su propio relato en la web: http://martinezsoler.com/2014/03/hoy-hace-38-anos-pense-que-me-moria/ [consultado el 3/11/2014].

38 "Nuestro director, torturado", Doblón, 13/03/1976.
} 
evidenciar la escenificación del poder que hacía Televisión Española ${ }^{39}$. Desde el Salón del Tinell, y retrasmitido en directo por televisión, Juan Carlos inició su discurso en catalán (primera vez que un rey se dirigía en catalán en una intervención pública) ${ }^{40}$. Tras el discurso, los Reyes continuaron su estancia con la visita a la abadía de Montserrat, cuna espiritual y cultural de Cataluña, y a la zona obrera de Cornellà. Si a la llegada de los Reyes a Cataluña el 16 de febrero no se había producido una gran acogida, a su salida, el 22 de febrero, parte de la sociedad catalana le rindió homenaje. TVE no volvería a movilizar tantos dispositivos hasta junio con la visita del rey Juan Carlos a Washington.

Tras la prohibición de Periodistas, el programa volvió a antena con un tema popular (el fútbol) que atrajo a la audiencia. Se proyectó un documental sobre el Real Madrid titulado Goles, lágrimas y triunfos ${ }^{41}$. Entre los invitados se encontraba el presidente del Athletic Club de Bilbao, un árbitro y jugadores de fútbol. Sin duda, el fútbol, máximo exponente en la esfera del entretenimiento, fue uno de los pilares de la programación desde enero de $1963^{42}$. Sin embargo, al igual que hiciese en programas anteriores, La clave sorprendió por el tratamiento y los parámetros que siguió El negocio del fútbol (ficha 5). El propio debate y el enfoque del mismo dependerían de las preguntas y las problemáticas que se querían abordar: ¿Está politizado el fútbol?

El periodista Joaquín María Pujal argumentó que había pruebas evidentes de esa politización y como ejemplos el eslogan del F.C. Barcelona (Més que un club), o el caso del Athletic Club de Bilbao, un equipo en el que solo jugaban jugadores vascos. Se debatieron temas como la nacionalización de jugadores, en unos momentos en los que solo se permitía por club un máximo de dos jugadores extranjeros no oriundos (jugadores nacidos en América de ascendencia española), y los «trapicheos» que se producían en algunos casos cuando trataban

\footnotetext{
39 «De toda la cobertura informativa y editorial se desprende la imagen del rey Don Juan Carlos como un decisivo e influyente actor político durante todo el viaje», C. Barrera y R. Zugasti, "Imagen pública de Cataluña y de Juan Carlos I en su primer viaje como rey en febrero de 1976”, en Anàlisi, n 30, 2003, p. 75.

40 "Los Reyes de España inician su primera visita oficial a Cataluña”, $A B C, 17 / 02 / 1976$, pp. 94-95. El discurso íntegro puede consultarse en Visita a Cataluña de sus Majestades los Reyes de España: 16 al 21 de febrero de 1976, Ediciones del Movimiento, Universidad Complutense de Madrid, 1976.

${ }^{41}$ En el Centro de Documentación no se conserva la primera parte del programa (la correspondiente a la introducción de los invitados -así como una posible crítica de José Luis Balbín a la prohibición anterior- pero sí la segunda cinta que corresponde al debate.

${ }^{42}$ Cfr. J. S. Duran Froix, La télévision espagnole en point de mire. Atelier d’Études sur la Télévision Espagnole, vol I. CREC, abril de 2013, p. 6.
} 
de demostrar la ascendencia española ${ }^{43}$. Se abordó el fútbol como negocio (en el que el F.C. Barcelona se gastaba a diario un millón de pesetas). Llamativo es que las presiones de TVE llegaban hasta la UEFA. El 3 de marzo de 1976 coincidían los partidos del Real Madrid y del F.C. Barcelona. La UEFA, que no permitía retransmitir dos partidos a la misma hora, acabó cediendo a las presiones procedentes de España adelantando un día el partido del F.C. Barcelona.

Pero es en la esfera informativa donde mejor se visualizan las posibilidades del medio como instrumento político. El 27 de febrero de 1976, el programa El Gobierno Informa (dirigido por Victoriano Fernández Asís) entrevistó a Manuel Fraga. El rey Juan Carlos, satisfecho con la entrevista, llamó por teléfono a Fraga para felicitarle. WikiLeaks hizo público un cable que mostraba cierta desconfianza del rey hacia Fraga ${ }^{44}$, si bien, en la obra Legitimidad y representación (1973), Fraga expresaba la función de la monarquía como forma de Estado: «La Monarquía puede prestar, en las sociedades en Transición, unos servicios incomparables, si logra construirse en el centro seguro de un sistema dinámico, como árbitro, como moderador, como integrador y como garantía de un proceso de reforma social» ${ }^{45}$. La televisión mostraba y ocultaba dependiendo de los intereses del gobierno. De nuevo pasaban desapercibidos en televisión sucesos como los ocurridos en Vitoria en marzo de 1976. Durante una huelga, cinco trabajadores asesinados y más de cien heridos, muchos por armas de fuego. «Alteraciones del orden público», según la terminología que se utilizaba entonces, que fueron fuertemente reprimidas ${ }^{46}$.

De «gran impacto popular», según la prensa de la época, fue el programa Brujería (ficha 6), con la proyección de la película La semilla del diablo (Rosemary's Baby, Roman Polanski, 1968). Mientras su director lamentaba la ausencia en el debate de un exorcista ${ }^{47}$, la prensa se

\footnotetext{
${ }^{43}$ Centro de Documentación RTVE. El negocio del fútbol (ficha 5). Emisión: 22 de febrero de 1976. Dedicaría otra emisión al fútbol en 1978 con Mundiales de fútbol (ficha 51), que contó con Di Stéfano y Kubala entre sus invitados.

${ }^{44}$ WikiLeaks: "King's views on political situation", Department of State/Secretary of State, 1 de marzo de 1976, p. 2 .

${ }^{45}$ M. Fraga Iribarne, Legitimidad y representación, Grijalbo, Barcelona, 1973, p. 274.

${ }^{46}$ Como argumentaría Manuel Vázquez Montalbán, «la lucha obrera había sido duramente reprimida por las fuerzas del orden público, pero aquella tarde, desbordados los efectivos de la Policía, sustituyeron las balas de goma y los gases lacrimógenos por las balas de verdad contra los 5.000 manifestantes (trabajadores) que habían acudido a la Iglesia de San Francisco de Asís» (Vázquez Montalbán 2005: 104). La obra Crónica sentimental de la transición recogía los artículos escritos para el suplemento dominical de El País en 1984 y fue publicado por primera vez en 1985.

${ }^{47}$ Centro de Documentación RTVE. Brujería (ficha 6). Emisión: 22 de febrero de 1976. En 1980 dedicó otra entrega con el mismo título, Brujería (ficha 142).
} 
congratulaba porque era uno de «los programas más interesantes de la actual programación en ambas cadenas ${ }^{48}$. Esa misma semana se produjeron nuevos nombramientos en TVE que afectaron principalmente a los Servicios Informativos ${ }^{49}$. Pero la prensa era escéptica en relación a la televisión: «la actual información que se le da por nuestro primer instrumento de comunicación continúa siendo deficiente» ${ }^{50}$. La falta de libertad informativa mermaba la credibilidad de los programas informativos, que era aprovechada por programas como La clave (que gozaba de mayor libertad al emitir por la segunda cadena). Un ejemplo de ello, tal como denunciaba la revista Triunfo, era el programa dirigido por José María Íñigo, Directísimo (19751976) con sus «entrevistas breves y controladas (...) como si hubiese existido una de esas órdenes superiores que están instrumentando la televisión» ${ }^{51}$.

En la primera entrevista que concede José Luis Balbín como director de La clave, dejaba claro que el objetivo del programa era plantear un debate lo más abierto posible buscando «siempre a los mejores invitados, aquellos que puedan decirnos más cosas. Porque (...) el interés del programa reside ahí» ${ }^{52}$. Precisamente esa semana se encontraba, entre los invitados al programa La conquista del espacio (ficha 7), Neil Armstrong, primer hombre en pisar la Luna $^{53}$. Le abonaron 300.000 pesetas, dinero que el astronauta destinaría a fines benéficos, aunque la norma general era abonar a los invitados únicamente el viaje, la estancia y la comida $^{54}$.

La clave inició con El hambre (ficha 8), una serie de temas que buscaban concienciar a la sociedad. Pese a anunciar la película Los olvidados (Luis Buñuel, 1950), finalmente se proyectó Las uvas de la ira (The Grapes of Wrath, John Ford, 1940), basada en la novela

\footnotetext{
${ }^{48}$ Enrique del Corral, $A B C, 2 / 03 / 1976$ p. 126 . «Sin duda y con mucha diferencia sobre los demás, La clave ha sido el mejor programa de la semana (...) en las películas han acertado casi siempre (...). Emitir La semilla del diablo fue un gran acierto - uno más en un programa que fue casi perfecto-. Por otra parte, creemos que José Luis Balbín está logrando una comunicación muy especial con el telespectador. Esa forma de empezar el coloquio rindiendo cuentas a los telespectadores, preocupándose por las críticas que el programa recibe». Blanco y Negro, 6/03/1976, p. 69.

${ }^{49}$ Mauro Muñiz fue nombrado nuevo jefe de los Servicios Informativos.

${ }^{50}$ Blanco y Negro, 6/03/1976, p. 69.

${ }^{51}$ Triunfo, $\mathrm{n}^{\mathrm{o}}$ 687, 27 de marzo de 1976, p. 17.

52 José Luis Balbín, en Mediterráneo, 14/03/1976, p. 10.

${ }^{53}$ Centro de Documentación RTVE. La conquista del espacio (ficha 7). Emisión: 7 de marzo de 1976.

${ }^{54}$ La astróloga francesa Germaine Soleil (más conocida como Madame Soleil) cobró 20.000 pesetas por asistir al programa. Fuente: "Balbín, el hombre de La clave en televisión”, Mediterráneo, 14/03/1976, p. 10. A la altura de 1979 «tan solo diez de los setecientos invitados que han intervenido en La clave, han cobrado», en "La clave", El País, 31/03/1979. Sin embargo, en las distintas entrevistas que mantuve con José Luis Balbín y José Luis Merino, me indicaron que solo cobraron Neil Armstrong y Truman Capote.
} 
homónima de John Steinbeck. No se explicó el porqué del cambio pero algunas críticas de los telespectadores (cambios de última hora o la falta de antelación en anunciar el filme) le sirvieron al equipo para mejorar el programa. A raíz de ellas se introdujo una breve reseña filmográfica y una bibliografía. Se inició así una apuesta por mantener la misión educativa y formativa, y fomentar su carácter pedagógico. Durante el coloquio se cuestionó la obra de Adam Smith, La riqueza de las naciones (1776), y se debatieron temas como si era necesario seguir la doctrina laissez faire (dejen hacer) o plantear un nuevo orden mundial debido a que «cada vez los ricos son más ricos y los pobres más pobres» ${ }^{55}$. José Luis Balbín finalizó el programa con la frase pronunciada por Indira Gandhi el 1 de febrero de 1968 en la sesión inaugural de la Conferencia de las Naciones Unidas: «la cuestión no es si el mundo desarrollado se puede permitir el lujo de ayudar a los países subdesarrollados o en vías de desarrollo, la cuestión es si el mundo desarrollado puede permitirse el lujo de no ayudar» ${ }^{56}$.

La reacción del público a través de llamadas telefónicas, cartas al programa o a la prensa, es proporcional al incremento de audiencia que tenía semana a semana ${ }^{57}$. En esta primera entrevista también destacaba el importante nivel de audiencia, la duración del programa o el presupuesto. «Actualmente hemos reducido bastante el presupuesto. Puedo decirte que ahora un programa vale 800.000 pesetas» ${ }^{58}$. Sin embargo, en Televisión Española se estaban produciendo supresiones de programas de gran éxito como Paisaje con figuras (de Antonio Gala), o Vivir para ver (de Alfredo Amestoy), y pronto llegaron rumores de no renovar La clave, único programa de debates que había en la parrilla televisiva. El director de TVE, Rafael Ramos Losada, diseñó un nuevo esquema en televisión (que entraría en vigor el 19 de abril de 1976), con el propósito de lograr «una televisión más sonriente, más sorpresiva, menos hipotecada, en fin, ante temáticas fijas en las que la ficción no refuerce desproporcionadamente situaciones dramáticas, terroríficas o antisociales» ${ }^{59}$.

La clave debatió en marzo sobre petróleo con La banca del oro negro (ficha 9). Su director inició el programa con una fuerte crítica hacia a los que no habían querido asistir,

\footnotetext{
${ }^{55}$ Centro de Documentación RTVE. El hambre (ficha 8). Emisión: 14 de marzo de 1976.

${ }^{56}$ Ibídem. El fundido de la emisión se produjo tras unas imágenes que mostraban la pobreza (de África) acompañadas de la canción compuesta por Paul McCartney Yesterday. En 1985 abordó de nuevo el tema con Escasez en la abundancia (ficha 358).

57 «La clave, cada domingo está mejor. Los invitados son idóneos y el tema interesa por los diferentes enfoques que se le suelen dar», Blanco y Negro, 20/03/1976, p. 69.

58 José Luis Balbín, Mediterráneo, 14/03/1976, p. 10.

${ }^{59}$ Enrique del Corral, $A B C, 4 / 04 / 1976$, p. 126.
} 
motivo por el que no daban a tiempo los nombres de los invitados. «Algunos se han disculpado sin una causa justificada (...) sencillamente estamos debatiendo y a nadie se le lleva a la pared. (...) Muy a menudo, algunos invitados nos dicen si viene uno, él no va... ${ }^{60}$, y al final, de los seis invitados (o cuatro como fue en este caso) ninguno pertenece a la lista inicial. El debate giró en torno al límite de reservas (reconocidas oficialmente y no reconocidas), y la escalada del precio del barril, que había pasado de $2 \$$ en octubre de 1973 a los $12 \$$ de marzo de $1976^{61}$.

El siguiente programa fue Campos de Internamiento (ficha 10). Se proyectó la película Regresaron tres (Three Came Home, Jean Negulesco, 1950). Se debatió sobre la proliferación en el mundo de los campos de concentración y de los campos de refugiados, y entre los invitados asistió Wolf Rudiger Hess, hijo de Rudolf Hess (exjefe del Partido Nacionalsocialista Obrero Alemán, y último condenado a muerte en Nuremberg). Hess había visitado a su padre ese viernes. Lo encontró mentalmente bien después de treinta y cinco años de cárcel (diez en soledad) en la prisión de Spandau, en Berlín. En sus propias palabras, «cuatro países que se denominan humanitarios y civilizados, dejar a un hombre viejo de una forma cruel en una cárcel solo (...). Una cárcel que se construyó en su origen para seiscientas personas. Sin radio ni televisión. No puede recibir visitas, solo treinta minutos al mes, de la madre y el hijo. Tiene prohibido hablar de temas históricos y políticos» ${ }^{62}$.

Para el catedrático de derecho internacional Mariano Aguilar (padre de preso político), le parecía absurdo que Rudolf Hess continuara en prisión. El historiador Ricardo de la Cierva, vinculado al régimen ${ }^{63}$, argumentó que «el sufrimiento humano no se debe elevar a categoría ideológica», siendo la reconciliación el objetivo supremo a seguir. Y Alfredo Malibrán (condenado a muerte en Cuba que pasó once años en prisión), diría que «en el contexto de una guerra, el campo de concentración es necesario. También en tiempo de paz, después de una guerra civil. Pero es inconcebible que hayan pasado tantos años en los respectivos países desde la revolución rusa o la revolución cubana». Este programa, por tanto, muestra la problemática de basar el análisis del debate exclusivamente en términos del mejor argumento $^{64}$.

\footnotetext{
${ }^{60}$ Centro de Documentación RTVE. La banca del oro negro (ficha 9). Emisión: 14 de marzo de 1976.

${ }^{61}$ Las políticas de ajuste contra la crisis económica se materializaron en octubre de 1977 con los Pactos de la Moncloa. Véase A. Carreras y X. Tafunell, Historia económica de la España contemporánea (1789-2009), Crítica, Barcelona, 2010, pp. 367-399.

${ }^{62}$ Centro de Documentación RTVE. Campos de internamiento (ficha 10). Emisión: 21 de marzo de 1976.

${ }^{63}$ Posteriormente fue ministro de Cultura en 1980 por Unión de Centro Democrático (UCD).

${ }^{64}$ Es el caso de la obra de N. Verheyen, Diskussionslust. Eine Kulturgeschichte des »besseren Arguments «, en Westdeutschland, Vandenhoeck \& Ruprecht, Universidad de Berlín, 2003.
} 
En los años ochenta se intensificaría el debate acerca de liberar por razones humanitarias a Rudolf Hess, pero el gobierno británico mantuvo su decisión de no liberarle. Hess murió en 1987 a los 93 años de edad.

Al día siguiente del debate, 29 de marzo, la policía detuvo a los seis representantes de Coordinación Democrática que trataban de presentar ante los medios de comunicación el manifiesto de unión. Se liberaron a los dos socialistas pero el resto, entre los que figuraba Marcelino Camacho, permanecieron en la cárcel, lo que provocó una nueva manifestación en Madrid reclamando amnistía que fue fuertemente reprimida por las fuerzas del orden y omitida en TVE.

\subsection{Final de etapa. Good night, and good luck}

Un día antes de emitir El negocio de la educación (ficha 11), saltó a la prensa que el programa no continuaba: «La clave ha sido desde el comienzo uno de esos programas que molestan a los de siempre; y molestan tanto porque se hace en directo como por los temas que toca, que si bien no son de una rabiosa actualidad, algunos se han tratado con unos enfoques verdaderamente insólitos en televisión» ${ }^{65}$. ¿Qué motivos llevaron a suprimir un programa de éxito y audiencia? Las razones de Prado del Rey que publicó la prensa decían que «el programa ha cumplido su ciclo de trece espacios, y que por tanto ya está bien ${ }^{66}$. Lo que no publicaba era que la decisión fue tomada por el director general de RTVE, Gabriel Peña Aranda. Para evitar la suspensión, José Luis Balbín había propuesto reducir 400.000 pesetas por emisión; una propuesta que no fue aceptada ${ }^{67}$. No era el factor económico precisamente el problema sino aquello que pudiesen decir invitados relevantes en directo. Como argumentan Manuel Palacio y Carmen Ciller «a los políticos del momento no les gustaba que los ciudadanos opinasen con las únicas ataduras de un cierto autocontrol y que los públicos televisivos escuchasen opiniones diversas» (Palacio y Ciller 2014: 231).

El 4 de abril se confirmó la suspensión. Ese día, La clave debatió sobre El negocio de la educación (ficha 11), proyectando esta vez sí Los olvidados (Luis Buñuel, 1950). El programa suscitó un debate que puso en evidencia los postulados del sistema educativo. Se habló de analfabetismo, formación profesional, educación gratuita hasta los 14 años, y

\footnotetext{
65 “La clave, «desclavada» definitivamente, Blanco y negro, 3/04/1976, p. 69.

${ }^{66}$ Ibídem.

${ }^{67}$ En esos momentos una emisión, dependiendo de los invitados, costaba entre 1 millón y 1.800.000 pesetas.
} 
presupuestos destinados a educación. Las cifras oficiales que ofrecía Ángel Martínez (procurador en Cortes), eran contrastadas con las que aportaba el propio programa, lo que obligaba a los políticos a preparar bien el debate. Francisco Ignacio Taibo argumentó que «un mejor Estado es aquel que dedica más dinero en educación». Por su parte, Eloisa Rubio, ama de casa, destacó la necesidad de una «escolarización gratuita» que no se haría efectiva hasta julio de 1985 con la Ley Orgánica reguladora del Derecho a la Educación (LODE), que recogía la enseñanza básica, obligatoria y gratuita para toda la población menor de 14 años ${ }^{68}$.

Al finalizar, José Luis Balbín leyó el siguiente comunicado:

«La clave en directo termina aquí. Lo digo sin demasiado dolor pero sí con un poco de pena, y no es paradoja. Todo un equipo de excelentes profesionales se ha desvivido semana a semana a lo largo de trece programas para ofrecerle temas de todo tipo, no específicamente políticos, no es necesario. Se trataba de probar que ustedes sí tienen interés por los temas serios, y para ser serios éstos no tienen por qué resultar aburridos. Se trataba de probar también, y sobre todo, que contra lo que insinúan, cada vez menos, los españoles son capaces de opinar, discutir incluso contradecirse sin que haya sangre (...). En otros países, en otras televisiones, la de Francia por ejemplo, por citar la más cercana, los espectadores coloquian así desde hace quince años. Durante un trimestre escaso, ustedes han demostrado que aquí también se puede. (...) Esta experiencia hará que volvamos a conversar pronto. Hasta entonces pues, gracias por todo y muy buenas noches» ${ }^{69}$.

Eran las últimas palabras en directo. La semana siguiente, el 11 de abril, se emitió en diferido ¿Hay falsos en pintura? (ficha 12$)^{70}$. El equipo tenía preparado «un programa grabado, a forma de comodín (por si fallara una semana algo)» ${ }^{71}$, que se utilizó esa semana. Se debatió sobre el negocio del arte y la falsificación de obras (algunas de tanta calidad que llegaban incluso a engañar a los expertos). Finalizaba así la primera etapa tras 12 programas, uno prohibido (Periodistas), nueve emisiones en directo, y el paso de más de 60 invitados. José Luis Balbín volvió a los pasillos de televisión y La clave no regresó hasta dos semanas después de las elecciones del 15 de junio de 1977, primeras elecciones en más de cuarenta años. Pero antes cabría reparar en la lucha y las aspiraciones de unos y otros. El referéndum de 1976 ejemplifica como ninguno otro, la desigual disputa entre los rupturistas y reformistas.

\footnotetext{
${ }^{68}$ Ley Orgánica 8/1985, de 3 de julio de 1985.

${ }^{69}$ Centro de Documentación RTVE. El negocio de la educación (ficha 11). Emisión: 4 de abril de 1976.

70 “La clave desaparece”, ABC, 7/04/1976, p. 118.

${ }^{71}$ José Luis Balbín, entrevista en Mediterráneo, 14/03/1976, p. 10.
} 


\subsubsection{Entre reforma y ruptura: el Referéndum de 1976}

Dos expresiones que se han utilizado en multitud de ocasiones para definir la Transición española han sido las de «ruptura pactada»y «de la Ley a la Ley». La primera, para indicar que el resultado de dicha transición fue fruto de una cooperación entre las élites procedentes del régimen anterior y la oposición democrática. La segunda, para definir el proceso desde la legalidad del régimen anterior a una nueva legalidad sin quiebra de la misma ${ }^{72}$. La oposición (partidos, sindicatos y grupos), coaligados principalmente en torno al PCE y al PSOE, propugnaban mayores parcelas de libertad y una ruptura que condujera a una democracia plena $^{73}$. En sus primeras formulaciones, la ruptura implicaba la formación de un gobierno provisional que convocara elecciones en el plazo de un año, la restauración de los derechos de reunión y asociación, la inmediata legalización de los partidos políticos, la plena amnistía y el retorno a España de los exiliados ${ }^{74}$. Tras el referéndum de diciembre de 1976se acabaron rompiendo las expectativas de aquellos para los que la ruptura significaba una demolición de la legalidad vigente, saliendo reforzada la tesis de ruptura pactada (entendida como pactar la reforma, el cambio), que no fue sino un término para sintetizar el acuerdo alcanzado entre las distintas posiciones enfrentadas. Pronto fue sustituido por el de «consenso», menos conflictual que enfrentamiento o ruptura, y que evitaba sobre todo la fragmentación del acuerdo nacional en torno al sistema democrático que nacía en dicho proceso.

Pero antes de llegar al referéndum, a mediados de febrero de 1976, Cuadernos para el Diálogo ${ }^{75}$ y el periódico La Vanguardia hicieron público un informe sobre la suspensión de programas y listas negras en televisión ${ }^{76}$. La prensa se convirtió durante todo el periodo en un

\footnotetext{
${ }^{72}$ Como hemos explicado previamente existe una amplia producción historiográfica sobre la Transición española. Pero destacamos sin lugar a dudas las obras de R. G. Cotarelo (ed.), Transición política y consolidación democrática (1975-1986), CIS, Madrid, 1992; J. Aróstegui "La Transición política y la construcción de la democracia (1975-1996)”, en J. Martínez (ed.), Historia de España. Siglo XX, 1939-1996, Cátedra, Madrid, 1999, pp. 245-362. De F. Gallego, El mito de la Transición. La crisis del franquismo y los orígenes de la democracia (1973-1977), Crítica, Barcelona, 2008; y R. Quirosa-Cheyrouze (ed.), Prensa y democracia: los medios de comunicación en la Transición, Biblioteca Nueva, Madrid, 2009.

${ }^{73}$ La Junta Democrática (PCE) y la Plataforma de Convergencia Democrática (PSOE) se unieron el 26 de marzo de 1976 en un único organismo, Coordinación Democrática, conocida como Platajunta. Paulatinamente se fue sustituyendo la aspiración de «Gobierno provisional» por «Gobierno de amplio consenso democrático». Véase S. Juliá, “El Rey y Suárez conducen la transición”, en Protagonistas del siglo XX, El País, Madrid, 1999.

${ }^{74}$ Entre otros líderes, posición defendida por Felipe González en Suresnes durante el XIII Congreso del PSOE en octubre de 1974. Véase "Felipe González, al frente del partido de Largo Caballero", El País, 13/05/1976.

${ }^{75}$ Cuadernos para el Diálogo fue una revista mensual de ensayo (1963-1976), y posteriormente semanario de información general (1976-1978), en la que participaron personalidades de todo signo.

${ }^{76}$ Se prohibía la entrada a algunos trabajadores a las instalaciones de TVE, en Prado del Rey, como fueron los casos del guionista y escritor Antonio Abellán o del presentador Alfredo Amestoy. La Vanguardia, 27/05/1976, p. 31 .
} 
lugar de denuncia de lo que ocurría en TVE, pero también en fuente de problemas para muchos periodistas ${ }^{77}$. RTVE abrió un expediente a José Luis Balbín por unas declaraciones hechas en el diario La Nueva España de Oviedo en referencia a presiones en televisión. A través de medidas como «no hacer declaraciones cuando se suspende un programa», se evidenciaba el funcionamiento de la televisión en esos momentos ${ }^{78}$. Un poder, el de la prensa, que también se observa a nivel internacional. El 26 de abril el semanario norteamericano Newsweek publicó una entrevista al monarca, calificando al presidente del gobierno Arias Navarro, de "desastre sin paliativos" $" 79$. Como bien argumenta Ernesto Cruzado «No se sabe en qué momento concreto don Juan Carlos decidió prescindir de su presidente, pero sin duda fue aquel en el que comprendió que el coste de mantener a Arias estaba resultando excesivo» ${ }^{80}$. Pero la reacción del presidente fue también inesperada al utilizar la televisión para dirigirse a la nación ${ }^{81}$. Su dimisión no llegaría hasta el 1 de julio.

Tal y como argumenta José Ramón Pérez Ornia, con Carlos Arias Navarro en la presidencia, se mantuvo el continuismo en RTVE e incluso se produjo un recrudecimiento de la censura con listas negras incluidas (Pérez Ornia 1989: 65). «Televisión Española, aparte de la llamada lista negra, cuenta en su plantilla con una docena de despedidos o represaliados por motivos extralaborales» ${ }^{82}$. Efectivamente, en los primeros cinco meses de 1976 se habían producido «30 procesamientos de periodistas, tres encarcelamientos, ocho condenas de inhabilitación profesional y diez secuestros de publicaciones» (Bustamante 2006: 91), que muestran el férreo control de los medios de comunicación a inicios de la Transición democrática.

\footnotetext{
${ }^{77}$ Antonio Gala fue procesado por el Juzgado de Orden Público por artículos escritos en Sábado Gráfico. Ana Cristina Navarro fue amenazada de despido por realizar un reportaje sobre la unificación de Vietnam en el programa Informe Semanal, que provocó fuertes críticas en periódicos como El Alcázar, Fuerza Nueva y ABC. Fuente: "Se prohíbe la entrada a Alfredo Amestoy entrar en Prado del Rey”, El País, 26/05/1976.

78 «Hay trabajadores de TVE (guionistas, presentadores, actores, directores, realizadores...) dispuestos a enfrentarse con la casa para que esta situación de auténtico desconcierto profesional no continúe», Blanco y Negro, 5/06/1976, p. 71. Véase también el artículo titulado "Contra la censura”, Mediterráneo, 15/08/1976, p. 12.

79 «El Gobierno prohíbe la entrada en España de la revista y se apresura a dar un desmentido. Hay que apreciar que éste es dado por el Gobierno no por la Zarzuela, que no realiza ningún comentario», E. Cruzado, "La dimisión de Arias Navarro, factor clave para la transición. El papel de la prensa escrita en la crisis". Actas de las VI Jornadas de Castilla-La Mancha sobre Investigación en Archivos, Guadalajara, 4-7 de noviembre 2003, Vol. 2, 2004 , pp. 10-12. Cfr. V. Martín, Televisión Española y la Transición democrática, op. cit. p. 68.

${ }^{80}$ E. Cruzado, "La dimisión de Arias Navarro, factor clave para la transición”, op. cit. p. 17.

${ }^{81}$ Discurso televisado el 28 de abril de 1976 en el identifica la reforma política con la continuidad del franquismo.

82 “Concentración de profesionales de RTVE, a favor de la amnistía laboral”, El País, 9/07/1976.
} 
Televisión Española es resultado, por tanto, de una televisión centralista, paternalista, de carácter unidireccional y fuertemente controlada por las estructuras de la dictadura. La prensa denunció regularmente el caos en el que vivía $\mathrm{TVE}^{83}$, pero lo que realmente se mostraba con la supresión de programas era el miedo de los reformistas del régimen en perder el control del medio. La clave se adelantó en proclamar libertad, independencia, pluralismo político, participación del público... objetivos que en televisión tan solo serían proclamados oficialmente tras el nombramiento de Adolfo Suárez. En esos momentos, a 31 de mayo de 1976, venía de regularse en España el derecho de reunión ${ }^{84}$.

Con motivo de la primera visita oficial del rey Juan Carlos a los Estados Unidos, en junio de 1976, y como hemos adelantado previamente, Televisión Española movilizó todos sus medios para dar la mayor cobertura informativa. Fue tal la movilización que algunos autores argumentan que de Gabriel Peña Aranda tan solo se recuerda una cosa: el viaje a América de los Reyes (Munsó Cabús 2001: 139) ${ }^{85}$. Ante el Congreso de los Estados Unidos, el Rey manifestó su intención de conducir al país por una vía democrática, lo que le valió un fuerte apoyo internacional. Mientras en España, El País -periódico fundado el 4 de mayo- se hizo eco de un escrito firmado por cien profesionales de los Servicios Informativos a raíz del viaje por «el papel que se nos obliga a jugar» ${ }^{86}$. El propio ministro de Información y Turismo Adolfo Martín Gamero amenazó con dimitir si el gobierno cerraba durante cuatro meses el semanario Cambio 16, expedientado por la portada del número 235, que incluía en su interior una caricatura del propio don Juan Carlos ${ }^{87}$.

Tras la dimisión de Carlos Arias Navarro el 1 de julio de 1976 llegó el nombramiento de Adolfo Suárez tras la terna del Consejo del Reino. Su nombramiento se produjo el 5 de julio de 1976. Suárez había nacido en 1932 en Cebreros (Ávila), y había desempeñado el cargo de gobernador civil y jefe provincial del Movimiento de Segovia. El nuevo presidente conocía bien

\footnotetext{
${ }^{83}$ «Si la pasada semana decíamos que en Prado del Rey imperaba una especie de "Ley de la selva” (...) en esta ocasión ya no queda ni eso, ahora solo se observa un desmadre, desconsolador. Y lo peor de todo -o lo mejor- es que muchos de los que estaban callados les estén entrando ganas de hablar. Incluso algunos ya han amenazado con hacerlo ¿Comprenderán por qué decíamos al principio que se acercaba un verano muy calentito en Prado del Rey?», Blanco y Negro, 5/06/1976, p. 71.

${ }^{84} \mathrm{BOE}, \mathrm{n}^{\mathrm{o}} 130,31$ de mayo de 1976.

${ }^{85}$ Cfr. V. Martín, Televisión Española y Transición democrática, op. cit. p. 48.

${ }^{86}$ Fuente: "La información en Radio y Televisión no es objetiva", El País, 11/06/1976. Cfr. M. Palacio, La televisión durante la Transición democrática, op. cit. p. 100. Sobre el papel de dicho diario durante el proceso de Transición, véase L. Negró, El diario El País y la cultura de las elites durante la transición, Foca, Madrid, 2006.

${ }^{87}$ Fuente: "El rey que viajó", Cambio 16, no 235, 7-13 de junio de 1976, p. 11.
} 
las posibilidades que ofrecía el medio televisivo: había ocupado el cargo de secretario de las Comisiones Asesoras de RTVE (1964), la jefatura de programas (1965-67), la dirección de la primera cadena (1967) y la dirección general de RTVE (1969 y 1973) ${ }^{88}$.

Al día siguiente de su nombramiento, el 6 de julio de 1976, apareció en televisión para presentarse ante los españoles ${ }^{89}$, y el 23 de julio nombró a Rafael Ansón director general de RTVE $^{90}$. Como indica Manuel Palacio, «a diferencia de lo ocurrido en cualquier otro momento anterior, la búsqueda del director general se convierte en exclusiva responsabilidad del presidente del gobierno» (Palacio 2012: 149). Rafael Ansón tenía cuarenta años, diplomado en psicología y administración en la Escuela Nacional de Administración Francesa (ENA), doctor en derecho y experto en relaciones públicas, persuasión y propaganda ${ }^{91}$. Como argumenta Virginia Martín, «entre el director general y el presidente existía desde tiempo atrás una estrecha amistad que se había forjado ya en las oficinas de prensa de la Presidencia del Gobierno, donde Suárez había trabajado en el departamento de relaciones públicas junto a Rafael Ansón» (Martín 2013: 50).

Rafael Ansón ocupó el cargo de director general de RTVE desde el 23 de julio de 1976 hasta el 17 de noviembre de 1977. Es durante este periodo donde se dibuja «un modelo televisivo español para la salida de la dictadura» (Palacio 2012: 107), pero siguiendo las directrices marcadas y el control desde dentro del gobierno. A la altura de julio de 1976, Televisión Española tenía una programación de 95 horas semanales en las dos cadenas y cerca de siete mil personas forman la plantilla de RTVE. Durante el tiempo que está al frente de RTVE, Rafael Ansón desempeñó un papel determinante: realizó una renovación de la estructura de los Servicios Informativos que le permitió controlar los contenidos televisivos, y consolidó en televisión las figuras de Adolfo Suárez y Juan Carlos ${ }^{92}$. Fue asesor en las campañas

\footnotetext{
${ }^{88}$ Como argumenta Manuel Palacio, el nuevo presidente «cree firmemente que el medio televisivo constituye un elemento central de la comunicación social y política de la España que sale de la dictadura» (Palacio 2012: 117). Para una mayor ampliación de RTVE bajo la dirección de Adolfo Suárez, véase G. Morán, Adolfo Suárez, historia de una ambición, Planeta., Barcelona, 1979.

${ }^{89}$ Un análisis del mensaje en V. Martín, Televisión Española y la Transición democrática, op. cit. pp. 72-79, y M. Palacio, La televisión durante la Transición española, op. cit. pp. 116-123.

${ }^{90}$ Entre los nuevos nombramientos destacamos a Leopoldo Calvo Sotelo, ministro de Obras Públicas, Rodolfo Martín Villa, ministro de la Gobernación, y Andrés Reguera, ministro de Información y Turismo.

${ }^{91}$ En 1973 fue director del Instituto de la Opinión Pública (IOP), que había sido fundado en 1963 con el objetivo de investigar la opinión pública nacional e internacional. Véase Rafael Ansón (Dir.), Revista Española de la Opinión Pública, no 33, julio-septiembre 1973, Centro de Investigaciones Sociológicas, Madrid, p. 1.

${ }^{92}$ Fuente: RTVE, 1976, p. 6. Rafael Ansón siguió la labor de sus predecesores proyectando la mejor imagen de la Monarquía. «La monarquía española - todos lo hemos visto-, que reanuda una tradición secular, tiene ganada la
} 
electorales del referéndum de diciembre de 1976 y en las elecciones de junio de 1977, que lo convirtieron en el «artífice central de las operaciones que interrelacionan Adolfo Suárez, transición democrática y marketing» (Palacio 2012: 128). Su hermano, Luis María Ansón (profesor de José Luis Balbín en la Escuela Oficial de Periodismo), fue designado en septiembre de 1976 «presidente y director general de la Agencia EFE, el otro gran aparato de comunicación estatal, en donde se mantendría hasta la llegada de los socialistas» (Bustamante 2006: 65-66). Ambos fueron invitados a La clave ${ }^{93}$.

El camino hacia el referéndum se inició en televisión el 10 de septiembre de 1976, cuando Adolfo Suárez presentó ante las cámaras de TVE el proyecto de Ley para la Reforma Política. Según datos ofrecidos por la prensa «uno de cada tres españoles vio en directo o diferido por televisión el mensaje presidencial» ${ }^{94}$. Un $76 \%$ de los españoles calificó este mensaje de bueno o muy bueno y solo un $2 \%$ lo calificó de malo ${ }^{95}$. Dos días antes había presentado el proyecto a los altos mandos militares (Palacio 2012: 114 y Martín 2013: 86). Escrita por Torcuato Fernández-Miranda, la Ley para la Reforma Política ha sido calificada por algunos autores de pieza maestra de la Transición ${ }^{96}$. Aprobada por las Cortes el 18 de noviembre, y sometida a referéndum el 15 de diciembre de 1976, permitió la creación de las bases jurídicas necesarias para pasar de la legalidad franquista a la legalidad democrática ${ }^{97}$.

Sin embargo, tras el nombramiento de Adolfo Suárez, continuó el control y la exclusividad informativa. A inicios de septiembre, la Dirección General de RTVE envió a los directores de emisoras privadas un oficio (que filtró la prensa en octubre), recordando sus limitaciones: «las emisoras no podrán realizar información general a partir de este momento, en tanto no sean autorizadas» ${ }^{98}$. La prensa fue muy crítica desde la llegada del ministro de

\footnotetext{
simpatía, la amistad, el respeto de los países más importantes del mundo. RTVE es consciente y está orgullosa de su bien cumplida misión», RTVE, 1976, p. 31.

${ }^{93}$ Rafael Ansón en Líderes de opinión (ficha 335), y Luis María Ansón en Periodistas (ficha 5-C), que finalmente fue prohibido. Luis María Ansón dirigía las revistas Blanco y Negro (dominical de ABC), Gaceta Ilustrada, y un programa en TVE los viernes, La prensa en el debate, con el que trataba de potenciar el periodismo escrito en televisión. Fuente: RTVE, 1976, p. 51. El tercero de los hermanos, Francisco Ansón, había ocupado la dirección del Departamento de Estudios e Investigación de Audiencias, y la jefatura de los Servicios de Estudio de Contenido de TVE.

94 “La intervención del presidente causó buena impresión a la mayoría”, El País, 19/09/1976.

${ }^{5}$ V. Martín, Televisión Española y la Transición democrática, op. cit. p. 88.

${ }^{96}$ M. Redero San Román, Estudios de historia de la UGT, Ediciones Universidad de Salamanca, p. 156; o C. Barrera, Historia del proceso democrático en España: tardofranquismo, transición y democracia, Fragua, Madrid, 2002, p. 81.

${ }^{97}$ Ley 1/1977, de 4 de enero de 1977.

98 "La Administración reafirma su exclusividad informativa”, El País, 10/09/1976.
} 
Información y Turismo Andrés Reguera ${ }^{99}$. En declaraciones a la prensa condicionaba la libertad informativa a «unos matices de objetividad de planteamientos y unos límites -la Monarquía, la unidad nacional y el respeto a las Fuerzas Armadas, que no son discutibles» ${ }^{100}$. En octubre (mes en el que Televisión Española celebraba su veinte aniversario), se procedió a la reorganización de la dirección general creando un Consejo General para RTVE ${ }^{101}$. El director de TVE, Ramos Losada, argumentaría en una entrevista que había que superar el esquema tradicional en el que se había asentado la televisión hasta esos momentos: «Estamos en los tiempos en que las audiencias no quieren ser pasivas y exigen su participación en la programación» ${ }^{102}$. El titular que introducía la entrevista, «Pronto habrá programas de opinión y debate», mostraba el vacío existente en la televisión pública desde la suspensión de La clave.

Estando en los pasillos de TVE, José Luis Balbín fue nombrado jefe del gabinete de prensa del ministro de la Gobernación, Rodolfo Martín Villa ${ }^{103}$. En una entrevista en 2010 diría: «conocía a Rodolfo Martín Villa de la época de estudiantes y mandó policías a mi casa. 'Venimos a buscarle de parte del ministro del Interior'. Fui y Martín Villa me dijo: 'Te necesito aquí'. 'No me interesa'. 'Da igual', y me obligó, relativamente, a quedar. Duré tres meses, que por cierto nunca me pagaron» ${ }^{104}$.

En noviembre de 1976 surgieron rumores de su regreso. Blanco y Negro se preguntaba si alguien estaba intentado vetar a José Luis Balbín y si existía alguna razón oculta ${ }^{105}$. Ese mes, el Ministerio de Información y Turismo, como vimos en el capítulo biográfico, recogió un nuevo dato que integró en el expediente personal de José Luis Balbín: «Políticamente pertenece

\footnotetext{
99 «La frustración profesional de los crédulos no ha podido ser más rotunda. La principal ocasión que tenían los informadores (...) sobre los temas de actualidad palpitante -la rueda de prensa tras el consejo de ministros-, acabó justamente con la llegada al Ministerio de Información y Turismo», "Un ministro sin estrenar", El País, 29/10/1976.

100 "La libertad informativa va ligada a unos límites indiscutibles", El País, 28/09/1976. Esa misma semana el Ministerio incautó la revista Interviú por la publicación de un reportaje sobre el aniversario de las ejecuciones de militantes de ETA y FRAP. Fuente: "Secuestro de Interviü", El País, 30/09/1976. Hay que tener en cuenta que a inicios de la Transición continuaba vigente la Ley de Prensa e Imprenta de 1966, derogada por el Real Decreto de 1 de abril de 1977 sobre la libertad de expresión que suprimía las limitaciones de prensa con tres excepciones sensibles: el respeto a la Monarquía, a la unidad nacional y a las Fuerzas Armadas. Véase M. Cruz y S. Sueiro "La prensa", en J. Tusell (coord.), La transición a la democracia y el reinado de Juan Carlos I, Espasa Calpe, 2003, pp. 711-736.

${ }^{101}$ Andrés Reguera, El País, 30/10/1976.

${ }^{102}$ Rafael Ramos Losada, $A B C$, 25/09/1976, p. 93.

${ }^{103}$ Ministerio de Información y Turismo: Gabinete de Enlace, caja 42/08788, exp. 3. AGA.

${ }^{104}$ La Nueva España, 22/03/2010.

${ }^{105}$ Blanco y negro, 20/11/1976, p. 67.
} 
al grupo demócrata-cristiano de D. Federico Silva Muñoz» ${ }^{106}$. Silva Muñoz fue ministro de Obras Públicas entre 1965 y 1969, y en 1976, uno de los candidatos en la terna del Consejo del Reino para sustituir a Carlos Arias Navarro, de la que salió finalmente el presidente Adolfo Suárez ${ }^{107}$.

Sin embargo, como hemos visto previamente, José Luis Balbín no pertenecía al grupo de Federico Silva Muñoz. Como argumenta María de la Paz Pando, «fue común entre muchos de los pertenecientes al grupo herreriano de la Asociación Católica Nacional de Propagandistas (ACNP) que colaboró con el franquismo autodenominarse 'democratacristianos', con independencia de su adscripción posterior o no a la democracia política» ${ }^{108}$.

La campaña oficial hacia el referéndum comenzó el 25 de noviembre y finalizó el 14 de diciembre de 1976 Los Reyes de España visitaron las instalaciones de TVE en plena campaña ${ }^{109}$. Para el ministro de Información y Turismo «el próximo referéndum puede ser decisivo para la evolución de las libertades informativas en España, puesto que deja paso a un entorno político-social más abierto y más pluralista en el que la prensa podrá desenvolverse con más amplitud y posibilidades» ${ }^{110}$. Se refería a ensanchar las fronteras del campo informativo, eso sí, una vez trascurrido el referéndum. Con Rafael Ansón se incrementaron los esfuerzos en favor del sí, impregnando Televisión Española de programas y spots televisivos proreferéndum, y aniquilando cualquier tipo de oposición o abstención ${ }^{111}$. La restructuración de los Servicios Informativos había servido para aumentar la competencia y calidad, pero también el control del contenido.

¿Aprueba el Proyecto de Ley para la Reforma Política? El referéndum del 15 de diciembre de 1976 dio como resultado la aprobación del proyecto con el apoyo del 94,17\% de

\footnotetext{
106 Ministerio de Información y Turismo: Gabinete de Enlace, caja 42/08788, exp. 3. Dossier informativo sobre José Luis Balbín Meana -Años 1974-1976. Archivo General de la Administración.

107 Véase la obra de F. Silva Muñoz, Memorias políticas, Planeta, Barcelona, 1993.

108 Véase la tesis doctoral de $\mathrm{M}^{\mathrm{a}}$ de la Paz Pando, Los democristianos y el proyecto político de «Cuadernos para el Diálogo», 1963-1969, Universidad de Salamanca, Salamanca, 2005, p. 159.

109 Véase: Noticiarios y Documentales (NO-DO), no 1766A, 29-11-1976.

${ }^{110}$ Andrés Reguera, en una conferencia pronunciada el 2 de diciembre de 1976 en Club Siglo XXI.

111 TVE tenía como precedente en el franquismo la campaña mediática a favor de Franco en la Plaza de Oriente el 1 de octubre de 1975. Para el referéndum, se incrementó la cobertura informativa y los programas dedicados al sí. También la publicidad institucional traducida en todos los idiomas del Estado, y una serie de eslóganes que impregnaron la televisión y la calle: "Si votas hoy podrás decidir mañana", "La reforma política es el paso más serio hacia la democracia", "Para que calle la demagogia, referéndum 15 de diciembre", "Tu voz es tu voto"...
} 
los votantes $(77,8 \% \text { de los electores })^{112}$. En este sentido, como argumenta Vidal-Beneyto, cuatro fueron los objetivos de la Ley para la Reforma Política: 1. Legitimación popular de la Corona por vía indirecta del Parlamento y la Constitución. 2. Recuperación «democrática» de la clase política franquista reformista. 3. Consolidación y mantenimiento en la nueva democracia de la dirección política en manos de la derecha. 4. Confiar la actividad democrática al dominio estrictamente político y, en su interior, al derecho de voto ${ }^{113}$. Tras el referéndum, la oposición democrática, sin una posición firme (ni ningún espacio televisivo), perdió definitivamente la batalla por conducir el proceso de transición. Las circunstancias políticas habían cambiado, y la oposición democrática fue renunciando -a diferentes velocidades- al proyecto de ruptura democrática ${ }^{114}$. Muchos vieron en el referéndum el final de las opciones políticas de dirigir el proceso hacia la democracia ${ }^{115}$. Otros, lo utilizaron como instrumento de presión para forzar la negociación. Una vez aprobada la ley ${ }^{116}$, la oposición entró en negociaciones: de enero a junio de 1977 se materializaron los pactos entre los reformistas y la oposición: libertad de partidos ${ }^{117}$, libertad de expresión ${ }^{118}$, disolución del Movimiento ${ }^{119}$, convocatoria de elecciones $^{120}$ y, hasta finales de año, Amnistía ${ }^{121}$ y Pactos de la Moncloa, firmados en octubre de 1977.

A finales de año, $A B C$ calificó el año 1976 de «año más difícil para TVE. Quizá lo haya sido, para España social, política y económica» ${ }^{122}$. La credibilidad de la televisión, tras un descenso desde mediados de 1975, se había revitalizado a inicios de 1976 con nuevos programas, concretamente en la segunda cadena, pero la retirada de estos mismos programas, mermó de nuevo la credibilidad televisiva. Publicaciones posteriores de RTVE, confirmaron

\footnotetext{
112 Véase S. Juliá, "En torno a los proyectos de transición y sus imprevistos resultados", en C. Molinero (ed.), La transición treinta años después. De la dictadura a la instauración de la democracia, Península, Barcelona, 2006, pp. 59-80.

${ }^{113}$ J. Vidal-Beneyto, “Le Revers de la Médaille”, en L'Espagne Démocratique, Pouvoirs, no 8, 1984, p. 56.

${ }^{114}$ C. Barrera, "El debate sobre la televisión y el referéndum de la Ley para la reforma política de 1976", en A. Company, J. Pons y S. Serra (coords.), La comunicació audiovisual en la història. V Encontre d'Historiadors de la Comunicació. Aportacions de la comunicació i construcció de la història del segle XX. Universitat de les Illes Balears, Palma, vol. 2, 2003. pp. 491-508.

${ }^{115}$ R. del Águila, "La dinámica de la legitimidad en el discurso político de la Transición”, en R. Cotarelo (Comp.), Transición política y consolidación democrática... op. cit. pp. 65-66.

${ }^{116}$ Ley 1/1977, de 4 de enero sobre la Reforma Política. BOE, n 4, 5/01/1977, pp. 170-171.

${ }^{117}$ Decreto Ley 12/1977, de 8 de febrero sobre Partidos Políticos.

${ }^{118}$ Ley 19/1977, de 1 de abril sobre Libertad de Expresión.

${ }^{119}$ Decreto-ley 23/1977, de 1 de abril.

${ }^{120}$ Real Decreto Ley 20/1977, de 18 de marzo sobre Normas Electorales.

${ }^{121}$ Ley 46/1977, de 15 de octubre.

${ }^{122} A B C, 26 / 12 / 1976$, p. 157.
} 
que la mayor audiencia en 1976 en la segunda cadena se había producido el domingo, coincidiendo con programa La clave ${ }^{123}$. Estar fuera de la parrilla, convertía al programa en una ausencia significativa. En enero de 1977, José Luis Balbín mantuvo una entrevista con Rafael Ansón: «me habló del propósito de recuperarme a toda costa (...) aunque [puse] la condición de que no sufriera ninguna modificación de fondo, pues de otra forma no lo haría» ${ }^{124}$. Quizás por ello el programa no regresó hasta después de las elecciones de junio de 1977.

En 1977, y tras la constitución del Consejo General, el ministro Andrés Reguera inició una segunda fase en RTVE: preparar la norma jurídica para «consolidar definitivamente RTVE como una gran institución del Estado al servicio de la comunidad nacional, tal y como exige la estabilización de ese futuro democrático que ya estamos tocando con los dedos, en el contexto permanente de la Monarquía» ${ }^{125}$. Desde la Dirección General de Radiodifusión se envió de nuevo una circular dirigida a todos los directores de emisoras privadas en España limitando la información radiofónica de partidos políticos, propaganda o información ${ }^{126}$. Recordaba las tres limitaciones en materia de libertad de expresión, «aquéllas que afectan a los puntos fundamentales del Estado: la Corona, las Fuerzas Armadas y la unidad nacional» ${ }^{127}$. En la práctica se materializaba con el secuestro de libros (como el de José Fortes y Restituto Valero Qué son las Fuerzas Armadas), o las multas (como la de 50.000 pesetas impuesta a la revista Ozono por los artículos referentes a «una supuesta defensa de la homosexualidad, ataques a la unidad nacional y a los sentimientos religiosos» ${ }^{128}$ ). También en televisión se prohibían programas si aparecía algún dirigente no deseado como Raúl Morodó, dirigente del Partido Socialista Popular ${ }^{129}$, o el político catalán Jordi Pujol en Informe especial ${ }^{130}$.

En abril, diecisiete partidos hicieron público un documento acusando al gobierno de vulnerar los principios de neutralidad e igualdad de oportunidades por la discriminación en el uso de espacios de Radiotelevisión ${ }^{131}$. A partir del 10 de febrero de 1977 comenzaron a

\footnotetext{
${ }^{123}$ Mensaje y Medios, Instituto Oficial de Radiodifusión y televisión, n 1, octubre de 1977, Madrid, p. 93.

${ }^{124}$ Diario 16, 20/01/1977, p. 31.

125 Andrés Reguera, en "RTVE no puede estar controlada solo por el Gobierno", El País, 6/02/1977.

126 "Prohibida la información sobre partidos políticos en las emisoras privadas”, El País, 24/02/1977.

127 “Tres límites a la libertad de expresión: el Rey, el Ejército y la unidad nacional”, El País, 13/03/1977.

128 "Multa de 50.000 pesetas a la revista Ozono", El País, 15/03/1977. Sobre esta cuestión véase, F. Rojas, "La represión cultural durante la Transición: los últimos 'libros prohibidos' (1975-79)”, Represura, no 3, mayo 2007.

129 "La Administración anula un programa de la SER y la BBC”, El País, 11/03/1977.

130 "RTVE suspendió anoche una entrevista a Jordi Pujol”, El País, 13/03/1977.

131 "El Gobierno no se ha mostrado neutral antes las elecciones”, El País, 6/04/1977.
} 
legalizarse los partidos políticos (9 de abril para el Partido Comunista), sin apenas tiempo para preparar las primeras elecciones libres desde 1936 (convocadas para el 15 de junio de 1977). Algunos dirigentes como José María Gil-Robles lamentaron la precipitación con la que se habían convocado las elecciones ${ }^{132}$. Televisión Española se preparó para movilizar todos sus dispositivos en las que serían las primeras elecciones democráticas.

\subsection{El discurso televisivo en las elecciones del 15 de junio de 1977}

Tanto Adolfo Suárez como Rafael Ansón habían ocupado la Dirección general de RTVE y eran conscientes del poder que tenía la televisión. Si Adolfo Suárez se encargó de impulsar la imagen pública del príncipe Juan Carlos entre 1969 y 1973 (prácticamente desconocido a nivel nacional e internacional), ahora en las elecciones Rafael Ansón impulsaría la suya. Un aspecto esencial fue impulsar la imagen de modernidad del nuevo presidente. Adolfo Suárez tenía 44 años y representaba una nueva generación de políticos españoles. Rafael Ansón dirigió la maquinaria televisiva hasta el punto, que si bien no ocultó en ningún momento cuáles eran sus propósitos, hizo y deshizo a su gusto. Un ejemplo fue el programa España, paso a paso, con el que se quería realizar antes de las elecciones un retrato político, económico, social y cultural de las regiones de España ${ }^{133}$. Ansón decidió programarlo para después del cierre de emisión y tras las imágenes de la bandera nacional. A la poca audiencia, algunas regiones ni se emitieron ${ }^{134}$. De estas maniobras se haría eco José Ramón Pérez Ornia años más tarde, en $1979^{135}$.

Durante la campaña electoral, la obsesión por los minutados y el cronómetro -una constante en todo el proceso- muestra no solo el férreo control a la que estaba sometida la televisión, también la atenta mirada que se hace de ella. En la primera aparición en televisión de Santiago Carrillo, el 5 de mayo de 1977, la prensa resaltó que fue de un minuto y veinte segundos. Mientras la alocución de Adolfo Suárez días antes, en la que se presentaba como

\footnotetext{
132 «No ha habido tiempo de depurar las ideologías, ha faltado oportunidad de perfilar los programas (...). No se ha dado tiempo a levantar construcciones medianamente sólidas, y la opinión se encamina a las urnas sin haber podido contrastar las ideologías, comprobar la disciplina de los grupos, medir la capacidad de los que se han erigido en directores», José María Gil-Robles, Diario 16, 11/05/1977, p. 5.

${ }^{133}$ Programa dirigido por Fernando Onega y Ladislao Azcona entre el 10 de abril y el 10 de mayo de 1977.

${ }^{134}$ Fuente: "El arte de programar”, El País, 13/14/1979.

135 “Incidentes 1 y 2", El País, 17/04/1979, y 18/04/1979. Entre algunos de los programas que no se emitieron se encontraba el capítulo "El siglo de oro español" de la serie de dibujos animados Érase una vez... el hombre (Il était une fois... l'Homme, Albert Barillé, 1978). Los responsables de televisión no estaban de acuerdo con la versión que los franceses hacían de la historia de España, ejemplo del control político en televisión respecto a los procesos históricos y la representación de la historia y la memoria.
} 
candidato del reciente partido Unión de Centro Democrático (UCD), había sido de 32 minutos $^{136}$. En la campaña electoral del 24 de mayo al 13 de junio de 1977, la importancia acordada a los discursos de los principales líderes frente a las cámaras evidencia la lucha desatada por controlar políticamente la televisión ${ }^{137}$. Por el decreto de 3 de mayo de 1977, los partidos políticos contaban con espacios gratuitos en televisión. Algunos partidos protestaron por considerar que el procedimiento de distribución de espacios no se hizo por sorteo. Conscientes del papel que jugaba la televisión, los partidos centraron su atención en el cronómetro $^{138}$. Las quejas de la oposición en relación a la televisión se fundamentaban en saber si se vulneraban los tiempos cedidos para cada uno de los partidos políticos. En este sentido, «el acento se ponía en las condiciones, en los medios, en el procedimiento y, no tanto, en la discusión frontal sobre los fines» (Aguilar 1992: 67). Televisión Española respetó los tiempos concedidos en los discursos electorales pero no por ello garantizó la igualdad a todas las formaciones que concurrían a las elecciones, alejándose de la neutralidad a sabiendas que la televisión condicionaría el proceso electoral ${ }^{139}$. UCD dispuso de cuantiosos recursos, y entre ellos, se encontraba la televisión.

El comité de Radio y Televisión (creado el 20 de mayo de 1977) fue el órgano encargado de controlar los medios de comunicación y la programación durante la campaña electoral. Los partidos políticos que presentaron candidatos en veinticinco o más provincias dispusieron gratuitamente de tres espacios de diez minutos en TVE, y de tres espacios de quince minutos en $\mathrm{RNE}^{140}$. Críticos como Francisco Umbral eran tajantes: «Los que mandan han disfrutado de la tele durante veinte años o los que lleve funcionando el invento. Veinte años frente a diez minutos me parece una ligera desproporción (...). Después de cuarenta años de dictadura, ahora quieren resolver la democracia en diez minutos» ${ }^{141}$. En el último espacio antes de las elecciones, el 13 de junio de 1977, intervinieron por sorteo los nueve partidos políticos con candidaturas

\footnotetext{
${ }^{136}$ Fuente: "El presidente del Gobierno candidato por la Unión del Centro", El País, 4/05/1977.

137 Un mayor análisis de cada una de las intervenciones, en V. Martín, Televisión Española y Transición democrática. op. cit. pp. 106-121 y 154-182.

${ }^{138}$ Véanse E. Arnaldo, "Procesos electorales y opinión pública”, Revista de las Cortes Generales, n 34, 1995, p. 175, y J. G. Requena, El discurso televisivo: espectáculo de la postmodernidad, Cátedra, Madrid, 1988.

${ }^{139}$ Sobre la influencia de la televisión en las campañas electorales, véase J. Curran, D. Morley y V. Walkerdine, Estudios culturales y comunicación. Análisis, producción y consumo cultural de las políticas de identidad y el posmodernismo, Paidós, Barcelona, 1996.

${ }^{140}$ Fuente: “Acceso gratuito de los grupos políticos a los medios de comunicación oficiales”, El País, 8/05/1977.

${ }^{141}$ Francisco Umbral, “Diez minutos”, El País, 15/05/1977.
} 
en veinticinco o más distritos electorales ${ }^{142}$. Tras registro ante notario (y escuchadas por el comité), fueron emitidas ${ }^{143}$.

Manuel Fraga, Carlos Arias Navarro ${ }^{144}$, y Santiago Carrillo se presentaron ante las cámaras con discursos «poco acordes con los tiempos» ${ }^{145}$, que contrastaban con los discursos de Felipe González (PSOE) y Adolfo Suárez (UCD) ${ }^{146}$. La víspera de las elecciones, el vicepresidente primero del Gobierno, el teniente general Gutiérrez Mellado, se encargó de dirigir un mensaje a los españoles de «serenidad y confianza» ${ }^{147}$. En estas elecciones, la televisión concedió importancia a la imagen proyectada ante la opinión pública, al superar de manera categórica los mítines públicos y los carteles murales como forma de transmisión efectiva del mensaje ${ }^{148}$. TVE anunció el resultado de las elecciones con un «clamoroso triunfo del presidente Suárez». El Congreso de los Diputados estaría formado por 350 diputados, elegidos por un sistema de escrutinio proporcional siguiendo el método d'Hondt, que favoreció a las candidaturas mayoritarias en España.

El País inició una dura crítica sobre el control de TVE. «La actual Televisión Española permanece dirigida y manipulada con criterios antidemocráticos. (...) hay que decir que RTVE ha sido menos un medio informativo -o de transmisión de cultura, o hasta de ocio- que un medio de poder ${ }^{149}$. Al día siguiente, ocho representantes de los partidos políticos, a excepción de UCD y Alianza Popular, exigieron a RTVE un fiel reflejo de la realidad, conscientes -tras perder las elecciones- que la televisión condicionaba la opinión pública ${ }^{150}$. Para ello sería necesario antes crear un estatuto jurídico para RTVE y sus más de 7.000 trabajadores.

\footnotetext{
${ }^{142}$ Para un análisis en mayor profundidad, véase V. Martín, Televisión Española y Transición democrática. op. cit. pp. 160-182.

${ }^{143}$ Propaganda electoral de los líderes de los partidos politicos con motivo de las elecciones generales de 1977. Emisión: 13 de junio de 1977. Cfr. V. Martín, Televisión Española y Transición democrática. op. cit. p. 156.

${ }^{144}$ En su intervención utilizó imágenes del Rey y del Príncipe de Asturias provocando críticas del resto de grupos.

145 «Los comunistas lo que queremos es que no vuelva a haber una guerra civil, que cada español pueda pasear por las calles sin temor a ser asesinado», en “Últimas intervenciones de los líderes en Televisión”, El País, 14/06/1973.

${ }^{146}$ Centro de Documentación RTVE. Propaganda electoral de los líderes de los partidos políticos con motivo de las elecciones generales de 1977. Emisión: 13 de junio de 1977.

${ }^{147}$ Centro de Documentación RTVE. Mensaje a los españoles del vicepresidente primero del Gobierno, Teniente General Gutiérrez Mellado. Emisión: 14 de junio de 1977.

${ }^{148}$ Fuente: “Últimas intervenciones de los líderes en Televisión”, El País, 14/06/1973.

149 “La televisión es de todos", El País, 18/06/1977.

150 «Es evidente que mientras pertenezca en exclusiva a grupos o intereses sectoriales -el de determinados grupos de presión, gubernamentales, políticos, o incluso privados- favorecerá preferentemente a sus propietarios. Y esto no es admisible». El País, 19/06/1977.
} 


\subsection{El regreso de La clave (1977-1978)}

Transcurridas las elecciones del 15 de junio de 1977, el objetivo entre las distintas opciones políticas fue llegar a consensos y a pactos que lograran sustituir las discrepancias por acuerdos. La segunda etapa del programa transcurre entre el 30 de julio de 1977 y el 6 de diciembre de 1978. Pasaron dos directores generales en RTVE: Rafael Ansón y Fernando AriasSalgado. Con Rafael Ansón, como hemos visto, se utilizó la televisión como un instrumento de propaganda del aperturismo democrático. La clave regresó quince meses después de la última emisión, cuando «soplaron vientos políticos más aperturistas» ${ }^{151}$. «Se comentó que los telespectadores no estaban preparados para la polémica y que iban a surgir muchos insultos, cuando la verdad, es que la experiencia les demostró lo contrario. Nosotros pensábamos que los que no estaban preparados para la polémica eran los que lo prohibían, y que como a esos señores les quedaba poco de vida, ya volveríamos y así ha sido ${ }^{152}$. El programa regresó con un cambio en el día de emisión, el sábado, y un nuevo realizador, Adriano del Valle. La clave tuvo que enfrentarse a las luchas por la audiencia frente a programas de éxito confirmado en la primera cadena como Informe semanal (que iniciaba a las 21:00 horas), o Sábado, cine (a las 22:00 horas), dirigido por su compañero de promoción en Periodismo, Manuel Martín Ferrand. Como veremos más adelante, es en esta etapa donde La clave articula el debate televisivo. Se emitirían un total de 159 programas y llegarían los debates en color.

La clave regresó el 30 de julio de 1977 a las 21:30 horas con un programa especial titulado Recuerdo de la etapa anterior (ficha 13), dedicado a quienes no habían podido ver el programa en $1976^{153}$. Con este programa inició un tipo de emisiones que realizó en otras ocasiones con motivo de algún aniversario como La clave de los debates (ficha 112) en 1979 o Las 400 claves (ficha 400) en 1985. En esta ocasión, el coloquio - con invitados que ya habían asistido en 1976- se ilustró con una antología de los temas y de las secuencias más interesantes de aquel primer año. José Luis Balbín recordaba en la introducción que «este programa quiere presentar claves para un problema, y no pretende hacer moral» ${ }^{154}$. El coloquio giró en torno a la necesidad del debate como técnica democrática ${ }^{155}$. Al terminar el programa, su director

\footnotetext{
${ }^{151}$ José Luis Balbín, en A. Font, La Transición política española... op. cit., p. 462.

152 Diario 16, 6/07/1977, p. 27.

153 “La clave: terminó la cuarentena”, Blanco y Negro, 27/07/1977, p. 10.

${ }^{154}$ Centro de Documentación RTVE. Recuerdo de la etapa anterior (ficha 13). Emisión: 30 de julio de 1977.

155 Para cada uno de los invitados, el éxito se debía a una razón concreta. Para Ricardo Bofill, por tratarse de verdaderos coloquios en directo. Para Francisco Ignacio Taibo, por los invitados. Para John L. Acuff, por el tipo
} 
anunció algunos temas que se verían en esta nueva temporada, como el de las autonomías. Tema colateral al de la unidad nacional, que junto al Rey y al Ejército, eran los límites permitidos en televisión como habían reconocido los anteriores directores generales de RTVE. El debate sobre las autonomías no llegaría hasta 1983.

El 6 de agosto de 1977, José Luis Balbín presentó el primer programa de la nueva temporada, Los emigrantes (ficha 14). El tratamiento de la emigración en televisión partió de la llamada tercera vía del cine español con la película Españolas en París (Roberto Bodegas, $1971)^{156}$. A inicios de los sesenta y finales de los setenta, más de 600.000 españoles vivían en Francia. Una emigración económica, que convirtió a los españoles en la comunidad más importante del país galo. Casi la mitad eran mujeres y unas 40.000 trabajaban en París como sirvientas. Procedían de todos los puntos de España, y la mayoría había cruzado por primera vez la frontera ${ }^{157}$.

Le siguió el programa Un mundo contaminado (ficha 17). En un cable estadounidense publicado en WikiLeaks y fechado en julio de 1977 -el programa se emitió en agosto- se informaba de la intervención en La clave del senador Edmund Muskie (Secretario de Estado de Estados Unidos entre 1980 y 1981 con Jimmy Carter de Presidente) $)^{158}$.

A partir de septiembre de 1977, el programa añade a su repertorio temas de marcada sensibilidad (o polémicos) como fue el caso de Drogas (ficha 18). Se proyectó la película Días de vino y rosas (Days of Wine and Roses, Blake Edwards, 1962), y entre los invitados, José María Calviño (director general de RTVE en la etapa socialista que suprimirá definitivamente el programa), un experto japonés en el tratamiento de drogas, y una actriz ex drogadicta.

\footnotetext{
de discusión que se hacía y que Estados Unidos debería adoptar. Maxime Sanders por su parte resaltó la traducción simultánea, que no existía en Reino Unido, y José Luis San Pedro, la elección de los temas.

${ }^{156}$ La "tercera vía" se ha definido como un «intento de hablar de la España real utilizando las vías que el sistema no tapona de antemano». M. Bayón, José Sacristán: la memoria de la tribu, Filmoteca regional de Murcia, 1989, p. 38. Trataría de nuevo el tema en 1980 con Emigrantes de regreso (ficha 169) y la película La piel quemada (Josep Maria Forn, 1967).

${ }^{157}$ Regresaron las críticas favorables. Para Enrique del Corral, un programa «a medida de José Luis Balbín, quien posee indudable autoridad ante las cámaras y como director del coloquio, al que imprime vivacidad y claridad (...) para quien la televisión es su mar de buena navegación». Más escueta fue la crítica sobre la película «que tuvo interés por supuesto, e intención, como es lógico», $A B C, 13 / 08 / 1977$, p. 14.

158 «El director del programa de televisión La clave planea invitar al senador Muskie a participar en un programa previsto para el 27 de agosto. El programa, dirigido por José Luis Balbín y Rafael Benedito, es un programa semanal dedicado a temas de interés público con la presencia de personalidades españolas y extranjeras importantes. El programa del 27 de agosto estará dedicado a contaminación ambiental, el acuerdo entre industrialización, el respeto al medio ambiente y cómo las naciones abordan esta problemática. El formato del programa es una discusión en torno a una mesa redonda». WikiLeaks, "Discusión senador Muskie a Madrid", 22 de julio de 1977. (traducción propia).
} 
La clave abordaba en directo una temática ausente en las televisiones europeas en los años setenta. En este sentido, para entender cómo La clave construye un debate de carácter educativo-formativo en televisión sobre las drogas, es determinante el contexto en el que se produce. En España no existe en esos momentos ningún centro especializado en el tratamiento o rehabilitación de drogadictos. En abril de 1977, el jefe de la Brigada Especial de Estupefacientes había sido contundente: «no es que en nuestro país no exista una adecuada infraestructura en este campo; es que ni siquiera existe un solo centro especializado para tal fin, con lo cual, lógicamente, el toxicómano se encuentra sin control, al tiempo que aumenta el riesgo de actuar como elemento multiplicador de estupefacientes» ${ }^{159}$. ¿Qué tipo de drogas circulaban en España? ¿Cómo había evolucionado su tráfico y consumo? ${ }^{160}$ El programa destacó precisamente por lograr debatir un tema tabú en televisión y mostrar su problemática, que tuvo pronta reacción en la prensa ${ }^{161}$.

El siguiente programa abordó el tema del periodismo, programa que había sido suspendido en febrero de 1976. En esta ocasión, para abordarlo en mayor profundidad, el equipo preparó dos programas. El primero, La empresa de informar (ficha 19), con la proyección de Luna Nueva (His Girl Friday, Howard Hawks, 1940), y el segundo, Buscar la noticia (ficha 27), con la proyección de Corredor sin retorno (Shock Corridor, Samuel Fuller, 1963). Siguiendo la trayectoria de 1976, José Luis Balbín, implicó a la prensa en el programa e intervinieron empresarios y directores de distintos periódicos. Entre los invitados extranjeros Jacques Fauvet (Le Monde), Indro Montanelli (Il Giornale), y Philip M. Foisie (Washington Post). De los siguientes programas: ¿Guerra Atómica? (ficha 20), Ancianos (ficha 21) y Bandidos generosos (ficha 22), destacamos el último por debatir sobre el bandolerismo como fenómeno social y cultural. Tuvo como invitado a Mateo Emiliano Zapata, hijo del revolucionario mexicano Emiliano Zapata ${ }^{162}$.

\footnotetext{
159 “Informe: España se droga”, Blanco y negro, 27/04/1977, p. 30. En el informe se denunciaba la situación actual de la droga en España, país considerado tradicionalmente de tráfico y que cambiaba a de consumo. Véanse las páginas 29-33; "Los mercados del opio", $A B C, 17 / 07 / 1977$, p. 3; y "Detenidos cuatro traficantes de drogas", $E l$ País, 9/09/1977.

${ }^{160}$ Centro de Documentación RTVE. Drogas (ficha 18). Emisión: 3 de septiembre de 1977. Trató de nuevo el tema en 1982 con Siempre la droga (ficha 218), y la película Comando Antidroga (Gordon's War, Ossie Davis, 1973). Si en 1977 algunas preguntas abordadas fueron: ¿se puede hablar de drogas duras y blandas? ¿La dependencia física puede provocar la muerte?; en 1982, surgieron cuestiones referentes a su legalización. Centro de Documentación RTVE. Siempre la droga (ficha 218). Emisión: 19 de marzo de 1982.

${ }^{161}$ Periodistas de Blanco y Negro sentenciaron con un rotundo: «Periodismo en La clave: ahora sí», Blanco y Negro, 7/09/1977, p. 10.

162 «Para conseguir su presencia en el programa tuvimos que recurrir incluso a inscribirle en el Registro Civil y conseguir su pasaporte». José Luis Balbín en Sistemas políticos (ficha 105), el 26 de mayo de 1979.
} 
El programa también comenzó a destacar por abordar temas de la actualidad española. Para José Luis Balbín «lo prioritario es el tema, a ser posible de actualidad, aunque difícilmente ésta puede ser inmediata» ${ }^{163}$. Un ejemplo de ello fue Fuentes alternativas de energía (ficha 25), programa realizado desde Barcelona coincidiendo con el simposio internacional sobre fuentes de energía y desarrollo. WikiLeaks hizo público un cable que mostraba la preocupación de Estados Unidos en el plan de energía del presidente estadounidense Jimmy Carter, y la implicación internacional que pudiese tener el invitado a La clave Terence O'Rourke (asesor personal de la Casa Blanca en temas energéticos y medioambientales), que llevaba a cabo una serie de reuniones diplomáticas con países de la Comunidad Europea y representantes de China, Rusia, Japón, Arabia Saudí, los países del Golfo Pérsico, Ghana... ${ }^{164}$. A raíz de la crisis energética, EE.UU. aplicó una serie de medidas con el objetivo de estimular la conservación energética y el desarrollo de los recursos energéticos nacionales.

Mientras tanto, en España, fueron firmados en octubre de 1977 los Pactos de la Moncloa. El 2 de noviembre se acordó la creación del Consejo Rector de Televisión, que tendría como función diseñar el Estatuto de RTVE. Integrado por 36 miembros (mitad en representación de los grupos parlamentarios y mitad designados por el Gobierno), un año después, todavía no habría acuerdo sobre su composición ni sobre el sistema de votaciones ${ }^{165}$.

La primera clave sociopolítica se realizó el 12 de noviembre de 1977 con el título Pena de muerte (ficha 28). Coloquio calificado de polémico, José Luis Balbín plantearía toda una serie de preguntas: ¿Por qué los partidos políticos no abordan el tema de la pena de muerte? ¿Por qué se mata? Se proyectó la película A sangre fría (In Cold Blood, Richard Brooks, 1967), adaptación de la novela homónima de Truman Capote (futuro invitado al programa), y un fragmento del documental Queridísimos verdugos (Basilio Martín Patino, 1973), cuyo director figuraba entre los invitados ${ }^{166}$. Le acompañaban el secretario general de Amnistía Internacional, el vicepresidente de la Asociación contra la Pena de Muerte, un magistrado que había firmado

\footnotetext{
${ }^{163}$ Declaraciones de José Luis Balbín, en Blanco y Negro, 5/10/1977, p. 10.

164 «O’Rourke tuvo tanto interés en el plan energético que cambió la presentación planeada en un simposio internacional privado de alto nivel en materia energética (para el que fue invitado a Barcelona), hablando a favor del plan energético de Carter. Solicitó y recibió después ayuda con la traducción simultánea (...). Participó en el programa televisado de asuntos públicos La clave, junto a otros distinguidos participantes sobre materia energética. O'Rouque lo califica de excelente, recomendado para uso futuro de la agencia». Fuente: WikiLeaks, 11 de noviembre de 1977. Implicaciones nacionales e internacionales del plan energético del presidente Carter, 18 de octubre 1977. [traducción propia].
}

165 “RTVE 1978/2", El País, 3/01/1979.

${ }^{166}$ Durante el debate, Martín Patino defendió que su película pretendía «hacer un alegato contra la pena de vida, contra la ínfima calidad de vida». 
una sentencia de muerte pero se declaraba en contra, y un conmutado de pena de muerte. También participaron un jurista, un padre dominico, y el abogado José María Ruiz Gallardón, para quien «hay casos en los que la aplicación de la pena de muerte, de alguna manera, sirve eficazmente para que no se produzcan, por terceras personas, otras muertes violentas» ${ }^{167}$.

Hemos seleccionado precisamente este tipo de emisiones porque nos permite identificar la posición que adopta el programa. Como argumentan Manuel Palacio y Carmen Ciller, «en ese momento la pena capital estaba en vigor en el ordenamiento legal español y su abolición era una reivindicación que unía a todo el pensamiento progresista» (Palacio y Ciller 2014: 232). La clave, por primera vez, declaraba públicamente su posición al respecto. Véanse las palabras con las que finalizaba el programa José Luis Balbín:

«El equipo de La clave no toma partido tradicionalmente porque de lo que se trata es que se puedan debatir diferentes posiciones y puntos de vista. En este caso concreto, sin que sirva de precedente, los integrantes de La clave votaron. Todos estaban a favor de la abolición de la pena de muerte salvo un voto» ${ }^{168}$.

Como argumentan Manuel Palacio y Carmen Ciller «se convierte en un alegato en contra de los puntos de vista más conservadores y de facto es uno de los puntos de no retorno que atraviesa el programa de José Luis Balbín. La repercusión pública de La clave comienza a crecer de una manera exponencial» (Palacio y Ciller 2014: 232). El crítico de $A B C$ Enrique del Corral calificó Pena de muerte de «programa estelar. Completísimo. Necesita de coordinación agotadora para conjuntar no pocos elementos». Del Corral desvelaba a qué se debía el éxito de La clave: elección de la película, reunión previa sobre cada tema, colaboración de algún extranjero con un buen traductor «pasando por las mil y una incidencias del directo (...). El resultado es (...) de pálpito indiscutible y de interés en cada ocasión. Creo, modestamente, que La clave mejora, si cabe, su modelo francés» ${ }^{169}$. Baget Herms, por su parte, en su valoración personal de «lo mejor y lo peor de 1977» (lista que publicaría la revista TP a finales de año), calificó este programa como uno de los mejores de $1977^{170}$.

\footnotetext{
${ }^{167}$ Centro de Documentación RTVE. Pena de muerte (ficha 28). Emisión: 12 de noviembre de 1977.

168 «Nosotros nos pronunciamos ante el público. En dos ocasiones, solo dos veces. Personalmente una fue en un programa sobre la pena de muerte, y me signifiqué en contra. (...) Yo expliqué: Tengo que decir que este programa lo hemos discutido en la redacción. Y resulta que en la redacción había partidarios de la pena de muerte», José Luis Balbín, en F. J. Satué, Los secretos de la Transición, op. cit. p. 494.

${ }^{169}$ E. del Corral, Crítica diaria, $A B C, 13 / 12 / 1977$, p. 110.

${ }^{170} T P, \mathrm{n}^{\circ}$ 610, 12-18 de diciembre de 1977. Cfr. M. Palacio y C. Ciller, “La clave de TVE...”, en Estudios sobre el Mensaje Periodístico, op. cit. p. 232.
} 
Aunque la Constitución de 1978 contemplaba la abolición de la pena de muerte, excepto lo que dispusiesen las leyes penales militares en tiempos de guerra (artículo 15), la pena de muerte no se abolió en todas las circunstancias hasta $2010^{171}$.

\subsubsection{El cese de Rafael Ansón y la llegada de Fernando Arias-Salgado}

Una emisión de televisión provocó el cese de Rafael Ansón como director general de RTVE. El 17 de noviembre de 1977 presentó su dimisión «después de la emisión de un programa de canciones de Luis Pastor, entonces militante de USO (Unión Sindical Obrera), que había aparecido en pantalla acompañado por banderas republicanas» (Sinova 1981: 44 y Bustamante 2006: 61). Al día siguiente, el Consejo de Ministros nombró a Fernando AriasSalgado nuevo director general de RTVE ${ }^{172}$. Sobre las irregulares que se producían en el interior de RTVE (supresión de programas, despido de trabajadores, cambios en su estructura interna sin justificación...), Arias-Salgado indicó en una de sus primeras declaraciones públicas: «Sé que el problema existe, pero no conozco su magnitud» ${ }^{173}$. Como veremos más adelante, dos años después se hizo pública una auditoría de Hacienda saliendo a la luz la caótica situación en RTVE.

Desde octubre se especuló en prensa el cambio del programa a la primera cadena, aunque la duración del mismo podía ser un inconveniente. «Irá los viernes a las 20:15 horas y hasta el cierre (...) dado el carácter de película y coloquio del programa de Balbín y sus adeptos cultos. (...) La clave, repetimos por última vez, es programa importante que no hay por qué andar bailando. Su día y su hora deber ser sagrados, como en todos los programas. Pero en éste, más» ${ }^{174}$. En 1977, según datos de la propia RTVE, el 93\% de los hogares españoles poseía un aparato de televisión, y en relación a los índices de audiencia, la máxima audiencia se producía con La clave entre las 22:00 h y 22:30 h con más de dos millones de telespectadores ${ }^{175}$.

\footnotetext{
${ }^{171}$ BOE, $\mathrm{n}^{\mathrm{o}} 77$, de 30 de marzo de 2010, pp. 29743-29748.

${ }^{172}$ Arias-Salgado juró el cargo de director general el 21 de noviembre de 1977. Hasta el momento había ocupado el cargo de secretario general técnico del Ministerio de Asuntos Exteriores con el primer Gobierno de la Monarquía.

${ }^{173}$ Entrevista Fernando Arias-Salgado, El País, 19/11/1977.

174 "La clave", Hoja del lunes, 5/12/1977, p. 41.

${ }^{175}$ Informe RTVE, 1978. Manuel Palacio argumenta que «se produjo un salto cualitativo y cada programa alcanzaba una audiencia acumulada cercana a los dos millones de espectadores, que puede considerarse un gran éxito para la cadena» (Palacio 2012: 259).
} 
El 24 de noviembre de 1977, España se convirtió en miembro del Consejo de Europa. Dos días después La clave realizó el primer programa de la serie claves políticas, con el título ¿Por qué políticos? (ficha 30) y la película Tempestad sobre Washington (Advise and Consent, Otto Preminger, 1962). Pocas veces en el programa debatieron menos de cinco invitados (como fue el caso, con dos invitados nacionales y dos internacionales). La razón la expuso su director al finalizar el debate cuando leyó un comunicado para justificar su opción de no incluir a los partidos políticos: «para evitar que esto pudiera convertirse en un programa de propaganda política» ${ }^{176}$.

RTVE definiría el año 1977 del «año de la normalización democrática, de las Elecciones, de los Pactos de la Moncloa y, también, de la crisis económica. RTVE fue, en todo los casos, informadora de los hechos más relevantes de 1977, mediante sus Servicios Informativos. Otras veces, como en el caso de los viajes de los Reyes o del Presidente, sus retransmisiones sirvieron para acercar al telespectador la imagen de un nuevo estilo de relación internacional. Aun hubo otras ocasiones en que RTVE fue algo más que informadora» ${ }^{177}$. Mientras que en su seno, entre el 18 y el 22 de diciembre se producía la primera huelga en RTVE a raíz de una ordenanza laboral para la reclasificación de personal. La propia dirección general de RTVE envió telegramas a distintos trabajadores invitándoles a no secundar la huelga, bajo amenaza de despido ${ }^{178}$.

En enero de 1978 Fernando Arias-Salgado nombró a su nuevo equipo rector: Rafael Ramos Losada (director adjunto), Feliciano Lorenzo Gelices (gerencia), José María Carcasona (programación) y Fernando Bofill (Informativos) ${ }^{179}$. Con Miguel Martín en la gerencia se realizó la separación -hasta el momento inexistente- de un director para la primera cadena (Jesús López Navarro), y otro para la segunda (Miguel Ángel Toledano), saliendo reforzado el cargo de director de los Servicios Informativos. Sin embargo, la dimisión de los cuatro directores de los telediarios (Azcona, Sotillos, Macía y Gozalo) acabó con el primer intento de revolucionar los informativos. El País dedicó un editorial a la televisión ante el aumento de cargos directivos, publicidad, informes del comité de corrupción, irregularidades y protestas de

\footnotetext{
${ }^{176}$ Centro de Documentación RTVE. ¿Por qué políticos? (ficha 30). Emisión: 26 de noviembre de 1977.

${ }^{177}$ RTVE Informe 1978, RTVE, Madrid, 1978.

178 “Los trabajadores de RTVE pueden volver a la huelga el próximo día 18”, El País, 23/12/1978.

${ }^{179}$ El nuevo equipo duró un año. En agosto de 1978 Miguel Martín sustituyó a Ramos Losada en la gerencia, y el cese de Lorenzo Gelices el 20 de enero de 1979, puso fin al primer equipo de Arias-Salgado.
} 
sus trabajadores: «es mala, es corrupta, es cara, es monopolística, es oficial, es vergonzante, es triste» $^{180}$.

En 1978 se emitieron 52 programas y dos fueron suspendidos. Como argumentan Palacio y Ciller, «según va avanzando el año 1978 puede decirse que en cierto sentido el programa gira hacia la izquierda y El País se convierte en el principal valedor de los combates de Balbín contra la dirección de Televisión Española» (Palacio y Ciller 2014: 233). Esto se debe a que ha convertido su programa en una emisión independiente de la propia TVE en el sentido que no va a dejarse guiar por ninguna directriz que llegue desde los altos cargos directivos. La última palabra la tendrán los propios integrantes del programa. Y si se produce alguna injerencia la denunciará ante la prensa. Volveremos a esta idea más adelante, con ejemplos evidentes en algunos programas concretos. Pero si José Luis Balbín podía permitirse estas palabras era por galardones como el Premio a la libertad de expresión concedido por la Unión de Periodistas.

En 1978 pasaron invitados relevantes como fue el caso del profesor de economía de la Universidad de Harvard John K. Galbraith ${ }^{181}$. También se abordaron dos claves políticas que se analizarán en nuestro último capítulo: Parlamentarismo (ficha 38) y La Constitución (ficha 72). En la primera se proyectó la película Caballero sin espada (Mr. Smith Goes to Washington, Frank Capra, 1939), y supuso toda una defensa en favor de la democracia. Al igual que hiciese en el programa ¿Por qué políticos? (ficha 30), el equipo de La clave decidió apartar del coloquio a los políticos «para que haya un distanciamiento que La clave quiere mantener» ${ }^{182}$. La segunda, titulada La Constitución (ficha 72), se emitió el 30 de septiembre de 1978, proyectándose Esta tierra es mía (This Land is Mine, Jean Renoir, 1943), alegato a la democracia frente al nacionalismo nazi y una firme defensa de los derechos humanos. Ambos programas cosecharon favorables críticas y la prensa no dudó en hablar de «la superación de su homólogo francés, por la película y el panel de invitados» ${ }^{183}$.

Pero antes, en febrero, La clave dedicó una emisión a los Errores judiciales (ficha 41), que tuvo su polémica por la participación del fiscal de la Audiencia Territorial de Madrid, Jesús

\footnotetext{
180 "El editorial que nunca existió”, El País, 03/01/1978.

${ }^{181}$ Fue invitado en el programa La crisis del dinero (ficha 36). «Nos enteramos de que estaba esquiando en Suiza con su mujer, en 1978. Rafael Benedito, uno de los miembros del equipo, fue allí y habló con la esposa. Le dijo que ya estaba bien de pasar frío en Suiza y que vinieran unos días a España. Cuando Galbraith terminó de esquiar aquel día, su mujer lo convenció de inmediato». Ladislao de Arriba, en La Nueva España, 17/11/2010.

${ }^{182}$ Centro de Documentación RTVE. Parlamentarismo (ficha 38). Emisión: 4 de febrero de 1978.

${ }^{183}$ Hoja del lunes, 27/02/1978, p. 39.
} 
Vicente Chamorro. El fiscal fue apercibido por su participación sin autorización oficial de sus superiores jerárquicos. Tanto los invitados al debate como su director fueron llamados a declarar como testigos en el expediente abierto por fiscal del Reino Juan Manuel Fanjul. Más de cuarenta miembros de las carreras judiciales enviaron un escrito al fiscal del Reino por la violación que suponía coartar la libertad de expresión a los fiscales ${ }^{184}$. Tras los recursos legales presentados, el expediente y la sanción fueron anulados en $1979^{185}$.

El 11 de marzo de 1978 La clave emitió Divorcio (ficha 43). José Luis Balbín señaló que «los programas de más eco son los que coincide el tema con parte de las crisis de valores que sufre la sociedad en la que vivimos. Digo sufre y quizá diga mal. (...) Hay que decirlo, las presiones son fuertes. No vienen solo desde lo oficial. (...) Las presiones son frecuentes en temas políticos como este y La clave no va a aceptarlas de ningún caso» ${ }^{186}$. Sin embargo, como argumenta Manuel Palacio, el largometraje de humor Divorcio a la Italiana (Divorzio all'italiana, Pietro Germi, 1961) fue finalmente sustituido por El novio de mi mujer (Divorce American Style, Bud Yonkin, 1967) (Palacio 2012: 252). El título del largometraje debió molestar a los responsables de TVE y La clave poco pudo hacer, pues la contratación de películas no dependía exclusivamente del programa sino de la propia TVE.

Entre los invitados a debatir sobre el divorcio, tres a favor y tres en contra. Durante el coloquio, la única mujer invitada al debate dijo: «La mujer está discriminada. Aquí se ve en el debate que soy la única representante». José Luis Balbín, al ver que algunos invitados llegaban llenos de papeles y apuntes, les advirtió que no quería ver en el programa una serie de monólogos sucesivos sino que, precisamente, se trataba de un programa de debate: «¿Están todos ustedes de acuerdo en que debe haber la posibilidad de divorcio en España, sí o no?». Algunas líneas por la que discurrió el debate fueron la distinción entre matrimonio canónico y civil, las irregularidades que se producían en los Tribunales eclesiásticos y la última encuesta de FOESSA sobre el divorcio (18\% muy de acuerdo, 53\% de acuerdo, 17\% desacuerdo, 10\% totalmente desacuerdo).

\footnotetext{
${ }^{184}$ Fuentes: "Solidaridad de cuarenta y dos fiscales y magistrados con el señor Chamorro", El País, 17/03/1978, y "Participantes en La clave llamados a declarar", Diario 16, 17/03/1978, p. 8.

185 También se debatió sobre el significado de las elecciones del 15 de junio de 1977 en Elecciones (ficha 42); emisión que será analizada en un apartado correspondiente al dedicar a los comicios distintos programas.

${ }^{186}$ Centro de Documentación RTVE: Divorcio (ficha 43). Emisión: 11 de marzo de 1978.
} 
Un mes más tarde, La clave evidenciaría las contradicciones sociales que atravesaba España al mostrar que en 1978 no se podía debatir en televisión sobre la homosexualidad ${ }^{187}$. Como argumenta Manuel Palacio, «primer gran aldabonazo público de que en la España de la segunda Transición existía algún problema con la homosexualidad» (Palacio 2012: 253). El tema programado el 8 de abril de 1978 resultaba problemático para los responsables de TVE. También la película Esos tres (These Three, William Wyler, 1936), basada en la obra de teatro de Lillian Hellman que no llegó a emitirse por tratar la homosexualidad (femenina, en este caso). Se sustituyó por El pequeño salvaje (L'enfant sauvage, François Truffaut, 1969), y sobre la película versó el programa Civilización (ficha 47).

Este programa nos permite ver La clave como el "baremo de los techos de libertad alcanzados durante la transición en TVE” (Pérez Ornia 1988: 50) ${ }^{188}$. El programa se cambió a última hora por unas declaraciones de Francisco Llavero (catedrático de psiquiatría de la Universidad de Salamanca) que llegaron a oídos del ministro del Interior Rodolfo Martín Villa e influyeron para que el programa no saliese en antena ${ }^{189}$. Llavero definía a los homosexuales de "invertidos" y "desviados", y acusaba de los efectos desastrosos que representaba tratar el tema de la homosexualidad, afirmando que esa exhibición de pornografía podía constituir incluso delito ${ }^{190}$.

La clave, pues, tuvo que esperar hasta el 29 de julio de 1983, cinco años después, para poder tratar el tema. En esos momentos, y sin existir precedente alguno en televisión, la homosexualidad era un tema tabú ${ }^{191}$. También en el cine se había censurado la película Los placeres ocultos (Eloy de la Iglesia, 1977) por temática homosexual ${ }^{192}$. Desde el 4 de agosto de 1970 se encontraba vigente en España la Ley de Peligrosidad y Rehabilitación Social (sustituta

\footnotetext{
${ }^{187}$ Informe Semanal había podido tratar la Ley de Peligrosidad Social un mes antes, el 4 de febrero de 1978. En el reportaje fueron entrevistadas dos prostitutas, tres homosexuales, un sexólogo, un abogado y un teólogo.

${ }^{188}$ Cfr. V. Martín, "El parlamento catódico: los programas de debate sobre la actualidad política durante la transición (1976-1979)", en Estudios sobre el Mensaje Periodístico. Vol. 20, Núm. especial (2014), p. 127.

${ }^{189}$ Véase M. Palacio, La televisión durante la Transición española, op. cit. pp. 253 y 254.

190 "Puntualización sobre la homosexualidad”, El País, 11/04/1978. A partir de ahí, se inició una discusión con Enrique Gimbernat (catedrático de derecho penal e invitado al programa sobre homosexualidad en 1983). "Respuesta a un psiquiatra sobre el tema de la homosexualidad", 20/04/1978. "Respuesta de un psiquiatra a un penalista sobre el tema de la homosexualidad", 30/05/1978. "Segunda respuesta a un psiquiatra", 23/06/1978. "La anti homosexualidad del profesor Llavero: una cuestión política", 23/06/1978.

191 La primera manifestación a favor de los derechos de los homosexuales fue la organizada por el Front d'Alliberament Gai de Catalunya (FAGC), el 26 de junio de 1977. Y hasta ese año no encontramos las primeras publicaciones de carácter homosexual en España como fue el boletín Nosotros. Fuente: "Nosotros, boletín del Movimiento Democrático de Homosexuales", El País, 14/10/1977.
}

192 "Hay que conseguir la disolución de los organismos censores”, El País, 17/02/1977. 
de la Ley de vagos y maleantes) y, entrada la democracia, todavía se detenían en España a homosexuales por asistir a conferencias que simplemente abordaran el tema ${ }^{193}$.

Hasta la Constitución del 6 de diciembre de 1978, y como muestra de la variedad temática, La clave realizó Huelga (ficha 50) ${ }^{194}$, Cáncer (ficha 52) ${ }^{195}$, y El papa (ficha 74) ${ }^{196}$. Destacamos El drama de la enseñanza superior (ficha 71), que dejó un debate dialéctico de altura entre Daniel Cohn-Bendit y Enrique Tierno Galván, y Caciques (ficha 77-C) que fue prohibido $^{197}$. Se suspendió debido a los problemas de censura interna que existía en el interior de Televisión Española. La ambigüedad habitual del programa a la hora de escoger el tema no logró en esta ocasión escapar de los responsables de TVE. La clave, programa de debates, se quedaba en esta ocasión, sin debate, y tuvo que esperar dos años, hasta 1980, para poder debatir sobre caciquismo (ficha 138). El País denunció «problemas de censura interna» a pocos días de aprobar una Constitución ${ }^{198}$. Varias personas llamaron al periódico para denunciar lo que consideraban «un atentado a la libertad de expresión» ${ }^{199}$. En octubre de 1978, José Luis Balbín patentó la marca La clave a su nombre, lo que significaba que los derechos del programa eran suyos y no de RTVE 200 .

\footnotetext{
193 “Treinta homosexuales, detenidos durante una conferencia gay”, El País, 7/10/1980.

${ }^{194}$ En un momento en que «se discutía si el derecho a la huelga debía incluirse como tal en la Constitución» (Palacio 2012: 262). Se proyectó la película polaca, La perla de la corona (Perla w Koronie, Kazimier Kutz, 1972), que narraba el desarrollo de una huelga de mineros en la Silesia de los años treinta.
}

${ }^{195}$ Con dos invitados Premio Nobel en Medicina: el español Severo Ochoa (Premio Nobel en 1959), y el italiano Renato Dulbecco (Premio Nobel en 1975).

${ }^{196}$ Programa que coincidió con la apertura del cónclave para elegir sucesor de Juan Pablo I, con conexiones desde Roma. El programa fue interrumpido bruscamente a media noche por órdenes de la dirección.

${ }^{197}$ Se sustituyó por Los orígenes del hombre, pero finalmente solo se proyectó la película El planeta de los simios (Planet of the Apes, Franklin J. Schaffner, 1968).

${ }^{198}$ Fuente: "Protesta por la supresión del coloquio de La clave", El País, 12/11/1978.

199 Ibídem. Algunos telespectadores protestaron por «las dificultades que viene teniendo desde su inicio, especialmente de censura, quiero expresar mi protesta e indignación contra aquellos directivos de TVE que al parecer lo único importante para ellos es que el pueblo español carezca de juicio crítico (...). Si bien no me sorprende la postura censora y de lavar cerebros de TVE, sí pediría a sus directivos que intentaran correr tras la realidad social del país que se les escapa de las manos, dando oportunidad a los espectadores de documentarse y posteriormente definirse ante posturas y temas reales de nuestra sociedad, como la homosexualidad, el caciquismo y un grandísimo etcétera de realidades sociales intocables por este medio de comunicación», "La clave", cartas al director, El País, 16/11/1978.

${ }^{200}$ En octubre de 1978 quedó registrada La clave a nombre de José Luis Balbín. Oficina de Patentes y Marcas. En la actualidad (2018) ha surgido de nuevo un conflicto entre el periodista y RTVE después de que esta última haya subido a la web algunos de los programas, ya que no existe ningún contrato de cesión de derechos de propiedad intelectual. Véase "Polvorín entre José Luis Balbín y RTVE por los derechos de 'La Clave'”, El confidencial, $9 / 06 / 2018$. 



\section{Capítulo 5. El debate en España. De la Constitución al golpe de Estado}

Este capítulo se inicia precisamente con la aprobación por referéndum de la Constitución española el 6 de diciembre de 1978, y se prolonga hasta el golpe de Estado que tuvo lugar el 23 de febrero de 1981. Siguiendo la estructura del capítulo anterior, nos proponemos observar el papel que desempeña el programa -una vez adquirida su capacidad de estructurar espacios de debate- en la articulación y construcción política del debate televisivo.

\subsection{La Constitución española del 6 de diciembre de 1978}

La Constitución fue aprobada en el referéndum del 6 de diciembre de 1978 por el 87,78\% de votantes. Fernando Morán criticó que Televisión Española presentara «la Constitución como a un producto, aislada de las realidades sociales, culturales, económicas, ideológicas que enmarca; separada del momento histórico (...) en un país donde la lectura de periódicos y revistas es la menor de Europa, con una audiencia televisiva altísima» ${ }^{1}$. El 2 de diciembre de 1978, a cuatro días del referéndum constitucional, La clave realizó el que era ya el tercer debate dedicado a la Constitución. Como argumenta Virginia Martín «otro ejemplo del interés que mostró en debatir ante los espectadores sobre el articulado constitucional» (Martín 2013: 226). Se trataba del programa Mayores para todo (ficha 80), con el que se quiso abordar el establecimiento de la mayoría de edad a los dieciocho años. Para ello intervinieron representantes de las juventudes de diversos partidos y tendencias ideológicas de mayor representatividad. Tras la película alemana El puente (Die Brücke, Bernhard Wicki, 1959) Alianza Popular llamó por teléfono para advertir al programa que el invitado de AP no representaba AP. El debate lo inició el representante de las juventudes socialistas con estas palabras: «Las cuatro organizaciones aquí presentes (se refería a UCD, socialistas, comunistas y la Joven Guardia Roja), queremos mostrar nuestra intranquilidad de sentarnos en una mesa donde estuviese Fuerza Nueva. Organizaciones cuyos militantes son perseguidos o se les propina tremendas palizas en las calles, o sedes incendiadas, o sus representantes pidan en la Plaza de Oriente un 20-N la disolución de las Cortes elegidas democráticamente. La democracia tiene un límite» ${ }^{2}$.

\footnotetext{
${ }^{1}$ En esta crítica excluía en cambio los coloquios de La clave. Véase "La televisión, el referéndum constitucional... y después", El País, 22/11/1978.

${ }^{2}$ Centro de Documentación RTVE. Mayores para todo (ficha 80). Emisión: 2 de diciembre de 1978.
} 
Con esta emisión La clave apostaba por continuar con la misión formativa del programa al dar la palabra a los jóvenes. Una semana después sin embargo, de nuevo La clave mostraba la problemática que suponía abordar la temática sexual en Televisión Española. Esta vez, a través de la película. El País denunció que «una escena de amor» del largometraje cubano Los días del agua (Manuel Octavio Gómez, 1971) había sido la razón del cambio de película en el programa Los curanderos (ficha 81) para proyectarse finalmente Murmullos en la ciudad (People Will Talk, Joseph L. Mankiewicz, 1951) ${ }^{3}$.

En 1978 se observa un incremento de artículos referentes a La clave en periódicos como El País o $A B C$, que no solo anunciaban el tema, la película y los invitados. Artículos que sin duda incrementaban la repercusión del programa. Pero la duración del debate había descendido (en esos momentos de aproximadamente una hora y cuarto), con un espacio intermedio para la publicidad $^{4}$. Pérez Ornia publicó datos de la audiencia de 1978. La primera cadena tenía una audiencia media de 13,5 millones de espectadores y su máxima audiencia se situaba los sábados a las 21:30 horas con 14.283.000 espectadores. La segunda cadena tenía una media de 218.000 de espectadores y su «máxima audiencia, los sábados con 2.181 .000 espectadores, coincidiendo con La clave» ${ }^{5}$. Ornia realizó además un análisis de la audiencia de La clave: tras máximos de dos millones, descendía entre las 22:00 h y 22:30 h a 707.000 espectadores, y entre las 22:30 h y 23:00 h a 279.000 espectadores. La prensa calificaba a los telespectadores de La clave de «minoritarios y muy especializados» ${ }^{6}$. Sin embargo, multiplicando por diez el número de telespectadores que la media de la UHF, observamos que La clave tenía una audiencia que superaba a muchos programas de la primera cadena. Y en poco más de dos años pasaría de dos millones a más de cuatro millones de telespectadores.

A inicios de 1979, la plantilla de TVE era de casi 8.000 empleados ${ }^{7}$. José Luis Balbín comenzó el año con unas declaraciones en El País denunciando que el programa estaba siendo objeto de injerencias y censuras: «Ni siquiera en los tiempos de Arias Navarro se había llegado

\footnotetext{
3 “TVE justifica su propia censura”, El País, 31/10/1978.

${ }^{4}$ Aunque alargar o reducir el tiempo del coloquio no significaba necesariamente un tratamiento más profundo del tema, algunos telespectadores pidieron alargar la duración de programa porque «cuando el tema llega a su punto álgido, el señor Balbín nos anuncia que quedan diez minutos y debe pasarse a las preguntas de los espectadores. Carece así de la flexibilidad de programación necesaria para un programa-coloquio que se emite los sábados». Fuente: Cartas al director. El País, 9/12/1978.

5 “La audiencia del UHF”, El País, 20/04/1979.

6 “TVE justifica su propia censura”, El País, 31/10/1978.

7 “TVE. ¡Vaya lata!”, Diario 16, 26/12/1978. También hizo públicas las retribuciones del personal de RTVE.
} 
al extremo de censurarnos cuatro programas» ${ }^{8}$. Enumeraba una lista de programas que habían sido prohibidos: Homosexuales, Caciques, La Banca, y Madres solteras. Esa noche, La clave abordó Alcoholismo (ficha 87). España era en esos momentos «el cuarto país de Europa en cuanto al consumo de alcohol, con una media de catorce litros anuales por persona» ${ }^{9}$.

José Luis Balbín se utilizó de la prensa, medio que dominaba, para reflexionar sobre el presente y futuro de la televisión. Para él, entre televisión pública o privada, había otra televisión posible: «la institucional, mejor que la estatal todavía. Una televisión gestionada por el gobierno de cada momento, pero controlada por una amplia representación del espacio social: asociaciones de ciudadanos, de la familia, de la información, de la universidad, de la cultura..., incluso de los partidos políticos. Los partidos, sí, mas no en exclusiva. Lo contrario nos llevaría de nuevo a la televisión política...» ${ }^{10}$.

En el camino hacia las elecciones generales del 1 de marzo de 1979 continuaban produciéndose ceses en Televisión Española ${ }^{11}$. La campaña electoral en televisión se inició en febrero. El día 2 se aprobó un decreto que modificaba las normas electorales en vigor (decreto de 7 de mayo de 1977), dificultando el acceso en televisión a pequeñas formaciones ${ }^{12}$. La modificación, a escasos días de las elecciones, beneficiaba a las fuerzas políticas de mayor entidad. Mientras el decreto anterior garantizaba el derecho a espacios gratuitos para todos los partidos políticos, el nuevo decreto de UCD (con la complicidad de PSOE, PCE y CD) los limitaba ${ }^{13}$. Los afectados recurrieron y lograron ampliar a diecisiete las fuerzas políticas con espacios en $\mathrm{TVE}^{14}$.

La importancia de la televisión se evidencia en las maniobras que se producen en ella. A mediados de febrero, el PSOE denunció intentos del director general de RTVE, Fernando

\footnotetext{
${ }^{8}$ José Luis Balbín, “La clave”, El País, 20/01/1979.

9 J. R. Pérez Ornia, “La clave”, El País, 20/01/1979.

${ }^{10}$ José Luis Balbín, “Qué televisión”, Hoja del lunes, Madrid, 12/03/1979, p. 3. También cuestionó «el desastre administrativo» en el que vivía RTVE a consecuencia de un crecimiento demasiado rápido e «insuficientemente planificado», o la «falta de calidad» de TVE en relación a otras televisiones como «la RAI italiana, por citar la de más o menos un país equiparable»o «la BBC, por citar un organismo en el que algunos creen ver la meta a alcanzar».

${ }^{11}$ El más destacado fue el de Pedro Macía, director de la primera edición de Telediario, cesado por negarse a dar una información sobre la huelga de Renfe que consideraba falsa.

12 “El gobierno limitará la intervención en RTVE de las fuerzas electorales minoritarios”, El País, 24/01/1979.

${ }^{13}$ Véase "El gobierno limita el uso de RTVE para las fuerzas electorales minoritarias", El País, 3/02/1979.

14 Fuente: "El derecho a media hora de propaganda electoral en TVE se amplia de siete a diecisiete fuerzas políticas", El País, 11/02/1979.
} 
Arias-Salgado, de obligar a los socialistas a entregar la grabación un día antes con el objetivo, según el PSOE, «que el señor Suárez conociera previamente el contenido de la intervención del líder socialista ${ }^{15}$. El PSOE no dudó en atacar la política que llevaba a cabo el presidente del Gobierno en TVE ${ }^{16}$. Felipe González acusó al Gobierno de usar la televisión «de forma escandalosa y abusiva» y retó a Adolfo Suárez a un cara a cara en TVE. Adolfo Suárez respondió: «Si Felipe González quiere un debate en TVE, tendrá que ganárselo» ${ }^{17}$.

En 1979 La clave emitió un total de 52 programas. A inicios de año, abordaría temas como el Fraude fiscal (89), la Eutanasia (90), El negocio de la muerte (93), la Fuga de cerebros (94), y las Sociedades secretas (96). Este último contó con la participación de un miembro del Ku Klux Klan, Bill Wilkinson, que acudió al debate ataviado con la vestimenta del Gran Dragón de la orden del Ku Klux Klan, defendiendo la inferioridad de la raza negra y la obligación de combatirla $^{18}$.

Gran expectación causó el 31 de marzo El compromiso del intelectual (ficha 97). La clave contó con la presencia del escritor Truman Capote. Sin embargo, los responsables de RTVE, Miguel Martín (director de TVE) y Javier Juan Aracil (director gerente para la producción de TVE), se negaron a pagar los honorarios del escritor. Truman Capote pedía inicialmente 350.000 pesetas que fueron finalmente rebajadas a 100.000. El día antes de la emisión no se había resuelto el problema y fue el equipo de La clave quien puso el dinero de su bolsillo $^{19}$. El escritor de A sangre fría pudo finalmente acudir a Madrid y participar en el programa. Se proyectó La vida de Emilio Zola (The Life of Emile Zola, William Dieterle, 1937), film inédito en España ${ }^{20}$. Entre los invitados, escritores y filósofos como Fernando Savater, Heleño Saña, Carlos París y Rafael Calvo Serer ${ }^{21}$. Durante el debate, Carlos París argumentó que en esos momentos parecía haber ciertos temas que era prudente no radicalizar,

\footnotetext{
15 “Suárez se esforzó en demostrar que cumplió lo prometido", El País, 16/02/1979.

16 «Suárez sabe de la importancia política del medio, porque no en vano su paso por TVE supuso un peldaño importante en su carrera», "Los socialistas atacan a UCD y a Suárez «por la política de TVE»”, El País, 3/02/1979.

17 “Felipe González reta al presidente del Gobierno a un debate en TVE”, El País, 17/02/1979.

${ }^{18}$ Centro de Documentación RTVE. Sociedades secretas (ficha 96). Emisión: 24 de marzo de 1979.

${ }^{19}$ Conversación con José Luis Merino, Madrid, 14/08/2014. Véase también “Truman Capote, una sombra que pasa por Madrid", El País, 31/03/1979.

${ }^{20}$ La filmografía propuesta por La clave fue la siguiente: Wilson (Henry King, 1944), Las aventuras de Mark Twain (The Adventures of Mark Twain, Irving Rapper, 1944), El rey loco (Ludwig II: Glanz und Ende eines Königs, Helmut Käutner, 1955), Yo acuso (I Accuse!, José Ferrer, 1958), El soñador rebelde (Young Cassidy, John Ford/ Jack Cardiff, 1965), Un hombre para la eternidad (A Man for All Seasons, Fred Zinneman, 1966), y El primer círculo (Den første kreds, Aleksander Ford, 1971).

${ }^{21}$ Centro Documentación RTVE. El compromiso del intelectual (ficha 97). Emisión: 31 de marzo de 1979.
} 
como el militarismo, a raíz del Consejo de guerra del grupo de teatro Els Joglars por la crítica que hizo en 1977 al Ejército del franquismo ${ }^{22}$.

¿Era La clave un programa intelectual? José Vidal-Beneyto (sociólogo y politólogo español), escribió en 1979 un artículo titulado "La clave de La clave o la verdad a medias", argumentando que en sus tres años de emisión «La clave es, en su intención y formato, el programa intelectual más ambicioso de TVE, lo que le constituye en plataforma teórica por excelencia de nuestro sistema televisivo. Su análisis y evaluación tiene que ser, consecuentemente, concordes con ese planteamiento y destino» ${ }^{23}$. El sociólogo centraba sus observaciones en tres aspectos: su audiencia (entre dos y tres millones de espectadores), las películas que proyectaba, y en el efecto multiplicador del programa. «Lo primero que se advierte en el programa es su propósito de traer a presencia del televidente los grandes problemas que, por su relación con la vida real, han sido objeto de un silencio sistemático en TVE» ${ }^{24}$. Como argumenta Beneyto, creemos que esta es una de las mayores aportaciones del programa. Poner en el centro de la atención mediática, aprovechando la capacidad de difusión del medio televisivo, temáticas que la sociedad española necesitaba debatir debido a su silencio sistemático. Pero como hemos visto, no todas las temáticas que se quisieron abordar pudieron realizarse. Desde sus inicios tuvo problemas para realizar programas que abordaran temas como la UMD, el periodismo, el divorcio, la homosexualidad, el caciquismo, la Banca, o madres solteras. Una lista que pronto se incrementaría con otras temáticas. La crítica que hacía VidalBeneyto a La clave era la regla que parecía seguir a la hora de escoger a los invitados: no busca a las personas más cualificadas científicamente y profesionalmente, sino a las más conocidas, lo que neutraliza los perfiles antagónicos ${ }^{25}$.

Un año más tarde, Francisco Umbral escribió sobre los intelectuales españoles (José Luis López Aranguren, Fernando Savater, Ramón Tamames, Enrique Tierno Galván, Camilo José Cela, Amando de Miguel) ${ }^{26}$. Todos ellos pasarían en algún momento por el programa, ayudando a la creación de una opinión cualificada. Precisamente Lola Respaldiza (coordinadora

\footnotetext{
22 «En otoño de 1977, Els Joglars realizó una gira por el País Vasco presentando su espectáculo La Torna, representación satírica donde se trataba la polémica ejecución por garrote vil de Heinz Chez y del anarquista Salvador Puig Antich en 1974» (Quaggio 2014: 116).

23 “La clave de La clave o la verdad a medias", El País, 20/07/1979.

${ }^{24}$ Ibídem.

${ }^{25}$ El propio Beneyto asistiría como invitado en La clave hasta en tres ocasiones, en 1982, 1983 y 1984.

${ }^{26}$ Francisco Umbral, "Los intelectuales", El País, 31/05/1980. Sobre el papel de los intelectuales, véase especialmente J. Muñoz Soro (ed.), “Los intelectuales en la transición”, Ayer, 81, 2011.
} 
del programa) gestionaba en esos momentos la intervención de Herbert Marcuse en mayo (Sistemas políticos). Entre abril y diciembre de 1979, UCD y PSOE negociaron el Estatuto de RTVE (que se promulgaría en enero de 1980 y se aplicaría en enero de 1981). Ambos partidos pactaron el texto de dicho Estatuto y algunos nombramientos como el de Fernando Castedo.

Pero antes, el 14 de julio de 1979, La clave celebró su programa número cien en televisión. Pérez Ornia entrevistó a José Luis Balbín y escribió un artículo repasando la trayectoria del programa. «En esos cien temas, el telespectador ha podido conocer las opiniones de más de seiscientas personalidades de todo el mundo: ministros de todos los países, 36 políticos españoles de todas las tendencias» ${ }^{27}$. En esta entrevista, José Luis Balbín calificó la etapa de Gabriel Peña Aranda «de funesta memoria para mí en la historia de TVE», criticando también la etapa de Arias-Salgado, al reconocer que la etapa brillante del programa se detenía precisamente con su llegada. En poco más de un año, como veremos a continuación, AriasSalgado pondrá fin a La clave. Pero en esos momentos, lo que más molestaba al director de $L a$ clave eran las descortesías de los directivos como retrasar el pago de 100.000 pesetas a Truman Capote, o la copia que hacían de La clave otros programas grabados: «No hay directo. Los programas grabados están sujetos a la manipulación porque te cortan lo que quieran» ${ }^{28}$. Efectivamente, TVE reproducía otros programas de similar formato a La clave pero controlables desde las altos cargos del Ente. Otra crítica que hacía José Luis Balbín en un año de galardones (premio nacional Ondas, premio Pablo Iglesias, mejor presentador para $A B C \ldots$ ).

Con La clave de los debates (ficha 112), se celebró el programa número cien. En él se abordó el concepto de debate y la necesidad de controversia y confrontación, y para ello, se proyectó una antología de las mejores intervenciones. Sin embargo, para su director, la realidad era distinta: «En estos últimos meses se nos ha dicho siempre que no a todo (...). Nos dijeron que no incluso a la forma de conmemorar el número cien. (...) Esperamos que mejore la televisión de todos los españoles y que podamos, entre otras muchas esperanzas, emitir los prohibidos debates sobre homosexuales, caciques, la banca y los dineros de la Iglesia. Por cierto, tenemos otro más censurado, bajo el título de Contubernio, y que debería emitirse el

\footnotetext{
27 “La clave, único programa de debate en directo de TVE, cumple hoy el número cien”, El País, 14/07/1979. La clave era para Pérez Ornia un programa amenazado siempre de censuras, cortes e interrupciones. Dificultades que habían crecido en proporción al aumento de «telespectadores por un UHF que se ve en solo medio país y mal».

${ }^{28}$ Ibídem. En un breve repaso a la trayectoria del programa, José Luis Balbín diría: «Hemos tendido épocas buenas y malas. Algunos altibajos han sido culpa nuestra, otros deben achacarse a los directivos y a la propia TVE. La única etapa brillante coincidió con los meses de que van desde la salida de Ansón a la llegada de Arias-Salgado. Después, a partir del nombramiento de Manuel Martín, en agosto de 1978, vino el declive total».
} 
próximo mes de septiembre» ${ }^{29}$. Contubernio era el término con el que el franquismo trató de ridiculizar el Congreso del Movimiento Europeo que tuvo lugar en Múnich en 1962. De todos ellos, solo este último no llegaría a emitirse en La clave.

La articulación del debate televisivo se va a producir porque previamente el programa había asentado las bases de dicho debate. En este sentido, si en un primer momento, su director bloqueó el acceso a los políticos porque no quería politizar el programa, acaba accediendo a su entrada, pero con un matiz que va a ser determinante: el equipo el programa será quien elija a los partidos políticos presentes en el debate. El funcionamiento era el siguiente: en pro de mantener la independencia del programa, La clave elegiría a los partidos presentes en el debate, y estos elegirían a sus representantes. Una estrategia a seguir que, sin embargo, provocó desde su implantación (y será una constante hasta el final del programa), continuas críticas de los propios partidos por los desequilibrios en la distribución de invitados o por no haber sido invitados. Sin embargo, esta decisión será la que provoque que La clave se convierta, ahora sí, en el programa político por excelencia de la televisión, aumentando su incidencia directa en el campo político y en los representantes que en él aparecen.

Entre la multitud de programas que La clave abordó en $1979^{30}$, destaca El poder (ficha 98) ${ }^{31}$. Se proyectó Julio Cesar (Julius Caesar, Joseph L. Mankiewicz, 1953) de toda la filmografía propuesta ${ }^{32}$. Intervinieron, entre otros, el fiscal del Tribunal Supremo Eduardo Jauralde, el líder revolucionario alemán Rudi Dutschke, el diputado socialista Enrique Múgica, y Gerhard Reddemann ${ }^{33}$. Su director inició el coloquio con una definición de poder: «Es un peligroso dominio. Una necesaria estructura técnica, foco de opresión, un instrumento de ordenada racionalidad, de equidad, de eficacia, de justicia, de liberación, todo ello a la vez.

\footnotetext{
${ }^{29}$ José Luis Balbín, “La clave, único programa de debate en directo de TVE, cumple hoy el número cien”, El País, 14/07/1979. Enrique del Corral destacó la labor de José Luis Balbín, «cuya sólida formación y amplísima cultura le confiere especiales resonancias para un programa tan complejo formalmente y tan difícil de conducir», aunque lamentaba el ámbito minoritario de la segunda cadena (y que provocaba menor resonancia e impacto del programa), E. Corral, “José Luis Balbín y La clave”, ABC, 20/07/1979, p. 94.

${ }^{30}$ Peligro nuclear (ficha 106), Vida en el espacio (ficha 107), Agresividad (ficha 108), Sindicatos (ficha 109), Seguridad (ficha 110), La Bolsa (ficha 111), La generación del 98 (ficha 118), Retorno al carbón (ficha 121), El petróleo (ficha 128)...

${ }^{31}$ El tema del poder sería abordado en otras ocasiones: Religión y poder (ficha 193), La información y el poder (ficha 230), Poderes fácticos (ficha 254), El poder judicial (ficha 312)...

${ }^{32}$ La toma del poder por parte de Luis XIV (La prise de pouvoir par Louis XIV, Roberto Rossellini, 1966), Z. (Costa-Gravas, 1968), Macbeth (Orson Welles, 1974), Todos los hombres del presidente (All the President's Men, Alan J. Pakula, 1976), Los tres días del Cóndor (Three Days of the Condor, Sydney Pollack, 1975), y Muerte de un presidente (Śmierć Prezydenta, Jerzy Kawalerowicz, 1977).

${ }^{33}$ Sobre esta emisión, véase también, Francisco J. Satué, Los secretos de la Transición, op. cit. p. 528.
} 
¿Qué es para vosotros el poder?» ${ }^{34}$. Durante el coloquio se abordó el peligro que suponía la concentración de poderes y se realizaron toda una serie de preguntas: ¿Hay alguna sociedad en la que funciona bien el equilibrio de poderes? ¿El poder político puede representar realmente el sentimiento de una nación? ¿Puede alguien ostentar el poder en nombre del Pueblo cuando este cambia de opinión en días, a veces, en horas? Al finalizar el debate se incluyó una sección bibliográfica con obras tan significativas como Política, de Aristóteles (1509), Leviatán, de Hobbes (1651), El espíritu de las leyes, de Montesquieu (1748), El contrato social, de Rousseau (1761), y De la division du travail social, de Durkheim (1893).

En relación a claves políticas de 1979 que serán analizadas en nuestro último capítulo, destacamos La democracia (ficha 103) y Sistemas políticos (ficha 105). Se emitieron ambas en mayo y fueron calificadas en prensa de excepcionales por tema e invitados ${ }^{35}$. Otro programa destacado fue El riesgo del periodista (ficha 115), con la proyección de la película El cuarto poder (Deadline, Richard Brooks, 1952). Entre los invitados, dos españoles, Juan Luis Cebrián (director de El País) y Alfonso Rojo (reportero de Cambio 16), y cuatro invitados extranjeros (redactores o corresponsales de distintos medios internacionales). Bastan algunos de los titulares de la prensa en 1979 para evidenciar los riesgos que corría el periodista por hacer su trabajo: «El Gobierno español expulsa a un periodista holandés», «Agresión a un redactor en una manifestación ultraderechista», «Periodista alemán asesinado en Beirut», «La mafia asesina a un periodista en Italia», «Cuatro periodistas, ejecutados en Uganda» ${ }^{36}$.

A mediados de 1979 se hizo público el rechazo a la programación televisiva con una pérdida de dos millones de telespectadores ${ }^{37}$. Desde que cesara en la dirección de televisión Miguel Martín -el 4 de julio de 1979- habían transcurrido meses sin un nuevo director, y la plantilla, en cambio, no dejaba de incrementarse con nuevos altos cargos ${ }^{38}$. Además salió a la luz un informe confidencial de 1975 que evidenció el desorden administrativo de la televisión hasta esos momentos. TVE había venido modificando su estructura orgánica continuamente modificando dependencias y competencias sin ningún tipo de control ${ }^{39}$.

\footnotetext{
${ }^{34}$ Centro de Documentación RTVE. El poder (ficha 98). Emisión: 7 de abril de 1979.

${ }^{35}$ La hoja del lunes, Madrid, 28/05/1979, p. 39.

36 “El riesgo de informar”, El País, 4/08/1979

${ }^{37}$ Fuente: “TVE perdió casi dos millones de espectadores en los últimos cuatro meses”, El País, 9/08/1979.

${ }^{38}$ Fuente: J. R. Pérez Ornia, “TVE y RNE, sin cabezas”, El País, 5/09/1979

${ }^{39}$ Análisis de clima de RTVE, RTVE, 1975.
} 
Aprovechando tal vez la falta de control, La clave abordó La banca (ficha 126), tema prohibido durante casi un año por los directivos, y Marxismo (ficha 129), emitido el 10 de noviembre de $1979^{40}$. De este último trascendió el fuerte enfrentamiento dialéctico entre el filósofo francés Bernard-Henry Levy y el secretario general del Partido Comunista Santiago Carrillo. José Luis Balbín, por primera vez en un debate, advertía a un invitado de cortarle el sonido por las continuas interrupciones. En este caso de Bernard-Henry Levy a Santiago Carrillo $^{41}$. También hubo en este programa un fuerte enfrentamiento entre José Luis Balbín y el realizador Adriano del Valle. La causa principal fue que José Luis Balbín quería cortar el sonido a Bernard-Henry Levy por sus constantes interrupciones al resto de invitados; consigna que no fue atendida por Adriano del Valle ${ }^{42}$. Este enfrentamiento acabó con la ausencia de José Luis Balbín en el programa Los dineros de la Iglesia (ficha 133) -uno de los temas prohibidos en su día por los directivos de TVE- y, como ahora veremos, con la apertura de un expediente ${ }^{43}$. Javier Vázquez apareció en pantalla el 8 de diciembre de 1979 indicando que su director no presentaría el programa por «razones administrativas» ${ }^{44}$.

El conflicto se había trasladado a la prensa, que se había convertido entonces, en el campo de batalla. Allí expusieron sus reacciones y acusaciones: si uno no acudía a las reuniones del equipo (Adriano del Valle), el otro llegaba tarde a su propio programa (José Luis Balbín) ${ }^{45}$. José Luis Balbín declaró que se trataba «únicamente de un problema entre el realizador y el director. Se ha demostrado que somos incompatibles y esto tenía una fácil solución: echar a uno de los dos. A mi entender en este caso, a quien debía echarse del programa era al realizador por la sencilla razón que él quiere hacer un programa distinto al que estamos haciendo todo el equipo, al que se incorporó posteriormente» ${ }^{46}$.

\footnotetext{
${ }^{40}$ Centro de Documentación RTVE. Marxismo (ficha 129). Emisión: 10 de noviembre de 1979. Cfr. M. Palacio y C. Ciller, "La clave de TVE...”, en Estudios sobre el Mensaje Periodístico, op. cit. p. 237.

41 "Enfrentamiento Carrillo-Henry Levy en RTVE", El País, 11/12/1979. "La sonrisa de los budas", El País, 13/11/1979, y "La clave del marxismo", El País, 16/11/1979.

${ }^{42}$ José Luis Balbín alegó que él era el director del programa y debían atenderse sus indicaciones. Por su parte, Adriano del Valle señaló que desde el momento en que comenzaba a emitirse La clave él era el responsable y, por tanto, era suya la competencia de continuar la emisión sin censurar a ningún invitado. Al día siguiente, la prensa filtró que José Luis Balbín había pedido su traslado a otro programa por incompatibilidad de criterios con el realizador, a lo que no accedieron los responsables de RTVE.

${ }^{43}$ Véanse "Balbín se niega a salir en pantalla", El País, 11/12/1979, "Los problemas del directo y del diferido", El País, 27/11/1979, y “Abierto un expediente al director de La clave”, El País, 14/12/1979.

${ }^{44}$ Centro de Documentación RTVE. Los dineros de la Iglesia (ficha 133). Emisión: 8 de diciembre de 1979.

${ }^{45}$ E. del Corral, Crítica diaria, “Éramos pocos...”, $A B C, 13 / 12 / 1979$, p. 110.

${ }^{46}$ José Luis Balbín, en El Periódico de Catalunya, 20/12/1979, p. 31.
} 
El conflicto de nuevo se trasladó de la prensa a la dirección de RTVE. El 23 de noviembre, Luis Ezcurra Carrillo (subdirector general de RTVE y director en funciones de TVE), ordenó la apertura de una investigación por «la incompatibilidad de criterios entre el realizador del programa, Adriano del Valle -muy poco dado a progresismos y aperturas- y el siempre liberal José Luis Balbín» ${ }^{47}$. Algunos directivos propusieron que el debate fuese moderado por otros directores o presentadores de televisión como Joaquín Soler Serrano (director de A fondo y Sin fronteras) o José Antonio Silva (presentador de Tribuna de la historia), negándose rotundamente José Luis Balbín por no pertenecer al equipo de La clave.

Esta disputa muestra, en cambio, algo mucho más problemático: cómo funcionaba Televisión Española en 1979. El inspector general de servicios de RTVE envió una circular a distintos realizadores para preguntarles sobre el programa La clave:

1. ¿Cuál es la competencia y responsabilidad del realizador de un programa en directo, como es La clave?

2. ¿Puede el director, moderador o presentador del programa ordenar el corte de sonido?

3. ¿Puede el realizador oponerse al corte de sonido ordenado?

4. ¿Qué criterio debe imperar en dicho supuesto? ${ }^{48}$

Preguntas que evidenciaban que ni los directivos (ni inspectores) sabían cuáles eran las competencias de sus propios trabajadores (que según la legislación, el director era el máximo responsable de los contenidos del programa). Además, como anunciaba la prensa, era «la primera vez en la historia de TVE que la dirección consulta directamente a sus trabajadores ${ }^{49}$. A mediados de diciembre se tomó una decisión. La dirección de TVE ordenó la apertura de un expediente disciplinario a José Luis Balbín por no haberse presentado al programa Los dineros de la Iglesia. Tras este expediente, se especuló sobre si La clave debía continuar en antena, si había que cesar a José Luis Balbín o simplemente emitirse en diferido. El director de La clave, en declaraciones a la prensa argumentaría que él estaba dispuesto a continuar siempre que fuese en directo. «Esta ha sido la pretensión que ha tenido la dirección desde hace mucho tiempo (...). La clave tiene sentido si se hace en directo» ${ }^{50}$.

\footnotetext{
${ }^{47}$ Destino, no 2202, 19/12/1979, p. 44.

48 “Abierto un expediente al director de La clave", El País, 14/12/1979.

${ }^{49}$ Ibídem.

${ }^{50}$ El Periódico de Catalunya, 20/12/1979, p. 31.
} 
Ambos profesionales se reunieron de nuevo la semana siguiente en África negra (ficha 134) y el programa recibió de nuevo el aplauso de la prensa. Esta vez la crítica se dirigió hacia el abuso de cortes y anuncios durante el debate (con treinta minutos de publicidad ${ }^{51}$. Destacable fue que La clave no realizó su primera clave histórica hasta finales de 1979 titulada Extranjeros en la Guerra Civil (ficha 131), que analizaremos en nuestro último capítulo. Finalizó el año con un debate sobre La justicia (ficha 135) y un programa en diferido: De niños a niños (ficha 136). José Luis Balbín fue galardonado con el premio de mejor de televisión por un jurado compuesto de 49 profesionales de televisión ${ }^{52}$. Aprovechó de nuevo para lamentar que todavía existiese censura en La clave: «cuando se censura nuestro programa no se censura algo que ya está hecho, sino que se censura un tema determinado» ${ }^{53}$.

\subsection{El Estatuto de RTVE y la auditoría de Hacienda}

En diciembre de 1979 se tramitó el Estatuto de RTVE, al que José Luis Balbín valoraba de «bastante malo, por lo que puede suponer una excesiva intervención de los partidos políticos en los cargos directivos de TVE» ${ }^{54}$. TVE sufrió una remodelación para adaptarse a las nuevas estructuras democráticas. En enero de 1980, tras consenso entre UCD y PSOE, se promulgó la Ley reguladora del Estatuto de la Radio y la Televisión ${ }^{55}$. La televisión quedó establecida como un servicio público cuyo titular era el gobierno. El fuerte carácter intervencionista favoreció la dependencia del medio respecto al ejecutivo.

En 1980 se produciría la segunda supresión de La clave, esta vez, con Fernando AriasSalgado. Tras una primera emisión en diferido, el programa debatió sobre Caciques (ficha 138), tema prohibido en noviembre de 1978. Se proyectó la película Ciudadano Kane (Citizen Kane, Orson Welles, 1941), inspirada en el magnate estadounidense de los medios de comunicación William Randolph Hearst. La controversia (que empezaba a ser habitual en La clave), se produjo por la participación de Sebastián Auger (presidente del consejo de administración del grupo Mundo y editor del diario Informaciones). El día antes, representantes de estos periódicos entregaron una carta José Luis Balbín, que participaba en una rueda de prensa, solicitando

\footnotetext{
${ }^{51}$ E. del Corral, Crítica diaria, "Profesionales, nada menos...”, $A B C, 18 / 12 / 1979$, p. 116.

52 Véase Blanco y Negro, 19/12/1979, pp. 79-81.

${ }^{53}$ Ibídem, p. 81.

${ }^{54}$ El Periódico de Catalunya, 20/12/1979, p. 31.

${ }^{55}$ La ley fue aprobada en las Cortes y publicada en el Boletín Oficial del Estado como Ley/41980 de 10 de enero.
} 
retirar la invitación del programa a Sebastián Auger dada la situación de la empresa que dirigía y el peligro de cierre de cuatro periódicos del grupo Mundo. Según El País, el director del programa les contestó «que no le retiraría la invitación al mencionado empresario periodístico, aunque anunció que sometería el tema a la votación del equipo» ${ }^{56}$. Finalmente, Sebastián Auger no participó en el programa. José Luis Balbín inició el debate con la siguiente pregunta: ¿Creen ustedes que es posible que en España se dé la figura de un empresario periodístico que llegue a tener el poder social político del personaje de esta película ${ }^{57}$ Respuesta que podría haber ofrecido el ausente empresario, editor de Informaciones, y de siete entidades catalanas responsables de la edición de cuatro periódicos de Barcelona.

Una semana más tarde, el 19 de enero de 1980, La clave realizó OTAN (ficha 139), con la película Estado de alarma (The Bedford Incident, James B. Harris, 1965). El programa era de gran actualidad al producirse el viaje a Estados Unidos del presidente Adolfo Suárez, y la visita a España del canciller de la República Federal de Alemania. La clave convocó a expertos y políticos (entre los que figuraban el ex primer ministro de Bélgica Pierre Harmel, y el secretario general adjunto para Asuntos Políticos de la OTAN Hans Christian Lankes) para debatir sobre la eventual incorporación de España a la Alianza Atlántica. El País publicó que «en un principio, solo UCD y el PCE eran partidos invitados, pero luego PSOE y AP impusieron su presencia, a base de presiones y en contra de la independencia del programa» ${ }^{58}$.

Es importante subrayar el tema de la OTAN (que trató hasta en tres ocasiones) para entender el desarrollo y evolución de La clave, ya que precisamente fue el tema que ocasionó la supresión definitiva del programa en 1985. Tras esta emisión de 1980, La clave realizó dos programas más, ambos en 1985. El primero titulado OTAN: de salida ¿qué? (ficha 373), haciendo referencia al ambiguo eslogan del Partido Socialista y para el cual se proyectó un documental realizado expresamente por y para La clave logrando uno de los objetivos ansiados de su director: emitir producción propia como hacía Les Dossier de l'écran. Esta emisión, como veremos más adelante, provocó un enorme escándalo y romperá definitivamente las relaciones con el Partido Socialista quien, a partir de entonces, verá a La clave como un programa que hay que eliminar de la parrilla televisiva. El segundo programa, titulado La movida nacional (ficha

\footnotetext{
56 “Conflicto sobre la participación de Auger en La clave”, El País, 12/01/1980.

${ }^{57}$ Centro de Documentación RTVE. Caciques (ficha 138). Emisión: 12 de enero de 1980.

58 “Oliart: Gibraltar, obstáculo para entrar en la OTAN”, El País, 22/01/1980.
} 
408-C), es el detonante de la suspensión definitiva de La clave. Emisión que además nunca salió en antena al ser suspendida en Televisión Española el 27 de diciembre de 1985.

Tras la emisión de la OTAN de 1980 José Luis Balbín concede una entrevista en la que habla sobre la dificultad de traer a invitados:

«Evidentemente, los grupos que más reticencias tienen con respecto al programa son los que representan al establishment del país: la Iglesia, los jueces y los militares. Son tres estamentos típicos que en cuanto tocamos un tema que tiene relación con ellos no quieren saber nada. Nos ocurre lo mismo con la administración pública, aunque ahora ha cambiado un poco. Al principio, la administración pública no quería mandar a nadie. ¿Qué ocurrió? Que si tú tocas un tema como el del urbanismo, y el Ministerio de la Vivienda no quiere mandar a nadie, evidentemente si va al programa uno del Partido Comunista va a poner a parir al ministro de turno. Y claro, finalmente se han dado cuenta de que les conviene tener a un representante. Yo no soy comunista y por eso te lo digo, pero lo cierto es que el Partido Comunista, cada vez que le hemos pedido un representante, nos lo ha mandado y jamás nos ha puesto la menor condición. Con otros grupos es diferente; nos dicen: “¿y quiénes son los otros?”, “¿y quién va a ir?”, “si éste va, yo no voy”, etcétera. Generalmente los partidos minoritarios extraparlamentarios tampoco nos ponen ninguna dificultad como Fuerza Nueva, la ORT, y el PTE. Quizás porque estos grupos no están en el Parlamento y por eso son más agradecidos» 59 .

Ese mismo mes, en enero de 1980, coincidiendo con el mandato de Fernando AriasSalgado, José Ramón Pérez Ornia publicó en El País el informe de la auditoria de Hacienda a RTVE que ponía de manifiesto ante la opinión pública el verdadero estado de la televisión pública en España: irregularidades administrativas, corrupción, malversación, descontrol, conflictos laborales, expedientes, dimisiones, denuncias, escándalos... ${ }^{60}$. Ante el contundente informe, el director general tuvo que hacer frente todo tipo de críticas aunque logró mantener el apoyo institucional encabezado por su hermano, Rafael Arias-Salgado, ministro de la Presidencia. El 29 de febrero de 1980 se le impuso una multa por no presentar en el plazo el balance de RTVE para el ejercicio de 1978.

\footnotetext{
${ }^{59}$ Interviú, $\mathrm{n}^{\circ}$ 194, 31 enero-6 febrero 1980, p. 78.

${ }^{60}$ El problema radicaba en la dificultad de descifrar la estructura y composición de RTVE (no solo quién la preside, también qué funciones desempeñaban cada uno de los cargos).
} 
Por primera vez -aunque no la última- La clave pasó del formato televisivo a la calle ${ }^{61}$. Tras El Islam (ficha 141), Poder municipal. La gran ciudad (ficha 144), y Radiodifusión (ficha 146), se prohibió Poder municipal en pequeñas poblaciones (ficha 146-C). La decisión la tomó el director general de RTVE el 11 de marzo, cuatro días antes de la emisión (a pesar de haberse anunciado el programa con un mes de antelación). La nota de la oficina de prensa de TVE expuso el motivo: «en evitación de la posible influencia que el espacio pudiera tener en el desarrollo de la campaña electoral para el Parlamento de Cataluña» ${ }^{62}$.

La prensa criticó las razones alegadas por la dirección de TVE porque La clave sí había podido emitirse en fechas próximas al referéndum de Andalucía y a las elecciones al parlamento del País Vasco. Además, ninguno de los invitados era catalán. Eduardo Martín Toval, diputado general de la campaña electoral socialista afirmó que «RTVE ha vuelto a demostrar su carácter de mero instrumento al servicio de la política de UCD» ${ }^{63}$. En sustitución, se emitió la película El gran Ziegfeld (The Great Ziegfeld, Robert Z. Leonard, 1936), de casi tres horas de duración. Una película que tenía preparada el equipo ante el temor de suspender Extranjeros en la Guerra Civil (ficha 131), primer programa sobre la historia reciente anteriormente aludido. Esta prohibición evidenció una vez más la preocupación de los políticos por la posible repercusión que podía llegar a tener este programa ante unas elecciones. El 26 de abril (mes y medio después de la suspensión), se emitió con distintos invitados Poder municipal en pequeñas poblaciones (ficha 152).

En abril de 1980, por primera vez un tribunal de justicia reconoció un caso de corrupción en Radiotelevisión Española ${ }^{64}$. El llamado affaire Maldonado ${ }^{65}$ destapó que la cobertura del segundo canal en 1980 solo cubría el 50\% de la población. Tele Radio y otras publicaciones de RTVE cifraban la cobertura en torno al 70\%, con una audiencia media de 485.000 espectadores entre semana, y 2.620.000 espectadores los sábados durante La clave (casi la misma audiencia

\footnotetext{
${ }^{61}$ Para la presentación del libro Operación Guernika, del periodista Faustino González-Aller se realizó en Barcelona El método de La clave. Se proyectó Cómo robar un millón de dólares (How to Steal a Million, William Wyler, 1966), y entre los invitados, Manuel Leguineche, José Mario Armero, y Manuel Vázquez Montalbán.

62 “Arias-Salgado prohíbe un debate en TVE sobre el poder municipal”, El País, 15/03/1980.

${ }^{63}$ La Vanguardia, 15/03/1980, p. 9. A la suspensión de La clave, también «se ha silenciado casi por completo la estancia en Cataluña de Felipe González, el solo anuncio de la visita de Adolfo Suárez ha merecido una atención descaradamente preferente. No cabe duda que RTVE es un arma propagandística más de UCD».

${ }^{64}$ Véase "Primer fallo judicial contra la corrupción en RTVE”, El País, 2/04/1980.

${ }^{65}$ En 1972, bajo la dirección de Adolfo Suárez, se concedió un contrato a José María Maldonado y se adjudicó a su empresa, Nortrom, la fabricación de «prácticamente todos los componentes de la red de UHF, frecuencias moduladas y ondas medias que necesitaba el Estado» (Tijeras 2012: 7), que fue la causante de mala infraestructura de la UHF. Fuente: "Maldonado, causante de la gran sombra del UHF", El País, 2/04/1980.
} 
que tenía Radio Nacional de España con 2.666.000 radioyentes) ${ }^{66}$. A raíz del informe de la auditoría de Hacienda, el PSOE interpuso una querella criminal contra las irregularidades financieras de RTVE, dirigida contra el director general de RTVE, Fernando Arias-Salgado y su antecesor, Rafael Ansón. Más tarde, el Tribunal Supremo pidió una fianza de un millón de pesetas como requisito para tramitar dicha querella.

Mientras el PSOE planteaba una moción de censura contra Adolfo Suárez en mayo de 1980, La clave dedicaba un programa a la Seguridad jurídica (ficha 154), con la participación del fiscal de la Audiencia Territorial de Madrid, Jesús Vicente Chamorro, expedientado por participar dos años antes en Errores judiciales (ficha 41). El fiscal Chamorro era conocido dentro de la Administración de justicia por sus posiciones democráticas y críticas ${ }^{67}$. La confirmación de su asistencia provocó que el representante de la Administración no participara. El Ministerio de justicia había anunciado la participación de Manuel Marín (subsecretario de Justicia) pero, tras pedir a la dirección de La clave la lista de participantes al debate, anuló la participación del subsecretario y comunicó que no enviaría a ningún representante ${ }^{68}$. En su lugar asistió Juan Luis Cebrián (director de El País), recientemente condenado por el Tribunal Supremo por el editorial titulado "Prensa y democracia" de 1978.

En este sentido, El País publicó una lista de personas procesadas en causas relacionadas con la libertad de expresión: «Sesenta periodistas, escritores e intelectuales se encuentran sometidos actualmente a más de cuatrocientas causas relacionadas con el ejercicio de la libertad de expresión. (...) Los procesamientos por presuntos delitos contra el Ejército o la Guardia Civil ocupan el primer lugar» ${ }^{69}$. Existían otros muchos casos, como el de Xavier Vinader. La banda terrorista ETA asesinó a dos personas que habían sido nombradas por Vinader en dos reportajes en Interviú, en el que se denunciaba la guerra sucia. Vinader fue condenado por un

\footnotetext{
${ }^{66}$ Datos del semanario oficial Tele Radio que proporciona José Ramón Pérez Ornia, El País, 24/04/1980.

${ }^{67}$ «El Ministerio de justicia, por otra parte, habría intentado hasta última hora de ayer, según fuentes judiciales, presionar sobre un determinado fiscal de ideas abiertamente derechistas para que interviniera en el coloquio de $L a$ clave, a fin de contrarrestar las posiciones avanzadas que presumiblemente mantendrá el fiscal Chamorro», "La justicia, de nuevo en La clave", El País, 10/05/1980. En declaraciones al periódico, el fiscal confirmó la versión dada por José Luis Balbín y añadiría: «Participo en este debate de La clave no como fiscal, sino en calidad de persona particular y ciudadano español».

${ }^{68}$ José Luis Balbín manifestó que «el Ministerio de Justicia se muestra reticente a enviarnos a alguno de sus representantes cuando se trata de debatir algún tema de justicia», "La justicia, de nuevo en La clave", El País, $10 / 05 / 1980$.

69 "Sesenta personas procesadas en más de cuatrocientas causas relacionadas con la libertad de expresión", El País, 11/05/1980. Entre los artículos que habían provocado procesamientos estaban: "Siete travestis se confiesan", Galicia Deportiva, 23/01/1978, "Dirección General de Seguridad: siguen torturando", La Calle, 27/03/1979, "Una intentona militar ha sido abortada en Madrid", Diario 16, 25/01/1980, y "La extraña muerte de Agustín Rueda", El País, 27/01/1980.
} 
delito de inducción al asesinato. En relación al cine, también se prohibía la película El crimen de Cuenca (Pilar Miró, 1979), por injurias y calumnias a la Guardia Civil. La película pudo ser estrenada finalmente en 1981. Todos los participantes en el debate defendieron la tesis que la sociedad española vivía en esos momentos en un clima de verdadera inseguridad jurídica ${ }^{70}$.

Entre las claves políticas e históricas de 1980 que analizaremos en el último capítulo se encuentran Futuro de la democracia (ficha 162), con la proyección de la película El Estado de la Unión (State of the Union, Frank Capra, 1948); y Muerte de García Lorca (ficha 160), con la película sueca Federico García Lorca: Asesinato en Granada (Federico García Lorca: Mordel skede i Granada, Humberto López, 1977). A finales de abril, el secretario de Estado para la Sanidad, había enviado una carta al director general de RTVE, pidiendo que no aparecieran personajes públicos fumando en televisión. A este respecto, se ha de señalar que La clave fue desde la primera emisión un espacio de intensas humaredas.

\subsection{La segunda supresión del programa}

La segunda supresión del programa comenzó a fraguarse en mayo de 1980 cuando se inició en Televisión Española una política de reducción de gastos. El hecho de realizar La clave en sábado suponía tener que abonar las horas extraordinarias de todos los trabajadores, por lo que se decidió emitir en diferido a partir de julio ${ }^{71}$. Pero eran conscientes que suprimir en televisión el directo de los programas significaba perder La clave.

Fernando Arias-Salgado compareció ante la Comisión de Control Parlamentario de RTVE, presidida por Antonio de Senillosa, el 26 y 27 de junio de 1980. Fue la primera rendición de cuentas que se hizo de televisión (y la primera vez que se grabó íntegramente una comisión). Desde que había sido nombrado director general de RTVE el 19 de noviembre de 1977, se habían multiplicado los cargos en RTVE dando lugar a una estructura amorfa. Alfonso Guerra, junto a los representantes comunistas, pidió el cese inmediato del director general, tachándole de ser el último director del franquismo, y habló de censura en la televisión con la posible desaparición de La clave. El director general respondió: «Mientras La clave sea excelente como lo es ahora, no hay problemas de desaparición» ${ }^{72}$.

\footnotetext{
${ }^{70}$ Centro de Documentación RTVE. Seguridad jurídica (ficha 154). Emisión: 10 de mayo de 1980.

${ }^{71}$ Fuente: "La clave se emitirá en diferido", El País, 28/05/1980.

72 “El director general de RTVE se sometió a un intenso interrogatorio parlamentario”, El País, 28/06/1980.
} 


\section{Primera Comisión de Control Parlamentario a RTVE}

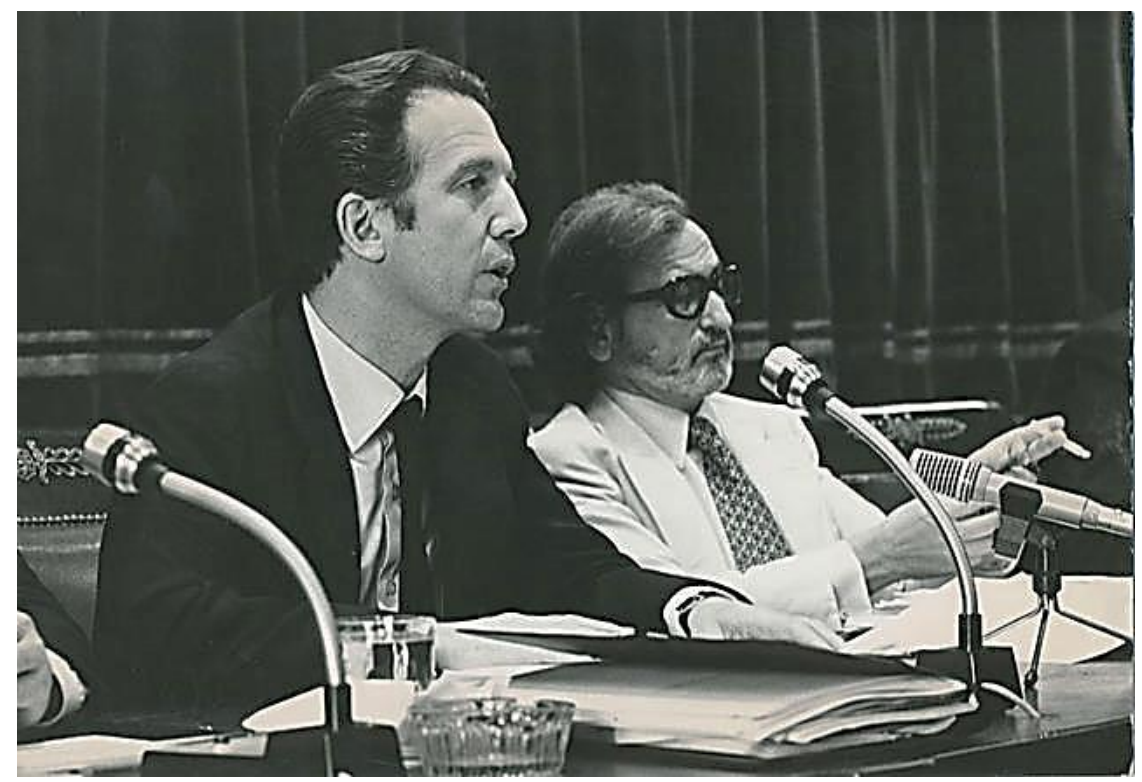

Fotografía no 9. Fernando Arias-Salgado (a la izquierda) y Antonio de Senillosa ante la Comisión de Control Parlamentario de RTVE. Fuente: Europa Press.

Dos meses después La clave desapareció de la programación. Para TVE suponía un problema pagar las horas extraordinarias los fines de semana, así que todos sus programas (incluidos los informativos) serían en diferido. El 30 de julio, Antonio de Senillosa mantuvo conversaciones con José Luis Balbín, Fernando Arias-Salgado y Ricardo de la Cierva (ministro de Cultura), advirtiéndole a este último que podía haber problemas con La clave si se emitía en diferido. José Luis Balbín estaba dispuesto a seguir con la emisión en directo y amenazaba en prensa que desaparecería La clave si dejaba de emitirse en directo ${ }^{73}$. «Nuestro programa siempre ha sido así, nunca hemos sabido con certeza si lo que programábamos se iba a llevar a la práctica. Nosotros por ahora, pensamos que continuaremos pero, en TV, nunca se sabe. Desde que salió el primer espacio, hemos vivido en esta intranquilidad, estamos acostumbrados» ${ }^{74}$.

El 22 de julio, Luis Ezcurra propuso a José Luis Balbín grabar previamente el programa y emitirlo al día siguiente en diferido con el fin de evitar el abono de las horas extraordinarias. «Yo le expuse las razones por las que me negaba a ello: en primer lugar, porque La clave había nacido como un programa en directo y eso formaba parte del pacto que firmó TVE cuando aceptó la idea; y en segundo lugar porque la participación de los televidentes, que es fundamental, debía excluirse si el debate se grababa» ${ }^{75}$. El viernes 5, día previsto por Ezcurra

\footnotetext{
${ }^{73}$ Fuente: $A B C, 28 / 06 / 1980$, p. 93.

${ }^{74}$ Mediterráneo, 5/07/1980, p. 14.

${ }^{75}$ Entrevista a José Luis Balbín en Blanco y Negro, 17/09/1980, p. 58.
} 
para grabar El juego, José Luis Balbín no se presentó. El jefe de inspección de los servicios de TVE, Fernando España, levantó acta de la negativa a grabar el programa y leyó una nota a José Luis Balbín en la que le hacía responsable de los gastos ocasionados en el montaje del plató, que ascendía a varios millones.

Al día siguiente la prensa se hizo eco de la suspensión ${ }^{76}$. TVE facilitó el siguiente comunicado: «Televisión Española lamenta no ofrecer hoy a sus telespectadores el programa La clave. El alto costo de la producción de programas en sábados y festivos ha obligado a la Junta de Televisión Española a ordenar la grabación, en jornada laboral normal (...). Televisión Española entiende que estas normas son transitorias y aunque han afectado a muchos programas, entre ellos algunos de actualidad, no ha encontrado más resistencia que en la dirección del programa La clave (...). Televisión Española desea hacer público su interés en la continuidad de La clave y confía en la solución del problema que ahora impide su presentación» ${ }^{77}$.

La clave se suspendió porque la dirección de TVE quiso emitir el programa en diferido, negándose José Luis Balbín, que ofreció incluso la posibilidad de emitirlo en directo los viernes. En declaraciones en prensa diría: «nuestra negativa a que se emitiese en diferido era conocida por la dirección de Televisión Española y por la opinión pública. Enlatar el programa y distribuirlo cuando ellos decidan es una forma encubierta de censura, y nosotros hemos sufrido muchos casos de censura en La clave, desde programas censurados íntegramente hasta debates, como el del Estatuto de los Trabajadores, cuyas emisiones fueron prohibidas mientras eran temas de actualidad. La clave se concibió como un programa en directo, y no me pueden llevar esposado a dirigir el programa en diferido. No es que ahora me niegue a grabarlo, sino que me negaré siempre» ${ }^{78}$.

En lugar de La clave se proyectó la película Los mejores años de nuestra vida (The Best Years of Our Lives, William Wyler, 1946) de casi tres horas de duración. La clave había programado las tres primeras semanas de septiembre (El Juego, Revolución electrónica, y La carrera de armamentos), y en ese periodo de tiempo no cesaron las reacciones en prensa ${ }^{79}$. A

\footnotetext{
76 “Hoy no se emite La clave”, El País, 6/09/1980; ABC, 6/09/1980, p. 69; y Mediterráneo, 6/09/1980, p. 9.

${ }^{77}$ Comunicado extraído de El País, 6/09/1980.

78 "Hoy no se emite La clave”, El País, 6/09/1980

79 "La suspensión de La clave puede responder a razones de censura, según el director del programa", El País, 7/09/1980. «Televisión Española es la única del mundo occidental que considera que los informativos de actualidad pueden ser emitidos en diferido», "Réplica de José Luis Balbín a TVE”, El País, 7/09/1980.
} 
la suspensión de La clave, El País dedicó el siguiente editorial: «uno de los escasos espacios transmitidos en directo que hacían reconciliarse a los espectadores con la programación televisiva, y que servían para demostrar que los males de Prado del Rey no proceden de la falta de profesionales con talento, sino de la sobreabundancia de mandos incompetentes. La cúpula de Televisión ha conminado a José Luis Balbín, realizador de un programa que ha conquistado la popularidad gracias a la importancia de los temas sometidos a discusión y a los criterios de imparcialidad y pluralismo con que son elegidos los participantes, para que suspenda las transmisiones en directo y grabe con anterioridad los debates» ${ }^{80}$.

La Comisión de Control de RTVE rechazó el 10 de septiembre las comparecencias de José Luis Balbín y Luis Ezcurra por 17 votos en contra y 12 a favor. Algunos rechazaron la propuesta a la espera del informe solicitado a RTVE. Ese día, Luis Ezcurra lanzó un ultimátum a José Luis Balbín: «de no efectuarse el próximo viernes la grabación del programa que debe difundirse el sábado, la gerencia de Televisión, sin más comunicaciones a la dirección de $L a$ clave ni a su jefe de producción dejará de convocar nuevas grabaciones» ${ }^{81}$. José Luis Balbín respondió a través de la agencia Efe que La clave no se emitiría más, como ocurrió por segunda semana consecutiva. Era la supresión definitiva del programa. El vacío dejado por La clave fue cubierto por un documental y un coloquio en diferido del programa La tribuna de la historia.

A finales de noviembre de 1980 tuvo lugar la primera reunión del Consejo de Administración de RTVE. Según el Estatuto debía estar compuesto entre personas de relevantes méritos profesionales, pero en la práctica eran «militantes de partido que siguieron fielmente las indicaciones del partido» (Sinova 1983: 50). En la primera reunión se limitaron a presentar la propuesta del nombramiento del nuevo director general, Fernando Castedo. Arias-Salgado fue cesado «tras escándalos financieros sonoros y duros enfrentamientos con la oposición» (Bustamante 2006: 61), aunque muy pronto fue nombrado embajador en Londres.

\subsection{Fernando Castedo y el golpe de Estado de 1981}

La tercera etapa de La clave se inicia en 1981 con el nombramiento de Fernando Castedo como director general de RTVE, y finaliza con el triunfo al PSOE en las elecciones de octubre de 1982. Durante estos dos años pasaron tres directores generales de RTVE, emitiéndose 83

\footnotetext{
80 "Más difícil todavía" (Editorial), El País, 7/09/1980. Juan Luis Cebrián parecía devolverle el favor por la invitación a La clave, pudiéndose defender por la condena del Tribunal Supremo.

${ }^{81}$ Véase "Segunda suspensión de La clave”, El País, 13/09/1980.
} 
programas y prohibiéndose uno. La clave regresó en abril, dos meses después del golpe de Estado del 23 de febrero de 1981. Tuvo un presupuesto de 2.800 .000 pesetas por programa y un remanente trimestral (cada 13 programas) de 8 millones de pesetas. Esto suponía una mejora (un millón más por programa) respecto al presupuesto inicial aprobado en 1975. El presupuesto no utilizado se dedicó a introducir mejoras como realizar producción propia, es decir, poder filmar expresamente documentales para introducir los debates, al igual que hacía Les Dossiers de l'écran ${ }^{82}$. Todas las etapas son imprescindibles para entender el programa, pero creemos que esta etapa, como trataremos de demostrar más adelante, es fundamental en la construcción política del debate televisivo.

El 9 de enero de 1981, Fernando Castedo Álvarez es nombrado director general de RTVE. Por primera vez, el nombramiento del máximo cargo de la televisión ha sido negociado entre el gobierno (UCD) y el principal partido de la oposición (PSOE). El 14 de enero tomó posesión en el cargo como «primer director general de RTVE ya con las reglas estrictamente democráticas emanadas del Estatuto de la Radio y la Televisión» (Palacio 2012: 12). Tres días después, nombró a su equipo directivo, repleto de periodistas: Miguel Ángel Toledano (director de TVE), Iñaki Gabilondo (director de los Servicios Informativos) y José Luis Balbín (director de Programas Especiales), área de nueva creación en la estructura de RTVE.

En prensa se presentaron las credenciales del nuevo director general. Fernando Castedo había nacido en Madrid en 1941, era abogado del Estado y profesor de Derecho Mercantil en la Escuela de Inspección Financiera ${ }^{83}$, y había prestado servicios en las delegaciones de Hacienda de Santander y Madrid. Fue jefe del Gabinete de Estudios de la Dirección General de lo Contencioso del Estado y, en 1974, se había encargado de la Secretaría General Técnica del Ministerio de Información y Turismo. Perteneció al comité político del Partido Popular, y con uno de sus líderes, Pío Cabanillas, llegó al Ministerio de Cultura en 1977, donde fue subsecretario hasta abril de 1979. Hasta el momento de su nombramiento había ocupado el cargo de secretario general del Instituto de Cooperación Iberoamericana ${ }^{84}$.

El recién llegado director inició el cargo con tensiones. RTVE acababa de retirarse de una coproducción con la BBC, después de exigir ajustar comentarios y recortar imágenes, y haberse negado su director. Se trataba en concreto de las imágenes del príncipe de España

\footnotetext{
${ }^{82}$ Fuente: "El retorno de La clave”, El País, 25/02/1981.

${ }^{83}$ En la carrera de Derecho conoció a José Luis Balbín, con quien todavía hoy, conserva una gran amistad.

${ }^{84}$ J. R. Pérez Ornia, "Hoy será nombrado Fernando Castedo director general de RTVE”, El País, 9/01/1981.
} 
prestando juramento en 1969 como sucesor de la Jefatura de Estado ante las Cortes franquistas $^{85}$. Y a las pocas semanas, el 29 de enero de 1981, Adolfo Suárez presentó su dimisión de la presidencia del Gobierno y pronunció su último discurso ante las cámaras de Televisión Española ${ }^{86}$. El tratamiento que el Telediario dio de la dimisión, provocó que algunos medios hablaran (a los 20 días en el cargo) de la dimisión de Fernando Castedo, llamativo si se compara con los casi cuatro años del anterior director general. Y los problemas no acabaron ahí. El 4 de febrero, durante la visita de los Reyes a la Casa de Juntas de Guernica, un grupo de parlamentarios de Herri Batasuna interrumpió el discurso que pronunciaba el rey Juan Carlos ${ }^{87}$. Imágenes ausentes en gran parte de los documentales sobre la Transición española contrastan con la enorme difusión de las imágenes del golpe de Estado.

Desde los inicios de la Transición venían observándose los problemas en la adaptación del aparato franquista en el camino hacia democracia y el malestar existente en ciertos sectores del Ejército. Un repaso a la prensa de la época muestra una división ideológica entre partidarios de la continuidad del franquismo y los que optaban por el aperturismo. El 23 de septiembre de 1979, en la portada de $A B C$ aparecía el capitán general Milans del Bosch describiendo las causas de ese malestar: «El balance de la Transición no ofrece un saldo positivo: terrorismo, inseguridad, inflación, crisis económica, paro, pornografía, y sobre todo, crisis de autoridad» ${ }^{88}$. A estas causas se añadían otras como la legalización del Partido Comunista en abril de 1976, los relevos militares, el terrorismo de extrema derecha y extrema izquierda, y el llamado proceso de las autonomías ${ }^{89}$.

El 23 de febrero de 1981 se hizo un golpe de Estado en el Palacio de los Congresos de Madrid mientras se producía la segunda votación de la investidura como presidente de Leopoldo Calvo Sotelo. La votación, retransmitida en directo en la radio (a través de Radio Nacional y la cadena SER), estaba siendo grabada por Televisión Española que retransmitía

\footnotetext{
${ }^{85}$ Fuente: “TVE intentó censurar, sin éxito, la película de la BBC sobre el rey Juan Carlos”, El País, 15/01/1981.

${ }^{86}$ Ese mismo día La clave abordó La ley electoral (ficha 211), que contó con la participación de Theodore C. Sorensen (asesor electoral del presidente John F. Kennedy) y representantes políticos de los cuatro partidos mayoritarios, UCD, PSOE, PCE y AP. Se proyectó El candidato (The Candidate, Michael Ritchie, 1972), y se debatió sobre la desproporción que ocasionaba la ley por la regla d'Hondt, listas abiertas o cerradas, y el importante volumen de cuneros. Abordaría de nuevo el tema en 1984 con Ley electoral II (ficha 342).

${ }^{87}$ Véase "El Rey defiende en Guernica la democracia y las instituciones tradicionales vascas", El País, 5/02/1981.

${ }^{88} A B C, 23 / 09 / 1979$ (en portada y pp. 105-107).

${ }^{89}$ VV.AA., Historia de España Contemporánea. Siglos XIX y XX, Madrid, Silex ediciones, 2008, vol. V, p. 276.
} 
para las instalaciones de Prado del Rey ${ }^{90}$. A las 18:22 horas (aprovechando que los diputados en pleno votaban), el teniente coronel Antonio Tejero -junto con otros guardias civiles- asaltó el Congreso. Los treinta y cuatro minutos que constituyen la grabación del asalto no se emitieron en directo en televisión, sino que lo hicieron al día siguiente, 24 de febrero, en torno a las 12:50 h, es decir, dieciocho horas después de la irrupción de Tejero y una vez liberados todos los diputados. Lo hicieron en varias ocasiones en forma de resumen (Cercas 2010: 15) ${ }^{91}$.

Las instalaciones en Prado del Rey permanecieron ocupadas por varios destacamentos alrededor de dos horas. Fernando Castedo poseía las imágenes del golpe, aunque éstas todavía no se habían emitido. Sabino Fernández Campo (secretario de la Casa Real), llamó a Fernando Castedo pidiéndole el envío de un equipo de grabación y otro de filmación a La Zarzuela. La idea de retransmitir las imágenes del golpe en esos momentos fue descartada por el director general de Seguridad, Francisco Laína, quien apareció en televisión poco después de las 21:00 horas. A las 21:20 h, las fuerzas que habían ocupado las instalaciones en Prado del Rey, recibieron una llamada telefónica del jefe de la casa Real (Marqués de Mondéjar), obligando la retirada de tropas de Televisión Española. En torno a las 23:00 h, Televisión Española - de la voz de Iñaki Gabilondo y Pilar Miró- anunciaron una alocución del Rey a la nación, sin fijar la hora. Jesús Picatoste (director adjunto de RTVE) y Pedro Erquicia (subdirector de los Servicios Informativos), fueron los encargados de grabar el mensaje del Rey. Llegaron a La Zarzuela pasadas las once y media de la noche. Siete horas después del golpe, a la una de la madrugada y catorce minutos, se retransmitió el mensaje del Rey a la nación, repetido en varias ocasiones a lo largo de la noche. En documentación desclasificada en 2011, figuraba el télex que el rey Juan Carlos envió al teniente general Milans del Bosch a las 2:30 h de la madrugada para poner fin al movimiento golpista ${ }^{92}$.

El final del golpe de Estado se produjo a las once de la mañana del martes 24 de febrero de 1981, cuando el director general de la Guardia Civil comunicó que Antonio Tejero estaba dispuesto a entregarse bajo condiciones. El llamado Pacto del Capó escenificó el final del golpe. Esa noche miles de personas se manifestaron en Madrid. El día después, editoriales y primeras

\footnotetext{
${ }^{90}$ M. Palacio, La televisión durante la Transición española, op. cit. p. 341. El autor además denuncia la confusión de recuerdos y memorias de una retransmisión que no fue en directo.

${ }^{91}$ Cfr. M. Palacio, La televisión durante la Transición... op. cit. p. 341. En los archivos de Prado del Rey podemos encontrar la grabación de 34 minutos de las imágenes grabadas del golpe en el interior del Congreso.

${ }^{92}$ Véase "El Rey a Milans el 23-F: "Quien se subleve estará dispuesto a provocar una guerra civil y será responsable de ello"”, El periódico, 22/02/2011, y "El mensaje del rey a Milans del Bosch tras parar el 23F: "Ya no puedo volverme atrás"', Eldiario.es, 22/02/2017.
} 
páginas en prensa -y en televisión- anunciaron la victoria de la democracia, daban por fracasado el intento de golpe de Estado, y destacaban la intervención del rey Juan Carlos en la madrugada paralizando el golpe de Estado $^{93}$. Pero cómo medir el papel jugado por los medios de comunicación como la prensa (El País especialmente), la radio, y la televisión. En relación a este último medio, los telespectadores podían ver no solo las imágenes del golpe, también las narraciones que ya habían comenzado a circular en el espacio público desde la entrada de Tejero en el Congreso de los Diputados. El 27 de febrero se produjo una enorme manifestación bajo el lema "Por la libertad, la democracia y la Constitución", única pancarta autorizada 94 . A fecha de hoy, mucha información sobre el golpe de Estado continúa clasificada.

Tras el golpe de Estado, Televisión Española aplazó la nueva programación hasta el 20 de abril ${ }^{95}$. El nuevo esquema preveía un replanteamiento de los informativos y un incremento de programas producidos por la propia TVE, en detrimento de los extranjeros, estadounidenses en particular. Esta tendencia, como hemos visto, también se observa en La clave con el descenso de películas procedentes de Estados Unidos a partir de 1982. También se anunciaron algunas variaciones en La clave: se emitiría en directo el viernes en lugar del sábado. Para su director, «al emitirlo los viernes, queda resuelto el problema de no generar horas extraordinarias para su producción en fin de semana. Quienes decidieron prohibirlo no tenían, por tanto, razones válidas para hacerlo» ${ }^{96}$. También hubo nuevo realizador, Carmelo J. Barrera (en sustitución del díscolo Adriano del Valle), y nuevo redactor jefe, José Luis Merino (en sustitución de Javier Vázquez, quien pasaba a dirigir otro de los programas especiales ideados por José Luis Balbín: Tertulia con... Fernando Fernán-Gómez, de poco éxito). Las últimas novedades fueron la ampliación de la duración total hasta las cuatro horas, y una modificación en la estructura del programa: entre la introducción y la película se intercaló un Telediario, y se inició una colaboración directa entre los Servicios Informativos de TVE y José Luis Balbín.

En el nuevo equipo de Fernando Castedo José Luis Balbín se encargó de la sección Programas Especiales, nueva área creada en el organigrama de TVE. «Me he propuesto cambiar

\footnotetext{
93 “La democracia, con el Rey”, El País, 25/02/1981, y “La democracia se ha fortalecido”, El País, 26/02/1981.

${ }^{94}$ Fuente: $A B C$, Sevilla, 28/02/1981, pp. 5-6.

${ }^{95}$ Informe Semanal construyó el primer relato audiovisual del golpe de Estado el 28 de febrero de 1981. En él, el realizador Pepe Marín relató que tenía cinco cámaras dentro del hemiciclo, de las que acabó con una sola. Pero gracias a ella, y al reportero Pedro Francisco Martín apagando el visor de la cámara, se logró grabar el golpe de Estado. Véase Informe Semanal, “18 horas de tensión”, TVE, 1981.

${ }^{96}$ Declaraciones al periódico El País, "La televisión en España, primer debate de La clave”, 24/04/1981.
} 
y mejorar la calidad media de los programas» ${ }^{97}$. «Para cambiar la televisión en profundidad se necesita mucho tiempo, pero creo que la programación funcionará mejor, entre otras cosas porque no me parece fácil dejarla tan mal como estaba» ${ }^{98}$. Desde allí lanzó nuevos programas para incitar el diálogo y la reflexión como Tome la palabra ${ }^{99}$, La bolsa y la vida ${ }^{100}$, y Mano a mano $^{101}$.

El regreso de La clave se hizo el 30 de abril de 1981, tras un paréntesis de casi nueve meses. Lo hizo con Televisión en España (ficha 171) para abordar los medios de comunicación y la manipulación ${ }^{102}$. En esta ocasión, José Luis Balbín inició el programa con las siguientes palabras: «Hubo un tiempo en que no había la menor duda, la televisión era directamente del Gobierno. Todos los cargos eran nombrados por el Gobierno. Estaba sometida a los mismos rigores de censura que pudiera haber en otros medios de comunicación» ${ }^{103}$.

Tras la introducción y presentación de los invitados, se proyectó la película Un rostro en la multitud (A Face in the Crowd, Elia Kazan, 1957) ${ }^{104}$. Ya se había debatido antes sobre el fenómeno televisivo, su influencia e impacto en Futuro de la televisión (ficha 173), y lo haría después con Lo de la tele (1983), Impacto de los medios de comunicación (1984), y El Estatuto de RTVE (1985).

\footnotetext{
${ }^{97}$ Mediterráneo, 7/03/1981, p. 8.

98 “José Luis Balbín: Hacia una programación especial de calidad”, El País, 24/02/1981.

${ }^{99}$ Dirigido por Alfonso Díez, quería ser el equivalente en televisión de la sección de prensa Cartas al director. Con doble emisión (viernes en primera cadena y sábados en UHF), fue un programa dedicado exclusivamente al telespectador al que se le ofrecía la posibilidad de expresar una queja mediante una carta, por teléfono o incluso mandando una cámara a su casa. Los límites del programa, no admitir anónimos, intervenciones de dos a tres minutos, y moverse «dentro del marco de respeto a la Constitución, a la Ley Antiterrorista y al Estatuto de RTVE», Mediterráneo, 26/08/1981, p. 14.

100 Dirigido por Enrique Meneses, tenía el objetivo de defender al consumidor e informarle de sus derechos. El primer número trató sobre el abuso de las tarifas eléctricas.

${ }^{101}$ Programa de debate bajo la dirección del periodista catalán Joaquim Maria Puyal.

102 «Es el debate en que peor lo voy a pasar porque tengo que limitarme a moderarlo sin poder opinar sobre un tema que tanto me interesa», José Luis Balbín, "La televisión en España, primer debate de La clave", El País, 24/04/1981.

${ }^{103}$ Centro de Documentación RTVE: La televisión en España (ficha 171). Emisión: 30 de abril de 1981.

104 «Tenemos que admitirlo, la política ha entrado en la era de la televisión. En lugar de largos debates públicos, la gente quiere eslóganes pegadizos: "La hora del cambio", "La confusión de Washington", "El impulso para la banca", grandes titulares y glamour». Fragmento de la película Un rostro en la multitud (A Face in the Crowd, Elia Kazan, 1957). En gran parte de los debates sobre televisión La clave quiso proyectar la película estadounidense Network: Un mundo implacable (Network, Sidney Lumet, 1976), que no emitió por derechos de antena. En Futuro de la televisión (ficha 73), se proyectó la película El televisor (Narciso Ibáñez Serrador, 1974), quien figuró entre los invitados. Lo de la tele (ficha 277), se ilustró con Historias de la televisión (José Luis Sáenz de Heredia, 1965), Impacto de los medios de comunicación (ficha 324), con El gran carnaval (Ace in the Hole, Billy Wilder, 1951), y en El Estatuto de RTVE (ficha 403), con la película El asesinato de la hermana George (The Killing of Sister George, Robert Aldrich, 1969).
} 
En Futuro de la televisión de 1978, expertos de ámbito internacional habían debatido sobre el impacto de los medios de comunicación, la penetración de la televisión, su repercusión directa e indirecta en el telespectador, su influencia social, la publicidad, la persuasión. Para Arthur Conte (último director de la ORTF, y asesor del presidente Valéry Giscard d'Estaing), «la impresión física de un hombre ante las pantallas es mucho más importante que lo que está diciendo ${ }^{105}$. En 1981, entre los invitados para debatir Televisión en España figuraban directivos y profesionales del medio como Miguel Ángel Toledano (director de TVE e impulsor de La clave en sus inicios), y el periodista Manuel Martín Ferrand (compañero de promoción en Periodismo). También representantes de los partidos políticos y miembros de la Comisión de Control Parlamentario de RTVE del Congreso como Antonio de Senillosa (presidente de dicha comisión), Pilar Brabo (PCE), Pedro Bofill (PSOE), y José Ignacio Wert (vocal del Consejo de Administración de RTVE por UCD).

¿Se notan las diferencias según los diferentes directores generales de los diferentes gobiernos? Durante el coloquio se debatieron múltiples temas y se hizo referencia a las tres misiones fundacionales de la televisión: informar, educar y entretener. Miguel Ángel Toledano indicó que el segundo canal cubría el 85-90\% de la audiencia (que no había que confundir con territorio), y el periodista Vicente Romero trató de documentar las presiones en TVE: «Al mes de trabajar yo aquí, el director general José María Calviño recibió esta carta del Ministerio de Asuntos Exteriores de la directora general de Iberoamérica, actual embajadora de Costa Rica, protestando por un programa de TVE sobre Perú en el que se defendían los derechos humanos» ${ }^{106}$. Otros temas fueron la situación actual y monopolio de TVE, su baja calidad, la independencia de la televisión, el modelo a seguir de la BBC, la publicidad, las irregularidades contables, la necesidad de mecanismos de control y, de nuevo, el tema de televisión pública o privada. Hubo la habitual crítica desde distintos sectores por no tener presencia en el programa. En este caso, la crítica vino de la Asociación Española de Espectadores de Televisión por no tener ningún representante ${ }^{107}$.

En relación al Estatuto de RTVE, el mandato de Fernando Castedo ha sido considerado «como la única plena, aunque breve y conflictiva, etapa de aplicación completa de espíritu del

\footnotetext{
105 Premisa que dio lugar a una controversia entre Arthur Conte y Gianni Starera, quien calificó al presidente Giscard d'Estaing de «pura propaganda» en la campaña contra François Mitterand. Centro de Documentación RTVE. El futuro de la televisión (ficha 73). Emisión: 7 de octubre de 1978.

${ }^{106}$ Centro de Documentación RTVE: La televisión en España (ficha 171). Emisión: 30 de abril de 1981.

107 “Protestas de la Asociación Española de Espectadores”, El País, 29/04/1981.
} 
Estatuto, porque su nombramiento se produce pocos días antes de la dimisión de Adolfo Suárez, el 29 de enero de 1981, lo que desencadenará un cambio de fuerzas en el partido de la UCD y en el gobierno» (Bustamante 2006: 80). Con el Estatuto de RTVE, tanto el director general, como el consejo de administración, son nombrados por un mandato de cuatro años, salvo disolución anticipada del Parlamento. Pero, como ahora veremos, Fernando Castedo estuvo en el cargo tan solo nueve meses. Militante de UCD, Castedo, fue atacado por parte de su propio partido mientras este se desintegraba. En 1986, José Luis Balbín reconoció que hubo en 1981 un pacto entre el PSOE y el director general de TVE Fernando Castedo. «El pacto con los socialistas en TVE lo hicimos en mi casa Guerra, Calviño, Castedo y yo. Consistía sencillamente en hacer una televisión en la que estuviesen representados proporcionalmente todos los partidos» ${ }^{108}$.

En mayo de 1981 La clave abordó El divorcio (ficha 173), proyectando, esta vez sí, Divorcio a la italiana (Divorzio all'italiana, Pietro Germi, 1961). El divorcio ya había sido abordado en 1978 (ficha 43). Pero si en aquel primer programa se abordó de una manera más didáctica, en 1981 el tema puso de manifiesto la grave crisis que atravesaba UCD, dividida en facciones. ¿Se encuentra muy dividido UCD en relación al divorcio?, preguntó José Luis Balbín a Javier Moscoso (portavoz de UCD): «Hay discrepancias» ${ }^{109}$. Si la encuesta de FOESSA de 1978 sobre la aceptación del divorcio daba los siguientes resultados (18\% muy de acuerdo, 53\% de acuerdo, $17 \%$ desacuerdo, $10 \%$ totalmente desacuerdo ${ }^{110}$, la encuesta de 1981 encargada por el ministro de Cultura (Íñigo Cavero), mostraba que un 70\% de los españoles entendían que era necesaria una ley de divorcio.

La clave no fue el único programa que abordó el divorcio (también lo hizo En este país, de Lalo Azcona, que estrenaba esa misma semana) ${ }^{111}$. Un mes más tarde, el 22 de junio de 1981, el pleno del Congreso aprobó la Ley de divorcio y el procedimiento a seguir en las causas de nulidad, separación y divorcio ${ }^{112}$. La clave trató el tema antes de aprobarse la ley, avanzándose a la legislación como ya venía haciendo en algunas temáticas (legalización del juego, aborto, homosexualidad...). La empresa Estudio General de Medios hizo público en septiembre los datos de audiencia de este periodo. Más de diecinueve millones de españoles

\footnotetext{
108 “Balbín reconoce, tres años después, que censuró a Alonso Puerta en La clave”, El País, 13/09/1986.

${ }^{109}$ Centro de Documentación RTVE: El divorcio (ficha 173). Emisión: 8 de mayo de 1981.

${ }^{110}$ Centro de Documentación RTVE: Divorcio (ficha 43). Emisión: 11 de marzo de 1978.

${ }^{111}$ Para $A B C$, «Tanto divorcio en tan poco días parece demasié», $A B C, 6 / 05 / 1981$, p. 101.

${ }^{112}$ Ley 30/1981, de 7 de julio. «BOE» $\mathrm{n}^{\circ} 172$, de 20 de julio de 1981, pp. 16457 a 16462.
} 
mayores de quince años veían a diario la televisión, y una noticia un poco alarmante: RTVE venía desconociendo su verdadera audiencia desde 1979. La segunda cadena tenía un promedio de poco más de tres millones de espectadores (representando una subida de $4 \%$ en un año), y la mayor audiencia se producía los viernes durante La clave, con 4.291.000 espectadores en el momento de la película ${ }^{113}$.

El 21 de mayo de 1981 Iñaki Gabilondo fue destituido como director de los Servicios Informativos de TVE a raíz de la emisión de unos reportajes sobre el paro en el Telediario. En una entrevista concedida a Pérez Ornia un mes antes había declarado: «Ya no puede repetirse la historia de que el director general sea quien mande en los informativos (...). Vivimos tiempos de particular expectación, a la que hay que sumar los acontecimientos políticos y sus consecuentes movimientos de tierra» ${ }^{114}$. Pero una vez más, se evidenció con su destitución la correlación de fuerzas en TVE. Una vez destituido Iñaki Gabilondo, declaró que «los Servicios Informativos ofrecieron el triste espectáculo de permitir el asalto al programa de la OTAN, quizá porque José Luis Balbín estaba fuera de Madrid» ${ }^{115}$. Asalto, anormalidades, injerencias... formaban parte del vocabulario de los periodistas para describir las conexiones entre el poder político y el medio televisivo ${ }^{116}$.

En esta ocasión no era La clave sino el programa En este país el que provocaba una reunión de urgencia del Consejo de Administración de RTVE (presidido por Carmen Llorca), por «las presuntas presiones e irregularidades introducidas por dos ministros, el de Defensa (Alberto Oliart) y el de Asuntos Exteriores (Carlos Robles Piquer)» ${ }^{117}$. En este país quería dedicar un programa al ingreso de España en la OTAN y acabó mostrando la sensibilidad in crescendo que adquiría el tema en televisión.

El 22 de mayo de 1981, tres meses después del golpe de Estado, La clave realizó Las armas de la democracia (ficha 175). «Nos planteamos en La clave el problema de cómo se defiende una democracia. ¿Cuál es la fuerza de una democracia? ¿Cuáles son sus armas?»118. El panel de invitados lo formaba Alfonso Guerra (PSOE), Jorge Verstrynge (AP), José Ramón

\footnotetext{
${ }^{113}$ Fuente: “19 millones de españoles ven diariamente los programas de televisión”, El País, 9/09/1981.

114 “Iñaki Gabilondo: El acceso a los telediarios se va a poner caro para ministros y políticos”, El País, 9/04/1981.

115 “Destituido el director de los Servicios Informativos de Televisión Española”, El País, 22/05/1981.

116 Véase Jesús García Jiménez (Comp.), Radiotelevisión Española y la Constitución, Universidad Internacional Menéndez Pelayo, Madrid, 1981.

117 “El director general de RTVE no piensa dimitir”, El País, 22/05/1981. En cinco meses, Carlos Robles Piquer sería nombrado director general de RTVE sustituyendo a Fernando Castedo.

${ }^{118}$ Centro de Documentación RTVE. Las armas de la democracia (ficha 175). Emisión: 22 de mayo de 1981.
} 
Caso (UCD) y Simón Sánchez Montero (PCE). También figuraban el periodista Juan Luis Cebrián, Gerhard Reddemann y José María de Areilza (exministro de Asuntos Exteriores en el primer gobierno de la Monarquía y presidente de la Asamblea del Consejo de Europa en Estrasburgo). Para ilustrar el debate se proyectó la película Muerte de un presidente (Śmierć Prezydenta, Jerzy Kawalerowicz, 1977), que fue la película más utilizada (se proyectó hasta en tres ocasiones) ${ }^{119}$.

A raíz del film, Carlos Ollero (catedrático de teoría de Estado) argumentó que la película había distorsionado el planteamiento del tema y, por tanto, condicionaba el debate. Alfonso Guerra resaltó que la democracia «tiene un germen de debilidad. Aquellos que no aceptan la democracia, no aceptan el resultado democrático. ¿Qué se puede hacer en un país donde los que han tenido en sus manos el poder autoritariamente, dejan de tenerlo? (...). Toda España ha podido oír a través de la SER a un Guardia Civil que le dice a un periodista: o cortas esto o te mato. ¡Y este señor está en la calle!». Para Verstrynge, la causa fundamental del 23-F era la falta de «un proceso de socialización democrática suficiente que familiarizara a los españoles con los mecanismos democráticos». Y argumentó que temas importantes se habían sacado del Parlamento para discutirlos en algún restaurante. Juan Luis Cebrián, por su parte, mostró su preocupación por la reciente destitución del director de los Servicios Informativos, Iñaki Gabilondo, por un Telediario «que ponía de relieve los problemas del paro en Andalucía y la situación de protesta e indignación popular». Durante el debate se habló sobre la ausencia de ruptura democrática en el proceso de Transición, el abandono de la clase política, la estabilidad de la democracia y especialmente, del 23-F.

«¿Qué hace el Congreso, que ha estado secuestrado a punta de metralleta durante toda una noche, y no organiza una comisión de encuesta para saber por qué ha sucedido esto?», se preguntó Alfonso Guerra durante el debate. Para José María de Areilza, la causa profunda del golpe estuvo en que una gran parte de la sociedad española, sectores minoritarios -pero fácticamente importantes- «no han asumido la democracia, el juego democrático, las libertades civiles, la voluntad popular, el sufragio universal y el pluralismo». Para José Ramón Caso, eran las Fuerzas Armadas las que habían salvado la democracia y añadió que «el éxito de la Transición española se ha basado en buscar siempre la legalidad, en juzgar las conductas de acuerdo la ley». Reddemann (único extranjero en el debate), argumentó a este respecto: «Todos

\footnotetext{
${ }^{119}$ Muerte de un presidente narraba los hechos acontecidos en Polonia al final de la Primera Guerra Mundial. En 1922, la Asamblea Nacional eligió presidente de la República a Gabriel Narutowicz, intelectual liberal que acaba de regresar del exilio en Suiza. Cinco días después de su elección, mientras visitaba una exposición de pintura, fue asesinado.
} 
vimos en la televisión lo que pasaba. Después de una Transición lograda se había llegado al golpe de Estado. Cuarenta años de dominio autoritario no pueden desaparecer sin dejar huella en un pueblo» ${ }^{120}$.

Las armas de las que disponía la democracia eran para Carlos Ollero tres: dialécticas (argumentos para defender y propugnar que la democracia era el mejor sistema de los posibles), institucionales (instrumentos que todo orden democrático tiene para salvar la democracia en momentos de peligro), y de clase política (que requiere conciencia que una democracia imperfecta puede convertirse en un peligro para esa misma democracia). Verstrynge añadió a esta lista, el imperio de la ley, el cumplimiento de la Constitución y una ley antiterrorista. Al finalizar el debate, se añadieron -de pasada- dos armas más a largo plazo: educación y hábitos democráticos, como también se vieron en algunas de las preguntas de los telespectadores: ¿Consideran ustedes la enseñanza y la instrucción buenas armas para la convivencia democrática? ¿Por qué entonces no se nos instruye a los españoles más y mejor, sobre todo utilizando un medio del alcance de la televisión? ${ }^{121}$

La semana siguiente, a raíz de la polémica suscitada por la serie de televisión Cervantes (dirigida por Alfonso Ungría y supervisada por Camilo José Cela), La clave realizó el programa Cervantes (ficha 176). La controversia había surgido porque algunos pasajes cuya historicidad era dudosa aparecían como ciertos en la serie. Como argumenta Manuel Palacio, «un combate más sobre las disputas por la hegemonía en el espacio público entre el posfranquismo y la democracia» (Palacio 2012: 332). Como apunta Palacio «todo empezó por una carta/telegrama que en abril de 1981 un erudito local cervantino, Ángel Ligero Móstoles, envió al ministro de Cultura, al director general de RTVE y al director de la Real Academia de Lengua haciendo constar su protesta por el tratamiento dado a la biografía de Miguel de Cervantes» (Palacio 2012: 333). «Algún comentario tachaba de intolerable la interpretación libertina y amoral del pasado glorioso y que se reflejase una España en la que predominan prostíbulos (...) o en las que aparece algún gay» (Palacio 2012: 333).

\footnotetext{
${ }^{120}$ Centro de Documentación RTVE. Las armas de la democracia (ficha 175). Emisión: 22 de mayo de 1981.

${ }^{121}$ Otras preguntas fueron: ¿Por qué no figura en la Constitución el derecho de resistencia que es considerado como un derecho fundamental por la declaración de derechos del hombre y se incluye en constituciones como la alemana y la portuguesa? ¿Cómo pueden decir que nuestro país es una democracia cuando al tener que tomar decisiones tan importantes como el divorcio, el aborto, el ingreso en la OTAN, no se someten éstas a referéndum? ¿Piensa que es democrático que en el Parlamento la mayoría de los diputados solo acuda cuando va a participar en una votación? ¿Les parece que los piquetes de huelga son democráticos?
} 
Las tres semanas de antelación con las que se preparaba cada programa permitían a $L a$ clave abordar los temas conociendo el desarrollo de los hechos. La clave abordó el tema tras seis capítulos de la serie Cervantes. Es interesante observar la trayectoria en la construcción de este debate. De la televisión (origen inicial de la polémica), se pasa a la prensa, para trasladarse de nuevo a la televisión. Entre los invitados Ángel Ligero Móstoles (quien había denunciado los errores biográficos en la serie), Alfonso Ungría (director de la serie) y Guillermo Díaz-Plaja (académico de la Real Academia de Lengua). Completaron el panel otros profesores y escritores.

El profesor de literatura del Instituto Cervantes, Alberto Sánchez, requerido en otras televisiones como la francesa o la británica BBC en programas sobre Cervantes, no había sido consultado para la elaboración del guion, y en su opinión (recogida en prensa), los ingleses no hubiesen hecho eso con Shakespeare, ni los alemanes con Goethe, ni los rusos con Tolstoi. Afirmaba que el telefilm infantil Don Quijote de la Mancha (producido por Cruz DelgadoRomagosa) era mucho más correcto a pesar del público al que se dirigía ${ }^{122}$. Tal vez por esta razón Carlos Pumares optó por ilustrar el debate con Don Quijote de la Mancha (Rafael Gil, 1947), y no con un capítulo o un montaje sobre la serie Cervantes $^{123}$.

Si en mayo Iñaki Gabilondo había sido cesado por los reportajes del paro, La clave estaba dispuesta a arriesgarse y dedicar un programa sobre El paro juvenil y sus consecuencias (ficha 177). De nuevo, un ejemplo de los riegos que estaba dispuesto a correr José Luis Balbín pero sobre todo mostrar la influencia, capacidad y poder que tenía La clave para abordar temas que se impedían en otros programas. Sin embargo, no fue este programa el blanco de las críticas sino justo el siguiente: El idioma de Cataluña (ficha 178), con Rodolfo Martín Villa entre los invitados. Pablo Corbalán (crítico televisivo), escribía en $A B C$ que La clave perdían interés y prestigio en la discusión pública gracias a la Constitución y al reconocimiento de la libertad de expresión programas como ${ }^{124}$. También fueron críticos el ministro de Cultura, Íñigo Cavero, y el subsecretario, Eugenio Nasarre (quien en un año ocuparía la dirección general de RTVE), suscribiendo las críticas del ministro. Según Nasarre «esas declaraciones hay que considerarlas como una actuación del libre ejercicio de expresión y crítica de cualquier ciudadano en relación

\footnotetext{
122 Véase "Debate sobre La clave", El País, 29/05/1981.

${ }^{123}$ Sobre la película, véase M. Mañas Martínez, “Don Quijote de la Mancha, de Rafael Gil. Una adaptación literaria del cine español en las conmemoraciones cervantinas de 1947”, Anales cervantinos, t. 38, 2006, pp. 67-93.

124 "La relatividad", $A B C, 7 / 06 / 1981$. Para El País, «un debate cuyos interlocutores no parece que hayan sido elegidos con criterios de mayor amplitud cultural», "La clave: debate en directo sobre el idioma en Cataluña", $E l$ País, 12/06/1981.
} 
con las actividades de un ente público» ${ }^{125}$. Pero una vez él en el cargo de director general, el libre ejercicio de expresión y crítica no serán tan de su agrado. Pero sin duda, se trataba de una maniobra -iniciada desde el Gobierno- para forzar la dimisión de Fernando Castedo ante las elecciones gallegas del 20 de octubre de 1981.

El fracaso de UCD en estas elecciones fue el detonante para el cese de Fernando Castedo (Bustamante 2006: 61) ${ }^{126}$. Alianza Popular se convirtió en la primera fuerza, y el porcentaje de abstención (57,3\%), fue el más bajo en unas elecciones autonómicas ${ }^{127}$. El 23 de octubre, el día en que Fernando Castedo presentó su dimisión, La clave debatió sobre las motivaciones que dieron lugar a la Guerra Civil bajo el título Cincuenta años después (ficha 197) ${ }^{128}$. Esa misma noche, el ya exdirector general reunió a José Luis Balbín, Jesús Picatoste (director de su gabinete técnico), Miguel Ángel Toledano (director de Televisión Española), y Eduardo Sotillos (director de Radio Nacional) para explicarles las razones de su dimisión ${ }^{129}$. La presión de los sectores más conservadores de UCD y de la derecha acabó con la claudicación de Fernando Castedo (que pronto pasó a la presidencia del Banco Hipotecario).

Es llamativo que el mismo 23 de octubre de 1981 se publica en el BOE la dimisión de Fernando Castedo, el cese de Carlos Robles Piquer como Secretario de Estado de Asuntos Exteriores y su nombramiento como director general de $\mathrm{TVE}^{130}$. La rapidez con la que se producen los nombramientos y ceses muestra el tiempo que llevaban algunos sectores detrás de la destitución de Castedo. Al día siguiente, un numeroso grupo de profesionales, entre los que se encontraba José Luis Balbín, se solidarizó con el director cesado haciendo público un comunicado en el que renunciaban a dimitir de sus cargos (aunque conociendo el funcionamiento de la televisión, probablemente ya sabían que serían destituidos).

\footnotetext{
125 "El subsecretario de Cultura suscribe las críticas de Cavero a RTVE”, El País, 17/07/1981.

${ }^{126}$ Como indicó Enrique Bustamante, Fernando Castedo fue cesado «por haber creído en la autonomía predicada en la nueva ley para RTVE, aunque también por el fracaso de UCD en las elecciones gallegas de octubre de 1981» (Bustamante 2006: 61).

${ }^{127}$ La baja participación muestra la importancia que se concedía al medio televisivo, hasta ese momento un eficaz instrumento de movilización del gobierno. La participación para el Parlamento catalán había sido de un $61 \%$ y para el Parlamento Vasco del 59\%.

${ }^{128}$ Se proyectó la película Caudillo (Basilio Martín Patino, 1976). El programa será analizado en nuestro último capítulo.

129 "La noche en que fue forzado el cese", El País, 24/10/1981.

${ }^{130}$ BOE, 24 de octubre de 1981, n 255 , p. 24954.
} 
«Denunciamos la coacción moral del poder ejecutivo sobre el primer director general del Estatuto de la democracia» ${ }^{131}$.

Una vez dimitido, Juan Ramón Pérez Ornia entrevistó a Fernando Castedo: ¿Cree usted que su dimisión significa que el Estatuto de RTVE no se puede cumplir? El exdirector respondió que «la dimisión pone en peligro, o mejor, no favorece la ejecución real del Estatuto, esa ley transformadora que ha querido llevar a cabo el último proceso de la transición política. La radio y la televisión eran, respectivamente, el último paso para efectuar la transición democrática. Lo demuestran el cúmulo de agresiones, ataques y juicios encontrados que la gestión ha provocado en los últimos meses» ${ }^{132}$.

Con la llegada de Carlos Robles Piquer se puso fin a la democratización en TVE que se había iniciado con Fernando Castedo. El nombramiento de Carlos Robles Piquer como director general de RTVE era toda una apuesta del Gobierno por recuperar el control de TVE. La importancia de la televisión residía en situar en el cargo a una persona de absoluta confianza. Amigo desde la adolescencia de Leopoldo Calvo Sotelo, en 1941 habían concurrido juntos al premio extraordinario del examen de Estado posterior al bachillerato. Su nombramiento conllevó una cadena de ceses, y varios directivos, se enteraron de la noticia de su cese viendo el Telediario $^{133}$. Como fue el caso de José Luis Balbín, quien era cesado como director de Programas Especiales (área que desaparecía con la restructuración y de la que dependían quince programas -todos de producción propia- que acabaron integrándose en otras áreas).

Tras una conversación con Carlos Robles Piquer (aconsejándole mejorar algunos aspectos del programa), José Luis Balbín acudió a la prensa para expresar su temor a una próxima supresión de La clave ${ }^{134}$. El 12 de noviembre, Carlos Robles Piquer se reunió con Ladislao Azcona y con José Luis Balbín para pedirles información sobre sus respectivos programas. En este país, iba a emitir una reconstrucción del día que murió Francisco Franco, bajo el título 20-N: el día más largo, y La clave, una emisión dedicada a la figura de José Antonio Primo de Rivera ${ }^{135}$.

\footnotetext{
131 “Un numeroso grupo de profesionales de RTVE se solidariza con el director cesante”, El País, 24/10/1981.

132 “Fernando Castedo: mi dimisión supone la quiebra de la transición democrática en RTVE”, El País, 25/10/1981.

133 “Directivos de Televisión Española conocen su cese por un telediario”, El País, 27/10/1981.

134 “La supresión de los programas especiales supone eliminar el 10\% de la programación de Televisión”, El País, 3/12/1981.

${ }^{135}$ Esa misma noche diversos profesionales (entre los que se encontraba José Luis Balbín) celebraron un acto para defender la libertad de expresión y rendir homenaje a Fernando Castedo (por su destitución) y a Xavier Vinader
} 
Desoyendo las propuestas presentadas por el director general, el 20 de noviembre de 1981 se emitió José Antonio (ficha 201), con algún incidente como veremos en nuestro último capítulo. Ante una posible y eminente suspensión de La clave, José Luis Balbín y el equipo del programa realizaron toda una serie de programas en cadena calificados de sensibles: el primero, Rearme (ficha 202), en torno a la proliferación militar a la que habían llegado los dos bloques, con la proyección de la película Teléfono rojo, volamos hacia Moscú (Dr. Strangelove or How I Learned to Stop Worrying and Love the Bomb, Stanley Kubrick, 1964). El segundo, Libertad de información (ficha 203), y la película Sucedió una noche (It Happened One Night, Frank Capra, 1934), coincidiendo con la condena de siete años de cárcel al periodista Xavier Vinader.

Y por último, el más polémico, Militares y periodistas (ficha 205). El programa, de nuevo en diferido, mostraba las dificultades de abordar el tema de los militares en España ${ }^{136}$. A ello se añadía que el día antes, a primera hora de la madrugada, unos desconocidos dispararon contra las instalaciones de Prado del Rey y se dieron a la fuga ${ }^{137}$. Se debatió en torno a la relación entre los profesionales del Ejército y del periodismo. El tema militar, sensible durante todo el proceso, e intensificado por el intento de golpe de Estado de ese año, evidenció una nueva injerencia exterior. La disputa entre José Luis Balbín y Manuel Calvo Hernando (director de TVE), a raíz de la elección de los invitados. Entre ellos, tres militares -que acudieron con el uniforme militar- y tres profesionales del periodismo: Guillermo Luca de Tena (director de $A B C$ ), José Oneto (director de Cambio 16), y Miguel Ángel Aguilar (corresponsal político de El País). Se proyectó la película Siete días de mayo (Seven Days in May, John Frankenheimer, 1964), de carácter antigolpista. Con un lenguaje más moderado, José Luis Balbín introdujo el programa subrayando que el objetivo de esas doscientas claves era «contribuir, a través de ideas encontradas, discutidas civilizadamente, a la concordia nacional» ${ }^{138}$. Pero de nuevo un logro, al poder debatir en televisión un tema como el de los militares. En 1985 abordaría de nuevo el tema militar con Militares hacia la democracia (ficha 401).

(para el que el fiscal pedía veintisiete años de cárcel). Fuente: "El acto de defensa del Estatuto de RTVE fue un alegato a favor de la libertad", El País, 13/11/1981.

136 También se quiso debatir sobre la sentencia del golpe de Estado, pero nunca abordó este tema. Fuente: José Luis Balbín durante el debate Elecciones. De las parciales a las generales (ficha 229), emitido el 4 de junio de 1982.

${ }^{137}$ Fuente: “Atentado fallido contra los guardias civiles que custodian RTVE”, El País, 17/12/1981.

${ }^{138}$ Centro de Documentación RTVE. Militares y periodistas (ficha 205). Emisión: 18 de diciembre de 1981. 



\section{Capítulo 6. La clave durante la etapa socialista (1982-1985)}

«La política produce extraños compañeros de cama» El mejor hombre (The Best Man, Franklin J. Schaffner, 1964).

\subsection{La entrada en la OTAN y las elecciones generales de 1982}

El 30 de mayo de 1982 España se convirtió en miembro de pleno derecho en la Organización del Tratado del Atlántico Norte (OTAN). Los debates parlamentarios se iniciaron en octubre de 1981. UCD, Alianza Popular y los nacionalistas vascos y catalanes apoyaron el ingreso en la OTAN, mientras que la izquierda, tanto el Partido Comunista de España (PCE) como el Partido Socialista Obrero Español (PSOE) lideraron la oposición a la entrada en dicha organización. Tras las elecciones de octubre de 1982, con Felipe González en la presidencia del Gobierno, el PSOE dio un giro proatlantista y acabó aceptando la adhesión de España a la OTAN $^{1}$.

La clave realizó en 1982 gran variedad de programas (El defensor del pueblo, La autonomía universitaria, El dinero de la política...), antes de celebrar la Copa Mundial de Fútbol que tuvo lugar en España durante los meses de junio y julio. En un periodo de tres semanas dejó de emitirse La clave, ejemplo del declive de la misión educativa/formativa y la apuesta por el entretenimiento como modelo televisivo. El 22 de julio de 1982 Carlos Robles Piquer dimite como director general a raíz de la emisión en junio de un informe titulado "Golpe a la turca"2.

Eugenio Nasarre Goicoechea fue nombrado nuevo director general de RTVE. Tenía 36 años y pertenecía al grupo democristiano. Para Justino Sinova, Nasarre tuvo que hacer frente a cuatro problemas, y uno de ellos fue «la acción subversiva y dislocante de José Luis Balbín» (Sinova 1983: 98) ${ }^{3}$. Se refería al ciclo de emisiones que La clave dedicó a las elecciones, y especialmente al programa Guerras médicas, que si bien fue prohibido en septiembre (ficha 239-C), acabó siendo emitido en diciembre (ficha 252), una vez destituido Eugenio Nasarre. Cuando La clave preparaba el coloquio sobre la organización sanitaria y la medicina privada

\footnotetext{
${ }^{1}$ En octubre de 1984 hizo explícita su posición cuando presentó en el Debate de la Nación el llamado "Decálogo sobre política de paz y seguridad", cuyo primer punto fue la continuidad de España en la OTAN.

${ }^{2}$ Informe realizado por Jesús González que emitió el programa Secuencias del mundo el 18 de junio de 1982.

${ }^{3}$ Los otros tres problemas: el hostigamiento de los hombres de Adolfo Suárez para que saliese más en televisión, la información y el tratamiento en el viaje a España del papa Juan Pablo II, y la agresión de las fuerzas de la derecha instaladas en televisión (Sinova 1983: 98).
} 
como alternativa a la estatal, Carmen Llorca (vocal del Consejo de Administración de RTVE y representante de Alianza Popular) «planteó al director general que la presencia del diputado socialista Ciriaco de Vicente entre los invitados al coloquio podría ser inconveniente en vísperas de la campaña electoral» (Sinova 1983: 102).

El Consejo de Administración recomendó que la composición de invitados fuera equilibrada: que todos fueran profesionales de la sanidad o que todos fueran representantes de grupos parlamentarios. Ciriaco de Vicente era el único invitado no profesional de la medicina. Como argumenta Sinova, José Luis Balbín, «lejos de someterse al criterio de los más altos organismos de RTVE, anunció públicamente que él no aceptaba imposiciones» (Sinova 1983: 102). El programa quedó finalmente suspendido y la prensa criticó que se suspendiese todo un programa por un invitado ${ }^{4}$. Los cuatro consejeros socialistas en el Consejo de Administración de RTVE redactaron un comunicado afirmando que «es una decisión personal y arbitraria del director general, Eugenio Nasarre (...). Es de lamentar que se adopte una decisión tan grave sin consulta si quiera telefónica a los distintos portavoces o grupos en el Consejo de Administración» ${ }^{5}$.

Aunque el ciclo sobre las elecciones merece su atención ya que con él se observa la construcción del debate político ${ }^{6}$. La clave ya había tratado en 1978 el significado de las elecciones celebradas el 15 de junio de 1977, con Elecciones (ficha 42), proyectándose la película El último hurra (The Last Hurrah, John Ford, 1958). También en junio de 1982 realizó Elecciones. De las parciales a las generales (ficha 229), y la película El mejor hombre (The Best Man, Franklin J. Schaffner, 1964), estreno en televisión. En septiembre-octubre de 1982, La clave articuló el debate sobre las elecciones. Lo hizo en dos partes ${ }^{7}$. La primera, en septiembre de 1982, con Elecciones I. Los que no están (ficha 241) y la película Octubre (Oktyabr, Sergéi M. Eisenstein, 1927), estreno en televisión. La segunda, en octubre de 1982, con Elecciones II. ¿Para quién los votos?, (ficha 242) y la película El político (All the King's Men, Robert Rossen, 1949).

\footnotetext{
${ }^{4}$ Véase "El veto a Ciriaco de Vicente impide emitir hoy La clave", El País, 10/09/1982.

5 “La suspensión de La clave es una decisión arbitraria", Mediterráneo, 11/09/1982, p. 22.

${ }^{6}$ También inició en 1982 un ciclo sobre la ley electoral. En enero Ley electoral (ficha 211) y la película El candidato (The Candidate, Michael Ritchie, 1972), y en 1984 Ley Electoral. II. (ficha 342) y la película Un león en las calles (A lion in the streets, Raoul Walsh, 1953).

${ }^{7}$ El equipo del programa quiso realizar tres programas en vísperas de campaña electoral aunque finalmente fueron dos al quedar excluido uno dedicado a los partidos nacionalistas.
} 
Con este ciclo, La clave quería debatir sobre el grado de democratización, los mecanismos de representación y, concretamente, sobre el sistema electoral español. Elecciones. Los que no están, (ficha 241), se emitió el 24 de septiembre de 1982. Estuvo dedicado a aquellos partidos que, habiendo participado en las elecciones generales de 1977 y de 1979, no habían conseguido ningún escaño. La segunda parte, Elecciones ¿Para quién los votos?, (ficha 242), se emitió el 1 de octubre de 1982 (récord de audiencia La clave hasta ese momento y una de las mayores audiencias hasta el final del programa). Sin embargo, esta emisión provocó más de un conflicto con los responsables de RTVE. El director general de RTVE, Eugenio Nasarre, estaba preparando en vísperas de la campaña electoral una serie de entrevistas a los principales líderes políticos en la primera cadena, y ese 1 de octubre, coincidía con la última entrevista a Landelino Lavilla (presidente de UCD). El director general de RTVE creyó solucionar el problema aplazando La clave al lunes. Pero José Luis Balbín informó a José María Calviño, y este presentó en el Consejo de Administración «una moción oponiéndose a ese cambio de La clave y el director general perdió la votación porque los dos consejeros de CDS apoyaron a los socialistas» (Sinova 1983: 103).

El conflicto entre José Luis Balbín y Eugenio Nasarre hizo que La clave se programara a las doce de la medianoche, pues tuvo que esperar a que Landelino Lavilla terminara su entrevista -previamente grabada- para intervenir a continuación en La clave ${ }^{8}$. Esperar a que terminara la entrevista grabada al líder de UCD en la primea cadena para empezar La clave, muestra la importancia adquirida por el programa. Pues, de emitir al mismo tiempo la entrevista de Eugenio Nasarre y el programa La clave, hubiese mostrado el fracaso de audiencia de dicha entrevista, algo de lo que era consciente Eugenio Nasarre ante el apabullante poder de convocatoria (y expectación) que generaba el programa de José Luis Balbín.

Dar inicio al debate a medianoche solo hizo crecer la expectación creada alrededor de La clave. José Luis Balbín utilizó la introducción para explicar cómo se había preparado el programa y justificar la selección de invitados: Manuel Fraga Iribarne (AP), Alfonso Guerra (PSOE), Santiago Carrillo (PCE), Miquel Roca i Junyent (CIU), Xabier Arzalluz. (PNV), Luis Uruñuela (PSA) y Agustín Rodríguez Sahagún (CDS), aunque como diría su director en la introducción, había sido Adolfo Suárez quien se había comprometido a asistir ${ }^{9}$.

\footnotetext{
${ }^{8}$ Además, Landelino Lavilla se incorporó en el transcurso de la película al encontrarse en un acto en Getafe.

${ }^{9}$ Véase en el anexo 5 una fotografía de Manuel Fraga mientras se prepara para intervenir en La clave.
} 


\section{¿Para quién los votos?}

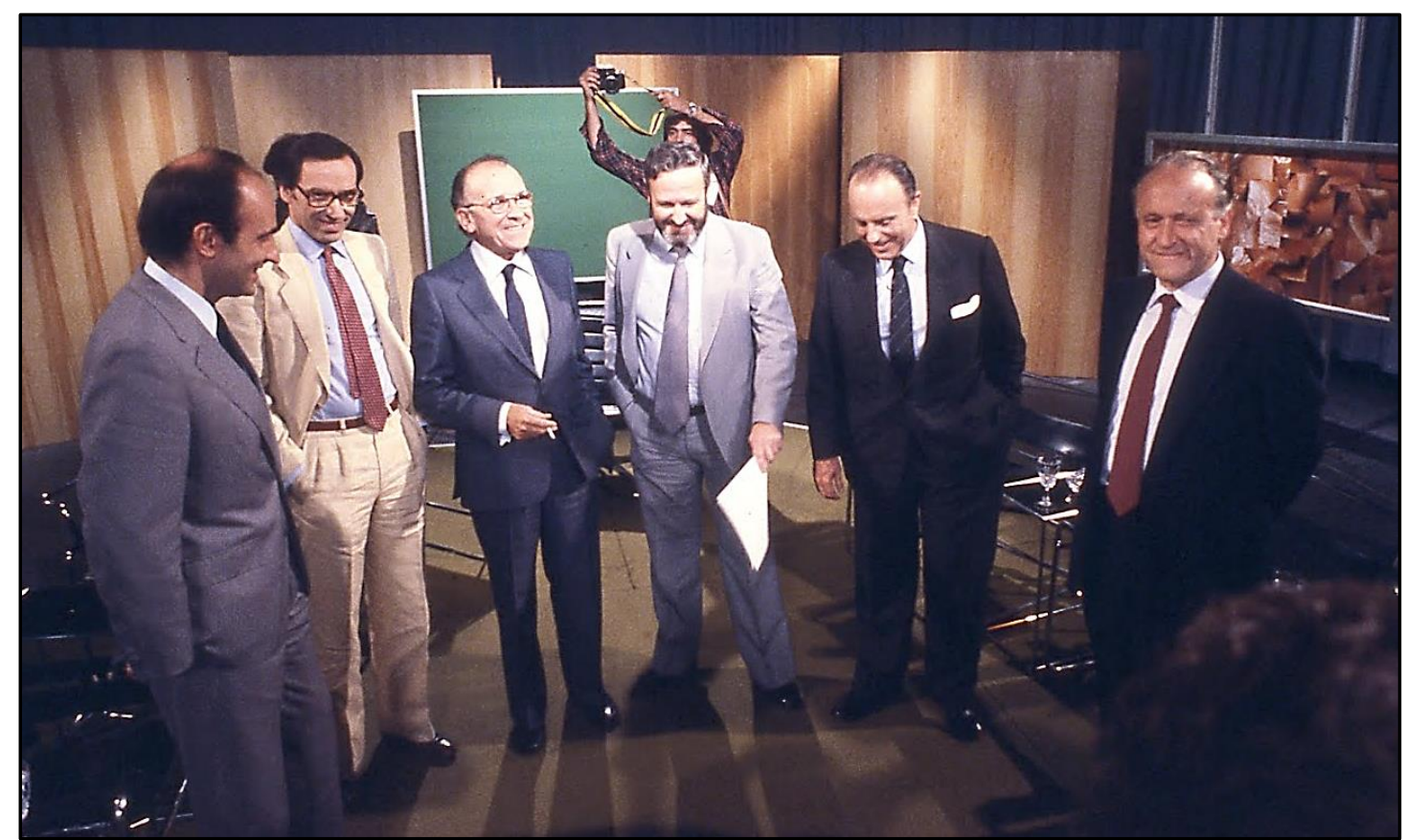

Fotografía $\mathrm{n}^{\circ} 10$. José Luis Balbín y representantes de los principales partidos políticos momentos antes de iniciar el programa Elecciones II. ¿Para quién los votos?, el 10 de octubre de 1982.

Como ya hemos señalado, se proyectó la película El político (All the King's Men, Robert Rossen, 1949), basada en la novela de Robert Penn, All the King's Men (1949), que narra la trayectoria política de un hombre honrado que acaba tan corrupto como aquellos a los que en sus inicios criticó. La película permitió abrir el debate ya que planteaba para Manuel Fraga «las relaciones entre ética y política, entre poder y corrupción». La principal diferencia entre EEUU y España radicaba para Luis Uruñuela en que en España «ni siquiera se puede hacer una película de la propia corrupción que existe». Del mismo modo que para Miquel Roca, para quien «lo más importante de la película es que existe» ${ }^{10}$.

¿La política corrompe? ¿En qué medida los sondeos pueden influir a favor o en contra? Las líneas por las que transcurrió el inicio del debate fueron el modelo de sociedad, los dos millones de parados en España, y la igualdad del hombre y la mujer (de nuevo entre invitados varones). José Luis Balbín, en un momento del debate intervino para decir: «Lo que están diciendo lo van a decir todos. Lo que conviene que sepa el elector es la diferencia entre ustedes».

Manuel Fraga argumentó que «la democracia no es solamente una colección de formalidades externas. Cuando la democracia no lleva dentro la virtud de los ciudadanos,

\footnotetext{
${ }^{10}$ Centro de Documentación RTVE. Elecciones II. ¿Para quién los votos? (ficha 242). Emisión: 1 de octubre de 1982.
} 
cuando no se educa para ella, cuando existe manipulación, cuando no se debaten los temas sino que simplemente se someten a votación, entonces deja de existir la democracia». Xabier Arzalluz aprovechó su intervención para interpelar al telespectador: «nuestros telespectadores, que se entiende que son el pueblo soberano, tal vez no tan soberano, porque si el pueblo, con su voto pudiese hacer todo lo que se quisiera, andaríamos en una democracia más avanzada y no estamos en esa situación. Lo que yo también, como político, malgré moi, quisiera decirle al pueblo es si también él cambia, o si todavía persisten unas posturas en las que está acostumbrado a que le cambien, si cae en la cuenta de la responsabilidad que supone un régimen democrático, y si todavía existe la recomendación del hijo y el enchufe del otro y el chollo de más allá». Tras una intervención de Manuel Fraga, Santiago Carrillo dijo: «Estamos de acuerdo que hay que resolver esos problemas como dice el señor Fraga. Por primera vez estamos de acuerdo. No estamos de acuerdo en cómo». Para Alfonso Guerra era necesario decirle la verdad al pueblo español «aunque duela», y Rodríguez Sahagún trataría de cambiar el enfoque teórico que estaba adquiriendo el debate para «bajar de la Universidad a la calle» y poder «hablar del paro» ${ }^{11}$.

Durante la semana habían recibido preguntas por correo y durante la emisión anunciaron que ya eran más de 475 preguntas de los telespectadores, lo que suponía un récord en el programa. Al finalizar el debate, a modo de curiosidad, se ofreció el minutado de cada uno de los invitados: Alfonso Guerra (14 minutos), Santiago Carrillo (12 minutos), Landelino Lavilla (10 minutos), y Manuel Fraga (8 minutos). Los de menos tiempo Luis Uruñuela, Miquel Roca y Xabier Arzalluz ( 7 minutos cada uno). Este minutado fue una excepción porque el modelo de debate televisivo que pretendía La clave era el de construir el debate in situ dando libertad de oratoria a sus invitados, que podían interpelarse unos a otros. La clave finalizó el programa entrada las dos de la madrugada. A todos los participantes se les invitó a asistir al programa que tendría lugar el día después de las elecciones del 28 de octubre bajo título ¿Qué gobierno? (ficha 246), y la película Las fuerzas vivas (Luis Alcoriza, 1976). De todos ellos, solo acudió Alfonso Guerra.

Al día siguiente, en el editorial de Diario 16 se podía leer: «una de las más escandalosas demostraciones del desprecio al ciudadano que puedan recordarse», siendo lo más inaceptable que «esa visión tenga que hacerse, además, a través de un programa concreto y tan discutible como el que protagoniza el señor Balbín» ${ }^{12}$.

\footnotetext{
${ }^{11}$ Ibídem.

${ }^{12}$ Diario 16 (Editorial), 3/10/1982.
} 
Es precisamente en el camino hacia las elecciones generales del 28 de octubre de 1982, donde La clave comienza a construir el debate político en televisión. Tras Elecciones ¿para quién los votos? nos centramos en el primer debate electoral que se va a llevar a cabo en televisión el 26 de octubre, dos días antes de las elecciones generales de octubre de 1982. A comienzos de la campaña electoral, Felipe González recibe la propuesta del presidente de Alianza Popular, Manuel Fraga, para llevar a cabo un «debate a dos». Después llegarían propuestas de otros líderes políticos como Jordi Pujol, Landelino Lavilla o Leopoldo Calvo Sotelo. Pero, Felipe González solo se mostraba partidario de debatir con el que era el actual presidente del Gobierno, Leopoldo Calvo Sotelo. La situación creada hizo que la Junta Electoral adoptara la resolución de recomendar un debate múltiple en televisión con los cinco líderes de los partidos nacionales (PSOE, AP, UCD, CDS, PCE).

Cinco representantes de estos partidos se reunieron el 24 de octubre con el director general, Eugenio Nasarre, para establecer las líneas generales sobre las que se guiaría el debate. La sesión se inició a las diez de la mañana. El portavoz del PSOE (Roberto Dorado) no garantizó la presencia de Felipe González al debate, llevando a otros partidos a decir que sus líderes tampoco acudirían. La sesión se reanudó a las cinco de la tarde. El portavoz socialista confirmó la disposición de su secretario general de acudir al debate con tres condiciones: ausencia de temas previos a tratar, sin tiempos de intervención, y que el moderador fuese José Luis Balbín ${ }^{13}$. Sin embargo, ya habiendo realizado La clave un debate previo (Elecciones ¿Para quién los votos?), algunos líderes se mostraron reticentes a la idea de que fuese José Luis Balbín el moderador. Se propusieron otros nombres: Miguel Ángel Gonzalo (director de TVE), Juan Roldán (director de los Servicios Informativos), e incluso algunos periodistas como Ladislao Azcona o Pedro Macía ${ }^{14}$. Finalmente, tras no llegar a un acuerdo en las reglas del debate ni en el moderador, se canceló el debate electoral. El día antes de las elecciones, la prensa anunció que no habría debate electoral al no llegar a un acuerdo los representantes de los cinco partidos mayoritarios $^{15}$.

La clave, en definitiva, ya había hecho y televisado el debate electoral, y evidenció su influencia en el debate político. El debate electoral había estado a punto de estructurarse como

\footnotetext{
${ }^{13}$ El portavoz socialista diría que «la máxima experiencia en estos debates como moderador la tiene José Luis Balbín», "No habrá debate televisivo entre dirigentes políticos", Hoja del lunes, 25/10/1982, p. 4.

14 También dos redactores de El País o Justino Sinova, director adjunto de Diario 16 (Sinova 1983: 103).

15 "Roto el debate en televisión”, Hoja del lunes, 25/10/1982, y "El PSOE impidió el debate electoral en televisión" $A B C, 25 / 10 / 1982$, pp. 1 y 17.
} 
una clave más, con los líderes de los cinco partidos políticos de ámbito nacional y José Luis Balbín como moderador. Llamativas son las dificultades encontradas para realizar un debate electoral durante la Transición española. Los telespectadores tendrán que esperar más de diez años, hasta 1993, para ver en televisión el primer debate electoral ${ }^{16}$.

Las elecciones del 28 de octubre dieron el triunfo al PSOE como fuerza política más votada, y Felipe González fue elegido nuevo Presidente del Gobierno el 1 de diciembre. En RTVE, Eugenio Nasarre es sustituido por José María Calviño. El 10 de diciembre toman posesión los cargos en el nuevo equipo rector de RTVE: Antonio López García (director de TVE), Ramón Gómez Redondo (director de programas) y José Luis Balbín (director de los Servicios Informativos).

El mismo día de su nombramiento, La clave realizó el programa Guerras médicas (ficha 252), suspendido en septiembre por veto al diputado socialista Ciriaco de Vicente. José Luis Balbín inició el debate con las siguientes palabras:

«El director general hoy saliente nos dijo que el programa no era objetivo porque uno de nuestros invitados era en aquel momento un destacado dirigente del PSOE, que se había distinguido precisamente en su defensa de la salud pública y que podía parecer que era darle ventaja al PSOE. Criterios que no compartimos. Primero, porque nosotros no habíamos convocado elecciones, y cuando habíamos programado el programa eso no estaba previsto. Y en segundo lugar, y sobre todo, porque no entrábamos en el reparto y minutado porque lo que queremos es que haya diversidad de opiniones e incluso diferentes puntos de vista de los diferentes estamentos sociales» ${ }^{17}$.

El último programa del año fue The Beatles (ficha 253), grupo de música que inspiró la contracultura juvenil de la década de los sesenta con canciones que fueron un reflejo de una juventud que se oponía a la sociedad de consumo y que cuestionaba algunas actitudes establecidas sobre el sexo, las drogas o la política. Se proyectó el documental All you need is love (Tony Palmer, 1977).

\footnotetext{
${ }^{16}$ El 23 de mayo de 1993 tuvo lugar en televisión el primer debate electoral entre Felipe González y José María Aznar. Se emitió en Antena 3 y tuvo un 62\% de audiencia. Una semana más tarde, el 31 de mayo, se emitió el segundo cara a cara en Tele 5, bajo el título "El debate decisivo", con un 75,4\% de audiencia. La cadena pública ofreció debates electorales entre varios representantes pero con niveles de audiencia más bajos. En 1996, la fórmula del cara a cara se puso en cuestión y partidos políticos y profesionales de los medios exigieron debates de tres, cinco y/o seis fuerzas políticas. Fuente: "El debate a debate", Tele Radio, n” 78, febrero de 1996, pp. 24-27.

${ }^{17}$ Centro de Documentación RTVE. Guerras médicas (ficha 252). Emisión: 10 de diciembre de 1982.
} 


\subsection{José Luis Balbín y los Servicios Informativos (1982-1983)}

Esta etapa se inició el 10 de diciembre 1982 y finalizó el 22 septiembre de 1983. Transcurrió, por tanto, mientras José Luis Balbín ocupó el cargo de director de los Servicios Informativos. Como vimos anteriormente, algunos autores calificaron este periodo de "balbinato", en referencia al poder que adquirió su director, que dirigía los Servicios Informativos y continuaba dirigiendo La clave. Las elecciones de octubre de 1982 llevaron a nuevo Gobierno (PSOE), y a nuevo director general de RTVE (José María Calviño), abogado gallego de treinta y nueve años. En una conversación con periodistas a la que posteriormente aludiremos, se definió a sí mismo de esta forma: «antes que nada demócrata. Después, incuestionablemente, de izquierdas. Anti-nada. Bueno, antifascista, eso sí». ¿Republicano? «Eso está superado. Yo creo que el primer republicano es el Rey. En esta país la Monarquía no está en cuestión» ${ }^{18}$.

José Luis Balbín inició el año 1983 con uno de los cargos más importantes en RTVE. La clave lo hizo con Poderes fácticos (ficha 254), título que parecía la antesala de lo que iba a ocurrir en el segundo programa Balance de los municipios de izquierda (ficha 254-C). Estaba previsto para el 14 de enero de 1983 pero fue suspendido y sustituido por Napoleón en España (ficha 255), grabado previamente. Al día siguiente, los periódicos relataron una intromisión más del poder político en televisión. Pero lo que iba a ser una nueva injerencia del poder político (en esta ocasión, y por primera vez, a manos del PSOE), acabó convirtiéndose en una escenificación del control político de TVE tras el cambio producido en España con las elecciones de 1982. Al mes de tomar posesión en el cargo, desde el Consejo de Administración se pidió la dimisión de José Luis Balbín como director de los Servicios Informativos.

De todos los programas de La clave (emitidos o prohibidos), Balance de los municipios de izquierda es, sin lugar a dudas, el de mayor repercusión en prensa, solo comparable con la supresión final del programa. El que se llamó posteriormente el "affaire Alonso Puerta" evidenció la reacción de la derecha al perder el control televisivo en manos del PSOE. El periodista Justino Sinova se sirvió de lo ocurrido en La clave para escribir parte del libro La gran mentira ${ }^{19}$. Una obra que, con el propósito de explicar la manipulación socialista en televisión, no deja de ser una crítica constante al gobierno socialista, al director general de RTVE, y al director de los Servicios Informativos. Sinova publicó el libro en julio de 1983, tras

\footnotetext{
18 “El director general de RTVE considera que él no es ningún «error a corregir»”, El País, 25/01/1983.

${ }^{19}$ J. Sinova, La gran mentira. El tinglado de la televisión al descubierto, Planeta, Barcelona, 1983.
} 
una disputa entre José Luis Balbín y Diario 16 (del que Sinova era director adjunto), a raíz de un artículo publicado unos meses antes, y al que José Luis Balbín denuncia por calumnias a su persona $^{20}$. La gran mentira, toma como punto de partida la promulgación del Estatuto de RTVE el 10 de enero de 1980 ( $\sin$ hacer la mínima alusión a la televisión realizada hasta entonces), y se inicia precisamente con el asunto Alonso Puerta, al que califica como «uno de los mayores escándalos de la historia de la Televisión Española (...). Una intromisión inaceptable del poder político en un medio público de información» (Sinova 1983: 18).

En 1986, una vez suspendida definitivamente La clave, José Luis Balbín reconocería ante los medios que Alonso Puerta había sido censurado. «Yo afirmo que el socialismo, en mis tiempos en TVE, imponía listas negras. Alonso Puerta es un ejemplo claro y todo por haber denunciado un caso de corrupción en el Ayuntamiento de Madrid» ${ }^{21}$. Sin embargo, ¿qué ocurrió exactamente? ¿A quién atribuirle esta suspensión?

Tanto Justino Sinova como Diario 16 hicieron un seguimiento exhaustivo de esta prohibición durante meses. Diez días después de la suspensión, el 24 de enero, Sinova escribió un artículo titulado "El escándalo de TVE”, en el que calificaba lo ocurrido en La clave de «la mayor tomadura de pelo de que ha sido objeto la opinión pública en los últimos años» ${ }^{22}$. Para Sinova, más de veinte personas implicadas, que nosotros reducimos a cuatro: Alonso Puerta, José Luis Balbín, José María Calviño y Enrique Tierno Galván.

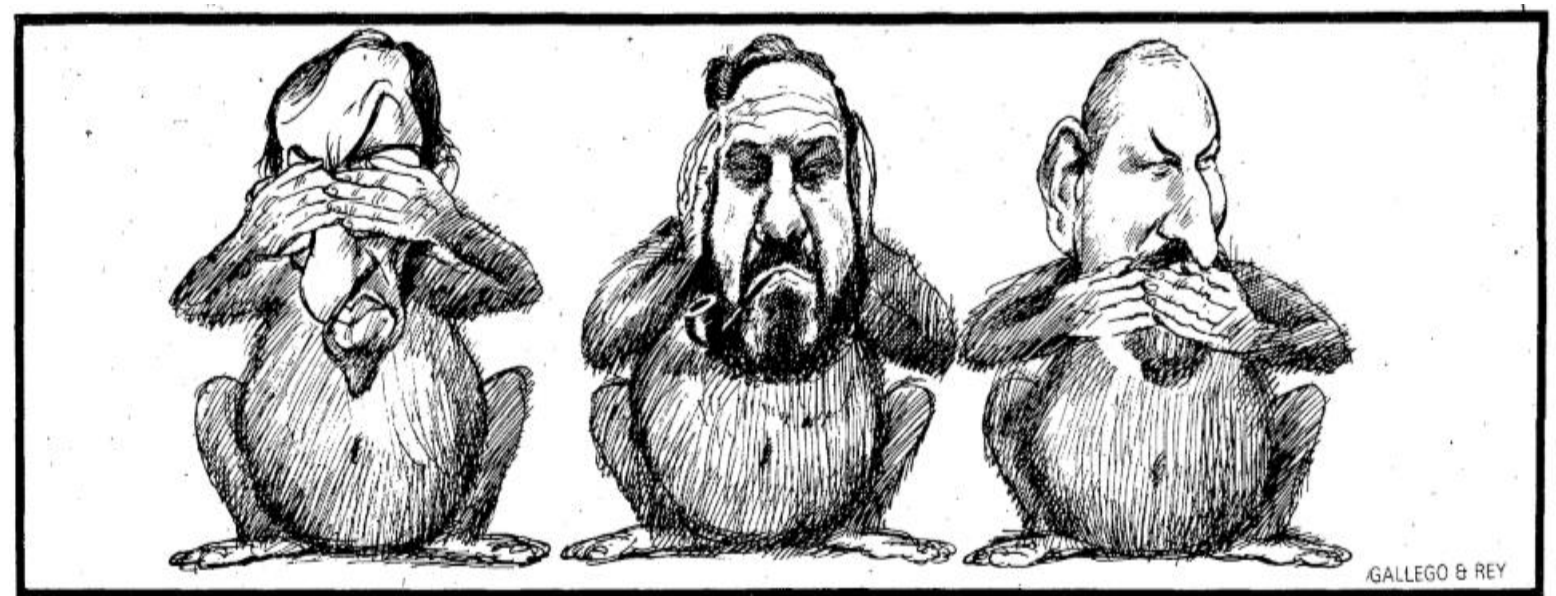

Fotografía n ${ }^{\circ} 11$. Caricatura extraída de la portada de Diario $16,20 / 01 / 1983^{23}$.

\footnotetext{
${ }^{20}$ Se trataba del artículo "Los chanchullos de la tele: tres Balbines en La clave", Cambio 16, 24/03/1985. Véase también "Tres balbines en La clave: él, su hermana y su cuñada", Diario 16, 25/03/1983, p. 47.

21 "Balbín reconoce, tres años después, que se censuró a Alonso Puerta en La clave", El País, 13/09/1986. En la entrevista de 2012 en Periodista Digital también reconoció que se trató de una censura encubierta.

22 Justino Sinova, “El escándalo de TVE”, Diario 16, 24/01/1983.

${ }^{23}$ Caricatura que hace referencia a Alfonso Guerra, José Luis Balbín y José María Calviño como «Los tres monos sabios», símbolo de La clave, pero en esta ocasión: «no ver, no escuchar, no decir».
} 


\subsubsection{El caso Alonso Puerta}

José Alonso Puerta fue un concejal socialista expulsado del partido en octubre de 1981 por destapar un caso de corrupción en el Ayuntamiento de Madrid. Había denunciado la existencia de comisiones ilegales relacionadas con contratas municipales de la limpieza de la capital que implicaban a los delegados de Hacienda y de Saneamiento, Baltasar Aymerich y Jesús Espelosín respectivamente. Tras su expulsión presentó una querella criminal contra los políticos responsables de contratar estas empresas de limpieza y contra aquellas personas que pudiesen estar implicadas en el caso ${ }^{24}$. Todo basculó el 4 de enero de 1983 cuando Juan Testa invitó a Alonso Puerta a La clave.

El PSOE llevaba escaso tiempo en el Gobierno y la aparición de Alonso Puerta en televisión suponía tener que hacer frente al grave problema de la corrupción. Joaquín Leguina (diputado por Madrid), inició una serie de gestiones para detener la aparición en televisión del exdirigente socialista ${ }^{25}$. José Luis Balbín era amigo de Alonso Puerta, al que conocía de su época estudiantil. Como relataría posteriormente, «la semana antes, las llamadas que tuve de la Moncloa y de Calviño fueron interminables. Querían que lo desinvitase $»^{26}$. Comenzaron unas presiones que no se detuvieron hasta el último momento. La víspera de la emisión, José Luis Balbín no acudió con el resto de los invitados a la tradicional cena antes del programa ${ }^{27}$. Como relataría meses después Justino Sinova: «A Puerta le extrañó que a aquella cena en el restaurante Nicolasa, de la calle Velázquez, no asistiera Balbín. (...) En otro restaurante situado en la otra punta de Madrid, Los Porches, compartían mesa y mantel Enrique Tierno Galván, José María Calviño, Ana Tutor y José Luis Balbín. Objetivo: sustituir a Puerta» (Sinova 1983: 19-20).

De la cena salió la idea de suspender el programa. Los invitados, ya en Madrid, fueron informados de la suspensión a través de una nota dejada en el hotel. Al día siguiente, 14 de enero, Televisión Española comunicó el cambio de La clave por enfermedad de su director. Para Diario 16 «con tan mala fortuna de ir a elegir el de Napoleón, en España justo el día en que de nuevo los camiones de productos agrícolas españoles han sido atacados en Francia» ${ }^{28}$.

\footnotetext{
${ }^{24}$ Fuente: “Admitida la querella presentada por Alonso Puerta por supuesto cohecho en el Ayuntamiento de Madrid", El País, 19/12/1981.

${ }^{25}$ Fuente: Diario 16, 15/01/1983. Joaquín Leguina había sido desde diciembre de 1979 secretario general de la Federación Socialista Madrileña y, en julio de 1983, fue nombrado presidente de la Comunidad de Madrid.

${ }^{26}$ José Luis Balbín, La Nueva España, 24/03/2010. Véase también la entrevista online en Periodista Digital, $13 / 03 / 2012$

27 “La enfermedad de Balbín, una dolencia «diplomática», $A B C, 16 / 01 / 1983$, p. 73.

28 "El Gobierno impidió la emisión de La clave”, Diario 16, 15/01/1983, p. 9.
} 
Ese mismo viernes, José Luis Balbín se marchó a Alemania. Solía hacer este tipo de escapadas al extranjero, aunque era la primera vez que lo hacía ocupando el cargo de director de los Servicios Informativos y habiéndose suspendido un programa. Aprovechó la ocasión para visitar al profesor Dieter Nohlen, politólogo de la Universidad de Heilderberg, con el objetivo de traerle al programa Incompatibilidades 83 (ficha 256) ${ }^{29}$. Estuvo ilocalizable todo el viaje, del viernes 14 al martes 18 de enero, lo que para Diario 16 «atenuó las consecuencias políticas de dicha suspensión y obligó a una auténtica labor detectivesca para conocer nuevos datos que aportaran alguna luz sobre la enfermedad de José Luis Balbín» ${ }^{30}$. El día siguiente de la suspensión La clave saltó a las portadas de Diario 16 y El País ${ }^{31}$. El interés mostrado por la prensa en este hecho nos ha permitido reconstruir lo sucedido pero, al mismo tiempo, es una muestra del minucioso seguimiento que la prensa hizo de un programa de televisión ${ }^{32}$.

Desde el primer momento, Diario 16 y la prensa en general, empezó a cuestionar el relato. No se entendía que una "repentina enfermedad", provocara la suspensión del programa. No era la primera vez que José Luis Balbín era sustituido, ya en otras ocasiones lo habían hecho Javier Vázquez o José Luis Merino. Pero la enfermedad de José Luis Balbín duró el tiempo que un taxista madrileño realizó una llamada a la emisora Antena 3 Radio informando que acababa de llevar al director de La clave a un domicilio en Madrid acompañado de una mujer ${ }^{33}$.

«Dos redactores de Diario 16 se personaron en el domicilio de José Luis Balbín para comprobar si se encontraba en su casa, pero las repetidas llamadas al portero automático no obtuvieron contestación. Ya en la puerta de su piso se encontraron con que el timbre no sonaba (...). Una vecina manifestó a este periódico que no podía asegurar si Balbín se encontraba en casa, puesto que a veces era muy difícil que abriese la puerta ${ }^{34}$.

A este periodismo de investigación le siguieron editoriales y artículos durante los meses de enero y febrero. Lo que debería haber sido una prohibición más se convirtió en una serie de escritos frívolos y de atención desmesurada. En su editorial, Diario 16 afirmó que «los señores Calviño y Balbín, aparecen en estos momento como artífices o al menos como ejecutores del

\footnotetext{
${ }^{29}$ Programa que abordó la ley de incompatibilidades en el sector público (aprobada en junio de 1982 y en vigor desde el 1 de enero de 1983). Esta ley suscitó una fuerte controversia, principalmente entre la clase médica.

30 “Balbín tiene que explicar por qué se suspendió La clave del viernes", Diario 16, 17/01/1983.

31 "El Gobierno impidió la emisión de La clave", Diario 16, 15/01/1983, y "Discrepancias en el equipo directivo de TVE por el veto a Alonso Puerta", El País, 16/01/1983.

32 Fuente: “José Luis Balbín regresó anoche de Alemania”, Mediterráneo, 19/01/1983, p. 23.

33 “La enfermedad de Balbín, una dolencia «diplomática»", $A B C, 16 / 01 / 1983$, p. 73.

34 “Balbín tiene que explicar por qué se suspendió La clave del viernes”, Diario 16, 17/01/1983.
} 
más burdo e insultante engaño urdido desde la pequeña pantalla contra la ciudadanía durante la etapa democrática» ${ }^{35}$. «No vamos a consentir que se eche tierra sobre el asunto, porque tendría que ser la suficiente como para atorar los ojos y los oídos de toda la nación. El medio de comunicación más poderoso e influyente del país no puede quedar en manos de dos señores ${ }^{36}$.

A su regreso de Alemania, y vista la enorme expectación, José Luis Balbín convocó una rueda de prensa para explicar los motivos de la suspensión del programa ${ }^{37}$. Al día siguiente, el Consejo de Administración de RTVE llamó a declarar a José Luis Balbín. La prensa filtró las conversaciones: cuatro consejeros de UCD y uno de AP pidieron a José María Calviño el cese del director de los Servicios Informativos, y emitir el programa suspendido Balance de los municipios de izquierda ${ }^{38}$.

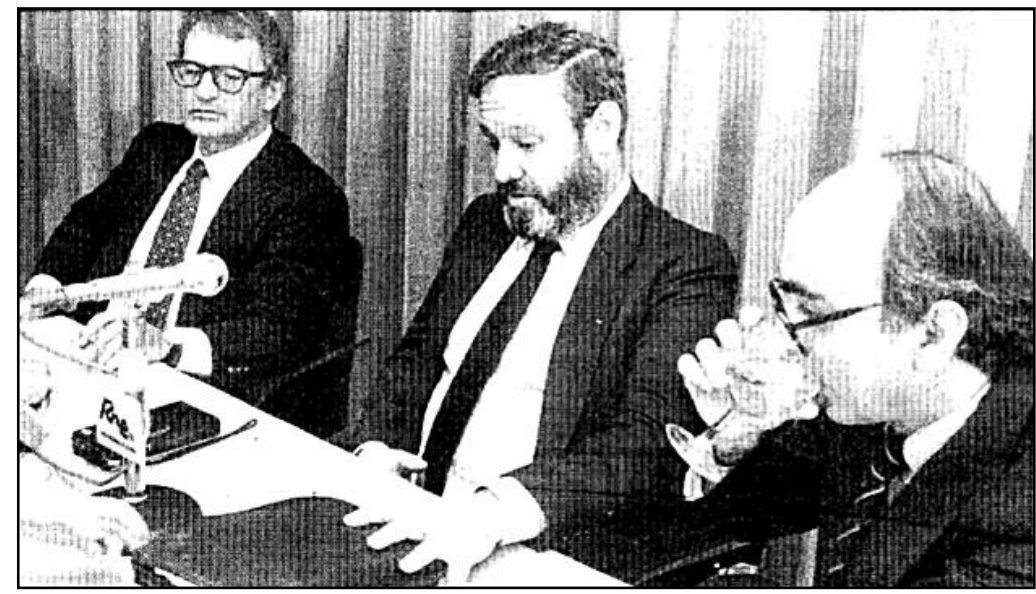

Fotografía no 12 . De izquierda a derecha, Carlos Luis Álvarez, José Luis Balbín y Enrique Vázquez, durante la rueda de prensa del 19 de enero de 1983. Fuente: Diario 16, 20/01/1983, p. 4.

Duras críticas desde Diario $16^{39}$, fue precisamente en este periódico donde se realizó el mejor análisis de lo sucedido: «La cabeza de Balbín ha sido reclamada ya, pero no caerá... ¿Por qué iba a caer? ¿Quién iba dimitirle? ¿Los amigos de aquéllos a cuyas presiones o sugerencias cedió?» ${ }^{40}$.

\footnotetext{
35 "Mentirosos, a su casa" (Editorial), Diario 16, 17/01/1983, p. 1.

${ }^{36}$ Ibídem, p. 2.

${ }^{37}$ Fuente: "Balbín o la expectación”, Mediterráneo, 20/01/1983, p. 29. Las causas que dio fue que el jueves empezó a encontrarse mal y pasó toda la noche con taquicardia. Argumentos que posteriormente se volverían en su contra y muchos artículos en prensa buscarían mermar su credibilidad en televisión.

${ }^{38}$ Fuentes: "UCD y AP piden el cese de Balbín”, Diario 16, 21/01/1983, y "En el Consejo de RTVE se pide el cese de José Luis Balbín”, ABC, 21/01/1983, p. 37.

${ }^{39}$ Véase "Una nueva enfermedad: La «taquicardia balbiniana»", Diario 16, 22/01/1983.

${ }^{40}$ Gloria Díez, “La verdad sobre el caso Balbín”, Diario 16, 21/01/1983.
} 
¿A quién se refiere con aquéllos? El portavoz socialista, Eduardo Sotillos, salió al paso de las cuestiones diciendo: «El Gobierno nada tiene que decir sobre La clave, excepto que no ha tenido la más mínima participación en la suspensión de este programa» ${ }^{41}$. El propio presidente del Gobierno, entrevistado esa noche desde el Palacio de la Moncloa por Ramón Colom (en un primer momento se había hablado de conducir la entrevista José Luis Balbín), hizo referencia a los medios de comunicación de manera informal pero categórica, negando las injerencias ${ }^{42}$. En algunos periódicos se publicó que el vicepresidente del Gobierno, Alfonso Guerra, había intervenido personalmente ${ }^{43}$, y este tuvo que hacer unas declaraciones para desmentir su implicación en el asunto ${ }^{44}$.

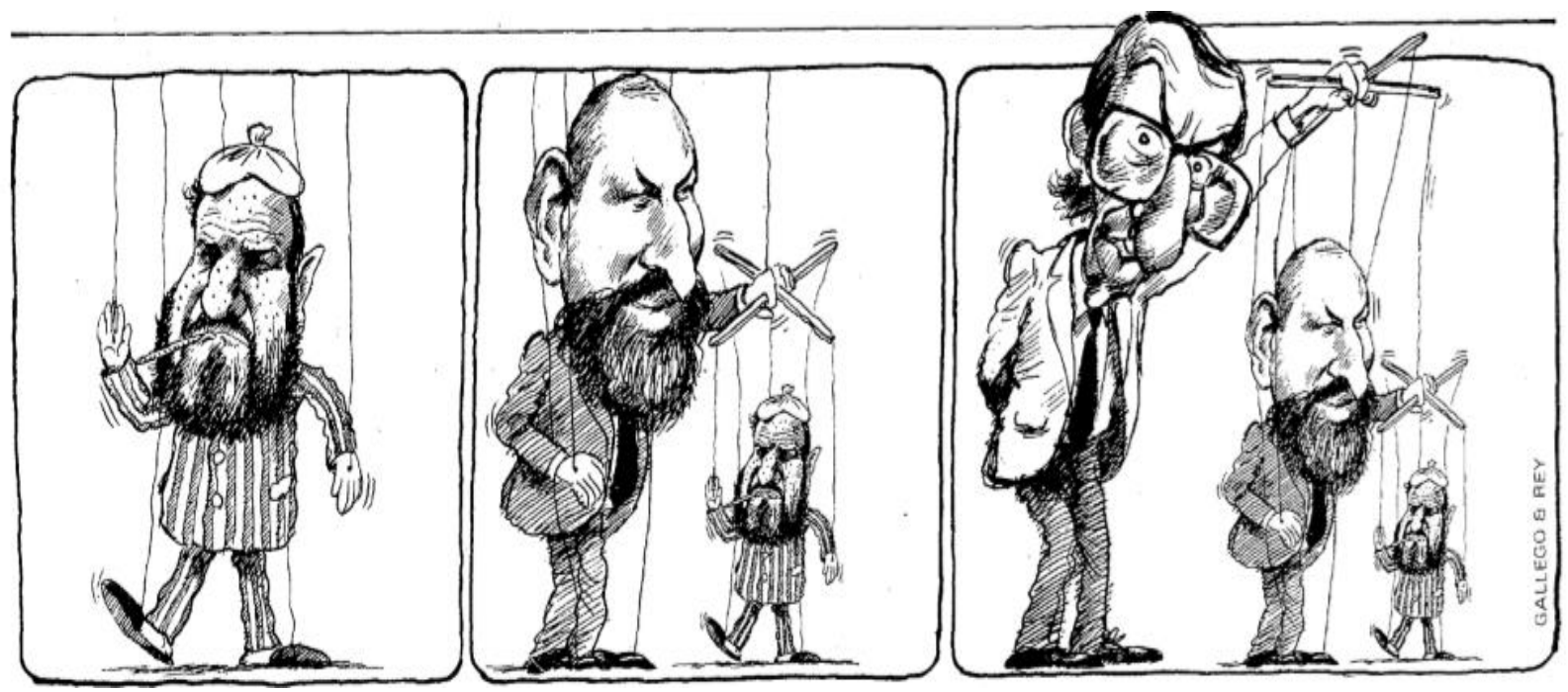

Fotografía no ${ }^{13}$. Caricatura extraída de Diario 16, 17/01/1983, p. 8.

Es determinante el poder político que representa un instrumento como la televisión durante el proceso de Transición, que incluso el presidente y el vicepresidente del Gobierno deben hacer declaraciones respecto a las injerencias que se producían alrededor de ella. Sin embargo, ¿de quién fue la idea de la suspensión?, ¿de Alfonso Guerra?, ¿de José María Calviño?, ¿o de Enrique Tierno Galván? Efectivamente, como nos dijo José Luis Balbín en la entrevista realizada en Estrasburgo, fue Enrique Tierno Galván (junto a José María Calviño) quienes le convencieron que lo mejor era prohibir el programa: «Es verdad que yo tenía que ver

\footnotetext{
${ }^{41}$ ABC Sevilla, 20/01/1983, p. 5.

42 "No a las injerencias" (Editorial), Mediterráneo, 23/01/1983, p. 2, y "Felipe González será entrevistado por Ramón Colom para TVE”, Mediterráneo, 20/01/1983, p. 23.

${ }^{43}$ Guillermo Luca de Tena, "La clave, censurada” (Editorial), ABC, 18/01/1983.

44 «No os dejéis presionar por nadie. Ni del Gobierno, ni del PSOE. Por nadie» afirmaría el Presidente de Gobierno Felipe González. Por su parte, Alfonso Guerra diría: «Yo no tengo nada que ver con eso, a Calviño no le conozco y a Balbín solo lo he visto en La clave», Mediterráneo, 21/01/1983, p. 22.
} 
unas películas en Alemania (...). Yo le dije a Tierno Galván, tener en cuenta una cosa, que vais a tener que hacerlo, se va a armar tal follón que vais a tener que hacer el programa» ${ }^{45}$.

José Luis Balbín no hubiese permitido una incidencia política en La clave, si no hubiese sido por la intervención directa de Enrique Tierno Galván, a quien le tenía un profundo respeto $^{46}$. Esta prohibición evidenció no solo la existencia de presiones e injerencias políticas en televisión sino también cómo funcionaban. Pese al exhaustivo seguimiento realizado por los principales rotativos españoles, en prensa nunca se publicó el nombre de Enrique Tierno Galván $^{47}$. En la habitual reunión que algunos periodistas mantenían con personalidades de la vida nacional, conocido como "Los desayunos del Ritz" (otra muestra de la connivencia entre política y periodismo durante la Transición), José María Calviño declaró que no pensaba dimitir ni cesar a José Luis Balbín: «Un Gobierno con diez millones de votos no necesita evitar que aparezca un Alonso Puerta por televisión, en segunda cadena, y un día que hay el Un, dos, tres» ${ }^{48}$.

El programa Balance de los municipios de izquierda finalmente acabó emitiéndose el 4 de febrero con el mismo panel de invitados previsto en su día. No hubo cena previa y tuvo una audiencia de 5 millones de espectadores ${ }^{49}$. En la introducción del programa José Luis Balbín dijo: «El programa se ha convertido en noticia, en mucho más de lo que debería ser, creo yo, y no lamentaría nada que lo siguiera siendo esta noche ${ }^{50}$. Pero la resonancia alcanzada duró todavía algunos meses. Diario 16 focalizó su mirada a partir de entonces, sino antes, en José Luis Balbín, y fueron constantes los ataques al director de La clave publicando cualquier noticia sobre su vida personal: «¿Estará La clave (...) en el Bocaccio madrileño, donde Balbín reposa noche tras noche hasta llegar la madrugada?» 51 .

\footnotetext{
${ }^{45}$ Véase en el DVD anexo la entrevista realizada a José Luis Balbín en Estrasburgo el 16 de abril de 2014.

${ }^{46}$ Conversación mantenida con José Luis Balbín en Madrid el 18 de agosto de 2014.

${ }^{47}$ Su vinculación podría mostrar la conexión directa del PSOE en La clave. "José Luis Balbín no ha sido localizado por la dirección general de RTVE", $A B C$, 18/01/1983, p. 40; "La clave, censurada", ABC, 18/01/1983; "La Comisión de Control Parlamentario pedirá la dimisión de Calviño", $A B C, 18 / 01 / 1983$, p. 40; "Balbín, sorprendido por el escándalo La clave", $A B C, 19 / 01 / 1983$, p. 38; "Balbín explicará hoy los motivos de su enfermedad", $A B C$, 20/01/1983, p. 84; "En el Consejo de RTVE se pide el cese de José Luis Balbín”, ABC, 21/01/1983, p. 37.

${ }^{48} A B C$, Sevilla, 25/01/1983, p. 3, y “El director general de RTVE considera que él no es ningún «error a corregir»”, El País, 25/01/1983.

${ }^{49}$ Diario 16, 5/02/1983, p. 22.

${ }^{50}$ Centro de Documentación RTVE. Balance de los municipios de izquierda (ficha 254-B). Emisión: 4 de febrero de 1983.

51 "La última enfermedad de La clave”, Diario 16, 18/01/1983 y “Gritos y susurros”, Diario 16, 19/01/1093.
} 
A mediados de febrero José María Calviño se sometió a las preguntas de la oposición ante la Comisión de Control Parlamentario de RTVE por lo sucedido en La clave ${ }^{52}$. El director general compareció durante más de una hora en el Congreso. Allí repitió que ni el Gobierno ni el partido habían influido en el programa La clave $^{53}$. A finales de julio, Carlos Luis Álvarez publicó en Interviú que nunca hubo enfermedad de José Luis Balbín. Algunos rotativos se hicieron eco de las declaraciones y publicaron los nombres de algunos de los responsables directos en la suspensión del programa ${ }^{54}$.

En 1983 José Luis Balbín comenzó a pensar en un sucesor para el programa por el conflicto de incompatibilidades que había surgido a raíz de su nombramiento como director de los Servicios Informativos ${ }^{55}$. José Luis Balbín llegó a proponer algunas soluciones para seguir dirigiendo y presentando el programa a los directivos: no cobrar las remuneraciones correspondientes al programa, trasladar La clave a la dirección de los Servicios Informativos (cuyo titular era él mismo) o, en último caso, designar un director entre los actuales miembros del equipo de La clave ${ }^{56}$. Se barajaron los nombres de Joaquín Ruiz-Giménez Aguilar como presentador y Javier Vázquez como director ${ }^{57}$.

José Luis Balbín tenía registrado el programa La clave a su nombre desde octubre de 1978, por los vaivenes políticos que pudiesen ocurrir. En 1986 declaró que llegó a un acuerdo con José María Calviño para que el programa lo hiciera alguien vinculado al equipo. «Lo que yo no consentía era que el responsable fuera un hombre del PSOE. Yo aposté por Javier Vázquez -entonces subdirector- y Calviño dijo que muy bien. Pero ahí se acabó la historia (...) la opinión pública no sabía que lo que se jugaba en aquel momento era que el programa fuera o no del PSOE» ${ }^{58}$.

El 11 de marzo de 1983, con ocasión del primer centenario de la muerte Karl Marx, La clave debatió sobre el marxismo bajo título Karl Marx, un siglo de marxismo (ficha 263). Se proyectó la película húngara Carlota (Sárika, drágám, Pál Sándor, 1971). También dedicó una

\footnotetext{
${ }^{52}$ Diario de Sesiones. Congreso de los Diputados, 1983. II legislatura, no 6. Comisión de Control RTVE, p. 265.

${ }^{53}$ Fuente: “Calviño y la oposición, mano a mano”, Mediterráneo, 17/02/1983, p. 29.

${ }^{54}$ Fuentes: $A B C, 21 / 07 / 1983$, p. 65, y Mediterráneo, 21/07/1983, p. 31.

55 También abordó en La clave Incompatibilidades 83 (ficha 256). A finales de año se aprobó la Ley 25/1983, de 26 de diciembre, sobre incompatibilidades de altos cargos.

56 Fuente: "Carlota, un filme para el debate sobre el marxismo", El País, 11/03/1983.

${ }^{57}$ Fuente: “Balbín o la expectación”, Mediterráneo, 20/01/1983, p. 29.

${ }^{58}$ Historia de TVE. Coleccionable. Diario $Y a, 1986$, p. 120.
} 
emisión al término de cantautor, su apropiación y sus connotaciones políticas en ¿Dónde están los cantautores? (ficha 264). Pero las críticas continuaron: «El director-propietariopresentador-moderador y seguramente algún etcétera más de La clave, debió haber abandonado el programa en el mismo momento en que fue nombrado director de informativos de TVE» ${ }^{59}$. Pese a ellas, y al conflicto de incompatibilidades, José Luis Balbín compaginó ambas funciones hasta septiembre de 1983, cuando fue destituido de los Servicios Informativos ${ }^{60}$.

José Luis Balbín presentó una querella el 26 de marzo de 1983 contra la revista Cambio 16 por el dossier titulado "Los chanchullos de la tele: tres Balbines en La clave", que también reprodujo parcialmente Diario $16^{61}$. En él se hablaba del enchufismo realizado por José Luis Balbín en su programa en el que colaboraban tres familiares suyos. José Luis Balbín respondió a la polémica primero en prensa: «Estoy harto de calumnias y mentiras sobre mí. Desde que me nombraron director de los informativos, y quizás antes, he sufrido una persecución implacable por parte de varios medios y en especial por el Grupo $16 »^{62}$, y posteriormente a los tribunales querellándose contra Cambio 16 y Diario 16.

Por último, vista la procedencia de los vocales, obviar que no se cumplía la condición de «relevantes méritos profesionales» que marcaba el Estatuto de RTVE para formar parte del Consejo de Administración. La desintegración de UCD -y la fundación del nuevo partido CDS (Centro Democrático Social)- provocó a inicios de 1983 que el Parlamento no lograse ponerse de acuerdo para la renovación del Consejo de Administración de RTVE. Dos de sus vocales pasaron a CDS y cuatro al partido de Manuel Fraga, Alianza Popular (AP). Esta situación de caos en el Consejo de Administración duró hasta junio de 1983, con una nueva composición: «siete propuestos por el PSOE, cuatro por el grupo Popular (denominación del grupo parlamentario de la coalición de oposición aglutinada por Manuel Fraga) y uno independiente pactado a su vez por las dos formaciones políticas» (Sinova 1983: 52-53).

\footnotetext{
${ }^{59}$ Mediterráneo, 24/03/1983, p. 29.

60 José María Calviño sí destituyó en marzo a Mauro Muñiz y Manuel Almendros, director y subdirector de programas informativos especiales de TVE.

61 “Tres balbines en La clave: él, su hermana y su cuñada”, Diario 16, 25/03/1983, p. 47. Diario 16 fue muy crítico con José Luis Balbín desde su nombramiento como director de los Servicios Informativos: «de los peores que se recuerdan desde hace bastantes años», "Radio Televisión Española está en pie de guerra", Diario 16, 11/03/1983, p. 9.

${ }^{62}$ El Periódico de Catalunya, 26/03/1983, p. 46, y Mediterráneo, 27/03/1983, p. 37. (Juan Tomas de Salas era el presidente del grupo, y Pedro J. Ramírez director de Diario 16).
} 


\subsubsection{La España autonómica}

La clave contribuyó a proyectar una imagen de la nueva realidad en toda la geografía del país. La preocupación del programa por las autonomías se inició en torno a la lengua y la polémica de los términos español/castellano ${ }^{63}$. Sin embargo, fue tras las elecciones municipales y autonómicas de 1983 cuando La clave realizó un ciclo dedicado a las comunidades autónomas con el subtítulo de "Las Autonomías por dentro". Estos programas seguían un mismo eje: se contaba con personalidades políticas representativas de dicha región, y se realizaban en sitios emblemáticos de la propia comunidad autónoma. El ciclo se inició el 27 de abril de 1983 con La nueva España Autonómica (ficha 274), y posteriormente los programas dedicados a la Comunidad Valenciana (298), Cataluña (316), Navarra (330), Cantabria (350), Madrid (359) ${ }^{64}$, Canarias (365), Andalucía (377), Baleares (387) y Galicia (399).

El dedicado a Cataluña (realizado desde Sant Cugat del Vallés), se pudo hacer tras resolver un conflicto con TV3 por programar el mismo día, misma hora y mismos invitados, un debate con las distintas fuerzas que iban a concurrir a la presidencia de la Generalitat, que fue fuertemente criticado por los comunistas catalanes por excluirles del debate ${ }^{65}$. El de Andalucía se hizo desde Sevilla y participaron entre otros Luis Rosales, Julio Anguita y Juan Manuel Sánchez Gordillo ${ }^{66}$. En el caso de Galicia (desde la Capilla de los Reyes Católicos en Santiago de Compostela) se produjeron disturbios que acabaron alterando incluso la emisión. Militantes del Bloque (partido nacionalista) impidieron la presentación de los invitados provocando un retraso en la emisión, lo que llevó a ambientar la programación con vídeos musicales. A través de esta acción querían denunciar cómo se había montado dicho debate, en el que solo se permitía la presencia de alternativas de matiz centralista ${ }^{67}$. Sin presentación, el programa tuvo que realizarse en las instalaciones de TVE empezando directamente por la película ${ }^{68}$. Galicia fue la última emisión dedicada a las Autonomías por dentro. En el caso de País Vasco, José Luis Balbín diría que no pudo hacer el programa correspondiente porque no quisieron sentarse en

\footnotetext{
${ }^{63}$ Con El idioma de Cataluña (178) en 1981, y Bilingüismo (236) en 1982, debatió sobre las lenguas oficiales (catalán, valenciano, gallego y euskera) que existían en las respectivas comunidades autónomas.

${ }^{64}$ En 1982 había dedicado una emisión titulada Madrid ¿Distrito federal? (ficha 231).

65 “Comunistas catalanes molestos con Balbín”, $A B C, 19 / 03 / 1984$, p. 77.

${ }^{66}$ Centro de Documentación RTVE. Andalucía. Las Autonomías por dentro (ficha 377). Emisión: 17 de mayo de 1985.

${ }^{67}$ Centro de Documentación RTVE. Galicia. Las Autonomías por dentro (ficha 399). Emisión: 18 de octubre de 1985.

68 "Militantes del Bloque alteraron el comienzo de La clave", $A B C, 19 / 10 / 1985$, p. 31.
} 
La clave $^{69}$. Con este ciclo, La clave evidenció que para muchos protagonistas de la Transición el problema de España no era su democratización, sino el concepto de nación ${ }^{70}$.

El 8 de mayo se celebraron elecciones municipales en España. La clave debatió sobre El mejor Alcalde... (ficha 272), y le siguieron una entrega sobre Hitler (ficha 273), que contó con la presencia de Wolf Rudiger Hess y Ramón Serrano Suñer, y a mediados de junio, Lo de la tele (ficha 277), y la película Historias de la televisión (José Luis Sáenz de Heredia, 1965). Participaron en este último el director general José María Calviño y el portavoz del Gobierno Eduardo Sotillos. Con un título informal que pretendía tratar la televisión desde otra perspectiva, acabó siendo un debate sobre televisión pública-privada, índices de audiencia (entre 19 y 21 millones de espectadores) y financiación ${ }^{71}$. Federico Jiménez Losantos criticó el programa en Diario 16 con un artículo titulado "Totalitarismo y televisión" atacando la independencia de José Luis Balbín por hacer el programa a medida de las directrices del partido socialista en detrimento de las demás opciones ${ }^{72}$.

Como se observa, desde el nombramiento de José Luis Balbín en los Servicios Informativos, la prensa conservadora fue muy crítica con La clave. ABC la calificaba de «uno de los programas más onerosos en su especialidad de toda la historia del Ente. Su precio, sin embargo, tiene una clara rentabilidad política porque, sistemáticamente, se coloca al servicio de la actualidad profunda que puede interesar a los que ahora están en el poder y que interesaban otros temas cuando estaban en la oposición ${ }^{73}$. Ese mismo día, en el periódico Mediterráneo se podía leer: «Paso a paso, en silencio, hemos estado esperando a que alguna vez el Sr. Balbín, jefe de informativos de TVE, diera una oportunidad para pensar que las cosas son diferentes. Lo malo es que mientras esperábamos hemos caído no ya en la desesperación, sino en la depresión, en el asco» ${ }^{74}$.

Pero las críticas procedentes desde la prensa conservadora no fueron el único conflicto. En julio de 1983 tuvo una disputa con Antonio López (director de TVE y militante del PSOE), por el nombramiento del jefe de información internacional de TVE. En sustitución de Díaz Manresa, José Luis Balbín propuso el nombramiento de Mario Rodríguez de Aragón (exdirector

\footnotetext{
${ }^{69}$ José Luis Balbín durante Lo que va de ayer a hoy (ficha 356). Emisión: 21 de diciembre de 1984.

${ }^{70}$ Véase J. Subirats, y R. Gallego (ed.), Veinte años de Autonomías en España. CIS, Madrid, 2002.

${ }^{71}$ Centro de Documentación RTVE. Lo de la tele (ficha 277). Emisión: 17 de junio de 1983.

${ }^{72}$ Federico Jiménez Losantos, Diario 16, 20/06/1983.

${ }^{73}$ ABC, 7/07/1983, p. 101.

74 “¿Dimitirá Antonio López?”, Mediterráneo, 7/07/1983, p. 21.
} 
de Sábado Gráfico, miembro de la Platajunta en París y antiguo militante del Partido del Trabajo de España, PTE). Sin haber sido nombrado -y sin contar con el consentimiento de Antonio López- José Luis Balbín llevó a Rodríguez Aragón a la recepción del rey Juan Carlos con los directivos de los Servicios Informativos ${ }^{75}$. El conflicto llegó a un impasse cuando Antonio López se negó a firmar dicha propuesta. Finalmente, el director general José María Calviño, haciendo causa común con José Luis Balbín, nombró a Rodríguez Aragón con un cargo en el Ente, el de subdirector de relaciones externas de $\mathrm{RTVE}^{76}$.

Al día siguiente, 15 de julio de 1983, La clave debatió La Transición política (ficha 281). Una clave política y al mismo tiempo histórica (por ser un debate sobre el propio proceso de Transición) que prestamos especial atención en nuestro último capítulo. En esta ocasión, el equipo de La clave no pidió a los partidos políticos que enviasen representantes, sino que el programa elegiría directamente a los invitados (de nuevo un cambio cualitativo en el programa). Se emitió el documental La vieja memoria (Jaime Camino, 1977), y los participantes fueron Manuel Martínez Azaña (sobrino político del expresidente del Gobierno de España durante la Segunda República Manuel Azaña), Jordi Solé Tura (Partido Socialista Unificado de Cataluña), Joaquín Ruiz-Giménez (expresidente de Izquierda Democrática y primer Defensor del Pueblo en España), Fernando Suárez González (vicepresidente de Alianza Popular), Julio Busquets (diputado del PSOE), Joaquín Satrústegui (exdiputado de UCD) y el dibujante Máximo. Durante el debate se hicieron referencias a la Guerra Civil, a la idea de dos Españas enfrentadas, al juancarlismo, al 23-F, al papel de Adolfo Suárez, al terrorismo, a las autonomías, y a la idea de patria. No hubo la habitual bibliografía al finalizar el debate.

La semana siguiente La clave abordó la Reconversión industrial (ficha 282). Participaron, entre otros, Rodrigo Rato, Marcelino Camacho y Ramón Tamames, y pese a las habituales críticas desde $A B C^{77}$ y Diario $16^{78}$, La clave logró finalmente emitir Homosexuales (ficha 283), uno de los temas prohibidos en anteriores etapas ${ }^{79}$. Sin embargo, la fecha elegida (29 de julio de 1983) coincidió con el inicio de las vacaciones (recurso que ya venía siendo

\footnotetext{
${ }^{75}$ Fuentes: "Puede hacer crack la cúpula socialista en TVE", Diario 16, 23/06/1983, p. 39, y "Enfrentamiento López-Balbín”, $A B C$, 3/07/983, p. 102.

${ }^{76}$ Fuente: “«Parche» al conflicto López-Balbín”, ABC 14/07/1983, p. 64.

77 «Balbín hizo una tertulia de concurrencia desproporcionada, gravitando hacia la izquierda el peso de los comparecientes (...). La clave se ha ganado el suspenso para septiembre», $A B C, 26 / 07 / 1983$, p. 84.

${ }^{78}$ En la portada de esa semana aparecía una caricatura de José Luis Balbín y José María Calviño con el título: “Un par de caraduras", Diario 16, 25/07/1983. Aseguraban que José Luis Balbín presentó denuncias falsas en su etapa de corresponsal de TVE en París en 1974.

${ }^{79}$ Centro de Documentación RTVE. Homosexuales (ficha 283). Emisión: 29 de julio de 1983.
} 
habitual en política y en televisión). A pesar de ello, logró ofrecer visibilidad a un colectivo muy vulnerable todavía en $1983^{80}$. La clave, hay que recordar, ya había intentado realizar una emisión sobre la homosexualidad el 8 de abril de 1978, que no salió en antena por las declaraciones del catedrático de psiquiatría de la Universidad de Salamanca, Francisco Llavero (quien habría influido al ministro del Interior Rodolfo Martín Villa para que no saliese en antena).

En 1983, por tanto, La clave pudo introducir el tema de la homosexualidad en el debate televisivo. Se proyectó la película El funcionario desnudo (The Naked Civil Servant, Jack Gold, 1975), película estadounidense realizada para televisión y estreno en TVE. Entre los invitados figuraban un psiquiatra y un médico, ambos conservadores, que provocaron la crítica desde $E l$ País ${ }^{81}$. Llama la atención, en cambio, la ausencia de un representante eclesiástico, habitual en estos temas, como también señalan Juan Carlos Alfeo y Beatriz González, quienes añaden que «los discursos políticos, científicos/clínicos y jurídicos capitalizaban, como no podía ser de otro modo en aquel momento, la competencia para discernir los puntos esenciales de la cuestión» ${ }^{82}$.

En relación a la homosexualidad en televisión, Sinova aseguraba que la primera vez que habló en televisión un homosexual fue el 13 de enero de 1983 en el programa Buenas noches, de Mercedes Milá (Sinova 1983: 114). Si esta afirmación es matizable ${ }^{83}$, no su significado, pues continuaba siendo una temática tabú en televisión. Si un programa logra introducir por primera vez en televisión una temática silenciada hasta esos momentos, ¿continúa siendo la misma desigualdad después de la emisión? Manuel Palacio argumenta que «el paso inicial del largo camino hacia la normalización se dio con el reportaje que Informe semanal realizó con motivo del día del orgullo gay en 1981» (Palacio 2012: 255).

Sin lugar a dudas, La clave ayudó a quebrar el gran tabú que suponía la homosexualidad, no solo en televisión. Si bien el programa no acabó con las desigualdades, tampoco podemos negar que aquellas que persistían eran vividas de la misma manera. Desde el 4 de agosto de 1970 estaba vigente en España la ley sobre peligrosidad y rehabilitación social, que no se derogó hasta 1995. También deberíamos tener en cuenta que hasta 1990 la Organización Mundial de

\footnotetext{
${ }^{80}$ Hasta 1977 no encontramos las primeras publicaciones de carácter homosexual en España, como el boletín Nosotros. Fuente: “Nosotros, boletín del Movimiento Democrático de Homosexuales”, El País, 14/10/1977.

${ }^{81}$ El País, 14/08/1983.

${ }^{82}$ J. C. Alfeo y B. González, Negociación de la visibilidad homosexual en la ficción televisiva española, Facultad de Ciencias de la Información. Depto. de Comunicación audiovisual y Publicidad. Formato electrónico, p. 10.

${ }^{83}$ Y no solo porque Informe Semanal entrevistó a tres homosexuales el 4 de febrero de 1978.
} 
la Salud (OMS) calificó la homosexualidad de enfermedad mental. El 29 de junio de 2005 el Congreso de los Diputados aprobó la modificación del Código Penal permitiendo en España el matrimonio homosexual ${ }^{84}$.

Una breve comparación con la televisión francesa nos puede aportar una mejor contextualización sobre la importancia de La clave al debatir sobre la homosexualidad. La primera emisión en Francia sobre homosexualidad la realizó el 21 de enero de 1975 Les Dossiers de l'écran (ocho años antes que La clave), que contrasta, en cambio, con la ley aprobada por la Asamblea General el 12 de febrero de 2013 (ocho años después que España). El programa tuvo una audiencia de 19 millones de espectadores (Pivert 2009: 13), y el film elegido para ilustrar el debate fue Las amistades particulares (Les Amitiés Particulières, Jean Delannoy, 1964), basada en la obra homónima escrita en 1943 por Roger Peyrefitte (uno de los primeros invitados en pasar por La clave $)^{85}$. Uno de los aspectos relevantes de programas como Les Dossiers de l'écran y La clave se observa en la construcción de una cultura democrática a través de la formación ciudadana, como analizaremos en nuestro último capítulo ${ }^{86}$.

Dos días antes de emitir Homosexuales, en julio, volvió de nuevo el asunto de la prohibición en enero de Alonso Puerta, a raíz de unas declaraciones al semanario Interviú de Carlos Luis Álvarez. José Luis Balbín y Antonio López (director de TVE) tuvieron que declarar sobre Alonso Puerta ante el Consejo de Administración de RTVE. Ambos negarían la existencia de presiones y el Consejo de Administración de RTVE cerró finalmente el caso Alonso Puerta ${ }^{87}$. La Asociación de Espectadores de Televisión Española hizo pública una nota pidiendo la dimisión de José María Calviño, Antonio López y José Luis Balbín por «la falta de democracia, pluralismo y libertad de expresión existente en ese medio» ${ }^{88}$. Y mientras, en Valencia, interrumpía en la programación una televisión pirata ${ }^{89}$.

\footnotetext{
${ }^{84}$ Ley 13/2005, de 1 de julio, por la que se modifica el Código Civil en materia de derecho a contraer matrimonio.

${ }^{85}$ Participó en el programa ¿Hay falsos en pintura? (ficha 12), emitido el 11 de abril de 1976.

${ }^{86}$ Toda cultura política influye en las instituciones a la vez que es influida por ellas (Peschard 2012: 32). Entre los programas emitidos en agosto (en diferido), destacamos Hombres para el siglo XXI (ficha 287) en el que participaron como invitados niños entre nueve y catorce años de edad. Toda una muestra del carácter formativo y educativo de La clave.

${ }^{87}$ Fuente: "Balbín: No hubo presiones para la suspensión de La clave”, ABC, 28/07/1983, p. 63.

88 “Piden la dimisión de los principales directivos de TVE”, $A B C, 18 / 07 / 1983$, p. 54.

${ }^{89}$ La autodenominada Telemediterráneo salió en pantalla con la imagen de una calavera. Uno de sus miembros, en declaraciones a la prensa, dijo que trataban de «hacer una televisión que muestre la realidad valenciana y no su reflejo desde Madrid», "Televisión pirata interrumpe la programación en Valencia”, ABC, 18/07/1983, p. 54.
} 
En Televisión Española continuaron las destituciones. Un reportaje emitido el 12 de septiembre en el Telediario con entrevistas a tres detenidos, presuntos homicidas, provocó una protesta desde el Consejo General del Poder Judicial y la dimisión al día siguiente de Asunción Valdés como directora de la primera edición del Telediario ${ }^{90}$. En prensa se barajó la destitución de José Luis Balbín (quien se encontraba de vacaciones en Ibiza) de los Servicios Informativos. En solidaridad con Asunción Valdés, responsables del servicio informativo pusieron su cargo a disposición del director general, que únicamente aceptó la dimisión del coordinador de información del telediario por su responsabilidad en la emisión de las entrevistas ${ }^{91}$. Todo ello en una semana de debate parlamentario en el Congreso de los Diputados en la que el Presidente del gobierno declaró no gustarle la televisión ${ }^{92}$.

Los continuos problemas de José Luis Balbín desde inicios de 1983 (Alonso Puerta, incompatibilidad de cargos $^{93}$, querella a Diario $16^{94}$, conflicto con Antonio López ${ }^{95}$ ), hicieron que José María Calviño presentara al Consejo de Administración el 21 de septiembre de 1983 la propuesta de destitución de José Luis Balbín como director de los Servicios Informativos ${ }^{96}$. Su sustituto fue Enrique Vázquez. El nombramiento del nuevo director de los Servicios informativos fue acogido con escepticismo. Los consejeros socialistas de RTVE mostraron su preocupación por el nombramiento, mientras que $A B C$ lo calificaba directamente de "proruso"97. El cese de José Luis Balbín, tras nueve meses en el cargo, se hizo efectivo el 30 de septiembre. Su única actividad en Prado del Rey sería a partir de entonces dirigir y presentar La clave.

El mismo 30 de septiembre La clave abordó el Aborto (ficha 292). Tema de gran actualidad, el día antes se había producido el denominado proceso de Bilbao, juicio ante el Tribunal Supremo contra once mujeres de extracción humilde que abortaron en Bilbao. También coincidió con la polémica surgida entre el Gobierno y la Conferencia Episcopal (que

\footnotetext{
90 “Dimite Asunción Valdés, directora del telediario de la tarde”, El País, 14/09/1983.

91 “Calviño acepta la dimisión de Ángel Urreiztieta, Mediterráneo, 17/09/1983, p. 23.

92 Durante la sesión de control, el nombre de José Luis Balbín aparece en dieciocho ocasiones. Fuente: Diario de Sesiones del Congreso de los Diputados, Comisión de Control Parlamentario de RTVE, 64, 1983, pp. 2187 - 2203.

${ }^{93}$ Ramón Gómez Redondo, director de programas, amenazó con dimitir si para octubre no se resolvía el problema de incompatibilidades de José Luis Balbín.

${ }^{94}$ La querella a Cambio 16 por el artículo "Los chanchullos de la tele: tres Balbines en La clave", 24/03/1985.

${ }^{95}$ Conflicto con el director de TVE a raíz del nombramiento de Mario Rodríguez Aragón.

${ }^{96}$ Fuente: "Balbín, cesado", Mediterráneo, 22/09/1983, p. 32.

97 "Preocupación de los consejeros socialistas", $A B C, 23 / 09 / 1983$, p. 100. "Los Servicios de Inteligencia soviéticos, satisfechos por el nombramiento de Vázquez como Jefe de los Informativos de TVE”, ABC, 22/09/1983, p. 100.
} 
dio luz verde a unos textos religiosos que relacionaban el aborto con el terrorismo ${ }^{98}$. Se proyectó la película Españolas en París (Roberto Bodegas, 1971), y entre los invitados se encontraban el ginecólogo Ángel Sopeña, la abogada Cristina Almeida y el también abogado y diputado del Grupo Popular José María Ruiz-Gallardón. Hubo cuatro invitados a favor y cuatro en contra, y el programa provocó el récord de preguntas de los telespectadores que hasta el momento compartían La Transición política (ficha 281) y Homosexuales (ficha 283).

El debate se abordó desde el plano moral y el plano legal. Para Bernard Nathason, único invitado extranjero: «Todos los argumentos que planteemos a favor del aborto son argumentos para el infanticidio, para matar niños». Para Cristina Almeida «Lo verdaderamente progresista no consiste en decir que se mate al feto o al ser concebido no nacido. Lo verdaderamente progresista es atender a ese ser y dotarle de posibilidades para que desarrolle su vida» ${ }^{99}$. Se aportaron datos como los 300.000 abortos anuales que se producían en España y el importante flujo migratorio hacia Inglaterra. Al acabar el programa, se ofreció a los telespectadores la habitual bibliografía ${ }^{100}$.

Habría que destacar la importancia de esta emisión si tenemos en cuenta que era la primera vez en televisión que se abordaba el aborto. En España no hubo información sobre sexualidad en cuarenta años, y entrada la democracia continuaban prohibiéndose programas de televisión que trataban la educación sexual (un ejemplo el programa Escuela de Salud ${ }^{101}$ ). De ahí la importancia de los medios de comunicación en visualizar temáticas. En prensa, la portada de El País Semanal, el 3 de octubre de 1976, protagonizada por españolas que abortaban en Londres $^{102}$. En 1978, Pilar Jaime González había escrito un artículo en El País, del que destacamos el siguiente extracto:

«Las mujeres, señores, estamos hartas de pagar el más alto coste social por su política de ignorancia, de miedo, de oportunismo; de arriesgar de continuo nuestra vida, nuestra salud

\footnotetext{
98 Véase Diego Galán, “Españolas en París, 12 años después”, El País, 30/09/1983.

${ }^{99}$ Centro de Documentación RTVE. Aborto (ficha 292). Emisión: 30 de septiembre de 1983.

${ }^{100}$ En esta ocasión tres fueron las obras recomendadas: J. Jiménez Vargas, Aborto y contraceptivos (1979), VVAA, El aborto: un tema para el debate (1982), y J. C. Wilke, Manual sobre el aborto (1983).

101 «Francisco Ansón Oliart, hermano del director general de RTVE y responsable de contenidos del organismo, parece ser el causante de que el programa Escuela de Salud no se haya emitido en dos ocasiones», en "Televisión Española censura un programa sobre educación sexual”, Diario 16, 10/02/1983, p. 39. Ese mismo año se había suspendido un documental sobre planificación familiar en el programa Viéndolas venir «a causa de la inclusión de unas imágenes en las que se veía el pene de un hombre colocándose un preservativo», Diario 16, 11/02/1983, p. 46.
}

102 Véanse El País Semanal, 3/10/1976, y “A Londres o a la abortera del barrio”, El País, 5/05/2013. 
o nuestra fertilidad ante cualquiera de las opciones que tomemos: si elegimos parir, tenemos elevadísimos índices de subnormalidades por traumas en el parto, por provocaciones precipitadas, por falta y deficiencia de la atención sanitaria, por masificación; si queremos anticoncepción, ésta será sin control o cara, desatendida siempre, desinformada de continuo, arbitraria la inmensa mayoría. Si necesitamos abortar: clandestinidad, riesgos legales, físicos, psíquicos, etcétera. Las mujeres, hoy, tenemos muy claro que cualquiera que sea la opción elegida siempre lo es a tumba abierta, a todo riesgo, y que también, una vez más, las responsabilidades que ello conlleva caen irreversiblemente sobre nosotras» ${ }^{103}$.

A partir de 1979, en El País comenzaron a ser más frecuentes artículos referentes al aborto $^{104}$. La interrupción del embarazo en España era un delito penado con seis años de cárcel, y a la altura de 1981 continuaban produciéndose detenciones ${ }^{105}$. El 6 de octubre de 1983, un mes más tarde la emisión de La clave, el Congreso de los Diputados aprobó el proyecto de ley que modificaba el Código Penal ${ }^{106}$.

Es con su destitución como director los Servicios Informativos que finaliza esta etapa. En palabras posteriores, una vez suspendida definitivamente La clave, José Luis Balbín diría:

«Como director de informativos de TVE intenté llevar a cabo esta idea: la libertad de expresión y la autonomía de los directores de los programas debe ser siempre respetada» ${ }^{107}$. «En la primera reunión que mantuve con ellos les dije: yo soy responsable de todo y mi intención es no imponeros nada. Aunque os llame Felipe González, podéis colgarle el teléfono tranquilamente y que me llame a mí o que llame al director general. Como asuntos de consulta recomendada, José Luis Balbín recuerda que enumeró los relacionados con el terrorismo y con la Casa Real. En estos casos -recuerda Balbín que les dijo- lo consultáis conmigo» ${ }^{108}$.

\footnotetext{
${ }^{103}$ Pilar Jaime González, "El aborto en España”, El País, 21/12/1978.

${ }^{104}$ Ejemplos de ello, Rosa Montero, “Aborto", El País, 31/03/1979, Rosalina Santa Olalla, "Sobre el aborto”, El País, 27/10/1979, y Empar Pineda, "Aborto y realidad social”, El País, 27/10/1979.

105 Jaime Millas, "Detenidas nueve personas relacionadas con presuntas prácticas abortivas”, El País, 17/07/1981.

${ }^{106}$ La primera despenalización parcial del aborto en tres supuestos se aprobó en julio de 1985. Ley Orgánica 9/85 de 5 de julio 1985, en vigor desde el 1 de agosto de 1985.

107 "Historia de TVE". Coleccionable. Diario Ya, 1986, p. 120. «Nombré a Asunción Valdés para el primer Telediario, la primera vez que una mujer ocupaba ese sitio, a Luis Mariñas para el de las nueve, pasé a Joaquín Arozarnena a la Segunda Cadena y puse a Pablo Sebastián en la Última edición. Tanto que se habló de mi nepotismo, ninguno de los citados era amigo personal mío, ni uno solo. Al que más conocía era a Manuel Campo, que había descubierto yo al presentar el programa El testigo», "Historia de TVE", en Ya, op. cit. p. 121.

108 "Historia de TVE", Ya, 1986, p. 121.
} 
En octubre de 1983, La clave dedicó una emisión a la ocupación de fincas en Andalucía con una emisión titulada Tierras en discordia. De nuevo la reforma agraria (ficha 294) ${ }^{109}$. Desde $A B C$ se criticó la emisión y se pidió el final del programa ${ }^{110}$. José Luis Balbín finalizó la etapa al frente de los Servicios Informativos, uno de los cargos más influyentes en TVE con un nuevo conflicto interno, esta vez con Clara Isabel Francia, directora de la segunda cadena. Un conflicto por saber, a quién competía en última instancia, el programa: si a la propia directora de la segunda cadena o a José Luis Balbín. La clave se había integrado al área de informativos, dependiendo de Enrique Vázquez, lo que suponía escapar del control de Clara Isabel Francia. El conflicto acabó cuando esta última presentó su dimisión como directora de la segunda cadena en octubre de $1983^{111}$.

\subsection{La etapa final de La clave (1983-1985)}

La última etapa del programa se inició con la destitución de José Luis Balbín de los Servicios Informativos en septiembre de 1983, y finalizó con la supresión definitiva del programa el 27 de diciembre de 1985. El último programa, prohibido en Televisión Española, se celebró en un céntrico hotel de Madrid, sin película previa, y abarrotado de gente. Se debatió sobre la OTAN y giró en torno a la libertad de expresión. En esta etapa de poco más de dos años, La clave emitió 155 programas y se prohibieron dos. José Luis Balbín inició la etapa con unas declaraciones argumentando que hubo tres temas prohibidos con Eugenio Nasarre: el aborto, los militares republicanos y el Opus Dei. Con el partido socialista recibían presiones «incluso de la ejecutiva (...). Antes no solo había presiones, había también órdenes. Ahora, en cambio, hay presiones y no consiguen lo que quieren» ${ }^{112}$. Sin embargo, el mismo día de las

\footnotetext{
${ }^{109}$ En junio de 1983, un centenar de trabajadores, miembros de cooperativas agrarias, ocuparon dos fincas del patrimonio expropiado a Rumasa que derivaron en acciones de protesta, "Crece la presión de los campesinos en Andalucía", $A B C$, 14/06/1983, p. 14.

${ }^{110}$ Criticaron el programa «en tres niveles: la oportunidad -ipor qué se aleja, desde el cambio socialista de las urgencias dialécticas de la vida española?-; el tratamiento -iqué retórico, satrápico, pedantesco, insuficiente, distanciado de los datos profundos y no en los de oficio de almanaque nos parece el hilo conductor!-, y, por último, la intención del mensaje, proclive siempre a la indicación pro comunista. (...) No entramos en problemas internos del mismo programa, para no echar leña al fuego, en relación con el nepotismo, el amiguismo y la promoción política manipulada (...). La clave y Balbín, ya no valen, seguramente. Dejen paso a otros», "El fin de La clave", $A B C, 11 / 10 / 1983$, p. 101.

${ }^{111}$ Fuente: "Clara Isabel Francia: una dimisión no política, sino profesional", Mediterráneo, 14/10/1983, p. 33.

${ }^{112}$ Mediterráneo, 27/09/1983, p. 37.
} 
declaraciones se produjeron nuevas dimisiones como la del director de TVE Antonio López y la de ocho responsables del área técnica de TVE ${ }^{113}$.

Liberado del cargo directivo, destacamos los meses finales de 1983 como uno de los finales de año de mayor calidad en la historia del programa y de la televisión. En noviembre de 1983, el programa realizó una clave histórica y una clave política que serán analizadas en nuestro último capítulo. Se trató de El Valle de los Caídos (ficha 299), y La difícil convivencia (ficha 300), con la que se conmemoraban los 300 programas en antena. El Valle de los Caídos (ficha 299), giró en torno al gigantesco mausoleo que el general Francisco Franco ordenó construir al finalizar la Guerra Civil, y en el que trabajaron presos políticos. En este coloquio observaremos la idea de las dos Españas como dos posiciones enfrentadas sobre su historia inmediata. También La difícil convivencia (ficha 300) giró en torno a la bipolarización, el bipartidismo, la paz y la política de bloques. Se proyectó la película polaca Muerte de un presidente (Śmierć Prezydenta, Jerzy Kawalerowicz, 1977), utilizada en otros debates. Los invitados fueron Emilio Romero, Jordi Solé Tura, Ramón País, Manuel Fernández-Monzón, Fernando Castedo, Guido Brunner, Blanca Andreu y Carmen García Bloise.

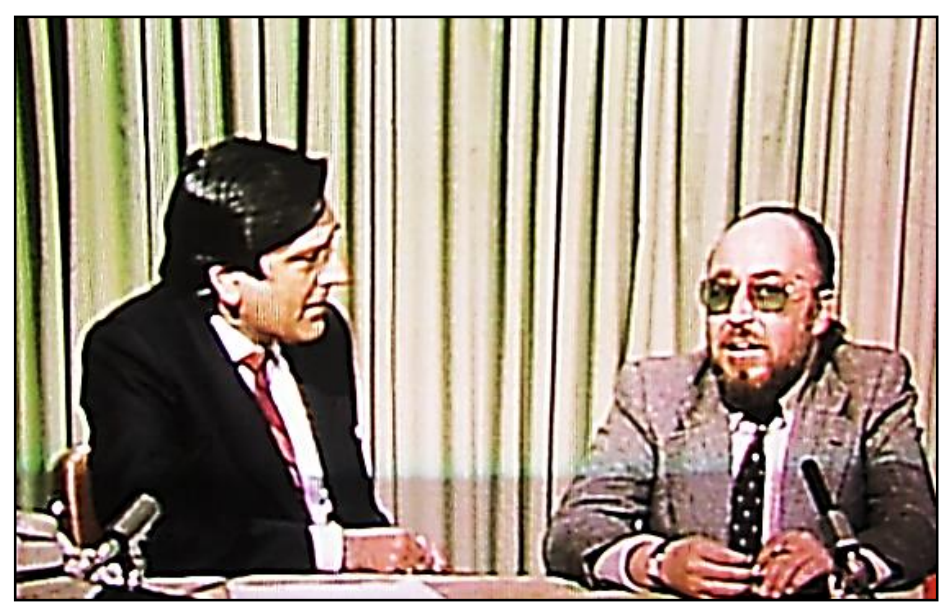

Fotografía no 14 . Javier Vázquez entrevista a Miguel Ángel Toledano durante La difícil convivencia (ficha 300). Fuente: Archivo de RTVE.

Javier Vázquez inició el programa con un resumen de La clave desde su fundación con imágenes de la celebración que había tenido lugar la noche anterior en Madrid. A continuación, entrevistó a Miguel Ángel Toledano (uno de los responsables directos que hizo posible el

\footnotetext{
${ }^{113}$ Fuentes: "Antonio López dimite como director de TVE", $A B C$, 27/09/1983, p. 27, y "El cese del director de televisión origina dimisiones en cadena”, Mediterráneo, 5/10/1983, p. 31. «López puso su cargo a disposición del director general, según todos los indicios, porque se encuentra en desacuerdo con la política que ha seguido la alta dirección de RTVE, y en concreto con la resolución que se dio al caso del director de Informativos, José Luis Balbín, destituido la pasada semana», "Antonio López dimite como director de televisión Española, cinco días después del cese de Balbín”, El País, 27/09/1983. En sustitución de Antonio López fue nombrado Ramón Criado.
} 
surgimiento del programa en 1975), quien argumentó el porqué de la necesidad de un programa como La clave a inicios de la transición hacia la democracia: «La necesidad primordial era que hubiese un lugar, un sitio donde los españoles pudiesen discutir, expresarse con libertad, decir cuáles eran sus opiniones y contrastarlas» ${ }^{114}$.

El 16 de diciembre de 1983 La clave debatió Mujeres y política (ficha 303). Se proyectó la película Mi hija Hildegart (Fernando Fernán-Gómez, 1977), basada en el libro Aurora de sangre (vida y muerte de Hildegart) de Eduardo de Guzmán (1972), sobre los hechos que convulsionaron a la opinión pública en 1933 por la muerte de la niña Hildegart a manos de su madre Aurora Rodríguez. El movimiento feminista, el machismo, la discriminación, los distintos valores socializadores para el hombre y la mujer, el lenguaje, la independencia económica, el maltrato, y la necesidad de una ley de igualdad, fueron algunas de las líneas por las que discurrió el debate. Por primera vez en La clave, entre los invitados, hubo más mujeres que hombres. José Luis Balbín, hizo referencia al bajo número de mujeres en el programa, lamentando que «la fuerza de la mujer no está suficientemente representada en las instituciones y organismos públicos». Si bien es cierto, La clave no evitaba, sin embargo, unas diferencias de género que provenían más del contexto social y el status creado de la mujer que de la representación en organismos públicos ${ }^{115}$.

Para Amparo Rubiales dos elementos eran fundamentales para el cambio: la educación y el factor económico, y para Carmen Llorca, «dada la importancia de la televisión en la configuración de los modelos sociales, ¿cómo es que se permite que una ingente cantidad de anuncios publicitarios exploten la imagen de la mujer-objeto con fines exclusivamente comerciales?». Entre los invitados no faltaba quien representara la figura machista -en este caso, el escritor Juan Benet- que durante el debate argumentaría que «el papel de la mujer reside en elegir al macho» ${ }^{116}$.

Los hechos demostraban la situación especialmente desfavorable de la mujer: baja representación en el interior de los partidos políticos (y por tanto su acceso a ellos), desigualdad y falta de oportunidades en la incorporación en el mercado de trabajo, y a mismo trabajo diferente remuneración... La clave finalizó el año con La navidad también produce (ficha 304), debatiendo en torno al movimiento económico que se produce durante las fiestas de navidad.

\footnotetext{
${ }^{114}$ Miguel Ángel Toledano. Centro de Documentación RTVE. La difícil convivencia (ficha 300). Emisión: 25 de noviembre de 1983.

115 Véase la obra de S. de Beauvoir, Le Deuxième Sexe, Gallimard, París, 1949.

${ }^{116}$ Centro de Documentación RTVE. Mujeres y política (ficha 303). Emisión: 16 de diciembre de 1983.
} 
Si en 1977 ABC había calificado La clave de «estelar», en 1984 lo hizo con «un rotundo suspenso» ${ }^{117}$.

A inicios de 1984, La clave emitió El credo político (ficha 308), Alta sociedad (ficha 309), Seguridad aérea (ficha 311) ${ }^{118}$, y Seguridad social (ficha 317), que debatió sobre mendicidad, con un mendigo entre los invitados. En prensa se dijo: «La clave debiera seguir emitiéndose todas las semanas, pero por la mañana y en circuito cerrado, sobre pantalla gigante instalada en el hemiciclo del Congreso de los Diputados. (...) A lo mejor, alguno se entera de que existe la mendicidad e incluso propone alguna forma inteligente de remediarla o cortarla definitivamente» ${ }^{119}$.

Entre algunos programas de ese año destacamos Francia-España (ficha 315), con la proyección de la película La guerra ha terminado (La guerre est finie, Alain Resnais, 1966), que narra las actividades de resistencia contra la dictadura de un destacado miembro del Partido Comunista afincado en París y sus viajes clandestinos a España ${ }^{120}$. El coloquio sirvió para debatir sobre los aspectos históricos, culturales, económicos y políticos entre ambos países, pero también era de viva actualidad. Tres días antes, en aguas del Atlántico, «dos pesqueros españoles habían sido ametrallados por barcos de guerra franceses» ${ }^{121}$.

De especial relevancia fue $A$ la democracia desde la dictadura (ficha 323) el 4 de mayo de 1984. Intervinieron líderes políticos como el expresidente español Adolfo Suárez, el expresidente militar de Argentina Alejandro Agustín Lanusse, el expresidente de Portugal Mário Soares, el exministro de Estado de Marruecos Abderrahim Bouabid, el líder intelectual de la Primavera de Praga Antonín Liehm, y el líder de la oposición en Paraguay Euclides Acevedo. Se proyectó la película ¡Viva Zapata! (Elia Kazan, 1952) sobre la biografía del

\footnotetext{
117 «Los programas de debate abusaron de los temas políticos, en los que se desahució a la oposición y se utilizó el oportunismo, que no la fidelidad a la actualidad profunda, en los temas propuestos. En La clave hay que ser rigurosos, por sus costes y extravagancia horaria. Balbín ha recibido indicios suficientes para pensar en jubilar el programa, que nació como imitación de un espacio informativo francés», "Aprobados y suspensos", $A B C$, 28/12/1983, p. 93 .

${ }^{118}$ Se debatió sobre el accidente aéreo ocurrido en Barajas en 1984 y en el que fallecieron 181 personas.

119 "La clave de La clave", Hoja del lunes, 2/04/1984, p. 47.

${ }^{120}$ Sobre las relaciones bilaterales con otros países, La clave dedicó dos años antes Portugal y España (ficha 250), al que siguió Claveles en abril (ficha 320), a raíz del décimo aniversario de la revolución de los claveles. También dedicó Geografías míticas: América (ficha 346), Alemania ¿Una, dos? (ficha 351) y África pendiente (ficha 383).

121 “Indignación general por el ametrallamiento de dos pesqueros españoles”, $A B C, 9 / 03 / 1984$, p. 5.
} 
revolucionario mexicano Emiliano Zapata ${ }^{122}$. ¿Qué es la dictadura? ¿Cómo se implanta? ¿Quiénes son los interesados en perpetuar este sistema? Unas preguntas que abrirían algunas líneas por las que transcurrió el debate como las vinculaciones económicas e internacionales de las dictaduras, los derechos humanos, la carrera de armamentos, el papel de la prensa, y la necesidad de una educación y aprendizaje en democracia. Volveremos a ella en el siguiente capítulo.

Una semana después realizó Impacto de los medios de comunicación (ficha 324), con la película El gran carnaval (Ace in the Hole, Billy Wilder, 1951). Se formularon preguntas como: ¿Quién posee los medios de comunicación? ¿Cuál es su impacto e influencia? ¿Qué es la información? ¿Quiénes son sus actores? Enrique Bustamante argumentó que «el poder de los medios de comunicación es simplemente un instrumento del poder político-económico». Añadió que en España el poder informativo giraba en torno a tres polos fundamentales: el Estado (que cada vez más perdía poder informativo), las empresas privadas (que cada vez ganaban más poder informativo y estaban ligadas a la banca y a la industria), y las multinacionales -preferentemente norteamericanas- (que controlaban la financiación a través de los contenidos y de agencias publicitarias). La financiación desde la publicidad, la importancia de las audiencias, la noticia como mercancía, el monopolio informativo, el sensacionalismo de los medios de comunicación, los líderes de opinión, el mito de la objetividad, la autocensura, el monopolio informativo, y las filtraciones del Gobierno a la prensa (la información que no se roba no es información, es propaganda, diría Bustamante), fueron algunos temas que se abordaron antes del primer corte publicitario.

Poco habitual era que un miembro del equipo de redacción preguntara en la sección de los telespectadores, una excepción que creemos además relevante. «En el panel de aceptación de TVE, La clave ocupó habitualmente el primer lugar de la segunda cadena, hasta que empezó a aparecer dos veces, una referida a la película y otra al debate ¿No cree que tal decisión pueda deberse al número uno que tenía el programa en su conjunto?». José Luis Balbín diría que $L a$ clave no pretendía ser un programa mayoritario (lo fue por casualidad) y cuando comenzaron a hacerse encuestas (que no eran habituales en la segunda cadena), La clave era el de mayor audiencia. «La clave es un programa montado y preparado con una presentación para implicar

\footnotetext{
${ }^{122}$ Tras los procesos macartistas, Elia Kazan intenta mostrar cómo los líderes revolucionarios se corrompen cuando alcanzan el poder. Un relato más exhaustivo sobre la película, en B. Neve, Film and Politics in America: A Social Tradition, Routledge, Nueva York, 1992, pp. 191-194.
} 
a la gente según los personajes que haya, una película para que sea un incentivo, y un debate que es el fondo de la cuestión. Es el único programa que se encuesta separadamente» ${ }^{123}$.

Creemos importante señalar este argumento porque la razón oficial que ofrecerán los responsables de RTVE para suprimir definitivamente el programa en 1985 será la drástica bajada de audiencia ${ }^{124}$. Durante el debate, Enrique Bustamante argumentaría que era habitual su fragmentación porque se trataba de dos unidades de información con características cualitativas distintas. Sin embargo, la audiencia (concepto instrumental de los medios de comunicación), no solo era una forma de influencia, también una forma de legitimar el modelo comercial de la televisión ${ }^{125}$.

La clave realizó otros tres programas destacados y polémicos como Opus Dei (ficha 326) Impuestos ¿Para qué pagar? (ficha 327), y Anarquistas (ficha 328), en el que participó Federica Montseny. El más polémico fue, sin lugar a dudas, Opus Dei (ficha 326), con la proyección de la película La casa sin fronteras (Pedro Olea, 1972), que llevó al periódico ABC a dedicar toda la sección "Cartas al director" al programa emitido por La clave ${ }^{126}$. José Luis Balbín denunciaría meses más tarde en una entrevista que había comenzado a encontrar impedimentos para hacer correctamente el programa: habían reducido tres millones de pesetas del presupuesto, lo que mermaba en sus capacidades ${ }^{127}$.

En Salud para todos (ficha 332), debatieron sobre salud pública en un espacio precisamente no exento de humo. Dos semanas más tarde, el Grupo Popular, envió una carta al Consejo de Administración de RTVE manifestando su queja por permitir fumar delante de las cámaras. «No es lógico, por lo tanto, que se permita que en programas de tanta audiencia como

\footnotetext{
${ }^{123}$ Centro de Documentación RTVE. Impacto de los medios de comunicación (ficha 324). Emisión: 11 de mayo de 1984 .

${ }^{124}$ Los estudios de audiencia obedecen a unas razones y a unas directrices de las empresas de televisión. Fragmentar un programa en distintas unidades de medición es un instrumento que sirve también de manipulación informativa. Los programas, fragmentados previamente, sirven a las cadenas para publicitar los mejores datos de audiencia. En el caso de La clave, esta fragmentación sirvió en 1985 de justificación para alegar la bajada de audiencia y poder suspender el programa.

${ }^{125}$ La bibliografía recomendada: Un mundo, voces múltiples. Comunicación e información en nuestro tiempo (Seán MacBride, 1980), El uso de la comunicación social por los españoles (M. Martín Serrano, 1982), y La persuasión en la comunicación (Kathleen K. Reardon, 1983). Este programa conllevó las habituales críticas desde la prensa, "Balbín «comunicólogo»", $A B C, 14 / 05 / 1984$, p. 86.

${ }^{126}$ Véase "Cartas al director", $A B C, 29 / 05 / 1984$, p. 14. «Quizá la clara tendenciosidad del mismo presentador en los planteamientos temáticos y de protocolo de invitados (...) cuando no de "corte y confección" a quienes no sirvan las que parecen ser motivaciones profundas del espacio: radicalizar a la izquierda, desnaturalizar la democracia liberal y abrir competencias proselitistas a sus amigos de Moscú. Y si no vídeos. Si es que se conservan...», “¿A quién sirve La clave?”, ABC, 28/05/1984, p. 101.
}

${ }^{127}$ Fuente: $A B C, 4 / 08 / 1984$, p. 77. 
La clave haya a veces que apartar el humo para ver a los invitados; humo que por otra parte, sale en su mayoría de la flamante pipa del propio presentador» ${ }^{128}$. A este respecto, José Luis Balbín argumentó posteriormente: «yo impuse que los invitados pudieran beber y fumar, para que se sintieran a gusto y se relajaran. Era mucho tiempo en el plató» ${ }^{129}$. «Claro, traes a unos señores y los tienes allí varias horas, entre la presentación del coloquio, la proyección de la película y después el debate propiamente dicho, mirando a la cámara, hablando y sin beber y fumar..., aquello no podía dar la impresión de naturalidad que necesitábamos»» ${ }^{130}$.

En octubre de 1984 La clave realizó una clave histórica que analizaremos en nuestro último capítulo titulada La revolución de Asturias (ficha 345), con la proyección de la película Octubre (Oktyabr, Sergei M. Eisenstein, 1927). Tras ella, dedicó un programa a Dalí (347) con motivo de la salida del pintor del hospital tras las quemaduras sufridas en un incendio en su residencia y, siguiendo la actualidad política internacional, Elecciones "Made in USA" (348), sobre las elecciones presidenciales en EEUU. En la entrevista pudimos preguntar a José Luis Balbín sobre qué programa tuvo especial relevancia para él, y su respuesta fue ;Qué sabe nadie! Las folklóricas (ficha 352$)^{131}$.

Por último, también tendremos en cuenta en el siguiente capítulo la clave política que realizó a finales de 1984 con el título Lo que va de ayer a hoy (ficha 356). En ella se debatió en torno al proceso de transición en España. Se proyectó la película-documental Informe general sobre algunas cuestiones de interés para una proyección pública (1976), del director Pere Portabella, quien se encontraba entre los invitados junto a Rodolfo Martín Villa, Santiago Carrillo, José Prat (exsenador del PSOE), Luis Rufilanchas (PSOE), Eugenio del Río (Movimiento Comunista de España) y Enrique de la Mata (exsecretario del Consejo del Reino).

\footnotetext{
128 “Los humos de Calviño", $A B C, 19 / 07 / 1984$.

129 “José Luis Balbín: «Me jugué la vida a los chinos»”, La Razón.es, 29/11/2012.

${ }^{130}$ José Luis Balbín, en F. J. Satué, Los secretos de la Transición, op. cit. p. 489. Los fuertes intereses económicos de la industria tabaquera comenzarían a contrarrestarse en 2005 con la ley antitabaco (en vigor el 1 de enero de 2006), que prohibía fumar en los centros de trabajo (endureciéndose en 2011), con la prohibición de fumar en cualquier espacio de uso público. Según el artículo 9 de la ley 42/2010, "se prohíbe en todos los medios de comunicación, incluidos los servicios de la información, la emisión de programas o de imágenes en los que los presentadores, colaboradores o invitados aparezcan fumando".

${ }^{131}$ Programa en el que participaron entre otros, Manuel Vázquez Montalbán, Juanito Valderrama y las cantantes Lola Flores y Marifé de Triana. Se proyectó la película Los Tarantos (Francisco Rovira Beleta, 1963), tercera película española nominada al Oscar a mejor película extranjera de habla no inglesa, basada en la obra de teatro de Alfredo Mañas, Historia de los Tarantos (1962). Sirva como ejemplo la respuesta de Lola Flores a una pregunta de un telespectador sobre su abandono de la bata de cola. «QQué yo he abandonado la bata de cola? (...) pero si ese es mi seño personal (...) y moriré con ella. No en el escenario, por supuesto, haré lo posible pa que no, pero a lo mejor pido que en la caja me la metan... La bata de cola»", que llevó a las risas de todos los asistentes.
} 


\subsubsection{La supresión definitiva de 1985}

1985 fue el último año de La clave. Se emitieron 51 programas, siendo el último prohibido. Ese año, La clave colaboró con el departamento de cine de TVE $^{132}$. Entre algunos programas destacó Pluralismo informativo (ficha 368), con la participación de cuatro invitados a favor de la televisión privada y tres a favor de la pública. Entre estos últimos, figuraba el director general de RTVE José María Calviño, para quien la televisión había dado un cambio cualitativo desde su llegada. «El objetivo era transformar un medio que fue concebido como instrumento de propaganda política en un medio de información plural, de participación y de presencia de los grupos sociales más representativos» ${ }^{133}$. Durante el coloquio se argumentó que el $80 \%$ de la información que había en el mundo procedía de tres grandes agencias (las estadounidenses Associated Press y United Press International, y la inglesa Reuters, de las que se abastecía la española Efe). El predominio de las agencias de noticias internacionales sobre los flujos informativos y su vigencia como modelo comunicacional provocaba que la selección, elaboración y transmisión pudiesen ir en consonancia con los intereses geopolíticos, llevando a los periodistas a no saber distinguir entre noticia y propaganda ${ }^{134}$.

Había cierta expectación por ver precisamente la reacción que tendría José María Calviño con José Luis Balbín. Desde la dimisión de los Servicios Informativos habían comenzado a evidenciarse discrepancias entre $\operatorname{ambos}^{135}$. En relación a las palabras pronunciadas por José Luis Balbín en la Comisión de Control Parlamentario el 27 de noviembre de 1984, «que TVE está al servicio del aparato del PSOE, el director general pidió a Balbín que presentase las pruebas en que fundamenta su afirmación o, en caso contrario, que se calle» ${ }^{136}$. Pero como era habitual, José Luis Balbín se dedicó a moderar el debate sin participar en él.

Una de las claves políticas más destacadas del programa fue la realizada el 19 de abril de 1985 con el título OTAN, de salida ¿qué? (ficha 373). El título que escogió el programa hacía referencia a la ambigüedad del eslogan del partido socialista en el que basó su campaña

\footnotetext{
${ }^{132}$ Centro de Documentación RTVE. Avance programa especial de navidad. Emisión: 22 de diciembre de 1984.

${ }^{133}$ Centro de Documentación RTVE. Pluralismo informativo (ficha 368). Emisión: 15 de marzo de 1985.

${ }^{134}$ Antonio Asensio (presidente del grupo Z), argumentó que «el pluralismo informativo lo marca el mercado».

${ }^{135}$ Muchas de estas discrepancias se filtraron en prensa: «Las causas que han movido al director de La clave a volverle la espalda a Calviño son, según confiesa, que la actual dirección general está sirviendo de una forma incondicional al aparato del PSOE», "Tensiones entre Calviño y Balbín”, $A B C, 3 / 11 / 1984$, p. 68.

136 "Calviño se justifica ante la Comisión de Control Parlamentario", $A B C, 28 / 11 / 1984$, p. 107.
} 
electoral de 1982: "OTAN, de entrada no"137. Una vez ganadas las elecciones, el gobierno de Felipe González fue cambiando de posición hasta considerar que sacar España de la OTAN tendría consecuencias adversas ${ }^{138}$. En abril de 1985, Felipe González, bajo presiones -también desde su partido-, fijó la fecha del referéndum para marzo de 1986. Como argumentan Manuel Palacio y Carmen Ciller, a partir de este programa, las relaciones de José Luis Balbín con el partido socialista se deterioran (Palacio y Ciller 2014: 234). Efectivamente, esta emisión fue el punto de no retorno entre el programa y el partido socialista. Será necesario, por tanto, un análisis de la emisión en mayor profundidad que nos permita ofrecer datos relevantes y el contexto para entender la supresión definitiva del programa a finales de 1985. En la entrevista realizada por Francisco J. Satué, José Luis Balbín hablo de las dos únicas veces que se posicionó el programa: «Nosotros nos pronunciamos ante el público en dos ocasiones, solo dos veces. (...) sobre la pena de muerte, y me signifiqué en contra. (...) La otra vez fue sobre la OTAN» ${ }^{139}$.

Este será el contexto cuando La clave realice el programa; siendo uno de los debates de mayor altura dialéctica. José Luis Balbín consiguió en esta emisión culminar una de las aspiraciones iniciales del programa: realizar producción propia. Se proyectó el documental Hilos de una trama (José Luis Egea, 1985) ${ }^{140}$. El documental se inició y finalizó con extractos de la obra de Adolf Hitler Mi lucha (Mein Kampf, 1925). Escrito y dirigido especialmente para La clave, el documental recogía declaraciones realizadas por Felipe González como «hay que dejar claro que el ingreso de España en la OTAN no añade, a mi juicio, nada a la seguridad nacional», así como escenas que mostraban imágenes desde el aire de la cadena humana formando la frase OTAN NO. BASES FUERA, de la concentración por la paz y el desarme producida en Madrid el 15 de noviembre de 1981. Fue la primera -y última- que La clave realizó producción propia.

José Luis Merino salió en pantalla para indicar que durante la semana habían recibido numerosos correos de los espectadores y se estaban recibiendo más preguntas de lo habitual. En la introducción, José Luis Balbín volvió a criticar que ya no quisieran venir a La clave los

\footnotetext{
137 Sobre la ambigüedad del eslogan, Luis Solana, diputado del PSOE por Segovia (hermano del ministro de Cultura Javier Solana, y futuro director general de RTVE en 1989), escribió en Diario 16 que no existía tal ambigüedad: «No, no es ambiguo el mensaje del PSOE. Allá ellos con su OTAN pero nosotros no queremos entrar, nos parece malo para España y para la paz. ¡Ya lo creo que son claros los cartelones socialistas!», "OTAN, de entrada no", Diario 16, 24/09/1981. El 5 de diciembre de 1995, su hermano Javier Solana se convirtió en el nuevo secretario general de la Organización del Tratado del Atlántico Norte (OTAN).

138 Véase "La izquierda ante la OTAN", en Ayer, no 103, Marcial Pons, 2016.

${ }^{139}$ F. J. Satué, Los secretos de la Transición, op. cit. p. 494.

${ }^{140}$ Este documental, dividido en ocho episodios, se encuentra en los archivos de RTVE junto al programa.
} 
socialistas: «no ha venido uno desde que han ganado (...) nos gustaría estar informados». Entre los asistentes, partidarios del sí a la OTAN como el historiador Ángel Viñas (asesor del ministro de Asuntos Exteriores Fernando Morán), y partidarios del no como Ramón Tamames o José María Mohedano. Viñas, defensor de la posición del Gobierno, los calificó de demagógicos y afirmó que si se tenían en cuenta las afirmaciones de sus principales líderes en los últimos cinco años, el PSOE no era anti-OTAN. Ramón Tamames le respondió: «Me parece muy bien que usted esté en unos despachos muy alfombrados y con muebles muy caros, pero eso no le permite a usted utilizar la palabra demagógico tres veces y dirigirse a mí de esta forma. Así que le ruego un poco de educación, que es lo que una persona como usted debería empezar a tener. Según las encuestas más del $50 \%$ no quiere que haya bases norteamericanas en España, ni que pertenezca a la OTAN. El referéndum se ha movido. No hay fecha, ni pregunta clara, ni decisión que sea vinculante. Así que señor Viñas, procure usted no volver a incidir en ese tono y tengamos la noche tranquila» ${ }^{141}$.

El documental era un claro alegato en contra de la entrada de España en la OTAN, como manifestó José Luis Balbín durante el debate, y algunos invitados lo calificaron de partidista. José Luis Egea, director del documental, participó “desde la distancia”, «pues se me colocó en otro lugar distinto al plató en que se grababa la conversación entre los invitados» ${ }^{142}$. «Propuse al responsable de Cultura del diario El País escribir un artículo en la sección "Tribuna Libre" explicando mi punto de vista acerca del trabajo realizado por mí en el documental, pero por parte del periódico se rechazó total y frontalmente esa posibilidad contradiciendo flagrantemente el nombre de su sección periodística» ${ }^{143}$.

\footnotetext{
${ }^{141}$ Centro de Documentación RTVE. ¿OTAN, de salida qué? (ficha 373). Emisión: 19 de abril de 1985.

${ }^{142}$ Conversación con José Luis Egea, 9/05/2013. Le pregunté sobre el grado de libertad que tuvo para realizar este documental y si tuvo alguna indicación previa de José Luis Balbín. Esta fue su respuesta: «por parte de Balbín siempre tuve claro que podría actuar con la más absoluta libertad de escritura, realización, edición y sonorización de ese documental (...). Cuando fui a TVE para formalizar el contrato, la persona con la que traté fue Julián Cortés Cavanillas, un buen compañero de la especialidad de Producción en la Escuela Oficial de Cinematografía de Madrid, en la que yo estudié Dirección Realización. Poco después, en una segunda o tercera entrevista con Cortés Cavanillas, tuve una primera intuición de que algo 'raro' estaba empezando a suceder. Lo que me hizo pensar esto fue una pregunta que me deslizó Julián acerca de que si el documental iba a ser 'demasiado' en contra de la permanencia de España en la OTAN. Yo estaba empezando a realizarlo, por lo que cualquier afirmación en cualquier sentido era francamente prematura, y así se lo hice ver. Por otro lado, no entendía bien lo que ese 'demasiado' podría significar, aunque por supuesto me lo temía. La cosa no pasó entonces de ahí».

143 Conversación con José Luis Egea, 9/05/2013. «Hubo otra serie de pequeñas 'rarezas' en el transcurso de mi trabajo, que paso a exponer. Por motivos obvios e inherentes a la propia naturaleza del documental, la base narrativa de Hilos de una trama tenía que estar hecha con material de archivo. Por lo tanto, la búsqueda en los archivos de imagen de TVE era de primerísima importancia. (...) El caso es que, tiempo después y a lo largo de varios años, he tenido ocasión de ver por televisión las mismas imágenes de archivo que nosotros utilizamos pero con una mucha mayor calidad y duración de la que a nosotros se nos facilitó. Incluso algunas de ellas las he podido ver en color, cuando a nosotros se nos entregaron en un blanco y negro muy defectuoso. De todas formas, lo más
} 
En el coloquio se abordaron los costes de la OTAN, el cambio de opinión del PSOE, la política de defensa, el control de la OTAN por EEUU, los servicios de inteligencia... Se recibieron 550 preguntas, el programa se alargó 30 minutos más de lo habitual, y finalizó con la habitual bibliografía ${ }^{144}$. Fue un programa que tuvo una enorme repercusión, previo a las numerosas protestas y manifestaciones en contra de la OTAN de mayo de 1985, como la producida con la visita a España del presidente norteamericano Ronald Reagan.

Tras este programa, y tal vez por unas posibles críticas gubernamentales, La clave realizó Prohibido prohibir (ficha 375), sobre el intervencionismo del Estado, y El intelectual y la política (ficha 378), que se inició con la canción "Diguem no", del cantautor valenciano Raimon $^{145}$, invitado al programa junto a Alfonso Guerra (vicepresidente del gobierno), el escritor K. S. Karol y Antonín Liehm (líder intelectual de la Primavera de Praga). El debate se inició con la noción de intelectual orgánico según Gramsci, Max Webber y Noam Chomsky, y también se abordó l'affaire Dreyfus y la necesidad de un compromiso político ${ }^{146}$. Algunas de las preguntas formuladas fueron: ¿Qué es la intelligentsia? ¿Cuál es el papel del intelectual? ¿Debe comprometerse el intelectual en política? Calificaron de intelectuales figuras como Víctor Hugo, Jean-Paul Sartre, José Ortega y Gasset, Lenin, Trosky, Emilio Castelar, García Lorca... que le valieron una nueva crítica desde $A B C^{147}$.

El 12 de junio de 1985, España se integró oficialmente a la Comunidad Económica Europea (CEE) con la firma del tratado en el Palacio Real de Madrid. La clave dedicó un programa a la Crisis del gobierno (ficha 386), y otro a El sida (ficha 396), con la película Muerte en Venecia (Morte a Venezia, Luchino Visconti, 1971). De nuevo, una emisión pionera por la temática y por el tratamiento ya que nunca se había debatido en televisión sobre el sida (Síndrome de Inmunodeficiencia Adquirida). El debate giró en torno a su transmisión,

extraño de todo fue la desaparición de la noche a la mañana de un material que nos facilitaron en el archivo de TVE y que nosotros manteníamos colocado en las estanterías de la sala de edición. Se trataba de unas imágenes acerca del 'peligro comunista' hechas por los servicios de propaganda de la CIA en los años 50 (...). Nunca nadie de TVE nos pudo explicar quién, cuándo y cómo había desaparecido de la sala de edición dicho material, que nunca más pudimos nosotros encontrar ni ellos buscar».

144 Ángel Lobo, OTAN y España. El precio de una alianza (1981). Fernando de Salas, ¿Nos interesa la OTAN? (1981). VVAA, “La política de defensa española y la OTAN”, en Ideas para la democracia, n 1 (1984).

145 Sobre la canción protesta véanse, J. Turtós y M. Bonet, Cantautores en España, Celeste, Madrid, 1998, y D. Escamilla, Raimon, l'art de la memòria, Planeta, Barcelona, 1994.

${ }^{146}$ Centro de Documentación RTVE. El intelectual y la política (ficha 378). Emisión: 24 de mayo de 1985. Javier Muñoz Soro destaca la crisis de la cultura progresista en los años sesenta y cómo el intelectual universal es remplazado por especialistas en los setenta (Muñoz Soro 2011a: 22).

${ }^{147}$ En ella calificaban a José Luis Balbín de «mano soviética de Calviño», “QQué hacemos con la segunda?”, $A B C$, 11/06/1985, p. 117. 
prevención y posibles soluciones, apostando La clave por una educación preventiva. Ese mismo mes, el fallecimiento del actor estadounidense Roy Harold Scherer (más conocido como Rock Hudson), conmocionaría a la opinión pública internacional incrementando la atención sobre lo que todavía entonces se consideraba una extraña enfermedad.

El 25 de octubre de 1985 La clave celebró Las 400 claves (ficha 400), con invitados que ya habían estado en el programa (José Luis Sampedro, Cristina Almeida y Heleno Saña) y nuevos invitados como Gerardo Iglesias (secretario general del PCE desde 1982), y Fernando Arias-Salgado (exdirector general de RTVE). Al finalizar el programa preguntaron a AriasSalgado por la suspensión de La clave en 1980. Asumió la responsabilidad de la suspensión y lamentó las dificultades impuestas, que se debían a la importancia, impacto e influencia del programa en aquella época. «La televisión tiene una influencia extraordinaria en el país, en la sociedad española. Quizás se sobrevalora su importancia, pero el Gobierno presiona y tiene un contexto de preocupación» ${ }^{148}$.

Durante el debate, Javier Lacarra (jefe de coordinación de La clave en 1976) argumentó que lo que más preocupaba a la administración era el directo. Otro de los invitados, José María Marcos Lefler, espectador asiduo del programa, argumentó que La clave no tenía nada que envidiar a ninguna universidad pues funcionaba como una cátedra gratuita y cómoda para los telespectadores. Para Cristina Almeida La clave ayudó a la normalización de la vida cotidiana, a cambiar los esquemas y a normalizar los debates. Se recordaron algunos de los momentos del programa durante los diez años de debates como las discusiones y enfrentamientos entre algunos invitados. José Luis Balbín volvió hacer autocrítica ante la poca representatividad de la mujer en el programa, y anunció un debate sobre la Guardia Civil, que finalmente no hizo.

Sí hizo (aunque en diferido) el programa Militares hacia la democracia (ficha 401). Había sido grabado tres meses antes, y entre los invitados figuraba un miembro la organización militar clandestina Unión Militar Democrática (UMD). Se trataba de Luis Otero, que fue expulsado del Ejército y condenado a ocho años de prisión. Todavía en 1985, la UMD era un tema tabú en TVE. José Luis Balbín inició la presentación diciendo que le parecía una postura heroica, para dar paso a una lista de aquellos que no habían querido asistir ${ }^{149}$. Entre los que

\footnotetext{
${ }^{148}$ Fernando Arias-Salgado, Centro de Documentación RTVE. Las 400 claves (ficha 400). Emisión: 25 de octubre de 1985. Se proyectó la película Un rostro en la multitud (A Face in the Crowd, Elia Kazan, 1957).

${ }^{149}$ Nombró una larga lista en la que figuraban Narciso Serra (ministro de Defensa), el general Juan Luis Cano Hevia (exdirector de la Escuela Superior del Ejército), Alberto Oliart (exministro de Defensa), Leopoldo Calvo Sotelo (expresidente del Gobierno), y los generales Iniesta Cano y José Joaquín Prieto. El Coronel Luis Hernández del Pozo llamó al programa para decir que tenía prohibida su asistencia.
} 
asistieron, Jorge Verstrynge (secretario general de AP), Guillermo Galeote (presidente de la Comisión de Defensa del Congreso de los Diputados), y José Luis Buhigas (miembro del PCE). Durante el coloquio se abordaron temas como el militarismo como ideología, el golpe de Estado, la UMD, la OTAN, la democracia real, los servicios de inteligencia, la Guardia Civil, el patriotismo y «el peligro separatista» ${ }^{150}$, finalizando con la habitual bibliografía ${ }^{151}$.

La última clave histórica del programa que analizaremos en nuestro último capítulo fue Francisco Franco (ficha 402) y la película Caudillo (Basilio Martín Patino, 1977). Le siguió El Estatuto de RTVE (ficha 403), con el estreno en televisión de la película El asesinato de la hermana George (The Killing of Sister George, Robert Aldrich, 1968). Algunas de las preguntas formuladas durante el debate fueron: ¿Por qué reformar el Estatuto si éste no ha sido aplicado?, o ¿qué televisión va a haber en el futuro en España? Durante el coloquio se hicieron referencias a las misiones fundacionales de la televisión (informar, educar y entretener), a la necesidad de una televisión cultural, formativa e informativa como servicio público, a la independencia del medio, su credibilidad, y el modelo de televisión por el que debía guiarse TVE como la BBC inglesa, la televisión alemana y algunas cadenas privadas estadounidenses $^{152}$. Finalizamos este apartado precisamente con las palabras que José Luis Balbín utilizó al inicio del coloquio: «Hubo un tiempo en que no había la menor duda. La televisión era directamente del Gobierno. Todos los cargos eran nombrados por el Gobierno. Estaba sometida a los mismos rigores de censura que pudiera haber en otros medios de comunicación» ${ }^{153}$. Parecía indicar que aquel tiempo ya había acabado, pero todavía no sabía que en cinco emisiones La clave sería suprimida definitivamente de Televisión Española.

\subsubsection{Movida en el Palace}

Los rumores de una posible desaparición de La clave comenzaron a evidenciarse en Extranjeros en España (ficha 407), y especialmente Veinte años de Vaticano II (ficha 408), que fue el último programa en TVE. Se emitió el 20 de diciembre de 1985, y su director aprovechó

\footnotetext{
${ }^{150}$ Centro Documentación RTVE. Militares hacia la democracia (ficha 401). Emisión: 1 de noviembre de 1985.

151 Julio Busquets, El militar de carrera en España, Barcelona, 1971, y Manuel Ballbé, Orden público y militarismo en la España constitucional (1812-1983), Madrid, 1983.

152 También se abordó la influencia de la televisión, la necesidad de una ley de comunicación, y las injerencias directas de la política en los programas de debate e información.

${ }^{153}$ Centro de Documentación RTVE. El Estatuto de RTVE (ficha 403). Emisión: 15 de noviembre de 1985.
} 
la introducción para argumentar que nadie les había indicado nada y que estaban programando ya para inicios de 1986.

«Han dado a entender que La clave se acaba con el fin de año, y no es que yo lo diera a entender, sino que todo puede ocurrir, que esa es la cuestión. Nos queda el programa de la semana que viene pero lo cierto es que, en este momento, no sabemos absolutamente nada. Parece que otros saben más que nosotros, que es una cosa sorprendente, porque los responsables del programa somos nosotros y entre otras cosas, estamos preparando ya programas del mes de enero, entre otros, el primero, el del día 3, viernes, con el tema Pax, puesto que es el año de la paz y queremos abrirlo precisamente con ese tema» ${ }^{154}$.

La dirección de Televisión Española comunicó el 23 de diciembre que La clave no continuaba. Los responsables de TVE: Ramón Criado (director de TVE), Ramón Gómez Redondo (director de programación) y Enrique Nicanor (director de la segunda cadena), se reunieron con José Luis Balbín para anunciarle que el programa iba a ser suprimido en enero por razones de bajada de audiencia ${ }^{155}$. Resultados engañosos al presentar unos datos que, como hemos visto anteriormente, se debían al haber fraccionado el programa en dos bloques: uno para la película y otro para el debate. Sin embargo, en su conjunto, continuaba siendo el programa de mayor audiencia en la segunda cadena ${ }^{156}$. La emisión del viernes, titulada $\mathrm{La}$ movida sería, por tanto, la última emisión de La clave.

La movida pretendía ser inicialmente un debate sobre el movimiento cultural madrileño y para ello se proyectaría la película Pepi, Luci, Bom y otras chicas del Montón (Pedro Almodóvar, 1980). Los nombres de los invitados, personas relacionadas con dicho movimiento cultural, se publicaron en la prensa: Pedro Almodóvar, Moncho Alpuente, Antonio Lafuente, Pau Riba ${ }^{157}$. Nunca recibieron la invitación del programa porque una vez conocida la decisión de los responsables de Televisión Española de suprimir La clave de la programación (23 de diciembre), José Luis Balbín decidió cambiar los invitados y el tema del debate (que pasó a llamarse La movida nacional) ${ }^{158}$. En lugar de los invitados previstos, decidió llevar al programa

\footnotetext{
${ }^{154}$ Centro de Documentación RTVE. Veinte años de Vaticano II (ficha 408). Emisión: 20 de diciembre de 1985.

${ }^{155}$ Cfr. M. Palacio y C. Ciller, “La clave de TVE...”, en Estudios sobre el Mensaje Periodístico, op. cit. p. 234. Según datos procedentes del Estudio General de Medios, aludían la bajada de audiencia en casi dos terceras partes el último año. TVE facilitó una tabla de horas y audiencias en las que mostraba el descenso, pero no por ello dejaban de ser datos parciales al haberse fraccionado el programa.

156 José Luis Balbín dijo que se trataba de un ataque a la libertad de expresión y a la independencia profesional porque en televisión el tema de la OTAN no podía hablarse libremente. Fuente: $A B C, 24 / 12 / 1985$, p. 67.

157 “La Dirección de Televisión Española arremete duramente contra José Luis Balbín”, ABC, 27/12/1985, p. 70.

${ }^{158}$ Conversación con José Luis Balbín, Madrid, 18/08/2014.
} 
a cuatro partidarios del referéndum sobre la OTAN: Gerardo Iglesias (secretario general del PCE), Ramón Tamames (presidente de la Federación Progresista), José María Mohedano (abogado) y Alonso Puerta (el ex militante del PSOE vetado anteriormente en el programa Balance de los municipios de izquierda).

Los cuatro invitados confirmaron su asistencia el 26 de diciembre. José María Calviño, ordenó de inmediato la supresión del programa y el despido de su director. La dirección de TVE difundió ese día una nota para anunciar la sustitución de La clave por la película-musical Vuelve a mi lado (On a Clear Day You Can See Forever, Vincente Minnelli, 1970) ${ }^{159}$. El director del gabinete técnico de TVE declaró en $A B C$ que «al enterarse el director de programas de que Balbín había cambiado el tema del debate y los invitados para montar un show absolutamente personal, se decidió la suspensión, por considerar que dicha alteración es una falta de respeto y de arbitrariedad hacia la audiencia» ${ }^{160}$. El viernes 27 de diciembre, los medios nacionales se levantaron con un comunicado de TVE sobre la suspensión de La clave.

«Televisión Española comunica a todos los telespectadores que el programa La clave, que se iba a emitir hoy viernes por la segunda cadena, ha sido suspendido por decisión de la dirección. Las razones de esta suspensión radican exclusivamente en el injustificado y unilateral cambio de invitados y contenido de dicho programa respecto a lo previsto y anunciado. Dicho cambio de última hora, dictado por el hasta hoy entonces director de $L a$ clave, José Luis Balbín, supone, a juicio de la dirección de Televisión Española, un lamentable acto de arbitrariedad, así como una grave descortesía, tanto hacia los primeros invitados como hacia los espectadores en general. Televisión Española lamenta profundamente estos hechos, propiciados por quien entiende que la dirección de un programa equivale a la posesión de una patente de corso, sin otra ley ni otros límites que los caprichos o los intereses de quien la ejerce, y ruega disculpas, tanto a los primeros invitados como a los nuevos que hayan sido comprometidos por el hasta ahora director de La clave para utilizarlos como instrumento de sus propios intereses» ${ }^{161}$.

José Luis Balbín había declarado que el tema previsto lo había comunicado a la dirección de TVE hacía dos semanas y, aunque reconoció que la lista de invitados había variado,

\footnotetext{
${ }^{159}$ Nota que fue reproducida en prensa: «La dirección de TVE decidió anoche suspender el último programa de La clave, previsto para hoy, viernes, a causa del injustificado y unilateral cambio de invitados y contenido de dicho programa respecto a lo previsto y anunciado». El País, 27/12/1985.

${ }^{160} A B C, 27 / 12 / 1985$, p. 70.

${ }^{161}$ El comunicado ha sido extraído de la edición de $A B C$ Sevilla, 27/12/1985, p. 20.
} 
dijo: «Siempre sufre variaciones hasta que damos la lista definitiva» ${ }^{162}$. Al conocer la suspensión, anunció a los miembros del equipo La clave que tenía previsto realizar el debate a las ocho de esa tarde, en el Hotel Palace de Madrid. La idea de hacer el programa había surgido de los propios participantes la noche de la suspensión. Se realizaría sobre el mismo tema y con los mismos invitados, y sería abierto al público. Un centenar de personas se habían concentrado esa misma tarde frente a Torrespaña para protestar por la suspensión de La clave $e^{163}$.

\section{La última cena}

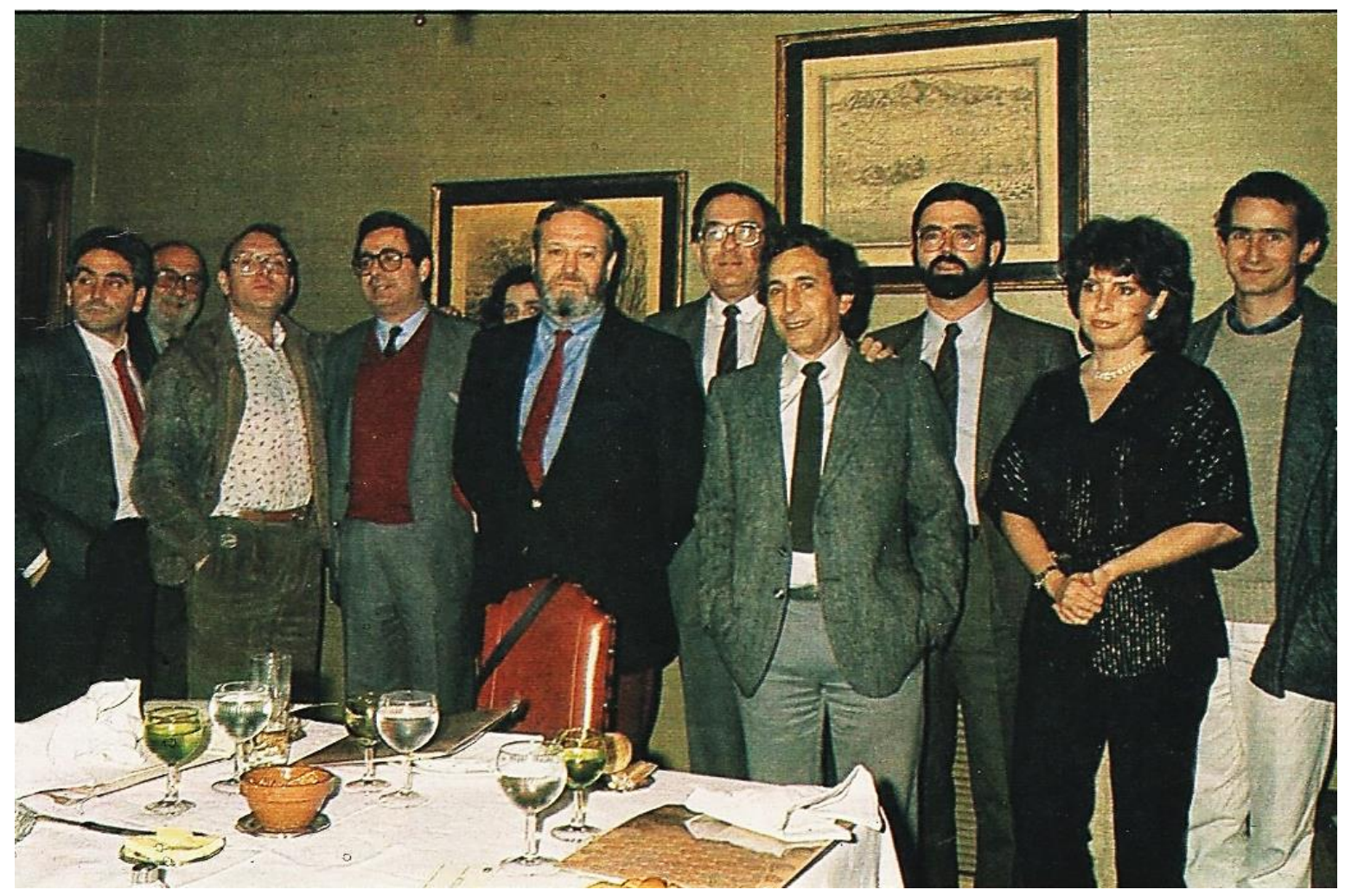

Fotografía $\mathrm{n}^{\circ}$ 15. José Luis Balbín y su equipo junto a José María Mohedano, Ramón Tamames y Alonso Puerta, el 26 de diciembre de 1985. Fuente: Interviú, $\mathrm{n}^{0} 503$ (31 de diciembre de 1985- 6 de enero de 1986), p. 91.

Fue así como se articuló el último debate: La movida nacional (ficha 408-B). Los invitados fueron José María Mohedano, Ramón Tamames, Gerardo Iglesias, Alonso Puerta, Fernando Castedo y Heleño Saña. Como nunca fue emitido en TVE no existe copia alguna en los archivos. Sin embargo, en la web puede verse un fragmento grabado por un espectador,

\footnotetext{
${ }^{162}$ Declaraciones de José Luis Balbín en El País 27/12/1985. Según fuentes del programa, habían sido invitados Felipe González (en calidad de secretario general del PSOE), Adolfo Suárez (secretario general del CDS) y Manuel Fraga (presidente nacional de AP), sin que hubieran recibido respuesta.

${ }^{163}$ La manifestación fue liderada por el PCE. Algunos portavoces argumentaron que la desaparición del programa suponía un nuevo intento de forzar el bipartidismo. «Un grupo de personas que participaron en pasados programas de La clave realizará hoy una protesta simbólica en Prado del Rey para expresar su disgusto por la desaparición del espacio. La protesta auspiciada por el PCE, consistirá en entregar al director general de RTVE, José María Calviño, el reloj que recibían como obsequio los participantes en dicho programa», $A B C, 27 / 12 / 1975$, p. 70.
} 
emitido en los años noventa en Antena 3 para un especial La clave. En el vídeo, cuya duración es de ocho minutos, hay fragmentos de la introducción y despedida de José Luis Balbín, así como una intervención de José María Mohedano. Se advierten ciertos aspectos a tener en cuenta, más cuando es la única grabación que se tiene del programa. En primer lugar, vemos cierta improvisación en un coloquio ajeno a las infraestructuras habituales en TVE. Podemos observar, además de los invitados, a una multitud de periodistas que abarrotan la sala y se entrecruzan en pantalla. Tras el aplauso de los asistentes José Luis Balbín dio inicio al debate con las siguientes palabras:

«En primer lugar, perdonen todos ustedes, pues la incomodidad del lugar..., pero la verdad es que más no se podía hacer en menos tiempo. La improvisación surgió de una idea anoche de los propios participantes que ya no podían y deberían participar en $L a$ clave de Televisión Española. Es evidente que ésta no es La clave de Televisión Española. Esta es sencillamente La clave».

Tras una breve pausa, continuó la introducción: «Quién nos ha visto y quién nos ve. En esta situación no nos vimos ni siquiera con en el régimen anterior [risas y aplausos]» ${ }^{164}$. El programa fue retirado definitivamente de TVE y José Luis Balbín despedido. Las reacciones sobre la suspensión no se hicieron esperar. La mayoría de los partidos políticos de la oposición se manifestaron en contra de la supresión del programa ${ }^{165}$. Tanto en radio como en prensa José Luis Balbín explicó las razones que se habían aducido para suprimir el programa: «No es correcto el pretexto de la disminución de audiencia. Los datos han sido manipulados y se han ocultado resultados de estudios de opinión y de audiencia (...). Voy a escribir un libro contando todos los casos sucedidos en La clave, con las correspondientes pruebas. Entre ellas el caso Alonso Puerta». Además denunció que «las presiones y decisiones se toman en Moncloa y luego son aplicadas en Televisión por los ejecutivos, el director general, el director del medio, y los directores de programas» ${ }^{166}$. José Luis Balbín acusó al Gobierno de intervenir en TVE

\footnotetext{
${ }^{164}$ A partir de ahí, otro fragmento muestra una intervención posterior de José María Mohedano, calificando La clave de símbolo de la Transición democrática y haciendo una dura crítica al PSOE: «el partido socialista está incapacitado para liderar el cambio social y político en España». El vídeo finaliza con su director despidiendo el programa. Se retransmitió por varias emisoras de radio y asistieron el presidente del Partido Demócrata Popular (PDP), Óscar Alzaga, y algunos diputados como Carlos Robles Piquer (exdirector general de RTVE), de quien José Luis Balbín, diría que «al menos nunca había suspendido La clave». ABC, 28/12/1985, p. 21. Óscar Alzaga calificó de despropósito no poder debatir de «temas sensibles que preocupan a la opinión pública, entre ellos, la gestión socialista en materia de libertades y el tema de la OTAN».

${ }^{165}$ El secretario general de Alianza Popular envió un telegrama a José Luis Balbín ante una medida «injusta e impopular» calificando a José Luis Balbín de «periodista de raza», $A B C, 28 / 12 / 1985$, p. 21.

166 "Las decisiones se toman en Moncloa y se ejecutan en Televisión”, $A B C, 28 / 12 / 1985$, p. 21.
} 
desde que llegó al poder: «me extraño de que algunos directivos de Televisión digan que el Gobierno no interviene, cuando esto no es verdad: desde el Gobierno se interviene, desde el primer día, y hay llamadas tanto del PSOE como del propio Gobierno» ${ }^{167}$.

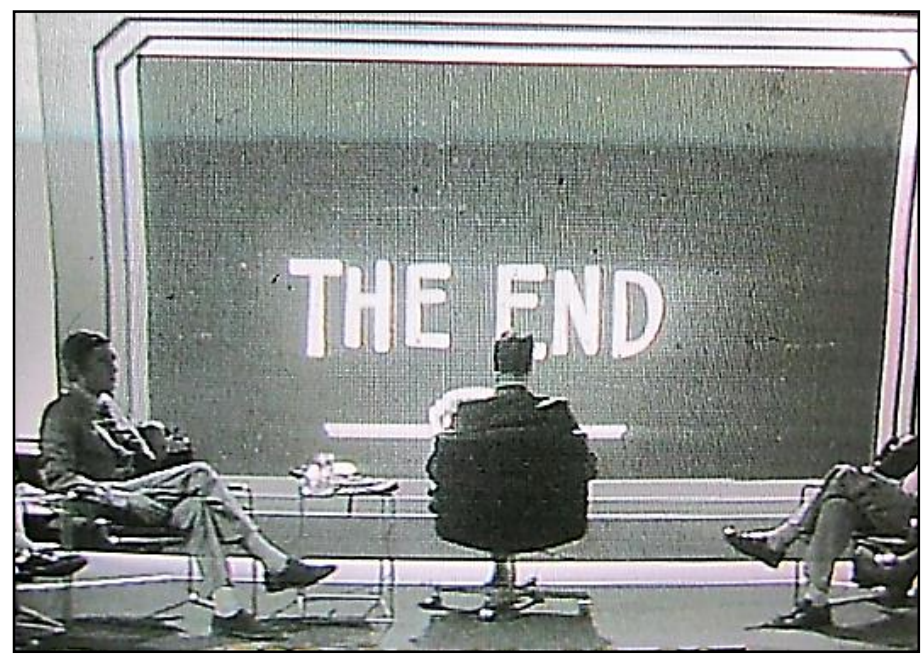

Fotografía n 16 . José Luis Balbín durante uno de los programas. Fuente: Centro de Documentación RTVE.

Tras diez años en antena y más de 400 emisiones finalizó definitivamente La clave. El programa que había estructurado el debate televisivo en España durante el proceso de Transición. Tras él, surgieron otros programas de similar formato (España, hoy, Tribuna de la historia, Sábado, cine...), que trataron de imitarlo en algunos aspectos. «En realidad me producía entonces una enorme tristeza que, por hacer un programa de televisión que no pretendía ir a favor ni en contra de ningún partido político, porque como periodista prefiero ser profesionalmente neutral, cada semana tuviera que acabar discutiendo con las más altas esferas del poder, a veces directamente con la Moncloa, o con el director general de turno» ${ }^{168}$.

Para finalizar el capítulo, es conveniente retomar el tema de la OTAN, pues, no solo fue uno de los temas más polémicos durante la Transición española, fue también el causante de la supresión definitiva del programa. España pertenecía a la OTAN desde el 30 de mayo de 1982. La polémica del referéndum surgió por el hecho de que el PSOE, antes de entrar en el Gobierno, se había manifestado en contra de su permanencia, y una vez en el poder, se posicionó en el sí al referéndum ${ }^{169}$. A diferencia de la mayor parte de programas de TVE (respaldando el sí que propugnaba el PSOE), La clave trató de hacer una emisión en contra de los intereses del gobierno; detonante para que los responsables decidieran suprimir definitivamente el programa.

\footnotetext{
${ }^{167} A B C, 28 / 12 / 1985$, p. 21.

168 Á. Font, La transición política española. Los años Pujol, P.C. Publi Corinti, Barcelona, 2003, pp. 449-468.

${ }^{169}$ Cfr. M. Palacio, La televisión durante la Transición española, op. cit. pp. 101-102.
} 
El 25 de enero de 1986 se celebró la asamblea constitutiva de la plataforma cívica para la salida de España de la OTAN. Los partidarios del no al referéndum buscaron converger. Junto a partidos políticos (como PCE, PSUC, Federación Progresista o Partido Carlista) formaron parte personalidades independientes en sintonía con la idea del no a la OTAN. Entre ellas, José María Mohedano, Antonio Gala, José Luis López Aranguren y José Luis Balbín ${ }^{170}$. En la asamblea trataron la redacción del manifiesto público, la financiación de la campaña, el control de los medios de comunicación y planificaron distintas acciones ${ }^{171}$.

El 12 de marzo de 1986 se celebró el referéndum sobre la permanencia de España en la OTAN. La consulta tuvo un carácter consultivo, no vinculante. El resultado fue el sí a la permanencia con el apoyo del 52,5\% de los votantes, frente al 39,8\% que votó no. La participación fue cercana al $60 \%$. No cabe duda, que la televisión, afín a los intereses del gobierno, ayudó a los partidarios del sí, con toda una serie de publicidad y programas que explicaban a los españoles los beneficios de pertenecer a la OTAN (con solo uno en contra, $L a$ clave).

En declaraciones posteriores, respecto a Adolfo Suárez, José Luis Balbín diría «sé que está muy enfermo, pero tendría mucho que contarnos si quisiera hacer un repaso de la Transición. Desde los follones con los militares hasta las verdaderas razones de su dimisión, desde la legalización del Partido Comunista hasta la forma en la que entramos en la OTAN, qué paso sobre ese referéndum, si fue o no pucherazo, y cómo se sientan las bases de lo que será después la guerra del Golfo». También habló sobre Felipe González: «Hace poco leí un artículo de Felipe González en el que echaba de menos aquellos tiempos en que los debates tenían altura. A mí me alegró mucho que González pensara eso, porque sin duda pensaba en nosotros, porque no había otros debates en el pasado. Lo que me extrañó es que González no recordase que fue él quien se cargó La clave» ${ }^{172}$.

En 1989, RTVE fue condenada a pagar a José Luis Balbín cinco millones de pesetas por haber atentado a su honor en el comunicado del cese del programa. El juez desestimó, en cambio, la petición de José Luis Balbín de reponer La clave ${ }^{173}$. Un año más tarde, en 1990, el programa regresaría en Antena 3 Televisión; una nueva etapa que duraría hasta 1993.

\footnotetext{
${ }^{170}$ Véase especialmente "La izquierda ante la OTAN", en Ayer, n 103, Marcial Pons, 2016.

${ }^{171}$ Cambio 16, n $\mathrm{n}^{\mathrm{7}}$ 736-743, 1986.

${ }^{172}$ Francisco J. Satué, Los secretos de la Transición, op. cit. 2005, p. 496.

173 "RTVE, condenada a indemnizar a Balbín por el comunicado de suspensión de La clave”, El País, 8/08/1987, y “El Supremo confirma que TVE lesionó el honor de Balbín”, El País, 19/04/1989.
} 



\section{Capítulo 7. La clave y la cultura política en la Transición española}

Como hemos visto anteriormente, la crisis del modelo fundacional de la televisión pública no impide que se introduzcan en España programas y formatos extranjeros así como otras formas de hacer y pensar la televisión. A la muerte del general Francisco Franco, La clave es uno de los programas que logra introducir el modelo fundacional en España. Si en anteriores capítulos hemos tratado de comprobar cómo el programa articula y construye el debate televisivo durante la Transición, en este capítulo defendemos además que la construcción de ese debate incide precisamente en la formación de una cultura política. Tras observar la capacidad del programa en articular las posiciones y demandas sociales en favor de determinadas políticas, proponemos una nueva vía interpretativa que nos permita profundizar el cambio de imaginario en España a través de las representaciones de la vida política ${ }^{1}$.

La televisión se utilizó para mostrar la modernización del país y sirvió también para presentar los rostros de los principales actores sociales en el proceso de transición en España. La presencia en televisión de valores culturales ayudó a socializar al individuo al generar, promover y transmitir valores cívicos. La clave impulsó en televisión la necesidad de instaurar un tipo de debate que reflejase la naciente sociedad democrática, inclusiva y segura, tras los profundos cambios producidos tras la muerte de Francisco Franco. Desde sus inicios, rompió con estereotipos y barreras culturales que habían calado en el pensamiento dominante durante la dictadura ${ }^{2}$. En este sentido, La clave fomentó la reflexión, la inclusión social, el intercambio de ideas, la implicación y participación de la sociedad en dicho proceso, y permitió inculcar valores como la tolerancia y el respeto hacia las diferentes posturas, ideas, y argumentos, aún si no se estaba de acuerdo. Pero su función está relacionada sobre todo en la formación de una ciudadanía democrática y el fomento de una determinada cultura política. Es decir, al tiempo que permitía la reflexión sobre diversos temas, emprendía una tarea pedagógica en la ciudadanía, noción en la que se sustenta la cultura política ${ }^{3}$. Más allá de la preferencia estética de una determinada emisión, atendemos en el capítulo los programas históricos y políticos con los que observar las disputas que se producen mientras se configura el nuevo sistema político.

\footnotetext{
${ }^{1}$ Véase B. Anderson, L'imaginaire national : Réflexions sur l'origine et l'essor du nationalisme, La Découverte, París, 1996. Imaginario que define como la manera de estar en el mundo a la que estamos todos sometidos, p. 9.

${ }^{2}$ Como argumenta Giulia Quaggio, «la Administración del Estado franquista fundó la propia política cultural sobre la socialización del nacionalismo español en clave tradicionalista, patriótica, centrándose en la supremacía de la lengua castellana» (Quaggio 2014: 36).

${ }^{3}$ Véanse S. García y S. Luckes, Ciudadanía: justicia social, identidad y participación. Siglo XXI, Madrid, 1999.
} 


\subsection{Debate y cultura política en España}

Los estudios de cultura política han tenido un papel muy destacado en la investigación sociopolítica española ${ }^{4}$. Trabajos acerca de los vínculos entre cultura y política se encuentran desde los inicios mismos del pensamiento político (Platón, Aristóteles, Montesquieu o Rousseau ya trataron de definir el concepto de cultura política). Por tanto, un primer paso es hacer referencia al debate epistemológico entre el conocimiento científico y su relación con la historia. Este pasa por delimitar un término, el de cultura política, que se vio redefinido como concepto analítico a través de la sociología europea (de la mano de Max Weber) ${ }^{5}$, el funcionalismo estructural (Talcott Parsons) ${ }^{6}$, y la sociología positivista americana (Gabriel A. Almond y Sidney Verba) ${ }^{7}$. Como argumenta Miguel Ángel Cabrera, «aunque el término había aparecido con anterioridad, su definición, su elaboración teórica y su utilización como concepto analítico fueron obra de los politólogos Gabriel Almond y Sidney Verba» (Cabrera 2010: 20).

En 1963, los politólogos Gabriel A. Almond y Sidney Verba escribieron The Civic Culture desde un enfoque psico-cultural. En esta obra examinaban los tipos de cultura política y el problema de la congruencia entre cultura y estructura (Almond y Verba 1970: 52). Los autores empleaban el término de cultura política para referirse a «orientaciones específicamente políticas, posturas relativas al sistema político y sus diferentes elementos, así como actitudes con relación al rol de uno mismo dentro de dicho sistema» (Almond y Verba 1970: 30). Los sociólogos estadounidenses concebían la cultura política, por lo tanto, como referentes simbólicos, creencias y actitudes sobre la política, y entendían por «cultura cívica», el surgimiento de una serie de valores que hacían posible o facilitaban la aparición y el funcionamiento de un régimen democrático.

Los autores establecían tres tipos ideales de cultura política: parroquial, de súbdito y participante ${ }^{8}$. Nos centramos principalmente en la llamada cultura política de participación, en

\footnotetext{
${ }^{4}$ Véanse M. Pérez Ledesma y M. Sierra (eds.), Culturas políticas: teoría e historia, Institución Fernando el Católico, Zaragoza, 2010. J. Botella, "En torno al concepto de cultura política: dificultades y recursos", en P. del Castillo y I. Crespo (ed.), Cultura política: Enfoques teóricos y análisis empíricos, Tirant lo Blanch, Valencia, 1997, y M. L. Morán, "La cultura política y la interpretación de las transiciones a la democracia. (Notas sobre el caso español)", en Política y Sociedad, no 20, 1995, pp. 97-110.

${ }^{5}$ M. Weber, Economía y sociedad, Fondo de Cultura Económica, México, 1974.

${ }^{6}$ T. Parsons, The Structure of Social Action, McGraw Hill, Nueva York, 1937.

7 Véase G. A. Almond y S. Verba, The Civic Culture. Political Attitudes and Democracy in Five Nations, Princenton University Press, Princenton, 1963. Obra traducida al castellano: La cultura cívica. Estudio sobre la participación política democrática en cinco naciones, Euramérica, Madrid, 1970.

${ }^{8}$ Parroquial, en un sistema con una distribución difusa del poder, sin roles o funciones políticas especializadas. De súbdito, en un sistema con un poder político centralizado y autónomo, donde el individuo solo posee orientaciones
} 
el que el ciudadano participa en el mismo sistema político (en elecciones, partidos, etc.) y es conocedor de sus diferentes elementos ${ }^{9}$. En España, durante el proceso de transición de la dictadura a la democracia, se pasó de una cultura de súbdito (franquismo), a una cultura mixta de súbdito y participación ${ }^{10}$. En otras palabras, una cultura política de participación que combinaba orientaciones de súbdito y parroquiales dando lugar a la transformación (que no eliminación) de sus instituciones.

Almond y Verba argumentaron que algunas de las estructuras incluidas de un modo predominante en el proceso político son los partidos políticos, los grupos de intereses y los medios de comunicación (Almond y Verba 1970: 32) ${ }^{11}$. Posteriormente, otros autores retomaran el concepto de cultura política desde diversos campos (ciencia política, sociología, psicología, antropología...) $)^{12}$. René Rémond señaló con acierto que las culturas políticas obedecen a una definición extensiva: comprenden ideas, valores, normas, sensibilidades y representaciones (es decir, la manera en la que los grupos y sus individuos representan el mundo $)^{13}$. En nuestro trabajo seguimos preferentemente el concepto de cultura política desarrollado por la historiografía francesa (especialmente autores como Jean-François Sirinelli y Serge Berstein $)^{14}$, con el objetivo de comprender la cohesión que existió entre un grupo de

políticas activas respecto al sistema. Y participante, en un sistema con un poder político centralizado pero no completamente autónomo sino que es responsable ante su población (Almond y Verba, 1963: 16-17).

${ }^{9}$ Como argumentan Almond y Verba, las actitudes favorables a la participación dentro del sistema político desempeñan un papel importante en la cultura cívica, pero igualmente influyen otras actitudes no políticas como la confianza en otras personas y la participación social en general (Almond y Verba 1970: 48-49).

${ }^{10}$ Siguiendo la idea de Almond y Verba, el paso de una cultura de súbdito a otra de participación, incluye «la difusión de orientaciones positivas respecto a una gran infraestructura democrática, la aceptación de normas de obligación cívica y el desarrollo de un sentido de competencia cívica en una proporción sustancial de la población» (Almond y Verba: 1970: 44). Una cultura política de participación donde los individuos participan en el proceso político pero no abandonan sus orientaciones como súbditos ni como parroquiales (Almond y Verba 1970: 48-49).

${ }^{11}$ Sobre la influencia de los medios de comunicación véanse las obras de M. Moragas, "Democracia y políticas de comunicación en el flujo internacional y la comunicación participativa", CEUMT, Barcelona, n 33, 1980, pp. 915; y "Comunicación de masas y tránsito político en España", en Comunicación y cultura, no 7, México, enero 1982, pp. 151-174; y M. L. Morán, “Algunas reflexiones en torno a la influencia de los medios de comunicación en la formación y características de la cultura política de los españoles”, en REIS, n 57, enero/marzo 1992.

${ }^{12}$ Véase R. Winocur (comp.), Culturas políticas a fin de siglo, Juan Pablos. Facultad Latinoamericana de Ciencias Sociales, México, 1997.

${ }^{13}$ R. Rémond (dir.), Pour une histoire politique, Le Seuil, París, 1988, p. 30. Sobre el término de representación véase la obra de H. F. Pitkin, El concepto de representación, Centro de Estudios Constitucionales, Madrid, 1985.

${ }^{14}$ J. F. Sirinelli, "Pour une histoire des cultures politiques : le référent républicain”, en D, Cefaï (dir.), Cultures politiques, PUF, 2001, París, p. 157 ; y S. Berstein, "L'historien et la culture politique", Vingtième Siècle, vol. 35, $\mathrm{n}^{\mathrm{o}}$ 1, julio-septiembre 1992, pp. 67-77, y "La culture politique", en J. P. Rioux y J. F. Sirinelli (dir.), Pour une histoire culturelle, Seuil, París, 1997, pp. 385-386. Sobre la historiografía francesa en España, véase B. Pellistrandi, La historiografía francesa del siglo XX y su acogida en España. Actas del coloquio internacional, Casa Velázquez, Madrid, 2002. 
personas, que por primera vez se sentaban a debatir en directo en la única televisión existente en el país.

Según la definición dada por Sirinelli, entendemos por cultura política el «conjunto de representaciones que crea, produce y transmite una comunidad, es decir, una visión del mundo compartida, una común lectura del pasado y una proyección en un futuro común (...) al mismo tiempo que normas, creencias y valores compartidos» ${ }^{15}$. Serge Berstein, por su parte, sintetizaría el concepto como «conjunto de representaciones que dan lugar a normas y valores, que constituyen la identidad de la tradición política» ${ }^{16}$. Y la socióloga mexicana Jacqueline Peschard lo definiría de «sistema político internalizado en creencias, concepciones, sentimientos y evaluaciones por una población, o por la mayoría de ella» (Peschard 2012: 10) ${ }^{17}$. En definitiva, diversas maneras de definir un mismo concepto, y que en todas ellas haría referencia tanto al medio cultural en el que el individuo está inmerso como al sistema de representaciones culturales compartidas por grupos humanos que el individuo ha interiorizado al socializarse ${ }^{18}$.

La clave no solo fue un programa que introdujo el debate televisivo para abordar temáticas que preocupaban a la sociedad española. También funcionó de plataforma con la que impulsar orientaciones y actitudes democráticas ${ }^{19}$. A través del medio televisivo explicó las reglas básicas de la democracia, fomentó el pluralismo y mostró el valor de la libertad de expresión. Como argumenta Juan Munsó Cabús, «se quiso demostrar que la libertad de expresión era algo más que un concepto abstracto» (Munsó 2001: 141). La clave permitió la formación y propagación de ideas a través de expertos que ayudaron a la formación ciudadana

\footnotetext{
${ }^{15}$ Traducción propia del original: «Ensemble de représentations qui soude un groupe humain, c'est-à-dire une vision du monde partagée, une commune lecture du passé, une projection dans l'avenir vécue ensemble. (...) en même temps que des normes, de croyances et de valeurs partagées». J. F. Sirinelli, "Pour une histoire des cultures politiques : le référent républicain”, en D. Cefaï (dir.), Cultures politiques, op. cit. p. 157.

16 Traducción propia del original: «L'ensemble des représentations, porteuses de normes et de valeurs, qui constituent l'identité des grandes familles politiques», S. Berstein, "Nature et fonctions des cultures politiques", en S. Berstein, (dir.). Les cultures politiques en France, Seuil, París, 2003, p. 13.

${ }^{17}$ Añade las relaciones de poder y autoridad alrededor de los cuales se estructura la vida política. «Es el imaginario colectivo construido en torno a los asuntos del poder, la influencia, la autoridad, y su contraparte, la sujeción, el sometimiento, la obediencia y, por supuesto, la resistencia y la rebelión» (Peschard 2012: 10).

${ }^{18}$ Véanse M. A. Cabrera, "La investigación histórica y el concepto de cultura política", en M. Pérez Ledesma y M. Sierra (eds.), Culturas políticas: teoría e historia, op. cit. pp. 36-39, y R. García, "Crítica de la teoría de la cultura política", en Política y Cultura, no 26, 2006, pp. 133-155.

${ }^{19}$ Entendemos por plataforma como lugar físico (es decir, un espacio donde debatir desde posiciones encontradas), y como conjunto de reivindicaciones defendidas por un grupo de profesionales (poder debatir en directo, poder hacerlo sobre cualquier tema y sin restricciones ni injerencias desde el exterior). Y, aunque no se lograron estas reivindicaciones (no todos fueron en directo, algunos temas no se debatieron y hubo injerencias), se mostraron los límites de la democracia televisiva acorde a la democracia política que trataba de construirse.
} 
y a la construcción de una cultura democrática a través de la televisión. La cultura política del debate hace referencia a la diversidad de temas, ideas y propuestas que integraban amplios conglomerados sociales, así como la normalización democrática de una sociedad a través del debate. Las estadísticas del programa indican que más de dos mil invitados (muchos de ellos expertos en un campo determinado) discutieron distintas temáticas, semana a semana, logrando instaurar en televisión el diálogo entre los distintos actores y las distintas mentalidades que formaban parte de la sociedad española.

Los medios de comunicación ayudaron en España a generar un cambio en el ámbito cultural y político. Es fundamental, por tanto, el papel que ocupan en el sistema político, así como su capacidad de representar, reconstruir e influir en la historia ${ }^{20}$. Ronald Inglehart, en su teoría de cambio cultural, examinó la socialización de nuevas orientaciones en la ciudadanía en distintos contextos económicos ${ }^{21}$. Y Jacqueline Peschard, por su parte, clasificó los factores que más influían en los cambios de los valores, símbolos y orientaciones de una población:

1) La amplitud con la que se difundan las nuevas ideas.

2) El grado de exposición del individuo a dichas ideas.

3) El prestigio de las ideas en cuestión, que depende de los logros que se les atribuyen.

4) El peso social específico que tenga el agente socializador (Peshard 2012: 45).

La clave es determinante en estos cuatro factores: la televisión como medio difusor de las nuevas ideas; su fuerte exposición a través de su enorme audiencia; el prestigio de estas ideas a través de expertos y especialistas; y su peso social como agente socializador a través del modelo educativo y formativo ${ }^{22}$. La clave trató de concienciar a la ciudadanía para la resolución de problemas en un momento en el que se viene produciendo un verdadero cambio político, económico y cultural. La clave tuvo un papel fundamental al democratizar la televisión y, a través de ella, incidir de manera directa en la articulación de una comunidad formada por millones de personas. Desde la misión educativa, el programa permitió definir, desglosar y desarrollar conceptos y temáticas que lo convierten en una herramienta de apoyo en el proceso de aprendizaje democrático y en un agente determinante en el proceso de transmisión. Sin

\footnotetext{
${ }^{20}$ V. Sánchez-Biosca et al. "Guerras: cine, imagen e imaginarios”, Historia Social, n” 63, 2009.

${ }^{21}$ R. Inglehart, Modernización y Posmodernización. El cambio cultural, económico y político en 43 sociedades, Siglo XXI/CIS, Madrid, 1998. Sobre el cambio social en España, véase J. J. González, y M. Requena (eds.), Tres décadas de cambio social en España, Alianza, Madrid, 2005.

${ }^{22}$ Es decir, la educación como «un agente de socialización específicamente democrático» (Peschard 2012: 44).
} 
embargo, en la construcción del debate político y social, ¿qué postura adoptó La clave en relación al sistema político? Y más fundamental, ¿qué sistema compartido representó?

Presentamos a continuación un estudio del debate histórico y político que fue llevado a cabo por La clave. Acudimos a siete debates históricos y a siete debates políticos con el objetivo de abordar el tipo de debate construido en torno al complejo proceso social que rodea la Transición española. La razón principal de esta elección se debe a querer evidenciar a través de las claves históricas la propia muestra que hizo el programa de su historia. Los programas políticos, en cambio, más extensos, han sido seleccionados a partir del impacto que tuvo en otros medios de comunicación y su incidencia directa en la noción de cultura política.

\subsection{Siete debates para la formación histórica}

Un factor que determina el acuerdo nacional al que se llega durante la Transición en España es el peso de su historia. La televisión contribuyó a crear referentes culturales en torno al nuevo sistema democrático compartido por una inmensa mayoría de ciudadanos, y en ese sistema de representación, La clave es esencial al debatir en televisión sobre su historia inmediata. De nuevo destacamos la idea de Berstein y Sirinelli, de que toda cultura política supone una lectura común del pasado y una proyección del futuro común (Berstein 1997: 372 y Sirinelli 2001: 157). En la construcción del debate histórico que se hace en este proceso es decisivo el papel que desempeña el recuerdo del pasado (y especialmente la experiencia y el recuerdo de la Guerra Civil, hito fundacional del franquismo). Por tanto, las representaciones de la Guerra Civil y el franquismo en el imaginario colectivo, tanto político, social y cultural, es uno de los dos temas de análisis en la presente investigación.

La clave permitió debatir y generar una (re)visión crítica de la historia dando la palabra, por primera vez en televisión, a historiadores y críticos que lograron desmontar la versión oficial de lo ocurrido en España durante la Guerra Civil y el franquismo. El historiador Ferran Gallego argumenta que «La tentación de ofrecer una imagen de simple consolidación de un esfuerzo común se basa en la necesidad de ofrecer una nueva identidad colectiva de los españoles y a la relación con el régimen, tras decenios de usurpación de referentes culturales aceptados de diversa forma por quienes habitan un país» (Gallego 2008: 209). Este discurso oficial construido en España después de la Guerra Civil pudo ser, por tanto, desmitificado en La clave por los invitados (y los más de 100 historiadores que pasaron por el programa). Trataremos de resolver qué identidad colectiva se representa y qué referentes culturales utiliza 
La clave en una Transición considerada, por parte de las instituciones públicas, de periodo de paz y concordia entre los españoles. En pleno debate entre memoria y olvido del pasado español durante la Transición, La clave fue un programa que reflexionó sobre la historia y la memoria ${ }^{23}$. De un lado, reflexionó sobre los relatos construidos del pasado. De otro, atizó sentimientos y propuso caminos de futuro. Sin embargo, si el programa fue capaz de articular y construir el debate televisivo durante la Transición española, surgen toda una serie de preguntas: ¿qué tipo de debate histórico se llevó a cabo en La clave? ¿Tuvo dificultades para realizar estos debates? ¿Cómo abordó de la Guerra Civil? ¿Lo hizo directamente o indirectamente? ¿Quiénes fueron los invitados? ¿Se llegó a un consenso?

En relación al conflicto que supuso la Guerra Civil, algunas de las claves que realizó el programa han sido estructuradas en siete debates históricos. Cronológicamente estos fueron los programas: 1. Extranjeros en la Guerra Civil (1979). 2. Muerte de García Lorca (1980). 3. José Antonio (1981). 4. Vivir en postguerra (1982). 5. El Valle de los Caídos (1983). 6. La revolución de Asturias (1984). 7. Francisco Franco (1985) ${ }^{24}$. Desde 1979, La clave emitió anualmente uno o varios programas dedicados a la guerra y al franquismo.

\section{Extranjeros en la Guerra Civil (ficha 131)}

El primer programa histórico no se produjo hasta el 24 de noviembre de 1979. Es de destacar, por tanto, que el primer programa que aborda en España la Guerra Civil es precisamente el realizado por La clave. Pérez Ornia advertía en 1979 que «se han escrito más de 30.000 libros sobre la Guerra Civil y TVE todavía no ha ofrecido un cuarto de hora sobre el acontecimiento español de este siglo. Como si en TVE hubiese dos siglos» ${ }^{25}$. Se tituló Extranjeros en la Guerra Civil. Se trató de un tema, como indica Manuel Palacio, «especialmente sensible para las políticas de memoria y los procesos de legitimación del franquismo» (Palacio 2012: 262). No es llamativo, en cambio, que la primera emisión sobre la Guerra Civil no sea precisamente la propia guerra sino la participación extranjera en ella. A un

\footnotetext{
${ }^{23}$ Nos centramos especialmente en la lectura compartida de un pasado en común. Sin embargo, el programa también proyectó una visión de futuro. Basta como ejemplo algunas de las emisiones: ¿Futuro sin libros? (ficha 49), Futuro de la televisión (73), El futuro de la humanidad (153), y Futuro de la democracia (162).

${ }^{24}$ A través de algunas películas también se habló de la Guerra Civil como fueron La guerra ha terminado (La guerre est finie, Alain Resnais, 1966), y El corazón del bosque (Manuel Gutiérrez Aragón, 1979), esta última interesada en los maquis en los años de posguerra. También contó con invitados protagonistas de ese momento histórico como Federica Montseny (Anarquistas), Enrique Líster (Polonia), Ernesto Giménez Caballero (Seguridad en la calle), Santiago Carrillo y José María Gil-Robles (Sistemas políticos).

25 “Sombras del ayer", El País, 31/05/1979.
} 
día de la emisión se desconocía si se emitiría el debate, por lo que el equipo de La clave preparó un plan de repuesto en caso de prohibición ${ }^{26}$. Tener preparado otro plan muestra las dificultades que provocaba la Guerra Civil en televisión. Se proyectó la película Sierra de Teruel (L'espoir, André Malraux, 1939), estrenada en España en junio de 1978. Un tipo de cine interpretado por combatientes de la Guerra Civil que había sido «rodado durante la contienda y considerado como el más bello ejemplo de cine republicano» (Palacio 2012: 262) ${ }^{27}$.

José Luis Balbín inició el programa con las siguientes palabras: «Hoy vamos a hablar otro de esos temas polémicos y creo que iba siendo hora. Extranjeros en la Guerra Civil. Es la primera vez que TVE aborda de una manera directa, espontánea, sin ningún tipo de guion previo, un tema como este. Es importante abordar nuestro pasado reciente ${ }^{28}$. Recordaba unas reglas a seguir: atenerse al título, no entrar en la injuria personal y respetar los turnos. Entre los invitados, cuatro protagonistas del momento: un fascista italiano al que no le gustaban las democracias populares (Renzo Lodoli) y tres ex brigadistas: Arthur London (checoslovaco), Albert Prago (norteamericano) y Henry Rol-Tanguy (francés). También se encontraban un catedrático de economía (Jesús Prados) y tres historiadores (Gabriel Jackson, José Luis Infiesta y Ramón Salas Larrazábal), este último además coronel del Ejército del Aire.

El norteamericano Albert Prago inició el turno de intervenciones con una lista de escritores e intelectuales que apoyaron al bando republicano: Neruda, Pablo Picasso, Albert Einstein, Ernest Hemingwey... «No conozco ninguna persona de prestigio internacional que haya apoyado a Franco. (...). La primera vez que disparé fue aquí en España. (...) Es muy importante que en televisión se hable de la guerra. Que el pueblo español asuma su historia». Prago criticó que el tema no estaba bien escogido porque no solo combatieron extranjeros en la Guerra Civil, que llevó a la inmediata réplica del ex brigadista francés: «No somos extranjeros somos voluntarios», y la primera discusión, que cerraría Salas Larrazábal citando a Camilo José Cela: «Los extranjeros, lo mejor que debían haber hecho era quedarse en casa». Durante todo el debate se habló de cifras, y no hubo una sola coincidencia entre las expuestas por los historiadores Gabriel Jackson y Salas Larrazábal. La pregunta inicial de José Luis Balbín ¿es

\footnotetext{
${ }^{26}$ Plan que consistía en la emisión de la película El gran Ziegfeld (The Great Ziegfeld, Robert Z. Leonard, 1936), de mayor duración, y con la que cubrir la programación ante una posible suspensión.

${ }^{27}$ Véase V. Sánchez Biosca y J. M. Company, "Sierra de Teruel: el compromiso, el texto", Revista de Occidente $\mathrm{n}^{\mathrm{o}}$ 53, 1985, pp. 13-22. Esta fue la filmografía que propuso La clave: Bloqueo (Blockade, William Dieterle, 1938), que denunciaba los bombardeos sobre la población civil en la España republicana, y los documentales Morir en Madrid (Mourir à Madrid, Frédéric Rossif, 1963), y Tierra de España (The Spanish Earth, Joris Ivens, 1937).

${ }^{28}$ Centro de Documentación RTVE. Extranjeros en la Guerra Civil (ficha 131). Emisión: 24 de noviembre de 1979.
} 
difícil para un historiador escribir con un mínimo de objetividad sobre la Guerra Civil?, mostró en realidad, la difícil objetividad de un país con dos relatos históricos.

José Luis Balbín finalizó el programa explicando los motivos que le habían llevado a realizar y abordar este debate: «que sirva para reflexionar y mejorar esta convivencia». Con el enfrentamiento de cifras y una bibliografía de casi quince obras para quien quisiera profundizar en el tema ${ }^{29}$, se había construido el primer debate televisivo sobre la Guerra Civil. Extranjeros en la Guerra Civil fue un programa que generó numerosas cartas a los periódicos. El periodista Jaime Campmany criticó a los invitados porque «se cabrearon, por si habían venido a la Guerra Civil más rusos o más italianos o más franceses» ${ }^{30}$, y $A B C$ criticó que había sido un «debate inclinado hacia un lado» ${ }^{31}$. Sin embargo, tras años de silencio sistemático, es destacable que fuese La clave el primero en abordar, aunque de manera indirecta, la Guerra Civil española.

\section{Muerte de García Lorca (ficha 160)}

Las reticencias de los directivos de TVE para abordar la figura de Federico García Lorca fueron muy evidentes durante todo el proceso de Transición. Tras años de «intentos zanjados por la dirección de RTVE con la explicación de que aún no es el momento» ${ }^{32}$, La clave logró realizar el 21 de junio de 1980 el programa Muerte de García Lorca. TVE no poseía ningún documental sobre García Lorca, así que se echó mano de un documental producido por la televisión sueca titulado Federico García Lorca: El asesinato en Granada (Humberto López, 1977). A TVE debió parecerle demasiado largo el título, o quizás las palabras asesinato o Lorca, pues tituló la película Muerte en Granada. El documental, filmado en Granada, intercalaba entrevistas con amigos, familiares e historiadores. Sobre su estreno en el segundo canal de TVE, el New York Times escribió en 1980 que fue la mayor audiencia de la televisión en España de aquellos años ${ }^{33}$.

\footnotetext{
${ }^{29}$ La Alemania nazi y el 18 de julio (A. Viñas), La intervención fascista en la Guerra Civil española (J. F. Coverdale), La República española y la Guerra Civil (G. Jackson), La guerra civil española (H. Thomas), La internacionalización de la Guerra Civil española (F. Schwartz), Intervención extranjera en la Guerra Civil (J. Salas), Breviario histórico de la guerra del 36: la guerra de las dos Españas (J. M. Garate), La historia se confiesa, y Leyenda y tragedia de las Brigadas Internacionales (R. de la Cierva), Voluntarios americanos en la Guerra Civil española (C. Eby), Las nieves del Kilimanjaro (H. King), La fiesta española (J. Vierne)...

${ }^{30}$ Jaime Campmany, La hoja del lunes, 26/11/1979, p. 5, y “iQue se maten ellos!”, ABC, 27/11/1979, p. 15.

${ }^{31}$ E. Corral, "Crítica diaria”, $A B C, 28 / 11 / 1979$, p. 102.

32 “La clave: muerte de García Lorca”, El País, 21/06/1980.

${ }^{33}$ A. Holmberg, "Five Years After Franco, Lorca Is Alive Again in Spain; Spain Rediscovers the Theater of Lorca", The New York Times, 19/10/1980, p. D3.
} 
El programa abordó las circunstancias de la muerte del poeta y dramaturgo asesinado a inicios de la Guerra Civil, en agosto de 1936. Entre los invitados, el historiador Ian Gibson y el académico (y amigo personal de García Lorca), Luis Rosales, para quien La clave cambió incluso las fechas de emisión. (El cambio de fechas muestra la importancia del equipo en contar expresamente con las figuras que pudiesen aportar más al debate). Al llegar a Granada para refugiarse, Lorca se presentó en el domicilio de Luis Rosales. A la pregunta del director: ¿Es doloroso hablar del tema de García Lorca en un programa de televisión como este? Luis Rosales respondió «Es duro y necesario» ${ }^{34}$. La muerte de García Lorca fue silenciada durante cuarenta años, y entrada la democracia, todavía algunas representaciones eran sistemáticamente prohibidas. Esa misma semana se había prohibido "Muerte de García Lorca" de José Antonio Rigau. No podían, en cambio, detener homenajes a su figura como el de Fuente Vaqueros (Granada), donde más de 10.000 personas asistieron a principios de mes a la inauguración oficial «del primer monumento público que se erige en España a Federico García Lorca» ${ }^{35}$.

Entre las preguntas de los telespectadores, leídas en esta ocasión por Rafael Benedito, dos preguntas fueron dirigidas a José Luis Balbín: ¿Cuándo va a celebrar una emisión La clave en la que se traten todos los asesinatos de izquierda? ¿Cree constructivo poner el dedo en la llaga de tantos españoles que habían conseguido olvidar hechos tan penosos? José Luis Balbín respondió: «Se han hecho pocos programas relacionados con la historia inmediata. Sería un horror condenar al silencio a la historia y no intentar saber qué es la historia» ${ }^{36}$. A finales ya de 2018, la muerte de García Lorca continúa siendo un misterio, y siguen sin encontrarse los restos del que ha sido considerado uno de los mayores poetas en lengua española. La clave, por tanto, fue de nuevo pionera en tratar un tema inédito y, sobre todo, de gran importancia en las políticas de memoria en España.

\section{José Antonio (ficha 201)}

En 1981, año del golpe de Estado en el Congreso de los Diputados, se realizaron tres claves históricas: El oro que se fue, Cincuenta años después, y José Antonio. Nos centraremos especialmente en la última de ellas. La primera, El oro que se fue (ficha 174), se emitió el 15 de mayo de 1981 (festivo en Madrid y por tanto en diferido). Se debatió sobre la financiación

\footnotetext{
${ }^{34}$ Centro de Documentación RTVE. Muerte de García Lorca. Emisión: 21 de julio de 1980.

35 “Multitudinario homenaje a García Lorca en Fuente Vaqueros”, El País, 10/06/1980.

${ }^{36}$ Centro de Documentación RTVE. Muerte de García Lorca (ficha 160). Emisión: 21 de julio de 1980.
} 
de la Guerra Civil (concretamente la venta de oro del banco de España para obtener divisas, la financiación que obtuvo Francisco Franco, y las expropiaciones que se producían en épocas de guerra por los países dominantes). Se proyectó la película El tren (The Train, John Frankenheimer, 1964), que narra el expolio nazi producido en París a pocos días de la liberación ${ }^{37}$. La segunda, Cincuenta años después (ficha 197), con la proyección de la película Caudillo (Basilio Martín Patino, 1976), se realizó el 23 de octubre de 1981, y en ella se abordaron las motivaciones que dieron lugar a la Guerra Civil $^{38}$.

La última, con el título de José Antonio, se produjo el 20 de noviembre de 1981. El programa se realizó coincidiendo con la fecha de la muerte de José Antonio Primo de Rivera en 1936 y con la congregación de nostálgicos del franquismo en la plaza de Oriente de Madrid. Durante el programa se proyectaron, en primer lugar, un reportaje dirigido por Carlos Pumares $^{39}$, unas breves imágenes de José Antonio procedentes del NO-DO, y el documental ¡Presente! En el enterramiento de José Antonio Primo de Rivera (Dirección Nacional de Cinematografía, 1939), que mostraba la ceremonia de exhumación del cuerpo del líder de la Falange y su traslado al Escorial en noviembre de $1939^{40}$.

Entre los invitados, dos grupos de posiciones antagónicas: por un lado el representado por Pilar Primo de Rivera (hermana de José Antonio), Raimundo Fernández-Cuesta (Jefe Nacional de Falange), Eduardo de Rojas Ordoñez (uno de los fundadores de Falange), y Ramón Serrano Suñer (cuñado de Franco y promotor del envío de la División Azul ${ }^{41}$, que participaba por primera vez en un programa de televisión) ${ }^{42}$. De otro, José Prat (senador del PSOE), el historiador Ian Gibson (que había participado en Muerte de García Lorca), y José Luis López Aranguren (catedrático de Ética que fue expulsado en 1965 de la universidad por haber participado en una protesta por la falta de libertad de expresión).

\footnotetext{
${ }^{37}$ Centro de Documentación RTVE. El oro que se fue (ficha 174). Emisión: 15 de mayo de 1981.

${ }^{38}$ Centro de Documentación RTVE. Cincuenta años después (ficha 197). Emisión: 23 de octubre de 1981.

${ }^{39}$ Carlos Pumares entrevistó a José Luis Sáenz de Heredia, quien estaba recopilando material para realizar una película sobre José Antonio, que finalmente no hizo.

${ }^{40}$ Sobre el documental véase V. Sánchez Biosca, "El Ausente, ¡Presente!: El carisma cinematográfico de José Antonio Primo de Rivera, entre líder y santo", Archivos de la Filmoteca, no 46, Filmoteca de la Generalitat Valenciana, Valencia, 2004, pp. 66-87.

${ }^{41}$ División de Infantería compuesta por voluntarios falangistas que combatieron contra la Unión Soviética junto con las tropas del Tercer Reich.

42 «La primera vez que Ramón Serrano Suñer estuvo en la televisión fue con nosotros», José Luis Balbí, en F. J. Satué, Los secretos de la Transición, op. cit. p. 495.
} 
Durante el debate Ian Gibson expuso las subvenciones que Falange había recibido en los años treinta, pese a que al entonces secretario de Falange Raimundo Fernández-Cuesta no le constaba. Al acabar el programa, en los pasillos se producía un altercado entre Gibson y algunos de los cuatro guardaespaldas que acompañaban al dirigente falangista ${ }^{43}$. La prensa relató así el incidente: «Los hechos se produjeron en los pasillos de las instalaciones de RTVE, cuando cuatro individuos que acompañaban a Fernández-Cuesta insultaron a Gibson, acusándole de haber llamado ladrón a José Antonio, al tiempo que le aconsejaban regresar a su país. Cuando uno de ellos empezaba a retorcer la oreja de Gibson, la intervención del propio Fernández Cuesta, y del director del programa José Luis Balbín, impidió que el incidente tuviera mayores consecuencias» ${ }^{44}$.

Cabría reparar que esa misma semana el programa En este país, de Ladislao Azcona, había realizado un reportaje sobre la muerte de Franco. El director general de RTVE Carlos Robles Piquer, había llamado a José Luis Balbín y a Ladislao de Azcona para conocer el contenido de dichos programas, una muestra de la vigilancia a la que continuaba sometida la televisión en 1981. Para Jaime Campmany $(A B C)$, se trataba de «dos excelentes programas sobre dos temas nada fáciles, sobre dos personajes que ya están en la Historia, pero que todavía pueden estar en la polémica, en la emoción, en el sentimiento o en el resentimiento» ${ }^{45}$. Desde El País, Antonio Tovar fue crítico porque «la actitud de la autoridad gubernativa y de los responsables de TVE no se distinguió precisamente por su celo en defensa del sistema democrático ${ }^{46}$. Es de destacar la importancia del directo, pues, aunque el director general de RTVE quisiera conocer el contenido del programa, no podía, ya que el discurso se construía en ese momento.

\section{Vivir en postguerra (ficha 232)}

La clave permitió abordar la posguerra española por primera vez en televisión. Vivir en postguerra se emitió el 16 de julio de 1982. Se proyectó la película Canciones para después de

\footnotetext{
${ }^{43}$ Cfr. M. Palacio y C. Ciller, “La clave de TVE...”, en Estudios sobre el Mensaje Periodístico, op. cit. p. 238. 44 “Agredido Ian Gibson por guardaespaldas de Fernández-Cuesta”, El País, 22/11/1981.

45 Jaime Campmany, "Toque de ánimas”, $A B C, 22 / 11 / 1981$, p. 5. «Subrayar que para hablar de éstos y de otros temas y de otros personajes de nuestro pasado más o menos cercano, de esta manera nos puede ayudar a los españoles a aprender algo que siempre nos ha hecho mucha falta: mirar atrás sin ira y mirar atrás sin nostalgia».

46 Antonio Tovar, "Peligros en la televisión”, El País, 24/11/1981. «Allí, ante los ojos incrédulos de muchos espectadores, se defendió que los conspiradores no querían la guerra civil, que intentar un golpe en las alturas, con éxito fulgurante, no es quebrantar ningún orden constitucional, ni provocar una guerra civil».
} 
una guerra (Basilio Martín Patino, 1971) sobre «algunas de las canciones más populares desde la guerra hasta el final de la década de los cuarenta. (...) que situaba su punto de partida en las celebraciones de la victoria tras la Guerra Civil y culminaba con las fotografías del príncipe Juan Carlos, un niño de apenas diez años que llegaba a España para estudiar y comenzar un camino hacia la restauración de la Monarquía» (Benet 2012: 360) ${ }^{47}$. Pese a realizarse clandestinamente en 1971 no fue estrenada hasta poco después de la muerte de Francisco Franco, en $1976^{48}$. Hay que tener en cuenta que hasta febrero de 1976 no se abolió la censura previa de guiones, instrumento de control ideológico del cine español ${ }^{49}$. El 1 de diciembre de 1977 se publicó en el BOE el decreto que suprimía la censura cinematográfica ${ }^{50}$, si bien en la práctica, continuaron las prohibiciones.

Participaron en el debate, el actor Fernando Fernán-Gómez, el escritor Carlos Luis Álvarez, más conocido como "Cándido", el historiador Rafael Abella, el magistrado del Tribunal Constitucional Plácido Fernández Viagas, el exgobernador civil y falangista José Manuel Pardo, y Eulogio de Vega, exalcalde socialista de Rueda (Valladolid), que estuvo veintiocho años escondido. Fue uno de los llamados topos, personas que tuvieron que vivir ocultas para evitar la represión franquista tras la Guerra Civil. Hasta 1969, año del decreto de Amnistía franquista y de los indultos, algunos españoles vivieron escondidos por miedo a las represalias.

Durante el coloquio se abordaron además de los llamados topos, las carencias de la posguerra, el estraperlo, los niños de la guerra, la represión, la ley de responsabilidades políticas, la autarquía, los inventos españoles. Cándido habló de la creación de una estructura mental de la sociedad española a través del dirigismo cultural. Es decir, se educaba en un sentido concreto, y se dirigía hacia la aceptación de unas ideas y la prohibición de otras ${ }^{51}$.

¿Cuánto duró la posguerra? España, a inicios de la posguerra, era un país en ruinas (políticamente, económicamente y, sobre todo, humanamente), con un millón de presos, con

\footnotetext{
${ }^{47}$ Sobre la película, como indica V. J. Benet, «su recuperación crítica, pero también innegablemente nostálgica, fue patente desde los años sesenta en la cultura española y este hecho nos abre camino hacia un terreno más denso y en cierto modo conflictivo (...) el concepto de memoria» (Benet 2012: 361).

${ }^{48}$ Véase M. Conesa Navarro, “Canciones para después de una guerra (1971). Una víctima más de la censura del Régimen”, en M. D. de la Calle Velasco y M. Redero San Román (eds.), Guerra Civil. Documentos y memoria, Universidad de Salamanca, 2006, pp. 85-95.

${ }^{49}$ Véase R. Ruzafa Ortega (ed.), La historia a través del cine. Transición y consolidación democrática en España, Universidad del País Vasco, Guipúzcoa, 2004, p. 24.

${ }^{50}$ BOE núm. 287, de 1 de diciembre de 1977, pp. 26420-26423.

${ }^{51}$ Centro de Documentación RTVE. Vivir en postguerra (ficha 232). Emisión: 16 de junio de 1982.
} 
carencias de agua, restricciones eléctricas, y hambre. Durante todos estos años, la política económica autárquica del gobierno de Franco no logró cubrir las necesidades básicas de alimentación de la población, y el Gobierno, decidió controlar la distribución de las mercancías a través de la Cartilla de Racionamiento (vigente hasta abril de 1952), asignando a cada persona cierta cantidad para los productos básicos alimenticios de primera necesidad (como azúcar, arroz, aceite, pan...). Ante la miseria de la población y la dramática escasez de alimentos, proliferó el estraperlo o mercado negro (en el que obtener esos productos aunque a un precio muy superior al oficialmente establecido). Siguiendo la terminología de la época, vencedores y vencidos frente a frente, debatieron durante casi dos horas sobre los años posteriores a la Guerra Civil.

\section{El Valle de los Caídos (ficha 299)}

El 18 de noviembre de 1983 se realizó El Valle de los Caídos. El debate giró en torno al gigantesco mausoleo ordenado construir por el general Francisco Franco al finalizar la Guerra Civil. Se proyectó la película Tierra de faraones (Land of the Pharaohs, Howard Hawks, 1955), aunque también se intercalaron durante el coloquio planos del Valle de los Caídos en la fase de construcción, y la visita que hizo el general Francisco Franco el 1 de abril de 1959. José Luis Balbín introdujo el programa con las siguientes palabras: «En los temas históricos siempre hay discusiones: ¿Es bueno o no rememorar lo que pasó en la Guerra Civil? Quizás, todavía las heridas no estén cerradas o es una provocación que produce perjuicios en vez de beneficios. Nosotros preferimos hablar» ${ }^{52}$.

Los siete invitados al debate fueron Gregorio Peces-Barba (padre del Presidente del congreso de los Diputados), Pedro Pérez Ranz (del Destacamento Penal de Cuelgamuros), Damián Rabal (hijo de trabajador en la construcción del monumento), y Daniel Sueiro (documentalista de La clave y autor del libro El Valle de los Caídos). También asistieron tres referentes franquistas: Juan de Ávalos (autor de las esculturas del mismo), Mónica Plaza (exconsejera nacional del Movimiento), y el falangista Jesús Suevos, quien había sido el primer director de RTVE: «Yo inauguré la televisión» ${ }^{53}$.

\footnotetext{
${ }^{52}$ Centro de Documentación RTVE. El Valle de los Caídos (ficha 299). Emisión: 18 de noviembre de 1983.

${ }^{53}$ Efectivamente, Jesús Suevos Fernández-Jove había sido elegido director general de RTVE el 28 de julio de 1951. Con él se inauguró oficialmente la televisión en España el 28 de octubre de 1956.
} 
En la construcción del mausoleo trabajaron presos políticos como Pedro Pérez, a quien se le condenó a pena de muerte tras la Guerra Civil. Durante los siete años que trabajó en la construcción del monumento franquista ganó 326 pesetas ( 2 euros). Precisamente fue quien inició el debate. Comenzó explicando cómo lo detuvieron y posteriormente las torturas a las que fue sometido: «en el Ayuntamiento se levantaron un Guardia Civil y un falangista. Me rompieron las muñecas. Después me hicieron la cruz gamada encima de la cabeza, con el pelo arrancado...». Ante la dramática escena, Mónica Plaza no estaría de acuerdo, pues la vida de Francisco Franco estaba «impregnada de conciliación». Jesús Suevos, por su parte, dijo que el Valle de los Caídos era «un monumento para todos los españoles», a lo que replicó PecesBarba, «veinte años después, no he encontrado ningún documento que hable de los dos bandos». Se remitía al decreto fundacional (BOE 1 de abril de 1940) y al discurso de inauguración (1 de abril de 1959), en los que se hablaba de héroes y mártires de la cruzada, de aquellos que cayeron por Dios y por la Patria, pero no de los vencidos.

Durante el coloquio se vieron, una vez más, dos posiciones enfrentadas sobre la historia de España. No la idea de dos Españas sino precisamente dos visiones y dos relatos de la historia de España. Sirva como ejemplo el siguiente fragmento de algunas de las intervenciones:

Mónica Plaza: «Lo defenderé siempre».

Juan de Ávalos: «¿Por qué discutir tanto?».

Daniel Sueiro: «No discutir. Avanzar. Conocer es positivo».

Jesús Suevos: «Creo que los vencedores de la Guerra Civil han sido extraordinariamente generosos con los vencidos porque cuando fueron liberados pudieron rehacer su vida». Damián Rabal: «Felicitar al señor Suevos y a Mónica Plaza por su gran sentido del humor, y ya no quiero decir nada más» ${ }^{54}$.

La clave, por primera vez en televisión, dio la palabra a presos republicanos que trabajaron en la construcción de uno de los mayores símbolos de la dictadura. Un tema, el de la simbología franquista, polémico hasta entrada y consolidada la democracia, que reflexionaba además sobre la impunidad de la dictadura. El programa recibió 550 llamadas telefónicas. Entre ellas, un telespectador preguntó: ¿Dónde está el sentido religioso si mientras se construía se estaba fusilando? Tras el debate, se ofreció una breve bibliografía para profundizar sobre el tema y hacer pedagogía de lo que representó el franquismo en la historia de España, y para terminar el programa, José Luis Balbín volvería a insistir en las trabas administrativas que

\footnotetext{
${ }^{54}$ Centro de Documentación RTVE. El Valle de los Caídos (ficha 299). Emisión: 18 de noviembre de 1983.
} 
tenían para hacer el programa «con más dificultades que hace seis años». Como hemos visto en los anteriores capítulos, los cambios en la dirección general de RTVE, afectaban directamente al programa. En este caso, José Luis Balbín acababa de ser cesado de la dirección de los Servicios Informativos de TVE y tras él, dimitía el director de TVE Antonio López y ocho responsables del área técnica de TVE.

\section{La revolución de Asturias (ficha 345)}

En 1984 la Fundación José Barreiro (institución socialista) celebró en Asturias «una serie de jornadas históricas para conmemorar el 50 aniversario de la revolución asturiana de octubre de $1934 »^{55}$. Hecho criticado por la derecha, La clave aprovechó la ocasión para debatir el 5 de octubre de 1984 La revolución de Asturias (50 años después). El programa se realizó desde la capilla del hotel Reconquista de Oviedo, en Asturias, y no se inició con la habitual melodía compuesta por Carmelo Bernaola sino con la canción "La añada", del cantautor Jerónimo Granda. Participaron tres historiadores: Paco Ignacio Taibo, Bernardo Díaz Nosty, y Ramón Salas Larrazábal (militar que ya había estado presente en Extranjeros en la Guerra Civil). También participaron los periodistas Ricardo Vázquez-Prada y Alberto Fernández (miembro comité de huelga de Mieres), la escritora Dolores Medio y José Manuel Fernández, de la Confederación Nacional de Trabajadores (CNT).

Antes de la presentación de los invitados se emitió el reportaje Asturias, tierra de contrastes, y tras la presentación de los invitados, la película Octubre (Oktyabr, Sergei M. Einsenstein, 1927). José Luis Balbín inició el debate con las habituales críticas que recibía $L a$ clave por el desequilibrio de invitados: «Nos podemos equivocar al invitar las personas. Lo único a que nos negamos es que nadie desde fuera del programa intente imponer su propio criterio sobre cómo debemos hacer» ${ }^{56}$.

¿Por qué se hizo la revolución de Asturias? ¿Quién la hizo? ¿Qué consecuencias trajo? Se abordaron temas como el significado de la II República, el fascismo y los asesinatos. Aunque el elemento de discusión entre los distintos invitados fue sin duda la revolución de Asturias de octubre de 1934. Asturias, de fuerte presencia minera, fue el lugar donde se inició una huelga

\footnotetext{
55 A. Shubert “Asturias, 1934-1984. 50 años para la reflexión”, Studia historica. Historia contemporánea, $\mathrm{n}^{\circ} 2$, 1984, pp. 245-246. Cfr. O. M. Morales, "La conflictividad social en Abenójar antes de la guerra, octubre de 1934”, en F. Alía Miranda y A. R. del Valle (coord.), La Guerra Civil en Castilla-La Mancha, 70 años después: actas del Congreso Internacional. Ed. Universidad de Castilla-La Mancha, 2008.

${ }^{56}$ Centro de Documentación RTVE. La revolución de Asturias (50 años después). Emisión: 5 de octubre de 1984.
} 
general tras la entrada en el Gobierno de la II República de tres ministros de la CEDA (Confederación Española de Derechas Autónomas). La izquierda española, encabezada por el PSOE, se sublevó en octubre de 1934 contra el Gobierno de la República ${ }^{57}$. No hubo la habitual bibliografía, y entre las preguntas de los telespectadores, José Luis Balbín destacó especialmente una realizada por un niño de nueve años: ¿Por qué hay guerras?

\section{Francisco Franco (ficha 402)}

El 8 de noviembre de 1985, La clave realizó la última clave histórica del programa titulada Francisco Franco. Se inició con imágenes de la fiesta organizada para conmemorar los 400 programas en la discoteca Bocaccio de Madrid con comentarios en off de José Luis Balbín. Los invitados fueron Juan Pablo Fusi (historiador), Narciso Perales (miembro de la llamada Falange Disidente), Fernando Vizcaíno Casas (escritor y abogado), Jorge Semprún (escritor y guionista), Blas Piñar (fundador de Fuerza Nueva), José Prat (senador socialista que ya había asistido en El Valle de los caídos), y Emilio Pardo (militar que se negó a sublevarse en 1936 y por lo que fue condenado a muerte). El programa tenía como objetivo abordar la obra y la figura de Francisco Franco durante los casi cuarenta años de dictadura.

Durante la semana se habían recibido muchas cartas en la redacción y, antes del debate, José Luis Merino leyó algunas preguntas ¿Es necesario que vuelvan los odios? ¿Cómo sois capaces de invitar en una democracia a Blas Piñar? José Luis Balbín inició el programa con la habitual lista de aquellos que habiendo sido invitados por La clave no habían querido asistir. Uno de ellos, Joaquín Gutiérrez Cano, vicepresidente de la Fundación Nacional Francisco Franco (que él mismo creó y cuya presidencia cedió a Carmen Franco Polo). Esa semana había escrito una carta dirigida a José Luis Balbín argumentando su ausencia, y éste no dudó en leerla delante de las cámaras: «Compruebo, una vez más el desequilibrio y la falta de imparcialidad con la que se aborda el tema desde su planteamiento inicial y no darse las adecuadas condiciones para mi presencia» ${ }^{58}$.

\footnotetext{
${ }^{57}$ Sobre la revolución de Asturias durante el periodo estudiado véanse J. A. Sánchez y S. García, La revolución de 1934 en Asturias, Ed. Nacional, Madrid, 1974. B. Díaz Nosty, La Comuna asturiana: revolución de octubre de 1934, Ed. Zero, Madrid, 1974. P. Preston, "La revolución de octubre: la lucha de las derechas por el poder", en Sistema, no 14, julio de 1976, pp. 95-116, y O. Múñiz, Asturias en la guerra civil, Ayalga, Gijón, 1976.

${ }^{58}$ Centro de Documentación RTVE. Francisco Franco (ficha 402). Emisión: 8 de noviembre de 1985. Se intentó además contar con la participación de algún familiar de Francisco Franco, con el expresidente Arias Navarro, Jesús Fueyo, Alejandro Fernández Sordo, José Antonio Girón, Jesús Solís... pero ninguno aceptó la invitación.
} 
Durante el debate se insertaron planos de la capilla ardiente de Francisco Franco (con los príncipes, familiares, y gente esperando a entrar en la capilla o pasando por delante del féretro). También se proyectó la película Caudillo (Basilio Martín Patino, 1977), que ya había sido utilizada previamente en Cincuenta años después. A partir de ella, se entró en debate. Para el historiador Juan Pablo Fusi era un material gráfico esplendido pues «la historia se hace también con documentos cinematográficos», y esta película expresaba perfectamente el paso en ambos bandos del idealismo al horror de la guerra. En cambio, para Vizcaíno Casas el film no era objetivo y contenía muchos errores. Del mismo modo que para Blas Piñar, «como relato documental muy deficiente, y como documento histórico, sectario».

En La clave fueron abundantes las polémicas sobre la elección de las películas que se proyectaban, pero Caudillo provocó tal controversia que José Luis Balbín tuvo que argumentar que había sido elegida porque un miembro del equipo de La clave (Juan Sierra, que había sido delegado nacional el Movimiento y procurador en Cortes), era partidario de su proyección. No fue la única polémica en el transcurso del programa, también lo fueron los versos de Pablo Neruda. Para Narciso Perales, no se podía tratar a Falange de modo tan frívolo, y añadía «no se pueden poner versos de Neruda, fue un gran poeta, pero fue antiespañol». Pablo Neruda había dedicado un poema al poeta Miguel Hernández que hacía referencia a Dámaso Alonso y Gerardo Diego. Este era el extracto en cuestión:

(...) Que sepan los que te mataron que pagarán con sangre.

Que sepan los que te dieron tormento que me verán un día.

Que sepan los malditos que hoy incluyen tu nombre

en sus libros, los Dámasos, los Gerardos, los hijos

de perra, silenciosos cómplices del verdugo,

que no será borrado tu martirio, y de tu muerte

caerá sobre toda su luna de cobardes $(\ldots)^{59}$.

La polémica se había incendiado con la afirmación de Blas Piñar durante el debate: «Llama a España hija de perra» ${ }^{60}$. Para Blas Piñar, Franco fue «un cristiano ejemplar, un

\footnotetext{
${ }^{59}$ Pablo Neruda, Obras completas I. RBA, Barcelona, 2005, p. 746.

${ }^{60}$ La frase en cuestión desató una enorme polémica en prensa. Desde Estados Unidos, el profesor Pedro Gutiérrez calificó el hecho de un enorme agravio: «el señor Piñar ratificó con una supuesta cita de Neruda en la que éste había llamado a España "hija de perra". Neruda nunca dijo tal cosa. Y aunque se busque minuciosamente y con lupa a lo largo de las diferentes ediciones de sus Obras completas, jamás se podrá encontrar tamaña insensatez. Pero el señor Piñar ha oído campanadas. A quien sí llamó Neruda "hijos de perra", y esto también puede comprobarse fácilmente en las diferentes ediciones de sus obras, fue a dos personas cuyos nombres el pudor me impide pronunciar. ¿Confusión del señor Piñar entre España y dos españoles? En cuanto a lo de "antiespañol", se
} 
hombre bueno, cauteloso, tímido, cortés, impenetrable, frio», adjetivos que tuvieron una rápida réplica en Jorge Semprún: «Me dan casi ganas de llorar en este momento al oíros hablar de Franco (...). No hagamos de Franco un humanista del siglo XX. Franco es un dictador» ${ }^{61}$. El coloquio se alargó de nuevo en la programación. Se habló de las distintas facetas que tuvo Francisco Franco (militar, político, estadista...), de la autarquía, de la Segunda Guerra Mundial, de la idea de España nacional católica... Esta emisión supuso el récord de preguntas de todo el programa en estos diez años (más de 600 preguntas), que no solo cuestiona el argumento de los responsables de TVE de declive de audiencia en La clave para su suspensión, sino que obvia el incremento de participación ciudadana. José Luis Balbín finalizó el programa argumentando que había sido un debate contradictorio pero que lo importante era que había podido hacerse. Es destacable que el propio director todavía tenga que denunciar a finales de 1985 las presiones y las dificultades para que un programa pueda o no hacerse, que muestra las dificultades y el control de la televisión durante todo el periodo de transición en España. El programa se despidió con imágenes de Franco, y la habitual bibliografía ${ }^{62}$.

En definitiva, en este repaso de los programas históricos destacamos, a modo de conclusión, la enorme capacidad que tuvo este programa en la formación de una cultura a partir del conocimiento, explicación y divulgación de un periodo de la historia reciente española inédito en televisión, lo que contribuye definitivamente en la elaboración de un discurso sobre el pasado. En primer lugar, por tanto, hay que tener en cuenta que La clave dedicó durante 1976 y 1985 toda una serie de programas para debatir sobre su historia inmediata, contradiciendo la amnesia que proponen algunos autores. La Guerra Civil se debatió en televisión durante la Transición. Lo hizo La clave en más de un programa y a través de personas relevantes, tanto historiadores como protagonistas de los hechos que se debatían. En plena disputa por la memoria histórica ${ }^{63}$, hablaron algunos de los más prestigiosos especialistas de la historia

\footnotetext{
debe añadir, y esto también se puede comprobar fácilmente, que Neruda nunca fue "antiespañol", sino que siempre fue "antifranquista". ¿Confusión de los señores Vizcaíno y Piñar entre antifranquista y antiespañol?», "Blas Piñar y Pablo Neruda", El País, 20/11/1985.

${ }^{61}$ Centro de Documentación RTVE. Francisco Franco (ficha 402). Emisión: 8 de noviembre de 1985.

${ }^{62}$ Franco. Autoritarismo y poder personal (J. P. Fusi, 1985). Franco y su tiempo (L. Suárez Fernández, 1984). Historia del franquismo (D. Sueiro y B. Díaz Nosty Barcelona, 1985).

${ }^{63}$ En la disputa sobre si la Transición se edificó sobre el olvido de los derrotados y represaliados, seguimos la tesis de Santos Juliá, en la que defiende que la Transición no dejó de lado la memoria de la Guerra Civil española. Véase Santos Juliá, "Echar al olvido: Memoria y amnistía en la transición”, Claves de razón práctica, nº 129, 2003, pp. 14-25. Véase la obra de V. Sánchez Biosca, "Políticas de la memoria. La guerra civil española en el cine y el reportaje televisivo", Archivos de la Filmoteca. Valencia. Filmoteca de la Generalitat Valenciana, n 49, 2005, pp. 32-53.
} 
contemporánea de España: Eric Hobsbawm, Gabriel Jackson, Juan Pablo Fusi, Ian Gibson, Manuel Tuñón de Lara, Bernardo Díaz Nosty, Rafael Abella...

En segundo lugar, y contrariamente al uso político que se hizo del término consenso para no cuestionar la Transición, La clave creó un espacio en el que precisamente el conflicto (y no consenso) servía como alternativa para la convivencia de posiciones diferentes, incluso antagónicas, que se sentaban por primera vez en un plató de televisión para exponer sus argumentos y puntos de vista, y defender sus diversas percepciones de los hechos. Así, los debates conceptuales desencadenados a raíz de la Guerra Civil, definieron los términos de las disputas: reconciliación, democracia, unidad, consenso...

En tercer lugar, La clave funcionó como un espacio formativo que permitía el acceso de la población a la información, su implicación ideológica y política a través del debate en directo. La participación del público en estos debates muestra al ciudadano como sujeto activo, así como su demanda y expectativa en tomar la palabra. Este programa brindaba al ciudadano un espacio en el que poder cumplir un rol decisivo en el uso de la libertad de expresión. Al mismo tiempo, fomentaba la formación de una ciudadanía activa, crítica y participativa alrededor de la historia inmediata que se estaba debatiendo en la España de la Transición.

Finalmente, La clave logró a través del debate, recuperar, explicar y proyectar la Guerra Civil española, poniendo en cuestión el relato impuesto por y desde el franquismo, permitiendo a los especialistas y actores de la contienda poner a disposición del telespectador su conocimiento histórico. Se conseguía por tanto permeabilizar y deconstruir el relato franquista, al tratar de imponer un discurso crítico de la historia, lo que permitía un cambio de mentalidad. Un hecho que quizás podría explicarse por una razón primordial: la creación y difusión de una determinada cultura política. Sin embargo, La clave mostraba también el problema que se estaba generando en el contexto político-cultural de la Transición. No era fácil resquebrajar una historia construida durante casi cuarenta años, cuando esta nunca se había condenado.

\subsection{Siete debates para la formación política}

Si en el debate histórico no se llegó precisamente a un consenso en la visión del pasado español más inmediato, ¿se podía lograr en el ámbito político? Tras la idea de cultura política existe, tal y como indica Jacqueline Peschard, «el supuesto implícito de que las sociedades necesitan de un consenso sobre valores y normas que respalde a sus instituciones políticas y 
que legitime sus procesos» (Peschard, 2012: 17) ${ }^{64}$. A lo largo de diez años de debates, La clave dedicó diferentes programas políticos que ayudaron a la formación ciudadana, a la socialización política y a la conformación de una cultura política en la sociedad española ${ }^{65}$. Estos programas ahondaron en la noción de diálogo a través de la confrontación de ideas que podían cambiar la representación y el imaginario político español. Pero, ¿qué papel desempeñó La clave en el debate político televisivo?

Hemos seleccionado un conjunto de programas con el propósito de abordar la formación de una cultura política a través debate político. Es, por tanto, una tematización centrada en analizar el sistema político español ${ }^{66}$. Conforman este bloque los siguientes programas: 1. ¿Por qué políticos? (1977). 2. Parlamentarismo y Constitución (1978). 3. Democracia y Sistemas políticos (1979). 4. Futuro de la democracia (1980). 5. Transición política y difícil convivencia (1983). 6. A la democracia desde la dictadura (1984). 7. Lo que va de ayer a hoy (1984).

\section{1. ¿Por qué políticos? (ficha 30)}

La primera clave política se realizó el 26 de noviembre de 1977. Fue uno de los programas con menor número de invitados, cuatro concretamente (dos invitados nacionales y dos internacionales). Hay que recordar que en esos momentos La clave optaba por no incluir a los partidos políticos para evitar «convertirse en un programa de propaganda política» ${ }^{67}$. Participaron dos exministros españoles: Joaquín Ruiz-Giménez (educación) y el abogado Antonio Garrigues (justicia) y dos extranjeros: Michel Jobert (presidente del Movimiento de los Demócratas de Francia) y Reginald Maudling (miembro del Parlamento del Reino Unido por el Partido Conservador). Se proyectó la película Tempestad sobre Washington (Advise and Consent, Otto Preminger, 1962), basada en la novela de Allen Drury (1959), que narraba los abusos y las prácticas tramposas en el Senado de los Estados Unidos. Sobre la película, Antonio

\footnotetext{
${ }^{64}$ Sobre la noción de consenso como procedimiento para obtener acuerdos, véase G. Sánchez Recio, "Consenso y desacuerdo en la democracia española actual", en Consenso y enfrentamiento en la Democracia española, Pasado y memoria, Revista de Historia Contemporánea, $\mathrm{n}^{\circ}$ 9, 2009, pp. 15-33.

${ }^{65}$ Sobre cultura política en España, véanse J. Montero y M. Torcal, "La cultura política de los españoles: pautas de continuidad y cambio", Sistema, $\mathrm{n}^{\circ}$ 99, 1990, pp. 39-74. J. Botella, "La cultura política en la España democrática", en R. Cotarelo (ed.), Transición política y consolidación democrática. España (1975-1986), CIS, Madrid, 1992. R. Gunther, Cultura y política en España, CEC, Madrid, 1993, pp. 121-136. S. M. Frías, Cultura política en España: conocimiento, actitudes y práctica, Col. Opiniones y Actitudes, 39, CIS, Madrid, 2001, y J. Cazorla, "La cultura política en España”, en S. Giner (ed.), España. Sociedad y política, Espasa, Madrid, 1990.

${ }^{66}$ Véase especialmente N. Lechner, "El malestar con la política y la reconstrucción de los mapas políticos", en R. Winocur (comp.), Culturas políticas a fin de siglo, Ed. Juan Pablos, México, 1997, pp. 15-35.

${ }^{67}$ Centro de Documentación RTVE. ¿Por qué políticos? (ficha 30). Emisión: 26 de noviembre de 1977.
} 
Garrigues señaló que «muestra una cosa muy interesante para los españoles en nuestro aprendizaje a la democracia que es cómo funciona el Senado de los americanos. La eficacia y el comedimiento con que esa institución funciona, yo creo que para nuestros senadores, aquí no hay ninguno pero si alguno me está oyendo, yo creo que es una buena lección para aprender» ${ }^{68}$.

¿Quiénes son los políticos? ¿Cómo se llega a la política? Durante el debate se hicieron referencias a la mentira como instrumento, a la honradez, a la figura del intelectual, y a la necesidad de aprender cómo funciona la democracia. El debate giró en torno al concepto de política, y a la fragilidad del político (deseo de poder, dinero, fama, influencia que puedan ejercer los grupos de presión económica...). También se hicieron referencias a algunos autores como José Ortega y Gasset (1983-1955) y Niccolò Maquiavelo (1469-1527). ¿El fin justifica los medios? ¿El poder corrompe? ¿Es posible un mundo sin políticos? ¿Es la demagogia una técnica inevitable?, fueron algunas de las preguntas que trataron de responder los invitados.

\section{Parlamentarismo (ficha 38) y Constitución (ficha 72)}

En 1978 se realizaron dos claves políticas. La primera, Parlamentarismo, con la película Caballero sin espada (Mr. Smith Goes to Washington, Frank Capra, 1939), alegato en favor de la democracia y de la Constitución se emitió el 4 de febrero de 1978. Al igual que ¿Por qué políticos?, en Parlamentarismo, La clave volvió a apartar del coloquio a los propios parlamentarios. Entre los invitados, tres nacionales (Luis Sánchez Agesta, José María GilRobles y Miguel Artola), y tres extranjeros (entre los que destacó la presencia de Adolf von Thadden, uno de los fundadores en 1964 del NPD) ${ }^{69}$. En el coloquio se debatieron temas como el referéndum, la elección de un sistema unicameral o bicameral, la división de poderes y su equilibrio, el bipartidismo, los lobbies...

Gil-Robles argumentó durante el debate: «Soy muy poco amigo de las fórmulas de la democracia directa. En países como Suiza, Dinamarca, donde hay una tradición y una formación cívica, dan resultados positivos. Pero en países que durante mucho tiempo han estado apartados de las vías democráticas, el referéndum puede ser, y de hecho ha sido, la vía fácil de la prolongación de situaciones políticas arbitrarias (...). Es muy difícil condensar el pensamiento político al que se somete al pueblo en una pregunta tan sencilla que pueda contestarse en un sí o con un no. (...) Esas preguntas encierran algo así como una trampa a

\footnotetext{
${ }^{68}$ Ibídem.

${ }^{69}$ Siglas del partido neonazi alemán: Partido Nacionaldemócrata de Alemania (NPD).
} 
la ingenuidad de los ciudadanos que están influidos por los medios de comunicación social. El Parlamento debe ser el medio constante de comunicación de la opinión pública con los representantes del Gobierno. No se puede desplazar por otros canales. No se puede sustituir esa labor formativa del Parlamento. En el momento en que se lleve a cabo una política de sustitución de la democracia representativa por la democracia directa o por la democracia televisiva estamos a dos pasos de concluir con la democracia verdadera. Eso lleva consigo un problema gravísimo, que es el de la regulación de un medio de poderosa penetración social como es la televisión» ${ }^{70}$.

También el catedrático de derecho político de la Universidad Complutense, Sánchez Agesta, advirtió que podría ser peligrosa una consulta directa en referéndum por la falta de tradición democrática en España ${ }^{71}$.

Un programa que giró en torno al conocimiento de las instituciones (el Parlamento) y los instrumentos democráticos con lo que contaba la sociedad española (el referéndum), que acabó siendo un ejemplo de la importancia del programa en favor de una determinada cultura política. A la importancia de formar a la ciudadanía, se observa también a un telespectador ávido por conocer dicho funcionamiento y ser partícipe de él ${ }^{72}$.

Aquello esencial, como argumenta Jean-François Sirinelli, «es que las culturas políticas deben comprenderse en término de constitución (cómo una forma de expresión política se elabora), pero también de circulación: por qué puentes estas formas constituidas circulan y se instan en el interior de un determinado grupo ${ }^{73}$. Una manera de entender por tanto la expresión política de una sociedad, sus cauces de circulación y su inserción en determinados grupos, es a través del debate político que se lleva a cabo de su propia Constitución.

La clave dedicó distintos programas a la Constitución y al conjunto de normas que eran compartidas por la sociedad española. El más destacado fue La Constitución (ficha 72), que se

\footnotetext{
${ }^{70}$ Centro de Documentación RTVE. Parlamentarismo (ficha 38). Emisión: 4 de febrero de 1978.

${ }^{71}$ Cfr. V. Philippe, Transition et télévision en Espagne... op. cit. p. 107.

${ }^{72}$ En la sección de preguntas destacan: ¿En el Parlamento es obligatorio votar según las directrices del partido?, y si es así, ¿no supone una coacción de la libertad individual de cada parlamentario? ¿Qué camino tienen que recorrer los electores para pedir responsabilidades a los parlamentarios que han elegido, cuando después de elegidos cambian de programa? ¿En desacuerdo las dos cámaras, qué criterio prevalece?

${ }^{73}$ Traducción propia del original: «Ce qui est essentiel, c'est que les cultures politiques doivent s'appréhender en terme de constitution (comment une forme d'expression politique s'élabore) mais aussi de circulation: par quels relais ces formes constituées circulent-elles au sein d'un groupe donné et comment s'y insèrent-elles?». J. F. Sirinelli, "Pour une histoire des cultures politiques : le référent républicain", en D. Cefaï (dir.), Cultures politiques, París, PUF, 2001, p. 157.
} 
emitió el 30 de septiembre de $1978^{74}$. El programa se realizó dos meses antes de ratificarse la Constitución por referéndum. Se proyectó la película Esta tierra es mía (This Land is Mine, Jean Renoir, 1943), alegato a favor de la democracia frente al nacionalismo nazi y una firme defensa de los derechos humanos ${ }^{75}$. Entre los invitados (y aquí observamos un cambio cualitativo en La clave), figuras de los cuatro principales partidos políticos: José Pedro Pérez Llorca (UCD), Gregorio Peces-Barba (PSOE), Jordi Solé Tura (PCE) y Félix Pastor (AP) ${ }^{76}$. Les acompañaron tres invitados extranjeros, el inglés Samuel Silkin (ministro de justicia), el suizo Jean Ziegler (profesor y diputado de la Confederación Helvética), y el estadounidense Theodore C. Sorensen (asesor político del presidente John F. Kennedy) ${ }^{77}$. Un debate de tres horas de duración en el que se abordaron temas de carácter general como el consenso, los derechos humanos y las nacionalidades ${ }^{78}$. De manera más específica para el caso español, se cuestionó la legitimidad democrática de una Constitución elaborada principalmente entre dos grupos. Tras el programa, se insertó la habitual bibliografía para aquellos que quisieran profundizar en el tema ${ }^{79}$.

\section{Democracia (ficha 103) y Sistemas políticos (ficha 105)}

En 1979 se realizaron dos claves políticas: la primera, La democracia, se emitió el 12 de mayo de 1979, con el estreno en televisión de la película Juárez (William Dieterle, 1939) ${ }^{80}$. Señalamos también la filmografía que se recomendó en este programa porque todas estas películas se proyectaron en La clave en alguna ocasión: Caballero sin espada (Mr. Smith Goes

\footnotetext{
${ }^{74}$ Sobre esta emisión, véase también V. Martín, Televisión Española y la Transición... op. cit. p. 225.

${ }^{75} \mathrm{Si}$ bien desde la óptica estadounidense al incluir el derecho a la propiedad privada.

${ }^{76}$ Exceptuando Félix Pastor, los tres invitados españoles, eran redactores en esos momentos de la Constitución.

${ }^{77}$ Como argumentan Palacio y Ciller, «el debate es un concepto cultural que aleja de su práctica cotidiana a muchos extranjeros, desconocedores de las formas orales de los españoles; tan es así que (...) [el] asesor político estadounidense dice que no conoce el derecho de interrupción» (Palacio y Ciller 2014: 237). José Luis Balbín, sin embargo, conocedor de esta práctica, no dudaba en interrumpir el debate para dar la palabra a los extranjeros.
}

${ }^{78}$ Una evolución del concepto de nacionalidad y la articulación político-institucional de las autonomías, en X. M. Núñez Seixas, "La nación en la España del siglo XXI: un debate inacabable", en Consenso y enfrentamiento en la Democracia española, Pasado y memoria, Revista de Historia Contemporánea, nº 9, 2009, pp. 129-148.

${ }^{79}$ Entre las obras recomendadas por el programa figuraban: Teoría de la Constitución (C. Schmitt), Historia del constitucionalismo español, y Derecho constitucional comparado (L. Sánchez de Agesta), Constitucionalismo y libertad (L. Quintana), Derecho constitucional comparado (M. García Pelayo), Teoría y práctica del gobierno moderno (H. Finner), Una Suiza por encima de toda sospecha (J. Ziegler), Constitución y periodos constituyentes en España (J. Solé Tura), y Teoría de la Constitución (K. Loewenstein).

\footnotetext{
${ }^{80}$ Sobre la película y su pretexto para difundir tres ideas (advertencia contra la invasión alemana, política de buena vecindad estadounidense y urgencia de implantar la democracia), véase C. A. Belmonte, "Juárez (Dieterle, 1939), un film mensaje de la buena vecindad americana”, en Letras Históricas, no 8, 2013, pp. 211-234.
} 
to Washington, Frank Capra, 1939), El politico (All the King's Men, Robert Rossen, 1949), El último Hurra (The Last Hurrah, John Ford, 1958), y El candidato (The Candidate, Michael Ritchie, 1972). Entre los invitados, Alain Krivine, fundador de la Liga Comunista Revolucionaria (LCR) y candidato a la presidencia de la República francesa, el periodista Emilio Romero, Antonio Jiménez Blanco (Presidente del grupo parlamentario de UCD), Antonio García Trevijano (fundador de la llamada Platajunta, que aparecía por primera vez en televisión), y los profesores, Hermann Oehling y Gregorio Peces-Barba (uno de los redactores de la Constitución).

A raíz de la película de Dieterle (a la que Emilio Romero no veía el menor asomo de democracia), se entró en coloquio. Peces-Barba inició el debate con una primera definición del concepto mismo de democracia: «Gobierno de la mayoría con respecto a las minorías, soberanía popular, integración de la resistencia, apertura hacia la igualdad, progreso en el marco de las reglas de juego que es la Constitución». Para Jiménez Blanco, la democracia se basa en «la dignidad de la persona humana y el progreso por la vía de la razón», y eran necesarias tres condiciones para su existencia: «economía de mercado, libertades públicas expresamente reconocidas, y consagración de los derechos humanos». Trevijano definió la democracia desde el campo formal como «método de legitimación y ejercicio del poder estatal que se caracteriza por dos notas irreductibles: el poder del Estado es legitimado por un procedimiento técnico de elección (directa o indirecta) de las personas que ocupan los cargos del Estado y ejercer el poder político. La segunda, la existencia de un órgano, también elegido por sufragio universal que controle el poder ejecutivo» ${ }^{81}$. Esta definición le sirvió para determinar que no existía democracia en España.

Tampoco existía democracia para Emilio Romero: «No considero el actual Estado español una democracia. No por contenidos, no por derechos sino porque formalmente las reglas de juego no son democráticas. La elaboración de la Constitución, las elecciones del 15 de junio y todo el procedimiento no ha sido democrático». Al ser interpelado en una de las preguntas por sus lealtades al régimen anterior, respondió: «Estoy legitimado ahora mismo para decir lo que me dé la gana». Alain Krivine, saliendo del esquema en el que transcurría el debate, interpeló al representante de UCD para hacerle toda una serie de preguntas: ¿Podemos construir la democracia en España manteniendo el antiguo aparato franquista? ¿Se puede construir la democracia encarcelando a mujeres culpables de abortar? ¿Se puede construir la democracia en

\footnotetext{
${ }^{81}$ Centro de Documentación RTVE: La democracia (ficha 103). Emisión: 12 de mayo de 1979.
} 
España enviando la policía contra el Pueblo Vasco? ¿Se puede construir la democracia con un sistema electoral no democrático ${ }^{82}$

Durante el transcurso del debate se definieron términos como parlamentarismo, constitución, democracia, y se formularían y se abordarían muchas preguntas: ¿Qué es un sistema democrático? ¿Qué pasa después de la construcción de una democracia? ¿Se limita la democracia a una lucha de partidos y numerosos gastos? ¿Es posible una democracia barata y austera? ¿Cómo se garantiza la defensa de los derechos de las minorías extraparlamentarias en una democracia como la española?

Dos semanas más tarde, el 16 de mayo de 1979, La clave realizó Sistemas políticos (ficha 105). Desde hacía semanas se había venido anunciando la participación de Herbert Marcuse en El compromiso del intelectual (ficha 97), aunque un problema de fechas provocó que cambiase su intervención en Sistemas políticos. Finalmente no pudo asistir al programa al ser ingresado en una clínica de Frankfurt por una bronconeumonía y ataque al corazón ${ }^{83}$. El filósofo había mantenido correspondencia con el equipo de La clave y envió a José Luis Balbín los diez folios sobre los que iba a versar su intervención, así como la prohibición expresa de no publicarse bajo ningún concepto ${ }^{84}$.

Marcuse murió dos meses más tarde, el 30 de julio de 1979. Tras su la muerte, desde La clave se filtraron a la prensa las notas con las que el filósofo y sociólogo de nacionalidad alemana y estadounidense pensaba desarrollar su intervención. En ellas, Marcuse trataba de abordar el marxismo en la sociedad del capitalismo avanzado a través de cuatro preguntas. Estas notas, hechas públicas en El País, pasaron desapercibidas ante la avalancha de artículos publicados con motivo de su fallecimiento (solo este periódico había publicado ese mismo día cuatro artículos en referencia al pensador alemán) ${ }^{85}$. A falta del original de diez hojas, traspapelado, estas notas que presentamos en los anexos, son el último escrito de Herbert Marcuse, una de las principales figuras de la primera generación de la Escuela de Frankfurt.

«Justo en los preámbulos del programa, llegó la noticia del atentado criminal en la cafetería California de Madrid, en el que fallecieron nueve personas» (Palacio y Ciller 2014: 238). José Luis Balbín inició el debate con las siguientes palabras: «Hoy, una nueva explosión

\footnotetext{
${ }^{82}$ Ibídem.

${ }^{83}$ Cfr. M. Palacio y C. Ciller, “La clave de TVE...”, en Estudios sobre el Mensaje Periodístico, op. cit. p. 238.

${ }^{84}$ Fuente: $A B C, 31 / 07 / 1979$, p. 27 (en web p. 35)

85 "Notas para la intervención de Marcuse en TVE”, El País, 31/07/1979. Véase anexo nº 7.
} 
grave en Madrid. No vamos a entrar en este tema porque no es un tema nuestro. El principio de este programa es precisamente el hecho de que la mayor parte nos entendemos coloquiando. No quiere decir que estemos de acuerdo, lo más difícil, por la falta de entrenamiento con el que nuestro país cuenta» ${ }^{86}$. Participaron cuatro invitados españoles: el periodista Carlos Luis Álvarez, el catedrático de derecho político Manuel Jiménez de Parga, y dos que no se veían en persona desde la Segunda República: Santiago Carrillo y José María Gil-Robles, que hicieron un llamamiento común al diálogo y la concordia entre españoles ${ }^{87}$.

Entre la filmografía propuesta, acabó proyectándose la película ;Viva Zapata! (Elia Kazan, 1952) $)^{88}$. El debate se inició con los cuatro sistemas políticos que proponía Maurice Duverger: regímenes capitalistas pluralistas (EEUU), regímenes monolíticos capitalistas (autoritarios o fascistas), socialistas dictatoriales (mundo comunista) y socialistas liberales (no había). Jiménez de Praga, completaba la clasificación con un hecho, según él, trascendental: la utilización política de la televisión: «Este poderosísimo instrumento de movilización de voluntades ajenas que es la televisión, ha supuesto el fin de una era histórica y el comienzo de otra. (...) La televisión ha sido más importante que la revolución francesa. (...) Les pregunto a mis alumnos si el levantamiento militar el 18 de julio de 1936 hubiera tenido el mismo resultado con la televisión. Yo pienso que no. (...) Los agentes, los actores, los métodos, la estrategia, o los fines, con la televisión son distintos (...). Abraham Lincoln jamás hubiera sido presidente en la era de la televisión porque era demasiado feo. Nixon perdió las elecciones con Kennedy precisamente por un debate televisado» ${ }^{89}$. El catedrático proponía una división en dos grandes bloques: países en los que la televisión es democráticamente compartida y países en los que la televisión es monopolio del gobierno.

Santiago Carrillo, a este respecto, argumentó que «no es el elemento que condiciona la forma de progreso, de desarrollo del mundo de hoy, pero la televisión no es un instrumento cualquiera. Es un instrumento muy serio. No se trata de saber o no utilizar la televisión, se trata de poder utilizarla. Los que ganaron las elecciones son los que pudieron utilizarla a fondo. Si

\footnotetext{
${ }^{86}$ Centro de Documentación RTVE. Sistemas políticos (ficha 105). Emisión: 26 de mayo de 1979.

${ }^{87}$ Véase M. Palacio y C. Ciller, “La clave de TVE...", en Estudios sobre el Mensaje Periodístico, op. cit. p. 238, en referencia a Alex Barnet, "La televisión de la A a la Z”, El periódico, 1985, p. 40.

${ }^{88}$ La filmografía que propuso La clave fue la siguiente: Octubre (Oktyabr, Sergei M. Eisenstein, 1927), La marsellesa (La Marseillaise, Jean Renoir, 1938), Caballero sin espada (Mr. Smith Goes to Washington, Frank Capra, 1939), Juárez (William Dieterle, 1939), El gatopardo (Il gatopardo, Luchino Visconti, 1963), Año uno (Anno uno, Roberto Rossellini, 1974), Muerte de un presidente (Śmierć Prezydenta, Jerzy Kawalerowicz, 1977), y Novecento (Bernardo Bertolucci, 1976).

${ }^{89}$ Centro de Documentación RTVE. Sistemas políticos (ficha 105). Emisión: 26 de mayo de 1979.
} 
hay un país en que es monopolio del Gobierno, este es España». Para Gil-Robles «lo grave es que ahora la televisión se quiera convertir en un monopolio no ya del Estado sino del Gobierno, con lo cual acaba la libertad de expresión, que es una de las condiciones esenciales para la existencia de los partidos políticos y para la existencia de la democracia». Tanto se habló de televisión que José Luis Balbín les advirtió que ya habían dedicado el programa Futuro de la televisión (ficha 73). La definición de democracia, la clasificación de sistemas políticos en democracias y no democracias y la necesidad de una labor de educación ciudadana, fueron algunas de las conclusiones alcanzadas ${ }^{90}$.

\section{Futuro de la democracia (ficha 162)}

El 5 de mayo de 1980, el día que los directivos de televisión habían previsto terminar con el directo del programa, La clave emitió en directo Futuro de la democracia. En la construcción de este debate, observamos, en primer lugar, un planteamiento de «proyección futura» en la que se sustenta una cultura política ${ }^{91}$. En segundo lugar, el carácter internacional de la emisión con seis invitados extranjeros y un español. Entre los invitados figuraban dos ex primeros ministros: Mário Soares (Portugal) y Olof Palme (Suecia) ${ }^{92}$, y figuras políticas como Franco Calamandrei (del Partido Comunista Italiano), Michel Jobert (exministro de Asuntos Exteriores de Francia), Julien Amery (exministro de Vivienda y Obras Públicas de Gran Bretaña), y Francisco Fernández Ordoñez (exministro español de Hacienda). El único que no pertenecía al ámbito de la política era el sociólogo francés Alain Touraine.

Se proyectó la película El Estado de la Unión (State of the Union, Frank Capra, 1948), a partir de la cual, se entró en debate. Para Olof Palme, el film era una buena ilustración en la lucha contra la crisis económica de los años treinta precisamente en un momento en el que Europa asistía a una fuerte crisis económica. Para Julien Amery, la película exponía la corrupción moral y financiera que podría afligir la democracia, mientras que para Franco Calamandrei la película no servía de mucho. Durante el debate se abordó el concepto de

\footnotetext{
${ }^{90}$ Para cerrar el programa, se propuso en la sección bibliográfica las siguientes obras: Instituciones políticas y derecho constitucional (M. Duverger), La libertad de los modernos (V. Cerroni), Los regímenes políticos contemporáneos (M. Jiménez de Parga), Derecho constitucional e instituciones políticas (A. Hauriou), Introducción a la ciencia política (K. L. Wolfgag), e Ideologías políticas contemporáneas (L. T. Sargent).

${ }^{91}$ J. F. Sirinelli, "Pour une histoire des cultures politiques", en D. Cefaï (dir.), Cultures politiques, op. cit. p. 157.

92 Olof Palme fue asesinado en Estocolmo el 28 de febrero de 1986 siendo Primer Ministro. Un asesinato que todavía hoy sigue sin resolverse. Olof Palme y su esposa Lisbet salían de un cine de Estocolmo cuando un hombre se le acercó por la espalda y le disparó causándole la muerte.
} 
democracia, los tipos de democracia, sus amenazas, la existencia previa de condiciones económicas (y de una burguesía), la democratización, la concentración de poderes, los partidos políticos (y su democracia interna), la democracia como modelo exportable, la importancia de la televisión (y su independencia), la violencia, el terrorismo...

Para Alain Touraine «la democracia fue inventada donde hubo mayor injusticia, porque la industrialización inglesa o francesa del siglo XIX fue de las más brutales y salvajes del mundo». Fernández Ordoñez señaló la brecha entre la élite política y la población y destacó la importancia de los medios de comunicación social: «La única forma para que el partido político realmente penetre en los problemas diarios del hombre de la calle es que tenga unos medios de comunicación. En España, hay un verdadero problema de comunicación, de información de los verdaderos problemas que se están discutiendo por los políticos». Para Mário Soares «es necesario que los partidos políticos tengan democracia interna». Y a este respecto, Olof Palme argumentaría que «los partidos, para sobrevivir, no pueden ser máquinas de recoger votos. No pueden ser únicamente foros donde se discuten los problemas políticos sino que también tienen que jugar un papel en la vida social diaria» ${ }^{93}$.

\section{Transición política (ficha 281) y Difícil convivencia (ficha 300)}

Algunos autores consideran la victoria del PSOE en las elecciones generales del 28 de octubre de 1982 el punto final del proceso de transición hacia la democracia ${ }^{94}$. No es de extrañar que en 1983 La clave debatiese en dos ocasiones sobre dicho proceso. Empezamos por la última, La difícil convivencia (ficha 300) realizada el 25 de noviembre de 1983. Se proyectó la película polaca Muerte de un presidente (Śmierć Prezydenta, Jerzy Kawalerowicz, 1977), utilizada en otros debates. Excepto dos invitados, todos habían pasado por el programa: Emilio Romero, Jordi Solé Tura, Ramón País, Manuel Fernández-Monzón y el exdirector general de RTVE, Fernando Castedo. También había pasado el único extranjero, el embajador de la República Federal Alemana Guido Brunner. Los nuevos invitados eran la joven poetisa Blanca Andreu y la secretaria de organización del PSOE Carmen García Bloise.

Javier Vázquez realizó un resumen de La clave desde su fundación, y entrevistó a Miguel Ángel Toledano (quien hizo posible el surgimiento del programa cuando era director

\footnotetext{
${ }^{93}$ Centro de Documentación RTVE. Futuro de la democracia (ficha 162). Emisión: 5 de julio de 1980.

${ }^{94}$ Véase J. Tusell, Historia de España en el siglo XX. Vol. IV. La transición democrática y el gobierno socialista, Taurus, Madrid, 1999.
} 
adjunto de TVE en 1975). Tras la entrevista, José Luis Balbín introdujo la emisión con un repaso de los diferentes directores generales de ese periodo, agradeciendo especialmente a Jesús Sancho Rof (quien aprobó el programa), Rafael Ansón (quien lo recuperó tras la primera prohibición), y sobre todo, a Fernando Castedo (invitado al coloquio y amigo desde que iniciasen ambos la carrera de Derecho). El debate giró en torno a la bipolarización, el bipartidismo, la paz y la política de bloques. Los términos más empleados fueron tolerancia, convivencia y paz (aunque para el militar Fernández-Monzón «la paz no es un valor supremo» ${ }^{95}$ ). Ramón País, catedrático de filosofía, señaló que no había que quedarse con «una democracia formal y pluralista, sino participativa», y Carmen García Bloise resaltó la necesidad de «educar al pueblo a ser ciudadano siendo tolerantes» ${ }^{96}$.

El 15 de julio de 1983 con el título La Transición política (ficha 281) se realizó una clave política y al mismo tiempo histórica. En esta ocasión, el equipo de La clave no pidió a los partidos políticos que enviasen sus representantes, sino que el programa elegiría a los invitados (lo que supuso de nuevo un cambio en La clave). José Luis Balbín inició el programa indicando los invitados que «no han asistido porque no pueden o quieren estar aquí: Adolfo Suárez González, Antonio Hernández Gil, Landelino Lavilla, Leopoldo Calvo Sotelo, Fernando Abril, Rodolfo Martín Villa, Gregorio Peces-Barba, Manuel García Pelayo, el general Gutiérrez Mellado, Rafael Calvo Ortega, Gabriel Cisneros, etcétera» ${ }^{97}$.

Los participantes en el debate fueron Manuel Martínez Azaña (sobrino político del expresidente del Gobierno de España durante la Segunda República, que había sido invitado apenas una hora antes), Jordi Solé Tura (Partido Socialista Unificado de Cataluña y uno de los redactores de la Constitución), Fernando Suárez González (vicepresidente de Alianza Popular), Julio Busquets (diputado del PSOE), Joaquín Satrústegui (exdiputado de UCD), el dibujante Máximo San Juan, y Joaquín Ruiz-Giménez (expresidente de Izquierda democrática y primer Defensor del Pueblo en España) $)^{98 .}$

\footnotetext{
${ }^{95}$ Fernández-Monzón había participado en Rearme (202), Militares y periodistas (205), y La información y el poder (230). El 19 de agosto de 1983, en «Tribuna abierta», de $A B C$, pidió «medidas ilegales, no democráticas ni de derecho», para resolver el problema político en el País Vasco. Y en declaraciones al semanario Interviú en mayo de ese año, lamentaría la «extrema dureza» de la sentencias a los condenados del 23-F.

${ }^{96}$ Centro de Documentación RTVE. La difícil convivencia (ficha 300). Emisión: 25 de noviembre de1983.

${ }^{97}$ Centro de Documentación RTVE. La Transición política (ficha 281). Emisión: 15 de julio de 1983.

${ }^{98}$ El Defensor del Pueblo fue implantado en España en diciembre de 1982, inspirado en la figura sueca del Ombudsman.
} 
Se emitió el documental La vieja memoria (1977), dirigido por Jaime Camino, y a quien le pidieron si podía reducir los tiempos del largometraje para adaptarlo al formato del programa. Como indica Vicente J. Benet «su propio título recogía ya una declaración de intenciones ante el valor de esa memoria del pasado» (Benet 2012: 365). A través de entrevistas (y sin la intervención de un narrador) el documental recuperaba la voz de los vencidos de la guerra y ofrecía una visión de la Guerra Civil alejada de la oficial del franquismo ${ }^{99}$. Para Martínez Azaña, en el documental aparecían anarquistas y comunistas «pero no los republicanos porque murieron casi todos en el exilio», y para Ruiz-Giménez, su importancia estaba en que «nos hace ver la dificultad que en sí mismo tenía la Transición». Satrústegui en cambio, rechazó el documental por ser solo una parte de la historia de la Transición.

El debate político se enlazó con el debate sobre el pasado español, iniciándose precisamente con el problema que había supuesto la Guerra Civil con dos Españas enfrentadas. El inicio de la Transición fue uno de los temas a los que no se llegó a un consenso. Para Fernando Suárez era imprescindible entender los antecedentes, la evolución de la sociedad, la industrialización, la alfabetización, y situaba la Transición desde la muerte del jefe del Estado (al igual que Máximo San Juan) hasta la Constitución (1978), o si se quería, hasta la llegada de los socialistas al Gobierno (1982). Para Satrústegui empezó en 1942 con don Juan de Borbón; y para Joaquín Ruiz-Giménez en los años setenta con la vertebración de la oposición. ¿Se daba por concluida la Transición española?

El debate fue planteado en torno a los términos de «reforma»y «ruptura». Julio Busquets argumentó que la Transición se produjo por la «suma de dos debilidades más el esfuerzo». Para Ruiz-Giménez «a la ruptura se llegó a través de la reforma», y para Azaña, «sí se ha hecho una ruptura, pero con la República, no con el franquismo» ${ }^{100}$. Se hicieron referencias al diálogo como metodología política, a Monarquía o República, al juancarlismo, al 23-F, al papel de Adolfo Suárez, al terrorismo, a las autonomías, a los símbolos, y al concepto de patria (con alusión a España o Estado español). Al finalizar el debate un telespectador preguntó: ¿Cómo quieren que haya convivencia si el mayor medio de difusión que es la televisión está fomentando la discordia?

\footnotetext{
99 Véase, V. Sánchez-Biosca, "Le cinéma analytique de la transition et le démontage des mythes franquistes", Cinémaction, $\mathrm{n}^{\mathrm{o}} 130,2009$, pp. 26-32.

${ }^{100}$ Centro de Documentación RTVE. La difícil convivencia (ficha 300). Emisión: 25 de noviembre de 1983.
} 


\section{A la democracia desde la dictadura (ficha 323)}

Siguiendo el camino abierto con La Transición política se realizó el 4 de mayo de 1984 A la democracia desde la dictadura. Entre sus invitados intervinieron líderes políticos de renombre internacional como el expresidente español (Adolfo Suárez), el expresidente militar de Argentina (Alejandro Agustín Lanusse), el expresidente de Portugal (Mário Soares), el exministro de Estado de Marruecos (Abderrahim Bouabid), el líder intelectual de la Primavera de Praga (Antonín Liehm), y el líder de la oposición en Paraguay (Euclides Acevedo). José Luis Balbín introdujo el programa con la habitual presentación de los invitados, en esta ocasión de cuarenta minutos. Un ejemplo fue la presentación de Adolfo Suárez: gobernador civil en Segovia (1968), director general de RTVE (1969), ministro secretario general del Movimiento (1975), presidente del Gobierno (1976), hasta su dimisión (1981). «¿Hay algo que añadir ahora que estamos en familia y no nos ve nadie sobre las razones de la dimisión?». Adolfo Suárez respondió:

«Bien, ahora que estamos en familia y como usted dice no nos ve nadie, más que unos millones de espectadores... [risas]. Ese día dije la verdad, lo que pasa es que no dije toda la verdad. (...) Hay muchísimos españoles que creen que en las elecciones generales eligen ellos directamente al Presidente del Gobierno, olvidando que lo que eligen son unos representantes (...). En el año 1980 había perdido bastante credibilidad ante la opinión pública española. Tenía incapacidad para conectar con el resto de las fuerzas políticas. La prensa calificó aquella etapa, “acoso y derribo de Suárez”. No tenía excesivas simpatías en muchísimos sectores económicos, sociales y de otro tipo. Lo más decisivo fue a finales de los ochenta. En UCD se produjo una corriente de diputados que manifestaba su disconformidad» ${ }^{101}$.

Tras la extensa introducción se proyectó la película ;Viva Zapata! (Elia Kazan, 1952), utilizada en Sistemas políticos (ficha 105). Durante el debate se insertaron imágenes referentes al país de cada uno de los invitados. ¿Qué es la dictadura? ¿Cómo se implanta? ¿Quiénes son los interesados en perpetuar este sistema? El debate giró en torno a la imposibilidad de exportan modelos de cambios políticos, las vinculaciones económicas e internacionales de las dictaduras, los derechos humanos, la tradición democrática de una sociedad, el aprendizaje democrático, y la necesidad de una educación democrática de los militares. Para Adolfo Suárez era necesario fomentar valores porque «todavía queda camino para consolidar la democracia». Para Lanusse,

${ }^{101}$ Centro de Documentación RTVE. A la democracia desde la dictadura (ficha 323). Emisión: 4 de mayo de 1984. 
era necesario educar al Pueblo porque «son los niveles más altos, los que disponen de poder económico, los que están interesados en la dictadura». Para Euclides Acevedo, «no es importante que el Pueblo se sienta explotado. Es más importante que conozca los mecanismos de explotación. Lo importante no es anhelar la democracia, sino conocer cómo se construye» ${ }^{102}$. La relación entre democracia y prosperidad económica, la carrera de armamentos, el papel de la prensa y la necesidad de establecer diálogo, fueron algunas de las conclusiones alcanzadas durante el debate. Se recibieron más de quinientas preguntas de los telespectadores.

\section{Lo que va de ayer a hoy (ficha 356)}

El 21 de diciembre de 1984 La clave abordaría de nuevo la Transición española con un programa titulado Lo que va de ayer a hoy. José Luis Balbín lo inició con una crítica al PSOE: «La clave en la época de UCD siempre tenía las peticiones de los socialistas más notorios para aparecer, y ahora desaparecen» ${ }^{103}$. Se proyectó el documental (no estrenado comercialmente) Informe general sobre algunas cuestiones de interés para una proyección pública (1977), de Pere Portabella, quien se encontraba entre los invitados ${ }^{104}$. Le pidieron reducir los tiempos para adaptarla al programa y eliminar la secuencia dedicada a la represión en el País Vasco. «El equipo de La clave me sugirió que esta secuencia podía distorsionar por motivar juicios no objetivos», diría su director en el transcurso del debate. Informe general es un film-documental que fue rodado en los meses posteriores a la muerte del general Francisco Franco, entre noviembre de 1976 y febrero-marzo de 1977, que recogía las opiniones de líderes de los grupos ilegales en esos momentos. Las intervenciones giraban sobre una única cuestión: cómo pasar de una dictadura a un Estado de derecho ${ }^{105}$. El propio director argumentó durante el debate que «la película no es objetiva. Es beligerante» ${ }^{106}$.

\footnotetext{
102 Ibídem.

${ }^{103}$ Centro de Documentación RTVE: Lo que va de ayer a hoy (ficha 356). Emisión: 21 de diciembre de 1984.

${ }^{104}$ Para José Luis Balbín, «lo ideal es que los directores de la película estuviesen presentes».

$105 \mathrm{http}: / / w w w . p e r e p o r t a b e l l a . c o m / e s / f i l m o g r a f i a / t o d o s / i n f o r m e-g e n e r a l-e s$ [consultado el 29/10/2016]. Como indica su web oficial, Informe general «trata de la futura representación política en la transición española, con una clara vocación democrática contradicha por su virtual "invisibilidad" durante treinta años».

106 Tal y como indica Vicente J. Benet, este documental ofrecía «un panorama vibrante de las contradicciones del presente» (Benet 2012: 364). José Luis Balbín recordó en 2005 que «en lugar de una película, lo que presentamos fue un montaje de intervenciones de políticos que debían reproducir lo que dijeron antaño en relación con el presente inmediato. El resultado de enfrentarse a las declaraciones de ayer era absolutamente esperpéntico», en F. J. Satué, Los secretos de la Transición, op. cit. p. 494.
} 
Además de Portabella, intervinieron Santiago Carrillo (PCE), José Prat (senador del PSOE), Luis Rufilanchas (PSOE), Eugenio del Río (Movimiento Comunista de España), Enrique de la Mata (exsecretario del Consejo del Reino), y Rodolfo Martín Villa (ex vicepresidente del Gobierno). Tras su presentación, se inició el debate con el tema del terrorismo. Eugenio del Río criticó que para hablar de terrorismo se eludiese la lucha de resistencia en el País Vasco. A continuación, Santiago Carrillo argumentó que en una dictadura toda lucha es legítima. «Yo no me arrepiento de haber visto con simpatía en la lucha contra el franquismo la acción de ETA». José Luis Balbín interrumpió el debate para decir que en $L a$ clave se podía hablar de todo siempre que «esté dentro de la Constitución que no sea apología del terrorismo. Pero se puede discutir sobre terrorismo, pero el tiempo es limitado. No quisiera que todo el discurso fuese solo terrorismo y solo al terrorismo en el País Vasco. ¿Piensan ustedes que ha ocurrido lo que dijeron que iba a ocurrir?». Ante la insistencia del terrorismo, prometió hacer un programa sobre el tema que nunca hizo.

A continuación se abordó la Ley para la Reforma Política y el binomio reforma y ruptura. Sin embargo, fue el tema de los reformistas del régimen el más polémico (iniciado por Rodolfo Martín Villa en su presentación, argumentando que el cambio político se produjo por jóvenes reformistas del interior y veteranos dirigentes del exterior), lo que produjo en el transcurso del debate una fuerte discusión. Esta es su transcripción:

Martín Villa: «A finales de 1975, la sociedad española era ya una sociedad democrática cuando muere Franco».

Eugenio del Río: «Yo estaba preparado a oír todo tipo de planteamientos, naturalmente. Pero lo que me supera profundamente y me asombra es que determinados sectores de la burocracia franquista, jóvenes e inexpertos, quizás se puedan atribuir ahora lo que se ha conseguido en este país de libertad o democracia. A mi juicio es relativamente poco, en parte debido a ustedes. Yo creo que si ustedes, en un momento dado empezaron a pensar en eso, es decir, en la conveniencia de adecentar la fachada política del franquismo fue porque lo consideraron necesario. ¿O es que ustedes tenían en su subconsciente un espíritu democrático que lo estaban reprimiendo hasta entonces? Precisamente ustedes daban ordenes de que nos torturaran».

Martín Villa: «Perdón, yo no he dado órdenes de que torturen».

Eugenio del Río: «No, no. Su papel no era dar órdenes que torturaran. Su papel era negar que había torturas, como es el papel de todos los ministerios del Interior».

Martín Villa: «Le ruego que trate de encontrar la más mínima prueba de que yo he dado órdenes de tortura. Ni una sola vez». 
Eugenio del Río: «Realmente sería una torpeza digna de un político jovencísimo inexperto». Santiago Carrillo: «Me he cuidado de no molestar a nadie recordándole sus orígenes franquistas. La evolución de una serie de personas desde el franquismo a la democracia es una evolución sincera» ${ }^{107}$.

Entre algunas de las preguntas de los telespectadores destacamos la dirigida al propio director de La clave. ¿Cómo puede decir usted tan alegremente que las secuencias del País Vasco en la película no se han dado por falta de tiempo y al mismo tiempo que los políticos vascos no se ponen de acuerdo en conversar entre sí en La clave, cuando esa redacción dirigida por usted no admite sistemáticamente cuestiones que plantean los telespectadores desde ópticas nacionalistas? También las dirigidas a Pere Portabella. ¿Cómo milita en un partido de extrema izquierda viviendo como un millonario?, y a Rodolfo Martín Villa y Enrique de la Mata ¿Qué credibilidad se le puede dar a Villa y de la Mata jurando los principios del Movimiento Nacional? Al finalizar el debate no hubo la habitual bibliografía.

En definitiva, La clave dedicó entre 1976 y 1985 toda una serie de programas políticos con una voluntad inequívoca de ruptura en relación al franquismo. Lo hizo a través de personas relevantes, tanto expertos como protagonistas de los hechos. Fue el caso del expresidente del Gobierno Adolfo Suárez, o de los siete redactores de la Constitución (Gabriel Cisneros, Gregorio Peces-Barba, Miguel Herrero, Miquel Roca, Manuel Fraga, José Pedro Pérez-Llorca y Jordi Solé). Hablaron líderes internacionales (Olof Palme, Mário Soares, Pierre Harmel, Alejandro Agustín Lanusse...), y algunos de los más prestigiosos especialistas (catedráticos, politólogos, sociólogos, filósofos...) como José Luis Sampedro, Alain Touraine, José VidalBeneyto, José Luis López Aranguren, Ramón País, Amando de Miguel, José Luis Abellán, Gustavo Bueno, Fernando Savater... A través de la libertad de expresión y de los expertos se expuso todo un argumentario que permitió a la sociedad española clarificar el funcionamiento de las instituciones políticas y explicar las reglas que conlleva toda democracia ${ }^{108}$.

Durante la Transición, La clave ayudó a la configuración sociopolítica española al constituirse en un espacio en el que reflexionar, debatir y negociar a través de la discrepancia. Lo que permitió socializar al individuo a través de una nueva cultura que apostaba en favor de la democracia. Pedagogía hacia un sistema político que no debía olvidar su pasado más

\footnotetext{
${ }^{107}$ Centro de Documentación RTVE: Lo que va de ayer a hoy (ficha 356). Emisión: 21 de diciembre de 1984.

${ }^{108}$ La clave funcionó en televisión como una cátedra (con más de 200 catedráticos) que ayudaba, a través del diálogo, a extender la educación, la cultura y el conocimiento, y a desglosar conceptos e instrumentos de la propia democracia que permitieron a la ciudadanía conocer el propio funcionamiento de sus instituciones.
} 
inmediato. La construcción, visualización y divulgación del debate televisivo fue una herramienta poderosa que permitió implicar a grandes sectores sociales y posicionar los debates históricos y políticos dentro de la agenda de la sociedad española. Es decir, La clave no solo fue determinante a la hora de influir en el espacio televisivo, también ocupó un lugar significativo en el espacio político al escenificar y al mostrar las aspiraciones que tenía la sociedad española.

Algunos autores como Virginia Martín argumentan que TVE actúo como «un pequeño parlamento en el que el enfoque y tratamiento de los temas políticos a debate reflejaban el espíritu de consenso que guiaba el proyecto de Transición a la par que socializaba en democracia a la audiencia» ${ }^{109}$. En este trabajo, en cambio, la investigación de los distintos programas políticos analizados muestra que la resolución del conflicto a través de la discrepancia se convierte en un factor básico para la convivencia democrática de una sociedad $^{110}$. La clave no solo fomentó la pluralidad política y la confrontación ideológica de sus líderes, también ofreció todo un conjunto de reflexiones sobre el tejido social en el que operaba dicho programa. Esta es por tanto, la confirmación de nuestra hipótesis. Siendo la Transición un sistema diseñado desde arriba, La clave visualiza como ningún otro programa las demandas, aspiraciones y presiones sociales procedentes de la propia sociedad española. $L a$ clave, en definitiva, construyó el debate televisivo que ayudaría a sentar las bases para la construcción de una cultura política democrática alejada las formas tradicionales que se habían dado en España para la resolución de conflictos como eran la violencia, el autoritarismo y la intolerancia. Y para ello utilizó el debate televisivo como instrumento político capaz de incidir en la mentalidad política de los españoles.

\footnotetext{
${ }^{109}$ V. Martín, "El parlamento catódico: los programas de debate sobre la actualidad política durante la transición (1976-1979), en Estudios sobre el Mensaje Periodístico, Vol. 20, Núm. especial (2014), p. 122.

${ }^{110}$ Sobre el funcionamiento del conflicto en el proceso de construcción de cultura democrática véase M. García Ferrando, "Los valores de los ciudadanos: conflictos y consensos", en F. Murillo et al. Transformaciones políticas y sociales en la España democrática, Tirant lo Blanch, Valencia, 2006.
} 


\section{Conclusiones}



Tras largos años de investigación es hora de llegar a una reflexión final y a una serie de conclusiones específicas que darán por finalizada esta tesis doctoral. No es nada llamativo, como hemos podido comprobar, que La clave haya sido considerado uno de los programas más prestigiosos que ha emitido Televisión Española a lo largo de su historia. Tampoco lo es el Premio Nacional de Televisión concedido a José Luis Balbín en 2015. Si hablar de La clave es hablar de la historia de la televisión, en este trabajo hemos querido ir un poco más allá al plantear una relación directa entre este programa y la formación de una cultura política democrática. Precisamente hemos tratado de medir el impacto que sobre la formación de una cultura política democrática pudo tener este programa, y cuyas características del debate televisivo (pluralismo, tolerancia, respeto a las diferentes opiniones...) se impregnarían en la sociedad española. Durante la Transición española, los debates de La clave contribuyeron al proyecto de cambio político tras una dictadura de casi cuarenta años.

Nuestra investigación se inició con la reconstrucción del programa La clave entre los años 1976 y 1985 (fecha de emisión, tema abordado, película proyectada e invitados). Una vez completada la información de las 408 emisiones, realizamos su visionado (tarea que fue llevada a cabo en el Centro de Documentación de Prado del Rey durante los meses de junio, julio y agosto de 2013, 2014 y 2015). Reconstruido el programa, se optó por una clasificación de las distintas emisiones a través de tres bloques temáticos y se planteó una primera hipótesis (articulada en torno a La clave como un instrumento del Estado para favorecer la instauración de la democracia en España y que, por tanto, trataba de servir de canal de orientación de cara a las transformaciones que necesitaba la sociedad española). Sin embargo, una revisión histórica de La clave a través de sus emisiones nos llevó a cuestionar la capacidad instrumental de dicho programa, mucho más independiente del que creíamos en un primer momento, y formular una nueva hipótesis de trabajo ${ }^{1}$.

\section{Hipótesis de la investigación}

La hipótesis que ha estructurado toda la investigación ha sido la siguiente: La clave no solo fue capaz de articular y construir el debate televisivo durante la Transición en España, sino que precisamente su originalidad -respecto a otros programas de similar formato- residió en su

\footnotetext{
${ }^{1}$ Aunque no estaba controlado por el poder político, en una entrevista en 2005, José Luis Balbín admite que en alguna ocasión hubo obligaciones por parte del gobierno. «Nos dijeron que era fundamental dedicar un programa a la Reforma de la Administración Pública. Fue una obligación», en F. J. Satué, Los secretos de la Transición. Del Batallón Vasco Español al proceso de los GAL, La esfera de los Libros, 2005, Madrid, p. 495.
} 
capacidad de favorecer la creación de una cultura política democrática. Siendo la televisión un producto diseñado desde arriba, este programa logra convertirse en un escenario que visualiza las aspiraciones, las demandas y las presiones de la sociedad española. La clave tuvo un papel significativo en Televisión Española mostrando a los ciudadanos lo que se podía debatir -y lo que no- en televisión. En sus debates, por tanto, se observa una mirada analítica del presente que invitaba a negociar y a encontrar soluciones políticas a los problemas de la sociedad española. Los encendidos debates nacionales de La clave influían y entraban directamente en la agenda política y en la sociedad española. Una influencia en el ámbito político que le comportó, en consecuencia, injerencias políticas y distintas prohibiciones. Pero el programa logró introducir características desde sus inicios que le permitieron adquirir una fuerte credibilidad llevando a La clave a convertirse semanalmente en una "singularidad" de la televisión realizada en esos momentos. Entre algunas de estas características destacan su realización en directo, su capacidad en mostrar y explicar sus mecanismos internos, su búsqueda de independencia del poder político y la participación del telespectador. La relevancia de incorporar en televisión estas novedades no solo estriba en el hecho de ofrecer a los telespectadores la pluralidad de ideas y de opiniones -muchas por cierto silenciadas durante el franquismo- también su legitimación. Hay que tener en cuenta, por tanto, que las características que introduce no solo lograban introducir cambios cualitativos, también rompían con la televisión realizada en el franquismo.

Una vez elaborado el aparato teórico y presentado un balance historiográfico y metodológico, procedimos a validar la hipótesis de la investigación a través de los datos empíricos empleados y estructurar los diferentes capítulos. La primera parte de la investigación fue estructurada en tres capítulos. El primero de ellos, "Televisión en España”, comenzó precisamente con una exposición del plan teórico que tenía como objetivo presentar un planteamiento de historia cultural del proceso de Transición desde la óptica televisiva. Con ello se pretendía trazar toda una serie de cuestiones epistemológicas y adoptar la metodología más adecuada para llevar a cabo este trabajo.

Con todas sus imperfecciones, TVE ha venido ocupando una posición central en la sociedad española. En este sentido, el capítulo pretendía contextualizar el programa a través del medio televisivo y observar el destacado papel que tuvo el modelo educativo de la televisión pública. Para ello, partíamos de los orígenes de la televisión como servicio público y centrábamos nuestra mirada en las misiones fundacionales: informar, educar y entretener. Como hemos podido comprobar, la influencia de las principales televisiones europeas, y en 
concreto, de la televisión francesa, fue determinante en Televisión Española a la hora de introducir formatos y programas extranjeros. Entre ellos, Les Dossier de l'écran, del que se inspiró posteriormente La clave. Sin embargo, ¿podía una emisión de televisión educar a una sociedad?

Este programa surge del modelo fundacional de la televisión pública (que además de informar y entretener, permitía educar y formar al ciudadano). La clave permitió situar el modelo educativo de la televisión pública al mismo nivel que otras televisiones occidentales. Sin embargo, como hemos visto, dicho modelo entró en crisis en gran parte de las televisiones europeas a finales de los años sesenta. Tras la crisis del modelo fundacional, la esfera del entretenimiento y la audiencia determinaron gran parte de directrices a seguir en el nuevo modelo de televisión pública y privada. En este modelo, sin lugar a dudas, se redujeron los espacios culturales dedicados a debatir, pensar o formarse, por una programación más encaminada a entretener al telespectador con un destacado desarrollo de la programación deportiva. Proporcionar, por tanto, una educación democrática a través de un programa de televisión fue clave para la España de la Transición. Su propuesta de debates entre expertos logró crear un espacio favorable al cambio político y a la democracia al divulgar temáticas y contenidos que pretendían dar respuesta a demandas sociales de la ciudadanía.

El segundo capítulo, “Apuntes para una biografía de José Luis Balbín”, pretendía responder a la pregunta inicial: ¿por qué los directivos de Televisión Española nombran a este periodista director de La clave? Partíamos, por tanto, alejados de la biografía política para centrarnos en la figura de un periodista. No se puede entender La clave sin atender la figura de José Luis Balbín. Asturiano de nacimiento, en 1958 se trasladó a Madrid para estudiar Derecho y Periodismo. En 1963 obtuvo el título de periodista en unos momentos en los que había pocos titulados que hablaran además otra lengua. Trabajó como corresponsal en el extranjero casi una década; estancia que le sirvió para adaptar posteriormente en España La clave. Sin embargo, la principal relevancia que extraemos de su trayectoria personal y profesional, son las determinantes redes de sociabilidad que explicarían las razones que llevaron a los directivos de RTVE a delegar en él la dirección del programa. En su estancia en Madrid (por el que pasó por distintos colegios mayores mientras estudiaba), se rodeó de figuras que tendrían especial importancia durante la Transición (Sabino Fernández Campo, Torcuato Fernández Miranda, Rodolfo Martín Villa...), y también en Televisión Española (Fernando Castedo, Jesús Sancho Rof, Miguel Ángel Toledano...). Redes de sociabilidad que permiten entender no solo su trayectoria, también la conformación de ciertos grupos durante la Transición española. 
En el tercer capítulo, "La clave y el debate televisivo", hemos presentado un análisis general del programa centrado en explicar el funcionamiento, el formato y la estructura del debate televisivo. Las entrevistas a miembros del equipo, invitados, y a su director, José Luis Balbín, se hicieron imprescindibles para entender el funcionamiento interno y avanzar en la investigación. Con su director nos reunimos en distintas ocasiones en Majadahonda (Madrid) y le invitamos a participar a unas jornadas sobre periodismo en Estrasburgo donde tuvimos la oportunidad de filmar una entrevista que presentamos en los anexos.

Como hemos podido comprobar, el análisis de las trayectorias y experiencias de los invitados en el momento del debate nos llevó a observar el alto porcentaje de académicos (profesores universitarios, juristas, economistas, filólogos, filósofos, historiadores, Premios Nobel...), el número de invitados extranjeros, o la baja participación de la mujer en el programa. Sin embargo, la formación de una opinión cualificada y la capacidad de extender contenidos a través de una gran audiencia son determinantes para entender la formación de una cultura política. El capítulo fue estructurado siguiendo el propio formato del programa con el que observar además de los invitados, la tematización, el cine emitido y la participación del telespectador.

En relación a la tematización, La clave abordó por primera vez en televisión temas inéditos hasta el momento que permitieron a la sociedad escuchar argumentos de expertos en esos campos. Un análisis de los diferentes temas nos ha permitido medir no solo el grado de libertad en televisión, también la tolerancia y aceptación de estas temáticas. La clave abrió nuevos caminos, enfoques y perspectivas en televisión al hablar de la eutanasia o del problema social que suponía la droga, tema tabú en un momento en el que no existía en España ningún centro especializado. Muchos temas afectaron directamente al campo de la política (el aborto, la adopción, la sanidad...), otros, mostraron nítidamente la posición del programa (la pena de muerte, las minorías, la violación de los derechos humanos, la justicia social, el consumidor, la OTAN...). Algunas temáticas expresaban con claridad sus preocupaciones más profundas (la desigualdad en el mundo, el hambre, las crisis, el impacto de los medios de comunicación...), y otras, nos advertían del grado de aceptación social (el divorcio, la homosexualidad, la autonomía universitaria...).

La clave habló de cultura en sus manifestaciones más clásicas (música, teatro, arquitectura, arte...), abriendo la puerta a otros campos como el folklore o la gastronomía. Abordó su historia inmediata (la Guerra Civil, el franquismo, la Transición), y habló de su proyecto de futuro (futuro de la humanidad, de la televisión, de la democracia). Criticó los 
abusos del sistema (el petróleo, la banca, el dinero de la Iglesia, el dinero de la política, el sistema capitalista, el negocio del suelo, de la salud, de la educación...), y apelaría al optimismo y a la esperanza del ser humano para superar las dificultades (solidaridad social, el defensor del Pueblo, las pensiones, la ecología...).

Sin embargo, en sus diez años de debates, La clave fue suspendida hasta en tres ocasiones (1976-1980-1985). Algunos de sus programas prohibidos (periodistas, poder municipal, guerras médicas...), y varias temáticas que nunca llegaron a concretarse. La temática que trató La clave fue tan amplia que finalmente resultaba más fácil hablar de aquellos temas que no había abordado. Además de expedientes administrativos y sancionadores, tuvo que hacer frente, como hemos podido comprobar, a determinadas presiones procedentes de los distintos gobiernos que trascurrieron entre 1976 y 1985.

Por último, en relación al cine, la película no solo servía para introducir el tema y entrar directamente en el propio debate. Tampoco se trataba de un simple complemento del programa, sino que los invitados, con sus intervenciones, llegaban a apropiarse de los contenidos de las mismas. A través de La clave se difunden grandes obras cinematográficas, algunas por primera vez en televisión, que enlazaban con los temas propuestos. El cine, emitido desde la televisión, se constituyó en una herramienta para fomentar la faceta formativa, y cuya principal finalidad era «mejorar el conocimiento, las estrategias o las actitudes y opiniones de los espectadores» (De La Torre 1996: 17). El objetivo de emitir producción propia nos advierte de la importancia que el programa acordaba al documento audiovisual y su propósito de abordar y poder concretar la temática que se quería presentar.

Tras el análisis general de La clave, hemos presentado la segunda parte de tesis doctoral en torno a tres capítulos (estructurados en las cinco grandes etapas por las que transcurre programa), y un último capítulo (en torno a la cultura política). Los tres primeros capítulos siguen la propia cronología del programa. No podemos sustraer La clave de su contexto porque este determina lo que fue el programa. Decidimos optar por seguir la cronología de la Transición con el objetivo de buscar un mecanismo explicativo de la historia cultural que acentuara la visión propiamente histórica. ¿Cuándo surgió realmente el programa? ¿Por qué lo hizo? ¿Evolucionó? ¿Se produjeron variaciones sobre lo previsto por causas externas?, para finalmente poder elucidar hasta qué punto fue La clave relevante para el proceso de transición.

La clave arroja mucha luz para el entendimiento de la televisión del período al que se refiere este trabajo. Si observamos en la trayectoria de La clave se produce en ella una evolución 
a lo largo de los años, que en algunos casos, viene marcada por los diferentes cambios que se producen en la dirección general de RTVE. Siguiendo la cronología histórica del programa, pasamos a ver en mayor profundidad las etapas analizadas y las conclusiones alcanzadas en cada una de ellas. El programa se aprobó en un momento en el que España tuvo que hacer frente a nuevas realidades políticas, económicas y culturales abiertas con la muerte del dictador.

\section{Génesis del programa e inicios del debate en España (1976)}

La primera etapa (enero y abril de 1976), mostró los recelos del poder ejecutivo en perder el control de la televisión, como quedó reflejado en el mandato de Gabriel Peña Aranda (con el recrudecimiento de la censura y la implantación abierta de listas negras en televisión). Juan Ramón Pérez Ornia definió el periodo de «pervivencia del franquismo» (Pérez Ornia 1988: 51), que no impidió, sin embargo, la entrada «en la parrilla todo tipo de espacios en contra de los presupuestos ideológicos de la dirección» (Palacio 2012: 10). Entre ellos, La clave, que se convertiría desde sus inicios en un altavoz con el que visibilizar y profundizar tanto temáticas como problemáticas del país.

La naturaleza, orientación y objetivos del programa se formularon en esta primera etapa. La clave introdujo novedades por primera vez en televisión que le permitieron erosionar la estructura televisiva desarrollada durante la dictadura. Lo que reafirmaba el carácter innovador de La clave era presentar el debate en televisión como instrumento de diálogo y como técnica democrática al facilitar la expresión de opiniones que habían estado ausentes durante la dictadura franquista. El programa contó entre sus invitados con expertos nacionales e internacionales; estos últimos pudiendo expresarse en su propia lengua. Pero no solo dio la palabra a expertos o políticos, también creó y fomentó un espacio de participación que permitía reforzar los vínculos de identificación entre televisión y ciudadanía. Sin ser un factor menor, por tanto, la plaza acordada al telespectador logró iniciar la construcción de un espacio social televisivo más amplio, menos unidireccional y más participativo.

En definitiva, la primera etapa del programa estuvo caracterizada por sentar las bases del debate televisivo no exenta de inseguridades y miedos al carecer de un programa nacional que sirviese de modelo en el que guiarse. Al lento desarrollo del primer gobierno de la Monarquía se sucedieron nuevas realidades y problemáticas sociales que impusieron un ritmo histórico diferente. 


\section{El regreso de La clave (1977-1978)}

Tras más de un año suspendido, La clave regresó dos semanas después de las elecciones generales del 15 de junio de 1977. La segunda etapa pretendía continuar con la propuesta inicial de debate en directo a través de opiniones divergentes entre sí. Para los responsables de televisión, en cambio, predicar la discrepancia no era, como hemos podido observar en la programación televisiva, lo ideal de cara al referéndum de diciembre de 1976 y a las elecciones del 15 de junio de 1977. No fue hasta 1977 cuando la plaza acordada al diálogo en televisión empieza a ocupar un lugar central en los argumentos de legitimidad entre los reformistas (que dirigían el proceso de Transición) y los rupturistas (que fueron dejando progresivamente sus aspiraciones a medida que avanzaba el proceso y se obtenían resultados) ${ }^{2}$. La clave articuló las distintas posibilidades emergentes y dominantes que le permitían definir un marco teórico que formulara principios a favor del cambio y, al mismo tiempo, denunciara posibles irregularidades en dicho proceso.

La segunda etapa fue la consolidación de La clave en la programación de televisión. A pesar de tener una cobertura más limitada (se emitía en la segunda cadena), el programa logró constituirse en una plataforma convergente de las diferentes ideologías que permitía acercar posturas, con una variedad temática preocupada por el pensamiento, el arte y la cultura (aunque también iniciaba en esta etapa una búsqueda de temáticas políticas o calificadas en la época de sensibles o tabús).

\section{Fernando Castedo y el golpe de Estado de 1981}

Fue la etapa de mayor apertura televisiva y se produjo con Fernando Castedo, primer director general de RTVE pactado entre el gobierno y la oposición. Las injerencias políticas se evidenciaron con la destitución de Fernando Castedo. En televisión, las continuas coerciones a la libertad de expresión mostrarían las dificultades por las que atravesaba Televisión Española. En cambio La clave demostró en esta etapa las posibilidades democráticas que ofrecía el debate televisivo a la hora de abordar temáticas con absoluta libertad, llegando a estructurar en televisión incluso el propio debate electoral. Una muestra de ello, fueron los preparativos para realizar el que debía ser el primer debate electoral en España, a pocos días de las elecciones de octubre de 1982. Un debate que a punto estuvo de estructurarse como una clave más, con el

\footnotetext{
${ }^{2} C f r$. R. del Águila, "La dinámica de la legitimidad en el discurso político de la Transición", en R. Cotarelo (Comp.), Transición política y consolidación democrática ... op. cit. p. 66.
} 
mismo formato de debate y con José Luis Balbín de moderador. Tras muchas especulaciones de cómo debía hacerse el debate electoral en televisión, la Junta Electoral Central adoptó la resolución de recomendar un debate múltiple en televisión entre los cinco líderes de los partidos nacionales de mayor representación (UCD, PSOE, AP, PCE, y CDS). Pero, al no llegar a un acuerdo los diferentes partidos políticos, pocos días antes de las elecciones fue suspendido el debate electoral. Sin embargo, La clave ya había realizado previamente el debate político con representantes de siete partidos. Entre ellos, Landelino Lavilla (UCD), Alfonso Guerra (PSOE), Manuel Fraga Iribarne (AP), Santiago Carrillo (PCE), Miquel Roca i Junyent (CIU), Xabier Arzalluz. (PNV), Luis Uruñuela (PSA) y Agustín Rodríguez Sahagún (CDS). Con la emisión titulada Elecciones ¿Para quién los votos?, (ficha 242), se realizó este debate electoral, a falta del oficial, el 1 de octubre de 1982.

\section{José Luis Balbín y los Servicios Informativos (1982-1983)}

Tras la victoria del Partido Socialista en octubre de 1982, José Luis Balbín ocupó uno de los cargos más importantes y relevantes de RTVE: la dirección de los Servicios Informativos. Fue la etapa de mayor crítica hacia el programa, con duras acusaciones desde diferentes sectores (particularmente desde la prensa conservadora), que mostraron claramente las reticencias de la derecha al perder el control político de la televisión. Un ejemplo de ello, como hemos visto, fue el caso Alonso Puerta y la emisión titulada Balance de los municipios de izquierda (ficha 254C). Como director de los Servicios Informativos, José Luis Balbín señaló los tres temas de consulta obligada: el terrorismo (especialmente de ETA), el Ejército y la Casa Real. A pesar de ello, y ante la desinformación y manipulación televisiva que existía en el medio de mayor difusión, La clave continuó su apuesta por temáticas controvertidas que aportaran la mayor información a la ciudadanía. Los diversos problemas de compatibilidad de cargos, y los conflictos surgidos con otros directivos del Ente (Antonio López, Clara Isabel Francia, o el propio director general José María Calviño), llevaron al cese de José Luis Balbín como director de los Servicios Informativos el 23 septiembre de 1983.

\section{La etapa final de La clave (1983-1985)}

La última etapa del programa se inició precisamente en septiembre de 1983 con la destitución de José Luis Balbín de los Servicios Informativos. En esta etapa se logró uno de los objetivos iniciales del programa: realizar producción propia. Se llevó a cabo en la emisión más 
crítica hacia un gobierno que se hizo en televisión en todo este periodo. Fue la emisión titulada OTAN, de salida ¿qué? (ficha 373) del 19 de abril de 1985. Se proyectó el documental Hilos de una trama (José Luis Egea, 1985), realizado expresamente para el programa. Precisamente la OTAN sería el tema que causaría su suspensión definitiva a finales de 1985. El 20 de diciembre de 1985 se emitió el último programa en Televisión Española con el título Veinte años de Vaticano II (ficha 408). El 23 de diciembre, los responsables de RTVE comunicaron a José Luis Balbín que La clave no continuaba por su descenso de audiencia. A la eminente suspensión, decidió cambiar los invitados y el tema del debate en el programa La movida nacional. En lugar de los invitados previstos, decidió llevar al debate a cuatro partidarios del referéndum sobre la OTAN: Gerardo Iglesias, Ramón Tamames, José María Mohedano y Alonso Puerta. Un cambio -y un tema- que provocó que los responsables de TVE suspendieran el programa. José Luis Balbín llevó entonces el programa hasta el Hotel Palace de Madrid. Junto a los cuatro invitados citados también asistieron Fernando Castedo y Heleño Saña, y fue allí, en el interior del Hotel Palace, donde se realizó el 27 de diciembre de 1985 el último debate de La clave.

El último capítulo de la tesis doctoral, "La cultura política durante la Transición española", como hemos dicho, se ha estructurado en torno al concepto de cultura política. $L a$ clave nos permite analizar los actores políticos y los agentes socializadores del proceso de Transición, pero también las visiones, los discursos y las representaciones de la sociedad española que irrumpieron en la democracia. El análisis histórico-político de La clave nos ha llevado a dos conclusiones fundamentales en la formación de una cultura política:

1. Desde su propio origen el programa apunta a la construcción televisada de la democracia en España. En este periodo, La clave se convierte en una plataforma defensora de valores democráticos frente al aparato franquista, y su debate, en un instrumento acelerador de cambios políticos. El conservadurismo social de la dictadura franquista entre 1939 y 1975 no pudo mantenerse intrínsecamente porque algunos de sus principios fueron cuestionados frontalmente a inicios de la Transición. De ahí la importancia de la estrategia democratizadora del programa, ya que permitió instaurar en televisión toda una serie de reglas democráticas que arraigaron en la sociedad y un diálogo entre los diferentes actores políticos. De esta forma, el enfoque, tratamiento y difusión de temas políticos e históricos también son un reflejo de los conflictos sociales y políticos que debía hacer frente la sociedad española en la Transición.

2. La clave hizo de la confrontación de ideas y la discrepancia el eje del debate televisivo, logrando imponer la negociación como forma de solucionar los conflictos. Si bien la 
discrepancia no implica necesariamente consenso, solo se puede llegar al consenso desde la discrepancia. El proceso de construcción del debate televisivo se revela así como una dinámica de permanente negociación y conflicto. Dicho debate funcionó durante la Transición como motor de consenso y como elemento vertebrador de una nueva cultura política. El programa y sus debates, por tanto, se convirtieron en un instrumento de acción política que fomentaba el pluralismo y la expresión de las diferentes opiniones existentes en España, lo que favoreció la conformación de una cultura política democrática que abogaba por el diálogo, la reflexión y el conocimiento.

\section{A modo de conclusión final}

Con este trabajo pretendíamos ilustrar, desde la óptica televisiva, algunas características de la cultura política española en el período de transición hacia la democracia. Hemos tratado de vincular en este trabajo el cambio político con el cambio social, con el propósito de observar cómo fue posible desarrollarse en España una nueva mentalidad. Una mentalidad a la que contribuyeron, través del medio televisivo, programas como La clave. ¿Podría este cambio de mentalidad explicar parte de las transformaciones de la Transición democrática ${ }^{3}$. Con sus propias reglas (debate en directo, temáticas sobre realidades concretas, presencia activa de personas de distinta ideología, respeto hacia otras ideas, participación ciudadana.... $)^{4}$, se configuró La clave en un espacio político de primer orden que permitía socializar valores.

Como hemos dicho previamente, la misión educativa fue uno de los pilares sobre los que se sustentó en sus orígenes la televisión pública. Esta misión garantizaba la incorporación de los derechos civiles como valores democráticos y como normas sociales. Junto a la independencia del poder judicial y a la libertad de prensa, también era necesaria una televisión libre de la influencia política que permitiese a los ciudadanos ejercer su derecho a voto. Por tanto, era fundamental en España educar en convivencia, democracia y ciudadanía para transformar dinámicas insertas en el sustrato social del franquismo. La clave no solo fue uno de

\footnotetext{
${ }^{3}$ En televisión hubo, como argumentaría Ramón Cotarelo, «programas que han hecho sin duda más por la democracia en España que los miles de proclamas y declaraciones de intención de los partidos de la oposición, muchos de los cuales, por no decir casi todos, prácticamente carecían de audiencia», R. Cotarelo, "Visiones de la Transición”, en Revista del Centro de Estudios Constitucionales, no 18, mayo-agosto de 1994, p. 31.

${ }^{4}$ El directo hacía que este programa pudiese escapar a uno de los muchos controles que se realizaban en televisión en esos momentos. El pluralismo político permitió que posturas aparentemente irreconciliables se sentaran a debatir. Y la participación del telespectador logró eliminar las barreras que excluían en televisión a la sociedad.
} 
los baluartes de lo que debía ser una televisión independiente, también fue un contrapeso del entretenimiento al promover la enseñanza y contribuir al conocimiento.

El análisis temático realizado revela el poder que tiene la televisión al tematizar e influir en la agenda social y política. La clave logró situar temáticas y conceptos en el centro del debate político español y, sobre estos conceptos, se tejieron muchos de los nuevos consensos. Sin embargo, esta tematización también nos ha permitido observar las dificultades que tuvo $L a$ clave -y Televisión Española- en abordar una serie de temáticas. Hemos seleccionado diez temas que La clave no pudo debatir y abordar en televisión en este periodo.

1. La Unión Militar Democrática (UMD).

2. La Monarquía y la figura de Juan Carlos.

3. El caso Xavier Vinader.

4. Militares republicanos.

5. Terrorismo (ETA, FRAP, muerte de Salvador Puig Antich...).

6. Las sentencias del golpe de Estado del 23 de febrero de 1981.

7. El Contubernio de Múnich.

8. Madres solteras.

9. Prostitución.

10. La matanza de Atocha de 1977.

Prohibidas sistemáticamente en La clave, estas temáticas revelan los tabús existentes en televisión durante el proceso de transición. Hubo además toda una serie de temas especialmente sensibles. En primer lugar, el bloque compuesto por los temas: Monarquía, Ejército, Iglesia, y terrorismo. Como argumenta Javier Muñoz Soro «la censura siguió vigilando las críticas contra la monarquía, el ejército, la iglesia o todo lo que se considerara dañino para una didáctica pública del consenso y la conciliación» ${ }^{5}$. Exceptuando la Iglesia, hay que recordar que eran los tres temas de obligada consulta cuando José Luis Balbín está al frente de los Servicios Informativos. El segundo bloque lo conforman temas como homosexuales, aborto, eutanasia, o alcoholismo. Temáticas que nos advierten de la posición del programa, pero que en muchos casos, si tenemos en cuenta las decisiones que adoptaron los responsables de televisión,

\footnotetext{
${ }^{5}$ Javier Muñoz Soro, “Los intelectuales en la Transición”, Ayer 81/2011, p. 20.
} 
situaban en el centro la propia moralidad española. Otro bloque compuesto por programas sobre la OTAN, la banca, el Opus Dei, o el caciquismo. Muchos de ellos finalmente pudieron debatirse, pero lo hicieron años después y tras muchos intentos. Por último, el bloque que conforman las claves históricas. Pese a las evidentes dificultades de abordar en televisión la Guerra Civil y el franquismo, La clave permite desmontar parte de la "amnesia" sobre la historia inmediata de la Transición (una transición como un acuerdo entre españoles que miraban al futuro pero renunciando a rendir cuentas y responsabilidades de su pasado inmediato) ${ }^{6}$. Más allá de la ideología individual, el debate permitía tomar conciencia de que el conocimiento no era neutro como tampoco lo eran los relatos históricos de la Guerra Civil, la pena de muerte, o el militarismo. Por último, hay que destacar que, a diferencia de Televisión Española, La clave sí centró su mirada en los focos históricamente más politizados del país: la clase obrera, la universidad, o los sectores nacionalistas de Cataluña y el País Vasco.

En este trabajo hemos presentado un análisis de La clave que nos permite entender la complejidad del medio televisivo en un contexto de transformación de un régimen dictatorial a otro democrático. Pero radiografiar La clave pretendía mostrar la importancia que tuvo el debate televisivo para la sociedad española. Tras la muerte de Francisco Franco, La clave aprovechó la apertura y el funcionamiento de la televisión para erigirse en una plataforma democrática, adelantándose a libertad informativa de los reformistas del régimen. Como un instrumento para interpretar la realidad, el debate de La clave creaba conciencia de los problemas y retos que tenía la sociedad española a finales del siglo XX y dotaba a los ciudadanos de conocimientos y mecanismos propios de las sociedades democráticas ${ }^{7}$.

En la joven democracia española, en términos democráticos, se utilizó la televisión como instrumento político. En televisión se observa una falta de análisis crítico sobre los principios mismos de una transición que escondía la continuidad de las élites, las injusticias sociales, la corrupción... e invisibilizaba, a los muertos y represaliados del régimen franquista.

El papel de los medios de comunicación en general, y el de la televisión en particular, es determinante para comprender la socialización de valores y referentes simbólicos. En el relato audiovisual posterior de la Transición, Televisión Española, siguiendo los intereses

\footnotetext{
${ }^{6}$ No por ello hubo temas que no pudieron concretarse como el anteriormente aludido sobre militares republicanos, o abordarse de una manera más directa, como el caso de la primera clave histórica del programa titulada Extranjeros en la Guerra Civil (ficha 131).

${ }^{7}$ El debate permitía no solo la apertura e introducción de temáticas que entraban de lleno en la esfera política, también permitía encauzar el lenguaje, apelar a valores o introducir discursos.
} 
políticos de los distintos gobiernos, transmite una visión del proceso que no cuestiona el «consenso» que fue alcanzado. La televisión es utilizada para vender una imagen democrática y para legitimar el modelo de transición llevado a cabo. Televisión Española fue una herramienta al servicio de la política pese a su definición de servicio público con la Constitución de 1978. Las dificultades para consagrarse como ente público se deben precisamente a que no hubo ruptura alguna con el régimen anterior, y siguió con un modelo continuista cuyo sistema fue regido por directivos afines al partido político que gobernaba.

La clave, por lo tanto, es un retrato de la sociedad española de ese momento. Su importancia radica no solo en la creación de un foro de discusión con el que ganar espacios de libertad, también por fomentar realidades que conllevan a una nueva cultura política. Ofreció el saber experto y el conocimiento especializado, componentes esenciales para hacer accesible los problemas que afectaban a la sociedad. Mediante la reflexión y el diálogo ayudó a cambiar leyes, resolver desafíos y formar a la ciudadanía. La clave, en definitiva, se constituyó en una infraestructura desde abajo que, desde presupuestos teóricos, permitió profundizar en las problemáticas de la sociedad española y, a partir de ellas, tejer consensos. A través de la pluralidad cultural y política de la sociedad española, este programa permitió abrir cauces para la participación política dentro de un sistema que tenía como una de sus bases estructurales la movilización política de la población. Los telespectadores podían escuchar argumentos a favor y en contra de distintas temáticas, reflexionar sobre el nuevo modelo de sociedad, más plural y democrática, y participar de él. Esta participación se configuró en torno a la necesidad de potenciar su intervención en los asuntos públicos.

La contribución cultural, social y política que hizo La clave en esta etapa ha convertido al programa en un emblema del diálogo en televisión de toda una generación durante la Transición. El debate no como punto de llegada, sino como todo un proceso. Porque no se trataba de educar al ciudadano sino de crear las condiciones para que el propio ciudadano pudiese aprender a discrepar. 


\section{BIBLIOGRAFÍA}

ADELL ARGILÉS, R. (1989). La transición política en la calle. Manifestaciones políticas de grupos y masas. Madrid, 1976-1987, UCM, Madrid.

AGUILERA, J. (1980). Principios de Historia de los medios audiovisuales, Tecnos, Madrid. (1989). Nueva dimensión de los medios audiovisuales, Mitre, Barcelona.

AGUILERA, M. (1985). El telediario: un proceso informativo, Mitre, Barcelona.

ALBERT, P. (1987). Historia de la radio y la televisión. Fondo de Cultura Económica, México, 1987.

(1994). Les médias dans le monde, Ellipses, París.

ALMOND, A. y VERBA, S. (1970). La cultura cívica. Estudio sobre la participación política democrática en cinco naciones, Euramérica, Madrid, 1970. De la obra original, The Civic Culture: Political Attitudes and Democracy in Five Nations, Little Brown \& Co, Boston, 1963. Versión revisada, The Civic Culture Revisited, Boston, Little Brown, 1980.

ALTAMIRANO, J. C. (2006). ¿TV or not TV?: una mirada interna de la televisión, Planeta, Santiago.

AMELA, V. M. (2008). Història cultural de l'audiovisual, UOC, Barcelona.

ANDERSON, B. (1996). L'imaginaire national : Réflexions sur l'origine et l'essor du nationalisme, La Découverte, París.

ARIAS, A. (1970). La televisión en España, Publicaciones españolas, Madrid.

ARÓSTEGUI, J. (1999). "La Transición política y la construcción de la democracia (1975-1996)", en J. Martínez (ed.), Historia de España. Siglo XX, 1939-1996, Cátedra, Madrid, pp. 245-362.

(2001). La investigación histórica: teoría y método, Crítica, Barcelona.

BABY, S. (2012). Le mythe de la transition pacifique. Violence et politique en Espagne (19751982), Casa de Velázquez, Madrid.

BADIE, B. (1986). Culture et politique, Economica, París.

BAGET HERMS, J. M. (1965). Televisión, un arte nuevo, Rialp, Madrid. (1975). 18 años de TVE, Diafora, Barcelona.

Barcelona. (1993). Historia de la televisión en España (1956-1975), Feed Back,

BAILLE, S. PHILIPPE, R. y BRAUDEL, F. (1963). Le Monde actuel. Histoire et civilisations, Belin, París.

BARRERA, C. (2003). "El debate sobre la televisión y el referéndum de la Ley para la reforma política de 1976", en A. Company, J. Pons y S. Serra (coords.) La comunicació audiovisual en la història. V Encontre d'Historiadors de la Comunicació. Aportacions de la comunicació i construcció de la història del segle XX. Universitat de les Illes Balears, Palma, vol. 2. pp. 491-508.

BARRIO, A., HOYOS, J. y SAAVEDRA, R. (2011). Nuevos horizontes del pasado. Culturas políticas, identidades y formas de representación, Universidad de Cantabria, 2011.

BARROSO, J. R. y TRANCHE, R. R. (1996). "La historia de la televisión en España”, en Archivos de la Filmoteca, Revista de estudios históricos sobre la imagen, n² 23-24, junio-octubre de 1996. 
BARTHES, R. (1987). El susurro del lenguaje. Más allá de la palabra y de la escritura, Paidós, Barcelona.

BECKER, J. (1994). "El pensamiento posmoderno. Su comportamiento en la teoría de la información”, en Telos, $\mathrm{n}^{\mathrm{o}}$ 38, pp. 17-38.

BENET, V. J. (2004). La cultura del cine. Introducción a la historia y la estética del cine, Paidós, Barcelona. (2012). El cine español. Una historia cultural, Paidós, Barcelona.

BENNASSAR, B. y BESSIERE, B. (2009). Espagne : histoire, culture, société, La Découverte, París.

BERNECKER, W. L. (1996). "El papel político del rey Juan Carlos en la Transición”, en Revista de Estudios políticos (Nueva Época), nº 92, abril-junio de 1996.

BERSTEIN, S. (1992). "L'historien et la culture politique", en Vingtième Siècle. Revue d'histoire, $\mathrm{n}^{\mathrm{o}} 35$, pp. 67-77.

(1997). "La culture politique", en J. P. Rioux y J. F. Sirinelli (dir.), Pour une histoire culturelle, Le Seuil, París, pp. 371-386.

(1999). Les cultures politiques en Frances, Le Seuil, París.

(2003). "Nature et fonctions des cultures politiques», en S. Berstein (dir.), Les cultures politiques en France, Le Seuil, París, pp. 11-36.

BESSIERE, B. (1992). La Culture espagnole : les mutations de l'après-franquisme, l'Harmattan, París.

BETHENCOURT, T. (1991). ¿Qué es la televisión?, Ediciones Granada, Madrid.

BLOCH, M. (1995). Histoire et historiens, Armand Colin, París.

BONAUT, J. (2009). Televisión y deporte. Origen y desarrollo histórico de la programación deportiva española (1956-1975), Librosenred, Buenos Aires.

BONET, L. (1999). "La politique culturelle en Espagne : évolution et enjeux", Pôle Sud, 10, pp. 58-74.

BORDERÍA, E. LAGUNA, A. y MARTÍNEZ, F. A. (1996). Historia de la Comunicación Social: Voces, Registros y Conciencias, Síntesis, Madrid.

BORDERÍA, E., MARTÍNEZ, F., y RÍUS, I. (2010). Política y comunicación en la historia contemporánea, Madrid, Fragua.

BOURDIEU, P. (1993). The field of cultural production: Essays on Art and Literature, Polity Press, Cambridge.

(1996). Sur la télévision, suivi de l'Emprise du journalisme, Raisons d'agir. París.

BOURDON, J. (1989). “Une histoire de l'histoire à la télévision”, Vingtième Siècle, revue d'histoire, vol. 24, $\mathrm{n}^{\mathrm{o}}$ 1, pp. 101-102.

(1995). “Genèse et actualité du service public", Dossiers de l'audiovisuel, n60, INA/La Documentation française, París, pp. 8-51.

(2001). “Une communauté inimaginable. L'Europe et ses politiques de L'image”, Mots. Les langages du politique, 67, pp. 150-167.

(2011). Du service public à la téléréalité. Une histoire culturelle des télévisions européennes, 1950-2010, Institut National de l'Audiovisuel, Bry-sur-Marne.

BRAUDEL, F. (1980). La historia y las ciencias sociales, Alianza, Madrid (5 $5^{\text {a }}$ edición). 
(1987). Grammaire des civilisations, Arthaud, París.

BROCHAND, C. y MOUSSEAU, J. (1982). Histoire de la télévision française, Nathan, París.

BURKE, P. (1996). La revolución historiográfica francesa: la escuela de los Annales, 1929-1989, Gedisa, Barcelona.

(2006). ¿Qué es la historia cultural?, Paidós, Barcelona. De la obra original, What is cultural history?, Polity Press, Cambridge, 2004.

(2006). Formas de historia cultural, Alianza, Madrid.

BURNS, R. W. (2001). John Logie Baird: Television Pioneer, The Institution of Engineering and Technology, Londres.

BUSTAMANTE, E. (2006). Radio y televisión en España. Historia de una asignatura pendiente de la democracia, Gedisa, Barcelona.

BUSQUETS BRAGULAT, J. (1986). "La Transición: conveniencia de su estudio", Revista española de investigaciones sociológicas, $\mathrm{n}^{\mathrm{0}} 36, \mathrm{pp} .7-12$.

CABRERA, M. A. (2010). "La investigación histórica y el concepto de cultura política", en M. Pérez Ledesma y M. Sierra (eds.), Culturas políticas: teoría e historia, Institución Fernando el Católico, Zaragoza, pp. 19-85.

CALLEJO, J. (1998). "Un análisis de la audiencia y su investigación con técnicas cualitativas", en J. Benavides (ed.), El debate de la Comunicación, Fundación General de la UCM, Madrid, pp. 501516 , (2001). Investigar las audiencias. Un análisis cuantitativo, Paidós, Barcelona, 2001.

CAPIN, J. (1980). L'effet télévision, Grasset, París.

CARR, E. H. (1985). ¿Qué es la historia?, Planeta, Barcelona.

CARR, R. y FUSI, J. P (1979). España de la dictadura a la democracia, Planeta, Barcelona.

CARRERAS, A. y TAFUNELL, X. (2010). Historia económica de la España contemporánea (1789-2009), Crítica, Barcelona.

CASSETI, F. y DI CHIO, F. (1999). Análisis de la televisión, Paidós, Barcelona.

CASTELLS, M. (2008). “Comunicación, poder y contrapoder en la sociedad red (I). Los medios y la política”, en Telos: Cuadernos de comunicación e innovación, $\mathrm{n}^{\circ}$ 74, pp. 13-24.

CASTILLO, P. y CRESPO, I. (1997). Cultura política: Enfoques teóricos y análisis empíricos, Tirant lo Blanch, Valencia.

CEBRIÁN HERREROS, M. (1978). Introducción al lenguaje de la televisión. Una perspectiva semiótica, Pirámide, Madrid.

(1981). Diccionario de Radio y TV. Bases de una delimitación terminológica, Ed. Alhambra, Madrid.

(1992). Géneros informativos audiovisuales: radio, televisión, periodismo gráfico, cine y vídeo, Ciencia 3, Madrid.

CERCAS, J. (2010), Anatomía de un instante, Debolsillo, Barcelona.

CERDÁN, J. (2002). "Dos o tres conclusiones, desde el presente, sobre el binomio Televisión/Transición”, en Área Abierta. Revista de comunicación audiovisual y publicitaria, $\mathrm{n}^{\circ} 3$, Universidad Complutense de Madrid, julio de 2002.

CHECA, A. (2008). Historia de la Comunicación: de la crónica a la disciplina científica, Netbiblo, La Coruña. 
CHARTIER, R. (1990). Les origines culturelles de la Révolution française, Le Seuil, París.

(1996). El mundo como representación. Historia cultural: entre práctica y representación, Gedisa, Barcelona. De la obra original, "Le monde comme représentation", Annales E.S.C., nº 6, noviembre-diciembre de 1989, pp. 1505-1520.

CHULIÁ, E. (2001). El poder y la palabra: prensa y poder político en las dictaduras: El régimen de Franco ante la prensa y el periodismo, Biblioteca Nueva/UNED, Madrid.

CHICHARRO MERAYO, M. y RUEDA LAFFOND, J. C. (2005). Imágenes y palabras. Medios de comunicación y públicos contemporáneos, CIS, Madrid.

COLEMAN, J. A. y ROLLET, B. (1997). Television in Europe. Intellect Books, Exeter.

COLOMER, J. M. (1990). El arte de la manipulación política, Anagrama, Barcelona.

Barcelona.

(1998). La Transición a la democracia: el modelo español, Anagrama,

CONTRERAS, J. M. y PALACIO, M. (2001). La programación televisiva, Síntesis, Madrid.

COSTA, P. O. (1986). La crisis de la televisión pública, Paidós, Barcelona.

COTARELO, R. (1992). Transición politica y consolidación democrática (1975-1986), CIS, Madrid.

(1994). "Visiones de la Transición", en Revista del Centro de Estudios Constitucionales, $\mathrm{n}^{\circ}$ 18, mayo-agosto 1994, pp. 9-78.

CURRAN, J., MORLEY, D. y WALKERDINE, V. (1998). Estudios culturales y comunicación, Paidós. Barcelona.

CURRAN, J. (2005). Medios de comunicación y poder en una sociedad democrática, Hacer, Barcelona.

DAYAN, D. y KATZ, E. (1995). La historia en directo. La retransmisión televisiva de los acontecimientos, Gustavo Gili, Barcelona.

DE LA TORRE, S. (1996). Cine formativo. Una estrategia innovadora en la enseñanza, Octaedro, Barcelona.

DE SANTIAGO GUERVOS, J. (1992). El léxico político de la Transición española, Universidad de Salamanca, Salamanca.

DESGOUTTE, J. P. (1978). La mise en scène du discours audiovisuel, L’Harmattan, París.

DEL ÁGUILA, R. (1982). "La transición a la democracia en España: reforma, ruptura y consenso", en Revista de Estudios Políticos, n $^{\circ} 25$, enero-febrero de 1982, Madrid.

DEL ÁGUILA, R. y COTARELO R. (1992). Transición política y consolidación democrática, España (1975-1986), Centro de Investigaciones Sociológicas, Madrid.

DEL ÁGUILA, R. y MONTORO, R. (1984). El discurso político de la Transición española, Centro de Investigaciones Sociológicas, Madrid.

DÍAZ, L. (1995). La televisión en España 1949-1995, Alianza, Madrid. (2006). 50 años de TVE, Alianza, Madrid.

DOSSE, F. (2007). El arte de la biografía: entre historia y ficción, Universidad Iberoamericana, México.

DURÁN, J. S. (2013). La télévision espagnole en point de mire. Centre de Recherche sur l'Espagne Contemporaine, Université de la Sorbonne Nouvelle - Paris III, París. 
DURAND, J. (1992). "La qualité des programmes de télévision, concepts et mesures", Dossiers de l'audiovisuel, $\mathrm{n}^{\circ}$ 43, mayo-junio de 1992, pp.12-64.

ECO, U. (1995). "Apocalyptic and Integrated Intellectuals: Mass communications and theories of mass culture", en Apocalypse Postponed, Flamingo, Londres, pp. 27-52 (edición original de 1964).

ESCARPIT, R. (1966). Culture et communication de masse, CRDP de Bordeaux, Burdeos.

ESTRADA, I. M. (2013). El documental cinematográfico y televisivo contemporáneo: memoria, sujeto y formación de la identidad democrática española, Tamesis Book, Woodbridge.

ESLAVA GALÁN, J. (2006). La Transición: memoria gráfica de la historia y la sociedad española del siglo XX, El País, Colección la Mirada del tiempo, $\mathrm{n}^{\circ}$ 7, Madrid.

ESQUENAZI, J. P. (1999). Télévision et démocratie. La politique à la télévision française, 19581990, PUF, París.

EVEN, M. (1989). L'Espagne et sa télévision, Institut National de l'Audiovisuel, París.

FERNÁNDEZ GARCÍA, T. y GARCÍA RICO, A. (2001). Medios de comunicación, sociedad y educación, Universidad de Castilla-La Mancha, Cuenca.

FONT, A. (2003), La transición política española. Los años Pujol, Publi Corinti, Barcelona, pp. 459-468.

FONTANA, J. (1992). La historia después del fin de la historia, Crítica, Barcelona.

FOUGEA, C. (1996). Télévision : mode d'emploi, Dixit, París.

FUENZALIDA, V. (1997). Televisión y cultura cotidiana: la influencia social de la TV percibida desde la cultura cotidiana de la audiencia, Corporación de Promoción Universitaria, Santiago de Chile.

FUKUYAMA, F. (1994). El fin de la historia y el último hombre, Planeta, Barcelona.

GALLEGO, F. (2008). El mito de la transición. La crisis del franquismo y los orígenes de la democracia (1973-1977), Crítica, Barcelona.

GARCÍA FERRANDO, M. (2006). "Los valores de los ciudadanos: conflictos y consensos”, en F. Murillo et al., Transformaciones políticas y sociales en la España democrática, Tirant lo Blanch, Valencia.

GARCÍA, S. y LUCKES, S. (1999). Ciudadanía: justicia social, identidad y participación, Siglo XXI, Madrid.

GARCÍA JIMÉNEZ, J. (1980). Radiotelevisión y política cultural en el franquismo, CSIC, Madrid.

GARCÍA MANTILLA, E. (1996). "TV española 1975-1982. Los cambios antes del cambio", Archivos de la filmoteca. Revista de estudios históricos sobre la imagen, $\mathrm{n}^{\mathrm{0}}$ 23-24, pp. 94-105.

GRACIA, J. (2006). Estado y cultura: el despertar de una conciencia crítica bajo el franquismo (1940-1962), Analgrama, Barcelona.

GRANDE, J. C. (1999). La influencia de la televisión, Editorial e Imprenta Universitaria, El Salvador.

GRIMSON, A. y VALERA, M. (1999). Audiencias, cultura y poder. Estudios sobre la televisión, Eudeba, Buenos Aires.

GUTIÉRREZ LOZANO, J. F. (2003). "La audiencia de la televisión en España y su historia. Un acercamiento a la memoria de los primeros telespectadores", en A. Company, J. Pons y S. Serra (eds.), La comunicació audiovisual en la història. Aportacions de la comunicació a la comprensió i construcció de la història del segle XX, Universitat de les Illes Balears, Palma, pp. 683-703. 
FAULKNER, S. (2013). History of Spanish Film: Cinema and Society 1910-2010, Bloomsbury Academic, Nueva York.

FERNÁNDEZ GARCÍA, T. y GARCÍA RICO, A. (2001). Medios de comunicación, sociedad y educación, Universidad de Castilla-La Mancha, Cuenca.

FERNÁNDEZ MIRANDA, A. (1995). Lo que el rey me ha pedido. Torcuato Fernández Miranda y la reforma política. Plaza \& Janés, Barcelona.

FERNÁNDEZ SANZ, J. J., RUEDA LAFFOND, J. C. y SANZ ESTABLÉS, C. (2003). Prensa y Periodismo Especializado. Historia y realidad actual, Ayuntamiento de Guadalajara.

FOUCAULT, M. (1975). Surveiller et punir. Naissance de la prison, Gallimard, París.

GILLESPIE, R., RODRIGO, F. y STORY, J. (1995). Las relaciones exteriores de la España democrática, Alianza, Madrid.

GÓMEZ ALONSO, R. (2004). "Investigar la historia de la televisión en España: algunos problemas documentales y metodológicos”, en Área Abierta, n 7 (enero 2004), Universidad Complutense de Madrid, pp. 1-8.

GONZÁLEZ CUEVAS, P. C. (1994). "La invenció d'una tradició: visió històrica de la monarquia durant la transició democràtica", en L'Avenç, nº 182, Barcelona.

GONZÁLEZ-DORIA, F. (1974). ¿Franquismo sin Franco...?, Cunillera, Madrid.

GONZÁLEZ REQUENA, J. (1988), El discurso televisivo: espectáculo de la posmodernidad, Cátedra, Madrid.

GONZÁLEZ SANTIAGO, M. (1990). La preparación de la Transición a la democracia en España, Prensas Universitarias, Zaragoza.

GORDON, M. (1991). La enseñanza del periodismo en el mundo occidental. Estudio histórico y comparado de tres escuelas, Universidad Complutense de Madrid, Madrid.

GUNTHER, R. (1992). Política y Cultura en España, Centro de Estudios Constitucionales, Madrid.

GUTIÉRREZ LOZANO, J. F. (2003). "La audiencia de la televisión en España y su historia. Un acercamiento a la memoria de los primeros telespectadores", en A. Company, J. Pons y S. Serra (eds.), La comunicació audiovisual en la història. Aportacions de la comunicació a la comprensió i construcció de la història del segle XX, Universitat de les Illes Balears, Palma, pp. 683-703.

HALLETT, M. (1978). John Logie Baird and Television, Priory Press, Hove.

HAMANN, K. (1998). "Civil society and democratic transition in Spain", en Perspectives on Political Science, vol. 27, pp. 135-141.

HERNÁNDEZ, E. (2002). "La dictadura franquista y la Universidad, 1951-1975. (Con especial atención al caso de Madrid)", en Cuadernos del Instituto Antonio Nebrija, n 5, Dykinson, Madrid, pp. 127-156.

HOBSBAWM, E. y RANGER, T. (2002). La invención de la tradición, Crítica, Barcelona.

HOLMBERG, A. (1980). "Five Years After Franco, Lorca Is Alive Again in Spain; Spain Rediscovers the Theater of Lorca", The New York Times, 19/10/1980, p. D3.

HOOG, E. (2010). La télé. Une histoire en direct, Gallimard, París.

HOPKIN, J. (1999). El partido de la Transición. Ascenso y caída de la UCD, Acento, Madrid.

HUERTAS, A. (2002). La audiencia investigada, Gedisa, Barcelona.

HUERTAS, F. (1994). Televisión y política, Editorial Complutense, Madrid. 
HUNNEUS, C. (1985). La Unión de Centro Democrático y la Transición a la democracia en España, CIS/ Siglo XXI de España, Madrid.

HUNTINGTON, S. P. (1994). La tercera ola. La democratización a finales del siglo XX, Paidós, Barcelona.

HURSH, D. W. y WAYNE ROSS, E. (2000). Democratic Social Education: Social Studies for Social Change, Routledge, Nueva York.

IBÁÑEZ, J. C. (2003). "Dinámicas culturales de los hábitos de recepción televisiva”, Archivos de la Filmoteca. Revista de estudios históricos sobre la imagen, $n^{\circ} 45$, Valencia.

(2006). "La clave", en M. Palacio, Las cosas que hemos visto. 50 años y más de TVE, Instituto de RTVE, Madrid, pp. 70-71.

ISAR, H. (1995). Le service public et la communication audiovisuelle, Economica, París.

JAHODA, M. (1981). “To publish or not to publish”, Journal of Social Issues, no 37, pp. 208-220.

JIMÉNEZ DE PARGA, M. (1993). La ilusión política. ¿Hay que reinventar la democracia en España?, Alianza, Madrid.

JOST, F. (1998). “Quand y a-t-il énonciation télévisuelle ?”, en J. Bourdon, y F. Jost, Penser la télévision, Nathan, París. (2007). Introduction à l'analyse de la TV, Ellipses, París. (2013). Comprendre la télévision et ses programmes, Armand Colin, París.

JULIÁ, S., PRADERA, J. y PRIETO, J. (1996). Memoria de la Transición, Taurus, Madrid.

JULIÁ, S. (2006). "En torno a los proyectos de transición y sus imprevistos resultados", en C. Molinero (ed.), La transición treinta años después. De la dictadura a la instauración de la democracia, Península, Barcelona, pp. 59-80.

KELLISON, C., MORROW, D. y MORROW, K. (2013). Producing for TV and New Media. A Real-World Approach for Producer, Focal Press, Nueva York.

LAFFOND, J. C. (2007). "Imágenes e imaginario para una historia de la televisión en la España del tardofranquismo", en H. Vivar y R. Vinader (Coords.), Televisión Española: Cincuenta años de telespectadores, Mezzadri-Gil; Instituto Oficial de Radio y Televisión y CES Felipe II, Madrid.

LECHNER, N. (1987). Cultura política y democratización, Consejo Latinoamericano de Ciencias Sociales, Buenos Aires.

LÉCUYER, M. C. y SERRANO, C. (1990). Otra España (documentos para un análisis: 19741989), Éditions Hispaniques, Alicante- París.

LEMUS, E. (2001). La Transición española más allá de la frontera, Septem, Oviedo.

LÉVY, M. F. y SICARD, M. N. (2008). Les lucarnes de l'Europe : Télévisions, cultures, identités, 1945-2005, Publications de la Sorbonne, París.

LÉVY, M. F. (2007). “Télévisión, publics, citoyenneté (1950-1974)”, en E. Cohen y M. F. Lévy (dir.), La télévision des trente glorieuses. Culture et politique (1945-1975), CNRS, París.

LINZ, J. J. y DE MIGUEL, A. (2001). "Para un mapa conceptual de las democracias", en Revista Politeia, no 26, pp. 25-46.

LIZCANO, P. (1981). La generación del 56. La Universidad contra Franco, Grijalbo, Barcelona.

LLORCA, C. (1971). Los teleclubs en España, Publicaciones Españolas, Madrid.

LÓPEZ PINTOR, R. (1981). "El estado de la opinión pública y la transición a la democracia", en Revista Española de Investigaciones Sociológicas, n 13 , pp. 7-47. 
(1982). La opinión pública española: del franquismo a la democracia, CIS,

Madrid.

LÓPEZ RODÓ, L. (1993). Claves de la Transición. Memorias IV. Plaza \& Janés/Cambio 16, Barcelona.

MAINER, J. C. y JULIÁ, S. (2000). El aprendizaje de la libertad, 1973-1986, Alianza, Madrid.

MAMERE, N. (1988). La dictature de l'Audimat. Voyage à l'intérieur du paysage audiovisuel français, La Découverte, París.

MANGINI, S. (1987). Rojos y rebeldes. La cultura de la disidencia durante el franquismo, Anthropos, Barcelona.

MARAVALL, J. M. (1982). La política de la transición, Taurus, Madrid,

MARÍN, C. (2006). Periodismo audiovisual: información, entretenimiento y tecnologías multimedia, Gedisa, Barcelona.

MARTÍN MUÑOZ, J. y LÓPEZ PAVILLARD, J. (1995). "La documentación audiovisual en RTVE", Documentación de las ciencias de la Información, $\mathrm{n}^{\circ}$ 18. Servicio de Publicaciones Universidad Complutense, Madrid, pp. 143-171.

MARTÍN SERRANO, M. (1981). "La influencia social de la televisión: niveles de influencia”, en Revista Española de Investigaciones Sociológicas, $\mathrm{n}^{\circ}$ 16, CIS, Madrid.

MARTÍN, V. (2013). Televisión Española y la Transición democrática. La comunicación política del Cambio (1976-1979), Ediciones Universidad de Valladolid, Valladolid.

(2014). "El parlamento catódico: los programas de debate sobre la actualidad política durante la transición (1976-1979), en Estudios sobre el Mensaje Periodístico, Vol. 20, Núm. especial, pp. 121-137.

MATTELART, A. (1995). La invención de la comunicación, Bosch, Barcelona.

MATTELART, A. y PIEMME, J. M. (1981). La televisión alternativa, Anagrama, Barcelona.

MATEOS, A. (2007). "Historia del presente, conciencia histórica y uso público del pasado", en Historia y memoria democrática, Envidia, Fuenlabrada.

MAXWELL, R. (1995). The Spectacle of Democracy. Spanish Television, Nationalism and Political Transition, University of Minnesota Press, Minneapolis.

MCLUHAN, M. y FIORE, Q. (1998). El medio es el masaje: un inventario de efectos, Paidós, Barcelona.

MCLUHAN, M. (2009). Comprender los medios de comunicación: Las extensiones del ser humano, Paidós, Barcelona.

MÉADEL, C. (2010). Quantifiquer le public. Histoire des mesures d'audience de la radio et de la télévision, Economica, París.

MENOR, J. (1992). "El fracaso de la nacionalización mediática: el ejemplo de la televisión del franquismo", en R. Pérez-Amat y A. Pérez-Ugena (codir.), Sociedad, integración y televisión en España, Laberinto, Madrid, pp. 27-40.

MINGUEZ, N. (2013). Ficción y no ficción en los discursos creativos de la cultura española, Iberoamericana, Madrid.

MOLINERO, C. (2006). La Transición treinta años después. De la dictadura a la instauración de la democracia, Península, Barcelona.

MOLINERO, C. y YSÀS, P. (2018). La Transición. Historia y relatos, Siglo XXI, Madrid. 
MONTERDE, J. E. (1993). Veinte años de cine español. Un cine bajo la paradoja, Paidós, Barcelona.

MONTERO DÍAZ, J. y RUEDA LAFFOND, J. C. (2001). Introducción a la Historia de la Comunicación Social, Ariel, Barcelona.

MORAGAS, M. (1982). “Comunicación de masas y transito político en España: 1975-1978”, en Comunicación y cultura, $\mathrm{n}^{\mathrm{o}}$ 7, México.

MORAN, A. (1998). Copycat TV: globalization, program formats and cultural identity, Luton Press, Luton.

MORÁN, M. L. (1995). "La cultura política y la interpretación de las transiciones a la democracia. (Notas sobre el caso español)”, en Política y Sociedad, n 20, pp. 97-110.

MORÁN, M. L. y BENEDICTO, J. (1995). La cultura política de los españoles. Un ensayo de reinterpretación, CIS, Madrid.

MORLEY, D. (1996). Televisión, audiencias y estudios culturales, Amorrortu, Buenos Aires.

MORODÓ, R. (1984). La transición política, Tecnos, Madrid.

MOUCHON, J. (1999). Política y medios. Los poderes bajo influencia, Gedisa, Barcelona.

MUNSÓ CABÚS, J. (2001). La otra cara de la televisión (45 años de historia y política audiovisual), Ediciones Flor del viento, Barcelona.

MUÑOZ SORO, J. (2011a). “Los intelectuales en la transición”, Ayer, nº 81.

(2011b). "La transición de los intelectuales antifranquistas", en Ayer, nº 81, pp.

$25-55$.

MURDOCH, G. (2000). “Talk-Shows. Democratic Debates and Tabloid Tales", en J. Wieten et al., Television across Europe. A comparative Introduction, Sage, Londres, pp. 198-220.

NAVARRO, J. (1995). Nosotros, la Transición, Temas de Hoy, Madrid.

NAVARRO, M. (1997). “Un acuerdo para la Transición”, en El País, 25/10/1997.

NEGRÓ, L. (2006). El diario El País y la cultura de las élites durante la transición, Foca Ediciones, Madrid.

NEL, N. (1990). Le débat télévisé, Armand Colin, París.

NEWCOMB, H. (2000). Television: The Critical View, Oxford University Press, Oxford.

OLMO, J. (1987). Historia de TVE. 23 fascículos editados los domingos por el diario Ya, abril de 1987.

ORTIZ HERAS, M. (2008). Los movimientos sociales en la crisis de la dictadura y la Transición, Almund, Ciudad Real.

ORTUÑO, P. (2005). Los socialistas europeos y la transición española, Marcial Pons, Madrid.

ORY, P. (2011). L'histoire culturelle, PUF, París.

PALACIO, M. (1992). Una historia de la televisión en España. Arqueología y modernidad, Consorcio Capital Europea de la Cultura, Madrid. (2001). Historia de la televisión en España, Gedisa, Madrid. (2006). Las cosas que hemos visto: 50 años y más de TVE, Instituto Oficial de Radiotelevisión Española, Madrid. (2012). La televisión durante la Transición española, Cátedra, Madrid. 
PALACIO, M. y CILLER, C. (2014). "La clave de TVE, un programa de debate en la historia...", en Estudios sobre el Mensaje Periodístico. Vol. 20. Núm. especial, pp. 227-241.

PALOMARES, C. (2006). Sobrevivir después de Franco. Evolución y triunfo del reformismo, Alianza, Madrid.

PASZTOR, E. H. (1956). Tele-Clubs in Rural France, Paperback, Universidad de California.

PAYNE, S. (1986). The politics of democratic Spain, The Chicago Council of Foreign Relations, Chicago.

PECES-BARBA, G. (1988). La elaboración de la Constitución de 1978, Centro de Estudios Constitucionales, Madrid.

PELLISTRANDI, B. y SIRINELLI, F. (2008). L'histoire culturelle en France et en Espagne, Collection de la Casa de Velázquez, $\mathrm{n}^{\circ}$ 106, Madrid.

PÉREZ CALDERÓN, M. (1965). La televisión, Editora Nacional, Madrid.

PÉREZ ORNIA, J. R. (1988). La televisión y los socialistas. Actividades del PSOE respecto a la televisión durante la Transición (1976-1981), Universidad Complutense, Madrid. (Tesis doctoral).

PÉREZ-AMAT, R. y PÉREZ-UGENA, A. (1992). Sociedad, integración y televisión en España, Laberinto, Madrid.

PÉREZ, J. M. (2004). TV educativo-cultural en España. Bases para un cambio de modelo, Fundación Alternativas, Madrid.

PÉREZ LEDESMA, M. y SIERRA, M. (2010). Culturas políticas: teoría e historia, Institución Fernando el Católico, Zaragoza.

PEREZ SANJUAN, O. (2008). Detrás de la Cámara. Historia de la televisión y de sus cincuenta años en España, Foro Histórico de las Telecomunicaciones, COIT/AEIT, Madrid.

PESCHARD, J. (2012). La cultura política democrática, Instituto Federal Electoral, México.

PESET, J. L. y HERNÁNDEZ SANDOICA, E. (2001). "La recepción de la cultura científica en la España del siglo XX: la universidad", en A. Morales Moya, Las claves de la España del siglo XX. La cultura, t. 8, Sociedad Estatal España Nuevo Milenio, Madrid, pp. 127-151.

PHILIPPE, V. (2007). Transition et télévision en Espagne. Le rôle de la TVE 1973-1978, L'Harmattan, París.

POIRRIER, P. (2004). Les enjeux de l'histoire culturelle, Seuil, París.

(2008). L'histoire culturelle : un «tournant mondial » dans l'historiographie?, Éditions Universitaires de Dijon.

POWELL, C. (1995). El piloto del cambio. El rey, la monarquía y la Transición a la democracia, Planeta, Barcelona.

Macmillan, Londres.

(1996). Juan Carlos of Spain. Self-made Monarch, St. Antony's College/

(2001). España en democracia, 1975-2000. Las claves de la profunda transformación de España, Plaza \& Janés, Barcelona.

PREGO, V. (1995). Así se hizo la Transición, Plaza \& Janés, Barcelona.

PYE, W. L. y VERBA, S. (1965). Political Culture and Political Development, University Press, Princeton.

QUADRA SALCEDO, T. (1976). El servicio público de la televisión, Instituto de Estudios Administrativos, Madrid. 
QUAGGIO, G. (2014). La cultura en Transición. Reconciliación y política cultural en España, 1976-1986, Alianza, Madrid.

QUIROSA-CHEYROUZE, R. (2009). Prensa y democracia. Los medios de comunicación en la Transición, Biblioteca Nueva, Madrid.

REDERO SAN ROMÁN, M. (1994). "La Transición a la democracia”, Ayer, n 15, Marcial Pons, Madrid.

REGUERA, I. y APARICIO, J. J. (2006). Carlos Pumares: Un grito en la noche, Editorial Club Universitario, Alicante.

RENAUDET, I. (2003). Un parlement de papier : la presse d'opposition au franquisme durant la dernière décennie de la dictature et la Transition démocratique, Casa de Velázquez, Madrid.

RODRÍGUEZ, A. (2015). España en su cine. Aprendiendo sociología con películas españolas, Dykinson, Madrid.

RODRÍGUEZ, F. (2003). Cultura y televisión. Una relación de conflicto, Gedisa, Madrid.

RODRÍGUEZ CORTEZO, J. (2008). Desde la calle: la transición, cómo se vivió, Vision Net, Madrid.

RODRÍGUEZ, N. y MARTÍNEZ, J. (1992). La televisión: historia y desarrollo (los pioneros de la televisión), Mitre/RTVE, Barcelona.

ROUQUETTE, S. (2001). L'impopulaire télévision populaire. Logiques sociales, professionnelles et normatives des palabres télévisées (1958-2000), L’Harmattan, París.

(2002). Vie et mort des débats télévisés. 1958-2000, De Boeck, Bruselas.

RUBIO, J. R. (1996). "La investigación de audiencia”, en J. Barroso y R. R. Tranche, "Televisión en España 1956-1996", Archivos de la filmoteca. Revista de estudios históricos sobre la imagen, ${ }^{\circ}$ 23-24, pp. 218-227.

RUEDA LAFFOND, J. C. y CHICHARRO, M. M, (2006). La televisión en España (1956-2006). Política, consumo y cultura televisiva, Fragua, Madrid.

(2010). "Ficción televisiva, comunidad de valores y cultura política en el último franquismo: Los Camioneros", en E. Bordería, F. Martínez y I. Rius (coord.), Política y comunicación en la historia contemporánea, Fragua, Madrid, pp. 599618.

RUEDA LAFFOND, J. C. y PELAZ, J. V. (2003). Cine, público y cultura. La dimensión social del entretenimiento cinematográfico, UCM, Madrid.

RUEDA LAFFOND, J. C. y CORONADO RUIZ, C. (2009). La mirada televisiva. Ficción y representación histórica en España, Fragua, Madrid.

RUEDA LAFFOND, J. C., CORONADO RUIZ, C. y SÁNCHEZ GARCÍA, R. (2009). "La historia televisada: una recapitulación sobre narrativas y estrategias historiográficas", Comunicación y Sociedad, Universidad de Guadalajara, $\mathrm{n}^{\mathrm{0}}$ 12, pp. 177-202.

RUIZ DEL OLMO, F. J. (1997). Orígenes de la televisión en España, Universidad de Málaga, Málaga.

SANABRIA MARTÍN, F. (1974). Radiotelevisión, Comunicación y cultura, Confederación Española de Cajas de Ahorro, Madrid.

SÁNCHEZ-BIOSCA, V. (1995). Una cultura de la fragmentación: pastiche, relato y cuerpo en el cine y la televisión, IVAC, Valencia. 
SÁNCHEZ FERRIZ, R. (1988). El Gobierno y la televisión española en Gobierno y administración en la Constitución, Dirección General del Servicio Jurídico del Estado, Vol. 2, I, pp. 1643-1678.

SÁNCHEZ NAVARRO, A. J. (1998). La Transición española en sus documentos, Centro de Estudios Políticos y Constitucionales/Boletín Oficial del Estado, Madrid.

SATUÉ, F. J. (2005). Los secretos de la Transición. Del Batallón Vasco Español al proceso de los GAL, La esfera de los Libros, Madrid, pp. 485- 496.

SECO SERRANO, C. (1989). Juan Carlos I, Anaya, Madrid.

SEOANE, M. C. y SAIZ, M. D. (1998). Historia del periodismo en España, Vol. 3: El siglo XX, Alianza, Madrid.

SERNA, J. (2005). La historia cultural, Akal, Madrid.

SEVILlano CALERO, F. (1998). Propaganda y medios de comunicación en el franquismo, Publicaciones de la Universidad de Alicante, Alicante.

SCHEMEIL, Y. (1985). "Les cultures politiques", en M. Grawitz y J. Leca, Traité de science politique, vol. 3 : L'action politique, PUF, París.

SINOVA, J. (1983). La gran mentira. El tinglado de la televisión al descubierto, Planeta, Barcelona.

SIRINELLI, J. F. (1997). Pour une histoire culturelle, Le Seuil, París.

(2001). "Pour une histoire des cultures politiques : le référent républicain", en Daniel Cefaï (dir.), Cultures politiques, PUF, París.

SMITH, A. (1979). Television and political Life. Studies in six European countries, MacMillan, Londres.

SORIN, P. (1996). Cines europeos, sociedades europeas: 1939-1990, Paidós, Barcelona.

SOTO, A. (1998). La transición a la democracia. España. 1975-1982, Alianza, Madrid.

STEVENSON, M. (1998). Culturas mediáticas. Teoría social y comunicación masiva, Amorrortu, Barcelona.

STRAUBHAAR, J. D. (2007). World Television: From Global to Local, Sage, California.

TEZANOS, J. F., COTARELO, R. y DE BLAS, A. (1989). La transición democrática española, Sistema, Madrid.

TIJERAS, R. (2012). "La transición en Radio Televisión Española bajo el influjo de Adolfo Suárez", en Comunicación 21 , Revista científica de estudios sobre cultura y medios, $\mathrm{n}^{\circ} 2$, abril de 2012, pp. 1-17.

TIMOTEO ÁlVAREZ, J. (1989). Historia de los medios de comunicación en España. Periodismo, imagen y publicidad (1900-1990), Ariel, Barcelona.

TRENZANO ROMERO, M. (1999). Cultura de masas y cambio político: El cine español de la transición, Centro de Investigaciones Sociológicas, Madrid.

THOMPSON, J. B. (1998). Los media y la modernidad. Una teoría de los medios de comunicación, Paidós, Barcelona.

THOMAS, R. (1978). Radiodifusión y democracia en Francia, Eunsa, Pamplona. (1993). Le sport et les médias, Vigot, París.

TUSELL, J. (1995). Juan Carlos I. La restauración de la Monarquía, Temas de Hoy, Madrid. 
(1996). "La Transición política: un planteamiento metodológico y algunas cuestiones decisivas”, en J. Tusell y A. Soto, (Eds.), Historia de la Transición 1975-1986, Alianza, Madrid.

(1997). La transición española a la democracia, Historia 16, Madrid.

(1999). Historia de España en el siglo XX. Vol. IV: La transición democrática y el gobierno socialista, Taurus, Madrid.

(2001). "Por una historia revisionista de la transición", en Claves de Razón Práctica, $\mathrm{n}^{\circ} 115$, septiembre de 2001, pp. 11-21.

(2003). "Una historia cultural: sobre "Pour une histoire culturelle", de Jean Pierre Rioux y Jean François Sirinelli (eds.)", en Saber leer, revista crítica de libros, no 164, abril, pp. 89.

Madrid. (2003b). La transición a la democracia y el reinado de Juan Carlos I, Espasa Calpe, (2007). La transición a la democracia. España, 1975-82, Madrid, Espasa.

TUSELL, J. y SOTO, A. (1996), Historia de la Transición 1975-1986, Alianza, Madrid.

TUSELL, J., MONTERO, F. y MARÍN, J. M. (1997). Las derechas en la España Contemporánea, Anthropos, Barcelona.

TUÑÓN DE LARA, M. et. al. (1991). Transición y democracia (1973-1985), Vol. X. Labor, Barcelona.

VÁZQUEZ MONTALBÁN, M. (1963). Informe sobre la Información, Fontanella, Barcelona. (1973). El libro gris de televisión, Ediciones 99, Madrid. (1985). Crónica sentimental de la Transición, Planeta, Barcelona.

VERHEYEN, N. (2003). Diskussionslust. Eine Kulturgeschichte des »besseren Arguments«, en Westdeutschland, Vandenhoeck \& Ruprecht, Universidad de Berlín.

VERÓN, E. (1998). Construir el acontecimiento, Gedisa, Barcelona.

VERSTRAETEN, H. (1996). "The media and the transformation of the public sphere", en European Journal of Communication, Vol. 11, $\mathrm{n}^{\circ}$ 3, pp. 347-370.

VIDAL-BENEYTO, J. (2007). Memoria democrática, Foca Ediciones, Madrid.

VIDAL PELAZ, J. V. y RUEDA LAFFOND, J. C. (2002). Ver Cine: los públicos cinematográficos en el siglo $X X$, Rialp, Madrid.

VILA SAN JUAN, J. F. (1981). La trastienda de tve, Plaza \& Janés, Barcelona.

VILCHES, L. et. al. (2007). Televisión y cultura, una relación posible, Consejo Nacional de la Cultura y las Artes, Santiago de Chile.

VV.AA. (1956). Press, film and radio in the world today, UNESCO, París.

VV.AA. (1969). La audiencia de la Televisión en España, Ministerio de Información y Turismo, Madrid.

VVAA. (1972). Cuadernos para el Diálogo, Extra XXXI, julio de 1972.

VVAA. (1989). Historia de los medios de comunicación en España, Ariel, Barcelona.

VVAA. (1996). Estudios culturales y comunicación. Análisis, producción y consumo cultural de las políticas de identidad y el posmodernismo, Paidós, Barcelona.

VVAA. (2002). "L'Espagne face à elle-même. Démocratie et problème national”, en Les 25 ans de l'Espagne démocratique, Vingtième Siècle, revue d'histoire, Presses de Sciences Po, $\mathrm{n}^{\mathrm{0}}$ 74, París. 
WOLF, M. (1991). La investigación de la comunicación de masas. Crítica y perspectivas, Paidós, Barcelona.

YSÀS, P. (2010). "La Transición española. Luces y sombras", en Ayer, Revista de Historia Contemporánea, $\mathrm{n}^{\circ}$ 79, Marcial Pons, Madrid, p. 31-57. Monográfico: Procesos de construcción de la democracia en España y Chile, Marcial Pons, Madrid.

\section{OTRAS FUENTES CONSULTADAS}

\section{Fuentes hemerográficas:}

$A B C$

Arriba

Cuadernos para el diálogo

Destino

Diario 16

El País

Interviú

La Hoja del lunes

La Nueva España

La Vanguardia

Mediterráneo, Pueblo

Tele-Radio

Tele-Programa

Triunfo

\section{Publicaciones de RTVE:}

RTVE (1976). RTVE, 1976, Instituto de RTVE, Madrid.

RTVE (1977). Mensaje y medios, Instituto de RTVE, Madrid, octubre.

RTVE (1978). Informe 1978, Madrid, RTVE.

RTVE (1980). RTVE, 79. Crónica de un año, Madrid, RTVE.

Páginas web consultadas:

http://www.rtve.es/archivo/

http://www.rtve.es/alacarta/videos/la-clave/ 
http://tv_mav.cnice.mec.es/siglo/50/index.swf

http://www.rtve.es/rtve/20111028/anos-television-espanola/471637.shtml

http://laclave.com/

http://www.rtve.es/archivo/mi-programa-preferido-de-la-tele/la-clave/

http://www.rtve.es/alacarta/videos-audios/noticiarios-nodo/

http://www.rtve.es/filmoteca/

http://www.reis.cis.es/REIS/html/index.html

http://www.rtve.es/alacarta/videos/archivos-tema/archivo-temas-lagrimas-delpresidente/868442/

http://www.rtve.es/rtve/20111028/55-anos-television-espanola/471637.shtml

http://www.rtve.es/alacarta/audios/radio/jose-luis-balbin-habla-2005-del-programaclave/757514/

http://www.rtve.es/alacarta/audios/esto-me-suena-las-tardes-del-ciudadano-garcia/esto-suenaclave-hoy-pone-jose-luis-balbin-15-11-11/1249757/

http://www.ivoox.com/otra-mirada-6-temp-la-clave-con-audios-mp3_rf_2008390_1.html

http://www.ivoox.com/hablando-periodismo-jordi-evole-jose-audios-

mp3_rf_2093918_1.html

http://cadenaser.com/programa/2013/10/22/audios/1382399479_660215.html

http://www.cedecom.es/noticias/jose-luis-balbin/

https://www.youtube.com/watch?v=LNKmFttx5II

https://www.youtube.com/watch?v=rOfjZNEsL7g

https://www.youtube.com/watch?v=Ga6vXB-BVTs

http://www.congreso.es/portal/page/portal/Congreso/Congreso/Hist_Normas/ConstEsp1812_ 1978/Const1978

http://www.rtve.es/television/23f/videos/

http://www.pereportabella.com/es/filmografia/todos/informe-general-es

http://utv.unistra.fr/video.php?id_video=618 


\section{ÍNDICE DE TABLAS Y FIGURAS}

No 1. Tabla. Distribución de programas emitidos y prohibidos entre 1976 y 1985.

$\mathbf{N}^{\circ}$ 2. Tabla. Periodos y etapas internas del programa La clave

$\mathbf{N}^{0}$ 3. Figura. Índice temático de los programas del libro-anuario LA CLAVE realizado en octubre de 1985 para conmemorar los 400 programas 117

No 4. Gráfica. Procedencia de películas emitidas entre 1976 y 1985 132

No 5. Gráfica. Nacionalidad de los invitados extranjeros al programa 140

\section{ÍNDICE DE FOTOGRAFÍAS}

Fotografía no 1. Retransmisión del partido de fútbol entre el Real Madrid y el F.C. Barcelona en el Santiago Bernabéu. Barcelona, 15 de febrero de 1959 .56

Fotografía no 2. José Luis Balbín en 1976. .73

Fotografía n⿳ 3. Ingreso de la cuota anual de afiliación al SEU. .84

Fotografía n⿳ 4. Nombramiento de José Luis Balbín Meana como Secretario del Departamento de Información de la Jefatura Nacional del SEU .85

Fotografía n⿳ 5. Historial académico y sindical de José Luis Balbín .92 
Fotografía nº 6. Dossier informativo de José Luis Balbín en 1976 procedente del Ministerio de

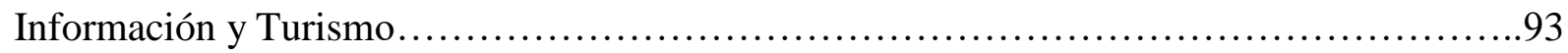

Fotografías no 7 y 8. El símbolo La clave .................................................................106

Fotografía no 9. Fernando Arias-Salgado comparece en 1980 ante la Comisión de Control

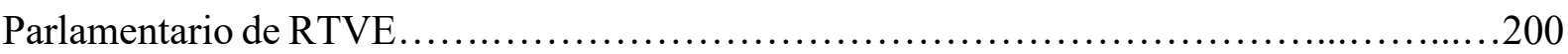

Fotografía no 10. Fotografía realizada del 10 de octubre de 1982 durante la presentación del programa Elecciones II. ¿Para quién los votos? .221

Fotografía n 11. Caricatura de Diario 16: Guerra, Balbín y Calviño en 1983 226

Fotografía no 12. José Luis Balbín convoca una rueda de prensa en 1983 para explicar la suspensión del programa Los Ayuntamientos de izquierda. .229

Fotografía no 13. Caricatura de Diario 16: el control gubernamental de TVE 230

Fotografía no 14. Entrevista a Miguel Ángel Toledano en 1983. 243

Fotografía n⿳0 15 . El equipo de La clave se reúne en un restaurante al conocer la suspensión del programa en diciembre de 1985 .257

Fotografía n⿳0 16. José Luis Balbín al finalizar uno de los programas .259 
Anexos 
Anexo 1. Certificado de notas y Plan de Estudios de la Escuela Oficial de Periodismo

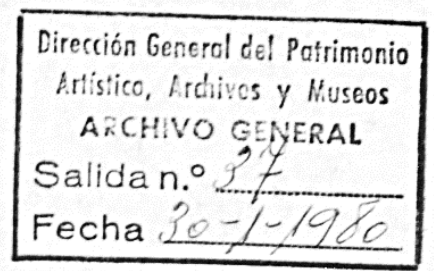

CASLOS IBANEZ GUTLEN, JEFE DEL ARCHIVO DEL

MINISTERIO DE CLLTURA,

\section{CERTIFICD:}

2us s=gin las zutecgdentes que obran on el Archi-

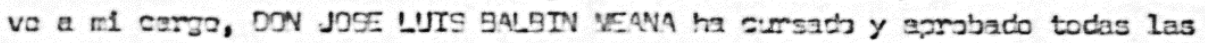
esignaturas del Plen de Estudios de la Escuela ofiaiel te Periodismo son las eiguientes callficecicnez:

PRII:ER CURSO 1960-6I

EI mundo actual .......................................... NOTABLE.

La España contemporfinea ..................................... NOTABLE.

Est1la periotistico .................................. NOTARLE.

Teoria $y$ técnica de la noticie .............................. SOERESALIENTE.

Francess ............................................. NGTAGLE.

Eeminario de reteceión ......................................... AFACBADO.

Seminerio te reporteje ....................................... NOTAELE.

Seminerio de critica periotistica .......................... SOBRESALIENTE.

SEGUNCO CUFSO 1961-E2

Logma y morel católicos ................................. NOTBaLE.

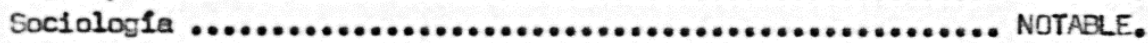

Teorfa y técnica de la publicidad ............................. APFIDBADO.

TÉcnica de las artes grăficas ................................. APRCBACO.

Francts ................................................ APRDBADO.

Ingl's ................................................... APROBADO.

Seminario de redacesión ........................................ APRDBADO.

Serinori jo de radtodt fusión ................................. NOTABLE.

Seminerlo de television ...................................... ARRDBADO.

Seminerio de prolicided .................................... APRUBACO.

TEFCEA CUASO 19E2-60

Historia del periodisno ...................................... AFFOBACM. TEconicas y organización do la trensmisión de noticias ....... NOTAELE.

Cultura españole contenparénea ............................... NOTAaLE.

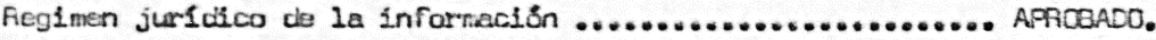

Sistenes econónicos y empresariales de información ........... APROBADO.

Précticas de inglés y frencés .............................. AFRCBACO.

Seminario de periodismo fthaico ............................... SOBRESALIENTE.

Seminario de periodismo televisivo .......................... NOTABLE.

Seminario de armado del periódico impreso ..................... NOTABLE.

Seminario de periodism radiofbnico ....................... NOTABLE.

EXALEN DE GRADO.- Convocatoría Junio 1963 ................... APADBADO.

$Y$ pera qus conste, a petición del interesado $y$ sum ta los debidos efectos, expido el presente cortificado en llactrid, a veintinueve de Enero de mil novecientos ochenta.

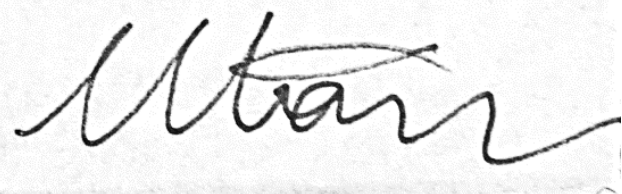


Anexo 2. Nombramiento de José Luis Balbín como Secretario del Departamento Nacional de Información del SEU

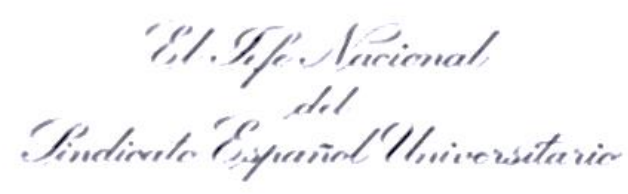

En uso de las atribuciones que me confieren las disposiciones vigentes del Sindicato Español Universitario,

Vengo en nombrar al camarada JOSE LUIS BALBIN MEANA, Secretario del Departamento Nacional de Información del S.E.U.

Y para que conste y surta los efec tos oportunos firmo el presente en $\mathrm{Ma}-$ drid a ocho de noviembre de mil noveecientos sesenta y tres.

- EL JEFE MACIONAL DEL S.E.U. -

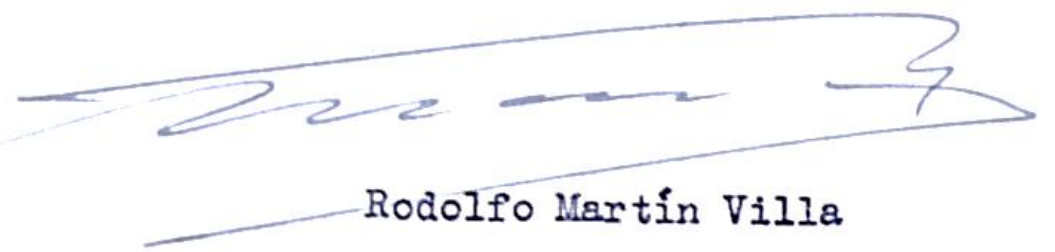


Anexo 3. Carta de José Luis Balbín enviada a Rodolfo Martín Villa en julio de 1970

Sr. D. Rodolfo Martin Ville, secretario general de la Organizacion Sindical.- Madrid.

Querido Rodolfo: si telefoneo o escribo, no es para darte la lata, sino para seber a qué atenerme de aquí al otoño, cuando llegue el momento de tomer decisiones. Como tu habías hablado de la primora veintena de julio, temí que hubieras abandonado el proyecto. Al parecer, no es asf. No es que yo tenge prisa. En absoluto. Precigamente si la muestro, es porque sería con voniente, antes de cualquier cambio, que ultimase mi "dossier" militar. cosa que no haré por la vía normal hasta después del 19 de sosto, porque así resultará burocrátichente más sencillo. Te repito lo de que thpoco quiero presionar mucho. Si tu no lo consideras conveniente, no me, va a sentar mal. (Siento que, con la abeorción de tiempo de túcarco y el trajín mío de Madrid, no haya podido contatte mig chismes politicos internacionalea. Lo haré por carta si, a la larka, me quedo on el extranjero).

Nunca te habría propuesto algo que no me creyese capaz do hacer bien. $\mathbf{Y}$ si aleo so me da, son los diputados centro europeos -comunietas incluídoo-, los sindicalistas reticontos y los emierantes contestarios. Cara a los omierantes, estoy convencido de que se podrla encauzar mejor su politización evi. dento. Cara a los políticos del país, me comprometo desie ya. a llovarte a cuantos quieras a España -si on su momento interesa-, y no solo a 10 s de eripos edictos, como se viene haciendo tra dicionłmente. Cuando avancé la idea de Escadinavia, fué porque creo, justamente, que no es tan diffcil mejorm unas roliaiones que, o mucho me equivoco, o son prácticamente inexistentes.

Evidentemente, Alematia se me darfa mejor, por tener ya alí mis conocimientos, incluso en la Federación Sindical. De otro lado, contaría con las facilidades que heredo de la mi antropía de Sorribes, puesto que él parece creer que es tanto más fiel a la causa cuanto más marca distanciasfect los que no son "Buyros" y más inmerso se dice en el eje ideolófico de la euerra mundial. Hay ese posible inconveniente de que Erice quiera intervenir, dado como es a eceparar actividad. No haberse de jado, yes un tanto que hay que apuntarle a Sorribes. Por eso, sabiéndome más lo de Centroeuropa, te apuntaba cuelquier otro -. -

Sí es cierto, en t'́odo caso, que esto de la radio y la te levisión no me va nada: el yicro" me pone nerviosísimo. Y ade más, me parece un periodismo poco serio. Al final, si tu pro yecto falla, estoy dispuesto a marchme para "ABC" a Viena, que es unq manera de marginarme un poco de la profesión para dedicarme a mis libros. Por el contrario,si voy a Bonn, creo que efectivmente podré seguir, si no ves inconveniente, con la corresponsalla de "Pueblo", puesto que Emilio Romero no parece encontrar ninguna persona a su gusto para sucederme.

Nada más, Rodolfo. Sólo que no te olvides de tenerme al tanto, si te es posible y sabes cómo van a suceder las cosas. Considéralo el ultimo recordtorio escrito. la próxima carta, si ha lugar, será más informativa:

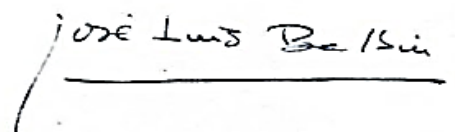


Anexo 4. Dossier informativo sobre José Luis Balbín en 1974. Ministerio de Información y Turismo

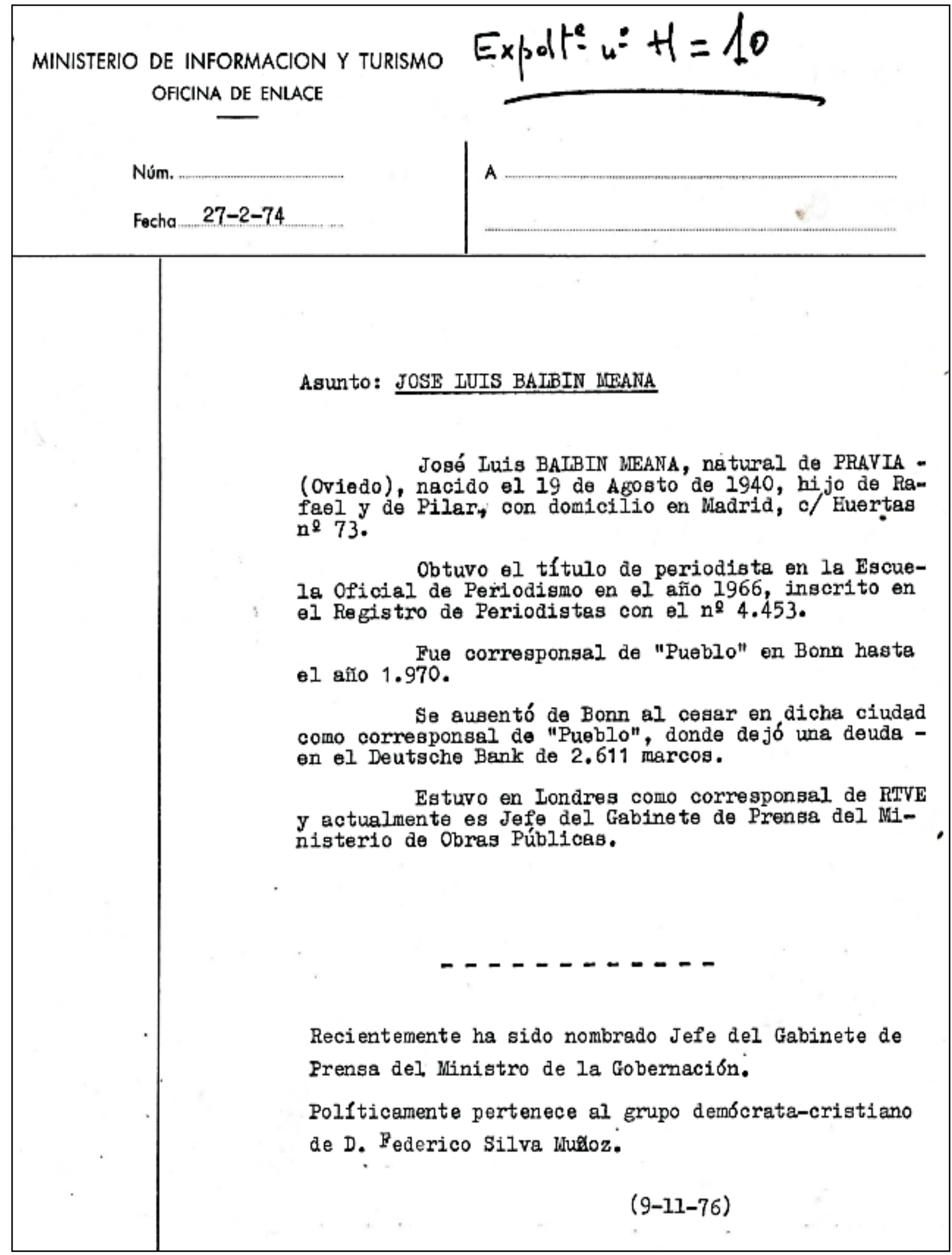




\section{Anexo 5. Fotografías}

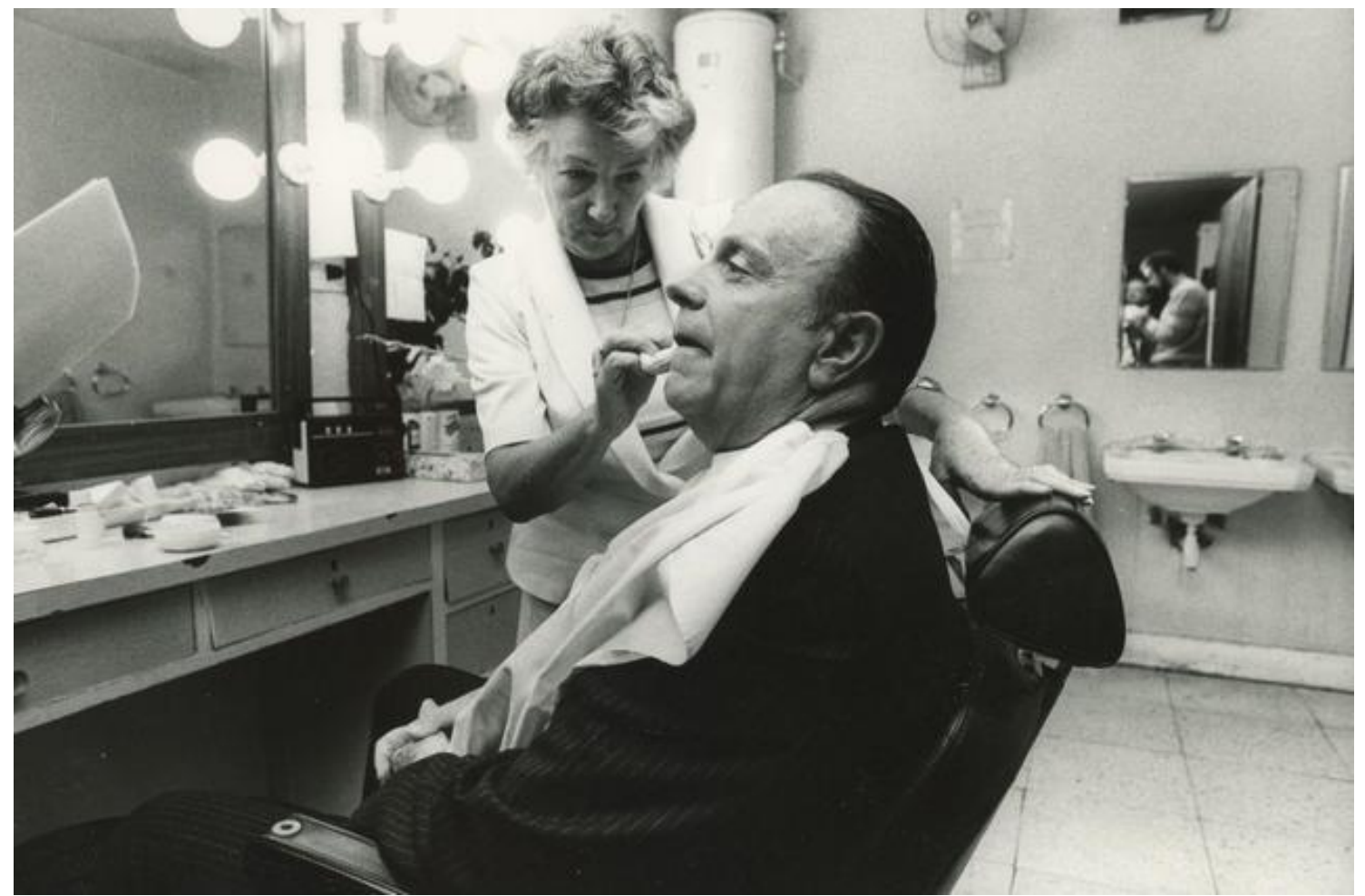

Manuel Fraga se prepara para intervenir en La clave en el programa Elecciones ¿Para quién los votos? (ficha 242), el 1 de octubre de 1982. Fotografía de Luis Magán.

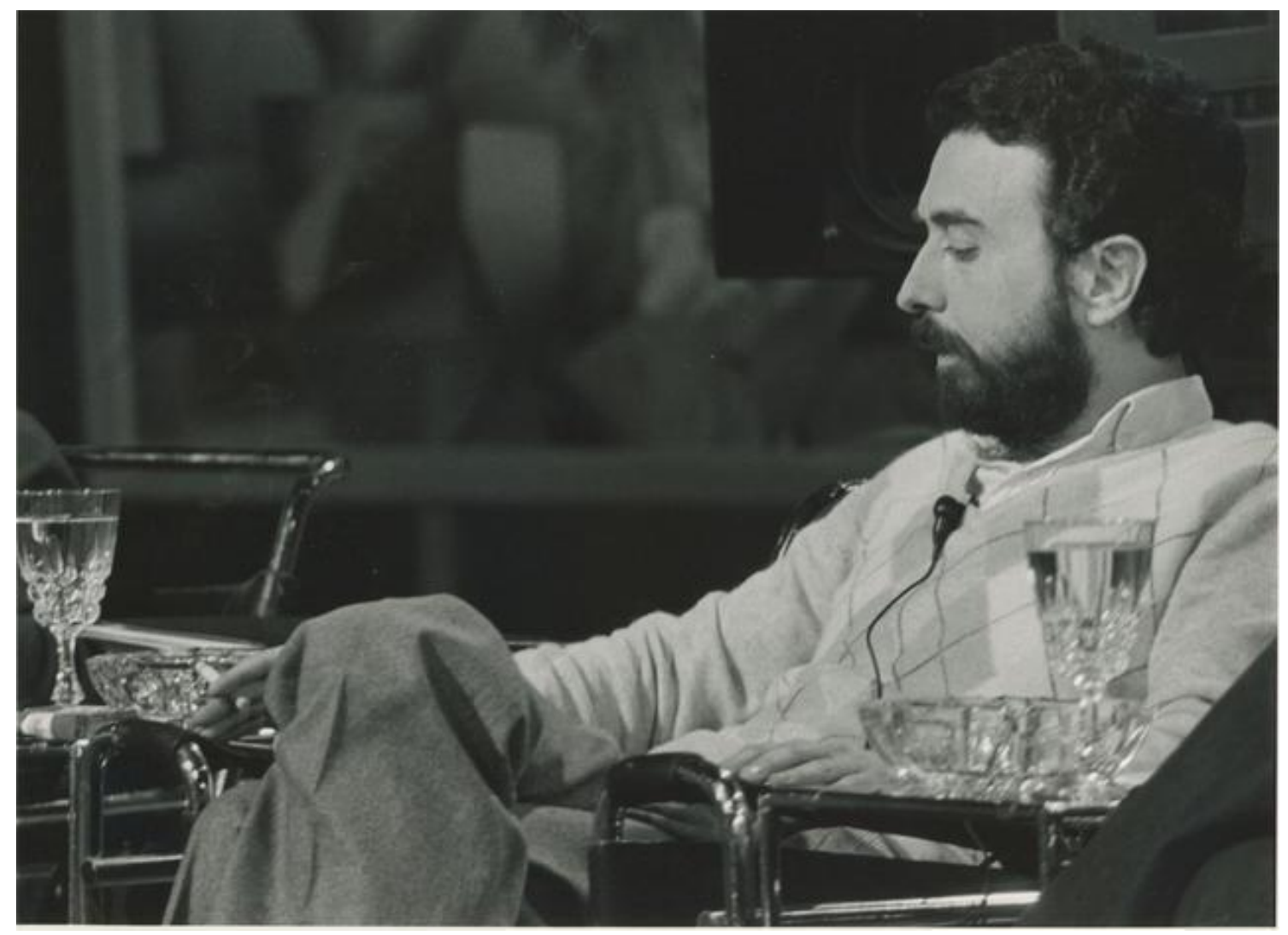

Retrato de José Luis Garci durante el programa El buen cine (ficha 269), el 22 de abril de 1983. 

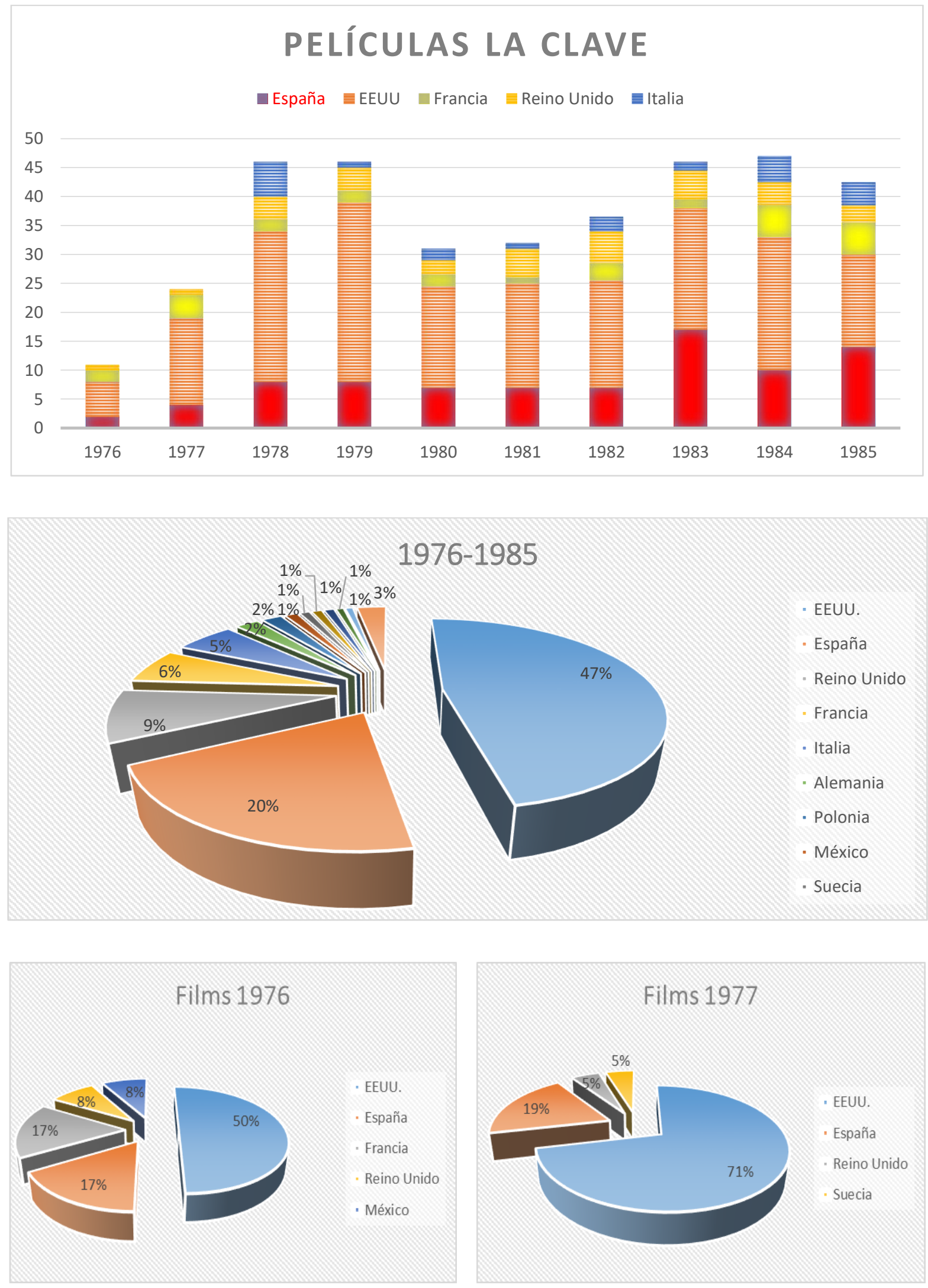

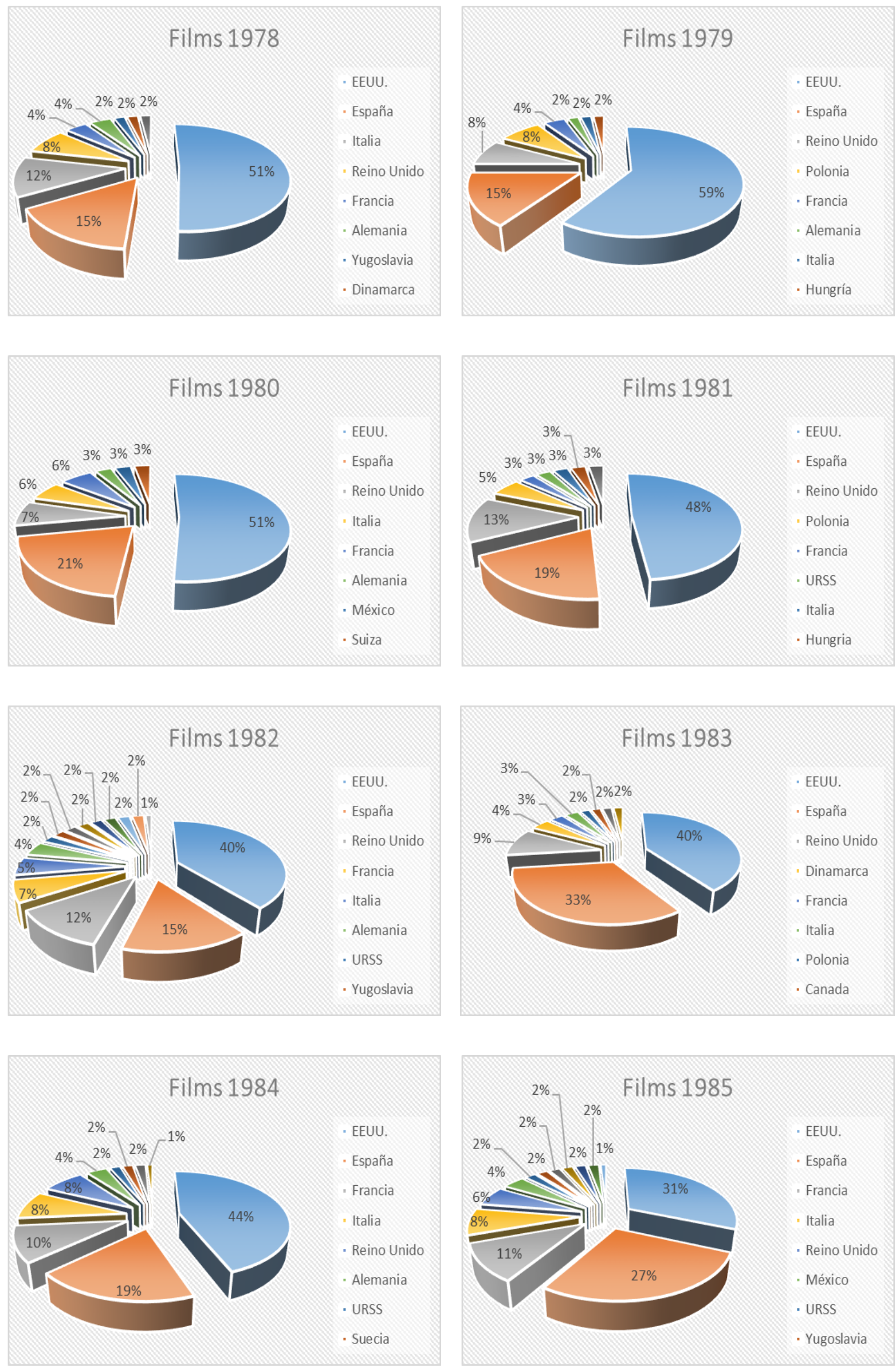


\section{El socialismo en la sociedad democrática avanzada}

Quisiera recordar brevemente la noción de Marx sobre el socialismo. Según Marx, en una sociedad socialista (no distingue esencialmente entre socialismo y comunismo):

- Los medios de producción y las fuerzas productivas en general son propiedad de la asociación de productores y están controlados por ellos.

- Primeramente, por los obreros industriales, y luego, mientras las diferencias de clase van desapareciendo, por todos los trabajadores, tanto manuales como intelectuales.

El control de las fuerzas productivas se ejerce en forma democrática en todos los niveles de la sociedad: locales, regionales, federales, en el lugar de trabajo, en sectores urbanos, en los pueblos, en el campo, etcétera.

Esta sería la democracia directa, con asambleas populares locales como la base de la pirámide, con delegados electos y revocables en cualquier momento por mayoría de voto.

¡El vértice de la pirámide es responsable de la base!

El control del proceso productivo tiene como objeto la abolición gradual de la pobreza y de la escasez, luego, el desarrollo de todas las facultades y necesidades individuales.

El requisito es la progresiva reducción del tiempo de trabajo invertido en trabajo social necesario, pero «enajenado», hasta que la proporción que existe en el capitalismo sea invertida:

- El tiempo libre para el desarrollo creador llega a ser el contenido vital, mientras el trabajo enajenado se reduce en gran parte.

Este programa socialista presupone un alto grado de desarrollo técnico, una gran riqueza social de recursos materiales e intelectuales, una clara conciencia de la posibilidad y necesidad de abolir el sistema capitalista y una clase obrera militante que luche por este fin.

Por tanto, Marx previó el triunfo de una revolución socialista, principalmente en los países industriales más avanzados.

Tal revolución no ha tenido lugar, aunque, según el concepto de Marx, el capitalismo avanzado estaría «maduro» para la transición al socialismo.

\section{Cuatro preguntas:}

1. ¿Por qué razones?

2. ¿Ha sido refutado el análisis de Marx?

3. ¿Podemos anticipar realistamente el colapso?

4. ¿Qué perspectivas existen para un cambio social radical y para la transición al socialismo?

1. Marx vio en la creciente productividad del trabajo la fuerza que impulsaba el avance del capitalismo y que, al mismo tiempo, produciría su colapso. ¿Por qué razón? Porque una creciente productividad significa una mecanización y racionalización crecientes, creando de esta manera una disminución en la proporción del trabajo humano físico. El resultado es la disminución de la fuente de ganancia; es decir, del poder del trabajo humano y de la tasa de ganancia.

Pero Marx subestimó las «tendencias contrarias», a saber: 
a) El crecimiento de la productividad fue tan grande que compensó la proporción desfavorable del trabajo vivo y del trabajo mecanizado.

b) La expansión imperialista del capital abrió grandes áreas del Tercer Mundo al mercado capitalista (fuente de mano de obra barata, energía. salarios, primas, etcétera).

c) La productividad, cada vez mayor, de la metrópoli y la explotación de los países subdesarrollados permitieron al capitalismo crear y mantener un alto nivel de vida para la privilegiada población de la metrópoli, que contrarrestó el desarrollo de una conciencia socialista radical.

d) El crecimiento de los grandes sindicatos protegió a la clase obrera de las formas más aborrecibles de explotación.

e) La dirección estatal (gubernamental) de un gran sector de la economía; la «economía mixta».

2. Estas «tendencias contrarias» que hacen posible la reestabilización del capitalismo no refutan el análisis de Marx del capitalismo, porque están implícitas y anticipadas en los conceptos mismos de Marx, bajo la categoría general de capitalismo de Estado. Marx consideró esta transformación del capitalismo como la última, antes de la transición al socialismo.

Es precisamente este concepto de transición el que debe ser reexaminado.

3. Las contradicciones internas continúan operando en el capitalismo avanzado:

a) La inflación, el desempleo estructural, la presión de la tasa de ganancia.

b) La existencia de conflictos dentro de la órbita capitalista: Europa occidental, Estados Unidos y Japón.

c) Las luchas de independencia en los países en vías de desarrollo.

d) Fuerza de la órbita comunista. La tendencia ambivalente es la siguiente: Permite también la reestabilización del capitalismo al abrir nuevos y vastos mercados.

4. El capitalismo responde frente a estas amenazas con una represión creciente:

a) Amplio control de la población a través de medios computarizados.

b) Fortalecimiento de las agencias de seguridad, la guardia nacional y la policía.

c) Racionalización de la economía: la creación de una gran reserva de desempleados de la industria.

d) Reducción de los derechos y libertades civiles: una tendencia hacia la democracia autoritaria.

La represión, en conjunción con el alto nivel de vida que todavía se sustenta, es, en gran medida, efectiva en mantener a la oposición (trabajadores y burgueses radicales) dentro del sistema (lucha economicista, más bien que lucha política de clases).

La oposición socialista, confrontada con un régimen capitalista que restringe los derechos y las libertades democráticas, se ve con el papel de «postergar» la estrategia revolucionaria y de concentrarse en la lucha para «salvar» Y extender los logros democráticos, ¡que siguen siendo una precondición para la transición al socialismo!

La democratización de la estrategia socialista en el interior del sistema capitalista se encuentra ante la perspectiva de ser integrada a la sociedad capitalista (al estilo de la socialdemocracia alemana): esto es hoy una posibilidad real:

- ¡Le corresponde a la oposición socialista comprobarlo o desmentirlo! 


\section{DVD}

Listado de programas e invitados

Entrevista a José Luis Balbín 